


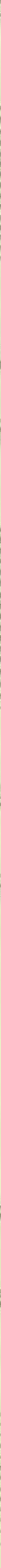




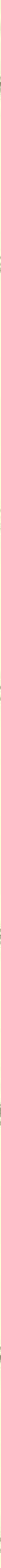


Digitized by the Internet Archive in 2007 with funding from Microsoft Corporation 




\section{FLORA OF THE}

\section{NORTHWEST COAST}

INCLUDING THE AREA WEST OF THE SUMMIT OF THE CASCADE MOUNTAINS FROM THE FORTY-NINTH PARALLEL SOUTH TO THE CALAPOOIA MOUNTAINS ON THE SOUTH BORDER OF LANE COUNTY, OREGON.

BY

CHARLES V. PIPER

PROFESSOR OF BOTANY, THE STATE COLLEGE OF WASHINGTON, I893-I903.

\section{AND}

\section{R. KENT BEATTIE}

PROFESSOR OF BOTANY, THE STATE COLLEGE OF WASHINGTON, I903-I9I2. 
Copyright, 1915, by

C. V. Piper and R. Kent Beattie

Issued November IO, I9I5 


\section{QK

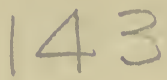 \\ P5}

\section{INTRODUCTION.}

The region covered by this flora is that lying between the summit of the Cascade Mountains and the Pacific Ocean from the 49th parallel of latitude across the southern portion of Vancouver Island, south to the headwaters of the Willamette River or, more specifically, to the southern boundary of Lane County, Oregon, marked in part by the Calapooia Mountains. In the Umpqua Valley just south of these mountains, many California plants reach their northern limits; while in the Rogue River Valley, the next southward, the flora is predominantly Californian.

The northern boundary chosen is, from a botanical standpoint, purely artificial. Naturally, as marked by the northern limit of the characteristic lowland trees, it would extend to about latitude $54^{\circ}$, that is, nearly to the southernmost extremity of Alaska.

In general the flora below 5,000 feet altitude is characterized by dense coniferous forests, the commonest tree being the Douglas spruce. Along the narrow river valleys, however, the tree flora is in large part made up of deciduous trees, such as alder, cottonwood, and maple. The only break in this continuous forest cover consisted originally of a series of prairies extending from the upper Willamette Valley northward to Vancouver Island. North of the head of Puget Sound, however, these prairies are small and are limited in the main to the extremities of points and to a portion of the islands in the Sound. In Washington these prairies are all gravelly and are mainly the deposit of glacial streams. In the Willamette Valley they appear at least in part to have been due to the periodic burning of the dry grass by the Indians.

The flora of the region may be classified into four life zones:

The Humid Transition zone includes the great forests of Douglas spruce, as well as the included prairie regions. Other characteristic trees are giant cedar, red alder, broadleaf maple and Scouler willow. Along the seacoast the Sitka spruce is abundant, accompanied by other northern plants. This coastal strip may be looked upon as a southward extension of the Canadian zone rather than as typical Humid Transition.

The Canadian zone is not sharply limited. Such trees as western white pine, amabilis fir, and Engelmann spruce mark it best. Western hemlock is particularly abundant in this zone but also descends to sea lever.

The Hudsonian zone is indicated by subalpine fir, Alaska cedar, black hemlock, and white-bark pine. At their extreme altitudinal limits all of these become prostrate mats of branches.

The Arctic zone consists of the alpine flora above the limits of trees.

From a botanical standpoint the region is of unusual interest on account of its màgnificent coniferous forests, its wonderful mountain meadows, and the large percentage of species that are peculiar to its flora. The extensive 
systems of high mountains within its limits contain a very varied flora and provide a wide field for further botanical explorations. Without doubt these mountains contain many species of plants new to botanists, while many others as yet are known from but single collections. The lack of a suitable handbook has doubtless deterred many from studying the plants of the region. If this book shall stimulate greater activity and interest in its flora, the authors will feel amply repaid for their labors.

The material upon which this flora is based is mainly that contained in the herbarium of the State College of Washington. Thanks are due to the officials of that institution for encouragement and support in the preparation of this volume. 


\section{ANALYTICAL KEYS TO THE FAMILIES.}

Plants with woody bundles, reproducing by spores.

Plants with woody bundles, reproducing by seeds.

Phylum PTERIDOPHYTA, v.

Phylum SPERMATOPHYTA, v.

\section{Phylum PTERIDOPHYTA.}

Leaves few, large; stems mostly underground.

Leaves 4-foliolate, clover-like; spore cases in closed pod-like sporocarps.

Leaves not 4-foliolate; spore cases not in sporocarps.

Spore cases in the tissue of a prominent and distinct fertile lobe of the leaf.

Spore cases formed of outgrowths from the surface of the leaf.

Leaves numerous, small; stems aerial and underground.

Leaves whorled; stems jointed, hollow.

Leaves not whorled; stems not jointed, solid.

Spore case in the enlarged base of the leaf; stems short, corm-like.

Spore case in the axil of the leaf; stems elongated.

Spores all alike.

Spores of two kinds, large and small.

Marsileaceae, 10.

Ophioglossaceae, 8.

Polypodiaceae, 1.

Equisetaceae, 11.

ISOETACEAE, 15.

LyCopodiaceaE, 13.

Selaginellaceae, 14.

\section{Phylum SPERMATOPHYTA.}

Ovules and seeds not in a closed cavity, usually on the face of an open scaleleaf; stigmas none.

Class Gymnospermae, v.

Ovules and seeds contained in a closed cavity surrounded by one or more closed and modified leaves forming an ovary; stigmas present.

Cotyledon one; stem with no distinction into bark, wood and pith (endogenous); leaves usually parallel-veined; parts of the flowers nearly always in threes.

Sub-class MoNocotyledones, v.

Cotyledons two; stem (with rare exceptions) of bark, wood and pith (exogenous); leaves usually net-veined; parts of the flower in fours, fives or sixes, never in threes. Sub-class Dicotyledones, vi.

Fruit a cone.

Class GYMNOSPERMAE.

Fruit drupe-like.
Pinaceae, 17. TAXACEAE, 16.

\section{Class ANGIOSPERMAE.}

Sub-class MONOCOTYLEDONES.

Plants small, floating, with no distinction of stem and leaves.

Plants with normal foliage.

LEMNACEAE, 86. 
Inflorescence a fleshy spadix.

Inflorescence not a fleshy spadix.

Perianth none, or of bristles, chaffy scales or a hyaline envelope.

Flowers in the axils of chaffy bracts.

Stems mostly hollow, jointed; leaves 2-ranked.

Stems solid; leaves 3-ranked.

Flowers not in the axils of chaffy bracts.

Perianth herbaceous or none.

Carpels 1-5, separate.

Carpels 3 or 6 , united into a compound ovary.

Perianth of bristles or chaffy scales.

Flowers in terminal cylindrical spikes.

Flowers in axillary globular heads.

Perianth present, the parts glume- or petallike.

Perianth of glume-like segments.

Perianth at least in part petal-like.

Carpels distinct.

Carpels united.

Ovary superior.

Flowers more or less irregular, surrounded by a spathe.

Flowers regular, without a spathe.

Ovary inferior.

Aquatic plants; flowers dioecious or polygamous.

Terrestrial plants; flowers perfect.

Flowers regular.

Flowers irregular.

Araceae, 85.

POACEAE, 31.

Cyperaceae, 65.

NAJADACEAE, 25.

SCHEUCHzeriaCEAE, 29.

TYPHACEAE, 23.

SPARGANIACEAE, 24.

JUNCACEAE, 87.

Alismaceae, 30 .

Pontederiaceae, 86.

LiLIACEAE, 92.

HydRocharitaceae, 30.

IRIDACEAE, 104.

ORCHIDACEAE, 106.

\section{Sub-class DICOTYLEDONES.}

I. Petals Distinct to the Base or Wanting.

\section{A. Petals None.}

Plants parasitic or saprophytic and usually without chlorophyll.

Flowers dioecious; stamens 2-6.

Flowers perfect; stamens 10.

Plants neither parasitic nor saprophytic but hav-

LORANTHACEAE, 122. Allotropa, 271. ing chlorophyll.

Trees or shrubs.

Leaves small, linear or scale-like; plants heath-like.

Leaves large; plants not heath-like.

Leaves opposite.

Leaves silvery-scurfy.

Leaves not silvery-scurfy.

Fruit a drupe.

Fruit a samara.

EMPETRACEAE, 232.

Elaeagnaceae, 244.

Garrya, 269. 
Fruit 2-celled, a double sa-

mara.
Fruit 1 -celled, a single samara.

Leaves alternate.

Aceraceae, 235.

OleaCEAE, 287.

Flowers not in aments.

Flowers or some of them in aments.

Staminate flowers in aments; pistillate flowers $1-3$ in a cluster.

Staminate and pistillate flowers both in aments.

Ovary 1-celled, many-ovuled; calyx not present.

Ovary 1-2-celled, each cell 1-ovuled.

Pistillate flowers 2-3 under each scale of the ament; fruit not waxy; calyx present.

Pistillate flowers 1 under each scale of the ament; fruit waxy; calyx not present.

Herbs (sometimes woody at base).

Rhamnus, 236.

FAgaceae, 121.

SAlicaceae, 112.

Betulaceae, 119.

MyricaCEAE, 118.

Leaves opposite.

Flowers monoecious.

Ovary 1-celled; stamens 2-5.

Ovary more than 1-celled; stamen 1.

Ovary 4-celled.

Ovary 3-celled.

Flowers perfect.

Leaves fleshy.

Leaves not fleshy.

Style 1.

Calyx petal-like.

Calyx not petal-like.

Styles 2-5.

Disk conspicuous; ovules on 2 parietal placentae.

Disk not conspicuous, if present; ovules on a basal

Leaves not opposite. or central placenta.

URTICACEAE, 122.

Callitrichaceae, 231.

EupHorbiaceae, 230.

Glaux, 285.

Nyctaginaceae, 135.

Isnardia, 247.

Chrysosplenium, 193.

Caryophyllaceae, 141.

Leaves whorled.

Calyx present, closely investing the ovary.

Calyx none.

Leaves not whorled.

Flowers monoecious.

Ovary 3-celled, 3-ovuled.

Ovary 1-celled, 1-ovuled.

Flowers with scarious bracts.

Flowers bractless, or, if bracted, the bracts not scarious.

Flowers perfect or dioecious.

Haloragidaceae, 253.

Ceratophyllaceae, 151.

Euphorbiaceae, 230.

Amaranthaceae, 134.

Chenopodiaceae, 132.

Pistils more than one. 


\section{Stamens perigynous.}

Stamens hypogynous. Pistil one.

Anthers opening by uplifted valves.

Anthers not opening by uplifted valves.

Ovary more than 1-celled.

Ovary 2-celled.

Ovary more than 2celled.

Ovary 6-celled. Ovary 3-5-celled.

Ovary 1-celled.

Ovary partly inferior.

Flowers on a scape.

Flowers on a leafy stem.

Ovary superior.

Fruit an akene.

Akene enclosed in the receptacle.

Akene not enclosed in the receptacle.

Fruit not an akene.

Fruit a utricle.

Fruit a capsule. Stamens 8. Stamens 5.
Rosaceae, 197.

RANUNCULACEAE, 151.

Achlys, 164.

Cruciferae, 166.

Aristolochiaceae, 124.

Aizoaceae, 136.

Heuchera, 196.

Santalaceae, 124.

Rosaceae, 197.

Polygonaceae, 125.

Chenopodiaceae, 132.

Chrysosplenium, 193.

Claytonia, 139.

\section{B. Petals Present.}

1. Stamens numerous, at least more than ten and more than twice the sepals or calyx-lobes.

Calyx free and separate from the ovary.

Pistils more than one.

Ovaries cohering in a ring around a central axis.

Ovaries separate, or, if united, not cohering in a ring around a central axis.

Stamens perigynous.

Stamens hypogynous.

Aquatic plants; leaves not dissected.

Terrestrial plants, or, if aquatic, the submersed leaves dissected.

Pistil one, with one to several styles and stig-

Malvaceae, 238.

ROSACEAE, 197.

NymphaEaceae, 150.

Ranunculaceae, 151. mas.

Leaves minutely punctate with pellucid dots.

Leaves not punctate with pellucid dots.

Ovary simple.

Stamens hypogynous.

Stamens perigynous.

Ovary compound.

RANUNCULACEAE, 151.

ROSACEAE, 197. 
Ovary 1-celled with a central placenta.

Ovary several-celled.

Ovary 5-celled.

Ovary 10-20-celled.

Calyx more or less coherent with the surface of the compound ovary.

Ovary more than 1-celled.

Leaves alternate, with stipules.

Leaves opposite, without stipules.

Ovary 1-celled.

Placenta basal; plants leafy.

Placenta parietal; plants leafless or with minute leaves.
Portulacaceae, 136.

Oxalidaceae, 229.

NymphaEACEAE, 150.
Rosaceaf, 197.

Philadelphus, 188.

Portulacaceae, 136.

Cactaceae, 244.

2. Stamens not more than twice as many as the petals.

Stamens opposite the petals.

Ovary 2-4-celled.

Ovary 1-celled.

Anthers opening by uplifted valves.

Anthers not opening by uplifted valves.

Stamens not opposite the petals.

Ovary at least half inferior.

Ovules and seeds more than one in each cell of the ovary.

Ovules and seeds but one in each cell of the ovary.

Petals 5.

Trees or shrubs; flowers in corymbs.

Herbs; flowers in umbels or heads.

Petals 2 or 4 .

Stamens 4; fruit a drupe.

Stamens 2 or 8 ; fruit indehiscent and nut- or bur-like.

Style 1; stigma 2-4-lobed.

Styles or sessile stigmas 4 .

Ovary wholly superior.

Ovaries two or more.

Ovaries somewhat united at the base, separate above.

Trees.

Herbs.

Ovaries entirely separate.

Stamens hypogynous.

Carpels numerous.

Carpels 4 or 5 .

Stamens perigynous or epipetalous.

Stamens just twice as many as the pistils.

Stamens not just twice as many as the pistils.

Leaves without stipules.

Ovary only one. Leaves with stipules.

Ovary 3 -5-lobed and beaked with a united style.
Rhamnaceae, 236.

Berberidaceae, 163.

Portulacaceae, 136.

ONagraceaf, 246.

Crataegus, 200.

UMBELLIFERAE, 255.

Cornaceae, 268.

ONAgraceae, 246.

Haloragidaceae, 253.

Aceraceae, 235.

SAXIfRAGACEAE, 184.

RanunCulaceae, 151.

Crassulaceae, 182.

Crassulaceae, 182.

SAXifragaceae, 184.

ROSACEAE, 197. 
Carpels 5; stipules present.

Carpels 2-4; stipules none.

Ovary neither lobed nor beaked.

Ovary simple with 1 parietal placenta.

Ovary compound, as shown by the number of cells, placentae, styles or stigmas.

Ovary 1-celled.

Corolla irregular.

Stamens 6; petals 4.

Stamens and petals 5 .

Corolla regular or nearly so.

Ovule 1.

Shrubs or trees.

Herbs.

Ovules more than 1.

Placenta central or basal.

Placentae parietal.

Leaves punctate with pellucid dots. Leaves not punctate.

Plants not green, parasitic or saprophytic.

Plants green, neither

parasitic nor saprophytic.

Leaves with bristly glandular hairs, forming insect traps.

Leaves without bristly glandular

Ovary 2-several-celled. hairs.

Stamens neither just as many nor twice as many as the petals.

Trees or shrubs.

Stamens 2. Herbs.

Stamens more than 2.

Stamens 6, tetradynamous.

Stamens 5, regular.

Stamens either just as many or twice as many as the petals.

Ovules 1 or 2 in each cell of the ovary.
Geraniaceae, 228.

LimnanthaceAE, 232.

Leguminosae, 212.

Papaveraceae, 164.

VIOLACEAE, $24 i$.

ANACARdiaceae, 233.

CRUCIFERAE, 166.

Caryophyllaceae, 141.

Hypericaceae, 239.

Pyrolaceae, 270.

Droseraceae, 182.

SAXIfRAgaceae, 184.

Oleaceae, 287.

ACERACEAE, 235.

Cruciferae, 166.

BALSAMINACEAE, 236. 
Herbs.

Shrubs or trees.

Leaves pinnatelyveined; shrubs.

Leaves palmatelyveined; trees.

Ovules several-many in each cell of the ovary.

Leaves opposite, with stipules.

Leaves, when opposite, without stipules.

Stamens on thecalyx. Style 1.

Styles 2 or 3 .

Stamens free from the calyx.

Style 1.

Herbs.

Shrubs.

Styles 2-5.

Stamens and calyx united to the ovary.

Stamens and

calyx

free

from

the ovary.

Leaves trifolio-

late.

Leaves simple.
Geraniaceae, 228.

Celastraceae, 234.

Aceraceae, 235.

Elatinaceae, 241.

LYTHRACEAE, 245.

SAXIFRAGACEAE, 184.

Pyrolaceae, 270.

ERICACEAE, 275.

Araliaceae, 254.

Oxalidaceae, 229.

Caryophyllaceae, 141.

II. Petals More or Less United into One Piece.

Stamens more numerous than the corolla-lobes.

Ovary 1-celled.

White or reddish chlorophyll-less parasitic or saprophytic herbs.

Green chlorophyll-bearing herbs, not parasitic nor saprophytic.

Ovary with 1 parietal placenta.

Ovary with 2 parietal placentae.

Ovary 3-many-celled.

Stamens united with the base of the corolla.

Stamens free from the corolla.

Chlorophyll-less parasitic or saprophytic herbs.

Chlorophyll-bearing herbs, not parasitic nor saprophytic.

Pyrolaceae, 270.

Leguminosae, 212.

Papaveraceae, 164.

Malvaceae, 238.

Pyrolaceae, 270.

ERICACEAE, 275.

Stamens as many as the corolla-lobes or fewer.

Stamens opposite the corolla-lobes.

Style 1 ; fruit a several to many-seeded capsule.

Primulaceae, 283.

Styles 5; fruit a 1 -seeded utricle.

Plumbaginaceae, 286. 
Stamens alternate with the corolla-lobes or fewer.

Ovary inferior.

Tendril-bearing herbs.

Tendrils none.

Flowers in an involucrate head on a common receptacle.

Anthers united into a ring or tube (syngenesious).

Anthers not united.

Flowers not in an involucrate head nor on a common receptacle.

Stamens on the ovary.

Stamens on the corolla.

Stamens 1-3.

Stamens 4 or 5 .

Leaves opposite or whorled, when opposite with stipules.

Leaves opposite, without

Ovary superior. stipules.

Cucurbitaceae, 341.

Corolla more or less irregular.

Ovules solitary in the cells of the ovary.

Ovary 4-lobed, the style rising from between the lobes.

Ovary not lobed, the style rising from its apex.

Ovules 2 or more, usually numerous, in each cell.

Ovary and pod 2-celled.

Ovary and pod 1-celled.

Chlorophyll-less terrestrial herbs.

Chlorophyll-bearing aquatic herbs.

LABIATAE, 306.

Compositae, 345.

DIPSACACEAE, 341.

Campanulaceae, 342.

VAlerianaceae, 339.

Rubiaceae, 334.

Caprifoliaceae, 336.

Verbenaceae, 305.

SCROPHULARIACEAE, 315.

OrobanchaceaE, 330 .

Corolla regular.

Stamens fewer than the corolla-lobes.

Trees or shrubs.

Herbs.

Corolla scarious.

Corolla not scarious.

Style 2-lobed.

Style simple.

Stamens as many as the corolla-lobes.

Ovaries 2, separate.

Ovary 1.

Ovary deeply 4-lobed around the style.

Leaves alternate.

Leaves opposite.

Ovary not deeply lobed.

Ovary 1-celled.

Leaves entire, opposite.

Leaves alternate or basal, rarely entire.

LENTIBULARIACEAE, 332.

Oleaceae, 287.

Plantaginaceae, 333.

Lycopus, 307.

Veronica, 322.

Apocynaceae, 290.

BORAGINACEAE, 299.

Mentha, 308.

Gentianaceae, 287. 
Corolla conspicuously bearded on the upper surface.

Menyanthaceae, 289.

Corolla not conspicuously bearded. HyDROPHYLLACEAE, 297. Ovary 2 or more celled.

Stamens free from the corolla.

Stamens on the corollatube.

Stamens 4.

Stamens 5.

Fruit a manyseeded pod or berry.

Fruit a few-

seeded pod.

Style 3-lobed. Polemoniaceae, 292.

Style undi-

ERICACEAe, 275.

Plantaginaceae, 333.

Solanaceae, 314.

vided

or 2-

cleft.

Whitish

or yel-

low

chloro-

phyll-

less

plants. Cuscutaceae, 291.

Green

plants. Convolvulaceae, 290. 



\section{FLORA OF THE NORTHWEST COAST}

\section{PHYLUM I. PTERIDOPHYTA. FERn Plants.}

Plant containing woody tissue and vessels in the stem and producing spores asexually which, on germination, develop very small structures called prothallia, on which are borne the sexual reproductive organs from which the asexual plant is developed. The sexual plant is rarely collected, and the classification is based mainly on the characters of the asexual plant.

\section{Class I. FILICINEAE.}

Plant highly organized, vascular, with green usually large leaves; spores borne within the tissue of, or in modified hairs on, modified or unmodified foliage leaves; stem solid, underground (in ours).

\section{Family 1. POLYPODIACEAE. Fern Family.}

Sporangia stalked, surrounded by a more or less complete vertical annulus and bursting transversely; fruit dots on the backs or the margins of the leaves, with or without indusia.

Indusium none.

Fruit dots usually linear, obscured by a powder on the under surface of the leaf.

Fruit dots roundish, not obscured by a powder. Leaves entire or simply pinnate.

Leaves bipinnatifid or ternate. Indusium present.

Fruit dots with marginal false indusia formed of the more or less altered edge of the leaf.

Sporangia on a marginal vein which connects the ends of the lateral veins.

Sporangia at or near the ends of unconnected veins.

False indusium continuous.

1. Ceropteris, 2.

2. Polypodium, 2.

3. Phegopteris, 3.

False indusium not continuous.

Fruit dots large, on a reflexed portion of the margin of the leaf.

Fruit dots minute, finally running

4. Pteridium, 4.

5. Cryptogramma, 4.

6. Adiantum, 4. 
segments which are small and beadlike (in ours).

7. Cheilanthes, 5 .

Fruit dots on the lower surface or margin of the leaf, each with a special indusium.

Fruit dots linear or oblong; indusium more than twice as long as broad.

Fruit dots all parallel with the midribs.

Veins free.

Veins forming a network.

Fruit dots all oblique to the midribs.

Fruit dots straight, on the upper side of the veins.

Fruit dots curved, of ten crossing the vein.

Fruit dots roundish; indusium less than twice

8. Struthiopteris, 5 .

9. WOODWARDIA, 5 .

10. Asplenium, 6.

11. Athyrium, 6.

as long as broad.

Indusium conspicuous, centrally attached.

Indusium rotund and attached at its center.

Indusium heart-shaped and attached at the middle of the sinus.

Indusium inconspicuous, not attached at the center.

Indusium hood-like or arched, attached by a broad base on the inner side partly under the fruit-dot, early withering.

Indusium rotund or star-shaped, attached under the fruit-dot.

12. Polystichum, 6.

13. DRYOPTERIS, 7.

14. FILIX, 8.

15. WoOdSIA, 8.

\section{CEROPTERIS.}

Fruit-dots oblong or linear, following the course of the veinlets, and like them simple, forked, pinnate or variously anastomosing, obscured by a yellowish or white powder on the back of the leaf (in ours); indusia wanting.

Ceropteris triangularis (Kaulf.) Underw. (Gymnogramme triangularis Kaulf.) Gold-back Fern. Stalks tufted, slender, dark brown, shiny, 15-30 cm. long; blades triangular or pentagonal, 5-12 cm. broad and long, pinnate; ıwer divisions largest, bipinnatifid, the others pinnately lobed; under surface of the leaf covered with a yellow powder.

Crevices of rocks, mostly near the sea coast. Vancouver Island to California and Arizona. Nanaimo, Mount Finlayson, Victoria, San Juan Island, Port Angeles, Eatonville. More common on the Oregon coast.

\section{POLYPODIUM.}

Fruit dots round, without indusia, on the back of the leaf, in one or more rows on each side of the midrib, or irregularly scattered; petioles jointed to the root-stock.

Leaves leathery; veins more or less netted.

P. scouleri.

Leaves membranous; veins free.

Leaflets attenuate, acute or acuminate.

Leaflets short, obtuse.

$P$. occidentale.

$P$. hesperium. 
Polypodium scouleri Hook. \& Grev. Leather-leaf Polypody. Rootstock stout, scaly, not licorice-flavored; leaves large, fleshy, 6-30 cm. long, 5-15 cm. wide; divisions obtuse, the lower ones largest.

On trees and rocks along the ocean coast, Vancouver Island to California.

Polypodium occidentale (Hook.) Maxon. ( $P$. falcatum Kellogg.) Licoriceroot Fern. Leaf-stalks pale green, 10-20 cm. long; blades thin, $20-40 \mathrm{~cm}$. long, 8-12 $\mathrm{cm}$. wide, divided to the midrib; divisions lanceolate, broadest at the base, sharply serrate, attenuate-acuminate; veins mostly 4-branched.

Common in moss on rocks, logs and trees, Alaska to California. The rootstocks taste much like licorice, and are eaten by children. Occasionally the divisions of the leaf are deeply cleft.

Polypodium hesperium Maxon. Leaves small, 5-15 cm. long, including the stalk; divisions few, short and obtuse.

In crevices of rocks, especially in the mountains. British Columbia to Montana and Arizona. The rootstocks taste like licorice.

\section{PHEGOPTERIS. BEECH FERN.}

Medium sized or small ferns; leaves twice to thrice pinnate or ternate; leaf-stalk continuous with the rootstock; fruit dots small, round, without an indusium, borne on the backs of the veins below or near their ends; veins free or reticulate.

United by some botanists with Dryopteris.

Plant densely tufted; leaves oblong-lanceolate, tripinnatifid. $\quad P$. alpestris.

Plant spreading by rootstocks; leaves triangular.

Leaves bipinnatifid; rachis winged.

Leaves ternate, the stalked divisions pinnate or bipinnate; rachis wingless.

P. phegopteris.

P. dryopteris.

Phegopteris alpestris (Hoppe) Mett. In crown-like tufts; rootstock short, stout; leaf-stalks $10-25 \mathrm{~cm}$. long, bearing a few brown scales; blades oblong-lanceolate, $30-60 \mathrm{~cm}$. long, tripinnatifid; ultimate divisions ovatelanceolate, doubly incised and toothed.

Common in rock talus in the mountains at $1500-2000 \mathrm{~m}$. elevation. British Columbia to Montana and California. Eurasia.

Phegopteris phegopteris (L.) Keyserling. Rootstocks creeping; leaf-stalks $15-20 \mathrm{~cm}$. long; blades triangular, longer than broad, 10-20 cm. long, pubescent on the veins beneath; divisions lanceolate, pinnately parted into many oblong obtuse lobes or segments.

Alaska to Greenland, south to Washington, Iowa and Virginia. Rare in our limits. Monte Cristo, Misses Coffin \& Goodspeed. Gorge of the Columbia River, Skamania County, Suksdorf.

Phegopteris dryopteris (L.) Fee. Rootstock slender, horizontally creeping; petioles $15-25 \mathrm{~cm}$. tall, pale straw-colored, shiny, bearing a few brownish scales toward the base; blades broadly triangular in outline, $10-20 \mathrm{~cm}$. wide, ternate, the lateral primary divisions bipinnate, the terminal usually tripinnate, all naked at the base; pinnae oblong, $2-5 \mathrm{~cm}$. long, glabrous, pinnately-cleft or divided into 15-25 obtuse lobes; fruit dots near the margin, on the ends of free veins.

In woods, especially at $400-1000 \mathrm{~m}$. elevation, but occasionally near sea level. Alaska to Oregon; widely distributed in the northern hemisphere. 


\section{PTERIDIUM.}

Large, mostly coarse ferns, with variously divided leaves; fruit dots marginal, linear, continuous on a slender thread-like receptacle which connects the tips of free veins; false indusium membranous, formed of the reflexed margin of the leaf.

Pteridium aquilinum pubescens Underw. Bracken or Brake. Rootstock stout, black, subterranean, horizontally-creeping; petioles $30-120 \mathrm{~cm}$. high, erect, pale-green or straw-colored; leaf-blades 60-120 cm. long, $30-90 \mathrm{~cm}$. wide, glabrous above, pubescent beneath, ternate, the three branches each bipinnate; ultimate segments oblong, acutish, mostly entire, the uppermost coalescent, the lower more or less lobed.

Common and difficult to eradicate from newly tilled land. In rich woods this fern is sometimes eight feet tall. British Columbia to California and Arizona.

\section{CRYPTOGRAMMA.}

Spore-cases on the back of the free forking veins, forming oblong or roundish fruit-dots, which at length run together and cover the backs of the smallest subdivisions of the leaf; indusium continuous, formed of the membranous somewhat altered margin of the leaf, at first reflexed along the two sides and meeting at the midrib, at length opening out flat.

Margins of the fertile leaflets scarious, forming a false indusium; ultimate segments of the sterile leaves linear-lanceolate, acute.

Margins of fertile leaflets not scarious; ultimate segments of the sterile leaves ovate, obtuse.

C. densa.

C. acrostichoides.

Cryptogramma densa (Brack.) Diels. (Pellaea densa (Brack.) Hook.) Densely tufted, $10-20 \mathrm{~cm}$. high; petioles dark brown, longer than the blades; blades 3-6 cm. long, ovate or ovate-oblong, tripinnate; leaflets crowded, linearlanceolate, 6-12 mm. long, mucronate, entire on the fertile leaves, serrate on the sterile ones.

In rock crevices in the mountains, British Columbia to Montana and California. Rare in our limits, Olympic Mountains, Clallam County, Washington, Elmer; Mt. Finlayson, British Columbia, Macoun.

Cryptogramma acrostichoides $\mathrm{R}$. Br. Stalks tufted, straw-colored; blades of two sorts, the outer sterile ones on shorter stalks, the ovate or obovate ultimate segments crenate or incised; the inner fertile ones long-stalked, the ultimate segments elliptic or oblong, pod-like.

Common among boulders at low elevations in the mountains, Alaska to Lake Superior, Colorado and California. First collected by Menzies at Nootka Sound.

\section{6. adiantum. Maiden Hair Fern.}

Fruit-dots marginal, short, covered by the reflexed portion of the more or less altered margin of the leaf which bears sporecases on its under side from the tips of the free forking veins.

Adiantum pedatum aleuticum Rupr. Maidenhair. Leafstalks dark brown or black, polished, $30-40 \mathrm{~cm}$. high; blades nearly circular, the principal 
divisions $10-25 \mathrm{~cm}$. long; ultimate divisions numerous, oblong or ovate, obtuse, lobed on the outer margin.

Wet banks and woods, not uncommon. Alaska to California.

\section{CHEILANTHES.}

Mostly pubescent or tomentose rock-loving and small ferns with much divided leaves; fruit dots on or near the ends of the veins, at first small and distinct, afterwards crowded; sporangia often concealed in the scales or hairs which in many species cover the segments.

The species occurring within our limits has the ultimate segments of the leaflets very small and circular in form and the false indusia formed by the incurving of the whole of the leaf margin.

Cheilanthes gracillima D. C. Eaton. Lace Fern. Petioles densely tufted, shining brown, 4-8 cm. high, bearing a few scattered lanceolate scales; blades $2-8 \mathrm{~cm}$. long, oblong-lanceolate, bipinnate; leaflets numerous, crowded, pinnately divided into 5-9 oval mostly entire segments, glabrate above, pubescent beneath with rusty matted woo.

Common in rock crevices in the mountains at $1000-1500 \mathrm{~m}$. altitude. British Columbia to Idaho and California. Common in the Olympic Mountains and on Vancouver Island.

\section{STRUTHIOPTERIS.}

Fruit-dots in a continuous band next the midrib of the contracted ultimate segments of the spore-bearing leaf, covered until mature by an elongated indusium parallel to and within the margin; veins of the sterile leaf segments oblique to the midrib, simple or forked and free; leaves pinnate, of two kinds, the sporebearing commonly much contracted.

Struthioperis spicant (L.) Weiss. Deer Fern. Tufted; sterile leaves short-stalked, linear-lanceolate in outline, $15-60 \mathrm{~cm}$. long, 3-9 cm. wide, the numerous segments oblong and obtuse; fertile leaves taller, longer-stalked and more erect, the segments longer, narrower and less crowded.

In wet places in woods, Alaska to California. Also in the Old World.

\section{WOODWARDIA.}

Fruit dots oblong or linear, sunk in cavities in the leaf, arranged in a chain-like row parallel and near to the midribs of the leaf-segments; indusium fixed by its outer margin to a vein and covering the cavity like a lid; veins more or less in a network.

Woodwardia spinulosa Mart. \& Gal. Rootstock stout, covered with pale-brown scales; leaves in a round cluster, long-stalked, ovate-oblong, pinnate, leathery, 1-2 m. long; principal divisions lanceolate, 10-40 cm. long, deeply pinnatifid, the lobes spinulose-serrate, acuminate.

In woods, British Columbia to Mexico. Near Tacoma, Flett; Texada Island, Anderson. More common southward. 


\section{ASPlenium. Spleenwort.}

Fruit dots oblong or linear, oblique, separate; indusium straight, attached to the upper side of the vein; veins free.

Rachis of the leaf brown; leaflets oval, slightly crenate. Rachis of the leaf green; leaflets ovate, deeply crenate.

A. trichomanes. A. viride.

Asplenium trichomanes L. Common Spleenwort. Leaf-stalks tufted, dark-brown, shiny; blades simply pinnate, linear in outline, $6-20 \mathrm{~cm}$. long; leaflets oval or oblong, unsymmetrical, obscurely crenate, 15-30 pairs, firm and evergreen, with a brown rachis.

Mossy rocks, rare in our limits. Alaska to Arizona. Widely distributed in the Northern Hemisphere.

Asplenium viride Huds. Much like $A$. trichomanes, but the thinner paler leaflets deeply crenate and the rachis of the leaf green.

Mount Baker, Washington, Flett; Ucluelet, Vancouver Island, British Columbia, Macoun. A rare but widely distributed fern. Alaska to Washington, Colorado and New England. Eurasia.

\section{ATHYRIUM.}

Large or small ferns with simple, lobed, 2-3-pinnate or pinnatifid leaves; fruit dots oblong or linear (nearly round when young), oblique, separate; indusium more or less curved, sometimes horseshoe-shaped, of ten crossing to the outer or lower side of the vein; veins free.

Athyrium cyclosorum Rupr. Rootstock creeping, short, densely covered by the bases of the petioles; petioles tufted, $20-30 \mathrm{~cm}$. long, straw-colored or brownish; blades delicate, glabrous, broadly oblong-lanceolate or oblongovate, acuminate at the apex, $30-90 \mathrm{~cm}$. long, bipinnate to tripinnatifid; leaflets oblong-lanceolate, 5-20 cm. long; ultimate segments oblong, obtuse, obscurely 9-13-lobed, the lobes serrate; terminal segments confluent; fruit dots short, straight or curved.

In swampy places, common. Very similar to the more eastern Lady-fern, A. filix-foemina. Alaska to Arizona and Nebraska.

\section{POLYSTICHUM.}

Large or medium sized ferns, mostly with firm evergreen leaves, pinnate, bipinnate or bipinnatifid, the leaflets serrate and usually auricled at the base on the upper side; veins free; indusium orbicular and peltate, depressed in the center and attached by a stalk to the middle of the fruit dot; fruit dots round.

Leaflets, at least the lower ones, lobed.

P. scopulinum. Leaflets all simple.

Leaf-stalk short; segments triangular or broadly lanceolate. P. lonchitis.

Leaf-stalk long; segments linear-lanceolate.

P. munitum.

Polystichum scopulinum (D. C. Eaton) Maxon. Leaves lanceolate in outline, short-stalked, 15-25 cm. long; divisions ovate, obtusish, serrate, the lower ones usually pinnately lobed.

In loose rocks in the mountains, rare. Eatonville, Flett; Mount Adams, Henderson. Washington and Idaho to California and Utah. 
Polystichum lonchitis (L.) Roth. Holly Fern. Leaves densely tufted, $20-40 \mathrm{~cm}$. long, very short stalked, pinnate; divisions broadly lanceolate, auricled on the upper side, spinulose-dentate, $2-4 \mathrm{~cm}$. long, the lowest ones much shorter and triangular.

In rocky places in the mountains. Alaska to Quebec, Colorado and California. Eurasia.

Polystichum munitum (Kaulf.) Presl. Pacific Christmas Fern. Leaves simply pinnate, 60-120 cm. long, forming a crown; petioles stout, chaffy with numerous brown scales; rachis also chaffy; leaflets linear or lanceolate-linear, acuminate, very sharply and of ten doubly serrate, sometimes chaffy on the midvein beneath, $3-10 \mathrm{~cm}$. long; fruit dots abundant, arranged in a row on each side of the midrib half-way to the margin.

Very common in the woods. Alaska to Idaho and California.

Polystichum munitum imbricans (D. C. Eaton) Maxon. Like the species but smaller, the leaves $20-40 \mathrm{~cm}$. long; divisions much overlapping each other, oblique to the rachis and cuspidate at the apex.

Among rocks in the mountains at 1000 to $1700 \mathrm{~m}$. elevation. British Columbia to California, rather rare.

Polystichum munitum inciso-serratum (D. C. Eaton) Maxon. Differs from the species mainly in the leaflets being deeply incised and the lobes serrate; the base of the leaflets usually conspicuously auriculate.

Rare, British Columbia to California.

\section{DRYOPTERIS. SHIELD FERN.}

Fruit-dots round, borne on the back or rarely at the apex of the veins; indusium flat or flattish, heart-shaped and attached at the middle of its sinus; veins nearly always free.

Veins simple or once forked; leaves glandular.

Veins freely forking; leaves not glandular.

Leaves bipinnate, thin and delicate.

Leaves tripinnate, firm, half-evergreen.

D. oreopteris.

D. spinulosa.

Dryopteris oreopteris (Sw.) Maxon. Tufted; leaf-stalks short, scaly at base; leaves bipinnatifid, broadly lanceolate, glandular, $60-90 \mathrm{~cm}$. long; ultimate segments oblong, nearly entire; indusia delicate, toothed on the margins.

In the mountains, Alaska to Washington. Eurasia. Shawnigan Lake, Vancouver Island, Macoun; Bridge Creek, Okanogan County, Elmer. Very rare south of Alaska.

Dryopteris spinulosa dilatata (Hoffm.) Underw. Wood Fern. A tufted delicate fern; leaf-stalks 15-40 cm. long with slender dark brown scales; blades tripinnate or tripinnatifid, broadly ovate in outline, $30-40 \mathrm{~cm}$. long; ultimate divisions oblong-lanceolate, the lowest ones longest, spinulose-toothed; indusia minutely glandular ciliate.

In rich woods, common. Alaska to Newfoundland, south to California, Montana and Virginia. Eurasia.

Dryopteris rigida arguta (Kaulf.) Underw. Leaf-stalks clustered; blades firm, half-evergreen, $30-90 \mathrm{~cm}$. long, ovate-lanceolate, bipinnate; ultimate segments oblong, incised and spinulose; indusia bearing stalked glands.

Principally in rocky places. Alaska to California, more common southward. Victoria, Anderson; Sauvies Island, Oregon, Howell. 


\section{FILIX.}

Delicate rock-ferns; leaves 2-3-pinnate or pinnatifid; leafstalks slender; fruit-dots round, borne on the backs of the veins; indusium attached by a broad base on the inner side partly under the fruit dot, early opening and withering away.

Filix fragilis (L.) Underw. Bladder Fern. Rootstock short; petioles 10$20 \mathrm{~cm}$. long; blades thin, oblong-lanceolate, only slightly tapering below, 10-25 $\mathrm{cm}$. long, 3-7 cm. wide, 2-3-pinnatifid or pinnate; leaflets lanceolate-ovate, irregularly pinnatifid with bluntly or sharply-toothed segments along the margined or winged rachis; texture membranous.

On moist cliffs in the mountains, rare in our limits. Alaska to California, eastward to Labrador. Eurasia.

\section{WOODSIA.}

Small or medium sized ferns, growing in rocky places; leaves once or twice pinnate or pinnatifid; fruit dots round, borne on the backs of simply forked free veins; indusium attached under the fruit dot, round or star-shaped, delicate, early withering.

Leaves glabrous or nearly so; lobes of the indusium hair-like. W. oregana. Leaves viscid-puberulent; lobes of the indusium broader at base. W. scopulina.

Woodsia oregana D. C. Eaton. Rootstock short; petioles glabrous, not jointed, brownish below; blades glabrous or slightly roughened, 5-28 cm. long, elliptic-lanceolate, the sterile shorter than the fertile; pinnae triangularoblong, obtuse, pinnatifid; lower leaflets reduced in size and somewhat remote from the others; rachis straw-colored; segments oblong or ovate, dentate or crenate, the teeth often reflexed and covering the fruit dots; indusium deeply cleft into hair-like segments.

Cowichan River, Vancouver Island, Macoun. Common east of the Cascade Mountains.

Woodsia scopulina D. C. Eaton. Densely tufted, whole plant puberulent with minute white jointed hairs and stalked glands; blades pinnate, $10-20 \mathrm{~cm}$. long, the numerous ultimate divisions oblong-ovate, acutish, deeply cleft into 5-7 pairs of short obtuse lobes; indusium deeply divided into segments that are broader at base.

On moist cliffs, rare in our limits. Victoria, Anderson; Cape Horn, Columbia River, Piper. British Columbia to Ontario, Arizona and California.

\section{Family 2. OPHIOGlOSSACEAE. Adder's Tongue Family.}

Plant consisting of an underground stem bearing one or more leaves which rise above ground and are divided usually into two parts, a fertile portion and a sterile portion, the latter being the foliage part of the leaf; frequently the fertile portion lacking in some of the leaves; sporangia borne within the tissue of the fertile portion, ringless, opening by a transverse slit.

Sterile portion of leaf simple.

Sterile portion of leaf compound.

I6. Ophioglossum, 9.

I7. BOTRYCHIUM, 9. 
16. Ophioglossum. Adder Tongue.

Rootstock erect and fleshy, with slender fleshy roots; sterile part of leaf somewhat fleshy, simple, entire; veins reticulated; fertile segment simple, unbranched, with two rows of sessile connate sporangia; spores numerous, sulphur-yellow.

Ophioglossum vulgatum L. Plant $5-40 \mathrm{~cm}$. high, the leaf usually solitary; sterile segment of leaf sessile, oblong to ovate, obtuse, 5-9 $\mathrm{cm}$. long; veins forming a loose network.

In moist meadows, rare. Falcon Valley, Mount Adams, and in Skamania County, Suksdorf.

\section{BOtRYCHIUM. Grape Fern.}

Rootstock very short, with clustered fleshy roots; sterile part of the leaf ternately or pinnately divided or compound; veins free; fertile segment 1-3-pinnate, each pinnule bearing a double row of sessile sporangia; spores numerous, sulphur-yellow.

Bud in a cavity at one side of the base of the stem; leaves thin, ternate, then pinnately much divided.

Bud inclosed in the base of the stalk; leaves thickish, rather

B. virginianum. fleshy.

Sterile portion of leaf arising near the base of the rather large leaf stalk; buds pilose.

Sterile portion of leaf arising near the middle of the usually small leaf stalk; buds glabrous.

Green part of leaf oblong, its segments fan-shaped. Segments truncate at base, overlapping.

Segments cuneate at base, distant.

Green part of leaf triangular or ovate, the segments not fan-shaped.

Segments lanceolate, acute; midvein continuous.

Segments ovate-oblong, obtuse; midvein dissipated.

B. silaifolium. 
Botrychium onondagense Underw. In habit like B. lunaria; leaf-segments $7-9$, not overlapping, broadly wedge-shaped.

Moist meadows, Olympic Mountains. Probably only a variant of $B$. lunaria to which it is reduced by some botanists.

Botrychium lanceolatum (Gmel.) Ångstroem. Plant 8-30 cm. high; sterile portion of the leaf sessile near the top, triangular, twice pinnatifid, rather thin; ultimate segments lanceolate, acute, toothed. Flett.

In the mountains, very rare. Mount Rainier, Allen; Olympic Mountains,

Botrychium ramosum (Roth) Ascherson. Somewhat fleshy, 10-25 cm. high; sterile segment of the leaf pinnate or bipinnatifid, short-petioled; ultimate segments oblong to ovate-oblong, obtuse; sporophyll bipinnate or tripinnate, erect on a long petiole.

Agassiz, B. C., Macoun; Mount Adams, Suksdorf. The American plant is sometimes considered distinct from that of the Old World under the name B. neglectum Wood.

\section{Family 3. MARSILEACEAE.}

Plant perennial, herbaceous, rooting in the mud, with slender creeping rootstock and 4 -foliolate or filiform leaves; sporangia borne within closed receptacles (the sporocarps) which arise from the rootstock near the leafstalks or are consolidated with them; spores of two kinds, large ones (megaspores) and small ones (microspores), both contained in the same sporocarp.

\section{MARSILEA.}

Marsh or aquatic plants; leaves slender petioled, quadrifoliolate, commonly floating on the surface of shallow water; sporocarps ovoid or bean-shaped, peduncled and rising from the petiole or from the rootstock at the base of the petiole, composed of two vertical valves having several transverse compartments (sori) in each valve; also provided inside with a ring which at the opening of the valves swells and tears the sori from their positions; sori composed of both megasporangia and microsporangia.

Marsilea vestita Hook. \& Grev. Rootstock slender, creeping; leaves more or less pubescent with white hairs; petioles slender, 4-12 cm. long; leaflets deltoid-obovate, 4-12 mm. long, mostly entire; sporocarps solitary on the stalks, 4-8 mm. long, 3-5 $\mathrm{mm}$. wide, with a short raphe, a short blunt lower tooth, and an acute upper one, densely pubescent with white appressed hairlike scales; sori $6-11$ in each valve.

Rare in our limits. Reported as common on Menzies Island opposite Fort Vancouver, Washington.

\section{Class II. EQUISETINEAE.}

Plants rush-like with hollow jointed stems rising from subterranean rootstocks; sterile leaves reduced-to scales, 
whorled, forming sheaths at the joints; fertile leaves forming a short spike terminating the stem; epidermis rough.

\section{Family 4. EQUiSETACEAE. Horsetail Family.}

Branches when present, whorled; sporangia 1-celled, clustered under the scales of the terminal cone-like spikes; spores of but one kind furnished with narrow ribbon-like appendages (elaters) attached at the middle, coiling around them when moist and spreading in the form of a cross when dry and mature; epidermis impregnated with silica, rough.

\section{EQUISETUM. HoRSETAIL.}

Perennial plants with extensively creeping rootstocks; stems simple or with whorled branches, furrowed lengthwise, mostly hollow; sporangia adhering on the under side of the shield-shaped scales of the spike, 1-celled, opening down the inner side; spores of one kind, with elaters.

Stems annual; spikes not mucronate at summit.

Stems of two kinds; the pale brown fertile ones appearing in spring before the green branched sterile ones.

Fertile stems branched and green when old, only the top withering.

Fertile stems dying after fruiting.

Sterile stems 6-19-furrowed, 30-60 cm. high. E. arvense.

$\begin{array}{ll}\text { Sterile stems 6-19-furrowed, } 30-60 \mathrm{~cm} \text {. high. } & \text { E. arvense. } \\ \text { Sterile stems 20-40-furrowed, } 60-120 \mathrm{~cm} \text {. high. } & \text { E. telmateia. }\end{array}$

Stems all similar, green, naked, branched, fruiting in summer.

Sheaths closely appressed; branchlets not wingangled.

Sheaths loose, especially the upper one; branchlets wing-angled.

Stems perennial; spikes mucronate at summit, fruiting in

E. fluviatile.

E. litorale. summer.

Plant tall and stout; stems many-grooved.

Branches numerous, regularly whorled.

Branches irregular, few or wanting.

Plants tufted, slender; stems 5-ro-grooved.

Sheaths 5-I0-toothed; stems hollow.

Sheaths 3-toothed; stems solid.
Equisetum pratense Ehrh. Stems annual, of two kinds, the fertile appear.

E. pratense.

Equisetum pratense Ehrh. Stems annual, of two kinds, the fertile appearing before the sterile, $15-30 \mathrm{~cm}$. high; fertile stems at length green and branched like the sterile ones; sterile stems with 8-20 ridges and furrows, the slender branches in whorls, mostly 3-angled; sheaths cylindric or somewhat broadened at top, those of the stem with 10-12 teeth, those of the branches 3-toothed.

Vancouver Island, Macoun.

Equisetum arvense L. Common Horsetail. Aerial stems annual, of two kinds, the fertile pale-brown and short-lived, appearing in early spring before 
the sterile; fertile stems $10-20 \mathrm{~cm}$. tall, simple, terete, bearing about four loose scarious distant sheaths, these whitish with about 12 brownish acuminate teeth; sterile stems pale green, $10-40 \mathrm{~cm}$. tall, marked with 6-19 furrows, with numerous whorls of mostly simple solid branches, these 4-angled or rarely 3-angled, the sheaths with as many teeth; spike $2-3 \mathrm{~cm}$. long.

Common in low ground. In rare cases fruiting spikes are found on green branched plants.

Equisetum telmateia Ehrh. Sterile stems stout, 60-120 cm. high, 20-40furrowed, with numerous whorls of long spreading 4 or 5 -angled branches; fertile stems $30-40 \mathrm{~cm}$. high, pale-brown, the sheaths loose, of ten longer than the internodes and deeply 20-30-toothed; spikes stout, $3-5 \mathrm{~cm}$. long.

Very common in moist soil and difficult to eradicate. Rarely spikes are found on the green branched plants.

Equisetum fluviatile L. Pipes. Stems 60-90 cm. high, rather soft, smooth, simple or with few branches; central cavity of the stem large; aircavities under the grooves wanting; sheaths closely appressed, the teeth rigid and acute; branches 4-6-angled, hollow, not wing-angled.

In shallow water at the margins of lakes and ponds.

Equisetum litorale Kühlewein. Stems $30-90 \mathrm{~cm}$. high, simple or with few or many branches; air cavities under the grooves present; sheaths loose, especially the upper, the teeth not rigid, membranous at margin, acute; branches 3-5-wing-angled, the smaller solid.

Shawnigan Lake, Vancouver Island, Macoun; Agassiz, British Columbia, Macoun. The spores of this species are said usually to be abortive and the elaters wanting. These facts combined with the erratic occurences of the plant lead to the suspicion that it is a hybrid.

Equisetum ramosissimum Desf. Stems 6-26-grooved; sheaths dilated, the leaves more or less distinct, each with $3-4$ ridges which do not extend into the teeth; branches 4 -angled.

Shawnigan Lake, Vancouver Island, Macoun.

Equisetum hyemale L. Scouring Rush. Aerial stems evergreen, all alike, 40-120 cm. tall, 5-20 mm. thick, marked with 20-48 furrows; ridges roughened usually with a single series of siliceous tubercles; sheath short, commonly marked with a black girdle at the base and another at the base of the earlyfalling teeth; spike nearly sessile in the uppermost sheath, $2-3 \mathrm{~cm}$. long, tipped with a rigid point.

Common and variable. Several subspecies have been described but they are not clearly separable.

Equisetum variegatum Schleich. Stems slender, tufted, ascending, 15-40 $\mathrm{cm}$. high, each 5-10-furrowed; sheaths loose, green below, black above, with 5-10 bristle-tipped white-margined teeth; central cavity of stem small.

Vancouver Island, Macoun, and probably farther south as it occurs in Klickitat County in eastern Washington.

Equisetum scirpoides Michx. Stems tufted, very slender, flexuous, 6-15 $\mathrm{cm}$. long, each 6 -furrowed; sheaths with 3 bristle-tipped teeth; central cavity of stem wanting. limits.

Hastings, British Columbia, Macoun, and probably to be found in our

\section{Class III. LYCOPODINEAE.}

Plant moss-like; stems branched, solid, with numerous small leaves; sporangia solitary in the axils of the leaves or on their upper surface. 


\section{Family 5. LYCOPODIACEAE.}

Plant somewhat moss-like in appearance, evergreen, usually branching; stem solid; leaves small, numerous, not whorled; spore-cases on the upper surfaces or in the axils of the leaves; spores of one kind.

\section{LYCOPODIUM. GROUND-PINE.}

Perennial, terestrial plants, with evergreen 1-nerved leaves, arranged in 4-16 ranks; spore-cases flattened, 1-celled, in the axils of ordinary leaves or of bracts arranged in spikes;' spores abundant, minute, sulphur-yellow.

Sporangia in the axils of ordinary leaves.

Sporangial leaves forming a terminal spike.

Sporangial leaves subterminal, the terminal leaves sterile.

Stems rigid; leaves all alike, ascending.

Stems not rigid; leaves spreading, of two sorts, long and short.

\section{L. inundatum.}

L. selago.

I. lucidulum.

Sporangia in the axils of modified leaves which are crowded in spikes.

Sterile branches flattened, the leaves on the under side reduced.

Stems of the fruiting branches leafy to the spikes or nearly so.

Stems of the fruiting branches with much reduced leaves.

Sterile branches not flattened, the leaves uniformly spreading.

Stems of the fruiting branches nearly naked.

Stems leafy up to the spikes or nearly so.

Leaves 6-8-ranked, spreading.

Leaves 5-ranked, appressed.

L. obscurum.

L. complanatum.

L. clavatum.

L. annotinum.

L. sitchense.

Lycopodium inundatum L. Stems creeping close to the earth, $3-12 \mathrm{~cm}$. long; fertile branches erect, $2-10 \mathrm{~cm}$. high, bearing solitary spikes; sporangial leaves like the sterile, lanceolate or awl-shaped, with thin margins.

In bogs, Olympia, Henderson; Spanaway Lake, Flett; Vancouver, British Columbia, Macoun.

Lycopodium selago L. Stems ascending or erect, rigid, not creeping, 6-10 $\mathrm{cm}$. high; leaves all alike, broadest at the hollowed base, acuminate or mucronate, closely appressed, some of them commonly bearing a bulblet in the axil; terminal leaves sterile, those just below bearing spore-cases.

Common in the mountains at $1500-2800 \mathrm{~m}$. elevation.

Lycopodium lucidulum Michx. Stems decumbent at base, 10-30 cm. high, simple or sparingly branched; leaves spreading or deflexed, linear-obovate, denticulate, acute, in alternate zones of longer and shorter leaves, the latter most commonly bearing the sporangia.

In deep woods, rare.

Lycopodium obscurum L. Stems erect, branched above, arising at intervals from subterranean rootstocks; leaves 6-ranked, linear-lanceolate, entire, acute, the lateral with spreading tips, the two upper and the lower ranks 
smaller and closely appressed; fruiting branches with leaves like the sterile, each bearing 1-3 spikes.

Known in our limits only from a station 23 miles northeast of Snoqualmie, Washington, L. A. Nelson.

Lycopodium complanatum L. Stems widely creeping, with suberect irregularly forked fan-like flattened branches; leaves 4-ranked, very small, closely appressed, the lateral with spreading tips, the dorsal and ventral smaller, wholly appressed; fruiting branches with much reduced leaves, each bearing 1-3 cylindric spikes.

Not definitely known in our limits but abundant at Lake Keechelus near the summit of the Cascade Mountains.

Lycopodium clavatum L. Running-pine. Stems prostrate, creeping, often very long; sterile branches similar but ascending; leaves pale green, awlshaped, bristle-tipped; fertile branches with minute leaves, erect, bearing 2-4 fruiting cones.

In woods, not common.

Lycopodium annotinum L. Stems creeping, often $1 \mathrm{~m}$. long; leaves dark green, linear-lanceolate, spreading, minutely serrate; fruiting cones solitary, sessile at the tips of ordinary branches.

In mountain woods, not common.

Lycopodium sitchense Rupr. Stems creeping, often half-buried, with erect forked branches, 5-7 cm. high; leaves lanceolate, acute, $5 \mathrm{~mm}$. long, 5ranked; fruiting cones on very short nearly naked penducles.

Common in wet meadows at $1200-1800 \mathrm{~m}$. altitude.

\section{Family 6. SELAGINELLACEAE.}

Terrestrial, annual or perennial moss-like plants with branching stems and scale-like leaves, which are many-ranked and uniform, or four-ranked and of two kinds spreading in two planes;sporangia 1-celled, solitary in the axils of leaves which are so arranged as to form more or less quadrangular spikes; spores of two kinds, some sporangia (megasporangia) containing four megaspores, others (microsporangia) containing numerous microspores.

\section{SELAGINELLA.}

-Sporangia solitary in the axils of leaves forming terminal conelike spikes; sporangia minute, subglobose, opening transversely; megaspores globose, four in each megasporangium; microspores small, numerous.

Leaves of two sorts, 4-ranked.

Leaves all alike, many-ranked.

S. douglasii.

Stems slender, elongate; leaves loosely imbricated.

Stems short; leaves closely imbricated.

S. struthioloides.

S. rupestris.

Selaginella douglasii (Hook.) Spring. Stems reclining, 10-40 cm. long, pinnately branched; lateral leaves oval, oblique, obtuse, $2 \mathrm{~mm}$. long; upper leaves half as long, oval, cuspidate, acuminate.

On wet rocks, local; abundant in the Cascade gorge of the Columbia River. 
Selaginella struthioloides (Presl) Underw. Stems weak, soft, 30-180 $\mathrm{cm}$. long, often more or less pendent, much branched; leaves about $1 \mathrm{~mm}$. long, linear-lanceolate, loosely imbricated, not bristle-tipped.

On trees along the coast, often hanging in great masses; Vancouver Island to the southern boundary of Oregon. First found at Nootka Sound.

Selaginella rupestris (L.) Spring. Stems loosely tufted, 10-25 cm. long, prostrate or ascending, much branched; leaves closely imbricate, narrowly lanceolate, ciliate margined, channeled on the back, each tipped with a slender white awn, 0.3-0.5 mm. long; spikes quadrangular, 1-1.5 cm. long; bracts like the leaves but the awns shorter and the margin more ciliate.

On rocks, often very abundant. Hieronymus has recently distinguished from true $S$. rupestris numerous new species and subspecies. The form common in our limits is $S$. sartorii oregonensis Hieronymus.

\section{Family 7. ISOETACEAE. Quillwort FAmily.}

Plant aquatic, usually submersed or sometimes growing on moist soil, consisting of a short, two or three-lobed fleshy stem with a dense tuft of fibrous roots and a compact cluster of rushor grass-like leaves; sporangia in small lobes enclosed in the bases of the leaves; spores of two kinds, large (megaspores) and small (microspores).

\section{ISOETES. QUILLWORT.}

Stem a fleshy corm rooting just above the base, surrounded above by the swollen bases of the awl-shaped linear leaves; sporangia large, enclosed in the bases of the leaves, those of the outer leaves with megaspores, those of the inner with microspores; the sides of the sporangia more or less covered with a fold of the inner side of the leaf base (velum).

Plants terrestrial, in muddy places; leaves with stomata.

Stems 3-lobed; leaves setaceous; velum complete.

Stems 2-lobed; leaves stout, rigid; velum incomplete. I. maritima.

Plants aquatic, often in deep water; stems bilobed.

Stomata none; leaves rigid.

Stomata present; leaves slender.

I. piperi.

I. echinospora.

Isoetes nuttallii A. Br. Growing in wet places; leaves 15-50, slender, bright green, $6-20 \mathrm{~cm}$. long; megaspores grayish, warty or rarely nearly smooth; microspores brown, papillose.

Vancouver Island to Oregon. Apparently rare, but quite inconspicuous.

Isoetes maritima Underw. Terrestrial in salt marshes; trunk slightly bilobed; leaves $8-15$, rigid, $2-5 \mathrm{~cm}$. long; megaspores densely spinulose, the spines blunt but rarely confluent; microspores smooth, white.

Known only from salt marshes at Alberni, Vancouver Island, Macoun.

Isoetes piperi A. A. Eaton. Leaves 10-20, 5-8 cm. long, somewhat spreading, rigid; velum incomplete; megaspores with low distinct warts; microspores smooth or nearly so.

Green Lake, Seattle, Piper. 
Isoetes echinospora braunii (Durieu) Engelm. Leaves 10-20, slender, spreading, not rigid, $6-15 \mathrm{~cm}$. long, with stomata present near the tips; sporangia broadly elliptic, spotted, more than half covered by the broad velum; macrospores spinulose but the spines often united into jagged crests; microspores smooth.

In quiet lakes and ponds, with muddy bottoms.

Isoetes echinospora flettii A. A. Eaton. Differs from I. echinospora braunii mainly by its spinulose microspores.

Spanaway Lake, Pierce County, Washington.

\section{PHYLUM II. SPERMATOPHYTA. SEED Plants.}

Highly organized plants, mostly producing flowers and always producing seeds, each of which contains a young plant (embryo) usually composed of a stem-like structure (caulicle or hypocotyl), one or more rudimentary leaves (cotyledons) and a terminal bud (plumule or epicotyl); megasporangia (ovules) usually borne on the side or face of an open or closed modified leaf (carpel); microsporangia (anther-sacs) on the end or side of a modified leaf (filament) and bearing numercus microspores (pollen grains).

\section{Class IV. GYMNOSPERMAE.}

Ovules (megasporangia) naked, not enclosed in an ovary, usually on the face of an open scale but sometimes on the axis, in which case the scale is rudimentary or wanting; stigmas none; cotyledons mostly several in a whorl, occasionally only two; perianth none.

\section{Family 8. TAXACEAE. YEW FAMILY.}

Trees or shrubs with evergreen linear leaves; flowers dioecious, the staminate of a few scaly bracts and a few naked stamens, the ovule-bearing of an erect ovule which in fruit becomes a bony seed surrounded by a fleshy disk.

\section{TAXUS. YEW.}

Evergreen trees or shrubs with spirally arranged, shortpetioled linear flat leaves, spreading so as to appear 2-ranked; aments very small, axillary and solitary, sessile or nearly so; staminate aments consisting of a few scaly bracts and 5-8 stamens; ovules solitary, axillary, erect, subtended by a fleshy 
ring-shaped disk; fruit consisting of the red fleshy dish which has become cup-shaped and nearly encloses the bony seed.

Taxus brevifolia Nutt. Western Yew. Small tree, 4-10 m. high, sometimes much larger, the bark loose and reddish; branches slender, horizontal or drooping; leaves horizontal, 1-2 cm. long, linear, acuminate, cuspidate, with revolute margins, shiny green above, glaucous beneath, abruptly narrowed at the base into a short petiole; staminate amennts globose, $3 \mathrm{~mm}$. broad; fruit bright red, insipid in taste; stone broadly ovate, acute, somewhat flattened, $3-4 \mathrm{~mm}$. long.

Quite common, especially along mountain streams. Very large trees become $75 \mathrm{~cm}$. in diameter. Extreme southern Alaska to Tulare County, California and eastward to the Blue and Bitterroot Mountains.

\section{Family 9. PINACEAE. Pine Family.}

Resinous trees or shrubs mostly with evergreen narrow entire or scale-like leaves; flowers in aments, usually monoecious, rarely dioecious; ovules solitary or several together on the surface of a scale, which in most genera is in the axile of a bract; fruit a cone with numerous several or few woody papery or fleshy scales; seed wingless or winged.

Scales of the cone few (3-12); leaf-buds naked; leaves mostly scale-like.

Cone modified into a fleshy, drupe-like fruit.

Cone composed of dry scales.

Scales of the globose cone peltate.

Scales of the oblong cone not peltate. Cone-scales 8-12, rather thin, imbricate. Cone-scales 6 , thick, valvate.

24. Juniperus, 17.

26. Chamaecyparis, 18.

26. Thuja, 18.

27. LiBOCEDRUS, 19.

Scales of the cones numerous; leaf-buds scaly; green leaves needle-like.

Cone-scales woody; leaves needle-shaped, $2-5$ in a sheath.

Cone-scales thin; leaves linear, scattered or clustered, not in sheaths.

Cones erect; scales deciduous.

Cones pendent; scales persistent.

Branchlets smooth; bracts 3-toothed. 30. Pseudotsuga, 21.

Branchlets roughened by the persistent leaf-bases.

Leave sessile, pungent-pointed. Leaves petioled, not pungent.

28. PinUs, 19.

29. AbIes, 20.

31. Picea, 22.

32. TSUGA, 22.

\section{JUNIPERUS. JUNIPER.}

Evergreen shrubs or small trees; leaves scale-like or needle-like, opposite or in whorls of three; flowers dioecious or monoecious, small and lateral; anther-cells 3-6, attached to the lower edge of the shield-shaped scale; ovule-bearing aments ovoid, of 3-6 fleshy coalescent scales, each 1-ovuled, in fruit forming a bluishblack berry. 
Prostrate shrub; leaves uniformly awl-like.

Erect shrub or tree; leaves of two forms, some scale-like, others awl-like.

J. sibirica.

J. scopulorum.

2o MtAdems Juniperus sibirica Burgsd. Mountain Juniper. A prostrate shrub; leaves linear-subulate, sharp-pointed, glaucous on the upper side, arianged in whorls of three; fruit dark blue, as large as a pea.

Common in the mountains at $900-1000 \mathrm{~m}$. elevation. Many botanists consider this a subspecies of J. communis L. under the name of $J$. communis montana Ait.

Juniperus scopulorum Sarg. Rocky Mountain Juniper. A shrub or scraggly tree, 1-6 m. high, much branched, the branches often drooping; foliage often glaucous; leaves small, acute, each with a linear indistinct gland on the back; berries blue-black with a thick whitish bloom, maturing the second year; seeds usually 2 , grooved longitudinally.

On the islands and mainland about the Gulf of Georgia and the northern part of Puget Sound. Not elsewhere known west of the Cascade Mountains but common from these mountains eastward to the Black Hills.

\section{CHAMAECYPARIS.}

Evergreen trees with flattened 2-ranked branchlets and small scale-like leaves; aments terminal; staminate small, globose, with shield-shaped filaments; pistillate erect, with 6-10 very thick scales in pairs; cones small, globose, maturing the first year; seeds few, at the base of each scale, angled or more or less winged.

Chamaecyparis nootkatensis (Lamb.) Spach. Alaska Cedar. Medium sized tree, $20-30 \mathrm{~m}$. tall, $30-100 \mathrm{~cm}$. in diameter; bark thin, pale gray; leaves small, sharply acute; cones globose, $8 \mathrm{~mm}$. in diameter.

Common in the mountains at $1200-1800 \mathrm{~m}$. elevation. Alaska Cedar ranges from Prince William Sound, Alaska, to Mount Hood, Oregon. It is not known to occur east of the Cascade Mountains. The tree first became known to botanists from specimens collected at Nootka Sound.

\section{ThUja. Arbor Vitae.}

Evergreen trees or shrubs; leaves small or minute, scale-like, appressed, opposite, 4-ranked; flowers monoecious, both kinds terminal, the staminate globose, the ovule-bearing ovoid or oblong, small, their scales opposite, each bearing 2, rarely 3-5 erect ovules; cones ovoid or oblong, mostly spreading or recurved, their scales 6-10, coriaceous, opposite, dry, spreading when mature.

Thuja plicata Donn. Giant Cedar. Handsome pyramidal tree, $30-5 n$ or even $80 \mathrm{~m}$. high, 1-5 m. in diameter, the trunk rapidly tapering from the large base; branches usually somewhat drooping; bark pale grayish, thin fibrous, longitudinally fissured; wood soft, the heart-wood reddish, odorous; leaves oblong-ovate, bright green, rapidly tapering to an acuminate cuspidate apex; staminate aments minute, dark purple; pistillate aments usually crowded near the tips of the branchlets; cones oblong, 1-1.5 cm. long, light colored, consisting of about 6 pairs of scales, these elliptical, mucronate on the back near the apex. 
A common lowland tree, especially in moist soil, ranging from Alaska to northern California. Found originally by Menzies at Nootka Sound. The northernmost station known is the head of Lynn Canal, Alaska.

\section{LIBOCEDRUS.}

Resinous trees with scaly bark and spreading branches; leaves scale-like, dimorphic, opposite, persistent; flowers naked, monoecious or dioecious, terminal, solitary; stamens numerous; anthercells usually 4 ; scales of pistillate cone 4 -or 6 , acuminate; ovules 2 ; fruit maturing in one season.

Libocedrus decurrens Torr. Incense Cedar. Tree, 30-50 m. high; bark fibrous, loose; leaves opposite, adnate, the acute tips spreading; cones 20-30 $\mathrm{mm}$. long.

In the mountains, Clackamas County, Oregon, and southward to Lower California.

\section{PINUS. PINE.}

Evergreen trees with two kinds of leaves; the primary ones scale-like with deciduous tips; the secondary ones forming the ordinary foliage, needle-like, arising from the axils of the former in clusters of 2-5; ovule-bearing aments solitary or clustered, each composed of numerous minute bracts, each with an ovulebearing scale in its axil; ament, upon maturing, becoming a cone, the scales elongating and becoming woody; seeds two on the base of each scale.

Leaves 5 in each fascicle; scales of the cones unarmed.

Cones ovoid to subglobose, 4-8 cm. long; wing of seed shorter than the body.

Cones cylindric-oblong; wing of seed longer than body. Seeds 5-7 mm. long; cones usually $10-20 \mathrm{~cm}$. long.

Seeds 9-12 mm. long; cones usually $20-30 \mathrm{~cm}$. long.

Leaves 2 or 3 in each fascicle; scales of the cones thickened, each armed with a sharp spine on the back.

Leaves in twos; cones small, 4-5 cm. long.

P. albicaulis.

Leaves in threes; cones larger.

Cones persistent for several years, formed well below the apex of the shoot; small tree.

P. monticola.

P. lambertiana.

P. contorta.

Cones falling after the second year, formed subterminally on the young shoot; large tree.

$P$. attenuata.

$P$. ponderosa.

Pinus albicaulis Engelm. White-bark Pine. Scraggly tree, 20-30 m. high; bark nearly white; leaves $4-7 \mathrm{~cm}$. long; cones oval, 5-7 cm. long, the scales much thickened; seeds large, edible.

British Columbia to Montana and California. In our limits only in the Cascade Mountains at 1500-2100 m. elevation.

Pinus monticola Dougl. Western White Pine. Tree 50-100 m. high, 1-2 $\mathrm{m}$. in diameter; bark gray, rather smooth, longitudinally cracked; leaves pale green, in fascicles of five, 4-7 cm. long; cones narrowly cylindrical, $15-30 \mathrm{~cm}$. long, about $4 \mathrm{~cm}$. thick.

This tree usually occurs in colonies along with the red fir. It ranges from the sea level to $1700 \mathrm{~m}$. altitude and extends from British Columbia to Montana and California. It does not extend farther north than Vancouver Island. 
Pinus lambertiana Dougl. Sugar Pine. Tree 50-100 m. high, 2-6 m. in diameter; bark brown, splitting into small plates; leaves $8-10 \mathrm{~cm}$. long; seed wings less than twice as long as broad.

In the mountains at 400-1000 m. elevation, Clackamas County, Oregon, and southward to Lower California. First found by Douglas in the mountains near the present site of Roseburg, Oregon.

Pinus contorta Dougl. Lodgepole Pine. Small tree, 10-20 m. tall, the dark bark usually deeply checked; leaves $4-8 \mathrm{~cm}$. long, dark green: cones small, ovoid, 4-5 cm. long; scales thickened at the apex, each armed with a stout point. P.

Common in sterile gravelly soil. It also occurs occasionally in peat bogs.

Yana In the mountains it often forms dense pure growths of small trees whence the name "lodgepole." The tree ranges from Alaska to the Black Hills, Colorado and California. Douglas's original specimens came from near the mouth of the Columbia River.

Pinus attenuata Lemmon. Knobcone Pine. Small pyramidal tree, 5-10, rarely $20-25 \mathrm{~m}$. high; bark thin, pale brown, scaly on the old trunk; leaves pale, $8-16 \mathrm{~cm}$. long; cones pale, narrowly ovate, unsymmetrical, reflexed, $7-12$ $\mathrm{cm}$. long, the scales on the outer side much thickened, each armed with a spine.

Lane County, Oregon, and south to southern California, in the mountains at 300-2000 m. elevation. The cones usually in whorls persist for many years and give the trees a very characteristic appearance.

Pinus ponderosa Dougl. Yellow or Bull Pine. Large tree, $30-80 \mathrm{~m}$. tall, $1-4 \mathrm{~m}$. in diameter, the reddish bark thick and deeply furrowed; leaves in fascicles of three,, $15-25 \mathrm{~cm}$. long, minutely serrulate; staminate aments cylindric, somewhat flexuous, 4-6 cm. long, crowded at the base of young shoots; pistillate aments 1-6, greenish or purplish, borne near the apex of the shoots of the season; cones brown, ovoid, 7-10 cm. long, 5-6 cm. thick, frequently in clusters of 3-5; scales much thickened near the apex, each bearing a stout sharp point.

Gravelly prairies, Pierce County, Washington, and southward. Abundant in the interior but rare along the coast. The timber of this tree is quite different from the true yellow pine of the interior. The coast tree has been considered a distinct species, $P$. benthamiana "Oregon Committee."

\section{ABIES. FIR.}

Evergreen trees with linear flat scattered sessile leaves, spreading so as to appear 2-ranked but in reality spirally arranged, commonly quite persistent in drying; staminate aments axillary; ovule-bearing aments lateral, erect; ovules two on the base of each scale, reflexed; scale shorter than or exceeding the thin papery bract; cones erect, subcylindrical or ovoid, their orbicular or broader scales deciduous from the persistent axis.

Cones with conspicuous exserted reflexed bracts.

A. nobilis.

Cones with the bracts concealed.

Cross section of leaf showing the two resin ducts surrounded by green tissue.

Cross section of leaf showing the resin ducts close to the lower surface.

Cones purple, large; bracts long attenunate at apex. A. lasiocarpa.

Cones usually green, medium sized; bracts not attenuate at apex. 
Leaves green and shiny above with stomata only on the lower side.

Leaves pale above and below and with stomata on both sides.

A. grandis.

A. concolor.

Abies nobilis Lindl. Noble Fir. Very large tree, 70-100 m. high, and 1-2 m. in diameter; leaves of the upper branches curved upwards, short, rigid, mostly acute, channeled above; cones $12-20 \mathrm{~cm}$. long, nearly covered by the large reflexed bracts.

In the mountains from Mount Baker and the Olympic Mountains to near the southern boundary of Oregon.

Abies lasiocarpa (Hook.) Nutt. Subalpine Fir. Narrowly conical usually densely branched trees, $20-30 \mathrm{~m}$. high and $20-40 \mathrm{~cm}$. in diameter; bark pale, rather smooth but with large resin blisters; leaves $3-5 \mathrm{~cm}$. long, acute, usually sharp-pointed, with abundant stomata on the upper leaf surface; cones narrowly barrel-shaped, usually dark-purple, puberulent, 5-10 cm. long; bracts lacerate, usually not exserted.

Alaska southward in the mountains to Oregon and Colorado. In the Cascade Mountains the southern limit is near Crater Lake, Oregon. It commonly occurs at $1500-2500 \mathrm{~m}$. altitude. In the Olympic Mountains, there is a form with the bracts exserted. This tree was first found by Douglas, probably in the Blue Mountains of eastern Washington and Oregon.

Abies amabilis (Loud.) Ferbes. Amabilis Fir. Graceful tree, $30-50 \mathrm{~m}$. high; leaves with few or no stomata on the upper surface, those of the lower branches flat, obtuse or retuse, those of the upper branches curved upward, mostly acute; cones dark-purple, $8-15 \mathrm{~cm}$. long, puberulent.

In the mountains mostly at 1000-1500 m. altitude, ranging from extreme southern Alaska in the Cascade Mountains to Crater Lake, Oregon, and in the Coast Mountains to Saddle Mountain, near Astoria, Oregon.

Abies grandis Lindl. White Fir. Large tree, sometimes $100 \mathrm{~m}$. tall and $2 \mathrm{~m}$. in diameter, with thin, dark gray, rather smooth bark; branches horizontal or the lower drooping; leaves linear, obtuse or notched, shining green above, marked beneath by two white lines, $18-30 \mathrm{~mm}$. long, usually arranged in two ranks, giving the foliage a flattened appearance; cones cylindric-oblong, 7-10 cm. long, dark green, more or less covered with drops of resin; scales broader than long, entire; bracts small, deeply notched, each sometimes bearing a short point.

Common in moist land at low altitudes, from the northern end of Vancouver Island to Sonoma County, California, and eastward to Montana and Wyoming.

Abies concolor (Gord.) Parry. Large tree, reaching a height of 50-70 m. and a diameter of 1-2 m.; bark ash-gray, deeply furrowed; leaves pale, those of the lower branches 2 -ranked, flat, obtuse or retuse, $5-7 \mathrm{~cm}$. long, those of the fruiting branches curved upward and acute; cones olive green or yellowish, sometimes purple tinged, $8-10 \mathrm{~cm}$. long; bracts small, narrowly oblong, truncate or slightly notched, sometimes bearing a short point.

In the Cascade Mountains of Oregon from Mount Jefferson southward through California; also in the Rocky Mountains of Colorado, Utah and Arizona.

\section{PSEUDOTSUGA.}

Very large trees, at first pyramidal and spruce-like, often in age more spreading; leaves linear, flat, somewhat 2-ranked by a twist at the base; aments from the axils of the leaves of the preceding year; staminate aments clustered in an oblong or 
cylindrical column, surrounded or partly enclosed by numerous, conspicuous, rotund bud-scales; ovule-bearing aments with the scales much shorter than the broadly linear acutely 2-lobed bracts; cones maturing the first year; scales persistent.

Pseudotsuga mucronata (Raf.) Sudw. Red Fir. Douglas Spruce. Very large tree, $50-100 \mathrm{~m}$. high, $1-4 \mathrm{~m}$. in diameter; bark thick, reddish within, deeply cracked longitudinally; branches usually short and horizontal; leaves linear, obtusish, $20-30 \mathrm{~mm}$. long, narrowed at the base, dark green above, paler beneath; staminate aments light brown, oblong-cylindric, $1 \mathrm{~cm}$. long, half enclosed in the large bracts; pistillate aments green or purplish; cones pendent, cylindric-ovoid, $6-10 \mathrm{~cm}$. long, the tridentate bracts conspicuously exceeding the scale.

The common forest tree of the region. Subalpine forms have the cones uniformly shorter and thicker. Red fir ranges from British Columbia to Mexico. It does not extend northward quite to the Alaska boundary. The first knowledge of the tree was Lewis's description of it as it occurs at the mouth of the Columbia River.

\section{PICEA. SPRUCE.}

Evergreen conical trees, with linear sharp pointed short foursided leaves, spreading in all directions, falling away from the twig in drying, leaving it covered with small projections; leafbuds scaly; staminate aments axillary, nearly sessile; ovulebearing aments terminal, ovoid or oblong; ovules two on the base of each scale, reflexed, ripening into two more or less winged seeds; cones ovoid or oblong, obtuse, pendulous, their scales numerous, spirally arranged, thin, obtuse, persistent.

Leaves distinctly flattened; lowland tree.

Leaves quadrangular; subalpine tree.

P. sitchensis.

$P$. engelmanni.

Picea sitchensis Carr. Sitka or Tideland Spruce. A very large tree, 50-70 $\mathrm{m}$. tall, and 2-3 m. in diameter; bark dark gray, scaly; twigs glabrous; leaves $10-15 \mathrm{~mm}$. long, distinctly flattened, very sharp pointed; cones oblong or oval, pale brown, $3-6 \mathrm{~cm}$. long, the oblong-ovate scales denticulate.

Common along the seacoast and on low river bottoms, ranging from Kodiak Island, Alaska, to Mendocino County, California. It was first found at Sitka by Mertens.

Picea engelmanni Parry. Engelmann Spruce. Handsome pyramidal tree, $30-40 \mathrm{~m}$. tall, the bark gray and scaly; branchlets pubescent; leaves darkgreen, quadrangular in cross section, very sharply pointed, $1.5-2 \mathrm{~cm}$. long; cones cylindric-ovate, 3-6 cm. long; scales ovate, truncate, rounded or retuse, crenulate.

From the Yukon to New Mexico and Arizona, mainly in the interior but occuring in the Cascade Mountains at $300-1000 \mathrm{~m}$. altitude from British Columbia to the southern boundary of Oregon.

Orack 5400 fo. $100 / 18$

\section{TSUGA. HeMLOCK.}

Evergreen trees with flat or angled leaves which appear 2-ranked; branchlets rough from persistent leaf-bases; staminate aments in subglobose clusters from the axils of leaves of the pre- 
vious year; ovule-bearing aments terminal on year-old branchlets; bract somewhat shorter than the cone-scale; cones maturing the first year, pendulous.

Leaves 8-18 $\mathrm{mm}$. long; cones $2 \mathrm{~cm}$. long.

Leaves 12-25 mm. long; cones 5-7 cm. long.

T. heterophylla.

T. mertensiana.

Tsuga heterophylla (Raf.) Sarg. Western Hemlock. Handsome tree, 30-60 m. tall and 50-200 cm. in diameter; branches slender, usually bent downward; leaves linear, flattened, unequal in length, 8-18 mm. long; cones oblong, 10-16 mm. long.

A common forest tree, most abundant at about $1000 \mathrm{~m}$. altitude. It ranges from Prince William Sound, Alaska, to Marin County, California. It was originally described by Lewis and Clarke from the mouth of the Columbia River.

Tsuga mertensiana (Bong.) Carr. Mountain ar Black Hemlock. Tree $30-50 \mathrm{~m}$. high and $50-200 \mathrm{~cm}$. in diameter; leaves $1-2 \mathrm{~cm}$. long, acutish, convex above, bearing stomata on both surfaces; cones oblong, dark purple, 5-7 cm. long.

Common in the mountains at about the limit of trees; at the highest altitude it becomes a prostrate shrub. The Black Hemlock ranges from Prince William Sound, Alaska, where it occurs at sea level, southward in the mountains to Montana and California. It was first found by Mertens on the mountain at Sitka.

E.L. Hoskin Class Y ANGOZOSPERMAE.

Ovules (megasporangia) enclosed in a cavity (the ovary) formed by the infolding and uniting of the margins of a modified rudimentary leaf (carpel), or of several such leaves joined together, in which the seeds are ripened; stigmas present; cotyledons one or two, very rarely wanting; perianth present or wanting.

\section{Sub-class I. MONOCOTYLEDONES.}

Embryo of the seed with but a single cotyledon, that is with the first leaves of the germinating plantlet alternate; stem composed of a mass of soft tissue in which the woody bundles appear in cross section to be irregularly imbedded, there being no distinction into bark, wood and pith; leaves usually parallel-veined, mostly alternate and entire, commonly sheathing the stem at the base and often with no distinction of blade and petiole; parts of the flowers mostly in threes.

Family 10. Typhaceae. Cat Tail Family.

Marsh or aquatic herbs with creeping rootstocks and linear flat sheathing leaves; stems erect, terete; flowers monoecious, 
densely crowded in a terminal spike, often subtended by spathaceous bracts; ovary one, $1-$ or 2 -celled, with as many persistent styles; fruit nutlike.

\section{TYPHA.}

Flowers in a dense cylindrical spike; staminate and pistillate portions of the spike contiguous; stamens with very short connate filaments, mixed with numerous long hairs; ovary longstalked, 1-celled, surrounded by numerous bristles and rudimentary ovaries; fruit minute, usually splitting on one side.

Typha latifolia L. Cat-tail. Stout, 1-3 m. tall; leaves flat, sheathing at base, $1-2 \mathrm{~cm}$. wide; pistillate and staminate portions of the spike close together, each $8-30 \mathrm{~cm}$. long, the pistillate dark brown; stigmas rhombicspatulate; pollen grains in fours.

Margins of lakes and ponds, abundant.

\section{Family 11. SPARGANIACEAE. BuR-REed FAMily.}

Marsh or pond herbs with creeping rootstocks and erect or floating stems; leaves linear, alternate, 2-ranked, sessile, sheathing at the base; flowers monoecious, densely crowded into globose heads which are in a raceme on the upper parts of the stem and branches, the staminate above; spathes linear; perianth of a few chaffy scales; stamens usually 5 ; fruit mostly 1 -celled, nut-like.

\section{SPARGANIUM. Bur REed.}

\section{Characters of the family.}

Heads all axillary; inflorescence branched.

S. androcladum.

Heads, or at least some of them, supra-axillary.

Leaves, or at least the larger ones, keeled; plants usually terrestrial.

Leaves not keeled; floating aquatics.

Beak of fruit short-conical; stigma oblong.

Beak of fruit slender; stigma linear.

S. simplex.

S. minimum.

S. angustifolium.

Sparganium androcladum (Engelm.) Morong. Stems stout, 40-100 cm. high; leaves 5-12 mm. wide, dark green; inflorescence branched, the branches strictly axillary, each bearing 3-7 staminate heads and usually 1 or 2 pistillate heads; fruiting heads $2-2.5 \mathrm{~cm}$. in diameter; fruit dull, the fusiform body 5-6 mm. long, the beak about $3 \mathrm{~mm}$. long.

Margins of ponds and lakes, common.

Sparganium simplex Huds. Stems rather stout, $30-60 \mathrm{~cm}$. high; leaves thin, $6-15 \mathrm{~mm}$. broad, scarious-margined below; inflorescence simple; fruiting heads $12-25 \mathrm{~mm}$. in diameter, some of them supra-axillary; fruit fusiform. somewhat shiny, the body $3-4 \mathrm{~mm}$. long, tipped with a beak about as long; stalk 1-2 $\mathrm{mm}$. long; stigmas linear.

More common than S. androcladum and occurring in similar places. 
Sparganium minimum Fries. Aquatic; stems very slender, $10-40 \mathrm{~cm}$. long; leaves thin and grass-like, $2-4 \mathrm{~mm}$. broad, floating; inflorescence simple; heads sessile or nearly so, the pistillate about $1 \mathrm{~cm}$. in diameter when mature; nutlets smooth, ovoid, conically short-beaked, easily detached.

In mountain ponds and lakes. San Juan Lake, Vancouver Island, Rosendahl \& Brand; Mount Rainier, Piper.

Sparganium angustifolium Michx. Aquatic; stems slender, $30-100 \mathrm{~cm}$. long; leaves very long and narrow, rather firm, $2-4 \mathrm{~mm}$. wide; inflorescence simple; heads sessile or the lower peduncled, the pistillate $15-20 \mathrm{~mm}$. in diameter when mature; nutlets abruptly slender-beaked, firmly attached.

In ponds and lakes; Mount Arrowsmith, Vancouver Island, Macoun.

\section{Family 12. NAJADACEAE. Pondweed Family.}

Submersed or floating fresh-water or marine aquatic herbs or marsh plants; leaves flat or filiform, opposite, alternate or whorled; flowers unisexual or perfect, mostly small, solitary axillary or in spikes; perianth none or sheath-like; stamens $1-4$; carpels $1-5$, each 1 -ovuled.

Flowers perfect; stamens more than one.

Perianth of 4 sepals; stamens 4; fruit sessile.

Perianth none; stamens 2; fruits stalked.

Flowers monoecious or dioecious; stamen solitary.

Leaves many, opposite; flowers axillary, sessile.

Monoecious; pistils $2-5$, in a cup-shaped involucre; stigmas short.

35. Potamogeton, 25.

36. RUPPIA, 27.

Dioecious; pistil solitary, naked; stigma slender. 38. NAjAS, 28.

Leaves alternate, rather few.

Stigma capitate; fertile flowers in an exserted naked spike; fresh water or marsh plant.

Stigma linear; fertile flowers on an enclosed spadix; marine plants.

Monoecious; fruit rounded at base.

Dioecious; fruit cordate at base.

39. Lilaea, 28.

40. Zostera, 28.

41. Phyllospadix, 28.

\section{POTAMOgeton. Pondweed.}

Leaves alternate or the uppermost opposite, of ten of two kinds, the submersed mostly linear, the floating lanceolate, ovate or oval; spathes enclosing the young buds, usually perishing soon after expanding; flowers small, perfect, spicate, green or red; perianth of 4 sepals, valvate in bud; stamens 4 , opposite the sepals; ovaries 4 , sessile, distinct, 1-celled, 1 -ovuled.

Leaves of two kinds, the floating ones thickish, the submersed thin and of different form.

Submersed leaves linear.

Floating leaves subcordate at base; stipules long.

Floating leaves acute at base; stipules short.

Submersed leaves lanceolate or oval.

Floating leaves oval, 30-50-nerved.

Floating leaves narrowly elliptic, 10-20-nerved.

P. natans.

P. epihydrus.

P. amplifolius. 
Stipules acuminate; fruiting spike $4-5 \mathrm{~cm}$. long.

Stipules obtuse; fruiting spikes $2-3 \mathrm{~cm}$. long.

Leaves alike, all submersed.

Leaves lanceolate to oblong.

Not clasping at base.

Half clasping at base.

Apex boat-shaped or hooded.

Leaves linear.

Apex acuminate, not hooded.

$P$. americanus.

$P$. heterophyllus.

$P$. heterophyllus.

P. praelongus.

$P$. richardsonii.

Stipules free from the base of the leaf.

Leaves tape-like; spike cylindric; fruit large.

P. zosterifolius.

Leaves very narrow; spike not cylindric; fruit small. $P$. pusillus.

Stipules adnate to the base of the leaf.

Leaves linear-lanceolate, 4-8 $\mathrm{mm}$. wide, ciliate, many-nerved.

Leaves linear-setaceous, $1 \mathrm{~mm}$. wide, not ciliate, 1-nerved

$P$. robbinsii.

$P$. pectinatus.

Potamogeton natans L. Floating leaves ovate or elliptical, somewhat cordate at base, $5-8 \mathrm{~cm}$. long; upper submerged leaves with a lanceolate blade, the lower linear and grass-like; upper stipules long, acute; spike $3-5 \mathrm{~cm}$. long, emersed.

Common in still ponds and lakes.

Potamogeton epihydrus Raf. ( $P$. nuttallii C. \& S.) Stems simple or branched, compressed, $60-120 \mathrm{~cm}$. long; floating leaves oblong, obtuse or acutish, each attenuate into a short petiole; submersed leaves numerous, linear, thin, 5-7-nerved, with a coarse cellular reticulation between the inner nerves; stipules short, obtuse; spikes $1-4 \mathrm{~cm}$. long, on stout peduncles; fruit obovoid, apiculate, 2-3 $\mathrm{mm}$. long, 3-keeled when dry.

Frequent in lakes and quiet rivers.

Potamogeton amplifolius Tuckerm. Stem stout, simple or branched; floating leaf-blades oblong-oval, acute, rounded at the base, 5-10 cm. long, long-petioled; submersed leaves mostly linear-lanceolate to lanceolate, the uppermost frequently oval or oblong; stipules large, 5-10 cm. long, acute; spike stout, dense, $2-4 \mathrm{~cm}$. long, stout peduncled; fruit large, 4-5 mm. long, with a broad beak.

Rarely collected in our limits; Coupeville, Gardner; Whatcom County, Washington, Suksdorf.

Potamogeton americanus C. \& S. ( $P$. lonchitis Tuckerm.) Stems slender, flaccid, branched, 50-100 cm. or more long; floating leaves narrowly elliptic, pointed at each end, 5-10 cm. long, many-nerved, narrowed at base into a petiole about as long; submersed leaves lanceolate; stipules narrow, 3-8 $\mathrm{cm}$. long; spike dense, $2-4 \mathrm{~cm}$. long, on rather stout peduncles; fruit about $3-4$ $\mathrm{mm}$. long.

In ponds and streams, not common.

Potamogeton heterophyllus Schreb. Floating leaves thin, obtuse, 9-15nerved, 3-5 cm. long; submersed leaves lanceolate or linear-lanceolate, 3-7nerved; stipules obtuse; fruit small, subglobose.

Victoria, Macoun, and common eastward.

Potamogeton praelongus Wulf. Leaves all submersed, numerous, oblong or oblong-lanceolate, obtuse, half-clasping at base, $5-20 \mathrm{~cm}$. long; peduncles usually very long; spikes $2-5 \mathrm{~cm}$. long, thick, loosely flowered; fruit sharply keeled when dry, 4-5 mm. long.

In lakes, rare in our limits. 
Potamogeton richardsonii (Benn.) Rydb. Leaves all submersed, lanceolate, acuminate, cordate and clasping at base, $6-10 \mathrm{~cm}$. long; stipules large, often split into shreds; peduncles rather short, thicker upward; spikes loose, $1-1.5 \mathrm{~cm}$. long.

Very common in lakes and ponds.

Potamogeton zosterifolius Schumacher. Stems branching, flattened; leaves grass-like, clasping at base, 3-nerved; stipules obtuse; spikes cylindric, $12-15$-flowered, shorter than the peduncles.

Quiet waters, rare.

Potamogeton pusillus L. Stems very slender, flattened, usually much branched; leaves all submersed, narrowly linear, $2-5 \mathrm{~cm}$. long, each bearing two glands at the sessile base; stipules obtuse, early disappearing; spikes interrupted, 5-8-flowered.

Common in still lakes.

Potamogeton robbinsii Oakes. Stems stout; leaves numerous, all submersed, linear or lanceolate, minutely serrulate, $8-12 \mathrm{~cm}$. long, 2-ranked; stipules obtuse; fruit obovoid, sharp beaked, conspicuously keeled.

In quiet lakes, very local and seldom fruiting; abundant in Lake Cushman, Mason County, Washington.

Potamogeton pectinatus L. Stems filiform, branched, $30-90 \mathrm{~cm}$. long; leaves narrowly linear, attenuate to the apex, 1-nerved, 2-10 cm. long; peduncles slender; flowers in whorls; fruit obliquely ovoid, compressed, turgid, $3.5-4.5 \mathrm{~mm}$. long; style straight or nearly so.

Columbia River, Scouler, Suksdorf; occurs most commonly in brackish water but rare in our limits.

\section{RUPPIA.}

Slender submersed branching herbs growing in salt or brackish water with thread-like stems and with thread-like alternate leaves broadly sheathing at the base; flowers perfect, two or more near each other on a spadix enclosed in the sheathing base of a leaf, later being thrust out; perianth none; stamens 2 , sessile; ovaries 4 , at first sessile, in fruit stalked.

Ruppia maritima L. Stems slender, much branched, leafy; leaves narrowly linear, 2-8 cm. long; spikes small, 2-8-flowered.

In brackish shallow water on the seashore. A polymorphous species, of which at least two subspecies occur in our limits.

Ruppia maritima intermedia (Thed.) Aschers. \& Graebn. Carpels ovoid, slightly oblique but not curved, bluntly and inconspicuously beaked.

Seattle, Piper.

Ruppia maritima rostrata Agardh. Carpels strongly oblique or curved and conspicuously beaked.

V'ictoria, British Columbia, Macoun; Seattle, Piper \& Smith.

\section{ZANNICHELLIA.}

Submersed herbs; leaves small, opposite, linear; flowers unisexual, in axillary clusters, each composed of one staminate and 2-5 pistillate flowers; staminate flower naked; pistillate flowers enclosed in a funnel-shaped undivided involucre; style short; stigma disk-shaped or bilobed; ovary flask-shaped. 
Zannichellia palustris L. Horned Pondweed. Stems slender, branching, leafy, 10-60 cm. long; leaves thin, filiform, 1-nerved, 5-8 cm. long; fruit nearly sessile, flattened, somewhat incurved, of ten more or less toothed on the back, 2-3 mm. long, about twice as long as the style.

In ponds and quiet streams, rare in our limits.

\section{NAJAS.}

Submersed aquatic herbs with slender branching stems; leaves numerous, short, opposite or in threes, linear; flowers monoecious or dioecious, solitary axillary, the staminate enclosed in a membranaceous sheath; stamen 1 ; carpel 1 , with a short style and a 1-celled 1-ovuled ovary.

Najas flexilis (Willd.) Rostk. \& Schmidt. Stems slender; leaves numerous, linear, acute or acuminate, $1-2 \mathrm{~cm}$. long, minutely serrulate, the sheath broadlyoblong; fruit $3 \mathrm{~mm}$. long, oblong-linear, tipped with the persistent style; seed pale-brown, shining.

In lakes and slow streams, common and widely spread.

\section{LILAEA.}

Marsh or freshwater grass-like plant with fibrous roots; leaves alternate; flowers monoecious, naked, in separate spikes or intermixed; staminate floret a solitary nearly sessile 2-celled anther subtended by a distinct bract; pistillate florets consisting of naked sessile ovaries; styles short in the upper florets, elongated in the lower ones; stigma cuspidate; ovule solitary.

Lilaea subulata HBK. (Heterostylus gramineus Hook.) Leaves grasslike, $15-30 \mathrm{~cm}$. long, 2-4 mm. broad, thin; peduncles shorter than the leaves; spikes crowded; spathe boat-shaped at base; styles of the lower flowers long and filiform, gradually reduced upwards; akenes elliptical, acute, wingmargined; lower ones largest and with a lateral tooth on each side at the base of the style.

In ponds, rare. Sumas River, Vancouver Island, Macoun; Oregon, Scouler, Howell.

\section{ZOSTERA.}

Submersed marine perennial herbs with creeping and rooting stems or rootstocks; leaves alternate, entire, ribbon-shaped; flowers monoecious; perianth none; flowers of single stamens and ovaries alternately in rows on a leaf-like spadix enclosed in the membranous base of a leaf.

Zostera marina L. Eel-grass. Leaves tape-like, obscurely 3-7-nerved, 50-100 cm. long.

Very common along the seashore just at low tide mark but very seldom flowering. There are perhaps two species on our coast.

\section{PHYLLOSPADIX.}

Perennial submersed marine herbs with thick rootstocks and slender stems; leaves elongated, linear; flowers dioecious; perianth none; staminate flower a single sessile 1-celled anther; 
pistillate flowers of sessile carpels in two vertical rows on the face of a broadly linear sessile spadix enclosed in a boat-shaped spathe.

Leaves $2-2.5 \mathrm{~mm}$. wide; spathes solitary or rarely two. $\quad P$. scouleri. Leaves $1-1.5 \mathrm{~mm}$. wide; spathes several, on short lateral peduncles. $P$. torreyi.

Phyllospadix scouleri Hook. Stems stout, $2-5 \mathrm{~cm}$. long, bearing a single spathe; leaves strongly 3 -nerved, $1-2 \mathrm{~m}$. long, $2-5 \mathrm{~cm}$. broad.

On rocky seacoasts, Vancouver Island, British Columbia to California. First found at the mouth of the Columbia River by Scouler.

Phyllospadix torreyi Wats. Stems slender, bearing one or two axillary peduncles at each joint; leaves narrow, $2 \mathrm{~mm}$. wide, 1-nerved or faintly 3 nerved, often a meter or more long.

Vancouver Island to California, on rocky shores.

\section{Family 13. SCHEUCHZERIACEAE. ARRow Grass}

FAMILY.

Swamp plants with narrow leaves and terminal racemose or spike-like inflorescences; flowers perfect or unisexual, naked or with a usually evanescent bract-like perianth; stamens 2 or 3 ; carpels 3-6, each 1-2-ovuled, more or less united till maturity, dehiscent or indehiscent.

Leaves all basal; flowers numerous, in spikes or racemes, on scapes.

Stem leafy; flowers few, in a loose raceme. 43. Scheuchzeria, 29.

\section{TRIGLOCHIN. ARROW GRASS.}

Flowers small, perfect, in a terminal spike-like raceme borne on a naked scape; perianth segments 3-6, greenish, evanescent; stamens 3-6; anthers 2-celled, on very short filaments; carpels $3-6$, united into a compound pistil; ovules solitary; capsule, when ripe, splitting into 3-6 carpels with a persistent central axis.

Triglochin maritima L. Scapes subterete, $20-40 \mathrm{~cm}$. high, exceeding the leaves; leaves thickish, narrow; raceme elongate, $15-40 \mathrm{~cm}$. long; fruit ovoid, angled, 5-6 mm. long; carpels usually 6 , sometimes 3 .

Common in marshes along the seashore.

\section{SCHEUCHZERIA.}

Rush-like bog perennials with creeping rootstocks and erect leafly stems; flowers small, in racemes; perianth 6-parted, regular, in two series.

Scheuchzeria palustris L. Stems flexuous, $15-20 \mathrm{~cm}$. high, exceeded by the leaves; raceme loose, few-flowered; bracts sheathing; carpels ovoid, divergent in fruit.

In sphagnum bogs, widespread but infrequent. Near Seattle, Piper; Tacoma, Flett. 


\section{Family 14. Alismaceae. Water Plantain Family.}

Aquatic or marsh herbs with fibrous roots, scape-like stems and basal long-petioled leaves; inflorescence a raceme or panicle; flowers regular, perfect, monoecious or dioecious; pedicels whorled and subtended by bracts; sepals 3 , persistent; petals 3 , deciduous; stamens 6 or more; ovaries numerous or rarely few, 1-celled, usually 1-ovuled; carpels becoming akenes in fruit; endosperm none.

Carpels in a ring upon a small flat receptacle; leaves ovate (in ours).

Carpels crowded in many series upon a large convex receptacle; leaves sagittate (in ours).

44. Alisma, 30.

45. SagitTaria, 30 .

\section{ALISMA.}

Perennial or rarely annual herbs with erect or floating leaves; inflorescence a panicle or umbel-like panicle; flowers perfect, small, numerous, on unequal pedicels; petals small; stamens 6 or 9 ; ovaries few or many, more or less in one whorl on a small flat receptacle.

Alisma plantago-aquatica L. Water Ṕlantain. Scapes stout, $30-100 \mathrm{~cm}$. tall; leaves all radical, erect or floating, the petioles usually long, the blades ovate or oblong, acute, rounded or subcordate at the base, 5-15 cm. long, 5-7nerved; flowers in a large panicle composed of 3-6 whorls of branches, these again branched once or twice; flowers on pedicels $1-5 \mathrm{~cm}$. long; petals white, hardly exceeding the sepals; akenes obliquely obovate, compressed.

Common in ponds and wet places.

45. SAGITTARIA. ARROWHEAD.

Perennial aquatic or marsh herbs with basal long-petioled leaves: flowers monoecious or dioecious, borne near the summits of the scapes in whorls of 3 , the staminate usually uppermost; petals usually conspicuous; stamens usually numerous; ovaries numerous, crowded in globose heads.

Sagittaria latifolia Willd. Wappato. Leaves sagittate, but varying greatly in width, 10-20 cm. long, long-petioled; petals white, 1-1.5 cm. long; akenes flat, each with a thin margin and bearing a stout lateral beak; rootstock tuberous.

Common in shallow water on the margins of lakes, the tubers eaten by the Indians. In lakes and rivers where the European carp is introduced the plant has become very rare as the fish eat the tubers.

\section{Family 15. HYDROCHARITACEAE. Frog's Bit FAMIly.}

Aquatic mostly perennial herbs with opposite or whorled leaves (in ours); flowers dioecious or polygamous, sessile or peduncled, surrounded by a membranous spathe; perianth 
regular, of 3 or 6 segments, these united and tubular at base; stamens $3-12$; stigmas 3 or 6 , bifid; ovary inferior; fruit indehiscent.

\section{ELODEA.}

Perennials with opposite or whorled 1-nerved leaves; flowers polygamo-dioecious, solitary and sessile in the axils; spathe tubular, 2-cleft; perianth of the staminate flowers with 3 . nearly separate sepals and 3 or more narrower petals; perianth of the pistillate flowers with a long scarious tube adherent to the ovary and a 6-parted limb; stamens 3-9, the short filaments united at base; stigmas 3-6, bifid.

Elodea canadensis Michx. (Anacharis canadensis Planch.) Waterweed. Stems $10-100 \mathrm{~cm}$. long; leaves in whorls of 3 or 4 , oval or oblong, acute, usually serrulate.

In ponds, not common in our limits.

\section{Family 16. Gram inede}

Annual or perennial herbs, rarely shrubs or trees; stems (culms) generally hollow; nodes closed; leaves 2-ranked, sheathing, the sheaths usually split to the base on the side opposite the blade; a scarious or membranous appendage (ligule) borne at the opening of the sheath, rarely obsolete; inflorescence a spike, a raceme or a panicle, consisting of spikelets composed of two to many 2-ranked imbricated bracts; the lowest two (glumes) without flowers or rarely wanting; one or more of the upper (lemma) containing in its axil a flower, which is usually enclosed by a bract-like, generally 2 -keeled, awnless organ (palea) opposite the lemma and with its back toward the axis (rachilla) of the spikelet; lemma sometimes bearing a hard thickening (callus) at the base; flowers perfect or sometimes monoecious or dioecious, subtended by 1-3 minute hyaline scales (lodicules); stamens $1-6$, usually 3 ; ovary 1 -celled, 1 -ovuled; styles $1-3$, commonly 2 and lateral; stigmas hairy or plumose; fruit a seed-like grain (caryopsis) or rarely a utricle; endosperm starchy.

Spikelets with two or more perfect flowers.

Spikelets sessile on the rachis; inflorescence a spike.

Spikelets pedicelled; inflorescence a panicle, spike-

Tribe 8. HORDEAE. like panicle or raceme.

Lemma shorter than the glumes, usually with a bent awn rising from the back.

Lemma longer than the glumes, awnless or with a straight apical awn.

Tribe 5. Aveneae.

Tribe 6. Festuceae. 
Spikelets with one perfect flower.

Spikelets with a staminate or neutral flower in addition to the perfect one.

Rachilla jointed below the glumes which fall with the seed.

Tribe 1. Paniceae.

Rachilla jointed above the glumes which do not fall with the seed.

Imperfect flower below the perfect.

Arrhenatherum in Tribe 5. AveneaE.

Imperfect flower above the perfect.

Holcus in Tribe 5. AveneaE.

Spikelets with only one flower.

Rachilla jointed below the glumes which fall with the seed.

Spikelets compressed dorsally or terete; glumes 2.

Tribe 1. Paniceae.

Spikelets compressed laterally; glumes none.

Tribe 2. Oryzeae.

Rachilla jointed above the glumes which do not fall with the seed.

First two lemmas empty, variously modified, the third with a flower.

Tribe 3. Phalarideae.

First lemma flower-bearing.

Spikelets crowded in two rows in onesided spikes.

Spikelets not in one-sided spikes.

Tribe 7. Chlorideae.

Spikelets in two opposite rows.

Hordeum in Tribe 8. HORDEAE. Spikelets not in two opposite rows. Tribe 4. AgrostideaE.

Tribe 1. Paniceae.

Spikelets in clustered racemes or spikes.

47. EchiNochloA, 34.

Spikelets not in clusters.

Inflorescence a dense spike-like panicle; pedicels bristly.

Inflorescence a loose panicle; pedicels not bristly.

Lemma one; spikelets in two rows on a flattened rachis.

Lemmas two; spikelets not in two rows on a flattened rachis.

48. Chaetochloa, 35.

49. Paspalum, 35.

50. Panicum, 35.

Tribe 2. ORYzEAE.

Spikelets perfect; glumes none; lemmas awnless.

51. Homalocenchrus, 36.

Tribe 3. Phalarideae.

First and second lemmas narrow, bristle-like; glumes strongly compressed.

First and second lemmas broadly ovate or oblong; glumes not strongly compressed.

Glumes very unequal; first and second lemmas much shorter than the glumes, awned.

- Glumes ncarly equal, scarcely exceeding the first and second lemmas which are awnless or short-awned.

52. Phalaris, 36.

53. Anthoxanthum, 37.

54. Hierochloe, 37. 
Tribe 4. Agrostideae.

Lemma with a long terminal awn and closely enveloping the grain.

Fruiting lemma thin and membranaceous.

Fruiting lemma firm and indurated.

Lemma awnless or short-awned and loosely enveloping the grain.

Inflorescence a dense spike-like raceme or panicle.

Lemma awnless.

Rachilla prolonged behind the floret.

Rachilla not prolonged behind the floret.

Lemma awned.

Glumes awned.

Glumes awnless.

55. Muhlenbergia, 37.

56. STIPA, 38.

Glumes saccate at base; palea none.

Glumes not saccate at base; palea present.

Inflorescence not spike-like.

Palea 1-nerved; stamen 1.

Palea 2-nerved; stamens 3.

Glumes none; plant very small.

Glumes 2; plant larger.

Callus with a tuft of long hairs at the base.

Callus naked.

59. Gastridium, 39.

57. Phleum, 38.

58. Polypogon, 39.

59. Gastridium, 39.

60. Alopecurus, 39.

61. Cinna, 40.

62. Coleanthus, 40 .

63. Calamagrostis, 41.

64. Agrostis, 42.

Tribe 5. Aveneae.

Perfect flower only one, the other staminate.

Lower flower perfect, awnless; upper staminate, awned.

Lower flower staminate, long awned; upper perfect, awnless.

65. Holcus, 44.

66. Arrhenatherum, 45.

Perfect flowers two or more.

Rachilla not prolonged beyond the upper flower.

Rachilla prolonged beyond the upper flower.

Awn of lemma from between the two terminal teeth.

68. Danthonia, 45.

Awn of lemma dorsal or none.

Spikelets large, more than $15 \mathrm{~mm}$. long.

Spikelets small, less than $15 \mathrm{~mm}$. long.

Lemma erose-truncate.

Lemma 2-toothed.

67. AIra, 45.

69. Avena, 46.

70. Deschampsia, 46.

71. Trisetum, 47.

Tribe 6. Festuceae.

Lemma 3-nerved, rarely $\mathrm{I}$-nerved.

Panicle loose; spikelets usually many-flowered.

Panicle dense, spike-like; spikelets 2-4-flowered.

Spikelets of two kinds in the same inflorescence, perfect and sterile.

73. Cynosurus, 48.

Spikelets all alike in the same inflorescence. 74. KoelerIA, 48. 
Lemma 5-nerved or more.

Keels of the palea winged.

Keels of the palea not winged.

Spikelets with the upper florets sterile and folded about each other.

Spikelets with the upper florets perfect, or

75. Pleuropogon, 49. narrow and abortive.

Spikelets cordate: lemmas cordate at base.

Spikelets not cordate; lemmas not cordate

76. MELICA, 49. at base.

Stigmas arising below the apex of the ovary.

Stigmas arising at the apex of the ovary.

Lemmas compressed and keeled.

Lemma awn-pointed.

Lemmas pointless.

Glumes 1-3-nerved.

Glumes 5-nerved or more.

Lemmas convex or rounded on the back.

Lemmas acute or awned.

Lemmas obtuse and scarious at apex.

Lemmas prominently 5-7nerved

77. BRIZA, 49.

78. BROMUS, 50 .

79. Dactylis, 52.

80. POA, 52.

81. Distichlis, 56.

82. Festuca, 56.

Lemmas obscurely 5-nerved. 84. PuCcinellia, 59.

\section{Tribe 7. Chlorideae.}

Spikelets not in digitate clusters.

Spikelets much flattened; glumes unequal, keeled.

Spikelets subterete; glumes equal, convex.

Spikelets in terminal digitate clusters.

Spikelets I-flowered; stems creeping.

Spikelets several-flowered; stems not creeping.

85. Spartina, 60.

86. BECKMANNia, 60.

87. Cynodon, 60.

88. Eleusine, 61.

Tribe 8. HORDEAE.

Spikelets solitary at each joint of the rachis.

Spikelets with one edge against the rachis; empty glume 1.

Spikelets with their sides against the rachis; empty glumes 2 .

Spikelets 2 to 4 at each notch of the rachis.

Rachis not readily breaking into joints; spikelets 1-7-flowered, 2-4 at each joint.

Rachis readily breaking into joints.

Spikelets I-flowered, three at each joint, only the central one perfect.

Spikelets 1-5-flowered, 2-4 at each joint, all perfect.

89. Lolium, 61.

90. Agropyron, 61.

91. Elymus, 62.

92. HORDEUM, 63.

93. Sitanion, 64.

47. ECHINOCHLOA.

Coarse annuals with long leaves; spikelets 1 -flowered, with sometimes a staminate flower below, nearly sessile in panicled 
1-sided spikes or racemes; glumes unequal, hispid, mucronate; sterile lemma similar and usually awned from the apex.

Echinochloa crus-galli (L.) Beauv. Barnyard grass. Glabrous; stems stout, branching at the base, 30-120 cm. tall; panicle dense, 10-20 cm. long, composed of many ascending or spreading racemes; spikelets green or purple, $3 \mathrm{~mm}$. long, densely crowded in 3 or 4 rows; sterile lemma awned or in some forms awnless.

Introduced from Europe, a weed in moist ground.

\section{CHAETOCHLOA.}

Annual grasses with erect stems and flat leaves; spikelets with one perfect flower and rarely also a staminate one, in spike-like panicles; pedicels bearing bristles; glumes and lower lemma membranous, the latter often containing a palea and rarely a staminate flower; upper lemma papery with a similar palea and a perfect flower.

Chaetochloa viridis (L.) Scribn. Green Foxtail. Annual, usually tufted, green; stems $30-90 \mathrm{~cm}$. high; leaf-blades flat, 4-10 $\mathrm{mm}$. wide, scabrous on the margins; spikes green, $3-5 \mathrm{~cm}$. long, the rachis villous; bristles $1-3$, upwardly barbed, 6-12 $\mathrm{mm}$. long; spikelets $2 \mathrm{~mm}$. long; fertile lemma faintly wrinkled.

Sparingly introduced.

\section{PASPALUM.}

Perennials with 1 -flowered spikelets in 2 rows along one side of a rachis forming racemes; lower glume usually wanting; lemma hard and firm, its margin inrolled; palea firm; grain oblong, inclosed within the hardened glume and palea.

Paspalum distichum L. Stems ascending from a creeping base; leaves 4 $12 \mathrm{~cm}$. long; spikes in terminal pairs, $2-5 \mathrm{~cm}$. long; spikelets acute, $2.5-3 \mathrm{~mm}$. long.

On overflowed river banks, especially along the Columbia River; probably introduced.

\section{PANICUM.}

Spikelets with one perfect flower, often with a staminate one below it; glumes 2, membranous; lemmas 2, the lower empty or including the staminate flower, the upper indurated, shining, enclosing a similar palea and the perfect flower; awns none (in ours); fruit a caryocist, the free grain enclosed in a box formed by the hardened lemma and palea.

Annual; panicle very long-rayed; spikelets acute.

Perennial; panicle rather short-rayed.

Basal leaves like the stem leaves; spikelets acute.

Basal leaves different from the stem leaves, usually forming a rosette; spikelets obtuse.

Spikelets $3 \mathrm{~mm}$. long, glabrous or nearly so.

Spikelets $2 \mathrm{~mm}$. long, pubescent.

Leaves glabrous on upper surface.

Leaves pubescent on upper surface.

P. barbipulvinatum.

$P$. agrostoides.

$P$. scribnerianum.

$P$. occidentale.

$P$. pacificum. 
Panicum barbipulvinatum Nash. Annual; stems erect or decumbent at the base, $15-50 \mathrm{~cm}$. tall, mostly simple; leaf blades $5-30 \mathrm{~cm}$. long, pubescent; sheaths villous; panicle $10-20 \mathrm{~cm}$. long, the capillary branches solitary or in twos, ascending, branched and spikelet-bearing above the middle; spikelets $3 \mathrm{~mm}$. long, ovoid, usually on peduncles as long or longer.

In dry soil. This species has commonly been confused with the eastern P. capillare $L$.

Panicum agrostoides Spreng. Tufted perennial, glabrous or nearly so; stems 40-100 cm. high, branched; leaf blades flat, 5-10 mm. wide; panicles $10-30 \mathrm{~cm}$. long with ascending rays bearing densely flowered branchlets mostly on the under side; spikelets $2 \mathrm{~mm}$. long; first glume half the length of the spikelet; pedicels bearing a few hairs. limits.

Sproat Lake, Vancouver Island, Macoun. Not otherwise known in our

Panicum scribnerianum Nash. Perennial, the stems $10-50 \mathrm{~cm}$. tall, erect or ascending, simple or branched above; stem leaves about 6 , the blades lanceolate, 4-10 cm. long, 6-15 mm. wide, stiff, ascending, glabrous or sometimes pilose below; sheaths usually pilose, loose; panicles oblong or pyramidal, 3-8 cm. long, loose, exserted or the smaller ones included; spikelets turgid, ovoid, $3 \mathrm{~mm}$. long.

Dry prairies.

Panicum occidentale Scribn. Stems $20-40 \mathrm{~cm}$. high; sheaths somewhat hairy; blades smooth above, usually hairy beneath; panicle well exserted; spikelets $2 \mathrm{~mm}$. long.

Rocky banks and prairies. Vancouver Island to Idaho and California.

Panicum pacificum Hitchc. \& Chase. Very similar to P. occidentale, but more pubescent throughout, and the stems more leafy.

Vancouver Island to California and Arizona.

\section{HOMALOCENCHRUS.}

Perennials with rough leaves and open panicles; spikelets with but one flower which is perfect; glumes none; lemmas awnless; grain closely enveloped by the glume.

Homalocenchrus oryzoides (L.) Poll. Panicle loose, the branches spreading; spikelets narrowly oblong, $4-5 \mathrm{~mm}$. long, loosely arranged; lemma hispidulous, the keel strongly ciliate.

Lake margins, infrequent in our limits. Seattle, Piper.

\section{PHALARIS.}

Annuals or perennials with spike-like or narrow panicles; spikelets crowded, 1 -flowered; glumes 2 , about equal, compressed; lemmas 3 , the first two much reduced and sterile, the third enclosing a palea and a perfect flower; stamens 3 .

Perennial; panicle branched; glumes wingless.

Annual; panicle very dense, ovoid; glumes wing-keeled.

Keel of glumes entire.

Keel of glumes toothed.

$P$. arundinacea.

Phalaris arundinacea L. Reed Canary-grass. Stout tufted perennial, 50-200 cm. tall; leaves flat, green, 6-10 mm. wide; panicle erect, $6-15 \mathrm{~cm}$. long; spikelets lanceolate, $5 \mathrm{~mm}$. long.

Margins of lakes and rivers, in wet ground. 
Phalaris canariensis L. Canary-grass. Annual, pale green, erect, 30-70 $\mathrm{cm}$. high; inflorescence ovoid or oblong-ovoid, $2-3 \mathrm{~cm}$. long; spikelets ovate, 5-6 mm. long; glumes white with green veins, the keel not toothed.

Introduced in waste places.

Phalaris minor Retz. Annual; stems erect, $30-80 \mathrm{~cm}$. high; inflorescence oblong to oblong-ovoid, $2-5 \mathrm{~cm}$. long; glumes oblong, pale, a green stripe on each side of the toothed keel.

On ballast, Nanaimo, Vancouver Island, Macoun.

\section{ANTHOXANTHUM.}

Aromatic annuals or perennials with narrow spike-like panicles; spikelets 1-flowered, narrow, somewhat compressed; glumes 2 , unequal, awnless or mucronate-pointed; lemmas shorter than the glumes, the first and second empty, 2-lobed, clothed with brown hairs and awned below the back; the third lemma fertile, shorter, hyaline, broadly obtuse, awnless; grain free.

Anthoxanthum odoratum L. Sweet Vernal-grass. Spikelets crowded, $8 \mathrm{~mm}$. long, usually brownish; first sterile lemma hairy, long-awned; second sterile lemma short-awned.

In pastures. Introduced from Europe. Sweet-scented on drying.

\section{HIEROCHLOE. VANILLA-GRASS.}

Fragrant perennial grasses with flat leaves and usually rather small and pyramidal terminal panicles; spikelets 3-flowered, the terminal flower perfect, the others staminate; rachilla jointed above the empty glumes; glumes 2 , nearly equal, about as long as the spikelet, acute, smooth; the first and second lemmas awnless or short-awned; the third lemma enclosing the perfect flower, becoming somewhat indurated in fruit; stamens in the staminate flowers 3 , in the perfect flower 2; styles distinct; stigmas plumose; grain free.

Panicle and spikelets greenish; glumes and lemmas obtuse $\quad H$. macrophylla. Panicle and spikelets brownish; glumes and lemmas acute. H. odorata.

Hierochloe macrophylla Thurb. Stems $1 \mathrm{~m}$. or less tail; leaves 30$40 \mathrm{~cm}$. long, 10-15 mm. broad, rough; panicle greenish, loose, the branches in pairs; glumes obtuse; fertile lemma obtuse, ciliate-margined, pubescent at the apex.

From the Columbia River southward.

Hierochloe odorata (L.) Wahlenb. Stems $30-60 \mathrm{~cm}$. high; leaves $10-20 \mathrm{~cm}$. long, 2-6 $\mathrm{mm}$. broad; panicle brownish, pyramidal, usually compact; glumes acute; fertile lemma acute.

Near Comox, Vancouver Island, Macoun. Reported from Nootka Sound by Hooker. A widespread northern grass.

\section{MUHLENBERGIA.}

Perennial grasses with small 1-flowered spikelets; glumes usually unequal and shorter than the lemma, acute or sometimes awned; lemma narrow, 3-5-nerved, with a straight awn from the apex or from between the teeth. 
Muhlenbergia racemosa (Michx.) BSP. Stems 30-90 cm. high, simple or nearly so; panicle narrowly oblong, $5-8 \mathrm{~cm}$. long, spike-like and usually interrupted; glumes bristle-tipped; lemma very acute.

Sumas Prairie, $49^{\circ}$ latitude, Lyall, and eastward.

\section{STIPA.}

Tufted grasses; inflorescence a panicle; spikelets 1-flowered, narrow; floret with a bearded and pointed callus at base; lemma 1 , indurated, bearing a twisted or bent awn which is articulated at the base; grain narrow, free, tightly closed in the lemma. All in our limits are perennials.

Awn 10-20 times as long as its lemma.

S. comata.

Awn 4-7 times as long as its lemma.

Callus very short, obtuse; glumes $8-12 \mathrm{~mm}$. long.

Callus acute; glumes 6-8 mm. long.

S. lemmoni.

S. minor.

Stipa comata Trin. \& Rupr. Tufted, pale green, $40-80 \mathrm{~cm}$. high; blades involute; ligule 4-5 mm. long, conspicuous; panicle open, $20-30 \mathrm{~cm}$. long, often included at base, the branches spreading and few-flowered; glumes 5nerved, subequal, 15-25 mm. long; lemma 10-12 mm. long; awn 10-15 cm. long.

Vancouver Island, Macoun, and common east of the Cascade Mountains.

Stipa lemmoni Scribn. (S. columbiana Macoun.). Stems 60-90 cm. high; leaf blades flat or involute, firm; sheaths smooth; ligule $1 \mathrm{~mm}$. long; panicle narrow with erect branches, $2-5 \mathrm{~cm}$. long; glumes subequal, scarious, lanceolate, acuminate, 8-12 mm. long; lemma short-pubescent, the body about $6 \mathrm{~mm}$. long; awn 15-20 mm. long, pubescent to the second bend.

In dry ground, British Columbia to California.

Stipa minor (Vasey) Scribn. Tufted, 50-100 cm. tall, dark green; leafblades involute, long-attenuate, $10-30 \mathrm{~cm}$. long, scabrous; sheaths shorter than the internodes, loose, smooth; ligule very short; panicle erect,rather dense, 8-20 cm. long, narrow, its base included in the uppermost sheath, the branches mostly in pairs; spikelets 8-12 $\mathrm{mm}$. long, purple-tinged; lemma sparsely appressed-hairy, the awns $20-30 \mathrm{~mm}$. long, bent near the middle, below which they are pubescent.

In dry ground, infrequent except in the interior.

\section{PHLEUM.}

Annuals or perennials; inflorescence a spike-like raceme; spikelets 1-flowered; glumes membranous, compressed, keeled, the apex obliquely truncate, the mid-nerve produced into an awn; lemma much shorter; grain ovoid, free, enclosed in the lemma and palea.

Spike-like racemes cylindric; awns of glumes short. $\quad P$. pratense. Spike-like racemes ovoid-oblong; awn as long as body of glume. P. alpinum.

Phleum pratense L. Timothy. Tall, erect, 60-150 cm. tall; leaf blades 15-20 cm. long, 8-10 mm. wide, smooth or scabrous; spike-like raceme narrowly cylindrical, erect, 5-15 cm. long; spikelets $2-5 \mathrm{~mm}$. long; empty glumes ciliate on the keels which are prolonged into awns $1 \mathrm{~mm}$. long.

Cultivated and running wild. 
Phleum alpinum L. Mountain Timothy. Stems $20-60 \mathrm{~cm}$. high; leaf blades flat, rather short; spike-like raceme usually purple, cylindric, $2-3 \mathrm{~cm}$. long; awns of glumes $2 \mathrm{~mm}$. long.

Common in mountain meadows, and along the seacoast to northern California.

\section{POLYPOGON.}

Annual grasses; inflorescence a spike-like panicle; spikelets 1-flowered; glumes each extended into an awn; lemma smaller, generally hyaline, short-awned; palea shorter than the lemma; grain free, enclosed in the lemma and palea.

Glumes notched at the apex, their awns 2-3 times as long; panicle dense, cylindric.

Glumes attenuate into awns of equal length; panicle lobed or interrupted.

P. monspeliensis.

Polypogon monspeliensis (L.) Desf. Annual, with erect or ascending stems, 8-30 cm. high; leaf blades flat, more or less scabrous; sheaths loose, shorter than the internodes; spike-like panicle densely flowered, oblong, rarely interrupted, 2-7 cm. long; glumes elliptic, notched at the apex, about $2 \mathrm{~mm}$. long, each bearing a terminal awn 3 or 4 times as long; lemma truncate, $1 \mathrm{~mm}$. long, bearing a terminal awn somewhat longer.

Moist places, especially where somewhat saline.

Polypogon littoralis (With.) Smith. Panicle dense, narrowly oblong, lobed or often interrupted.

Along the seashore, not common. Tacoma, Flett; Port Angeles, Elmer; Victoria, Vancouver Island, Macoun.

\section{GASTRIDIUM.}

Annual erect grasses with flat leaves; panicle dense, spike-like; spikelets 1-flowered, narrow, shiny; rachilla produced beyond the floret; glumes saccate at base, much longer than the lemma; lemma hyaline, awnless or awned from just below the apex.

Gastridium lendigerum (L.) Gaud. Tufted; stems $15-50 \mathrm{~cm}$. high, erect; blades flat, scabrous, 3-5 mm. wide; panicle pale green, shining, spike-like, 5-12 cm. long; glumes very acute; lemma hairy.

Umpqua Valley and southward, introduced. Perhaps not in our limits.

\section{ALOPECURUS.}

Annuals or perennials; inflorescence a spike-like panicle; spikelets 1-flowered, flattened; glumes acute, sometimes short-awned; lemma 3-nerved, awned on the back; palea usually present.

Spikelets $2.5 \mathrm{~mm}$. long; panicle slender, $4 \mathrm{~mm}$. thick. Spikelets larger; panicle stouter, $6 \mathrm{~mm}$. thick.

Anthers white; spikelets $4 \mathrm{~mm}$. long.

Anthers orange; spikelets more or less than $4 \mathrm{~mm}$. long.

Spikelets $5 \mathrm{~mm}$. long.

Spikelets $3 \mathrm{~mm}$. long.

Alopecurus geniculatus fulvus (Smith) Sonder. Pale green and glabrous or nearly so; stems decumbent and branched at base, 15-60 cm. long; leaf 
blades flat, somewhat scabrous above; sheaths little inflated; panicles slender, erect, 3-7 cm. long; spikelets $2.5 \mathrm{~mm}$. long; glumes ciliate on the keels; lemma shorter than the glumes, bearing a short awn.

In wet places, common.

Alopecurus saccatus Vasey. Pale green, glabrous, simple or tufted, 10-30 $\mathrm{cm}$. high, erect or geniculate at base; sheaths much inflated, about as long as the internodes; ligule well developed; blades short, $2-8 \mathrm{~cm}$. long, 2-4 mm. broad; panicles usually exserted, $2-5 \mathrm{~cm}$. long, thick, pale green or purplish; glumes strongly ciliate on the keels; lemma shorter than the glumes and bearing a divergent awn 6-7 mm. long.

In moist ground, rare, and local; near Yale, British Columbia, Macoun; Barlow Gate, Oregon, Howell.

Alopecurus pratensis L. Meadow Foxtail. Perennial, glabrous; stems $30-70 \mathrm{~cm}$. tall, erect; leaf blades flat, 4-10 cm. long; spike stout, $4-6 \mathrm{~cm}$. long; glumes united at base, equal, acute, ciliate on the keel; lemma obtuse, glabrous, shorter than the glumes, bearing from near the base a slightly exserted straight awn.

Sparingly introduced; native to Europe.

Alopecurus californicus Vasey. (A. pallescens Piper.) Perennial, tufted, pale green, the smooth stems $30-50 \mathrm{~cm}$. tall, erect or slightly geniculate at the base; stem leaves 3; sheaths rather loose and inflated, shorter than the internodes, smooth; blades flat, 6-12 $\mathrm{cm}$. long, 2-6 mm. wide, acuminate, strongly scabrous above, less so beneath; ligule scarious, 3-5 mm. long; panicle usually well exserted, pale and silvery, $2-7 \mathrm{~cm}$. long, about $5 \mathrm{~mm}$. thick, erect, straight or somewhat flexuous; glumes $2-5 \mathrm{~mm}$. long, nearly equal, strongly ciliate on the keels, obtuse; lemma hyaline, 2-4-nerved, as long as the glumes, obtuse, bearing from near the base a stout geniculate awn, $5 \mathrm{~mm}$. long, scabrous above the bend.

In wet places, rare in our limits; Victoria, British Columbia, Macoun; Medford, Oregon, Howell. A. howellii Vasey is apparently indistinguishable.

\section{CINNA.}

Tall perennial grasses with flat leaves, conspicuous hyaline ligules and usually many-flowered nodding panicles; spikelets 1-flowered; rachilla articulated below the glumes and prolonged behind the palea into a minute bristle; glumes narrow; lemma 3-5-nerved; palea 1-nerved; stamen 1.

Cinna latifolia (Trev.) Griseb. Stems solitary or few, erect, 60-120 cm. high; leaf blades flat, green, $1-1.5 \mathrm{~cm}$. broad, scabrous; panicle pale green, drooping, 10-30 cm. long; glumes subequal, scabrous, $4 \mathrm{~mm}$. long; lemma shorter, scabrous, bearing a short straight awn; palea 2-nerved.

Along streams and in swamps, common.

\section{COLEANTHUS.}

Small annuals with short leaves and umbel-like panicles; spikelets 1-flowered; glumes none; lemma ovate, keeled, usually with a short straight awn; grain free.

Coleanthus subtilis (Tratt.) Seidel. Very small purplish grass, $2-5 \mathrm{~cm}$. high; sheaths loose and dilated; blades $1 \mathrm{~cm}$. long; panicle 1-3 cm. long, often partly included in the upper sheath.

On the muddy banks of the Columbia River. 


\section{CALAMAGROSTIS.}

Tall perennial grasses with small spikelets in many-flowered terminal panicles; spikelets 1 -flowered, the pubescent rachilla prolonged behind the palea; glumes subequal, longer than the lemma which is hyaline and obtuse, and bears a dorsal awn; callus copiously hairy; palea shorter than the lemma; grain free, enclosed in the lemma.

Awns strongly geniculate; callus hairs much shorter than than the lemma.

Awn shorter than or little exceeding the glumes; glumes strongly keeled; tall sea-shore plant.

Awn greatly exceeding the glumes.

Panicle loose; leaves nearly as long as the stems.

Panicle dense; leaves shorter than the stems.

Awns straight; callus hairs not much shorter than the lemma.

Panicle loose and open.

Spikelets 4-6 $\mathrm{mm}$. long.

Spikelets 2-4 $\mathrm{mm}$. long.

Panicle narrow, rather close.

Panicle not spikelike.

Panicle dense, spike-like.

C. aleutica.

C. howellii.

C. vaseyi.

Glumes subcoriaceous, ovate, acute; panicle 4-6 $\mathrm{cm}$. long.

Glumes membranous, acuminate; panicle 5-20 $\mathrm{cm}$. long.

C. scabra.

C. canadensis.

C. inexpansa.

C. crassiglumis.

C. hyperborea.

Calamagrostis aleutica Trin. Very tall, 1-2 m. high; panicle pale, large and loose; glumes lanceolate, acuminate; callus hairs half as long as the lemma.

Along the ocean coast, Alaska to California.

Calamagrostis howellii Vasey. Densely tufted; stems $25-50 \mathrm{~cm}$. high; basal leaves numerous, loosely involute; panicle $8-10 \mathrm{~cm}$. long; glumes strongly keeled, subequal, 5-6 $\mathrm{mm}$. long.

Abundant on the rocky cliffs in the gorge of the Columbia River.

Calamagrostis vaseyi Beal. Stems tufted, $15-40 \mathrm{~cm}$. high; panicle purple, rather close, $6-10 \mathrm{~cm}$. long.

In rocky places, in the mountains, at about $2000 \mathrm{~m}$. altitude.

Calamagrostis scabra Presl. Bluetop. Stems about $1 \mathrm{~m}$. high; panicle loose, dark purple or rarely pale greenish; glumes sharp-acuminate; awn longer than the lemma.

Common in alpine meadows.

Calamagrostis canadensis (Michx.) Beauv. Stems tufted, slender, 60-120 $\mathrm{cm}$. high; leaves flat, somewhat involute, pale green, $15-25 \mathrm{~cm}$. long; panicle $10-20 \mathrm{~cm}$. long, purple, pyramidal, the slender branches in fives; spikelets 3-3.5 $\mathrm{mm}$. long; glumes equal, acute, hardly larger than the lemma; awn short, straight.

In wet meadows and along streams. long.

Calamagrostis canadensis acuminata Vasey. Spikelets larger, 4-5 mm.

With the species in wet meadows and along streams.

Calamagrostis inexpansa barbulata Kearney. Stems about $1 \mathrm{~m}$. high; leaves stiff; panicle purple, rather stiff; awn very short or wanting; callushairs nearly as long as the lemma.

In bogs, near Union City, Mason County, Washington, Piper. 
Calamagrostis crassigl umis Thurb. Stems 10-20 cm. high; panicle dense, $3-5 \mathrm{~cm}$. long; glumes ovate, acute; callus hairs nearly as long.

Vancouver Island to California.

Calamagrostis hyperborea Lange. Stems tufted, $40-90 \mathrm{~cm}$. high, stiffly erect; leaves stiff, erect, scabrous, somewhat involute; panicle erect, narrow, densely flowered, 8-12 cm. long; glumes scabrous, acute, 4-4.5 $\mathrm{mm}$. long.

Vancouver Island and eastward.

\section{AGROSTIS. BENT-GRASS.}

Annual or usually perennial grasses with small 1-flowered spikelets, usually in diffuse panicles; glumes membranous, keeled, acute; lemma shorter, obtuse, hyaline, sometimes bearing a dorsal awn; palea shorter than the lemma, sometimes minute or wanting; grain free, enclosed in the lemma.

Rachilla prolonged behind the palet.

Spikelets $3 \mathrm{~mm}$. long, usually purple.

Spikelets $2 \mathrm{~mm}$. long, usually pale.

Rachilla not prolonged behind the palet.

Palet evident, 2-nerved.

Palet one-fourth the length of the lemma; panicle contracted.

Palet about one-half the length of the lemma.

Panicle contracted, usually lobed.

Panicle not contracted.

Plants with extensive creeping stolons, these bearing short leaves.

Plants erect or decumbent, but without extensive creeping stolons.

Tall, 30-90 cm. high.

Dwarf, alpine, 10-20 cm. high.

Palet wanting or minute and nerveless.

Plants spreading by rhizomes.

Hairs at base of lemma $1-2 \mathrm{~mm}$. long.

Hairs at base of lemma minute or absent.

A. aequivalvis.

A. thurberiana.

Panicle contracted.

Panicle open.

Plants without rhizomes.

A. glomerata.

A. stolonifera.

A. maritima.

Panicle narrow, some of the branches short and spikelet-bearing to the base.

Lemma awned.

Lemma awnless.

Panicle 5-30 $\mathrm{cm}$. long; lowland plant.

Panicle $3-6 \mathrm{~cm}$. long; alpine plant.

A. alba.

A. humilis.

A. hallii.

A. pallens.

A. foliosa.

le open, usually without short branches spikelet-bearing to the base.

Awn of lemma attached near the base.

Awn of lemma, if present, attached at or above the middle.

Lemma awnless.

Panicle very diffuse.

Panicle loose but not diffuse.

A. microphylla.

Lemma awned.

Awn straight, included or but slightly exserted.

Awn exserted, bent.

A. exarata.

A. rossae.

A. howellii.

A. hyemalis.

A. oregonensis.

A. melaleuca.

A. longiligula. 
Agrostis aequivalvis Trin. Tufted; stems slender, 30-60 cm. high; blades narrow, $1 \mathrm{~mm}$. wide; panicle open with slender branches; glumes equal, acute; lemma obtuse, awnless.

Alaska to Oregon.

Agrostis thurberiana Hitchc. Stems tufted, 20-40 cm. high; blades 2-4 $\mathrm{mm}$. wide; panicle narrow, loose, usually drooping; glumes equal; lemma obtuse, 5-nerved. Utah.

In wet places in the mountains, rare. British Columbia to California and

Agrostis glomerata (Presl.) Kunth. (A. inflata Scribn.) Perennial; stems erect, $20-30 \mathrm{~cm}$. high, scabrous near the panicle; leaf sheaths striate, often inflated; blades $2-8 \mathrm{~mm}$. wide; panicle spike-like, $2-7 \mathrm{~cm}$. long, often lobed; spikelets $3 \mathrm{~mm}$. long; glumes equal, scabrous on the keel, sharp-pointed; lemma $2 \mathrm{~mm}$. long, awnless or with a short awn from the middle of the back; callus hairs short.

Along the seacoast, rare; Vancouver Island to northern California; probably only a subspecies of $A$. exarata Trin.

Agrostis stolonifera L. (A. verticillata Vill.) Stems $20-80 \mathrm{~cm}$. high, often decumbent at base, sometimes stoloniferous; leaf blades pale, acute, $3-4$ $\mathrm{mm}$. wide; panicle dense, verticillate or lobed, 3-10 cm. long, usually pale green; branches floriferous to the base; glumes equal, obtusish, $2 \mathrm{~mm}$. long; lemma $1 \mathrm{~mm}$. long, awnless, truncate and toothed at the apex; palea nearly as long as the lemma.

In wet places, sparingly introduced from Europe.

Agrostis maritima Lam. Tufted, the stems decumbent or spreading; leaves numerous, very short; ligules $2-3 \mathrm{~mm}$. long; panicle narrow, $2-5 \mathrm{~cm}$. long; lemma obtuse, the midvein protruding in a minute point.

In moist places near the seashore.

Agrostis alba L. Redtop. Perennial with creeping rootstocks; stems erect, 50-100 cm. tall; leaf blades flat, usually scabrous, the sheaths smooth; panicle 7-25 cm. long, open at first, then contracted, greenish or purple; palea present, one-third to one-half the length of the lemma.

Common in fields and meadows, especially in wet places.

Agrostis humilis Vasey. Stems $10-40 \mathrm{~cm}$. high; panicles narrow, 2-8 cm. long, usually purple; glumes equal; lemma awnless.

At high elevations in the mountains.

Agrostis hallii Vasey. Stems erect, $60-80 \mathrm{~cm}$. high; blades rather broad; ligule elongate; panicle narrow, $10-12 \mathrm{~cm}$. long; spikelets pale; glumes acuminate, about $4 \mathrm{~mm}$. long; lemma awnless, the hairs at the base nearly half as as long.

Oregon and California.

Agrostis pallens Trin. Stems $30-90 \mathrm{~cm}$. tall; blades rather narrow; panicle narrow, loose or in seashore forms contracted, pale green; spikelets $2.5-3 \mathrm{~mm}$. long; glumes equal; lemma awnless or with a minute awn.

Not common, but very variable.

Agrostis foliosa Vasey. Very similar to A. pallens Trin. but stems taller, $50-120 \mathrm{~cm}$. high; panicle open, with stiff ascending branches; lemma awnless or with a straight or bent awn.

In open places, British Columbia to California.

Agrostis microphylla Steud. (A. ampla Hitchc.) Stems $30-90 \mathrm{~cm}$. tall; blades flat, $2-8 \mathrm{~mm}$. wide; panicle narrow, compact, pale green; glumes acute, subequal; lemma one-third shorter.

In open ground, not common. 
Agrostis exarata Trin. Perennial, tufted, the stems $30-90 \mathrm{~cm}$. tall; leaves erect, the blades flat, 2-6 mm. broad, 5-10 cm. long, scabrous, the upper distant from the panicle; panicle strict, pale green, spike-like or interrupted, the short branches appressed and spikelet-bearing to the very base; glumes 2.5-3.5 mm. long, usually scabrous on the back.

Variable and very common.

Agrostis rossae Vasey. Tufted, $10-20 \mathrm{~cm}$. high; leaves mostly basal, 2-5 cm. long, 1-2 mm. broad, flat or folded; panicle narrow, erect, 3-6 cm. long, green or purple; glumes $2 \mathrm{~mm}$. long, not scabrous.

In alpine meadows, common.

Agrostis howellii Scribn. Stems $40-60 \mathrm{~cm}$. high; blades very long, 3-5 $\mathrm{mm}$. wide; panicle very loose; spikelets clustered near the tips of the branches; glumes acuminate, equal; lemma acute, awned from the back.

In rocky places in the Columbia Gap.

Agrostis hyemalis (Walt.) BSP. Annual, tufted, $15-90 \mathrm{~cm}$. tall; leaves flat or involute, narrow, very scabrous; panicle very loose, $15-30 \mathrm{~cm}$. long; branches in whorls of 2-12, capillary, $5-15 \mathrm{~cm}$. long, branched above the middle and spikelet-bearing only near the tips.

In moist places, common.

Agrostis oregonensis Vasey. Stems slender, $60-80 \mathrm{~cm}$. high; blades narrow; panicle pyramidal, nodding, open, the branches capillary; glumes subequal, scabrous on the keel; lemma shorter, obtuse, awnless.

In marshes, rare.

Agrostis melaleuca (Trin.) Hitchc. Perennial from creeping rootstocks, not tufted; stems erect, $30-50 \mathrm{~cm}$. high, leafy; leaf blades $1-3 \mathrm{~mm}$. wide; panicle oblong, 5-15 cm. long; glumes subequal, copper-colored, 2.5-3 $\mathrm{mm}$. long, acute, smooth; lemma nearly as long, bearing from the middle of the back a short straight scarcely exserted awn; palea minute or wanting.

In sphagnum marshes, Garibaldi, Oregon, Hitchcock; north to Alaska.

Agrostis longiligula Hitchc. Stems tall, 60-80 cm. high; leaf blades flat, scabrous, 3-4 mm. wide; ligule 5-6 $\mathrm{mm}$. long; panicle purple, rather dense, 10-18 cm. long; glumes 3-4 mm. long, acute, scabrous on the keel, hispidulous on the back, the upper a little shorter; lemma $2.5 \mathrm{~mm}$. long, scabrous on the nerves, bearing a bent awn $2.5 \mathrm{~mm}$. long; palea minute.

Alaska and Vancouver Island, Macoun, to northern California.

\section{HOLCUS.}

Annual or perennial grasses with densely-flowered terminal panicles; spikelets deciduous, 2-flowered, the lower flower perfect, the upper staminate; glumes membranous, keeled, the lower 1nerved, the upper 3-nerved and often short-awned; lemmas 2 , papery, that of the upper floret bearing a bent awn; palea narrow; grain oblong, free, enclosed in the lemma.

Holcus lanatus L. Velvet-grass or Mesquite. Perennial; the whole plant downy with pale pubescence; stems erect, 30-90 cm. high; leaf blades flat, rather broad and short; sheath loose, shorter than the internodes; panicle pale purplish, 5-10 cm. long, rather densely-flowered, the branches in twos or threes; spikelets 4-6 mm. long; upper glume short-awned near the apex; lemma of the staminate flower with a hook-like awn.

Abundantly introduced in fields and waysides. 


\section{ARRHENATHERUM.}

Tall perennials with long narrow panicles; spikelets 2-flowered, lower flower staminate, upper perfect; rachilla extending beyond the flowers; glumes thin-membranous, keeled, very acute or awn-pointed, unequal, persistent; lemmas 2, rigid, 5-7-nerved, deciduous, the first bearing a long bent and twisted dorsal awn inserted below the middle, the second unawned; palea hyaline, 2-keeled; grain ovoid, free.

Arrhenatherum elatius (L.) Beauv. Tall Oat-grass. Glabrous perennial, $100-150 \mathrm{~cm}$. high; stem leaves 3 , the blades flat, minutely scabrous, the sheaths shorter than the internodes; panicle shining, $15-25 \mathrm{~cm}$. long, rather narrow, the branches suberect; lemmas 6-7 $\mathrm{mm}$. long, the lower bearing a long dorsal geniculate awn.

Naturalized from Europe.

\section{AIRA.}

Delicate annuals with narrow leaves; spikelets small, 2-flowered; flowers perfect; rachilla jointed below the lemmas and not prolonged beyond the upper one; glumes nearly equal, awnless, acute, longer than the lemmas; lemmas each with a twisted awn on the back; grain usually adherent to the lemma and palea.

Panicle loose; lemma $2.5-3 \mathrm{~mm}$. long.

Panicle dense; lemma 3.5-4 mm. long.

A. caryophyllea.

A. praecox.

Aira caryophyllea L. Hair-grass. Stems $10-20 \mathrm{~cm}$. high; panicle very loose; spikelets $2.5-3 \mathrm{~mm}$. long, silvery, shining.

Introduced from Europe; common in dry soil.

Aira praecox L. Stems $5-10 \mathrm{~cm}$. high; panicle small and rather dense; spikelets $3.5-4 \mathrm{~mm}$. long, yellowish, shining.

Very sparingly introduced; a native of Europe.

\section{Elberofttoskin 68. DANTHONIA. Sefet 3,1919}

Flowers solitary or few in a small raceme or panicle; spikelets 3 to many-flowered, the flowers all perfect or the upper staminate; rachilla pubescent, extending beyond the flowers; glumes keeled, acute, subequal, persistent, generally extending beyond the uppermost lemma; lemmas rounded on the back, 2-toothed, deciduous, the bent awn flat and twisted at the base, arising from between the acute or awned teeth; palea hyaline, 2-keeled near the margins, obtuse or 2-toothed; grain free, enclosed in the lemma.

Spikelets ascending in a close panicle.

Callus very short, not hairy.

Callus elongate, densely hairy.

D. pinetorum.

D. intermedia.

Spikelets spreading, in a loose panicle or solitary.

Sheaths smooth.

Sheaths hairy.

D. californica.

D. americana. 
Danthonia pinetorum Piper. Densely tufted; leaves pale, narrow, involute, of ten curled; spikclets nearly sessile, pale; lemma loosely hairy, the apex bifid into 2 slender subulate teeth; awn $7 \mathrm{~mm}$. long.

In pine woods, Mason County, Washington, Piper; Nanaimo and Sproat Lake, Vancouver Island, Macoun. Very near the eastern D. spicata (L.) Beauv.

Danthonia intermedia Vasey. Stems $30-60 \mathrm{~cm}$. high; leaves bright green, soft, flat or involute; sheaths glabrous or sparsely hairy; spikelets $3-12$, usually purple, nearly sessile; lemma broadly lanceolate, 2-toothed.

In alpine meadows, British Columbia to Quebec, south to California and New Mexico.

Danthonia californica Boland. Erect, $50-100 \mathrm{~cm}$. tall; leaf blades flat, scabrous; sheaths loose, shortly retrorse-pubescent, and with a tuft of hairs at the throat; spikelets $1-2 \mathrm{~cm}$. long, $3-5$ in a raceme, rarely more numerous or even solitary, usually long-pedicelled; lemma abruptly acuminate, longciliate below the middle, 2 -cleft at apex, bearing an awn of about equal length.

In meadows, not common in our limits.

Danthonia americana Scribn. Much like $D$. californica but not so tall; spikelets usually 2 or 3 ; sheaths hairy; lemmas attenuate-acuminate.

In meadows, British Columbia to California.

69. AVENA. OAT.

Annuals with large spikelets; inflorescence a panicle; spikelets 2-many-flowered; lower flowers perfect, the upper of ten staminate; glumes somewhat unequal, membranous, persistent; lemmas deciduous, rounded on the back, acute, generally bearing a dorsal awn; apex of ten 2-toothed; palea narrow, 2-toothed; grain oblong, deeply furrowed, enclosed in the lemma and palea, free or sometimes adherent to the latter.

Avena fatua glabrata Peterm. Smooth Wild Oat. Stems stout, pale, smooth, 50-100 $\mathrm{cm}$. tall, erect; leaf blades broad and flat, the sheaths about equalling the internodes; panicle loose $15-30 \mathrm{~cm}$. long; spikelets, including awns, 3.5-4 cm. long, erect or drooping, on slender branches; lemma smonth, except the scabrous apex and the ring of stiff white hairs at the base, bearing on the back a geniculate, stout, twisted awn below the 2-cleft apex.

Sparingly introduced. 'The common wild oat, A. fatua L., has bristly red hairs on the lemma. It may also be expected in our limits.

\section{DESCHAMPSIA.}

Annuals or perennials; inflorescence a contracted or open panicle; spikelets 2-flowered, both flowers perfect, the hairy rachilla extending beyond the flowers as a bristle or rarely terminated by a staminate floret; glumes keeled, acute, membranous, shining, persistent; lemmas of about the same texture, deciduous, each bearing a dorsal awn, the apex erose-truncate; palea narrow; grain oblong, free, enclosed in the lemma.

Lower glume 1-nerved.

Glumes not longer than the florets.

Glumes longer than the florets.

D. caespitosa.

D. atropurpurea. 
Lower glume 3-nerved.

Annual; glumes 5-7 mm. long.

Perennial; glumes 3-4 $\mathrm{mm}$. long.

D. calycina.

D. elongata.

Deschampsia caespitosa (L.) Beauv. Silver-top. Densely tufted perennial; stems $60-150 \mathrm{~cm}$. high, much exceeding the numerous basal leaves; stem leaves 3 , the blades narrow, involute, 5-12 cm. long, scabrous, the smooth sheaths shorter than the internodes; panicle 10-30 cm. long, usually open, the capillary branches in whorls of $2-5$, flower-bearing above the middle; spikelets shining, greenish or purFlish, 2-3 mm. long; lemma hairy at the base, erose-toothed at the apex, bearing a slender awn near the base.

In moist soils, common. A very variable widespread grass.

Deschampsia atropurpurea (Wahlenb.) Scheele. Perennial; stems $30-90 \mathrm{~cm}$. high; leaves broad and flat; panicle rather close, purple; spikelets broad, flat, 5-6 $\mathrm{mm}$. long.

In mountain meadows, common.

Deschampsia calycina Presl. Annual; the slender stems erect, $15-40 \mathrm{~cm}$. tall; leaves narrow, involute, the blades $2-6 \mathrm{~cm}$. long; panicle very loose, $7-20$ $\mathrm{cm}$. long, with subequal branches mostly in twos, these capillary, branched above and bearing spikelets near the tips; spikelets pale green, sometimes purple-tingled, about $7 \mathrm{~mm}$. long; lemma long-hairy at the base, minutely toothed at the apex, bearing a geniculate awn three or four times as long.

In dry soil.

Deschampsia elongata (Hook.) Munro. Stems densely tufted, smooth, 30-90 cm. tall; leaves filiform, commonly involute, smooth; panicle narrow, $15-45 \mathrm{~cm}$. long, somewhat nodding; branches very unequal, ascending or appressed, very slender, naked below; spikelets pale green, usually purpletinged near the apex; lemmas hairy at base, shining,'irregularly toothed at apex, bearing a slender awn about twice as long.

Common in open places.

\section{TRISETUM.}

Ours all cespitose perennials; inflorescence a spike-like or open panicle; spikelets 2-4-flowered, the flowers all perfect or the uppermost staminate; rachilla glabrous or with long soft hairs, extending beyond the flowers; glumes unequal, acute, persistent; lemmas 2-4, usually shorter than the glumes, deciduous, 2-toothed, bearing a dorsal awn below the apex or sometimes awnless; palea narrow, hyaline, 2-toothed; grain free, enclosed in the lemma.

Panicle dense and spike-like.

Panicle loose and spreading.

Rays long and drooping; sheaths smooth.

Rays shorter, erect; sheaths hairy.

T. spicatum.

T. cernuum.

T. canescens.

Trisetum spicatum (L.) Richter. Densely tufted, 10-40 cm. high, pubescent to glabrous with the sheaths pubescent; panicle oblong-ovate, $5-15 \mathrm{~cm}$. long, shining and often brownish-purple; glumes ciliate on the keels, the lower short; lemma 5-6 mm. long, its awn divergent and about as long.

In mountain meadows at $1500-2000 \mathrm{~m}$. altitude.

Trisetum cernuum Trin. Stems $60-100 \mathrm{~cm}$. tall, erect, the nodes pale; leaf blades flat, merely scabrous, $15-20 \mathrm{~cm}$. long, 6-10 mm. wide; panicle 
10-15 cm. long, loose, nodding; branches in distant whorls, capillary, cernuous, flower-bearing above the middle; spikelets $2-4$-flowered, 6-7 $\mathrm{mm}$. long without the awn; lemma 3-4 mm. long, bearing an awn of about twice its length.

In open woods, common.

Trisetum canescens Buckl. Much like $T$. cernuum, the leaf blades and sheaths pubescent; nodes usually dark; panicle erect, 7-16 cm. long; lemma $7 \mathrm{~mm}$. long.

In coniferous woods.

\section{ERAGROSTIS.}

Annual or perennial grasses; inflorescence a contracted or open panicle; spikelets many-flowered, more or less flattened; glumes unequal, shorter than the lemmas, keeled, 1-nerved; lemmas membranous, keeled, 3-nerved, awnless; palea shorter than the lemmas, prominently 2-nerved or 2-keeled, usually persisting on the rachilla after the lemma has fallen; grain free, loosely enclosed in the lemma and palea.

Eragrostis hypnoides (Lam.) BSP. Stems prostrate, creeping, much branched from the base, forming dense circular mats; leaf blades $2-3 \mathrm{~cm}$. long, somewhat pubescent; sheaths loose, inflated, hairy; panicles very numerous, pale green, dense, $2-4 \mathrm{~cm}$. long, usually with their bases included in the uppermost sheaths; spikelets oblong, 4-7 mm. long.

On river banks, widely distributed; rare in our limits.

\section{CYNOSURUS.}

Annual or perennial cespitose grasses with flat leaves; spikelets of two forms in small fascicles which form a dense somewhat unilateral spike-like panicle; terminal spikelets of each fascicle 2-4-flowered, perfect, its rachilla jointed; lower spikelets sterile, with many empty lemmas; glumes 2, narrow lanceolate, acute; lemmas broader, membranous, 1-3-nerved, mucronate or awnpointed; empty lemmas of sterile spikelets spreading, subequal, linear, 1-nerved; styles distinct, short; stigmas loosely plumose.

Cynosurus cristatus L. Crested Dogstail. Stems erect, 30-60 cm. high; leaves firm, 1-4 mm. wide, glabrous; panicle spike-like, $5-10 \mathrm{~cm}$. long; spikelets both fertile and sterile in each cluster, the terminal one fertile; sterile spikelet larger, the glumes and lemmas much narrower and very scabrous.

Sparingly introduced from Europe. Seattle, Piper; Victoria, Fletcher.

\section{KOELERIA.}

Tufted perennial grasses with narrow leaves and densely flowered spike-like panicles; spikelets 2-4-flowered; rachilla articulated between the lemmas; glumes acute, subequal, keeled, scarious on the margins; lemmas 3-nerved, keeled, acute; palea hyaline, acute; grain free, enclosed in the lemma and palea.

Koeleria cristata (L.) Pers. Perennial, the erect stems densely tufted, 30-70 cm. tall, usually glabrous; leaves narrow, commonly involute; panicle clense, greenish or purplish, shining, 5-15 cm. long, often more or less interrupted; spikelets 4-5 $\mathrm{mm}$. long, 2-4-flowered.

Dry soil, infrequent in our limits. A very variable widespread grass. 


\section{PLEUROPOGON.}

Soft erect annuals or perennials with rather large spikelets in terminal racemes; spikelets with 8-15 perfect flowers; rachilla jointed above the glumes and between the flowers; glumes 2, 1-nerved, or the second imperfectly 3-nerved, awnless, unequal; lemmas longer than the glumes, 7-nerved, entire, or somewhat 2-toothed at the apex, with the midnerve extending into a short awn; keel of palea with a distinct crest or wing-like appendage; grain free.

Pleuropogon refractum Gray. Stems about $1 \mathrm{~m}$. high; leaves flat, 6-8 $\mathrm{nnm}$. wide; raceme slender; spikelets $2-4 \mathrm{~cm}$. long, horizontal or refracted, loosely flowered.

Along streams in moist woods, rare. Washington to California.

\section{MELICA.}

Perennial grasses with simple stems; inflorescence a contracted or open panicle; spikelets 1-several-flowered, often one-sided; rachilla extending beyond the flowers and usually bearing 2-3 empty club-shaped or hooded lemmas twisted around each other; glumes membranous, the lower 3-5-nerved, the upper 5-9-nerved; lemmas larger, rounded on the back, 5-7-nerved, awnless, the margins more or less scarious; palea broad, shorter than the lemma; grain free, enclosed in the lemma and palea.

Lemmas acuminate at apex; stems bulbous at base.

Lemma notched at apex; stems not bulbous.

Awns short or none.

Awns long.

M. subulata.

M. harfordii.

M. smithii.

Melica subulata (Griseb.) Scribn. Glabrous; stems tufted, usually few, bulbous at base; blades flat, shining; panicle narrow and rather loose, suberect, 10-20 cm. long; spikelets 3-5-flowered; glumes unequal, usually purplish; lemmas pubescent, $12 \mathrm{~mm}$. long.

In open woods, frequent. Alaska to California and Wyoming.

Melica harfordii Boland. Stems tall, tufted, the bases not bulbous; lemmas obtuse and notched at apex, $8 \mathrm{~mm}$. long, ciliate with long hairs for most of its length.

In dry rocky places, Vancouver Island to California.

Melica smithii (Porter) Vasey. Glabrous; stems tufted, usually few, not bulbous at base; blades flat; panicle loose, the solitary branches at length spreading or reflexed; spikelets 3-6-flowered; glumes unequal; lemmas glabrous, $10 \mathrm{~mm}$. long, the straight awns half as long or less.

Sumas Prairie, Lyall; and eastward.

\section{BRIZA.}

Annuals or perennials with flat or convolute leaves and loose and open or narrow and spike-like panicles; spikelets manyflowered, round-ovate or cordate; rachilla jointed above the glumes and between the florets; florets crowded, the upper usually 
imperfect; glumes 2, subequal, membranaceous with broad scarious margins, rounded on the back, shorter than the flowers; lemmas 5-many-nerved, cordate at base, awnless; palea much smaller than the lemma, obtuse; styles short, distinct; stigmas plumose.

Briza media L. Perennial, tufted; stems erect, of various lengths, 10-60 $\mathrm{cm}$. high on the same plant; leaf blades scabrous; panicle loose, pyramidal, 5-10 cm. long; spikelets ovate to cordate, 6-8 mm. long, 5-9-flowered.

Sparingly introduced from Europe. Reported from Nanaimo, Vancouver Island, Macoun.

78. BROMUS. BROME-GRASS.

Annuals, biennials or perennials with flat leaves and terminal panicles of large spikelets; peduncles thickened at the summit; spikelets few-many-flowered; glumes unequal, acute; lemmas rounded on the back, or sometimes compressed-keeled, 5-9nerved, the apex usually 2-toothed, generally bearing an awn from just below the summit; palea shorter than the lemma; grain adherent to the palea.

Spikelets strongly flattened; perennials.

Awns less than $7 \mathrm{~mm}$. long; leaves linear-lanceolate, flat, not pilose.

Awns more than $7 \mathrm{~mm}$. long.

Panicle very broad, the longest rays $15-25 \mathrm{~cm}$. long, drooping.

Panicle large but the rays not drooping.

B. marginatus.

Spikelets subterete, not strongly flattened.
Native perennials mostly with loose and droopin
lemma usually more or less long-hairy.
Panicle narrow, erect or nearly so.

Spikelets subterete, not strongly flattened.
Native perennials mostly with loose and drooping panicles;
lemma usually more or less long-hairy.
Panicle narrow, erect or nearly so.

Spikelets subterete, not strongly flattened.
Native perennials mostly with loose and droo
lemma usually more or less long-hairy.
Panicle narrow, erect or nearly so.

Spikelets subterete, not strongly flattened.
Native perennials mostly with loose and droo
lemma usually more or less long-hairy.
Panicle narrow, erect or nearly so.

Panicle broad, drooping.

Lemma evenly pubescent.

Lemma unevenly pubescent.

B. sitchensis.

B. hookerianus.

Introduced annuals or biennials.

Awns much longer than the body of the narrow lemma.

Lemma pubescent or rarely glabrous; awns 13-15 $\mathrm{mm}$. long.

Lemma not pubescent; awns $18-45 \mathrm{~mm}$. long.

Awns $35-45 \mathrm{~mm}$. long

Awns less than $30 \mathrm{~mm}$. long.

Panicle a dense head-like cluster.

Panicle loose.

$B$. vulgaris.

B. pacificus.

B. richardsonii. lemma.

Panicle dense, small.

Panicle loose, open.

Margins of the lemma inrolled in fruit.

Margins of the lemma not inrolled in fruit.

B. tectorum.

B. maximus.

B. rubens.

B. sterilis.

B. hordeaceus.

B. secalinus.

B. commutatus.

Bromus marginatus Nees. Perennial, tufted; the stout stems about $1 \mathrm{~m}$. high; leaf blades coarse, sparsely pubescent; panicle $15-25 \mathrm{~cm}$. long, rather narrow, the branches in whorls of $2-4$, about $7 \mathrm{~cm}$. long, and bearing two spikelets; spikelets $2.5-4 \mathrm{~cm}$. long, 5-7 $\mathrm{mm}$. wide, compressed and keeled, 
7-9-flowered; lemma rough-pubescent, 11-14 $\mathrm{mm}$. long, 2-toothed at apex, and bearing a stout awn 4-7 $\mathrm{mm}$. long.

A variable species, rare in our limits.

Bromus sitchensis Bong. Stout grass, 1-1.5 m. high, smooth or nearly so; panicle large, loose, drooping, 25-35 cm. long; lemma smooth or scabrous, $12-14 \mathrm{~mm}$. long.

Moist banks, along the seashore.

Bromus hookerianus (Thurb.) Shear. Much like B. sitchensis but smaller; panicle erect, the branches not drooping; lemmas scabrous.

In open places, common.

Bromus vulgaris eximius Shear. Perennial; stems slender, $80-100 \mathrm{~cm}$. tall; leaf blades $15-25 \mathrm{~cm}$. long, glabrous or sparsely pilose; sheaths pilose with spreading or reflexed hairs; ligule truncate, fringed, 3-5 $\mathrm{mm}$. long; panicle sparse, more or less nodding, 8-12 $\mathrm{cm}$. long; spikelets $2-3 \mathrm{~cm}$. long, 2-4 $\mathrm{mm}$. wide; lemma 8-10 $\mathrm{mm}$. long, sparsely pubescent on the back, somewhat ciliate on the margin, the awn 6-9 $\mathrm{mm}$. long.

Common in open woods.

Bromus vulgaris robustus Shear. Lemma pilose on the keel and margins near the base; leaves and leaf sheaths pubescent.

Infrequent.

Bromus pacificus Shear. Stems stout, about $1 \mathrm{~m}$. tall; leaf-blades large, 8-11 mm. broad; panicle large, drooping; lemmas pubescent, $11-12 \mathrm{~mm}$. long. Moist banks and copses, especially along the coast.

Bromus richardsonii pallidus (Hook.) Shear. Stems 60-120 cm. high; leaf blades broad, scabrous above, smooth beneath; panicle large, loose, drooping; spikelets pale, 6-11-flowered, $2-3 \mathrm{~cm}$. long; lemma 12-15 mm. long, villous at the margins of the lower half.

In mountain bogs, rare in our limits.

Bromus tectorum nudum Klett \& Richter. Annual; stems $30-60 \mathrm{~cm}$. high; leaf blades pubescent; panicle loose, one-sided, drooping, the branches slender; spikelets $15-20 \mathrm{~mm}$. long; glumes acute, the lower about half the length of the upper; lemma lanceolate, smooth, 11-13 $\mathrm{mm}$. long, bearing at the apex two narrow hyaline teeth and a straight awn 13-15 $\mathrm{mm}$. long.

Introduced from Europe. Seattle, Piper. Typical B. tectorum with the lemma scabrous to pubescent occurs at Puyallup, Washington.

Bromus maximus Desf. Stems $20-40 \mathrm{~cm}$. high; sheaths and blades pilose; panicle erect, 5-10 cm. long, somewhat one-sided, the branches rather short and erect or nearly so after flowering.

Sparingly introduced from Europe.

Bromus rubens L. Annual, tufted; stems $20-50 \mathrm{~cm}$. high, erect; sheaths and leaf blades pubescent; panicle ovoid, compact, 4-7 cm. long, reddish at maturity; spikelets 7-11-flowered, $2-2.5 \mathrm{~cm}$. long; glumes narrow, acuminate, subequal, lower 1-nerved, upper 3-nerved; lemma lanceolate, pubescent, 13-16 $\mathrm{mm}$. long, the apex cleft into two long hyaline teeth; awn straight, 18-22 mm. long.

Introduced from Europe.

Bromus sterilis L. Annual, the stout stems $50-100 \mathrm{~cm}$. high, usually decumbent at base; panicle 10-20 cm. long, loose and drooping, its branches in whorls of 2-6, long and slender, usually bearing but one spikelet; spikelets drooping, $2.5-3.5 \mathrm{~cm}$. long, 5-10-flowered; lemma narrowly lanceolate, 17-20 $\mathrm{mm}$. long, bearing a stout rough awn, 20-30 mm. long.

Introduced from Europe. 
Bromus hordeaceus L. Annual, erect, 20-60 cm. tall; leaf blades pilose or smooth, the sheaths pubescent with retrorse hairs; panicle narrow, dense, 5-10 cm. long; spikelets erect, 12-15 mm. long, 5-12-flowered; lemma pubescent, bearing a stout straight or somewhat twisted awn 6-9 $\mathrm{mm}$. long.

Common in waste places; introduced from Europe.

Bromus secalinus L. Chess or Cheat. Annual, erect, $30-70 \mathrm{~cm}$. tall; leaf blades 10-20 cm. long, sparsely hairy above, smooth beneath; sheaths glabrous; panicle 8-18 cm. long, pyramidal, erect at first, in fruit somewhat drooping; spikelets oblong-lanceolate, turgid in fruit, 10-18 $\mathrm{mm}$. long; lemma glabrous or nearly so, $6-8 \mathrm{~mm}$. long, its margins involute in fruit, tipped with an awn 2-5 $\mathrm{mm}$. long; palea nearly equal to the lemma.

Introduced from Europe.

Bromus commutatus Schrad. Very similar to B. secalinus; panicle more drooping; lemma broader, not inrolled in fruit, tipped with a stout straight awn 7-8 $\mathrm{mm}$. long.

Introduced from Europe.

79. DACTYLIS.

Perennial grasses with flat leaves; inflorescence a densely clustered or interrupted panicle; spikelets 3-5-flowered, shortpedicelled, in small fascicles, the flowers all perfect or the upper staminate; glumes thin, membranous, keeled, unequal, mucronate; lemmas larger than the glumes, rigid, 5-nerved, keeled, the midnerve extending into a point or short awn; palea shorter than the lemma; grain free, enclosed in the lemma and palea.

Dactylis glomerata L. Orchard-grass. Perennial, tufted, the stout stems 60-150 cm. tall; leaf blades flat, scabrous, 6-8 mm. broad; sheath scabrous, exceeding the internode; panicle $3-10 \mathrm{~cm}$. long, pyramidal-ovate, greenish or purplish; branches solitary, ascending, spikelet-bearing above; lemmas conspicuously ciliate on the keels.

Escaped from cultivation.

80. POA. BLUE-GRASS.

Annual or perennial grasses with simple stems and narrow usually flat leaves; inflorescence a contracted or open panicle, spikelets 2-6-flowered, compressed, the rachilla usually glabrous; flowers perfect or rarely dioecious; glumes membranous, keeled, 1-3-nerved; lemmas membranous, keeled, awnless, longer than the glumes, generally with a tuft of cobwebby hairs at the base, 5-7-nerved, the marginal nerves usually pubescent, of ten also the dorsal one; palea a little shorter than the lemma, 2-nerved or 2-keeled; grain free, or sometimes adherent to the palea.

Annual; lemma without cobwebby hairs at base. P. annua. Perennial.

Plants with creeping rootstocks.

Stem flattened, 2-edged; panicles small.

Stem cylindric.

Lemma webbed, that is with a tuft of long hairs at the base. 
Dioecious, seashore plant; spikelets $10-15 \mathrm{~mm}$. long.

Perfect; spikelets 4-5 $\mathrm{mm}$. long.

P. macrantha.

P. pratensis.

Lemma not webbed.

Low seashore plant with narrow involute leaves and small panicle; spikelets close.

Taller grass, not maritime, with flat or folded leaves; spikelets loose.

Plants tufted, without rootstocks.

$P$. confinis.

P. nervosa.

Lateral nerves of lemmas prominent; web present.

Lateral nerves of lemmas not prominent.

Web present at base of lemma.

Leaves flat or folded, not soft and flaccid.

Panicle short pyramidal; spikelets $6-7 \mathrm{~mm}$. long; low alpine plant.

Panicle ample, spreading; spikelets $3-4 \mathrm{~mm}$. long.

Leaves flat, rather short, soft and flaccid.

P.trivialis.

Panicle lax and spreading; spikelets 5-6 $\mathrm{mm}$. long; florets not early deciduous.

Panicle narrow, the rays usually erect; florets early deciduous.

Lemma glabrous or nearly so.

Lemma pubescent.

P. arctica.

P. triflora.

P. leptocoma.

P. bolanderi.

$P$. howellii.

Web absent, no tuft of hairs at base of lemma.

Nerves of the lemma pilose below.

Alpine plant; leaf blades flat, green, broad.

Maritime plant; leaf blades narrow or

folded, glaucescent.

Nerves of the lemma not pilose.

Stems low, 5-20 cm. high; grasses of the highest mountains.

Leaves soft; panicle purple, very short; plants $5-10 \mathrm{~cm}$. high.

Leaves rather rigid; panicle pale, narrow, elongated; plant $10-20 \mathrm{~cm}$. high.

Stems taller, usually $20-40 \mathrm{~cm}$. high, mostly

P.alpina.

$P$. pachypholis. grasses of rupestrine habitat.

Panicle close, erect; leaves flat.

Lemmas pubescent at base; leaves rather narrow, sometimes folded.

Lemmas glabrous; leaf blades broader.

Panicles loose; leaves narrow, flat or involute.

Ligules of the sterile shoots obsolete; of the stem leaves short and truncate.

Ligules well developed on all the leaves.

Rays of the panicle in about 5 series; ligules $2-5 \mathrm{~mm}$. long

Rays of the panicle in fewer series; ligules 1-2 $\mathrm{mm}$. long.

Panicle close; glumes firm; blades flat.

Panicle loose; glumes thin; blades involute.

P. lettermani.

P. suksdorfii.

P. sandbergii.

$P$. paddensis.

P. multnomae.

P. alcea.

P. saxatilis.

$P$. gracillima. 
Poa annua L. Annual Blue-grass. Annual, the compressed stems 5-15 $\mathrm{cm}$. tall; leaves glabrous, the blades short and soft; panicle pyramidal, sometimes 1-sided; spikelets 3-7-flowered, crowded, $4 \mathrm{~mm}$. long; lemma 3-3.5 $\mathrm{mm}$. long, not hairy at base.

Introduced; common along waysides and in cultivated ground.

Poa compressa L. Canada Blue-grass. Usually low, spreading by rootstocks and forming dense mats, the much compressed stems $15-40 \mathrm{~cm}$. high, decumbent at base, glabrous; panicle 3-7 cm. long, contracted, the branches spikelet-bearing to the base or nearly so; spikelets 3-9-flowered; lemmas obscurely nerved, the nerves slightly pubescent below.

Sparingly introduced.

Poa macrantha Vasey. Pale green; rootstocks extensively creeping, stout; leaves involute or folded; panicle $5-10 \mathrm{~cm}$. long; staminate spikelets yellowish, 10-15 mm. long; pistillate smaller.

Common in sand dunes along the coast.

Poa pratensis L. Kentucky Blue-grass. Perennial with conspicuous running rootstocks, the terete stems $30-90 \mathrm{~cm}$. tall; panicle pyramidal, open, $6-20 \mathrm{~cm}$. long, the ascending or spreading branches in whorls of $3-5$, spikeletbearing aboye the middle; spikelets 3-5-flowered; lemmas 3-5 mm. long with prominent intermediate nerves, silky-pubescent on the midnerve and margins, cobwebby at the base.

Meadows and pastures everywhere.

Poa confinis Vasey. Stems 5-15 cm. high; leaves numerous, very narrow, involute; panicle $1-3 \mathrm{~cm}$. long, the short branches in pairs; spikelets $3-5$ flowered; lemmas broadly ovate.

High sea beaches; common on the ocean coast.

Poa nervosa (Hook.) Vasey. Stems weak, 30-40 cm. high; leaves soft, green, flat or folded; panicle lax, 6-10 cm. long; spikelets pale green, compressed, the 4-7 florets distant; lemma thin, lanceolate, scabrous.

On moist wooded banks, rare. Nootka Sound, British Columbia, Scouler; Cape Horn, Washington, Piper; Multnomah Falls, Oregon, Piper.

Poa trivialis L. Rough Meadow-grass. Stems $30-60 \mathrm{~cm}$. high; sheaths and flat blades scabrous; ligule well developed; panicle rather loose; spikelets mostly 3-flowered; lemma 5-nerved, the nerves very prominent.

Sparingly introduced.

Poa arctica R. Br. Perennial by creeping rootstocks; stems slender, 2-3-jointed, erect, 10-30 cm. high; leaves green, flat or folded, 2-5 cm. long, 2-3 $\mathrm{mm}$. wide; panicle loose, pyramidal, erect or somewhat nodding, $3-8 \mathrm{~cm}$. long, the slender rays mostly in twos; spikelets oblong-obovate, 3-6-flowered, 6-7 mm. long; glumes ovate, acute, subequal; lemma purplish, ovate, obtusish, pubescent on the keel and lateral nerves below the middle, 3-4 $\mathrm{mm}$. long, the tuft of hairs at base nearly as long.

Mount Rainier, Piper, Allen; our form is not typical and has been mistaken for $P$. laxa Haenke.

Poa triflora Gilib. Fowl Meadow-grass. Tufted, the stems $60-90 \mathrm{~cm}$. high; leaves narrow, linear, smooth and soft; ligule conspicuous; panicle usually purple; $10-30 \mathrm{~cm}$. long, the branches mostly in fives; spikelets 2-5-flowered; lemma obscurely nerved.

In wet places, common.

Poa leptocoma Bong. Glabrous, bright green; stems slender, erect. 20-40 cm. high; leaves flat, flaccid, 5-12 cm. long, 3-4 mm. wide; panicle lax, 5-10 cm. long, more or less nodding, the capillary branches mostly in twos 
and 2-5 cm. long; spikelets compressed, 5-6 mm. long, 3-flowered; glumes slightly unequal, the upper longer and broader; lemma lance-ovate, acute, 3-4 mm. long, with a tuft of hairs at base and long-villous on the keel and marginal nerves below the middle.

Boggy places in the mountains.

Poa bolanderi Vasey. A glabrous, loosely tufted, short-lived perennial, 30-50 cm. high, erect; leaf blades few, thin, soft, rather short; panicle erect, narrow, 10-12 cm. long, the branches few at the well separated nodes and usually remaining erect; spikelets 1-3-flowered, $2-3 \mathrm{~mm}$. long; lemma smooth, the basal web scanty.

Vancouver Island to California.

Poa howellii Vasey. Very similar to $P$. bolanderi; lemma acute, pubescent; florets dropping very readily.

In dry woods, not rare. Vancouver Island to California.

Poa alpina L. Stems $15-30 \mathrm{~cm}$. high; blades short, linear, flat, 3-6 mm. wide; panicle usually purple, short pyramidal; spikelets broadly ovate, 3-9-flowered; lemma villous on the midrib and nerves below.

In the mountains, Alaska to Washington.

Poa pachypholis Piper. Densely tufted, $15-30 \mathrm{~cm}$. high; leaves glaucous, the blades narrow and involute; panicle short, thick, very close; glumes and lemma thick and firm; lemma pubescent on the lower half of the nerves.

Ocean Bluffs at Ilwaco, Washington.

Poa lettermani Vasey. Very dwarf, tufted, only 5-10 cm. high; panicle purple, 1-2 cm. long, oblong, quite dense; spikelets 2-4-flowered; lemma oblong, acutish, glabrous.

Mount Rainier, at $3000 \mathrm{~m}$. altitude.

Poa suksdorfii Vasey. Pale green, densely tufted, 10-20 cm. high; blades folded or involute, rather numerous; panicle narrow and spike-like, 3-8 cm. long; spikelets 1-3-flowered; lemma ovate, thin and papery, 4-5 mm. long.

In loose gravel in the mountains at high elevations.

Poa sandbergii Vasey. Perennial, glabrous, not glaucous, tufted; the stems $15-50 \mathrm{~cm}$. tall; basal leaves numerous, the blades $5-10 \mathrm{~cm}$. long, linear; stem leaves 2, low down, the blades 1-2 cm. long, the sheaths often purple; panicle 4-10 cm. long, narrow, the ascending branches in whorls of 2-5, spikelet-bearing near the top; spikelets 2-4-flowered, usually purplish; lemmas oblong, $3.5 \mathrm{~mm}$. long, sparsely pubescent above, villous near the base.

In dry places in the mountains, rare; common in the interior.

Poa paddensis Williams. ( $P$. purpurascens Vasey.) Densely tufted; stems $15-30 \mathrm{~cm}$. high; blades flat or loosely involute, $2-4 \mathrm{~mm}$. wide; panicle erect or spreading, dark purple, rather close; spikelets thick, 3-5-flowered; glumes ovate, acutish; lemmas ovate, sparsely scabrous.

In alpine meadows, common. Vancouver Island to Oregon.

Poa multnomae Piper. Densely tufted, 10-30 cm. high; basal leaves numerous, very narrow, smooth, folded; panicle loose; spikelets ovate-lanceolate, 3-5-flowered, 5-7 mm. long; lemma ovate, acutish, puberulent at base, scarious at apex.

On rock cliffs along the Columbia.

Poa alcea Piper. Much like P. multnomae but taller; ligules conspicuous; spikelets oblong, 6-9 mm. long, mostly 5-flowered.

On moist rock cliffs, Elk Rock, near Portland, Oregon, and southward.

Poa saxatilis Scribn. \& Williams. Densely tufted alpine perennial, 20-30 $\mathrm{cm}$. tall; basal leaves numerous, green, the blades $2-6 \mathrm{~cm}$. long, flat, slightly 
scabrous, about $2 \mathrm{~mm}$. broad; stem leaves 2 ; ligules well developed; sheaths ioose, becoming scarious; panicles green or purple, erect, rather loose, $4-7 \mathrm{~cm}$. long, the rays mostly in twos; spikelets lanceolate, 6-9 mm. long, loosely 3-5flowered; glumes subacute, smooth, subequal, about $4 \mathrm{~mm}$. long; lemma obscurely 5-nerved, oblong, subacute, scabrous on the back, puberulent at base and on the keel, 4-4.5 mm. long.

Rocky places at high altitudes.

Poa gracillima Vasey. Very similar to $P$. saxatilis which may not be distinct; leaf blades involute; panicle loose; spikelets $7 \mathrm{~mm}$. long; lemma thin, scabrous on the back, pubescent at base, scarious at apex.

On cliffs in the mountains.

\section{DISTICHLIS.}

Rather rigid erect grasses springing from creeping bases, with dense panicles of rather few large and compressed spikelets, which are usually more numerous and less crowded in the staminate than in the pistillate plants; spikelets 8-16-flowered, dioecious; glumes 2, keeled, acute, shorter than the lemmas; lemmas 3-many-nerved, acute; grain free.

Distichlis spicata (L.) Greene. Salt-grass. Extensively creeping; leaves rather rigid, smooth, involute; spikelets ovate or oblong, 8-16 $\mathrm{mm}$. long, smooth, 6-12-flowered.

Along the seashore, common.

\section{FestuCA. Fescue.}

Annuals or perennials with terminal panicles, sometimes reduced to racemes; spikelets 2 -many-flowered; glumes more or less unequal, acute, keeled, the lower 1-, rarely 3 -nerved, the upper 3-, rarely 5-nerved; lemmas lanceolate, firm in texture at least near the base, narrow, rounded on the back or slightly keeled, always 5-nerved, acute or usually awned; palea usually about equalling the lemma; grain glabrous, elongated, often adherent to the palea.

Annuals.

Spikelets densely 8-13-flowered.

Spikelets loosely $1-6$-flowered.

F. octoflora.

Branches of the short panicle divergent.

Florets $3-5$ in each spikelet; only the principal rays divergent.

Florets $1-3$ in each spikelet; all the spikelets divergent.

Branches of the elongated panicle erect or appressed.

Lemma ciliate.

Lemma not ciliate.

First glume one-third as long as second.

Perennials.

First glume two-thirds as long as second.

F. pacifica.

F. reflexa.

F. megalura.

F. myuros.

F. bromoides.

Callus and auricles conspicuously hairy.

F. aristulata.

Callus and auricles glabrous.

Leaves very narrow, mostly involute. 
Plant with creeping rootstocks.

F. rubra.

Plant tufted; rootstocks none.

Tufts separable with difficulty; lemmas acute, not awned.

Tufts easily separable; lemmas awned.

Panicle loose; lemmas long-awned.

Panicle close; lemmas not long-awned.

Leaves rather broad, flat.

Lemma firm, not at all keeled, awnless.

Lemma rather thin, keeled above the middle, awned.

Floret with a narrow stalk-like base.

Floret not stalk-like at base.

F. viridula.

F. occidentalis.

F. ovina.

F. elatior.

F. subuliflora.

F. subulata.

Festuca octoflora Walt. Tufted annual, $8-30 \mathrm{~cm}$. tall; panicle $2-6 \mathrm{~cm}$. long, rather dense, often one-sided; spikelets $6-10 \mathrm{~mm}$. long, 7-13-flowered; lemmas 3-4 mm. long, scabrous, attenuate into an awn about as long.

In dry open places.

Festuca pacifica Piper. Annual; stem single or a few in a loose tuft, 5-30 cm. tall; panicle 4-10 cm. long; branches mostly solitary, longest below, all erect at first but becoming spreading or reflexed by means of a prominent pulvinus at the base; spikelets 2-6-flowered; lemma 6-7 $\mathrm{mm}$. long, the awn two to three times as long.

In prairies, rare west of the Cascade Mountains.

Festuca reflexa Buckl. In habit like $F$. pacifica; panicle $5-12 \mathrm{~cm}$. long, the rays solitary; spikelets at length all spreading; lemma lanceolate, glabrous or scabrous, bearing a short or long awn.

Dry open places, Vancouver Island to California.

Festuca megalura Nutt. Tufted annual, 30-40 cm. tall, smooth; panicle spike-like, elongated, flexuous, 5-25 cm. long, pale-green; spikelets 4-5-flowered, $2-2.5 \mathrm{~cm}$. long, including the awns; lemma lanceolate, scabrous, the body $5 \mathrm{~mm}$., the awn 10-15 $\mathrm{mm}$. long.

Along roads and streets, native, but appearing as if introduced.

Festuca myuros L. Mouse-tail Fescue. Very similar to F. megalura, but the panicle usually smaller; lemma not ciliate; first glume very short.

Sparingly introduced; native of Europe.

Festuca bromoides L. Glabrous; stems $10-30 \mathrm{~cm}$. high; panicle usually dense, 5-10 cm. long; rays solitary; glumes subequal, the lower shorter.

Waysides, introduced from Europe.

Festuca aristulata (Torr.) Shear. ( $F$. californica Vasey.) Coarse tufted grass, $60-120 \mathrm{~cm}$. high, scabrous throughout; junction of sheath and blade white-hairy; panicle large and very loose; spikelets 5-flowered; lemma 8-10 $\mathrm{mm}$. long, lanceolate, scabrous.

Dry ground, upper Willamette Valley to California.

Festuca rubra L. Perennial, with short running rootstocks; the whole plant smooth; stems $60-100 \mathrm{~cm}$. tall, slender; leaves narrow, involute, 10-20 $\mathrm{cm}$. long; panicle narrow, erect; about $10 \mathrm{~cm}$. long, the short erect branches in twos, spikelet-bearing to the base; spikelets frequently purplish, $10-12 \mathrm{~cm}$. long, 5-6-flowered; lemma smooth, 5-6 mm. long, tipped with an awn 3-4 mm. long.

Mostly along the seashore. F. rubra kitaibeliana (Schult.) Piper is a subspecies distinguished by having pubescent lemmas.

Festuca viridula Vasey. Densely tufted, dark green, smooth; stems 50 $100 \mathrm{~cm}$. high; leaves narrow, erect, soft, 7-nerved, the basal ones involute; 
panicle loose and open, suberect, 10-15 cm. long; spikelets 3-6-flowered; lemma firm, keeled toward the apex, 5-nerved, acute or sometimes mucronate, smooth or nearly so, 6-7 mm. long.

Common in alpine meadows.

Festuca occidentalis Hook. Densely tufted, the whole plant smooth and bright green; stems $30-60 \mathrm{~cm}$. high; leaf blades smooth, becoming longitudinally grooved when dry; panicle narrow, loose, 8-20 cm. long, often drooping at the summit; spikelets green, 3-5-flowered; lemmas scabrous near the apex or smooth, 5-6 mm. long, bearing a slender awn of equal length.

In open woods, common.

Festuca ovina supina (Schur) Hack. Plant densely tufted, usually smooth; stems 10-20 cm. high; leaves firm, involute, not shrinking when dry; panicle strict, narrow, 2-4 cm. long; lemmas short-awned; ovary not hairy at apex.

In the mountains at high altitudes.

Festuca elatior L. Meadow Fescue. Perennial; the stout stem 100-150 $\mathrm{cm}$. tall, smooth and glabrous throughout; leaves flat, dark green, 7-15 cm. long, 3-4 mm. wide; panicle narrow, erect, $10-25 \mathrm{~cm}$. long, the branches solitary or in twos; spikelets rather crowded, lanceolate-oblong, 12-18 mm. long, 5-10-flowered; lemma scarious-margined, acute, awnless.

A native of Europe, escaped from cultivation.

Festuca subuliflora Scribn. Stems $60-80 \mathrm{~cm}$. high; leaves broad, flat or loosely involute; panicle broad, the spreading rays mostly solitary; spikelets large, loose; lemmas long awned, each narrowed at base into a stalk-like structure, so that the rachilla is apparently jointed between the florets.

In open woods, not common.

Festuca subulata Trin. Loosely tufted, glabrous or nearly so; stems 40 $120 \mathrm{~cm}$. high; leaf blades flat, thin, 3-10 mm. broad; panicle very loose and somewhat drooping, $15-40 \mathrm{~cm}$. long, rays in 3-5 sets; spikelets pale green, 3-5-flowered, 7-12 mm. long; lemma membranaceous, narrowly lanceolate, keeled its entire length, 5-7 mm. long, with an awn 5-20 $\mathrm{mm}$. long.

In moist woods, common.

\section{PANICULARIA.}

Tall aquatic perennial grasses with terminal panicles; spikelets few-many-flowered, terete, or somewhat flattened; glumes unequal, obtuse or acute, 1-3-nerved; lemmas membranous, obtuse, rounded on the back, 5-9-nerved, the nerves disappearing in the hyaline apex; palea scarcely shorter than the lemma, rarely longer; grain smooth, enclosed in the lemma and palea, free, or when dry slightly adhering to the latter.

Spikelets linear, 10-20 mm. long.

Lemma scabrid only on the nerves; glumes $2-3 \mathrm{~mm}$. long. P. borealis.

Lemma scabrid all over the back; glumes 1-2 mm. long.

Spikelets 10-15 mm. long; lemma $3 \mathrm{~mm}$. long, truncate. P. leptostachya.

Spikelets 18-20 mm. long; lemma 5-6 mm. long, acutish.

Spikelets ovate or oblong, 2-8 $\mathrm{mm}$. long

Lemma with 5 prominent nerves.

Lemma with 7 prominent nerves.

Spikelets 3-4 mm. long.

Spikelets 4-6 mm. long.

P. occidentalis.

$P$. pauciflora.

$P$. nervata.

P. americana. 
Panicularia borealis Nash. Stems weak, erect, glabrous, $50-100 \mathrm{~cm}$. tall; leaf blades $8-20 \mathrm{~cm}$. long, pale green, nearly smooth; sheaths loose, longer than the internodes; panicle lax, 15-30 cm. long, the branches single or in twos, usually short and erect; spikelets linear, 10-15 mm. long; lemmas thin, 3.5-4 $\mathrm{mm}$. long, 7-nerved, the nerves minutely hispid.

In shallow ponds and ditches.

Panicularia leptostachya (Buckl.) Piper n. comb. (Glyceria leptostachya Buckl.; Panicularia davyi Merrill.) Much like P. borealis; sheaths scabrous; spikelets $10-16 \mathrm{~mm}$. long; lemma scabrous all over the back, truncate; glumes very short.

In ponds, rare.

Panicularia occidentalis Piper n. sp. Pale green, flaccid, $60-90 \mathrm{~cm}$. high; sheaths smooth, longer than the internodes; ligules large, 4-8 mm. long; blades flat, scabrous above, smooth beneath, $5-9 \mathrm{~mm}$. broad, $8-20 \mathrm{~cm}$. long; panicle loose, spreading, usually enclosed at base, $30-50 \mathrm{~cm}$. long; branches in about 7 series, scabrous, a long one and one or two short ones at each joint; spikelets 18-20 mm. long, 6-9-flowered; rachilla slender, cernuous; glumes hyaline, the lower broadly ovate, obtuse, $1.5 \mathrm{~mm}$. long, the upper oblong, acutish, $3 \mathrm{~mm}$. long; lemma firm, strongly nerved, 5-6 $\mathrm{mm}$. long, acutish, narrowly hyaline-margined, scabrous-puberulent all over the back.

Type specimen collected at Vancouver, Washington, C. V. Piper no. 4905, June 5, 1904; also collected at Sauvies Island, Oregon, Thos. Howell, May 1881; Salem, Oregon, E. Hall, no. 630, in 1871. Most nearly related to $P$. leptostachya (Buckl.) Piper; differing in its broader leaf-blades, smooth sheaths and larger spikelets and florets.

Panicularia pauciflora (Presl) Kuntze. Stems 50-100 cm. high, smooth; leaf blades $10-20 \mathrm{~cm}$. long, nearly $1 \mathrm{~cm}$. broad, acute, scabrous; sheaths nearly equalling the internodes; panicle loose, $15-20 \mathrm{~cm}$. long, usually purplish, its base included in the upper sheath; branches slender, spreading, 2-5 at a node, flower-bearing above the middle; spikelets 4-5 $\mathrm{mm}$. long, 4-6-flowered; lemmas prominently 5 -nerved, rarely 7 -nerved.

Common in springy places.

Panicularia nervata elata (Nash) Piper. Stems 60-90 cm. high; leaves linear, dark-green, $15-30 \mathrm{~cm}$. long, 6-10 $\mathrm{mm}$. wide; panicle loose, at length drooping; spikelets $2-4 \mathrm{~mm}$. long.

In wet places, common.

Panicularia americana (Torr.) MacM. Reed Meadow-grass. Stems stout, $100-150 \mathrm{~cm}$. high; leaf blades 6-15 mm. wide; panicle large and loose, 20-40 $\mathrm{cm}$. long, nodding at the top; spikelets 4-7-flowered; upper glume $2-2.5 \mathrm{~mm}$. long.

In wet places, not common in our limits.

\section{PUCCINELLIA.}

Tufted perennial grasses of seacoast or alkaline regions; spikelets as in Panicularia, but lemmas firmer, usually smaller, often sub-acute and minutely pubescent at base, the nerves obscure.

Panicle narrow, its base usually inclosed in the upper sheath, erect or the short lower branches sometimes divergent.

Panicle well exserted, the branches becoming divaricate or reflexed.

P. angustata.

P. distans. 
Puccinellia angustata (R. Br.) Nash. Creeping by stolons; stems low, slender; leaves somewhat fleshy, narrow, involute; spikelets 3-7-flowered; first glume usually 1 -nerved.

Salt marshes along the coast.

Puccinellia distans (L.) Parl. (Poa nutkaensis Presl.) Not stoloniferous; stems geniculate, $20-60 \mathrm{~cm}$. high; blades not fleshy, flat or folded; panicle branches usually in fours or fives, spreading or reflexed; spikelets 3-6-flowered; first glume usually 3-nerved.

Seashores; very variable. Forms with the panicle narrow and the branches ascending have been referred perhaps correctly to the European $P$. festucaeformis (Host) Parl.

\section{SPARTINA. CORD-GRASS.}

Coarse perennial grasses with strong creeping rootstocks, rigid simple stems and long tough leaves; inflorescence of 1 -sided spreading or erect alternate spikes; spikelets 1 -flowered, narrow, deciduous, borne in two rows on the rachis, articulated with the very short pedicels below the glumes; glumes keeled, very unequal; lemma keeled, equalling or shorter than the second glume; palea of ten longer than its lemma; grain free.

Spartina michauxiana Hitchc. Stems 1-2 m. tall, simple, smooth; leaf blades flat, keeled, long-acuminate, involute in age, scabrous on the margins; spikes 5-20,5-12 cm. long, ascending, sometimes peduncled; spikelets closely imbricated; glumes very scabrous on the keels, awn-pointed; lemma scabrous on the midrib, which terminates below the 2-toothed apex.

Cascades of the Columbia River, Hall, perhaps in our limits.

\section{BECKMANNIA.}

Tall erect perennials; inflorescence a terminal panicle of erect spikes; spikelets 1-2-flowered, globose, compressed; glumes membranous, saccate, obtuse or abruptly acute; lemmas 1 or 2, narrow, thin-membranous; palea hyaline; grain oblong, free, enclosed in the lemma.

Beckmannia erucaeformis (L.) Host. Perennial, the stems stout, 60$90 \mathrm{~cm}$. tall, glabrous throughout; leaf blades $10-30 \mathrm{~cm}$. long, 6-10 mm. wide, scabrous, the loose sheaths exceeding the internodes; panicle narrow, 10-30 $\mathrm{cm}$. long, the densely-flowered branches mostly solitary and erect; spikelets nearly orbicular, flattened, $2 \mathrm{~mm}$. long.

In wet meadows, rare west of the Cascade Mountains. Victoria, Vancouver Island, Macoun; Colquitz River, Vancouver Island, Macoun; Willamette Valley.

\section{CYNODON.}

Low creeping perennials with short flat leaves and slender spikes digitately arranged at the ends of the branches; spikelets 1-flowered, awnless, sessile in two rows along one side of a slender rachis, forming unilateral spikes; rachilla jointed above the glumes and prolonged behind the palea into a slender bristle; glumes 2 , narrow, keeled, usually acute; lemma broader, usually a little longer than the glumes, obtuse, more or less pilose on the keel 
and margins; palea as long as the glume; styles distinct; grain free.

Cynodon dactylon (L.) Pers. Bermuda-grass. Low, 5-30 cm. high, loosely branched and extensively creeping by rootstocks or stolons, glabrous; leaf blades flat; ligules very short but bearing a ring of white bristles; branches of the umbel 4-6; spikelets $2 \mathrm{~mm}$. long.

Sparingly introduced.

\section{ELEUSINE.}

Tufted annuals with rather stout unilateral spikes digitately arranged at the tip of the stem; spikelets several-flowered, sessile, closely imbricated in 2 rows along one side of the rachis; rachilla jointed above the glumes; lemmas compressed, keeled, thin but rigid, obtuse; palea a little shorter than the lemma, compressed; seed finely striated.

Eleusine indica Gaertn. Goose-grass. Glabrous annual; stems flattened, erect or decumbent, $15-60 \mathrm{~cm}$. high; sheaths overlapping; spikes $3-8 \mathrm{~cm}$. long, 2-10 in an umbel, bearing the 3-5-flowered spikelets on the lower side.

Introduced from the oriental tropics.

\section{LOLIUM.}

Annuals or perennials with simple erect stems and simple terminal spikes; spikelets several-flowered, solitary and sessile in alternate notches of the rachis, one edge of the spikelet against the rachis; glume 1 ( 2 in the terminal spikelet), on the side away from the rachis, shorter or longer than the lemmas which are rounded on the back and 5-7-nerved, with an obtuse, acute or awned apex; grain smooth, adherent to the palea.

Glumes longer than the spikelet.

L. temulentum.

Glumes shorter than the spikelet.

Lemmas awned; young leaves involute.

Lemmas awnless; young leaves folded.

L. multiflorum.

L. perenne.

Lolium temulentum L. Darnel. Annual; spikelets 5-8-flowered; lemma awnless or short-awned.

Sparingly introduced.

Lolium multiflorum Lam. Italian Rye-grass. Glabrous, tufted; stems erect, $60-90 \mathrm{~cm}$. high; sheaths usually shorter than the internodes; blades $3-8 \mathrm{~mm}$. wide, involute in the bud; ligule short, truncate; spikes $20-30 \mathrm{~cm}$. long; spikelets 7-9-flowered; glumes shorter than the spikelet; lemma narrowly elliptic, the awn as long as the body.

Introduced from Europe.

Lolium perenne L. English or Perennial Rye-grass. Perennial; young leaves folded; spikelets 8-15-flowered, 8-12 $\mathrm{mm}$. long; lemmas 5-6 mm. long, awnless or short-awned.

Naturalized from Europe.

90. AGROPYRON. WHEAT-GRASS.

Perennials with simple stems and terminal spikes; spikelets 3-many-flowered, sessile, single and alternate at each notch of 
the usually continuous rachis, the side of the spikelet, that is the edge of the glumes, toward the rachis; lemmas rigid, rounded on the back, 5-7-nerved, usually acute or awned at the apex; palea often with hairy keels; grain pubescent at the apex.

Plants tufted, without rootstocks; spikelets subcylindric.

A. tenerum.

Plants with creeping rootstocks.

Spikelets compressed, spreading; leaves pale, rough on the back.

Spikelets subcylindric, erect; leaves green, smooth on the back.

A. occidentale.

A. repens.

Agropyron tenerum Vasey. Slender Wheat-grass. Perennial, tufted; stems erect, $30-100 \mathrm{~cm}$. high, rather slender, glabrous; stem leaves 3 or 4 , the blades becoming involute, scabrous on both sides, the sheaths glabrous and shorter than the internodes; spike 10-20 cm. long, narrow, the spikelets densely crowded; lemmas linear-oblong, 5-nerved, scabrous, acuminate or short-awned.

Rare west of the Cascade Mountains; common in the interior.

Agropyron occidentale Scribn. (A. smithii Rydb.) Bluestem. Whole plant pale or glaucous; stems erect, $30-100 \mathrm{~cm}$. high; leaves firm, the nerves thick and prominent; spike 8-15 cm. long, compact; spikelets 7-13-flowered, 12-20 $\mathrm{mm}$. long, glabrous; lemma firm, awn-pointed, the nerves faint.

High sea-beaches, rare; common in the interior.

Agropyron repens L. Couch or Quack-grass. Stems erect, 100-150 cm. high; leaf blades green, pilose above, the nerves not prominent; spike $5-15 \mathrm{~cm}$. long; spikelets 5-flowered; lemma glabrous or nearly so, strongly nerved, usually awn-pointed.

Sparingly introduced; a very pernicious weed.

\section{ELYMUS. RYE-GRASS.}

Perennial or annual grasses with spike-like inflorescences which do not readily break up into segments; spikelets 1 -7-flowered, 2-4 at each joint of the rachis or rarely solitary; glumes entire, equal, rigid, narrow; lemmas acute, acuminate or awned, entire.

Glumes subulate, obscurely nerved.

Annual; glumes awned.

Perennial plants with creeping rootstocks; glumes not awned.

Lemma glabrous, often glaucous; glumes not hirsute.

Lemma scabrous-puberulent; glumes sparsely hirsute.

E. caput-medusae.

Glumes lanceolate, distinctly nerved.

Culms very stout, $1-2 \mathrm{~m}$. tall; plants with rootstocks. E. arenarius.

Culms slender, seldom $1 \mathrm{~m}$. tall; plants without rootstocks.

Lemma not ciliate.

Lemma ciliate.

Awns long.

Awns short.

E. triticoides.

E. vancouverensis.

E. glaucus.

E. hirsutus.

E. virescens.

Elymus caput-medusae L. Glabrous annual; stems 20-50 cm. high, erect or geniculate at base; leaves $1-2 \mathrm{~mm}$. broad, becoming involute; spike stout, erect, green or becoming purplish, $1-4 \mathrm{~cm}$. long without the awns; 
spikelets 2 at each node, 1 - or rarely 2 -flowered; glumes subulate, rigid, 2-2.5 $\mathrm{cm}$. long; lemma lanceolate, very scabrous, tipped with a stout awn 5-10 $\mathrm{cm}$. long.

Introduced from Europe; abundant in the upper Willamette Valley.

Elymus triticoides Buckl. Stems erect, about $1 \mathrm{~m}$. tall, not densely tufted; leaves 4-6 mm. wide, sometimes scabrous; panicle spike-like or with some of the lower branches elongated, usually purplish, rather loose; lemma acuminately short-awned.

Rare west of the Cascade Mountains; common in the interior.

Elymus vancouverensis Vasey. Stems stout, $60-90 \mathrm{~cm}$. high; leaves thick, involute; spike dense, 10-12 cm. long; spikelets crowded; lemma scabrous-puberulent, mucronate or awn-pointed.

On high sandy beaches, rare. Near Victoria, British Columbia, Macoun; Coupeville, Washington, Gardner; Seattle, Piper, Howell.

Elymus arenarius L. Culms stout, 1-2 m. tall; spikes 10-20 cm. long, dense, erect; spikelets $2-3 \mathrm{~cm}$. long, appressed, 3-7-flowered; glumes lanceolate, acuminate, awnless; lemma scabrous to hairy, cuspidate at tip.

On high sea-beaches. Typical $E$. arenarius has the upper part of the culm and the glumes glabrous and does not occur in our limits. The common plant of the Alaska coast extending southward to Vancouver Island having sessile spikelets and pliant villous glumes is $E$. arenarius mollis Piper. n.comb. $E$. mollis Trin.). The plant of the Puget Sound region having pedicelled spikelets and stiff hispid to glabrate glumes is $E$. arenarius compositus (Abromeit) St. John. Both these subspecies have the culm pubescent near the top.

Elymus glaucus Buckl. Stems $50-100 \mathrm{~cm}$. tall, erect; leaf blades spreading or drooping, 10-30 cm. long, 6-16 mm. wide; spike-like panicle narrow, erect or rarely nodding above, $5-15 \mathrm{~cm}$. long, greenish or purplish, glaucescent; spikelets usually appressed, mostly in pairs, 3-6-flowered; glumes lanceolate; lemma not pubescent but rough near the apex, tipped with an awn about twice as long.

Common and variable.

Elymus hirsutus Presl. (E. borealis Scribn.) Much like E. glaucus but bright green; spike looser or interrupted, often nodding; lemma ciliate.

Alaska southward to the Olympic Mountains.

Elymus virescens Piper. Green and glabrous; stems $30-60 \mathrm{~cm}$. high; spike dense, erect, 6-8 cm. long; glumes 3-nerved, lanceolate; lemma lanceolate, obtusely cuspidate.

Olympic Mountains, head of Duckaboose River, in moist coniferous woods.

\section{HORDEUM. WILD BARLEY.}

Cespitose annuals or perennials with terminal cylindrical spikes; spikelets 1-flowered, usually in threes at each joint of the rachis, the lateral generally short-stalked and imperfect; rachilla produced beyond the flower; glumes rigid, the lower ones often reduced to awns and forming an apparent involucre around the spikelets; lemmas rounded on the back, 5-nerved at the apex, awned; palea scarcely shorter than the lemma; grain usually adherent to the lemma, hairy at the summit.

Floret of the central spikelet pedicelled; glumes ciliate.

H. murinum.

Floret of the central spikelet sessile; glumes not ciliate. 
Glumes not all subulate.

Glumes of middle spikelet lanceolate.

Glumes of middle spikelet setaceous.

H. pusillum.

H. gussoneanum.

Glumes all alike, subulate.

Lateral florets long-awned.

Awns 4-6 mm. long.

Awns 2-3 cm. long.

Lateral florets not awned.

Lateral florets neutral.

Lateral florets perfect.

H. jubatum.

H. caespitosum.

H. nodosum.

H. boreale.

Hordeum murinum L. Wall Barley. Stems 15-30 cm. tall; leaf blades 2-12 cm. long, 2-6 mm. wide; spikes 5-10 cm. long, thick; spikelets mostly in threes, all stalked; both glumes of the central spikelet and the inner glume of the lateral spikelets ciliate and flattened, bearing awns 20-25 mm. long; outer glumes of lateral spikelets neither flattened nor ciliate; lemma scabrous at the apex, long-awned.

A weed in waste places.

Hordeum pusillum Nutt. Stems $15-30 \mathrm{~cm}$. high; spikes $3-8 \mathrm{~cm}$. long; both glumes of the central spikelet lanceolate and the inner ones of the lateral spikelets dilated.

Vancouver Island, British Columbia, Macoun, perhaps introduced. Common eastward.

Hordeum gussoneanum Parl. Annual, glabrous, 10-30 cm. high; upper sheath inflated; spike cylindrical, green, $2-5 \mathrm{~cm}$. long; lemma $2-2.5 \mathrm{~cm}$. long, including the stiff straight awn.

Sparingly introduced from Europe.

Hordeum jubatum L. Squirrel Tail. Annual, tufted, erect, 30-60 cm. high, glabrous or sometimes pubescent; leaf blades flat, becoming involute, the sheaths shorter than the internodes; spike-like panicle pale green or yellowish, 7-10 cm. long, readily breaking apart; central spikelet sessile, fertile, the lateral ones peduncled and sterile; glumes all subulate, $3-6 \mathrm{~cm}$. long.

In salt marshes, not common.

Hordeum caespitosum Scribn. Much like $H$. jubatum but the spikes more slender and the awns shorter.

Tacoma, Leckenby; perhaps introduced.

Hordeum nodosum L. Annual or perennial, 30-90 cm. high, erect, leaf blades flat or involute, the sheaths smooth or hairy; panicle spike-like, $3-8 \mathrm{~cm}$. long, narrow, usually flexuous, readily separating into joints; central spikelet sessile, fertile, the lateral ones peduncled and sterile glumes all subulate, $2 \mathrm{~cm}$. or less in length.

In moist meadows and along the seashore.

Hordeum boreale Scribn. \& J. G. Smith. Similar in every way to $H$. nodosum except for the perfect lateral florets.

In moist ground, Alaska to Oregon; perhaps only a form of H. nodosum.

\section{SITANION.}

Cespitose perennials, with spikes which readily break up into segments; spikelets 2-3 at each joint of the rachis, rarely solitary, 1-5-flowered; glumes subulate and entire, or lanceolate and bifid, or parted into several long-awned lobes; lemmas lanceolate and 
acute, or those of the lowest floret sterile and subulate, entire with a single awn, or trifid and three-awned.

This genus is hardly distinct from Elymus.

Glumes 2-nerved; inflorescence 2-8 $\mathrm{mm}$. long.

Awns of lemmas 3-4 cm. long.

Awns of lemmas $4-5 \mathrm{~cm}$. long.

Glumes 3-5-nerved; inflorescence 10-15 cm. long.

Leaves glaucous, $5-8 \mathrm{~mm}$. broad.

Leaves green, $2-5 \mathrm{~mm}$. broad.

S. rigidum.

S. glabrum.

S. planifolium.

S. rubescens.

Sitanion rigidum J. G. Smith. Stèms 10-20 cm. high; leaf blades green or slightly glaucous, rigid, $2-5 \mathrm{~mm}$. wide, flat or at length involute; spike green, 2-8 $\mathrm{cm}$. long, erect or nearly so, often included at base in the upper sheath; glumes or glume divisions 4 and entire or 6 , that is the lateral ones divided to the base, all awned; lemma 7-9 $\mathrm{mm}$. long, tipped with a stout awn 3-4 mm. long.

In rocky soil in the mountains at $2000-2500 \mathrm{~m}$. altitude.

Sitanion glabrum J. G. Smith. Pale or somewhat glaucous, tufted; leaves flat, $2-5 \mathrm{~cm}$. wide; spike $5-8 \mathrm{~cm}$. long; glumes bifid, $6-8 \mathrm{~cm}$. long.

Dry rocky places in the mountains, at high altitudes.

Sitanion planifolium J. G. Smith. Tufted, 50-60 cm. high, more or less glaucous; leaf-blades 5-8 $\mathrm{mm}$. wide, flat, glabrous; spike suberect, purplish, 6-9 cm. long; glumes 6-7 mm. long, entire or bifid, tipped with an awn about $2 \mathrm{~cm}$. long; lemma $10 \mathrm{~mm}$. long, lancolate, minutely scabrous, bearing an awn 3-4 cm. long.

Olympic Mountains, Elmer; Mount Adams, Suksdorf.

Sitanion rubescens Piper. Stems tufted, $50-70 \mathrm{~cm}$. high; leaves flat; spikes erect, flexuous, $10-15 \mathrm{~cm}$. long, purplish; glumes 4 , entire or rarely bifid, 3 -nerved; lemma tipped with a slender awn about $4 \mathrm{~cm}$. long.

Dry rocky slopes of Mount Rainier.

\section{Family 17. CYPERACEAE. Sedge Family.}

Grass-like or rush-like herbs; stems slender, solid (rarely hollow), triangular, quadrangular, terete or flattened; leaves narrow with closed sheaths; flowers perfect or unisexual in spikes or spikelets, one in the axil of each scale (glume or bract); spikelets solitary or clustered, 1 to many-flowered; scales tworanked or in a spiral, persistent or deciduous; perianth hypogynous, composed of bristles or scales or wanting; stamens 1-3, rarely more; ovary 1 -celled, 1 -ovuled; style 2 or 3 -cleft; fruit a lenticular or triangular akene; endosperm mealy; embryo minute.

Flowers unisexual, borne in the same or more commonly separate spikelets.

Flowers of the spikelets all perfect, rarely partly 94. Carex, 66. aborted; spikelets all alike.

Spikelets with scales in two ranks.

Perianth none; spikelets in solitary or umbelled terminal heads.

Perianth of 6-9 bristles; spikelets axillary.

95. Cyperus, 81. 6

96. Dulichium, 82. 
Spikelets with scales spirally arranged and overlapping all around.

Spikelets 1-4-flowered, some of the flowers imperfect.

Spikelets with several-many perfect flowers.

Style swollen at the base, persistent on the akene.

Style not swollen at the base, deciduous.

Spikelets 1-many; bristles 1-6, short, rarely none.

Spikelets 1 or a few; bristles 6-many, soft, smooth, very long, slender, much exserted.

97. RYNCHOSPORA, 82.

98. Eleocharis, 82.

99. ScIRPUS, 83.

100. ERIOPHORUM, 84.

94. CAREX. SEDGE.

Grass-like plants, perennial by rootstocks; stems mostly triangular; leaves 3-ranked, the upper (bracts) elongated or very short and subtending the spikes of flowers, or wanting; flowers solitary in the axils of bracts (scales), monoecious or dioecious; spikes either wholly staminate, or pistillate, or sometimes androgynous; perianth none; staminate flowers of 3 stamens; pistillate flower of a single pistil with a style and 2-3 stigmas borne in the axil of a second bract (the perigynium) which completely encloses the akene; akene 3 -angled, lenticular or planoconvex.

Spikes solitary, terminal.

Key To Sections.

Spikes several.

Spikes all alike.

Spikes of two sorts.

I. Primocarex.

II. Vignea.

III. EUCAREX.

Section I. Primocarex.

Spike solitary, terminal.

Perigynia pubescent; plant dioecious.

C. stenochlaena.

Perigynia glabrous; plant not dioecious.

Spike ovoid, brown; perigynia thin and inflated.

Perigynia 6-7 $\mathrm{mm}$. long, much exceeding the scales; stems longer than the leaves.

Perigynia $5 \mathrm{~mm}$. long, slightly exceeding the scales; stems shorter than the leaves.

Spike not ovoid nor brown; perigynia not bladder-like.

C. breweri.

C. paddoensis.

Perigynia reflexed when fully mature, fusiform, beaked, stipitate at base.

Perigynia few, 3-5; scales pale.

Perigynia more numerous; scales colored.

Scales dark purple; spikes $8-10 \mathrm{~mm}$. thick; leaves flat, $3-4 \mathrm{~mm}$. wide.

Scales brownish; spikes 3-4 mm. thick; leaves involute, $2 \mathrm{~mm}$. wide.

C. pauciflora.

C. nigricans.

Perigynia not becoming reflexed; not stipitate (ex-

C. pyrenaica. cept $C$. circinata). 
Scales much longer than the few, 1-6, perigynia. C. geyeri.

Scales not longer than the several to numerous perigynia.

Perigynia broadly obtuse, beakless.

Perigynia narrowed to the bidentate apex.

Scales as long as or longer than the perigynia.

Scales shorter than the perigynia.

C. leptalea.

C. hepburne.

C. circinata.

Section II. VIgnea.

Spikes sessile, all alike, bearing the inconspicuous staminate flowers at the base, at the top, or rarely scattered; stigmas 2 , rarely 3 ; perigynia mostly plano-convex; akenes lenticular.

When the staminate flowers are below the pistillate, the base of the spike is commonly contracted; when above the pistillate, the upper scales are empty at maturity.

Staminate flowers borne at the top of the spike.

Perigynia plumb, nearly terete, pale green.

Perigynia strongly compressed.

Beak of perigynium much longer than the body. C. stipata.

Beak of perigynium shorter than the body.

Spikes somewhat paniculate; perigynia brown, biconvex.

Spikes aggregated into a head.
Stigmas 3; perigynia $12 \mathrm{~mm}$. long.
C. macrocephala.

Stigmas 2; perigynia much smaller.

Leaves equalling or exceeding the stem; head interrupted, 5-8 cm. long.

Leaves shorter than the stem; head densely ovoid.

Beak and top of perigynium rough on the angles.

C. cusickii.

C. tenella.

Beak and top of perigynium smooth.

Perigynia elliptic, narrowly wingmargined; seashore plant.

Perigynia ovate-lanceolate, not wing-margined; alpine plant.

Staminate flowers at the base of each spike or rarely scat-

C. vicaria.
C. hoodii.

C. pansa.

C. vernacula. tered.

Margins of perigynia not thin or winged.

Spikes crowded into a dense head.

Head pyramidal, 5-10 $\mathrm{mm}$. long; perigynia smooth on the margins.

Head oblong to ovoid, $15-30 \mathrm{~mm}$. long; perigynia strongly serrulate.

Spikes scattered.

Perigynium 4-4.5 mm. long.

Perigynium 2-2.5 $\mathrm{mm}$. long.

Perigynium not minutely puncticulate with

white dots, somewhat spongy at base.

Perigynium minutely puncticulate with white dots, not spongy at base.

Herbage glaucous; perigynia many, ascending, obscurely beaked.

Herbage green; perigynia few, spreading, distinctly beaked.

C. illota.

C. arcta.

C. bolanderi.

C. laeviculmis.

C. canescens.

C. brunnescens. 
Margins of perigynia thin or winged.

Perigynia spongy at base, spreading when mature. C. stellulata.

Perigynia not spongy at base, ascending or appressed.

Spikes crowded into a dense head, rarely one or two of the lower ones separate.

Bract leaf-like, longer than the head.

Bract not leaf-like, shorter than the head.

Perigynia brown, the margins very narrow and smooth.

Perigynia straw-colored, the margins winged and serrulate.

Head ovoid-pyramidal, very dense.

Head looser, some of the lower spikes of ten separate.

Spikes distinct, scattered or approximate, mostly oblong or ovoid.

Spikes scattered, silvery green.

Spikes approximate, straw-colored or brown.

Leaves involute or folded; heads often nodding; perigynia lanceolate.

Leaves flat; heads erect.

Heads straw-colored or pale-brownish; perigynia lanceolate.

Heads darker.

Scales ferruginous, dull; perigynia $4-4.5 \mathrm{~mm}$. long, reddish at the tip, the orifice not conspicuously white-hyaline.

Scales chestnut, shiny; perigynia $6 \mathrm{~mm}$. long, chestnut at the tip, the orifice conspicuously whitehyaline.

C. athrostachya.

C. illota.

C. pachystachya.

C. preslii.

C. feta.

C. phaeocephala.

C. scoparia.

\section{Section III. EUCAREX.}

Spikes of two sorts, the lower wholly pistillate, sessile or stalked, the upper one or two slender and wholly staminate, or sometimes bearing pistillate flowers at base or apex; stigmas 3 and akenes 3 -angled, or if stigmas 2 and akenes lenticular the lower spikes stalked.

Perigynia pubescent, the beak bidentate.

Cauline leaves present; bracts sheathing at base; perigynia ovoid, not stipitate; spikes dense, manyflowered.

Spikes loosely-flowered, approximate; stem not tall and slender.

Spikes densely-flowered, scattered; stem tall and slender.

Leaves flat, $2-5 \mathrm{~mm}$. broad.

Leaves involute, less than $2 \mathrm{~mm}$. broad.

C. leporina.

C. piperi.

Cauline leaves none, the radical numcrous; bracts sheath-
less; perigynia 3 -angled or subglobose, stipitate;

C. oregonensis.

Cauline leaves none, the radical numcrous; bracts sheath-
less; perigynia 3 -angled or subglobose, stipitate; spikes few-flowered.

Plant tufted; some of the flowering stems short and and hidden among the leaves; spikes pale.

Stems shorter than the leaves; lowest bract reddish and auricled at base; perigynia 1-4.

C. lanuginosa.

C. filiformis.

C. brevicaulis. 
Stems equalling or exceeding the leaves; lowest bract not colored nor auricled at base; perigynia 3-8.

C. rossii.

Plant stoloniferous; none of the flowering stems short and hidden among the leaves; spikes dark.

Perigynia obovoid, whitish.

Perigynia ellipsoid, brown at base.

C. vespertina.

C. verecunda.

Perigynia glabrous or merely granular-roughened.

Beak of membranaceous somewhat inflated perigynium deeply bidentate, the long teeth sharp and rigid; leaves conspicuously nodulose.

Pistillate spikes drooping.

Pistillate spikes erect or ascending.

Perigynia shiny, ascending, much inflated, Io $\mathrm{mm}$. long.

Perigynia not shiny, spreading, not much inflated, 4-8 mm. long.

Beak of perigynium wanting or if present entire or merely emarginate, or if bidentate the teeth short; leaves not conspicuously nodulose.

Stigmas 3 and akenes 3-angled.

Spikes narrowly cylindrical, 6-10 cm. long; perigynia granular, spreading; leaves $1-2 \mathrm{~cm}$. broad.

Spikes not so long and slender; perigynia smooth; leaves not so broad.

Perigynia spreading, the beak bidentate.

Perigynia not spreading, the beak entire or emarginate, scarcely bidentate.

Terminal spike pistillate above, staminate below.

Spikes erect; scales obtusish; perigynia inflated, $3 \mathrm{~mm}$. long.

Spikes more or less drooping; scales sharp-pointed; perigynium not inflated.

Scales acute or acuminate; perigynia nerveless, $3.5 \mathrm{~mm}$. long.

Scales mucronate; perigynia nerved, $5 \mathrm{~mm}$. long.

C. comosa.

C. exsiccata.

C. utriculata.

C. amplifolia.

C. oederi.

C. accedens.

c. atrata.

C. mertensii.

Terminal spike wholly staminate.

Pistillate spikes slender peduncled, usually drooping.

Scales acute or cuspidate, about as long as the perigynia.

Staminate spike linear; scales pale; leaves $1-3 \mathrm{~mm}$. broad; rootstock creeping.

Staminate spike oblong-cylindric; scales dark; leaves 4-8 $\mathrm{mm}$. broad, tufted.

Scales cuspidate or aristate, much

C. limosa. longer than the perigynia.

Perigynia broadly ovate to orbicular.

Perigynia elliptic-lanceolate.

C. paupercula.

C. macrochaeta.

Pistillate spikes erect.

Scales brown; leaves $2-5 \mathrm{~mm}$. broad. C. ablata.

Scales pale. 
Leaves 4-7 mm. wide; spike very loose.

Leaves $2 \mathrm{~mm}$. wide; spike dense.

Perigynium beakless; leaves glaucous.

Perigynium with a beak half as long as body; leaves not

Stigmas 2 and akenes lenticular. glaucous.

C. hendersonı.

C. livida.

C. californica.

Perigynium plump, not angled, beakless.

Mature perigynia subglobose or pyriform, not stipitate, glabrous, somewhat fleshy, translucent, strongly nerved.

Mature perigynia obovoid, stipitate, pulverulent, not fleshy nor translucent.

Perigynium compressed, plano-convex or biconvex, the beak entire or emarginate.

Scales pointed, longer than the perigynia.

Perigynia granular-roughened, 2-5 $\mathrm{mm}$. long; pistillate spikes slender, ascending, of ten cernuous; scales a little longer than the perigynia.

Perigynia not granular-roughened, $3 \mathrm{~mm}$. long; scales much longer than the perigynia.

Pistillate spikes nodding: perigynia elliptic, pale, dull, not turgid.

Pistillate spikes ascending or erect; perigynia nearly orbicular, dark, shiny, turgid.

Scales not longer than the perigynia; spikes erect.

Lowest leaves of the flowering stems reduced to sheaths.

Perigynia ovoid, $2 \mathrm{~mm}$. long; scales pale; pistillate spikes often very loose at base.

Perigynia ellipsoid, $3 \mathrm{~mm}$. long; scales dark; spikes dense.

C. aurea.

C. celsa.

C. sitchensis.

C. cryptocarpa.

C. magnifica.

C. interrupta.

C. nudata.

Lowest leaves of the flowering stems bearing blades.

Perigynia obscurely nerved; scales dark purple.

Beak of perigynium bent to one side.

Beak of perigynium straight.

Scales as long and broad as the perigynium.

Scales shorter and narrower than the perigynia.

Perigynia strongly nerved; scales purple.

C. scopulorum.

Scales not obtuse, about as long as the perigynia.

Spikes 1.5-2.5 cm. long; perigynia strong!y biconvex and brown when mature.

Spikes 3-4 cm. long; perigynia compressed, straw-colored.

C. rigida.

C. gymnoclada.
C. aperta.

C. angustata 
Scales obtuse or obtusish, purple with broad green midrib and pale margins; perigynia green or straw-colored.

Leaves 3-5 $\mathrm{mm}$. wide; staminate spikes often 2 .

Leaves 1-3 $\mathrm{mm}$. wide; staminate spike solitary.

Perigynium $2 \mathrm{~mm}$. long. $\quad$ C. kelloggii.
Perigynium $2.5-3 \mathrm{~mm}$. long.
Spikes scattered; perigynia
straight, appressed.
$\begin{aligned} & \text { Spikes aggregated; peri- } \\ & \text { gynia curved, spread- }\end{aligned}$
$\begin{array}{ll}\text { ing. } & \text { C. hindsii. }\end{array}$

Carex stenochlaena (Holm) Mackenzie. Tufted, glabrous, dioecious; stems erect, $15-40 \mathrm{~cm}$. high; leaves flat, 1-3 mm. wide, shorter than the stem; spike solitary, cylindric, erect, densely-flowered, 20-30 $\mathrm{mm}$. long; perigynia lanceolate, pubescent, 2-nerved, the short beak entire; scales dark brown, strongly ciliate, nearly as long as the perigynia.

In the mountains at about $2000 \mathrm{~m}$. altitude.

Carex breweri Boott. Tufted; culms 10-40 cm. high, smooth; leaves numerous, narrow, stiff, shorter than the stems; spike solitary, ovate to globular, obtuse, brown, 10-25 mm. long; staminate flowers at the top, few; perigynium ovoid, very thin, much inflated, finely nerved, short-beaked, 6-7 mm. long, the whitish orifice oblique; scales ovate, acute, hyaline-margined, shorter than the perigynium.

At high altitudes, Mount Hood and southward.

Carex paddoensis Suksdorf. Very similar to C. breweri; stems $10-15 \mathrm{~cm}$. high; leaves filiform, stiff, mostly exceeding the stems; heads solitary, darkbrown, ovoid and acute, about $1 \mathrm{~cm}$. long; perigynia elliptic-lanceolate, thin, not much inflated, obscurely nerved, $5 \mathrm{~mm}$. long, short-beaked; scales ovatelanceolate, acuminate, not hyaline-margined, about as long as the perigynia, firm, the tips spreading.

Mount Adams (by some called Mount Paddo), Suksdorf; abundant on Mount Rainier at $2700 \mathrm{~m}$. altitude, Piper, Allen.

Carex pauciflora Lightf. Rootstocks elongated; stems slender, 10-40 $\mathrm{cm}$. high; leaves shorter than the stem, flat, very narrow; spikelet solitary, few-flowered, staminate above; perigynia lanceolate, acuminate, obscurely nerved, green, $6-8 \mathrm{~mm}$. long, strongiy reflexed and readily deciduous when mature; stigmas 3 .

In bogs, rare in our limits.

Carex nigricans C. A. Mey. Rootstock creeping; stems 5-40 cm. high; leaves flat, $2 \mathrm{~mm}$. broad, shorter than the stems; spike solitary; staminate flowers many in the upper half of the spike; perigynia lanceolate, stipitate, spreading; scales dark brown, acute, about as long as the perigynia.

Common in the mountains above timber line.

Carex pyrenaica Wahlenb. Tufted; stems $5-15 \mathrm{~cm}$. high; leaves filiform, involute, longer or shorter than the stems; spike solitary, oblong, pale to dark brown; staminate flowers few at the summit of the spikes; perigynia lanceolate, stipitate, shiny, appressed; scales brown, acute, equalling the perigynia.

Common in the mountains at about $2500 \mathrm{~m}$. altitude.

Carex geyeri Boott. Densely tufted, $30-45 \mathrm{~cm}$. high; leaves flat, rigid, very scabrous, $2 \mathrm{~mm}$. wide, about as long as the stems; inflorescence a single 
terminal straw-colored spike, the upper and larger portion of which is staminate; pistillate flowers several, usually but one maturing; perigynium smooth, oblong, with a very short entire beak, 1-nerved on each side; scales pale or rusty, elongated, acuminate, exceeding the perigynia.

In dry pine woods.

Carex leptalea Wahlenb. Tufted, glabrous; stems very slender, erect, 15-50 $\mathrm{cm}$. high; leaves filiform, mostly shorter than the stems; spike solitary, linear, green, 5-15 mm. long; perigynia ellipsoid, contracted at base, many-nerved, smooth, beakless and obtuse; scales pale, ovate, cuspidate, about as long as the perigynia.

In bogs, not common.

Carex hepburni Boott. Densely tufted; stems filiform, erect, 5-20 cm. tall; leaves numerous, rigid, filiform, erect, mostly longer than the stems, their brownish sheaths persistent; spike solitary, 6-15 mm. long, $5 \mathrm{~mm}$. thick, brown; perigynium $4 \mathrm{~mm}$. long, lanceolate, pale, narrowed into a short serrulate bidentate beak; scales brown, obtuse, as long as the perigynia; stigmas 2 or 3 .

In the mountains at about $2500 \mathrm{~m}$. altitude. Very closely related to the European C. nardina Fries.

Carex circinata C. A. Mey. Tufted, glabrous; stems $5-20 \mathrm{~cm}$. high, usually curved; leaves filiform, firm, mostly curved, about as long as the stem; spike solitary, erect, $1-3 \mathrm{~cm}$. long; perigynium linear-oblong, faintly nerved, gradually attenuate into a 2-lipped scabrous-margined beak; scales linear, obtuse, purple except the white midrib; stigmas 2 or 3 .

Olympic Mountains, $2000 \mathrm{~m}$. altitude, Elmer; otherwise known only in Alaska.

Carex tenella Schkuhr. Loosely tufted; stems very slender, $20-50 \mathrm{~cm}$. high; leaves flat, soft, 1-2 mm. wide, shorter than the stem; spikes small, 1-6-flowered; bracts minute or wanting; perigynia ovoid, plump, many-nerved, smooth, the short beak entire; scales hyaline, ovate, acute, shorter than the perigynia.

In bogs, not common.

Carex stipata Muhl. Stems 50-100 cm. tall, sharp-angled; leaves flat, 6-8 $\mathrm{mm}$. wide, shorter than the stem; sheaths somewhat rugulose on the inner side; inflorescence a dense ovoid head of many crowded spikes, $3-5 \mathrm{~cm}$. long, straw-colored or olivaceous, commonly exceeded by the slender lowest bract; perigynia spongy at base, spreading, triangular-ovoid, many-nerved, each tapering into a stout 2-toothed serrulate beak, longer than the body; scales ovate, acuminate, much shorter than the perigynia.

Common in wet places in the woods.

Carex cusickii Mackenzie. (C. teretiuscula ampla Bailey.) Densely tufted, the slender stems $90-120 \mathrm{~cm}$. high; leaves narrow, 2-4 mm. broad, mostly shorter than the stems; spikes 6-20, brown, in elongated often nodding usually branched inflorescences, 5-12 cm. long; terminal florets staminate; perigynia spreading, ovoid, stipitate, nerved at the base on both sides, $3 \mathrm{~mm}$. long, the scrrulate beak as long as the thick body; scales brown, ovate, cuspidatc, as long as the perigynia.

In wet places, common.

Carex macrocephala Willd. (C. anthericoides Presl.) Dioecious; rootstocks extensively creeping, covered with the fibers of the old sheaths; stems stout, 3-angled, 15-30 cm. high; leaves firm, 3-10 mm. wide, mostly shorter than the stems; bracts shorter than the head; heads dense, brown, ovoid, erect, 5-7 cm. long; perigynia spreading, lanceolate, brown, strongly nerved, margined, irregularly serrulate, $12 \mathrm{~mm}$. long, the deeply bidentate beak as 
long as the body; scales lanceolate, erosely denticulate, attenuate-acuminate, brown with a paler midrib, shorter than the perigynia; stigmas 3 .

In sand dunes along the ocean coast.

Carex vicaria Bailey. Tufted; stems erect, slender, $30-90 \mathrm{~cm}$. high; leaves about as long as the stems, $2-5 \mathbf{m m}$. wide, their sheaths rugulose; lower bracts filiform, 1-4 cm. long; spikes rather loosely-flowered, 4-8 $\mathrm{mm}$. long, many in a narrow head 5-8 cm. long; perigynia yellow, broadly ovate, stipitate, indistinctly nerved on the inner face but conspicuously so on the back, the beak deeply bidentate, as long as the body; scales awn-pointed, brownish, shorter than the perigynia.

In wet meadows; very closely related to $C$. vulpinoidea Michx.

Carex hoodii Boott. Slender, erect, tufted, very smooth, 30-60 cm. high; leaves many, pale, 2-3 mm. broad, shorter than the stems; spikes 6-10, densely crowded into an ovoid or oblong head, 1-2 cm. long; perigynia spreading, lanceolate, rather thick, $5 \mathrm{~mm}$. long, dark when mature, obscurely nerved, narrowly wing-margined, somewhat stipitate at base, narrowed into a roughmargined beak nearly as long as the body; scales lance-ovate, acuminate, scarious margined, brownish, as long as the perigynia.

In moist places, not common. First found along the Columbia River by Douglas and by Scouler.

Carex pansa Bailey. Rootstocks horizontal, creeping; stems $15-30 \mathrm{~cm}$. high, erect, smooth except near the top; leaves pale, $2-3 \mathrm{~mm}$. broad, half the length of the stems; head ovoid, dark brown, consisting of 6-10 closely aggregated spikes; perigynia brown, elliptic, stipitate, flattened, smooth, narrowly winged, $4 \mathrm{~mm}$. long, the emarginate beak half as long as the body; scales ovate, acuminate, dark brown, scarious margined.

On old sand dunes along the ocean coast. First collected by Henderson at Clatsop, Oregon, and Ilwaco, Washington.

Carex vernacula Bailey. Stems $10-40 \mathrm{~cm}$. high, erect, scabrous; leaves flat, 2-4 mm. wide, long-pointed, shorter than the stems; bract leaf-like; spikes compacted into a globose or ovoid brown head, $1-4 \mathrm{~cm}$. long, or rarely one or more of the lower spikes distinct; perigynia membranaceous, lanceolate-ovate, shortly stipitate, narrowed into a stout bidentate beak; scales brown, acute or mucronate, shorter than the perigynia.

Mount Hood, Oregon, Howell.

Carex illota Bailey. Stems slender, erect, 15-40 cm. high; leaves flat, 1-2 mm. wide, shorter than the stems; spikes 3-6, compacted into an ovoid to globular brown head, 5-8 mm. in diameter; perigynia pale, plump, ovate, stipitate, strongly nerved, marginless, narrowed into a brown serrate bidentate beak shorter than the body; scales brown, obtuse, shorter than the perigynia.

In the mountains at about $2000 \mathrm{~m}$. altitude.

Carex arcta Boott. Loosely tufted, pale green; stems $20-60 \mathrm{~cm}$. high, smooth or nearly so; leaves pale green, $2.5-4 \mathrm{~mm}$. wide, usually longer than the stems; head ovoid-oblong, green or brownish, of 5-12 crowded spikes; spikes oblong or ovoid, 6-8 mm. long; perigynia spreading, ovate, somewhat cordate, gradually tapering into the serrulate beak, strongly nerved on the outer face, $2-3 \mathrm{~mm}$. long; scales hyaline, often brownish, acute, shorter than the perigynia.

In open rather dry woods.

Carex bolanderi Olney. Tufted, pale green; stems $20-100 \mathrm{~cm}$. long, rather slender, weak and spreading; leaves soft, smooth, 2-4 mm. wide, shorter than the stems; inflorescence of 4-10 scattered spikes; spikes oblong, 10-15 $\mathrm{mm}$. long, sessile or nearly so; perigynia lanceolate, faintly nerved, $4 \mathrm{~mm}$ : long, the body gradually tapering into the nearly equal serrulate deeply 2 -toothed beak; 
scales white, scarious, with a broad green midvein, ovate-lanceolate, acuminatecuspidate, as long as the perigynia.

In moist woods, common.

Carex laeviculmis Meinsch. Glabrous throughout, tufted; stems very slender, 30-50 cm. high; leaves numerous, flat, 1-1.5 mm. broad, shorter than the stems; spikes 3-7, sessile, 3-5 mm. long, separate, the lower ones distant; bract solitary, usually shorter than the inflorescence; perigynia spreading when mature, lanceolate, shortly stipitate, strongly curved, flat above, convex beneath, pale green, short-beaked, faintly 7 -nerved on each face, $2.5 \mathrm{~mm}$. long; scales ovate, obtuse, brownish, hyaline except the midrib, shorter than the perigynia.

In moist shady places in the mountains.

Carex canescens L. Loosely tufted, pale, somewhat glaucous; stems 15-50 $\mathrm{cm}$. high; leaves flat, soft, 2-4 mm. wide, mostly shorter than the stems; spikes 4-9, subglobose to cylindric, sessile, usually scattered in a loose inflorescence; perigynia oval to ovate, usually serrulate toward the tip, short-beaked; scales ovate, hyaline, shorter than the perigynia.

In moist places.

Carex brunnescens (Pers.) Poir. Tufted; stems slender, 15-50 cm. high, green; leaves flat, 1-3 mm. wide, shorter than the stem; spikes $3-7$, small, 4-10-flowered, scattered or approximate; lower bract bristle-like; perigynia ovoid, serrulate above, distinctly beaked, spreading when mature; scales ovate, brownish, shorter than the perigynia.

In open rather dry places in the mountains.

Carex stellulata Good. Tufted; stems very slender, $30-90 \mathrm{~cm}$. high; leaves narrow, 1-4 mm. wide, mostly shorter than the stems; inflorescence narrow, of 3-9 usually scattered spikes; spikes green, 12-40-flowered, the perigynia soon strongly reflexed; perigynia narrowly ovate, spongy at base, faintly nerved on the inner face, the margin thin but narrow, 3-4 $\mathrm{mm}$. long; scales brownish, ovate, acute, shorter than the perigynia.

In shady woods along streams; varies much in the size and proximity of the spikes.

Carex athrostachya Olney. Stems tufted, 30-60 cm. tall; leaves 2-3 mm. wide, shorter than the stems; inflorescence a dense ovoid straw-colored head composed of 5-20 crowded spikes, these staminate below; lower bracts $2-5 \mathrm{~cm}$. long, exceeding the head; perigynia lanceolate, spongy at base, the long beak 2-toothed, its margins serrulate; scales acuminate, about equalling the perigynia.

Rare in our limits but common east of the Cascade Mountains. Reported from Victoria, British Columbia, Macoun.

Carex pachystachya Cham. Stems tufted, 30-90 cm. tall; leaves flat, flaccid, 3-4 mm. broad, shorter than the stems; inflorescence a dense ovoid head 10-12 mm. long, composed of 6-12 crowded sessile brownish spikes; perigynia spreading, ovate-lanceolate, flat, about $4 \mathrm{~mm}$. long, the beak bidentate, serrulate on the thin margins; scales acutish, equalling the perigynia.

Very common in wet meadows.

Carex preslii Steud. (C. multimoda Bailey.) Very similar to $C$. pachystachya but the head less dense, one or more of the lower spikes clearly separate or if crowded the head oblong; perigynia indistinguishable.

Common in wet places up to $1500 \mathrm{~m}$. altitude. First collected by Haenke at Nootka Sound, British Columbia.

Carex feta Bailey. Stems slender, 60-80 cm. high; leaves flat, 1-2 mm. wide, shorter than the stem; spikes $3-8$, oblong, 5-10 $\mathrm{mm}$. long, distinct; 
perigynia broadly ovate, broad-winged, serrulate above, nerved, loosely arranged, $1.5 \mathrm{~mm}$. long; scales lanceolate, acutish, narrower than the perigynia but nearly as long.

In wet meadows, rare.

Carex phaeocephala Piper. Densely tufted, smooth throughout, pale green; stems $10-40 \mathrm{~cm}$. high; leaves mostly folded or involute, $2-3 \mathrm{~mm}$. wide, shorter than the stems, tough in texture and persistent when dry; bracts short, scarious; spikelets 3-7, distinct but crowded into an oblong-lanceolate erect or slightly nodding brown head $1-3 \mathrm{~cm}$. long, the lower spike often separated and short-peduncled, the other sessile; perigynia brown, lanceolate, wing-margined, the serrulate bidentate beak as long as the body; scales brown, acute, as long as the perigynia.

In rocky or sandy soil in the mountains, at about $2500 \mathrm{~m}$. altitude.

Carex scoparia Schkuhr. Stems erect, slender, 30-80 cm. high; leaves flat, 2-3 mm. wide, much shorter than the stems; bracts filiform; spikes 3-10, usually close together but distinct, oblong, pointed, straw-colored or brownish, 6-12 $\mathrm{mm}$. long; perigynium thin, appressed, broadly lanceolate, narrowly wingmargined, gradually tapering into a broad bidentate serrulate beak; scales acute or acuminate, shorter than the perigynia, pale brown.

In moist places, not common.

Carex leporina L. Tufted, slender, erect, $15-40 \mathrm{~cm}$. high, scabrous near the top; leaves shorter than the stems, $2-3 \mathrm{~mm}$. wide; bracts very small or absent; spikes 3-7, oblong-ovoid, dark brown, staminate at base, each 8-15 $\mathrm{mm}$. long, crowded into a head; scales lanceolate, acute, shining, brown with a scarious margin, about as wide and long as the perigynia; perigynia $4 \mathrm{~mm}$. long, ascending, narrowly ovoid, compressed, wing-margined, the roughish tapering 2-toothed reddish-tipped beak as long as the body; orifice not at all or but minutely hyaline.

Seattle, Piper; East Sound, Washington, Henderson; rare in our limits.

Carex piperi Mackenzie. (C. pratensis furva Bailey; C. furva Piper not Webb.) Stems slender, smooth, terete, stiffly erect, $40-60 \mathrm{~cm}$. high; leaves pale green, flat, $2-3 \mathrm{~mm}$. broad, much shorter than the stems; lower bract slender, shorter than the head; spikes 3-6, chestnut-brown, ovoid, acutish, 10-15 mm. long, close together in a head; scales chestnut-brown, shiny, lance-ovate, acute, thin margined, just exceeding the perigynia; perigynia ascending but not appressed, lanceolate, narrowly margined, $6 \mathrm{~mm}$. long, pale brown with chestnut-tipped 2-toothed beak and white hyaline orifice; beak gradually narrowed, as long as the body.

Damp meadows, Vancouver Island to Oregon.

Carex oregonensis Olney. Creeping with short rootstocks, glabrous, pale green; stems $30-40 \mathrm{~cm}$. high, smooth; leaves flat, $2-4 \mathrm{~mm}$. broad, pale, firm, scabrous on the margins, usually longer than the stems; bracts leaf-like with thin white auricles at base, the lower about as long as the inflorescence; spikes 4-7, erect, short-peduncled, close together, the upper 1-3 staminate; perigynia paler, ovoid, prominently nerved, pubescent, each gradually narrowed into the bidentate beak; scales pale, ovate, cuspidate, shorter than the perigynia, brown, except the hyaline margins and pale midrib.

In sandy ground in pine woods, mostly on the eastern slopes of the Cascade Mountains.

Carex lanuginosa Michx. Stems erect, slender, 30-60 cm. tall, roughangled; leaves flat, $2-5 \mathrm{~mm}$. wide, as long or nearly as long as the stem; staminate spikes $1-3$, sometimes pistillate at base; pistillate spikes $1-3$, mostly long-peduncled, $18-30 \mathrm{~mm}$. long; perigynia oval, densely pubescent, each with a short 2-toothed beak; bracts acute or acuminate, about equal to the perigynium. 
In wet meadows. Very similar to $C$. filiformis but stouter and with broader leaves.

Carex filiformis L. Stems slender, erect, $60-90 \mathrm{~cm}$. high, smooth, usually reddish at base; leaves involute, very narrow, scabrous on the margins, shorter than the stems; staminate spikes 1-3; pistillate 1-3, erect, sessile or shortpeduncled, $1-5 \mathrm{~cm}$. long; perigynia ovoid, densely short-pubescent, each with a short bidentate beak; scales ovate, thin, obtuse to acute, nearly as long as the perigynia.

In shallow water or wet meadows.

Carex brevicaulis Mackenzie. Loosely tufted, glabrous; stems $5-10 \mathrm{~cm}$. high, rough-angled; leaves $2-3 \mathrm{~mm}$. wide, flat, longer than the stems; bracts auricled and colored at base; spikes $3-5$, the terminal one staminate; the lower pistillate spike long-peduncled, the upper one or two sessile; perigynia pubescent, stipitate, globose, each abruptly contracted into a slender serrulate bidentate beak; scales ovate, acute or cuspidate, reddish brown, narrower and shorter than the perigynia.

In dry ground, Vancouver Island, British Columbia, to California; rare.

Carex rossii Boott. Densely tufted, the stems $20-40 \mathrm{~cm}$. tall; leaves pale, flat, scabrous, $1-3 . \mathrm{mm}$. wide, commonly equalling the stems; bracts not auricled at base; inflorescence of 1-4 spikes, the uppermost staminate; staminate spike slender, 3-8 $\mathrm{mm}$. long, pale, nearly sessile; pistillate spikes 1-3, distinct, loosely few-flowered; perigynia obovoid, pubescent, each with a 2 -toothed beak; scales purple with hyaline margins, or greenish, sharply acuminate, shorter and broader than the perigynia.

In stony soil, especially in the mountains.

Carex vespertina (Bailey) Howell. Rootstocks stout; stems erect, 20-50 $\mathrm{cm}$. high, rough-angled; leaves pale, $2-3 \mathrm{~mm}$. wide, firm, shorter than the stem; spikes $2-4$, the uppermost staminate, linear, $2-3 \mathrm{~cm}$. long, the others much smaller, sessile and separated; lower bract leaf-like, 1-3 cm. long; perigynia pale, obovoid, pubescent, the stout beaks deeply bidentate.

In rocky soil, Vancouver Island to Oregon; rather rare.

Carex verecunda Holm. (C. inops Bailey.) Rootstocks slender; stems erect, rough-angled, about $30 \mathrm{~cm}$. high; leaves narrow, rigid, much shorter than the stems; spikes 3 or 4 , sessile near the top of the stem, the terminal staminate, the others shorter and staminate at the top; perigynia pubescent above, ellipsoid, each abruptly narrowed into the slender deeply bidentate beak; scales brown with scarious margins, acute, about as long as the perigynia.

Known only from Mount Hood, Oregon, where it was first collected by Henderson.

Carex comosa Boott. Tufted, the stem stout, $50-150 \mathrm{~cm}$. high, rough and sharply angled; leaves broad, $6-15 \mathrm{~mm}$. wide, scabrous on the margins; spikes 4-6, drooping on slender peduncles, the uppermost staminate, linear, brownish, 3-9 cm. long, often partly pistillate; pistillate spikes pale green, cylindric, about $1.5 \mathrm{~cm}$. thick, densely flowered, of ten partly staminate; perigynia spreading, firm, lance-ovate, strongly many-nerved, each attenuate into a long 2-toothed beak, the teeth 1-2 mm. long and spreading; scales brownish, awned, about as long as the perigynia.

Usually in shallow water.

Carex exsiccata Bailey. Glabrous; stems $60-100 \mathrm{~cm}$. high, rough-angled; leaves flat, $2-5 \mathrm{~mm}$. broad, about as long as the stems; sheaths fibrillose; upper 3-4 spikes staminate; lower $2-4$ spikes pistillate, nearly sessile; cylindric, $2-5 \mathrm{~cm}$. long; perigynia straw-colored or brownish, slightly inflated, strongly 
nerved, ascending, lance-ovate, gradually narrowed into the bidentate beak; scales narrow, acute or acuminate, much shorter than the perigynia.

In swamps and often in shallow water; common.

Carex utriculata Boott. Glabrous; stems 40-100 cm. high, stout, smoothish, the angles obtuse; leaves flat, 2-10 $\mathrm{mm}$. wide, prominently nodulose, usually exceeding the stems; bracts similar; upper 2-4 spikes linear and staminate; lower 2-4 spikes pistillate, cylindric, erect, densely-flowered, peduncled, 3-12 cm. long; perigynia narrowly ovoid, somewhat inflated, each gradually narrowed into a slender bidentate beak, straw-colored or brownish, 5-10 mm. long; scales lanceolate, acute or the lower awn-pointed.

In swamps; common. By some botanists united with the European C. rostrata Stokes, from which it is scarcely distinct.

Carex amplifolia Boott. Stems $30-90 \mathrm{~cm}$. tall, scabrous on the sharp angles; leaves flat, $12-20 \mathrm{~mm}$. broad, longer than the stem; spikes $5-7$, the uppermost staminate, $5-8 \mathrm{~cm}$. long; pistillate spikes narrowly cylindrical, straight or curved, 6-10 cm. long, dark olivaceous, the lower ones long-peduncled; perigynium subglobose, glabrous, the beak with an oblique entire orifice, spreading, rusty; scales purple with a green midrib, shorter and narrower than the perigynia.

In wet places in woods; common. First collected by Douglas on the Columbia River.

Carex oederi Retz. (C. flava recterostrata Bailey). Glabrous, tufted; stems $10-40 \mathrm{~cm}$. high, erect; leaves $1-3 \mathrm{~mm}$. wide, often exceeding the stems; bracts leaf-like; spikes 3-10, the uppermost staminate; pistillate spikes sessile or short-peduncled, of ten close together, 5-15 $\mathrm{mm}$. long, the upper ones often staminate at the top; perigynia spreading, plump, broadly oval, each narrowed at base and contracted into a bidentate beak much shorter than the body; scales ovate, obtuse, much shorter than the perigynia.

In wet places, not common.

Carex accedens Holm. (C. spreta Bailey.) Glabrous; stems 40-50 cm. high, erect, scabrous; leaves flat, $2-4 \mathrm{~mm}$. broad, shorter than the stems; pistillate spikes 2 or 3 , oblong to ovoid, about $1 \mathrm{~cm}$. long, sessile, contiguous; perigynia broadly ellipsoid, thin, green, nerveless, minutely punctate, the very short beak entire; scales black with white nerves, obtuse, not as broad as the perigynia.

In wet meadows, especially where overflowed; not common. First collected near Portland, Oregon, by Howell.

Carex atrata L. Tufted; stems erect or nodding above, $20-40 \mathrm{~cm}$. high; leaves flat, 3-4 mm. wide, shorter than the stems; lowest bract nearly as long as the inflorescence; spikes 3-5, close together, oblong, densely-flowered, 1-2 $\mathrm{cm}$. long, the terminal one staminate at the base, all peduncled; perigynia oval or obovate, yellowish sprinkled with purple, each contracted at base and abruptly narrowed into a short bidentate beak; scales ovate, acute, dark purple with hyaline margins, longer than the perigynia.

Mount Rainier, Allen; Mount Adams, Flett.

Carex mertensii Prescott. Stems 40-90 cm. high, sharply angled; leaves flat, 3-7 $\mathrm{mm}$. broad, much shorter than the stems, conspicuously sheathing; bracts leaf-like, sheathless or nearly so, the lower exceeding the inflorescence; spikes 5-8, 2-5 cm. long, densely flowered, drooping on slender peduncles, more or less staminate at base, the upper one sometimes entirely staminate; perigynia broadly ovate, winged, very flat, pale, few-nerved, appressed; scales dark purple with pale midrib, shorter than the perigynia; stigmas 3 .

Along streams in the mountains, $1000-1500 \mathrm{~m}$. altitude. A very handsome species, first found by Mertens at Sitka, Alaska. 
Carex limosa L. Stoloniferous; stems rough-angled, slender, $15-40 \mathrm{~cm}$. high; leaves somewhat glaucous, mostly shorter than the stems, 1-3 mm. wide; bracts shorter than the inflorescence; terminal spikes staminate, erect, linear; pistillate spikes $1-3$, drooping on slender peduncles, $0.5-2 \mathrm{~cm}$. long; perigynia ovoid, flattened, narrowed at base, very short-beaked, glaucous; scales brownish, ovate, acute or short-cuspidate, slightly exceeding the perigynia.

In sphagnium bogs.

MtAdams Carex spectabilis Dewey. (C. invisa Bailey.). Glabrous; stems tufted, slender, 40-60 cm. high, erect, sharp-angled; leaves flat and smooth, 4-8 $\mathrm{mm}$. broad, nearly as long as the stems; bracts leaf-like, $4 \mathrm{~mm}$. wide, without sheaths, nearly equalling the inflorescence; spikes 3-6, short-cylindric, erect or nodding, sessile or the lower ones variously peduncled, the upper one staminate; pistillate spikes cylindric, $1-2.5 \mathrm{~cm}$. long, of ten loosely flowered at base, sometimes staminate at tip; perigynia ovate-elliptic, green with purple specks, few-nerved, flat, the short beak emarginate at orifice; scales dark-purple with white midvein, mucronate, shorter than the perigynia.

Common in high mountain meadows.

Carex paupercula Michx. Stems slender, 20-60 cm. high, the angles sharp and usually rough; leaves flat, $2-4 \mathrm{~mm}$. wide, usually shorter than the stem; bracts leaf-like, the lowest usually longer than the inflorescence; terminal spike staminate; lateral spikes 1-4, pistillate, slender-peduncled, sometimes drooping, 1-2 cm. long; perigynia ovoid, flattened, constricted at each end, glaucous; scales ovate-lanceolate, aristate, much longer than the perigynia, usually brownish.

Vancouver Island, Macoun. A widely spread species that has usually been referred to C. magellanica Lam.

Carex macrochaeta C. A. Mey. Loosely tufted, glabrous; stems 30-60 $\mathrm{cm}$. high, mostly rough-angled; leaves flat, firm, $2-4 \mathrm{~mm}$. wide, mostly shorter than the stems; spikes $3-5$, the lower ones nodding on slender peduncles, the upper one or two staminate and erect; pistillate spikes often staminate at top, cylindric, $2-3 \mathrm{~cm}$. long; perigynia elliptic, each with a very short entire beak, pale sprinkled with purple dots, $4-5 \mathrm{~mm}$. long; scales black, the white midrib prolonged into a long awn; stigmas 2 or rarely 3.

Multnomah Falls, Oregon, Piper. Rare in our limits.

Carex ablata Bailey. Stems slender, $30-60 \mathrm{~cm}$. high, smooth; leaves pale, flat, $2-5 \mathrm{~mm}$. wide, much shorter than the stems; bracts sheathing at base, usually much shorter than the inflorescence; spikes usually $5-7$, approximate, sessile, the lower ones often distant, the upper pistillate spikes cylindric, 1-2 $\mathrm{cm}$. long; perigynia lanceolate, obscurely nerved, pale green, glabrous, bidentate at apex; scales acutish, shorter than the perigynia, brown with a green midrib.

Common in the mountains at $2000 \mathrm{~m}$. altitude.

Carex hendersoni Bailey. Tufted, glabrous; stems slender, smooth, 60-90 $\mathrm{cm}$. high; leaves flat, 4-7 mm. broad, shorter than the stems; bracts leaf-like, exceeding the inflorescence; terminal spike linear, staminate, about $2 \mathrm{~cm}$. long; pistillate spikes about 4 , loosely-flowered, the upper one sessile, the lowest one distant and long-peduncled; perigynia 5-6 mm. long, triangular-ovoid, stipitate, green, strongly nerved, each tipped with an oblique beak half as long as the body; scales with a broad scarious margin, cuspidate, pale, shorter than the perigynia.

In rich woods. Named after Professor L. F. Henterson who found it near Portland, Oregon.

Carex livida (Wahlenb.) Willd. Creeping with long stolons; herbage glaucous; stems $15-50 \mathrm{~cm}$. high; leaves folded or involute, about $2 \mathrm{~mm}$. wide, shorter 
than the stems; bracts short, the lower about equalling the inflorescence; spikes $1-4$, the upper staminate; pistillate spikes sessile or the lower one stalked, erect; perigynia ovoid, narrowed at each end, faintly nerved, beakless, pale; scales ovate, obtuse, brownish, shorter than the perigynia.

In bogs, Alaska to Oregon. Port Renfrew, Vancouver Island, Brand \&。 Rosendahl.

Carex californica Bailey. Glabrous; stems arising from stout rootstocks, erect, $30-40 \mathrm{~cm}$. high, sharp-angled, smooth, the leafless basal sheaths purple; leaves flat, narrow, $2 \mathrm{~mm}$. wide; bracts sheathing, the lowest not equalling the stem; spikes 2 or 3 , the upper 1 , rarely 2 , staminate; pistillate short-peduncled, 2-3 cm. long; perigynia green, oblong-ovoid, each with a short entire beak; scales brownish, mostly obtuse, shorter than the perigynia; stigmas 3.

Rare. Skamania County, Washington, Suksdorf, to Mendocino County, California.

Carex aurea Nutt. Stems arising from long horizontal rootstocks, 10-30 $\mathrm{cm}$. high; leaves flat, pale green, 3-4 $\mathrm{mm}$. wide, usually overtopping the stems; bracts mostly exceeding the stem; spikes 3-6, all stalked, the uppermost staminate and linear, or rarely androgynous, the rest pistillate, narrowly cylindrical, loosely flowered, 1-3 cm. long; perigynia globose, very minutely beaked, reddish when mature, strongly nerved; scales brownish, ovate, obtuse, acute or cuspidate, mostly shorter than the perigynia.

In low meadows, not common.

Carex celsa (Bailey) Piper n. comb. (C. aurea celsa Bailey; C. hassei Bailey.) Very similar to $C$. aurea; spikes rather compactly flowered; perigynia obovoid, faintly nerved, short-stipitate, beakless; scales ovate, mostly obtuse, brown with a pale midrib, shorter than the perigynia. All.

In wet meadows, not common. Very similar to the European $C$. bicolor

Carex sitchensis Prescott. ( $C$. howellii Bailey.) Glabrous; stems stout, 1-2 $\mathrm{m}$. high, rough angled; leaves $5 \mathrm{~mm}$. broad, nearly as long as the stems; sheaths becoming brown and papery; staminate spikes 2 or 3 , erect, peduncled; pistillate spikes $3-5$, cylindric, densely flowered, 5-10 cm. long, usually cernuous, peduncled, the upper ones often staminate at top; perigynia elliptic, granular, nerved, each narrowed into a short entire beak; scales linear-lanceolate, a little longer than the perigynia, acuminate, brown with a white hyaline tip.

Near the ocean coast in marshes, Alaska to Oregon.

Carex cryptocarpa C. A. Mey. Somewhat tufted, glabrous; stems 30-90 $\mathrm{cm}$. high, sharp-angled, rough above; leaves flat, 2-5 $\mathrm{mm}$. broad, shorter than the stems; spikes 3-5, all more or less drooping on slender peduncles; staminate spikes 2 or 3 ; pistillate spikes mostly staminate at apex, $2-5 \mathrm{~cm}$. long; perigynia elliptic or oval, scabrous on the margins above, straw-colored, each with a short entire beak; scales dark, oblong-lanceolate, acute, much longer than the perigynia.

Abundant in marshes near the seashore.

Carex magnifica Dewey. Tufted, glabrous; stems stout, very sharp-angled and rough, 1-1.5 m. high; leaves pale, harsh and stiff, strongly keeled, 3-6 $\mathrm{mm}$. broad; spikes 5-7, dark purple, usually ascending, 2-6 cm. long; upper one or two wholly staminate, the others mainly pistillate but usually staminate at top; perigynia firm, brownish, nearly orbicular, nerveless, very short beaked, $2.5 \mathrm{~mm}$. long; scales dark purple, acute, much longer than the perigynia.

Very common especially in the marshes near the seashore. In most botanical works it has been taken for the very different $C$. sitchensis Prescott. 
Carex interrupta Boeckl. Stoloniferous; stems $40-50 \mathrm{~cm}$. high, slender, smooth; leaves $2-3 \mathrm{~mm}$. broad, flat; shorter than the stems; sheaths fibrillose; lowest bract leaf-like, nearly as long as the inflorescence; terminal spike and sometimes the next one staminate, $1.5-2.5 \mathrm{~cm}$. long; pistillate spikes 3 or 4 , narrowly cylindric, sessile or short-pedicelled, erect, 1-7 cm. long, densely flowered near the top, but often very loosely scattered toward the base; perigynia green or straw-colored, ovate, $2 \mathrm{~mm}$. long, smooth or with a few teeth near the top, the beak short and bidentate; scales ovate, obtuse, pale or brownish, longer than the perigynia.

Wet meadows and stream banks. First collected by Scouler on the lower Columbia River.

Carex nudata W. Boott. Tufted, glabrous; stems slender, $30-40 \mathrm{~cm}$. high, scabrous on the angles; leaves flat, 2-5 mm. broad, shorter than the stems, their sheaths slightly fibrillose; bracts with purple auricles at base, sheathless, the lower rarely equalling the inflorescence; spikes 4 or 5 , cylindric, $1-2.5 \mathrm{~cm}$. long, erect, peduncled, mostly contiguous; perigynia narrowly ellipsoid, strawcolored or often purple at tip, faintly nerved, finely punctate, quickly deciduous, $3 \mathrm{~mm}$. long; scales dark purple, mostly oblong and obtuse, about equalling the perigynia.

Along mountain streams, infrequent.

Carex scopulorum Holm. Stoloniferous, glabrous; stems $10-40 \mathrm{~cm}$. high, erect, scabrous, leafy at the base; leaves flat, shorter than the stems; bracts with black auricles, the lower nearly as long as the inflorescence; spikes 2-7, cylindric, 1-2 cm. long, ascending, the upper ones contiguous; terminal spike mostly staminate; perigynia stipitate, obovoid, turgid, 2-nerved, granular and purplish toward the tip, the short entire beak bent to one side; scales ovate, acute, black with a pale midrib; stigmas 2 .

Wet mountain meadows, abundant.

Carex rigida Good. Rhizomes stout, rather short; stems $30-50 \mathrm{~cm}$. high, stiff, erect, scabrous; leaves flat, $3-5 \mathrm{~mm}$. broad, mostly crowded near the base, shorter than the stem; bract black-auricled at base; spikes nearly black; staminate linear, 5-15 mm. long; pistillate 2, rarely 3, short-cylindric, sessile, erect, the lower in the axil of the bract, the upper often partly staminate; perigynia firm, nerveless, elliptic to obovoid, plano-convex, short-beaked, speckled with black near the tip, 2.5-3 mm. long; scales black, obtuse, as long as the perigynia.

A variable species; common in wet alpine meadows at about $1700 \mathrm{~m}$. altitude.

Carex gymnoclada Holm. Stoloniferous, glabrous; stems $30-50 \mathrm{~cm}$. high, erect, scabrous, leafless; leaves narrow, flat, as long as the stems; bracts sheathless, the lower nearly as long as the inflorescence; spikes usually 3 , cylindric, about $1 \mathrm{~cm}$. long, sessile or nearly so, erect, the terminal one staminate: perigynia ovate to oval, stipitate, faintly 2 -nerved, pale-green, the short beak entire; scales oval, acutish, black with a pale midrib, shorter than the perigynia; stigmas 2.

In mountain bogs, rare.

Carex aperta Boott. (C. bovina Howell.) Tufted, smooth throughout; stems $30-60 \mathrm{~cm}$. high; leaves flat but keeled, 4-6 mm. broad, rather shorter than the stems, pale green; spikes 3 or 4 , the terminal staminate, mostly short peduncled, erect; pistillate spikes $1-3 \mathrm{~cm}$. long, densely flowered, $5 \mathrm{~mm}$. thick; scales equalling the perigynia, acuminate, purple with a green midrib, divaricate at maturity; perigynia $2 \mathrm{~mm}$. long, turgid, broadest at the middle, tapering to each end, brown when mature, the two or three angles pale; beak short and entire.

This is the common "hay sedge" of the Columbia River bottoms where it was first collected by Douglas. 
Carex angustata Boott. (C. acutina Bailey.) Tufted, glabrous, pale green; stems $50-60 \mathrm{~cm}$. high, usually scabrous above; leaves flat, thin, equalling or shorter than the stems; lower bract as long as the inflorescence; spikes 4 or 5 , cylindrical, erect, approximate, 3-7 cm. long, the upper one or two staminate; perigynia oval or elliptic, thin, straw-colored, granular, faintly nerved, the short beak entire; scales obtuse, almost as long as the pergynia, not divaricate at maturity.

Infrequent; Portland, Oregon, Kellogg \& Harford; Mount Hood, Oregon, Henderson.

Carex dives Holm. Stems 30-60 cm. high, erect, very rough; leaves flat, broad, as long as the stems; bracts sheathless, leaf-like, the lowest exceeding the inflorescence; spikes $6-7$, the uppermost one or two staminate, the others pistillate, densely flowered, $4-10 \mathrm{~cm}$. long, peduncled, the lowest nodding; perigynia oval, compressed, granular, 2-nerved, denticulate above, $2.5 \mathrm{~mm}$. long, pale green with purplish blotches, the beak short and entire; scales oblong, purple with green midvein; stigmas 2 .

In swamps, British Columbia to California; rare.

Carex kelloggii Boott. Stems tufted, slender, $15-40 \mathrm{~cm}$. tall, erect; leaves numerous, flat, $2-3 \mathrm{~mm}$. wide, commonly as long as the stem, sometimes longer; spikes $4-15$, the bracts commonly exceeding the stem; staminate spike usually single, slender, purplish; pistillate spikes 3-many, mostly sessile or nearly so, greenish, dense, $2-4 \mathrm{~cm}$. long, $3 \mathrm{~mm}$. thick; perigynia ovate, plane, promptly deciduous, $2 \mathrm{~mm}$. long, smooth, flattened, 3 - or 4-nerved on the outer face, stipitate at the base, short-beaked, the beak emarginate; scales green with purple margins, obtusish, shorter than the perigynia.

On wet stream banks and lake shores, common.

Carex lenticularis Michx. Glabrous, tufted; stems erect, 30-60 cm. high; leaves $1-3 \mathrm{~mm}$. wide, equalling or exceeding the stems; lower bract sheathing, exceeding the spikes; spikes $3-8$, narrowly cylindric, $1-4 \mathrm{~cm}$. long, erect, close together, sessile or the lower short-peduncled; perigynia ovate, minutely granulate, faintly nerved, pale green or the nerves brownish, each with a very short entire beak; scales obtuse, green with broad hyaline margins, much shorter than the perigynia.

Rare in our limits.

Carex hindsii Clarke. Very similar to C. kelloggii; pistillate spikes 3 or 4 , stouter, $1-3 \mathrm{~cm}$. long, $5 \mathrm{~mm}$. thick; perigynia pale green, lanceolate, stipitate, curved and spreading, smooth, 7-nerved on the back, 5-nerved on the anterior face, flat and empty above, the short beak entire, $3 \mathrm{~mm}$. long; scales obtuse, purple with the midrib and margin pale.

Along the ocean coast, Vancouver Island to Oregon. First found at the mouth of the Columbia River by Hinds.

\section{CYPERUS.}

Annual or perennial; stems simple, 3-angled, leafy near the base, and with one or more leaves at the summit which form an involucre for the simple or compound umbellate or capitate inflorescence; rays of the umbel sheathed at the base, usually very unequal, one or more of the heads or spikes commonly sessile; spikelets flat or roundish, few to many-flowered; scales concave, 2-ranked, all but the lower one flower-bearing; flowers perfect; perianth none; stamens 1-3; akene lenticular or 3-angled.

Rachis wingless; scale tipped with a recurved awn.

Rachis winged; scale merely mucronate.

C. inflexus.

C. erythrorhizos. 
Cyperus inflexus Muhl. Annual; stems 1-15 cm. tall, ascending; leaves about $1 \mathrm{~mm}$. wide, often curved, about as long as the stems; bracts much longer than the inflorescence; spikelets ovate-lanceolate, 3-5 mm. long, in dense heads, umbellately arranged on unequal rays; scale green or brownish, the awn-like tip strongly recurved; stamen 1.

On river banks, rare. Somas Falls, Vancouver Island, Macoun; Kalama, Washington, Piper.

Cyperus erythrorhizos Muhl. Annual; stems usually 15-60 cm. tall, sometimes much smaller; leaves flat, commonly $2-4 \mathrm{~mm}$. broad, shorter than the stem; involucral leaves $4-8$, broad at base, far exceeding the inflorescence; spikelets bright chestnut, linear, 5-6 mm. long, densely crowded into flattened spikes, $1-3 \mathrm{~cm}$. long, the latter umbelled on the unequal branches of the primary umbel; scales oblong, keeled, the green midrib prolonged into a short mucronate tip; wings of the rachis separating to the base, forming pairs of small scales.

River banks, rare in our limits. Vancouver, Washington, Sheldon.

\section{DULICHIUM.}

Tall perennials with cylindrical jointed stems, leafy to the top; lower leaves reduced to sheaths; spikes axillary, peduncled, simple or compound; spikelets 2-ranked, flat, linear, manyflowered; scales 2-ranked; flowers perfect; perianth of 6-9 backwardly barbed bristles.

Dulichium arundinaceum (L.) Britt. Stems stout, 30-90 cm. tall, leafy; spikelets linear, $1-2.5 \mathrm{~cm}$. long, 6-10-flowered.

Borders of lakes and ponds, common.

\section{RYNCHOSPORA.}

Mostly leafy perennials with rootstocks, erect, 3 -angled or cylindrical stems and flat or inrolled leaves; spikelets variously clustered; scales thin, overlapping all around; upper flowers imperfect, the lower perfect; perianth of $1-20$, mostly 6 , barbed bristles, or none.

Rynchospora alba (L.) Vahl. Stems slender, 15-40 cm. high; leaves filiform, shorter than the stem; spikelets white, in 1-3 densely crowded corymbs; akene oblong-obovoid, tipped with a flattened triangular tubercle about half as long; bristles longer than the akene.

In sphagnum bogs, rare in our limits.

98. ELEOCHARIS. SPIKE RUSH.

Annual or perennial; stems simple, triangular, quadrangular, terete, flattened or grooved, the leaves reduced to sheaths or the lowest very rarely blade-bearing; spikelets solitary, terminal, erect, several-many-flowered, not subtended by an involucre; scales concave, in a spiral; perianth of 1-12 bristles usually barbed; stamens 2 or 3; akene 3-angled or biconvex; base of the style persistent on the summit of the akene forming a terminal tubercle. 
Styles 2-cleft; akenes biconvex.

Tubercles constricted basally; perennial with rootstocks.

Tubercles not constricted basally; annual, tufted.' Styles 3-cleft; akenes 3-angled.

Tubercles broad and short; akenes ribbed. $\quad E$. acicularis.

Tubercles subulate; akenes smooth.

E. palustris.

E. obtusa.

E. rostellata.

Eleocharis palustris (L.) Roem. \& Schult. Rootstocks extensively creeping; stems $30-70 \mathrm{~cm}$. tall; spike lanceolate-oblong, 1-2 cm. long; bristles 4, usually exceeding the obovate smooth biconvex akene; tubercle obtuse, contracted at its junction with the akene; style 2-cleft.

Abundant in wet ground and in shallow water.

Eleocharis obtusa (Willd.) Schult. Stems erect or ascending, densely tufted, 5-7 $\mathrm{cm}$. high; spikelets brownish, ovoid, obtuse, $2-13 \mathrm{~mm}$. long; bristles $6-8$, exceeding the brown shining akene; tubercle very short and broad, deltoid, acute.

In wet places, quite common.

Eleocharis acicularis (L.) Roem. \& Schult. Perennial by creeping rootstocks, usually forming extensive mats; stems very slender, $7-15 \mathrm{~cm}$. tall, erect; spikes 3-10-flowered, 3-5 mm. long; bristles 3 or 4 , shorter than the akene or wanting; akene oblong or obovoid, somewhat 3-angled, marked with 9-12 longitudinal ribs, with very numerous cross-lines between them; tubercle broad, contracted at its junction with the akene; style 3-cleft.

Abundant on the margins of ponds often forming a sward.

Eleocharis rostellata Torr. Perennial, the sterile shoots decumbent and rooting at the tips; fertile erect, wiry, $30-60 \mathrm{~cm}$. high; spikelets fusiform, 12-20-flowered; bristles longer than the akenes.

In marshes, rare. Vancouver Island, Macoun; Skamania County, Suksdorf.

\section{SCIRPUS.}

Annual or perennial; stems leafy or the leaves reduced to basal sheaths; spikelets terete (in ours), solitary, or in a terminal cluster which is subtended by a 1-several-leaved involucre; scales in a spiral, usually all fertile, one or two of the lowest sometimes empty; flowers perfect; perianth of 1-6 bristles, or sometimes none; stamens 2 or 3 ; style 2 or 3 -cleft, not swollen at the base; akene triangular, lenticular or plano-convex.

Spikelets solitary, terminal.

Involucral bract wanting.

Involucral bract present.

Bract 2-3 times as long as the spikelet.

S. nanus.

Bract not longer than the spikelet.

Perianth bristles none.

Perianth bristles 6 , smooth.

Spikelets several-many, rarely solitary.

S. subterminalis.

S. riparius.

S. cespitosus.

Stems terete; inflorescence umbellate.

Akenes $2.5-3 \mathrm{~mm}$. long, the scales one-fourth longer. S. occidentalis.

Akenes $2 \mathrm{~mm}$. long, the scales little longer. $\quad S$. validus.

Stems three-angled.

Involucral leaf solitary.

Involucral leaves several.

Spikelets 1-2 cm. long.

Spikelets 3-5 mm. long.

S. americanus.

S. robustus.

S. microcarpus. 
Scirpus nanus Spreng. Densely tufted, the stems flattened and grooved, 1-6 cm. high; roots with minute tubers; spikelet ovoid, greenish, bearing 2-4 or rarely more florets; scales acutish, the lowest usually larger; bristles when present longer than the smooth shining akene.

Common on brackish shores, but rarely blooming.

Scirpus subterminalis Torr. Usually aquatic; stems $30-90 \mathrm{~cm}$. high; bract appearing like a constriction of the stem; bristles 6 , barbed, shorter than the akene.

In mountain ponds, rare. Mount Mark, Vancouver Island, Macoun; Mount Adams, Howell, Suksdorf.

Scirpus riparius (R. Br.) Spreng. Stems tufted, 5-15 cm. high; spikelets oblong-ovate, 3-5 mm. long, pale brown; akenes obovoid, 3-angled, smooth dark-brown, $1 \mathrm{~mm}$. long.

In marshy places along the seashore. Seattle, Piper; Whidby Island, Gardner.

Scirpus cespitosus L. Densely tufted, the stems $10-30 \mathrm{~cm}$. high; spikelets oblong-ovate, pale brown, about $4 \mathrm{~mm}$. long; akenes oblong, 3-angled, smooth, brown, exceeded by the 6 smooth bristles.

Sub-alpine bogs, rare.

Scirpus occidentalis (Wats.) Chase. Western Bulrush or Tule. Stems 1-2 m. high, from stout scaly rootstocks; panicle loose, the suberect slender branches $1-9 \mathrm{~cm}$. long, slender; spikelets mostly in clusters of $2-7$, pale brown, subcylindric, 10-20 mm. long; scales oblong-ovate, viscid near the apex, aristate.

In shallow water along lake margins, very common and abundant.

Scirpus validus Vahl. Very similar to S. occidentalis; spikelets ovoid, 5-10 mm. long; scales broadly ovate, mucronate, somewhat pubescent; akene obovoid, plano-convex, $2 \mathrm{~mm}$. long. ward.

Rare in our limits, reported from Vancouver Island, Macoun; common east-

Scirpus americanus Pers. Stems sharply 3-angled, 20-90 cm. high, from stout elongated rootstocks; leaves 1-4, shorter than the stem, channeled; bract $2-10 \mathrm{~cm}$. long, pointed; spikelets $1-6$, ovoid, closely crowded; scales brown, ovate, 2-cleft at apex and often awned; bristles $2-6$, shorter than the plano-convex smooth akene.

In brackish marshes, infrequent.

Scirpus robustus Pursh. Stems stout, often $1 \mathrm{~m}$. tall; leaves about as long as the stem; spikelets brown, ovoid or oblong-ovoid, acutish, 10-20 mm. long; scales ovate, notched and awned.

Along the seashore, quite common.

Scirpus microcarpus Presl. Perennial, the stout stems about $1 \mathrm{~m}$. tall; leaves $8-10 \mathrm{~mm}$. broad, smooth beneath, rough on the margins and upper surface of the midvein, the upper leaf usually exceeding the stem; inflorescence a two to three times compound umbel, the primary rays $3-10 \mathrm{~cm}$. long, unequal; bracts leaf-like, about equalling the inflorescence; spikelets ovoid, numerous, dark green, 3-5 mm. long, in heads of 3-12 or more; scales broadly ovate, acute; stamens 2 ; styles bifid; bristles 4 ; nutlet white, oblong-lenticular, very short-beaked.

Common in wooded swamps.

100. ERIOPHORUM. COTTON-GRASS.

Bog perennials with rootstocks and erect triangular or nearly cylindrical stems; leaves linear or one or two of the upper ones 
reduced to bladeless sheaths; spikelets terminal, solitary, or in heads or umbels, with or without a 1-several-leaved involucre; scales in a spiral, overlapping; flowers perfect; perianth of 6 or numerous thread-like smooth soft bristles which project much beyond the scales at maturity.

Spikelets solitary; involucral bracts wanting.

Bristles copper-colored.

Bristles white.

E. chamissonis.

E. chamissonis albidum.

Spikelets several, subtended by 1 or more bracts; bristles white.

Leaves 3-sided; bract solitary; akene linear.

Leaves flat; bracts 2 or 3 ; akene obovoid.

E. gracile.

E. polystachion.

Eriophorum chamissonis C. A. Mey. Stems solitary, 20-40 cm. high; leaves very narrow, 3 -angled, channelled; spikelet erect; akenes oblong, acute; bristles $2-3 \mathrm{~cm}$. long, rusty or cinnamon-colored.

In sphagnum bogs, not rare.

Eriophorum chamissonis albidum (Nyl.) Fernald. Bristles white. Vancouver Island and eastward.

Eriophorum gracile Koch. Stems very slender; leaves very narrow, 3 -angled, channelled; scales mostly blunt at the tip; bristles white, $1.5-2 \mathrm{~cm}$. long.

In sphagnum bogs.

Eriophorum polystachion L. Stems rather stout; leaves linear, flat; spikelets several, nodding; scales acute; bristles white, $2-3 \mathrm{~cm}$. long.

In bogs, especially in the mountains.

\section{Family 18. ARACEAE. ARUM FAMILY.}

Plants with acrid or pungent juice and simple or compound leaves; flowers crowded on a spadix, perfect, monoecious or dioecious; spathe present or none; perianth of 4-6 sepals or none; fruit usually a $1-4$-celled 1 -seeded berry.

\section{LYSICHITON.}

Acaulescent swamp herbs with large leaves from a thick horizontal rootstock; spathe sheathing at base, with or without a broad colored lamina, at first enveloping the cylindrical spadix which later becomes exserted on a stout peduncle; flowers perfect, crowded, covering the spadix; perianth 4-lobed; stamens 4, opposite the perianth-segments; ovary 2-celled, 2-ovuled; fruits fleshy, somewhat immersed in the rachis and coalescent.

Lysichiton camtschatcense (L.) Schott. Yellow Skunk Cabbage. Leaves large, 30-90 cm. long, oblong, acute or acutish, narrowed at base into a short margined petiole; spathe golden-yellow, the blade boat-shaped, acute, narrowed into a sheathing petiole; peduncle stout, $20-30 \mathrm{~cm}$. long; spadix cylindric, in fruit 5-12 cm. long.

In swamps, common. Root very pungent. 


\section{Family 19. Lem NACEAE. Duckweed Family.}

Very small thallose plants floating free on the water, propagating by the division of the thallus; flowers $1-3$, monoecious, from the edge or upper surface, rare; fruit a 1-7-seeded utricle.

Thallus 1-5-nerved, with a single rootlet.

Thallus 5-12-nerved, with several rootlets.

102. LEMNA, 86.

103. SPIRODELA, 86.

\section{LEMNA.}

Thallus 1-5-nerved, producing a single rootlet beneath; flowers produced from a cleft in the margin of the thallus, usually 3 together, surrounded by a spathe, two staminate, each of a single stamen, the other pistillate of a single pistil; ovary 1-celled. Thalli oblong, separate or soon separating.

Thalli oblong, each narrowed into a sheath-like base, remaining connected.

L. minor.

Lemna minor L. Thalli round to elliptic-ovate, $2-5 \mathrm{~mm}$. long, very obscurely 3-nerved; seed oblong-obovate, amphitropous, each with a prominent operculum.

Very common on still ponds, often mixed with Spirodela.

Lemna trisulca L. Thalli thin, oblong to oblong-lanceolate, attenuate into a stalk-like base, usually several, remaining connected, each faintly 3nerved; seed ovate, amphitropous, with a small round operculum.

Still ponds and ditches, rare.

\section{SPIRODELA.}

Very similar to Lemna but rootlets several and with axile vascular tissues; anther-cells divided by a vertical partition and dehiscing longitudinally.

Spirodela polyrhiza (L.) Schleid. Thallus round-obovate, 3-8 $\mathrm{mm}$. long, thick, purple and rather convex beneath, dark green above, palmately mostly 7 -nerved.

Common on the surface of still ponds.

\section{Family 20. PONTEDERIACEAE. Pondweed Family.}

Aquatic herbs with perfect more or less irregular flowers, surrounded by a spathe; perianth of 6 petal-like segments free from the 3-celled ovary; stamens 3 or 6 , unequal or dissimilar, on the throat of the perianth; style 1 ; fruit a 1-3-celled capsule or 1 -celled utricle.

\section{HETERANTHERA.}

Low herbs living in mud or shallow water, with a 1-fewflowered spathe bursting from the sheathing side or base of a petiole; perianth-limb somewhat equally 6-parted; stamens in the throat, usually unequal; capsule 1 - or incompletely 3 -celled. 
Heteranthera dubia (Jacq.) MacM. Stems slender, branched, leafy, 30$100 \mathrm{~cm}$. long; leaves sessile, linear, acute; spathe terminal, 1-flowered; flowers small, pale yellow, the tube very slender, 3-6 cm. long; capsule 1-celled, 6-8 $\mathrm{mm}$. long.

In ponds, rare in our limits. Sauvies Island, Oregon, Howell.

\section{Family 21. JUNCACEAE. Rush FAmily.}

Grass-like, usually tufted herbs mostly perennials; inflorescence a compound panicle, corymb or umbel, with the flowers singly or loosely clustered or aggregated into spikes or heads, rarely reduced to a single flower; flowers small, regular, with or without bractlets; perianth 6-parted, the parts glumaceous; stamens 6, rarely 3 ; pistil superior, tricarpellary; ovary 3-celled, or 1-celled with 3 parietal placentae; ovules 3 -many; stigmas 3 ; fruit a loculicidal capsule; seeds 3-many, small.

Leaf-sheaths open; capsule 1- or 3-celled, many-seeded; placentae parietal or axial.

Leaf-sheaths closed; capsule 1-celled, 3-seeded; placentae basal.

I05. Juncus, 87.

I06. JunCOIDES, 91.

\section{JUNCUS. RUSH.}

Annual or perennial plants; stems leaf-bearing or scapose; leaves glabrous, cylindrical, flat or channeled; inflorescence a panicle or corymb, of ten one-sided, bearing its flowers either singly and with 2 bractlets or in heads and without bractlets, but each head in the axil of a bract; stamens 6 , rarely 3 ; ovary 1 -celled or 3-celled; placentae parietal or axial; seeds several to many.

Lowest leaf of the inflorescence appearing like a continuation of the stem, the inflorescence therefore seemingly lateral.

Flowers in compound panicles, usually numerous.

Stamens 3; leaf of the inflorescence much shorter than the stem.

Stamens 6.

Flowers 3-4.5 mm. long.

Flowers 5-6 mm. long.

Flowers few, 1-3 in each cluster.
Inner sheaths bristle-tipped; capsule retuse.
J. subtriflorus.

Inner sheaths leaf-bearing; capsule acute.

J. effusus.

J. balticus.

J. lescurii.

J. parryi.

Lowest leaf of the inflorescence not appearing like a continuation of the stem.

Leaves not provided with cross-partitions, either flat and grass-like or terete and channelled.

Flowers not bracteolate, in true heads.

Perianth shorter than the capsule; heads severalmany, 3-5-flowered.

Perianth longer than the capsule; heads solitary or few. 
Seeds not tailed.

Seeds tailed.

Flowers bracteolate, loosely scattered or somewhat

J. falcatus.

congested but not in heads.

Annuals; stems branched, leafy.

J. regelii.

Perennials; stems simple.

Perianth segments $2.5-3 \mathrm{~mm}$. long, obtuse. J. gerardi.

Perianth segments $3.5-5.5 \mathrm{~mm}$. long, sharppointed.

Auricle at summit of sheath, short and cartilaginous.

Auricle at summit of sheath, elongated and scarious.

Panicle loose; flowers pale green.

Panicle close; flowers fuscous.

J. bufonius.

with distinct cross-partitions.

Leaves provided with distinct
Blades of the leaves equitant.

Heads pale, numerous; stamens 6 .

Heads brown or black; stamens 3, rarely 6 .

J. dudleyi.

Blades of the leaves cylindric or only slightly com-

pressed.

Stamens 3.

Plant aquatic, some of the leaves floating. J. supiniformis.

Plant not aquatic.

Heads small, pale, several-many.

Stamens 6.

Heads large, dark, few.

J. tenuis.

J. occidentalis.

Capsules subulate; heads large; outer perianth segments longer.

J. oxymeris.

J. ensifolius.

Capsules not subulate.

Heads solitary, dark.

Heads several-many.

Capsule much longer than the perianth.

Capsule shorter than the perianth.

Perianth segments brown, acute.

J. acuminatus.

J. bolanderi.

Perianth segments pale, obtuse.

J. torreyi.

J. mertensianus.

J. oreganus.

J. nevadensis.

J. alpinus.

Juncus effusus L. Densely tufted, about $1 \mathrm{~m}$. high, forming tussocks in swamps; panicle compound, many-flowered; perianth-segments lanceolate, acuminate, as long as the obovate obtuse capsules.

A polymorphic species, of which three sub-species occur in our limits.

Juncus effusus pacificus Fernald \& Wiegand. Panicle loose; perianthsegments pale, $2.5-3.5 \mathrm{~mm}$. long.

Everywhere common in wet ground.

Juncus effusus hesperius Piper. Panicle compact; perianth segments dark brown, 2.4-2.9 mm. long; upper sheath loose, membranous, dull, greenishdrab above.

Often occurring with $J$. effusus pacificus but blooming about a wcek earlicr; common near the seacoast.

Juncus effusus gracilis Hook. Very similar to J. effusus hesperius but upper sheath close, coriaceous, shiny, usually chestnut-colored.

In swamps, not common.

Juncus balticus Willd. Stems erect, tcrete, naked, $30-60 \mathrm{~cm}$. tall, from stout horizontal rootstocks; leaves consisting only of sheaths; panicle appar- 
ently lateral, the elongated bract appearing like a continuation of the stem; panicle simple or compound, 1-10 cm. long; perianth segments lanceolate, acute, or obtusish, about $4 \mathrm{~mm}$. long, usually brown; stamens 6 ; capsule acutely angled and short-beaked; seeds oblong, the surface reticulated. Common in wet places, often in brackish marshes.

Juncus lescurii Boland. Stems stout, 30-100 cm. high, naked; flowers in a dense panicle; outer perianth segments 5-6 $\mathrm{mm}$. long, lanceolate, acuminate, longer than the obtuse inner ones; capsule not beaked.

In drifting sand along the ocean coast from Alaska to California.

Juncus subtriflorus (Meyer) Coville. Tufted; stems slender, 10-25 cm. high; inner leaf-blades reduced to bristles; bract as long as or longer than the inflorescence; perianth segments acute or acuminate, brownish, the outer longer, exceeding the brown oblong retuse capsule.

In the mountains at $1500-2000 \mathrm{~m}$. altitude.

Juncus parryi Engelm. Densely tufted; stems $20-40 \mathrm{~cm}$. high; inner leaf $8 / 2 \mathrm{~s} / 20 \mathrm{Mt} A$ blades not reduced; bract much exceeding the inflorescence; perianth segments brown, acute, the outer $7 \mathrm{~mm}$. long, slightly exceeding the inner; capsule oblong, acute, exceeding the perianth.

Growing in similar situations and often with $J$. subtriflorus. British Columbia to California and Colorado.

Juncus covillei Piper. Stems low, 10-20 cm. high; leaves flat, pale; panicle small, the heads 3-5-flowered; perianth segments brown with green midvein, shorter than the capsule.

On sandy lake shores, Vancouver Island to California.

Juncus falcatus Meyer. Stems usually 10-20 cm. high; leaves flat, 2-3 $\mathrm{mm}$. wide; flowers crowded into a single globose head, or rarely 2 or 3 ; outer perianth segments acuminate, $6 \mathrm{~mm}$. long, exceeding the inner obtuse ones; capsule oblong, retuse.

Along the coast, Vancouver Island to California.

Juncus regelii Buch. Perennial, stoloniferous, pale green; stems smooth or minutely scabrous; $12-50 \mathrm{~cm}$. high, erect; leaves flat, $1.5-2 \mathrm{~mm}$. broad; head solitary or sometimes 2 or 3 , globose, many-flowered; outer perianth segments lanceolate, acute; inner ovate, obtuse; all rough, brown with pale margins; stamens 6 ; capsule longer than the perianth; seeds linear, tailed at each end.

In springy places in the mountains, Washington, Oregon, Idaho and Utah.

Juncus bufonius L. Annual, branching from the base, 5-30 cm. tall; leaf blades flat or involute, slender; flowers loosely scattered, usually on but one side of the long branches of the panicle; perianth segments pale, scariousmargined, lanceolate, acuminate; stamens 6; capsule narrowly oblong, with a short blunt beak; seeds very finely reticulate.

Very common everywhere.

Juncus gerardi Loisel. Loosely tufted, 30-60 cm. high; leaves erect, usually flat; sheaths covering half the stem or more; panicle small, rather close, 2-7 cm. long; perianth greenish-brown, the outer segments linear, the inner oval.

Salt marshes, Vancouver Island and adjacent mainland, Macoun. Not otherwise known in the Pacific coast but common on the Atlantic coast.

Juncus dudleyi Wiegand. Densely tufted, stiffly erect, 30-50 cm. high; leaves short, usually less than half as long as the stems; auricles yellowish; panicle rather close, $2-7 \mathrm{~cm}$. long; perianth segments spreading, pale, $4-5 \mathrm{~mm}$. long, slightly exceeding the 1-celled ovoid capsule.

Cape Horn, Columbia River, Suksdorf. Easily distinguished by the cartilaginous auricles. 
Juncus tenuis Willd. Densely tufted, $15-30 \mathrm{~cm}$. tall; leaves flat or somewhat involute, narrow, shorter than the stems; auricles whitish, $1-1.5 \mathrm{~mm}$. long; panicle loose, seldom exceeded by the slender bract; perianth segments spreading, lanceolate, pale, 3-4 mm. long; capsule ovoid, thin-walled, round at the apex, 1-celled with 3 parietal placentae; seeds minutely reticulate.

In moist places, common.

Juncus occidentalis (Coville) Wiegand. In habit like J.tenuis, but stouter; panicles denser, sometimes glomerate; perianth yellowish, the segments erect, 4-5 mm. long; capsule ovoid, the walls firm.

Rare in our limits. Victoria, Macoun; Coupeville, Washington, Gardner.

Juncus oxymeris Engelm. Stems flattencd and two-edged, 60-100 cm. high, from stout rootstocks; leaves $5-8 \mathrm{~mm}$. broad; panicle compound, loose, 8-20 cm. long; perianth segments linear-lanceolate, acuminate, pale, shorter than the capsule; stamens 6.

In marshy places, not common. Vancouver Island to California.

Mt Ademe Juncus ensifolius Wiks. Rootstocks thick, creeping; stems leafy, 15-30 $\mathrm{cm}$. high; heads few, globose, dark brown or nearly black; perianth segments lanceolate, acuminate, $3 \mathrm{~mm}$. long; stamens 3 , rarely 6 ; capsule 3 -angled, acute, barely exceeding the perianth.

Very common, Alaska to Calitornia.

Juncus ensifolius major Hook. Differs from the species in being larger, $30-60 \mathrm{~cm}$. high, and in bearing more numerous smaller pale brown heads.

Common in wet places.

Juncus supiniformis Engelm. Tufted, with very short rhizomes; stems many, 3-10 cm. high, shorter than the leaves; leaves septate, very narrow, terete or somewhat compressed, the floating ones very slender, the emersed ones erect, rigid; heads several, 2-5-flowered, umbellate; perianth segments greenish or purplish, oblong-lanceolate, acute, equal in length; stamens 3 ; capsules 3-angled, mucronate, longer than the perianth.

In water, Vancouver Island, Macoun, and northern California.

Juncus acuminatus Michx. Stems tufted, 30-60 cm. tall; stem leaves 1-3, with prominent partitions; panicle loose, with ascending stout stiff branches; heads pale, 5-20-flowered; perianth scgments subequal, lanceolatesubulate, shorter than the acute capsule; stamens 3.

Rare in our limits, but widely spread, British Columbia to Maine and southward to Oregon and Georgia.

Juncus bolanderi Engelm. Stems 60-100 cm. high; leaves not flattened, the ligules very large; heads few, subglobose, 9-12 $\mathrm{mm}$. in diameter, manyflowered; perianth brown, the segments subequal, narrow and aristate, 2.5-3.5 mm. long; stamens 3; capsule obtuse, equalling or excecding the perianth.

Vancouver Island to northern California, near the coast, rather rare.

Juncus torreyi Coville. Stems $20-80 \mathrm{~cm}$. high, bearing 2 or 3 slender leaves; flowers crowded into $1-20$ palc heads, each $10-15 \mathrm{~mm}$. in diameter; perianth segments subulate, the outer longest.

Very rare in our limits. Coupeville, Washington, Gardner.

Mt Adame. Juncus mertensianus Bong. Stems terete, weak, crowded, $10-30 \mathrm{~cm}$. high, from short creeping rootstocks; leaves $5-15 \mathrm{~cm}$. long, about $2 \mathrm{~mm}$. wide; ligules scarious; heads solitary, globose, dark brown, about $1 \mathrm{~cm}$. broad; perianth segments lanceolate, acuminate, $3 \mathrm{~mm}$. long, exceeding the obtuse capsule.

In the mountains at $1500-2500 \mathrm{~m}$. elevation, common. 
Juncus oreganus Wats. ${ }^{-}$Stems slender, spreading, 15-20 cm. high; panicle loose; flowers in small heads; perianth segments chestnut-brown, with green midrib, the outer acute, the inner rather obtuse and a little longer; stamens 6 ; capsule brown, acute and mucronate, exceeding the perianth.

In bogs along the coast, rare. Ilwaco, Piper, Henderson; Seattle, Frye; International Boundary, Lyall; Sproat Lake, Vancouver Island, Macoun.

Juncus nevadensis Wats. Loosely tufted; stems slender, 10-40 cm. high, much exceeding the leaves; lowest leaves reduced to sheaths, the others with terete septate blades; cauline leaves 1 or 2 ; inflorescence umbellate, the hemispherical heads 3-10-flowered; perianth segments pale brown, equal, lanceolate, acute or mucronate, the inner hyaline-margined, $4 \mathrm{~mm}$. long; stamens 6 ; capsule 3-angled, mucronate, shorter than the perianth.

Vancouver Island to California.

Juncus alpinus affinis (R. Br.) Aschers. \& Graebn. (J. richardsonianus Schult.) Stems erect, $15-40 \mathrm{~cm}$. high, bearing 1 or 2 leaves; leaves terete, with conspicuous internal cross partitions; panicle sparse, the straight branches bearing scattered heads of 3-12 flowers; perianth segments pale green the outer longer than the obtuse inner ones; capsule acute, longer than the perianth.

Shores of lakes and streams, Vancouver Island, Macoun; Whatcom County, Washington, Gardner, Suksdorf.

\section{JUNCOIDES. WoOd RUSH.}

Perennial, with glabrous or sparingly pubescent herbage; stems leaf-bearing; leaf sheaths with united margins; blades grass-like; inflorescence umbellate, paniculate or congested into head-like clusters; flowers always bracteolate; ovary 1-celled with 3 basal ovules.

Flowers congested into I-several spike-like or head-like clusters.

Inflorescence nodding, nearly always of a single spike-like cluster.

Inflorescence erect, of 2-12 globose or oblong clusters.

Spikes loosely flowered, solitary or few, in a narrow panicle.

Spikes densely flowered, several to many, umbellate.

Flowers in clusters of 2 or 3 or solitary in an open panicle.

Leaves $10-12 \mathrm{~mm}$. broad; perianth brown, 3-3.5 mm. long.

Leaves $6-8$ or Io $\mathrm{mm}$. broad; perianth $1.5-2.5 \mathrm{~mm}$. long. Panicle rays divaricate; leaves without pilose hairs.

Panicle rays drooping; leaves with a few pilose hairs at base.

Flowers and capsules pale green; leaves thin, shining; seeds brown, ellipsoid.

Flowers and capsules dark brown; leaves thick, dull; seeds yellow, constricted at each end.

J. spicatum.

J. subsessile.

J. campestre.

\section{J. glabratum.}

J. divaricatum.

J. parviflorum.

J. majus.

Juncoides spicatum (L.) Kuntze. Tufted; stems $10-40 \mathrm{~cm}$. high; leaves narrow, folded, sparsely villous; perianth segments acuminate, brown with hyaline margins; capsule acute, shorter than the perianth.

In the mountains at high elevations.

Juncoides subsessile (Wats.) Piper n. comb. (Luzula comosa subsessilis Wats.) Loosely tufted; stems suberect, $10-30 \mathrm{~cm}$. high; leaves 3-4 $\mathrm{mm}$. 
broad; inflorescence narrow, erect, the lowest spike often long-peduncled; bracts ciliate, equalling or longer than the inflorescence; perianth segments lanceolate, acute, subequal, 3-3.5 mm. long, brown with scarious margins, the inner slightly broader and tridentate-mucronate at apex.

Known from Vancouver Island, Macoun, and California.

Juncoides campestre (L.) Kuntze. Stems tufted, 15-40 cm. tall, the whole plant loosely villous; leaves flat, $2-5 \mathrm{~mm}$. broad, $5-15 \mathrm{~cm}$. long; flowers in short spikes, these cymose; longest bract usually exceeding the inflorescence; spikes oblong, 5-15 $\mathrm{mm}$. long, on peduncles 1-5 cm. long, erect or nodding; perianth segments straw-colored or brownish, lanceolate, acuminate, $3 \mathrm{~mm}$. long; capsules obtuse, short-beaked, equalling the perianth.

Common in open woods; a widespread and very variab.e species. The following subspecies occur in our limits.

Juncoides campestre comosum (Meyer) Kuntze. Inflorescence usually loose; spikes elongate; perianth segments 3-4.5 mm. long, as long as the capsule; bracts ciliate.

In open woods.

Juncoides campestre congestum (Thuill.) Piper n. comb. (J. congestum Thuill.) Inflorescence dense, the heads congested; perianth $3.5-4 \mathrm{~mm}$. long, much exceeding the capsule.

In open woods.

Juncoides campestre multiflorum (Ehrh.) Sheldon. Inflorescence of several subglobose heads; perianth $2.5-3.5 \mathrm{~cm}$. long, pale brown, usually a iittle longer than the capsule.

Common in open woods.

1 t Adms Juncoides glabratum (Hoppe) Sheldon. Glabrous throughout; stems $30-50 \mathrm{~cm}$. high, from creeping rootstocks; leaves dark green, flat, $10-20 \mathrm{~cm}$. long, 10-12 mm. broad, acute; panicle loose and nodding; bracts small; perianth segments dark brown, lance-ovate, acute, shorter than the apiculate nearly black capsule.

In open woods at moderate elevations in the mountains, greedily eaten by horses.

Juncoides divaricatum (Wats.) Coville. Tufted; stems $15-30 \mathrm{~cm}$. high; leaves flat; panicle loose, broadly pyramidal, stiff; perianth segments brownish, shorter than the capsule.

At high elevations, Mount St. Helens and southward. Considered by Buchenau to be a subspecies of $J$. spadiceum.

Juncoides parviflorum (Ehrh.) Coville. Very similar to J. glabratum but taller and more slender; leaves usually with a few long hairs at base; panicle very loose; perianth segments straw-colored, lanceolate, acuminate, hardly equalling the straw-colored capsule.

In moist places, very common.

Juncoides majus (Hook.) Piper n.comb. (Juncoides piperi Coville; Luzula arcuata major Hook.) Densely tufted, 10-35 cm. high; leaves pale, firm, flat or revolute, 2-4 mm. broad; perianth segments acute, shorter than the capsule.

At high elevations in the mountains. British Columbia to Idaho and Oregon.

\section{Family 22. LILIACEAE. Lily Family.}

Terrestrial herbs or sometimes woody plants; stems usually from bulbs, corms, or more or less thickened rootstocks; flowers 
mostly perfect, regular; perianth not glumaceous, of 6 separate or united segments free from the ovary; stamens 6, opposite the perianth-segments; ovary 3 -celled; fruit a few to manyseeded 3-celled capsule or berry.

Plants with bulbs or corms.

Flowers in umbels.

Perianth-lobes united, funnelform; stamens on the throat.

Perianth-lobes not at all or but slightly united; stamens on the bases of the, lobes. 108. Allium, 95.

Flowers solitary, or in racemes, cymes, or panicles.

Perianth-segments unlike, the outer narrower.

Perianth-segments all alike or nearly so. Leaves or some of them on the stem.

Bulbs scaly; anthers versatile.

Nectary a linear groove; perianth not campanulate.

Nectary a shallow pit; perianth campanulate.

Bulbs corm-like; anthers not versatile.

Leaves only two, rather broad. 112. Erythronium, 97.

Leaves several, narrow, grasslike.

Leaves all linear, basal.

Flowers large, blue or white. 114. Quamasia, 98.

Flowers small, greenish-white or purplish.

Flowers erect; perianth-segments gland-bearing at base.

Flowers nodding; perianthsegments glandless.

Plants with rootstocks.

109. Calochortus, 96.

110. Lilium, 96.

111. Fritillaria, 97.

113. Lloydia, 98.

Leaves reduced to scales; branches threadlike, green.

Leaves not reduced to scales; branches normal.

Leaves all basal.

Leaves equitant.

Leaves not equitant.

115. ZigadeNUS, 99.

116. Stenanthium, 99.

Leaves cauline, at least in part.

Leaves in whorls of three below the flower.

Leaves not in whor!s.

Leaves opposite.

Leaves alternate.

Flowers axillary.

Perianth rotate.

Perianth narrowly campanulate.

Flowers terminal.

Leaves linear, rigid.

Leaves broader, not rigid.

117. Asparagus, 99.

118. Tofieldia, 100.

119. Clintonia, 100.

Flowers umbelled or solitary terminal.

120. Trillium, 100.

121. Scoliopus, 101.

122. Kruhsea, 101.

123. Streptopus, 101.

124. Xerophyllum, 102.

125. DisPorum, 102. 
Flowers racemed or panicled.

Flowers polygamous or monoecious, rather large.

Flowers perfect, small. Perianth-segments 6.

Perianth-segments 4.

\section{HOOKERA.}

Usually erect scapose herbs from a membranous-coated corm; leaves linear; inflorescence a several-bracted umbel of few to many flowers on jointed pedicels; perianth funnel-form not contracted at the throat, blue, purple, yellow or white, the segments united; stamens 3 , on the throat opposite the inner lobes and alternate to the sterile stamens, or 6 in one or two rows; ovary stalked or sessile, 3-celled, each cavity containing 3-8 seeds.

Anther-bearing stamens 3 .

Flowers in umbels, long-pedicelled.

Flowers nearly sessile, in a very short raceme. Anther-bearing stamens 6 .

Stamens in one row; flowers whitish.

Stamens in two rows; flowers blue or purplish. Filaments of inner stamens narrow. Filaments of inner stamens, broad.

H. coronaria.

H. pulchella.

H. hyacinthina.

H. douglasii.

H. howellii.

Hookera coronaria Salisb. Scapes $10-20 \mathrm{~cm}$. high, about as long as the narrow leaves; umbel with elongate spreading unequal rays; flowers deep blue, 2-4 cm. long; sterile stamens flat, erect, white, entire.

In gravelly prairies, Vancouver Island to California.

Hookera pulchella Salisb. Scapes $60-100 \mathrm{~cm}$. high, much exceeding the keeled glaucous leaves; flowers purple-blue, in a dense often elongated cluster; sterile stamens deeply cleft.

In dry prairies, Washington to California.

Hookera hyacinthina (Lindl.) Kuntze. Scapes 30-70 cm. tall; leaves linear-lanceolate, shorter than the stem, $5-8 \mathrm{~mm}$. broad; flowers numerous; perianth open-campanulate, white, each lobe with a green midvein, the tube about half as long as the lobes; stamens in one row, the filaments broadly dilated, equal; capsule subglobose.

In low meadows, Vancouver Island to California.

Hookera douglasii (Wats.) Piper. Wild Hyacinth. Scape tall; corm globose, the outer coats coarsely fibrous; leaves 2 or 3 , shorter than the stem, 2-4 mm. broad; flowers blue, usually numerous, in a dense umbel; pedicels $2-30 \mathrm{~mm}$. long; perianth tubular-campanulate, $2-3 \mathrm{~cm}$. long, the tube longer than the lobes; stamens in two rows, the upper and longer ones on the petals; filaments naked; capsule oblong-ovoid, short-stipitate.

In the vicinity of Victoria, Vancouver Island, Macoun. Common east of the Cascade Mountains to Wyoming and Utah. 
Hookera howellii (Wats.) Piper. Scapes $30-90 \mathrm{~cm}$. tall, much exceeding the leaves; flowers blue, in a rather loose umbei; stamens 6 , in 2 rows, the filaments of the inner ones dilated.

In open prairies; a rare species found originally in Klickitat County, Washington. Whidby Island, Gardner; Tacoma Flett.

\section{ALLIUM. ONION.}

Pungent herbs with the characteristic odor of the onion, the leaves and usually scapose erect stem from a coated bulb; leaves narrowly linear, or rarely lanceolate or oblong, sheathing; inflorescence a terminal simple umbel, in the axils of 2 or 3 membranous, separate or united bracts; pedicels slender, not jointed; flowers white or pink; perianth-segments 6 , separate or united by their very bases; stamens 6 , one on the base of each perianthsegment; ovary sessile or nearly so, completely or incompletely 3 -celled; ovules 1-6 in each cavity.

Bulbs oblong, cespitose, more or less rhizomatous.

Rhizome stout; flowers erect.

Rhizome scarcely developed; flowers nodding.

Bulbs globose to ovoid, loosely cespitose or solitary, not rhizomatous.

Bulb coats fibrous,

Bulb coats not fibrous, usually reticulate.

Leaves flat, rather broad; reticulations wanting; scape flattened, with crenulate edges.

Leaves narrow; reticulations polygonal, distinct; scape terete.

A. validum.

A. cernuum.

A. geyeri.

A. crenulatum.

A. acuminatum.

Allium validum Wats. Bulb on the tip of a stout elongated horizontal rhizome; scape $25-60 \mathrm{~cm}$. tall, angled below, 2-edged above; leaves nearly flat, $5-20 \mathrm{~mm}$. broad, about equalling the scape; umbel dense; flowers a deep rose-color; perianth-segments 6-8 $\mathrm{mm}$. long, narrow, acuminate.

In wet mountain meadows, Washington to California and Nevada. Mount Rainier, Flett.

Allium cernuum Roth. Bulbs elongated, often clustered on a short rhizome; leaves several, flat or channelled, $2-8 \mathrm{~mm}$. broad; scapes $20-40 \mathrm{~cm}$. high, usually exceeding the leaves; umbel loose, the pink flowers on nodding pedicels; perianth-segments $4-6 \mathrm{~mm}$. long, acute.

Common on rocks.

Allium geyeri Wats. Stems slender, $15-30 \mathrm{~cm}$. tall; bulbs elongate, the coats fibrous; leaves $2-4$, slender, blunt, $10-20 \mathrm{~cm}$. long; flowers a pale rosecolor; bracts broad; perianth segments ovate, acute or acuminate; ovary crested.

Vancouver Island, Macoun. Common east of the Cascade Mountains.

Allium crenulatum Wiegand. Bulbs globose or ovoid, the coats not reticulated; leaves flat, curved, 5-10 cm. long, 2-4 mm. wide; scape flattened, with margined often crenulate edges, about as long as the leaves; umbel small, the flowers deep red; perianth segments lanceolate, acute.

At high altitudes, in the Olympic Mountains, Piper, Flett. Perhaps only a form of $A$. tolmiei Baker.

Allium acuminatum Hook. Stems $10-20 \mathrm{~cm}$. tall; bulbs globose, the outer coats finely reticulate; leaves terete, narrow, shorter than the stem; 
flowers many, pink, on pedicels $2-3 \mathrm{~cm}$. long; perianth segments ovate, acuminate, $10-12 \mathrm{~mm}$. long; ovary only obscurely crested.

In stony open places, British Columbia to California and Utah.

109. CALOCHORTUS. MARIPOSA LiLy.

Branched or simple herbs with coated corms; leaves narrowly linear; flowers large, showy, peduncled; perianth-segments separate, spreading, whitish, purplish or variegated, the three outer sepal-like, narrow, the three inner petal-like, gland-bearing, and bearded or spotted within; stamens 6, hypogynous; ovary 3celled; ovules numerous.

Sepals each with a conspicuous pit at base; anthers apiculate.

Pit round; anthers as long as the filaments.

Pit linear; anthers shorter than the filaments.

Sepals without a pit at base; anthers acute.

Gland of each petal covered by a scale.

Gland of each petal naked.

c. mistrallie (Smiston)

C. subalpinus.

C. lobbii.

C. purdyi.

C. tolmiei.

dams head f Calochortus subalpinus Piper. Stems flexuous, $15-20 \mathrm{~cm}$. high; leaf 3-8 mm. 8/9 reck (meranatvide; sepals lance-ovate with a conspicuous round purple pit at base; petals cream-colored, sparsely bearded, except near the tip, the gland bordered above by a narrow entire scale; anthers long-apiculate, equalling or longer than the filaments.

In subalpine meadows, Mount Adams and southward.

Calochortus lobbii (Baker) Purdy. Very similar to C. subalpinus; pit at base of each sepal linear; petals bearded to the tip; anthers apiculate, shorter than the filaments.

Cascade Mountains of Oregon; perhaps not distinct from C. subalpinus.

Calochortus purdyi Eastwood. Stems $20-40 \mathrm{~cm}$. tall, usually branched; leaves linear-lanceolate, flat, 10-12 $\mathrm{mm}$. broad; sepals narrowly ovate, acuminate; petals broadly obovate, dirty-white or purple-tinged, bearded on the inner surface, the shallow honey-pit covered by a densely hairy narrow scale. In grassy meadows, rare. Seattle, Piper, and in the Willamette Valley,
Oregon.

Calochortus tolmiei Hook. \& Arn. Stems about $30 \mathrm{~cm}$. high, simple or branched; leaves 10-12 mm. broad; sepals oblong-lanceolate, acuminate; petals yellowish, tinged with purple, bearded, the deep gland near the base without a scale, but bordered above by a fringe of reflexed hairs; anthers acute.

Willamette Valley, Oregon. It is not clear that C. tolmiei and C. purdyi are really distinct.

\section{LILIUM.}

Perennial herbs with scaly bulbs and simple stems with numerous alternate or whorled narrow sessile leaves; flowers one to several, large, showy, erect or nodding; perianth funnelform or bell-shaped, the 6 segments spreading or recurved; anthers linear, versatile; style elongated; stigma 3 -lobed; capsule subcylindric; seeds numerous, in 2 rows in each cell.

Flowers orange with purplish dots.

Flowers white, becoming purplish.

L. columbianum.

L. washingtonianum. 
Lilium columbianum Hanson. ( $L$. parviflorum (Hook.) Holzinger.)

Stems 30-100 cm. high; leaves oblanceolate, 5-10 cm. long, mostly in whorls; flowers one or several, on curved or spreading pedicels; perianth segments orange, with numerous purple-brown spots.

Frequent in open woods and meadows.

Fok Lilium washingtonianum Kellogg. Stems 1-2 m. tall; leaves oblanceolate, acute, 5-12 cm. long, mostly in whorls of 6-12; flowers white, becoming purplish, 2-20 in a raceme; perianth-segments clawed, $7-10 \mathrm{~cm}$. long.

hin" From the Columbia River southward.

\section{FRITILLARIA.}

Bulbous herbs; stems simple, leafy; inflorescence of rather large nodding solitary or racemed leafy-bracted flowers; perianth mostly campanulate, of 6 separate and nearly equal oblong or ovate segments, each with a nectar-pit or spot at the base; stamens 6, hypogynous; ovary nearly or quite sessile, 3-celled; ovules numerous in each cavity.

Capsules acutely angled; flowers much mottled.

Capsules obtusely angled; flowers obscurely mottled.

F. lanceolata.

F. camtschatcensis.

Fritillaria lanceolata Pursh. Stems 30-90 cm. tall, glaucous; leaves in two or three whorls of 4-6, lanceolate, sessile, 5-12 cm. long; flowers 1-6, brown-purple with greenish-yellow spots; segments oblong-lanceolate; nectaries conspicuous; capsule $2-3 \mathrm{~cm}$. long, with 6 broad wings.

On open banks and prairies, Vancouver Island to California, eastward to Idaho.

Fritillaria camtschatcensis (L.) Ker-Gawl. Indian Rice. Much like $F$. lanceolata, the leaves rather broader; flowers often numerous; nerves of the sepals broadened into lamellae which bear scattered glands; capsule obtusely 5-angled.

Alaska to northern Washington, near the coast. The small bulblets are numerous and resemble rice-grains. They are eaten by the Alaska Indians.

\section{ERYTHRONIUM. ADDER'S TONGUE.}

Low herbs, from deep membranous-coated corms; stem simple; leaves but one pair, broad or narrow, usually below the middle of the stem where it rises from the ground and thus appearing basal; flowers large, nodding, bractless, solitary or several; perianth-segments separate, lanceolate, oblong or oblanceolate; stamens 6 , hypogynous, shorter than the perianth; ovary sessile, 3 -celled; ovules numerous or several in each cavity.

Leaves mottled; perianth-segments narrow, cream-colored. E. giganteum.

Leaves not mottled.

Perianth-segments broad, white.

Perianth-segments narrow, yellow.

E. montanum.

E. parviflorum.

Erythronium giganteum Lindl. Leaves lanceolate, usually broad, beautifully brown mottled; perianth segments cream-colored or nearly white, narrowly lanceolate, strongly recurved, each with a yellow and orange spot at the base.

In open meadows and prairies, Vancouver Island to Oregon. E. revolutum Smith is an older name for probably the same plant. 
Fak Hord Rom Erythronium montanum Wats. Theaves broadly lanceolate or ovate, usually abruptly narrowed at base, not mottled; perianth-segments broadly lanceolate, white, little recurved, each with an orange spot at base.

Common in alpine meadows of Washington and Oregon.

Erythronium parviflorum (Wats.) Goodding. Leaves oblong-lanceolate, not mottled; perianth-segments becoming recurved, bright yellow, with a pale spot at the base of each; anthers white.

In subalpine meadows, British Columbia to Oregon and Colorado.

\section{LLOYDIA.}

Low perennial herbs with slender coated bulbs and grass-like leaves; flowers small, white; perianth funnelform, the segments lanceolate, recurved; style short, entire; capsule obovoid, with small oblong seeds.

Lloydia serotina (L.) Sweet. Stems 5-12 cm. high; leaves very narrow, linear, equalling the stem; flower usually solitary; perianth segments oblanceolate, obtuse, 3-nerved, white.

High mountains, rare. Tami Hy Mountain, Macoun; Mount Baker, Flett: Olympic Mountains, Flett, Conard.

\section{QUAMASIA. CAMAS.}

Scapose herbs, with membranous-coated edible bulbs; leaves linear, basal; inflorescence a terminal raceme; flowers large, blue or white, bracted; pedicels jointed at the base of the flower; perianth-segments 6 , separate, equal, spreading, persistent, 1-9nerved; stamens at the bases of the perianth-segments; ovary 3-celled, sessile; ovules numerous in each cavity.

Perianth-segments narrowly lanceolate, irregular, one turning downward, the other upward, each twisting separately after blooming.

Perianth-segments broader, regularly disposed, connivent and twisting together after blooming.

Q. quamash.

Quamasia quamash (Pursh) Coville. Scape stout, 30-70 cm. tall; leaves several, mostly shorter than the stem, $5-10 \mathrm{~mm}$. broad, sometimes glaucous; raceme elongated, 10-30-flowered, the pedicels short; bracts narrowly lanceolate, about equalling the flowers; flowers dark blue or rarely white; perianth-segments unequally spreading, lanceolate, acute, $2 \mathrm{~cm}$. long, all 3 nerved, all 5-nerved or alternately 3- and 5-nerved; capsule oblong-ovate, somewhat 3-angled, 10-12 mm. long; seeds black, shining.

In wet meadows; the bulbs used by the Indians as food.

Quamasia leichtlinii (Baker) Coville. (Q. azurea Heller). Very similar to $Q$. quamash; perianth segments cream-colored or bright blue, regular, $2-3.5 \mathrm{~cm}$. long, becoming connivent and inter-twisted in age and falling together, all 3-nerved, 5-nerved, or 7-nerved or alternately 3 and 5 or 5 and 7 -nerved; capsule rather sharply 3 -angled, $15 \mathrm{~mm}$. long.

In grassy meadows, Vancouver Island to California. Typical Q. leichtlinii has cream-colored flowers, while the original specimens of $Q$. azurea are blue-flowered, but both color forms occur growing together. The bulbs are edible. 


\section{ZIGADENUS.}

Glabrous erect perennial herbs from coated bulbs each crowning a very short rhizome, and with leafy stems; leaves linear; inflorescence a terminal panicle or raceme; flowers perfect or polygamous, greenish, yellowish or white; perianth-segments lanceolate or ovate, separate or united below, sometimes adnate to the lower part of the ovary, each with one or two glands or a spot just above the narrowed base; stamens free from the perianthsegments, about equalling them in length; ovary 3-celled; ovules several or numerous in each cavity.

Petals 8-10 mm. long; gland obcordate.

Petals 6-8 mm. long; gland obovate.

Inflorescence racemose; petals obtuse.

Inflorescence paniculate; petals acute.

Z. elegans.

Z. venenosus.

Z. paniculatus.

Zigadenus elegans Pursh. Stems $15-60 \mathrm{~cm}$. tall; leaves flat, 4-12 mm. wide, very glaucous; flowers greenish, panicled; perianth segments lanceolate, short-clawed, $8-10 \mathrm{~mm}$. long, united to the base of the ovary.

In the mountains, rare in our limits. Olympic Mountains, Flett.

Zigadenus venenosus Wats. Death Camas. Stems $30-50 \mathrm{~cm}$. tall, from ovoid, dark-coated bulbs; leaves several, linear, keeled, 3-5 mm. broad, shorter than the stems; raceme many-flowered, 5-10 cm. long, much longer in fruit; flowers yellowish, on pedicels $5-10 \mathrm{~mm}$. long; bracts awl-shaped; perianthsegments clawed, elliptical, the blade obtuse; nectaries with thick margins.

Common in meadows and in hillsides, Vancouver Island to California. Bulbs poisonous.

Zigadenus paniculatus Wats. Similar to $Z$. venenosus but stouter and often taller; bulb larger, often elongate; leaves $6-15 \mathrm{~mm}$. broad, usually all sheathing; panicle many-flowered; flowers whitish; perianth segments deltoid-ovate, acute, abrupily narrowed to the claw; nectary not definitely margined.

A plant of the sage brush region; rare in our limits. Admiralty Head, Whidby Island, O. A. Piper.

\section{STENANTHIUM.}

Smooth perennial herbs; stem leafy from a bulbous base; leaves long and grass-like; flowers numerous, small, in a long terminal panicle; perianth spreading, the segments long, lanceolate and adhering to the base of the ovary; stamens short; seeds nearly wingless.

Stenanthium occidentale Gray. Bulb oblong-ovoid; stems $15-40 \mathrm{~cm}$. high; leaves linear-lanceolate, acuminate, shorter than the stem; flowers greenish or more commonly purplish-brown, nodding, in a simple or branched raceme; perianth segments lanceolate, acuminate, recurved at the tip, 12-16 mm. long.

In the mountains, rare.

\section{ASPARAGUS.}

Perennial herbs or half-shrubs with much branched stems from thick matted rootstocks; leaves reduced to scales, the upper ones 
bearing in their axils thread-like branchlets which function as leaves; flowers small, axillary; perianth-segments separate or united at the base; stamens 6, on the base of the perianth-segments; fruit a spherical 1-many-seeded berry.

Asparagus officinalis L. Stem erect, with spreading branches, 1-2 m. high; leaves scale-like, bearing in their axils clusters of thread-like green branchlets 6-15 mm. long; flowers solitary, drooping, greenish-yellow; perianth campanulate.

Readily escaping from cultivation.

\section{TOFIELDIA.}

Slender perennials with short creeping rootstocks and simple stems leafy at the base; perianth more or less spreading, persistent, the segments oblong or obovate, without claws; inner stamens on the base of the perianth-segments; styles awl-shaped; stigmas terminal; capsule 3-lobed, with many oblong seeds.

Tofieldia intermedia Rydb. Stems 30-50 cm. tall, viscid-pubescent; leaves much shorter than the stem, about $5 \mathrm{~mm}$. broad; raceme dense, viscidpubescent; perianth 3-5 $\mathrm{mm}$. long; capsules not stalked; seeds tailed at one end.

Common in bogs, especially in the mountains.

\section{CLINTONIA.}

Somewhat pubescent herbs, with slender rootstocks and erect simple scapes; leaves few, broad, petioled, sheathing, basal; flowers solitary-terminal or umbelled on the erect scapes, bractless; perianth-segments distinct, equal or nearly so, erect or spreading; stamens 6 , inserted at the base of the perianthsegments; ovary 2- or 3-celled; ovules 2-several in each cavity.

Clintonia uniflora (Schult.) Kunth. Rootstock creeping, slender; scapes slender, pubescent, naked or with one or two small linear bracts, $6-10 \mathrm{~cm}$. tall, bearing a solitary white flower or rarely two; proper stem short; leaves 2-5, oblong, acuminate, pubescent beneath, 10-20 cm. long; calyx pubescent on the outside; filaments attenuate from a thicker base, pubescent below; fruit globose or pyriform, blue.

Common in subalpine woods.

\section{TRILLIUM. WAKE ROBIN.}

Glabrous erect unbranched herbs, with short rootstocks; leaves 3 in a whorl at the summit of the stem just under the sessile or peduncled, solitary, bractless flower; perianth of two distinct series of segments, the outer 3 (sepals) green, the inner 3 (petals) white, pink, purple or sometimes greenish; stamens 6 , hypogynous; ovary sessile, 3-6-angled or lobed; ovules several or numerous in each cavity.

Flower sessile; leaves mottled. Flower stalked; leaves not mottled. 
Trillium chloropetalum (Torr.) Howell. Stems $30-40 \mathrm{~cm}$. high; leaves̊ ovate, often as broad as long, usually acute, commonly blotched with brownish spots; flowers sessile; petals oblanceolate, obtuse, white.

Roy, Washington, and southward.

Trillium ovatum Pursh. Stems $15-40 \mathrm{~cm}$. tall, from a stout horizontal rootstock, $2-5 \mathrm{~cm}$. long; leaves broadly ovate, acuminate or acute, $5-15 \mathrm{~cm}$. long, nearly sessile; flowers odorous; peduncles erect, 3-6 cm. long; petals lanceolate, acute, white, in age changing through various shades of pink to dark red, exceeding the green sepals; anthers yellow.

Very common in moist woods. Various abnormal forms are occasionally found, such as flowers with the parts in twos or fours, double flowers, etc.

\section{SCOLIOPUS.}

Very short stemmed glabrous perennials more or less punctate with purple dots and with short fibrous-rooted rhizomes; leaves 2 , thin, oval to lanceolate, sessile, many-nerved; flowers longpedicelled in an umbel; perianth of 6 spreading segments, the outer lanceolate, several-nerved, the inner narrowly linear, 3-nerved; stamens 3, at the base of the outer segments; style very short; stigmas linear; ovary sessile, attenuate upward, 1-celled; ovules several.

Scoliopus hallii Wats. Stem short, mostly subterranean; leaves broadly lanceolate, $8-12 \mathrm{~cm}$. long, acute; flowers $1-8$, on slender pedicels $5-8 \mathrm{~cm}$. long; perianth segments narrow, the outer broader and longer than the inner.

Along mountain streams, western Oregon.

\section{KRUHSEA.}

Perennial herbs with slender creeping rootstocks and leafy erect simple or branched stems; flowers solitary in the axils on slender not geniculate pedicels; perianth segments lanceolate, equal, spreading, all alike; anthers cordate, short-acuminate; berry globose, red.

Kruhsea streptopoides (Ledeb.) Kearney. Stems 10-60 cm. high, simple or branched; leaves ovate-lanceolate, acuminate, sessile, not ciliate; flowers brownish, the lanceolate attenuated perianth segments equal, spreading, about $3 \mathrm{~mm}$. long.

In mountain woods, Alaska to Washington. Chilliwack Valley, Macoun; Cascade Mountains, $49^{\circ}$, Lyall. Reported from Baker Lake, Muenscher.

\section{STREPTOPUS.}

Herbs with stout or slender rootstocks; leaves thin, sessile or clasping, alternate, many-nerved; flowers solitary or two together, axillary, slender-peduncled, greenish or purplish, small, nodding; peduncles bent or twisted at about the middle; perianth somewhat campanulate, its segments 6 , recurved or spreading, the outer flat, the inner keeled; stamens 6, hypogynous; ovary 3 -celled; ovules numerous, in two rows in each cavity. 
Streptopus amplexifolius (L.) DC. Stems branched, about $1 \mathrm{~m}$. tall, from horizontal creeping rootstocks, glabrous except at the base; leaves ovate, acuminate, cordate and clasping at base, 5-12 cm. long, usually glaucous, especially beneath; flowers solitary in the upper axils; pedicels bent at the base and geniculate in the middle, so that the flower is concealed by the leaf; perianth narrowly campanulate, the segments greenish, lanceolate, acuminate, strongly curved outward; anthers acuminate; berry oblong-globose, red, about $1 \mathrm{~cm}$. in diameter.

Common along streams and in springy places.

Streptopus curvipes Vail. Stems simple, 10-30 cm. tall, from creeping rootstocks; leaves oblong-lanceolate, acuminate, sessile, glabrous or sparsely pubescent, ciliate; perianth rose-colored, $8 \mathrm{~mm}$. long; fruit globose, at length red.

In the mountains, common at low elevations.

\section{XEROPHYLLUM.}

Perennials with a short thick woody rootstock and numerous radical stiff linear leaves; perianth white, of six separate spreading petal-like segments; stamens 6 , at the base of the perianthsegments; styles distinct, linear, reflexed; ovary sessile, ovate, 3-lobed.

Mt Adams Xerophyllum tenax (Pursh) Nutt. Pine Lily or Bear Grass. Basal leaves D. in Mom very numerous, harsh and stiff, linear, keeled, $5 \mathrm{~mm}$. broad, $60-90 \mathrm{~cm}$. long; cauline similar but smaller and ciliate at base; stems stout, 1-2 m. tall, stiff and erect; flowers white; raceme dense, at first pyramidal, then elongating, $15-40 \mathrm{~cm}$. long in bloom, longer in fruit; pedicels spreading in flower, erect in fruit, $2-3 \mathrm{~cm}$. long.

Common in open woods, especially in the mountains, but not known to occur on Vancouver Island or in western British Columbia.

\section{DISPORUM.}

More or less pubescent herbs with slender rootstocks; stems branching, scaly below, leafy above; leaves alternate, somewhat unsymmetrical, sessile or clasping; flowers terminal, drooping, whitish or greenish-yellow, solitary or few in simple umbels; perianth-segments 6 , narrow, equal, separate; stamens 6 , hypogynous; ovary 3 -celled; ovules 2 or sometimes several in each cavity.

Perianth broad at base.

D. smithii.

Perianth narrowed at base.

Fruit ovoid, pubescent; stigma entire. D. oreganum.

Fruit globose, papillose; stigma 3-cleft.

D. majus.

Disporum smithii (Hook.) Piper. Stems 30-90 cm. tall; leaves ovate or ovate-lanceolate, acute or acuminate, scarcely cordate at base; perianth bellshaped, broad at base, the segments erect; style 3-cleft; fruit oblong-ovoid, glabrous, except the blunt beak.

Along the coast, Nootka Sound, where it was first collected by Menzies, to northern California.

Disporum oreganum (Wats.) B. \& H. Stems $30-80 \mathrm{~cm}$. tall, branched; 
leaves ovate, long-acuminate, cordate at base; perianth narrow, the segments spreading; style entire; fruit ovoid, pubescent, orange-red.

Moist banks and rich woods, British Columbia to Idaho and Oregon.

Disporum majus (Hook.) Britt. Stems branched, 30-50 cm. tall, the branches pubescent; leaves oblong or oblong-ovate, long-acuminate, sessile and half-clasping, 5-7 cm. long, glabrous; flowers solitary or in pairs, yellowishwhite, on more or less curved pedicels, 5-8 $\mathrm{mm}$. long; perianth campanulate, the segments narrow, oblong or oblanceolate, $10-12 \mathrm{~mm}$. long; berry pyriformglobose, 6-8 mm. in diameter, roughened with minute shallow pits.

Silverton, Washington, Mrs. L. A. Bouck. Not elsewhere found west of the Cascade Mountains, but common in the interior from British Columbia and Alberta to Arizona.

\section{VERATRUM. FALSE HELlEBore.}

Tall perennial herbs, from short thick poisonous rootstocks; stem pubescent; leaves mostly broad, clasping, strongly veined and plaited; inflorescence pubescent, of terminal panicles; flowers greenish or yellowish-white, rather large, polygamous, on short stout pedicels; perianth-segments 6 , glandless or nearly so, adnate to the base of the ovary; stamens opposite the perianthsegments and free from them, short, mostly curved; ovary ovoid, 3 -celled, the cavities several-ovuled.

Flowers green, in a drooping panicle.

Flowers white, in an erect panicle.

V. viride.

$V$. caudatum.

Veratrum viride Ait. Green Hellebore. Stems stout, $100-150 \mathrm{~cm}$. tall; leaves ovate, or the upper lanceolate, pubescent beneath, 20-30 cm. long; panicle open, 30-60 cm. long, the lower branches more or less drooping, usually simple; perianth green, pubescent outside, the segments obovate, obtuse, about $8 \mathrm{~mm}$. long; principal bracts foliaceous, like the upper leaves.

In subalpine swamps, throughout our limits.

Veratrum caudatum Heller. White Hellebore. In habit like V. viride; panicle erect, the branches spreading, seldom nodding; principal bracts small, not foliaceous; perianth segments $15-20 \mathrm{~mm}$. long.

In wet meadows, Montesano, Heller; near Seattle, Piper. Perhaps only a form of $V$. californicum Durand.

\section{VAGNERA. FALSE SOLOMON'S SeAL.}

Herbs with slender or short and thick rootstocks; stem simple, scaly below, leafy above; leaves alternate, short-petioled or sessile, ovate, lanceolate or oblong; inflorescence a terminal raceme or panicle; flowers white or greenish, small; perianth of 6 separate spreading equal segments; stamens 6 , on the bases of the perianth-segments; ovary 3 -celled, sessile, subglobose; ovules 2 in each cavity.

Flowers small, many in a panicle.

Flowers larger, few in a simple raceme.

V. amplexicaulis.

$V$. sessilifolia.

Vagnera amplexicaulis (Nutt.) Greene. Rootstocks stout; stems 50-100 $\mathrm{cm}$. tall, usually puberulent; leaves oblong or ovate, acuminate, puberulent, 6-12 cm. long, sessile, clasping the stem somewhat; panicle pyramidal or 
narrow, 3-10 cm. long; pedicels very short; perianth spreading, the segments oblong, $2 \mathrm{~mm}$. long, as long as the ovary; filaments subulate, longer than the perianth; style about as long as the ovary.

On rich wooded banks.

Vagnera sessilifolia (Baker) Greene. Rootstocks slender; stems 30-60 $\mathrm{cm}$. tall, smooth; leaves broadly lanceolate, acuminate, flat, sessile, pubescent beneath, 10-15 cm. long; raceme open, 2-5 cm. long, 5-10-flowered; pedicels 4-12 $\mathrm{mm}$. long; perianth segments spreading, lanceolate, $4 \mathrm{~mm}$. long; stamens shorter than the styles.

In moist wooded copses.

\section{UNIFOLIUM.}

Perennial herbs with creeping rootstocks; leaves 2 or 3 , ovate to lanceolate, cordate; flowers solitary or fascicled in a simple raceme; perianth 4-parted; stamens 4; stigma 2-lobed; ovary 2-celled; fruit a 2-celled berry with 2 seeds in each cell.

Unifolium bifolium kamtschaticum (Gmel.) Piper. Basal leaves ovatereniform, acute or acuminate, $5-10 \mathrm{~cm}$. broad; cauline leaves usually 2 , cordate to sagittate, $5-10 \mathrm{~cm}$. long; perianth segments $2-3 \mathrm{~mm}$. long, becoming reflexed.

Moist places, very common.

\section{Family 23. IRIDACEAE. IRIS FAMILY.}

Perennial herbs; leaves narrow, equitant, 2-ranked; flowers perfect, regular or irregular, mostly clustered, subtended by bracts; perianth of 6 segments or 6-lobed, its tube adnate to the ovary, the segments or lobes in 2 series; stamens 3, inserted on the perianth opposite its outer series of segments or lobes; ovary inferior, mostly 3 -celled; ovules mostly numerous in each cell; style 3-cleft, its branches sometimes divided.

Flowers very large; styles petal-like.

129. IRIS, 104.

Flowers moderate in size; styles filiform.

Filaments united to the top; flowers usually blue. 130. SisyrinchiUm, 105.

Filaments not united to the top; flowers not blue.

Filaments united only at the base; flowers reddish-purple.

Filaments united for more than half their length; flowers yellow.

131. Olsynium, 106.

132. Hydastyuus, 106.

\section{IRIS.}

Herbs with creeping or horizontal, of ten woody and sometimes tuber-bearing rootstocks; stems erect; leaves erect or ascending, equitant; flowers large, regular, terminal, solitary or clustered; perianth of 6 clawed segments united below into a tube, the three outer dilated, spreading or reflexed, the three inner narrower, smaller, usually erect or in some species about as large as the 
outer; stamens inserted on the bases of the outer perianthsegments; ovary 3-celled; divisions of the style petal-like, arching over the stamens, bearing the stigmas immediately under their mostly 2-lobed tips; style-base adnate to the perianth-tube.

Bracts largely scarious; rootstock stout.

Bracts green, not scarious, rootstocks slender.

Flower solitary, purple; capsule oblong.

Flowers usually 2, whitish; capsule globose.

I. missouriensis.

I. tenax.

I. tenuis.

Iris missouriensis Nutt. Rootstocks stout, short, branched; stems 20-50 $\mathrm{cm}$. tall, naked or with one or two leaves; leaves pale or glaucous, usually shorter than the stem, 5-8 mm. wide; flowers violet-blue, rarely white, $2-4$ in each umbel; bracts scarious, $2-6 \mathrm{~cm}$. long, acute; sepals narrowly clawed, 5-6 cm. long, the honey guides yellowish; petals erect, shorter; capsule oblongobovoid, somewhat 3 -angled; seeds brown.

Whidby Island, Gardner; not otherwise known in our limits; common in the interior.

Iris tenax Dougl. Leaves numerous, $30-50 \mathrm{~cm}$. long, $4 \mathrm{~mm}$. broad, acuminate; stems shorter than the leaves, each bearing a solitary flower; sepals oblong, $5 \mathrm{~cm}$. long, purple; petals spatulate, nearly as long.

Prairies from Chehalis County, Washington, southward.

Iris tenuis Wats. Stems $20-25 \mathrm{~cm}$. high, bearing several short leaves, usually 2-flowered; leaves $8-10 \mathrm{~mm}$. broad, about equalling the stems; flowers white marked with yellow and purple; petals emarginate.

Cascade Mountains of northern Oregon along the Clackamas River.

\section{SISYRINCHIUM. BLUE-Eyed GRASS.}

Perennial tufted slender herbs, with short rootstocks; stems simple or branched, 2-edged or 2-winged; leaves linear, grasslike; flowers rather small, mostly blue, terminal, umbellate, with a pair of erect green bracts; perianth-tube short or none, the 6 spreading segments oblong or obovate, equal; filaments united to the top; ovary 3-celled, each cavity several-ovuled; stylebranches filiform, undivided, alternate with the anthers.

Stem usually 2-branched.

S. birameum.

Stem always simple.

Perianth segments $20 \mathrm{~mm}$. long; outer bract 5-7 cm. long. S. macounii.

Perianth segments $12-15 \mathrm{~mm}$. long; outer bract $2-5 \mathrm{~cm}$. long.

Leaves $1-3.5 \mathrm{~mm}$. broad, firm; stems $1-3 \mathrm{~mm}$. wide. S. idahoense.

Leaves 0.5-1.5 mm. broad, soft; stems 1-1.5 mm. wide. S. segetum.

Sisyrinchium birameum Piper. Loosely tufted, 40-50 cm. high, drying blackish; leaves firm, erect, about half as high as the stem; bracts purplish, subequal, shorter than the pedicels; flowers $2-5$ on slender pedicels; perianth dark blue with a yellow eye; capsule globose.

Vancouver, Washington, Piper.

Sisyrinchium macounii Bicknell. Pale green or glaucescent; stems tufted, simple, $30-50 \mathrm{~cm}$. high; leaves $20-30 \mathrm{~cm}$. long, $1.5-3 \mathrm{~mm}$. wide, very acute, smooth on the margins; spathes green or purple-margined, the outer 4-7 cm. long, the inner $2-3 \mathrm{~cm}$. long; flowers $2-4$, slender-pedicelled, purple with a yellow eye; perianth segments aristulate, $2 \mathrm{~cm}$. long.

Comox and other places on Vancouver Island, Macoun. 
Sisyrinchium idahoense Bicknell. Stems tufted, $20-45 \mathrm{~cm}$. tall, compressed and winged, the edges serrulate; leaves shorter than the stems, linear, acute, 1-3.5 $\mathrm{mm}$. wide, all radical, or occasionally one on the stem; bracts long and narrow; flowers 3-6, pedicelled, dark blue, with a small yellow center; perianth-segments $12-18 \mathrm{~mm}$. long, mucronate.

Wet meadows, Vancouver Island to Oregon and Idaho.

Sisyrinchium segetum Bicknell. Tufted, rather pale; stems slender, $10-20 \mathrm{~cm}$. high, exceeding the leaves, these about $2 \mathrm{~mm}$. wide; bracts purple, subequal, thin in texture; flowers violet-blue, on slender pedicels; capsule oblong.

In meadows, Washington and Oregon, west of the Cascade Mountains.

\section{OLSYNIUM.}

Very similar to Sisyrinchium but the filaments united only at the base and the flowers never blue.

Olsynium grandiflorum (Dougl.) Raf. Stems mostly solitary, 15-30 cm. tall, compressed; roots fascicled, stout; leaf-blades 5-10 cm. long, erect, shorter than the sheaths; flowers 1-4, the pedicels shorter than the largest bract; perianth segments reddish-purple, broadly lanceolate, acuminate, $15-18 \mathrm{~mm}$. long; filaments broad at the base, shorter than the 3-cleft style.

Victoria, British Columbia, Macoun; Whidby Island, Gardner. Rare west of the Cascade Mountains, but common in the interior.

\section{HYDASTYLUS.}

Annual or perennial herbs resembling Sisyrinchium; rootstocks poorly developed; leaves narrowly linear, the bases more or less membranously expanded; flowers on a scape, enclosed by a spathe of 2 bracts which enclose membranous scales; perianth yellow, the segments narrow, obtuse or acute; filaments free for at least half their length; anthers linear, versatile; styles slender, divergent; capsule oblong to globose, 3-celled, many or fewseeded; seeds rounded.

Pedicels $15-20 \mathrm{~mm}$. long; leaves $1-3 \mathrm{~mm}$. broad. Pedicels 10-15 mm. long; leaves 2-5 $\mathrm{mm}$. broad.

$H$. borealis.

H. brachypus.

Hydastylus borealis Bicknell. Stems 6-30 cm. high, exceeding the leaves; leaves 1-3 mm. wide; flowers on erect pedicels $15-22 \mathrm{~mm}$. long; perianth segments $8-10 \mathrm{~mm}$. long.

Along the seacoast.

Hydastylus brachypus Bicknell. Like $H$. borealis but with broader leaves and shorter pedicels.

In seashore meadows. Probably not distinct from $H$. borealis.

\section{Family 24. ORCHIDACEAE. ORCHId FAMILy.}

Perennial herbs, mostly with corms, bulbs or tubers; leaves entire, sheathing, sometimes reduced to scales; flowers perfect, irregular, bracted, solitary, spiked or racemed; perianth superior, of 6 segments, the three outer (sepals) alike or nearly so; two of 
the inner ones (petals) lateral, alike; the other one (lip) dissimilar, often markedly so, usually larger, often spurred, really anterior, sometimes inferior by the twisting of the ovary or pedicel; stamens variously united with the style into an unsymmetrical column; anther one sometimes two; pollen more or less coherent into masses (pollinia); ovary inferior, usually long and twisted, 3angled, 1-celled; ovules numerous, on three parietal placentae; seeds numerous; endosperm none.

Perfect anthers 2; lip large, sac-like.

133. Cypripedium, 107.

Perfect anther 1.

Plant saprophytic, without green herbage.

Flowers spurred, reddish or yellowish.

Flowers spurless, white.

Plants with ordinary green herbage.

Flower and leaf solitary; plant bulbous. 136. Cytherea, 108.

Flowers several-many in racemes.

Leaves only two.

137. OpHRys, 109.

Leaves more than two.

Flowers each with a distinct spur.

Leaves several, cauline, gradually reduced upwards.

134. Corallorhiza, 108.

135. Cephalanthera, 108.

Leaves two, basal; cauline reduced to bracts.

Lateral sepals adnate to the base of the lip.

Lateral sepals free.

Flowers spurless, the lip at most saccate.

Lip with 2 callosities at base; flowers spirally arranged in a dense spike.

Lip without basal callosities. Leaves white-reticulated. Leaves green.

138. LimNoRCHIS, 109.

139. Piperia, 110.

140. LySIAS, 111.

141. Ibidium, 111.

142. Peramium, 111.

143. EPIPACTIS, 112.

\section{CYPRIPEDIUM. LADY'S SLIPPER.}

Glandular-pubescent herbs with leafy stems or scapes and tufted roots of thick fibres; leaves large, broad, many-nerved; flowers solitary or several, drooping, large, showy; sepals spreading, separate or two of them united under the lip; lip a large inflated sac; column bearing a sessile or stalked anther on each side and a dilated petal-like sterile stamen above, covering the summit of the style; pollinia granular; stigma terminal, broad, obscurely 3-lobed.

Cypripedium montanum Dougl. Whole plant glandular-pubescent; stems $30-50 \mathrm{~cm}$. tall, erect; leaves 4-6, oval, acuminate, 6-12 cm. long; flowers 1-3, pedicelled; sepals brown, usually dark, narrowly lanceolate, 5-6 cm. long; upper petals like the sepals, but narrower and longer, wavy-twisted; lip white, 
veined with purple, oblong, $30-50 \mathrm{~mm}$. long; sterile anther somewhat triangular, yellow with purple spots, about $1 \mathrm{~cm}$. long.

In moist open woods, rare in our limits. Victoria, Vancouver Island, Fletcher; Seattle, Piper.

\section{CORALlORHIZA. Coral Root.}

Scapose herbs, saprophytes or root-parasites with large masses of coral-like branching roots; leaves all reduced to sheathing scales; flowers in terminal racemes; sepals nearly equal, the lateral ones united at the base with the foot of the column, forming a short spur or protuberance, usually adnate to the summit of the ovary; third sepal free; petals about as long as the sepals, 1-3-nerved; lip 3-ridged; column nearly free, slightly incurved, somewhat 2 -winged; anther terminal; pollinia 4 , in two pairs, oblique, free, soft-waxy.

Spur none; petals and sepals purple, veiny.

Spur prominent; petals and sepals 3 -nerved.

Spur wholly attached to the ovary.

Spur free for its apical half.

C. striata.

C. maculata.

C. mertensiana.

Corallorhiza striata Lindl. Whole plant reddish-purple, $15-40 \mathrm{~cm}$. high, the spike 15-25-flowered; sepals and petals each with 3 conspicuous nerves; lip entire, soniewhat fleshy, ovate, narrowed below, concave and bearing 2 short prominent ridges near the base.

In dry woods.

Corallorhiza maculata Raf. (C. multiflora occidentalis Lindl.) Whole plant reddish or sometimes yellowish, 20-30 cm. high; raceme 10-30-flowered; sepals and petals 6-8 $\mathrm{mm}$. long; lip broad and 3-lobed at base, spotted with crimson spots; spur wholly adnate to the ovary.

In deep woods not rare, especially at low altitudes in the mountains.

Corallorhiza mertensiana Bong. Scape $20-40 \mathrm{~cm}$. high; raceme manyflowered; sepals and petals 6-8 mm. long, dark-red; lip oblong, narrowed at base, entire; spur half-free from the ovary.

In mountain woods, common.

\section{CEPHALANTHERA.}

Leafy plants with creeping rootstocks, saprophytic with leaves reduced to scarious bracts (in ours); flowers erect, white, in a terminal raceme, very similar to Epipactis but with a longer and more slender column; stigma beakless; anther short-stalked, nearly or quite above the level of the stigma.

Cephalanthera austinae (Gray) Heller. Whole plant waxy white, 30-50 $\mathrm{cm}$. high, slender, erect; bracts linear-lanceolate, the lower with dilated sheaths; flowers 3-20, nearly sessile; sepals and petals oblong-lanceolate, subequal; lip short, saccate at base.

In deep woods, especially in the mountains. Very rare.

\section{CYTHEREA.}

Herbs with solid bulbs and coral-like roots; leaf at the base of the stem solitary, petioled; scape low, 1-flowered, sheathed by 
two or three loose scales; flower large, terminal, showy, bracted; sepals and petals similar, nearly equal; lip large, saccate or swollen, 2-lobed below; column dilated, petal-like, bearing the lid-like anther just below the summit; pollinia 2, waxy, each 2-parted.

Cytherea bulbosa (L.) House. Calypso. Stems 10-15 cm. tall, enwrapped toward the blade with 3-4 scarious sheaths, the uppermost prolonged into a narrow bract; leaf solitary, radical, ovate, acute, 3-5 cm. long, on a petiole about as long; sepals and petals ascending, lanceolate, purple, about $2 \mathrm{~cm}$. long; lip about as long, purple-lined, sac-like, two-lobed at the apex, with a patch of yellowish hairs within; the apex of the slipper prolonged into two tooth-like projections; column half as long as the petals.

In mossy woods, not rare.

\section{OPHRYS.}

Small herbs, with fibrous or sometimes rather fleshy roots; leaves two, opposite, green, near the middle of the stem; flowers in terminal racemes, spurless; sepals and petals nearly alike, spreading or reflexed, free; anther without a lid, erect, jointed to the column; pollinia 2, powdery.

Leaves cordate; lip narrow, not dilated at tip. $\quad 0$. cordata. Leaves not cordate; lip dilated at tip.

Lip sessile, not ciliate; ovary glabrous. $\quad$ o. caurina.

Lip clawed, ciliate; ovary glandular.

O. convallarioides.

Ophrys cordata (L.) R. Br. Stems slender, 10-20 cm. high; leaves ovate, cordate, mucronate; flowers very small, greenish or brownish; lip narrowly oblong, cleft to the middle, 4-5 $\mathrm{mm}$. long.

Common in mossy woods.

Ophrys caurina (Piper) Rydb. Stems slender, $15-30 \mathrm{~cm}$. high, glabrous below the leaves; the inflorescence glandular-puberulent; leaves sessile, ovate, obtuse or acutish, glabrous, $3-5 \mathrm{~cm}$. long; flowers small, the slender pedicels longer than the bract or the ovary; sepals and petals lanceolate, spreading; lip $4 \mathrm{~mm}$. long, cuneate, obovate, with a slender tooth on each side near the base; capsule ovoid, 5-6 mm. long.

In mossy woods, especially in the mountains.

Ophrys convallarioides (Sw.) W. F. Wight. Similar to O. caurina but not so tall; leaves broad, oval or ovate, obtuse; inflorescence glandular; flowers larger, the pedicels scarcely longer than the bracts or the ovary; lip large, $9 \mathrm{~mm}$. long, cuneate, retuse, with a short triangular tooth on each side near the base.

In moist woods.

\section{LIM NORCHIS.}

Leafy plants with thick fleshy roots or elongated conic undivided tubers, and small greenish or whitish flowers in a long spike; sepals and petals free and spreading, several-nerved; lip entire; beak of the stigma without appendages; anther-cells nearly parallel, wholly adnate; gland naked; pollinia granular with caudicula at the base. 
Flowers green or sometimes purple-tinged; spur clavate much shorter than the lanceolate lip; spike long and dense.

Flowers white.

Spur clavate, usually shorter than the lip. L. dilatata.

Spur not clavate, longer than the lip.

Spike moderately dense; spur acutish.

Spike very dense; spur obtuse.

L. leucostachys.

L. leucostachys robusta.

Limnorchis stricta (Lindl.) Rydb. Stems stout, leafy, 50-100 cm. tall; leaves lanceolate, acuminate, $10-15 \mathrm{~cm}$. long, gradually diminishing upward into the bracts; spike slender, 20-30 cm. long, loose, the lower flowers remote; bracts narrowly lanceolate, exceeding the lower flowers, equalling the upper ones; sepals 3-nerved; lip linear, thick, as long as the spur, which is inflated and very obtuse at the tip.

In swamps, common.

NT Adame Limnorchis dilatata (Pursh) Rydb. Stems slender, $20-40 \mathrm{~cm}$. high; leaves linear-lanceolate, $8-20 \mathrm{~cm}$. long; flowers white; lip broadly dilated at base, about as long as the blunt spur.

In wet alpine meadows, rare in our limits.

Limnorchis leucostachys (Lindl.) Rydb. Stem strictly erect, 30-90 cm. high, from a fusiform tuber; leaves lanceolate, acute, the upper ones smaller; spike 6-30 cm. long, usually rather dense; bracts acuminate, equalling or exceeding the ovary; sepals 5-6 mm. long, the upper one broader; lip lanceolate, 6-7 mm. long; spur 10-12 mm. long, slender, acute.

In marshes, common.

Limnorchis leucostachys robusta Rydb. Spike dense; spur obtuse.

More common than the species and in similar places.

\section{PIPERIA. Habenaria (Smeeter)}

Much like Limnorchis in the form of the flowers but the true leaves basal or nearly so, the cauline usually small or bract-like; flowers small, white or greenish; sepals ovate, 1-nerved, subequal; petals and lip of very much the same shape and slightly smaller and darker than the sepals; column very short; anther very large; cells parallel, the gland very small.

Spur short, slightly exceeding the lip.

P. unalaschensis.

Spur slender, 2-3 times as long as the lip.

Lip ovate to ovate-lanceolate.

Spike very dense; stems stout, $20-30 \mathrm{~cm}$. high.

Spike usually loose; stems $40-70 \mathrm{~cm}$. high.

Lip linear to lanceolate.

Spike dense; lip $6 \mathrm{~mm}$. long; spur 15-18 mm. long. P. multiflora.

Spike loose; lip 4-5 mm. long; spur 8-10 mm. long. P. leptopetala.

Piperia unalaschensis (Spreng.) Rydb. Stems stout, $20-40 \mathrm{~cm}$. tall, leafy at base, bracteate above; leaves $2-3$, oblanceolate, obtuse, about $15 \mathrm{~cm}$. long, usually withering before the flowers bloom; spike narrow, rather dense, $8-15 \mathrm{~cm}$. long; bracts triangular, acute or acuminate, shorter than the ovary, a few along the stem below the spike; flowers small, greenish; sepals and petals lanceolate, 1-nerved, $1.5-2 \mathrm{~mm}$. long; lip scarcely exceeding the petals; spur curved, about $3 \mathrm{~mm}$. long; capsule oblong, sessile.

Common in open woods. 
Piperia michaeli (Greene) Rydb. Stem stout, 20-30 cm. high; basal leaves elliptic to oblanceolate; stem leaves numerous, much reduced; spike thick and very dense; flowers greenish.

Along the sea coast, rare.

Piperia elegans (Lindl.) Rydb. Stouter than $P$. unalaschensis, somewhat taller; basal leaves 2-4, oblong or lanceolate, $10-15 \mathrm{~cm}$. long, 3-5 cm. wide, obtuse or acute; cauline bracts oblong, acuminate, $1-3 \mathrm{~cm}$. long; spikes usually dense, 8-20 cm. long; bracts ovate, acuminate, about equalling the white flowers or the mature ovary; sepals and petals similar, $4 \mathrm{~mm}$. long, obscurely 3-nerved; lip like the petals, the spur slender, 7-10 $\mathrm{mm}$. long; capsule oblong nearly sessile.

In open woods, very common.

Piperia multiflora Rydb. Much like $P$. elegans but stouter; spike dense; flowers usually white.

In open woods. Perhaps only a form of $P$. elegans.

Piperia leptopetala Rydb. Slender, 30-50 cm. high; basal leaves oblonglanceolate; spike long and loose; flowers greenish.

Growing with $P$. elegans, of which it may be only a form.

\section{LYSIAS.}

Leaves two, large, basal; sepals large and spreading; petals small and narrow; lip linear, entire; spur long; beak of stigma without appendages; anther-cells widely diverging and with small beak-like processes at the base.

Lysias orbiculata (Pursh) Rydb. Leaves elliptic to orbicular, prostrate on the ground, bright green and shining above, paler beneath, thick, usually 10-15 cm. long; scape 6-30 cm. high, bearing 1-3 lanceolate bracts; spike loose, 10-20-flowered; flowers white; lateral sepals ovate, the upper orbicular; lip linear-oblong, 15-20 mm. long; spur slender, 15-25 mm. long.

Rare in deep mountain woods.

\section{IBIDIUM. Spiranthes (sucettar)}

Roots clustered; stem bracted above, leaf-bearing below or at the base; flowers small, white, yellowish or greenish-white in a more or less spirally-twisted raceme; lateral sepals lanceolate, the upper united with the oblong petals; lip short-stalked with a callus on each side of the base, the summit somewhat dilated; column short, bearing the ovate stigma on the front and the 2-celled erect anther sessile or nearly so on the back.

Ibidium romanzoffianum (Cham.) House. Plants $8-40 \mathrm{~cm}$. tall, from roots 5-8 $\mathrm{mm}$. thick, leafy below and leafy-bracted above; leaves oblong-lanceolate to linear; scape glandular-pubescent above; cauline bracts $2-3$; raceme dense, cylindrical; perianth yellowish or whitish, 6-12 $\mathrm{mm}$. long; bracts of the raceme often much longer than the flowers; sepals and petals united.

In dry woods, common.

142. PERAMIUM. Soodyera (Swetser)

Herbs with bracted erect scapes and thick fleshy-fibrous roots; leaves basal, tufted, often blotched with white; flowers in bracted 
spikes; lateral sepals free, the upper ones united with the petals into a hood-like structure (galea); lip sessile, entire, roundish, ovate, concave or saccate, without protuberances, its apex reflexed; anther without a lid, erect or incumbent, attached to the column by a short stalk; pollinia composed of angular grains, one in each sac, attached to a small disk which coheres with the top of the stigma.

1o Adams conal $36-40 \mathrm{~cm}$ $6-8 \mathrm{~cm}$

Peramium decipiens (Hook.) Piper. Rattlesnake Plantain. Scape 15-30 $\mathrm{cm}$. tall, erect, glandular-puberulent, bearing several short bracts; leaves ovate, acute, with a broken white stripe down the midvein, $3-5 \mathrm{~cm}$. long, shortpetioled; spike bracteate, densely many-flowered, $6-10 \mathrm{~cm}$. long, one-sided; perianth glandular-hairy, white, the sepals and petals $6-8 \mathrm{~mm}$. long, about as long as the glandular ovary; lip concave, erect, the tip recurved, obtuse; column short, straight.

Common in mossy woods.

143. EPIPACTIS.

Tall stout leafy herbs with creeping rootstocks; leaves green, clasping the stem; flowers in terminal leafy-bracted racemes; sepals and petals separate; spur none; lip free, sessile, broad, concave below, the upper portion dilated and petal-like; column erect, short; anther 1, erect; capsule oblong, beakless.

Epipactis gigantea Dougl. Stout and leafy, 30-100 cm. high, nearly smooth; leaves ovate below, reduced to narrowly lanceolate upwards, 8-20 $\mathrm{cm}$. long, acute or acuminate, somewhat scabrous on the veins beneath; raceme pubescent; flowers $3-10$, greenish, strongly veined with purple, with large foliaceous bracts on slender pedicels, 4-6 mm. long; sepals ovate-lanceolate, $12-16 \mathrm{~mm}$. long, the upper concave; petals a little smaller, shorter; anther $4 \mathrm{~mm}$. long.

In moist places, rare.

\section{Sub-class II. DICOTYLEDONES.}

Embryo with two cotyledons; stem usually differentiated into bark, wood and pith; wood cells forming annual rings; leaves mostly net-veined; parts of flowers in fours or fives, rarely in twos or sixes.

\section{Family 25. SALICACEAE. Willow Family.}

-Trees or shrubs with light wood, bitter bark and brittle twigs; leaves alternate; stipules of ten minute; flowers solitary in the axil of each bract, dioecious, both staminate and pistillate in aments which expand with or before the leaves; staminate aments of ten pendulous; pistillate pendulous, erect or spreading; staminate flowers of 1-many hypogynous stamens, subtended by a gland-like or cup-shaped disk; pistillate flower consisting of a sessile 
or short-stipitate 1-celled ovary subtended by a minute disk; ovules usually numerous; fruit an ovoid or oblong or conic 2-4-valved capsule; seeds minute; endosperm none.

Ament bracts entire; stamens 1-10; stigmas short. Ament bracts fimbriate or incised; stamens numerous; stigmas elongated,

144. SALIX, 113.

145. Populus, 118.

\section{SALIX.* WILLOW.}

Trees or shrubs with single-scaled buds, the scales with an adherent membrane within; leaves short-petioled, mostly narrow, with broad or minute stipules; aments appearing before, with or after the leaves, erect or spreading; bracts of the aments mostly entire, small or minute; flowers each with one or two small glands at its base; stamens $1-10$, mostly 2 or 5 ; ovary sessile or shortstipitate, glabrous or pubescent.

Trees with longitudinally furrowed bark; petioles glandular; aments on leafy peduncles; stamens 5 or more.

Shrubs or small trees; bark not furrowed; stamens 2 or 1.

Scales yellow, deciduous; aments appearing long after the leaves, on long leafy peduncles.

Capsule $4 \mathrm{~mm}$. long, obtuse, glabrous; stigmas sessile, short; leaves glabrate.

Capsule 5-7 mm. long, acute, pubescent (becoming S. lasiandra lyallii. glabrate); styles 0.5 and stigmas $1 \mathrm{~mm}$. long.

Branchlets, leaves and capsules thinly villous; leaves acute to acuminate at both ends.

Branchlets, leaves and capsules densely villous; leaves sessile, rounded to acute at base.

Scales light brown to black, persistent; aments appearS. melanopsis.
S. fluviatilis (?).
S. sessilifolia.

ing before or with the leaves.

Capsule glabrous.

Low shrubs; scales very small, light brown.

Pedicels 3-5 $\mathrm{mm}$. long; leaves thin, coarsely reticulate with slender veins.

Pedicels 2-3.5 $\mathrm{mm}$. long; leaves thick, finely reticulate with coarse veins.

Tall shrubs or small trees; scales mostly black.

Pedicels 2-4 mm. long; styles $0.5 \mathrm{~mm}$. long. S. mackenziana.

Pedicels 1-2 mm. long; styles 1-1.5 mm. long.

Aments on leafy peduncles; low alpine shrubs.

Leaves glabrate above, glabrous and glaucous beneath.

Leaves tomentose and green on both sides, becoming glabrate.

Aments sessile or subsessile, elongated;

S. prolixa.

S. pedicellaris. tall coastal shrubs.

Branchlets and leaves glabrous

S. barclayi.

S. commutata.

* The treatment of the genus Salix has been revised and amplified with the assistance of Mr. C. R. Ball. 
throughout; blades broadly oblanceolate.

S. piperi.

Branchlets tomentose; leaves elliptic-ovate, tomentose beneath.

S. hookeriana.

Capsule pubescent.

Tall shrubs or small trees.

Styles 1-1.5 mm. long; scales obovate, black, long-pilose.

Capsules 3-4 mm. long; stamen 1; leaves spatulate-oblanceolate, silvery-silky beneath.

Capsules 6-8 mm. long; stamens 2.

Leaves elliptic-ovate, gray tomentose beneath.

Leaves obovate, glabrous and glaucous beneath.

S. sitchensis.

S. hookeriana.

S. pennata.

Styles 0.2-0.4 mm. long.

Leaves large, broadly obovate to elliptical; scales obovate, black; stigmas long.

Leaves small, narrowly oblanceolate; scales narrow, yellowish to brown; stigmas short.

Prostrate alpine shrubs; a few inches high.

Leaves lanceolate, acute at each end, green both sides; styles $2 \mathrm{~mm}$. long.

Leaves oval, obtuse at apex, reticulate, glaucous beneath; styles very short.

Leaves 1-3 cm. long; aments manyflowered.

Leaves 5-10 $\mathrm{mm}$. long; aments 3-6flowered.

\section{S. scouleriana.}

S. geyeriana.

S. cascadensis.

S. saximontana.

S. nivalis.

Salix lasiandra lyallii Sarg. Tree $10-20 \mathrm{~m}$. tall, with rough longitudinally fissured bark; leaves lanceolate, long-acuminate, crenate-serrulate, glaucous beneath, 8-16 cm. or more long, the short petioles and the very base of the leaf glandular; stipules ear-shaped, sometimes large; aments on leafy branchlets; staminate dense, $3-5 \mathrm{~cm}$. long; scales pale, lanceolate, more or less dentate; stamens 5 or more, the filaments hairy at the base; pistillate aments $3-10 \mathrm{~cm}$. long and rather loose, the pale lance-ovate scales hairy at the base, deciduous; capsule glabrous, 6-7 mm. long; pedicel about $2 \mathrm{~mm}$. long; style about $0.5 \mathrm{~mm}$. long.

Common along lake and river banks and in swamps.

Salix melanopsis Nutt. Shrub, 3-5 m. high; twigs dark, glabrous; leaves oblanceolate to elliptical, 5-10 cm. long, 6-15 cm. wide, glabrous or thinly pubescent, paler or sub-glaucous beneath, remotely denticulate or subentire; stipules triangular-ovate, acute, few-toothed; aments slender, $3-4 \mathrm{~cm}$. long, on elongated leafy branches; scales obtuse, tawny; capsules subsessile, ovoidconic, obtuse, $4 \mathrm{~mm}$. long, glabrous; stigmas sessile, short, divided.

Usually on gravelly banks of streams; rare in our limits.

Salix fluviatilis Nutt. (?) Shrub $2-6$ or 8 (?) m. high; branchlets pubescent to glabrous; stipules ovate-lanceolate, $2-6 \mathrm{~mm}$. long; leaves subsessile, narrowly lanceolate or elliptical (on fruiting branches often oblanceolate), acute or short acuminate at both ends, subaristate at the apex, 5-7 cm. long, 8-14 mm. wide (leaves subtending the branchlets much larger), remotely spinulosedenticulate, thinly pubescent, becoming glabrate (the young often silvery 
villous), green above, paler to glaucescent beneath; aments clustered, terminal on leafy branchlets; pistillate $3-7 \mathrm{~cm}$. long; ovary villous; capsule subsessile, lanceolate, 5-7 mm. long, thinly villous to glabrous; style about $0.5 \mathrm{~mm}$. long, divided; stigmas $1 \mathrm{~mm}$. long, divided, linear; staminate ament shorter; stamens 2; filaments pubescent; anthers $1 \mathrm{~mm}$. long; scales in both sexes $2.5-3.5 \mathrm{~mm}$. long, glabrous.

S. sessilifolia of authors, not of Nuttall. A distinct species probably but not certainly $S$. fluviatilis Nutt. On the Columbia River at and near the mouth of the Willamette and southward in Multnomah County, Oregon. Nuttall collected his original specimens on "the border of the Oregon, a little below its confluence with the Wahlamet."

Salix sessilifolia Nutt. Shrub 2-3 m. high; branchlets villous-tomentose with spreading hairs, those of the season densely so; stipules ovate-lanceolate, 1-4 $\mathrm{mm}$. long; leaves narrowly to broadly lanceolate or elliptic-lanceolate, $2.5-5 \mathrm{~cm}$. long, 8-15 mm. wide, the sprout leaves larger, acute to rounded at the base, acute or short-acuminate and subaristate at the apex, spinulosedenticulate, especially on the outer half, green and densely to thinly lanatetomentose with spreading hairs on both sides; aments appearing after the leaves, solitary (?), terminal or falsely lateral, on short leafy peduncles 1-5 $\mathrm{cm}$. long; pistillate aments $4-6 \mathrm{~cm}$. long, the deciduous yellow scales broadly elliptic-lanceolate, densely villous; pedicel $0.5 \mathrm{~mm}$. long, villous; capsule lanceolate, 5-6.5 mm. long, villous; style about $0.5 \mathrm{~mm}$. long, divided; stigmas nearly $1 \mathrm{~mm}$. long, divided; staminate aments not seen on typical material (on approximately typical specimens $3-4 \mathrm{~cm}$. long; scales elliptical, pilosepubescent; stamens 2; filaments pubescent, free; anthers about $1 \mathrm{~mm}$. long).

Common in the upper Willamette Valley and on the Umpqua at Roseburg. Nuttall's type in the British Museum is matched by Hall, no. 474, Western Oregon, and Cusick, no. 1514?, Linn County, Oregon. Henderson, April 25, 1885 , Oregon City, Oregon, and Ball, no. 1978, Corvallis, Oregon. Nuttall's original specimens were collected on the "rocky borders of the Oregon at the confluesnce of the Wahlamet."

Salix prolixa Anderss. Low shrub; branchlets slender, dark, glabrous; stipules minute or wanting; leaves oblanceolate or lanceolate to broadly lanceolate, acute, 3-6 cm. long, entire or very shallowly serrulate, green above, paler to glaucous beneath, glabrous, loosely reticulate on both surfaces with slender raised veins; aments on short leafy peduncles, appearing with the leaves; pistillate $3-5 \mathrm{~cm}$. long, very lax; scales tawny, oblanceolate, acute, very small, thinly tomentose; capsule $3-4 \mathrm{~mm}$. long, glabrous; pedicel slender, 3-5 $\mathrm{mm}$. long; style about $0.3 \mathrm{~mm}$. long; stigmas short; staminate aments 2-3 mm. long; stamens 2; filaments glabrous, free; anthers round, dark.

Rare in our limits; "not uncommon around Victoria, Vancouver Island," Macoun.

Salix pedicellaris hypoglauca Fernald. Shrub, 1-2 m. high, glabrous throughout; leaves elliptic to obovate, $2-4 \mathrm{~cm}$. long, entire, mostly obtuse, narrowed at the base, short-petioled, firm in texture, green above and glaucous beneath, finely reticulate on both sides; aments $1-2 \mathrm{~cm}$. long, appearing with the leaves and borne on leafy-bracted peduncles; stamens 2 ; capsules narrowly conic, 5-7 mm. long, glabrous; pedicels slender, $2-3 \mathrm{~cm}$. long, longer than the persistent acutish thinly villous scale; style very short.

In sphagnum bogs.

Salix mackenziana (Hook.) Barr. A shrub or small trees, 2-6 m. tall, with elongated dark sometimes tomentose branchlets; leaves lanceolate or ovate-lanceolate, to conic-lanceolate (often obovate while expanding), shortacuminate, rounded to cordate at the base, glandular-serrulate, $6-10 \mathrm{~cm}$. long, glabrous, glaucous beneath; petioles stoutish; stipules reniform to sublunate; 
aments appearing with the leaves, on short (4-8 mm.) peduncles bearing 2-3 small leaves; pistillate rather lax, $2.5-6 \mathrm{~cm}$. long; scales oblanccolate, obtusish, drying brown, thinly tomentose on the outside, densely so within; capsule 4.5-5.5 mm. long, glabrous; pedicel $2.5-4 \mathrm{~mm}$. long; style about $0.5 \mathrm{~mm}$. long; staminate aments shorter and more dense; stamens 2 ; filaments 2 , glabrous.

In moist ground, not common in our limits. This species and its subspecies S. mackenziana macrogemma Ball have been confused with the castern $S$. cordata Muhl.

Salix mackenziana macrogemma Ball, n. var. Branchlets densely pubescent-tomentose with gray hairs; buds elongated, 10-16 mm. long, lanceolate, acuminate, densely pilose-tomentose with long gray hairs; petioles and basal portion of midrib on upper surface pubescent, otherwise as in the species.

Seattle, Piper \& Smith; Portland, Henderson; Corvallis, Ball.

Salix barclayi Anderss. Shrub 1-4 m. high; leaves ovate-lanceolate to elliptic, broadly oblanceolate or obovate, acute to abruptly-acuminate or cuspidate, mostly rounded at base, $5-10 \mathrm{~cm}$. long, crenate-serrate to subentire, thinly tomentose but becoming glabrate above, paler to glaucous and glabrous beneath; aments borne on leafy peduncles, $2-4 \mathrm{~cm}$. long; the staminate $1-3 \mathrm{~cm}$. and the pistillate $2-6 \mathrm{~cm}$. long; scales linear-lanceolatc, acute, fuscous, villoustomentose; capsules $6-8 \mathrm{~mm}$. long, glabrous to pubescent; style $1-1.5 \mathrm{~mm}$. long; stigmas short; stamens 2; filaments glabrous, free.

In the mountains at about $2000 \mathrm{~m}$. altitude, usually forming thickets.

Salix commutata Bebb. Shrub 1-3 m. high; leaves oblong to broadly oblanceolate or obovate, $6-10 \mathrm{~cm}$. long, entire to minutely glandular-serrulate, cuspidate, densely tomentose on both sides when young, becoming glabrate in age, not paler beneath; aments appearing with the leaves, stout, $2-3$ or $4 \mathrm{~cm}$. long, on leafy peduncles, as in $S$. barclayi; scales brownish, oblanceolate, obtuse, woolly; capsule 5-7 mm. long, glabrous; pedicels $1 \mathrm{~mm}$. long; style 1-1.5 mm. long; stigmas short; stamens 2; filaments glabrous, free.

Higher altitudes in the mountains, often growing with $S$. barclayi.

Salix piperi Bebb. Large shrub, 5-6 m. tall; branchlets stout, glabrous, shining; leaves broadly elliptical or oblanceolate, obliquely acute or acuminate, serrulate, glabrous, shining green above, densely glaucous beneath; stipules rare, if present, semicordate or reniform; aments precocious or appearing with the leaves; staminate cylindrical, $3-5 \mathrm{~cm}$. long, short-peduncled; scales black, hairy; stamens 2, the glabrous filaments united at the base for half their length; pistillate aments $4-10 \mathrm{~cm}$. long, dense, on short leafy peduncles; capsules 6-7 mm. long, glabrous; pedicel and style $1 \mathrm{~mm}$. long.

Along streams and in swamps. Described from Seattle, at or near its northern li soumit; rangingthward through the Willamette Valley to Curry County, Oregon.

Salix hookeriana Barratt. Shrub or tree, 4-10 m. high, with rough darkgray bark; twigs densely pubescent and very brittle; leaves broadly lanceolate to elliptic-oval, acutc, crenate-serrate to subentire, dark green and glabrous above, densely white- (becoming rusty-) tomentose beneath, 3-12 cm. long; aments appearing before the leaves; staminate aments stout, short-cylindric, densely flowered, 2-5 cm. long, the obovate scales black, densely covered with long white hairs; pistillate aments $4-7 \mathrm{~cm}$. long, stout; capsules usually tomentose, sometimes glabrate; style $1 \mathrm{~mm}$. long; stigmas short.

A species occurring mainly near the ocean beach and rare along the shores of Puget Sound.

Salix sitchensis Sanson. Shrub with smooth gray bark, 2-7 m. high; branchlets slender, at first downy; leaves oblong, spatulate or somewhat obovate, mostly acute, dark green above, the veins conspicuous, covered beneath 
with an appressed satiny white pubescence, entire or obscurely crenate, 5-10 $\mathrm{cm}$. long; petioles short; aments long, slender, ascending, densely flowered, 2-8 cm. long; scales dark, villous; capsules ovate-conical, acute, silky-pubescent, subsessile; style elongate, 1-1.5 mm. long; stigmas thick, erect.

Common along rivers and lake shores. Abundant along mountain streams.

Salix pennata Ball. Low shrub with dark, divaricate, stoutish, glabrous branchlets and large chestnut-colored buds; leaves obovate or elliptic-obovate, 3- $6 \mathrm{~cm}$. long, acute, narrowed at base, entire, very dark green above, glaucous beneath, the raised midrib and parallel primary veins conspicuous beneath, glabrous; aments sessile, stout; pistillate $2.5-7 \mathrm{~cm}$. long; capsules subsessile, 6-8 $\mathrm{mm}$. long, densely silvery pubescent; style about $1.4 \mathrm{~mm}$. long; stigmas long; scales obovate, acute, black, densely pilose; stamens 2; filaments glabrous, free.

Mount Adams, Suksdorf; Mount Hood, Howell, Applegate. This species is closely related to $S$. chlorophylla Anderss. under which name it is mentioned in the Flora of Washington.

Salix scouleriana Barr. Shrub or small tree, 4-10 m. tall, with dull gray bark; leaves very variable, mostly oblanceolate to obovate, sometimes oblong or elliptical, mostly obtuse or abruptly acute at the apex and cuneate at base, $3-10$ or $12 \mathrm{~cm}$. long, entire to shallowly serrulate, thick, green and glabrate above, silvery to rusty (in age) pubescent to glabrous and glaucous and reticulate beneath; stipules minute to large, ear-shaped, denticulate; aments appearing before the leaves, densely flowered, sessile or the pistillate very short peduncled, $2-5 \mathrm{~cm}$. long; capsules long-beaked, 7-9 $\mathrm{mm}$. long, tomentose; pedicels pubescent, $1.5 \mathrm{~mm}$. long; stigmas sessile, long; scales obovate, black, long-hairy; stamens 2; filaments glabrous, free.

The commonest willow in our limits, occurring both in dry uplands and swamps. The young leaves and bark have a peculiar fetid odor. An immensely variable species especially as to foliage.

Salix geyeriana Anderss. Slender-stemmed shrub, 3-5 m. high; branchlets glaucous, glabrous; leaves elliptic-lanceolate or sometimes oblanceolate, acute at each end, dark green and thinly pubescent above, pale to glaucous and silky beneath, 2-6 cm. long, the entire margins revolute; aments shortcylindric, 1-2 cm. long, appearing with the leaves, on short leafy peduncles; stamens 2, the filaments pubescent below; capsules sharply tapering from an ovoid base, 5-7 mm. long, densely pubescent; pedicels pubescent, $2 \mathrm{~mm}$. long; style short; stigmas short, divided; scales usually dark, narrow, acute, thinly pilose.

A rather rare willow found in open places along streams.

Salix cascadensis Cockerell. (S. tenera Anderss., not A. Br.) Prostrate creeping shrub about $5 \mathrm{~cm}$. high; leaves narrowly elliptical to obovate, broadest at or above the middle, acute at each end or rarely obtuse at the apex, green and glabrous on both sides, 8-12 mm. long; aments small, subglobose, 5-20 mm. long, few-flowered; scales brownish, villous; capsules sessile, 4-5 $\mathrm{mm}$. long, tomentose; styles elongate, $1-1.5 \mathrm{~mm}$. long.

Mount Rainier, Flett; second summit west of Skagit River, lat. $49^{\circ}$, Macoun, probably the same peak where first collected by Lyall.

Salix saximontana Rydb. Densely cespitose and much branched, 3-6 $\mathrm{cm}$. high; leaves elliptic-oblong to suborbicular, obtuse or abruptly acute at the apex, $15-25 \mathrm{~mm}$. long, $10-15 \mathrm{~mm}$. wide, with entire and revolute margin, light green above, glaucous and strongly net-veined beneath, glabrous throughout; aments 1-2 cm. long, many-flowered; scales broadly obovate, obtuse or rounded at the apex, cuneate at the base, yellowish, nearly glabrous; capsules 3-4 $\mathrm{mm}$. long, densely white-tomentose. Flett.

At high elevations in the Cascade and Rocky Mountains. Mount Rainier, 
Salix nivalis Hook. A low creeping shrub, 2-3 cm. high, similar to $S$. saximontana but smaller in every way; leaves elliptic or somewhat obovate, mostly obtuse, glabrous, entire with revolute margins, 7-12 $\mathrm{mm}$. long, green and shining above, glaucous and strongly net-veined beneath; aments very small, 3-6-flowered, on naked peduncles; scales oblanceolate, yellowish, glabrous or nearly so; capsule $2.5-3 \mathrm{~mm}$. long, sessile, tomentose; stigmas short, sessile, divided.

On the higher peaks of the Cascade Mountains. Mount Rainier, Flett.

\section{POPULUS.}

Trees with scaly resinous buds and rounded or angled twigs; leaves long-petioled, broad or narrow; bracts of the aments fimbriate or incised; disk cup-shaped, oblique, lobed or entire; staminate aments dense, pendulous; pistillate aments sometimes raceme-like by the elongation of the pedicels, pendulous, erect or spreading; staminate flowers with 4-60 stamens; filaments distinct; ovary sessile; seed with a very conspicuous tuft of hair.

Bark smooth; petioles flattened; capsules oblong-conic, smooth.

Bark rough; petioles terete; capsules globose, hairy.

$P$. vancouveriana. P. trichocarpa.

Mt Adams Populus vancouveriana Trelease n. sp.* Tree 5-10 m. high; bark smooth, the conal whitish; twigs chestnut colored to dark purplish; buds smooth, conical, gummy, dark purple; leaves broadly ovate to suborbicular, acute or abruptly acuminate, undulate-crenulate, somewhat silky pubescent beneath when young, glabrous in age, mostly $4-6 \mathrm{~cm}$. long; petioles equalling or slightly longer than the blades; staminate aments $4-5 \mathrm{~cm}$. long, the bracts $5 \mathrm{~mm}$. long. cleft into numerous ciliate filiform lobes; stamens many; pistillate aments and fruit unknown.

Vancouver Island, Lyall, 1858-9 (type in Gray Herbarium); Victoria, Macoun, nos. 2131, 2132; Seattle, E. S. Meany (staminate aments described from this specimen in United States National Herbarium). Apparently confined to the region west of the Cascade Mountains from Vancouver Island southward at least to the head of Puget Sound. This aspen is easily distinguished from the eastern $P$. tremuloides Michx. and the Rocky Mountain $P$. aurea Tidestrom by the peculiar dentition of the leaves. The teeth are much larger than in any of its immediate allies and besides being crenulate are depressed so that each tooth viewed from the edge forms a double curve. Herbarium material of this aspen is very scanty and complete specimens showing pistillate flowers, fruit and the leaves of the sterile shoots are much desired.

Populus trichocarpa T. \& G. Cottonwood. Large tree, 10-30 m. tall, with rough fissured pale gray bark; leaves broadly ovate, rounded at the base, acuminate, 5-12 cm. long, puberulent when young, whitish beneath; petioles slender, terete, about equalling the blades; staminate aments dense, the bracts long-hairy; stamens 50-60; pistillate aments becoming loose; capsules nearly sessile, globose, puberulent or glabrate.

Banks of streams and lake shores.

Family 26. MYRICACEAE. Sweet Gale FAmily.

Shrubs or small trees with alternate usually waxy-dotted and fragrant leaves; flowers solitary in the axils of bracts, monoecious

* Description by Mr. Ivar Tidestrom. 
or dioecious; perianth none; stamens 2-16; ovary 1-celled, 1ovuled; fruit a drupe-like nut.

\section{MYRICA. BAYBERRY.}

Shrubs or small trees with dentate or serrate leaves; fruit coated with wax.

Leaves deciduous, obtuse, serrate at apex.

Leaves evergreen, acute, serrate from near the base.

M. gale.

M. californica.

Myrica gale L. Sweet Gale. Dioecious low shrub, 1-2 m. high; leaves oblanceolate, 2-6 cm. long; obtuse, serrate only at the apex, deciduous, appearing after the aments; staminate aments in clusters; pistillate aments subglobose in fruit, the nutlets resinous-waxy, each bearing two winglike bracts that are adnate at the base.

Common along lake margins.

Myrica californica Cham. Monoecious evergreen shrub or small tree, 1-10 m. high; leaves oblanceolate, acute, serrate; aments bearing both staminate and pistillate flowers, the latter near the apex; nutlet purplish, papillose, with 2 minute bractlets at base.

Only along the ocean coast.

\section{Family 27. BETULACEAE. Birch FAmily.}

Trees or shrubs; leaves alternate, petioled, simple, with deciduous stipules; flowers small, monoecious; in linear-cylindric, oblong or subglobose aments; staminate aments pendulous; pistillate aments erect, spreading or drooping, spike-like or capitate; staminate flowers $1-3$ in the axil of each bract, with a membranous 2-4-parted calyx, or calyx none, and 2-10 hypogynous stamens; pistillate flowers with or without a calyx adnate to the solitary 1-2-celled ovary; ovules $1-2$ in each cavity; fruit a small compressed or ovoid-globose mostly 1 -celled and 1-seeded nut or samara; endosperm none.

Fruit a nut enclosed in a leafy involucre.

Fruit cone-like, without an involucre.

Cone scales thin, deciduous; stamens 2.

Cone scales thick, persistent; stamens 4 .

148. Corylus, 120 .

147. Betula, 119.

149. Alnus, 120.

\section{BetUla. Birch.}

Trees and shrubs; leaves dentate or serrate; buds scaly; flowers all in aments, expanding before and with the leaves; pistillate aments erect or spreading; staminate flowers about 3 in the axil of each bract, with a membranous usually 4 -toothed perianth and 2 stamens, and subtended by 2 bractlets; pistillate flowers 2 or 3 (rarely 1 ) in the axil of each bract; perianth none; 
ovary sessile, 2-celled; nut small, with a wing, shorter than the bracts.

Shrub; branchlets warty with resiniferous glands. Tree; branchlets pubescent, not warty-glandular.

B. glandulosa.

B. occidentalis.

Betula glandulosa Michx. ( $B$. hallii Howell.) Low shrub, about $1 \mathrm{~m}$. high; twigs glandular-warty; leaves orbicular or obovate, cuneate at base, crenate-dentate, $1-3 \mathrm{~cm}$. long, glabrous on both sides.

Common in sphagnum bogs.

Betula occidentalis Hook. Tree $10-30 \mathrm{~m}$. high, with gray or darker bark; leaves ovate, acute or acuminate, punctate above with resiniferous glands, pubescent beneath, somewhat doubly dentate, slender-petioled; fertile aments cylindric, 3-4 cm. long, on slender peduncles.

From the Skagit River northward on the shores and islands of Puget Sound and Vancouver Island, British Columbia. Hardly distinct from the more eastern B. papyrifera Marsh. Perhaps the largest of all the birches.

\section{CORYLUS. HAZELNUT.}

Shrubs with broad thin serrate or incised leaves; staminate aments sessile at the ends of the twigs of the previous season, expanding much before the leaves; staminate flowers one in the axil of each bract, each of four stamens; calyx none; pistillate flowers clustered at the ends of short branches of the season, each composed of an incompletely 2 -celled ovary adherent to a calyx; nut wingless.

Corylus californica (A. DC.) Rose. Tall shrub, 2-10 m. high; branchlets pubescent; leaves oval or obovate, obscurely 6-10-lobed, serrate, subcordate at base, pubescent; involucre bristly, united to the summit, prolonged beyond the nut into a broad tubular beak; nut ovoid.

In open woods, common.

149. ALNUS. ALDER.

Trees or shrubs; leaves dentate or serrulate; buds few-scaled; both kinds of flowers in aments, expanding before, with or after the leaves, the staminate pendulous, the pistillate erect, clustered; staminate flowers 3 , sometimes 6 , in the axil of each bract, consisting of a mostly 4 -parted perianth and 4 stamens, and subtended by 1 or 2 bractlets; filaments short, simple; anther-sacs adnate; pistillate flowers 2 or 3 in the axil of each bract, without a perianth, but subtended by $2-4$ minute bractlets; ovary sessile, 2-celled; styles 2 ; bracts woody, persistent, 5 -toothed or erose; nut small, compressed, wingless or winged.

Tree; leaves rusty-pubescent beneath; cones longer than the peduncles.

Shrub; leaves glutinous, nearly glabrous; cones shorter than the peduncles.

A. oregona.

Alnus oregona Nutt. Red Alder. Tree, $10-20 \mathrm{~m}$. high, with pale smooth bark; twigs reddish-brown, somewhat pubescent when young; leaves ovate to 
elliptic, acutish, coarsely and doubly crenate-dentate, 5-30 cm. long; fertile aments ellipsoid, 1-2 cm. long, on stout peduncles shorter than the aments; winter buds acute, gummy.

A very common tree, especially in wet ground.

Alnus sinuata (Regel) Rydb. (A. sitchensis Sarg.) Small tree or shrub, $9 / 2 / 20$ Mo 3-5 m. tall, erect or ascending; bark rather dark, except on old stems; twigs chestnut brown; buds smooth, gummy; leaves ovate, acuminate, obtuse or chrre con cuneate at the base, bright green, doubly dentate, glabrous above, nearly so $S$ mm beneath, thin, very gummy when young, $5-8 \mathrm{~cm}$. long; petioles slender, $1-2 \mathrm{~cm}$. long; fruiting aments $1-1.5 \mathrm{~cm}$. long, on slender peduncles as long or longer.

Abundant in the mountains but rare at low altitudes, occasional at sea level.

\section{Family 28. FAGACEAE. BeEch FAMily.}

Monoecious trees with alternate simple pinnately-veined leaves, with early withering stipules; petals none; staminate flowers in aments, each of 4-20 stamens and a calyx; pistillate flowers solitary or several together, sessile, in an involucre which becomes a bur or cup, each flower composed of a calyx adherent to a 4-8-celled ovary; fruit a 1-seeded nut.

Nuts enclosed in a spiny involucre.

150. Castanopsis, 121.

Nuts (acorns) only partly enclosed in cups which are not spiny.

151. Quercus, 121.

150. CASTANOPSIS. ChINQUAPIN.

Evergreen trees or shrubs with scaly bark and numerous budscales; leaves coriaceous, entire or dentate, pinnately-veined; flowers in threes in cymes or the pistillate solitary or in twos, in slender erect aments from the axils of the leaves of the year; styles 3 , spreading, terminating in minute stigmas; ovary sessile, 3 -celled, with 2 ovules in each cell; fruit maturing at the end of the second season; involucre covered by spines, tubercles or ridges, enclosing 1-3 ovoid or globose rarely obscurely angled nuts.

Fok Castanopsis chrysophylla (Dougl.) A. DC. Chinquapin. Tree usually $10-20 \mathrm{~m}$. high; bark in broad plates, reddish brown; leaves evergreen, !nnceolate to elliptic, entire, usually acute, 2-10 cm. long, short-petioled, glabrous or chorstightly scurfy above, densely scurfy beneath with golden yellow scales; a ments pen 3-7 cm. long; fruiting involucre densely covered with branched spines and 7 (amy $\$$ plitting into 4 irregular divisions; nut solitary, 3-angled, edible.

Skamania County, Washington, to California.

\section{QUERCUS. OAK.}

Trees; flowers very small, green or yellow, appearing with the leaves; pistillate flowers one in each involucre; involucre enlarging in fruit into a hard cup around the base of the elongated 1-seeded nut (acorn), the 5 undeveloped ovules remaining at the base or top of the perfect seed. 
Leaves with obtuse lobes; involucre shallow.

Leaves with sharp-pointed lobes; involucre deep.

Q. garryana.

Q. californica.

Quercus garryana Dougl. Garry Oak. Usually a large tree, with rather thin deeply checked bark; leaves thick, $10-15 \mathrm{~cm}$. long, coarsely lobed; lobes obtuse or acutish, usually entire but often again lobed; nut ovoid or obovoid, obtuse, in a shallow cup.

Common, especially on gravelly prairies. First described from Vancouver, Washington. On the islands in the northern part of Puget Sound, this oak becomes a low shrub locally known as "Vine Oak." The leaves of this form, which has never been found fruiting, are exceedingly variable, the lobes mostly acute and over-lapping. Professor Greene considered this to represent a distinct species which he named $Q$. gilberti. In sheltered places, this oak assumes the ordinary foliage of the Garry oak.

Quercus californica (Torr.) Cooper. (Q. kelloggii Newberry.) California Black Oak. Tree 20-30 m. high with rough black bark; leaves $10-16 \mathrm{~cm}$. long, oval in outline, shiny, deeply lobed, the lobes sharp-pointed; nuts oblongovoid, 2-3 cm. long, in deep cups.

From the McKenzie River, Lane County, Oregon, southward through California.

Family 29. URTICACEAE. Nettle Family.

Herbs (in ours); leaves alternate or opposite, simple, with or without stipules; flowers small, monoecious, dioecious or polygnooús; af 2-5 nearly separate sepals or cup-shaped; petals none; stamens as many as the calyx-lobes and opposite them; ovary 1-celled, mostly superior; ovule solitary; fruit an akene; endosperm scanty or none.

\section{URTICA. NETTLE.}

Annual or perennial simple or branching herbs with stinging hairs; leaves opposite, 3-7-nerved, petioled, dentate or incised, with distinct stipules; flowers greenish, very small and numerous, dioecious or monoecious; staminate flowers with a deeply 4parted calyx and 4 stamens; pistillate flowers with 4 sepals, the two inner larger and in fruit enclosing the akene; the two outer smaller and spreading.

Urtica lyallii Wats. Perennial with creeping rootstocks; stems simple, erect, 1-2 m. high, merely bristly or glabrous; leaves broadly ovate, cordate, very coarsely dentate, green and usually glabrous above, pubescent or glabrous beneath, 8-16 cm. long; stipules large, obtuse; pe:ioles slender; flowers in loose panicles; akene ovate.

Common in moist soil. The stinging hairs cause severe irritation. First found by $D r$. Lyall on the northern boundary of Whatcom County.

\section{Family 30. LORANTHACEAE. Mistletoe Family.}

Parasitic shrubs or herbs, yellow or yellowish-green, growing on woody plants and absorbing food from their sap through 
specialized roots (haustoria); leaves opposite; flowers regular, terminal or axillary, clustered or solitary, dioecious (in ours); calyx-tube adnate to the ovary; stamens 2-6; ovary solitary, erect; style simple or none; stigma terminal; fruit a berry; seed solitary; endosperm usually copious and fleshy.

Leaves scale-like, united at base; anthers 1-celled; berry stalked.

Leaves flat; anthers 2-celled; berry sessile.

153. RAZOUMOFSKYA, 123.

154. PHORADENDRON, 123.

\section{RAZOUMOFSKYA. SNAPPERS.}

Small fleshy glabrous plants, parasitic on the branches of coniferous trees; branches 4-angled; leaves reduced to opposite connate scales: flowers dioecious, not bracted, solitary or several together in the axils of the scales; staminate flowers with 2-5parted calyx and usually an equal number of stamens; pistillate flowers with an inferior ovary; berry fleshy, ovoid, more or less flattened, when ripe violently ejecting the glutinous seed.

Staminate flowers in panicles; branches in pairs or whorls; on Pinus contorta.

\section{$R$, americana.}

Staminate flowers in simple or compound spikes; branches solitary.

Stems tufted, 3-12 cm. high; on Tsuga heterophylla. R. tsugensis.

Stems scattered, not so tall.

Stems $0.5-2 \mathrm{~cm}$. high; on Pseudotsuga mucronata. $R$. douglasii.

Stems 3-7 cm. high; on Abies.

$R$. douglasiiabietina.

Razoumof skya americana Nutt. Stems olivaceous, slender, much branched, the branches in pairs or whorls; staminate plants $6-10 \mathrm{~cm}$. long, the pistillate a little smaller; staminate flowers with ovate acutish lobes; fruit bluish-green, $4 \mathrm{~mm}$. long.

On Pinus conlorta, causing swellings and distortions. Victoria, Vancouver Island, British Columbia, Macoun; Mount Constitution, Orcas Island, Pratt.

Razoumofskya tsugensis Rosendahl. Stems slender, 3-12 cm. high, much branched, olive-yellow in color; fruit obovate, beaked, $4-5 \mathrm{~mm}$. long.

Only on the hemlock, but usually abundant when found.

Razoumofskya douglasii (Engelm.) Kuntze. Stems greenish yellow, scattered; branches pubescent; spikes about 5-flowered; sepals of the staminate flowers ovate-orbicular, acute, $1 \mathrm{~mm}$. long; fruit $5 \mathrm{~mm}$. long. River.

On the Douglas spruce; known in our limits only south of the Columbia

Razoumofskya douglasii abietina (Engelm.) Piper. Stems 3-7 cm. high, the branches spreading or recurved; staminate flowers $2.5 \mathrm{~mm}$. broad; fruit 4 $\mathrm{mm}$. long.

On Abies grandis and A. concolor; not known from north of the Columbia River in our limits.

\section{PHORADENDRON.}

Shrubs, parasitic on trees, with terete usually jointed and brittle twigs; leaves opposite, flat, entire or wavy, faintly nerved; flowers 
dioecious, axillary, spicate, bracted and small, solitary or several in the axil of each bract; staminate flowers with a usually 3-lobed globose or ovoid calyx with a sessile 2-celled anther at the base of each lobe; pistillate flowers with a similar calyx adherent to the inferior ovary; style short, obtuse or capitate; fruit a sessile ovoid or globose fleshy berry.

Phoradendron villosum Nutt. Plant much branched, greenish-yellow, $20-40 \mathrm{~cm}$. high, the stout terete branches pubescent; leaves thick, oblanceolate to nearly orbicular, $1-5 \mathrm{~cm}$. long, obtuse, 3-nerved, villous or pubescent; spikes slender, shorter than the leaves; berries white, 3-4 $\mathrm{mm}$. in diameter.

On oak trees, Willamette Valley and southward. The staminate flowers have the odor of pond lilies.

\section{Family 31. Santalaceae. Sandalwood Family.}

Herbs, shrubs or trees; leaves alternate or opposite, entire, without stipules; flowers clustered or solitary, axillary or terminal, perfect, monoecious or dioecious; calyx adnate to the base of the ovary, 4-5-cleft; petals none; stamens as many as the calyx-lobes and oppos te them; ovary 1-celled; ovules $2-4$; fruit a drupe or nut with only one seed.

\section{COMANDRA.}

Glabrous erect perennial herbs, sometimes parasitic on the roots of other plants; leaves alternate, oblong, oval, lanceolate or linear, entire, pinnately veined; flowers perfect, terminal or axillary, rarely solitary, cymose, bractless; calyx campanulate, the base of its tube adnate to the ovary; limb 5-lobed; stamens 5 , rarely 4 , at the bases of the calyx-lobes and between the lobes of the disk; fruit drupaceous, globose or ovoid, crowned by the persistent calyx.

Comandra umbellata (L.) Nutt. Stems branched, very leafy, $15-35 \mathrm{~cm}$. high; leaves oblong, acute, $2-3 \mathrm{~cm}$. long, the midribs pale; cymes severalflowered, clustered at the summit of the stem; fruit globose, tipped by the persistent oblong calyx-teeth.

In dry ground, rare in our linits.

\section{Family 32. ARISTOLOCHIACEAE. Birthwort Family.}

Low herbs or twining shrubs; leaves alternate or basal, petioled, mostly cordate or reniform, without stipules; flowers axillary or terminal, solitary or clustered, perfect, mostly large; calyx-tube at least at the base adnate to the ovary, its limb 3-lobed, 6-lobed or irregular; petals none; stamens 6-12, united with the style; ovary partly or wholly inferior, mostly 6-celled; ovules numerous in each cavity; fruit a 6-celled capsule or berry; seeds ovoid or oblong, angled or compressed. 


\section{ASARUM. WILD GINGER.}

Stemless perennial of ten clustered herbs, with slender aromatic branched rootstocks; roots thick, fibrous-fleshy; leaves longpetioled, reniform or cordate, entire; flowers solitary, large, peduncled, brown-purple or mottled, borne near the ground; calyx bell-shaped or hemispheric, adnate to the ovary, at least below, regularly 3-lobed; stamens 12 , inserted on the ovary; ovary partly or wholly inferior, 6-celled, the parietal placentae intruded; ovules numerous; capsule coriaceous; seeds compressed.

Asarum caudatum Lindl. Sparsely hairy throughout; rootstocks elongate, 10-30 cm. long; leaves reniform-cordate, $5-10 \mathrm{~cm}$. broad, obtuse or acutish; petioles slender, elongate; peduncles 1-4 cm. long; flowers brown-purple; calyx-lobes oblong-lanceolate, attenuate, $2-5 \mathrm{~cm}$. long.

In woods, common, the whole plant with the faint odor of ginger.

\section{Family 33. POLYGONACEAE. Buckwheat Family.}

Herbs or shrubs; leaves alternate or sometimes opposite or whorled, simple, mostly entire, with usually sheathing united stipules (ocreae); flowers small, regular, perfect, dioecious, monoecious or polygamous, in spikes, racemes, corymbs, umbels or panicles; petals none; calyx free from the ovary, 2-6-cleft or parted, the segments sometimes petal-like; stamens 4-9, inserted near the base of the calyx or in staminate flowers crowded toward the center; pistil 1; ovary superior, 1-celled; ovule 1; fruit a lenticular or 3 -angled, rarely 4 -angled akene; endosperm mealy.

Flowers involucrate; stipules wanting.

Flowers not involucrate; stipules sheath-like.

Leaves reniform; sepals 4.

Leaves not reniform; sepals 6. (sometrmes 5)

Sepals unequal, the inner becomming much larger; stigmas tufted.

Sepals equal; stigmas capitate.
157. Eriogonum, 125.

158. OXYRIA, 126.

159. Rumex, 127.

160. Polygonum, 128.

\section{ERIOGONUM.}

Annual or perennial acaulescent or leafy-stemmed herbs or shrubs; stems simple or branched, often tufted; leaves entire, alternate or whorled; flowers small, in fascicles, subtended by a 5-8-toothed or cleft campanulate or cylindric involucre; inflorescence cymose, umbellate or capitate; calyx 6-cleft or parted, usually colored; segments equal or the outer ones larger; stamens 9; akenes pyramidal, 3-angled, more or less swollen near the base, invested by the calyx-segments or winged.

The species in our limits are all perennials.

Perianth not attenuate into a slender stipe-like base.

Outer perianth-segments like the inner.

E. nudum. 
Outer perianth-segments broader than the inner.

Involucre campanulate; perianth 3-4 mm. long. E. ovalifolium.

Involucre turbinate; perianth 5-6 mm. long. E. vineum.

Perianth attenuate and stipe-like at base.

Umbel compound; leaves oblong-ovate, usually cordate at base.

Umbel simple; leaves not as above.

Perianth yellow, glabrous; lobes of the involucre inflexed.

E. compositum.

Perianth pinkish, villous; lobes of the involucre erect.

E. umbellatum.

E. pyrolaefolium.

Eriogonum nudum Dougl. Leaves ovate or oblong, obtuse, tomentose beneath, 2-5 cm. long, mostly basal, on slender petioles; stems $30-50 \mathrm{~cm}$. high, glabrous; panicle sparingly branched; involucres glabrous; flowers glabrous or nearly so, white or rose-tinged, in clusters of 3-6.

Upper Willamette Valley and southward.

Eriogonum ovalifolium Nutt. A much branched tufted plant, densely white-tomentose to the flowers; leaves broadly ovate or orbicular, obtuse, 5-12 mm. long; peduncles slender, 5-20 cm. high; involucres campanulate, 4-5 mm. long; flowers in a dense head-like umbel, usually yellowish, 3-5 mm. long.

At high altitudes in the mountains.

Eriogonum vineum Small. Very similar to $E$. ovalifolium; involucres turbinate or vase-shaped, 4.5-5.5 $\mathrm{mm}$. long; perianth wine-red, 5-6 mm. long.

In rocky soil at high altitudes. Perhaps not distinct from E. ovalifolium.

Eriogonum compositum Dougl. Stems stout, simple, 20-30 cm. tall, glabrous or nearly so; leaves ovate or oblong-ovate, cordate, acute, densely white-woolly beneath, green and less so above, 4-10 cm. long, on petioles as long or longer; umbels 6-10-rayed, mostly compound, rather dense; principal bracts linear or oblanceolate; branches very short, $2-4 \mathrm{~cm}$. long; involucres pubescent, deeply 5-lobed, the lobes acute, spreading; flowers white or yellow, sparsely pilose.

In gravelly soil in open places.

Mt Adams Eriogonum umbellatum Torr. (E. montanum Howell.) Stems woody and much branched, $15-20 \mathrm{~cm}$. high; leaves spatulate, the blade oblong to orbicular, 1-4 cm. long, densely white tomentose beneath, green and glabrous above; peduncles $10-30 \mathrm{~cm}$. high, bearing a simple umbel of 3-10 rays with a fm whorl of foliaceous bracts at the base; involucre turbinate, somewhat woolly, deeply lobed, the lobes becoming reflexed; perianth bright-yellow, stipe-like at base, 4-5 mm. long, glabrous.

On the high peaks of the Cascade Mountains, perhaps only on the eastern watershed.

Mt.Adams Eriogonum pyrolaefolium coryphaeum T. \& G. Loosely tufted; leaves oblong or obovate, densely tomentose beneath, greener above, $2-3 \mathrm{~cm}$. long; peduncles 5-8 cm. high, smooth; flowers rose-colored, in dense umbels; perianth villous.

At high elevations in the mountains.

158. OXYRIA.

Perennial alpine herbs with long-petioled mostly basal leaves; stipules sheathing the stems; flowers perfect, without an involucre; calyx of 4 distinct herbaceous sepals, the two outer spreading, the inner erect; stamens 6 ; stigmas 2 ; akene compressed, 2-winged. 
Oxyria digyna (L.) Hill. Mountain Sorrel. Leaves fleshy, broadly reniform, often emarginate, $2-5 \mathrm{~cm}$. broad; stems $8-30 \mathrm{~cm}$. high; fruit orbicular, usually bright red.

In rocky places in the mountains.

159. RUMEX. DOCK.

Perennial or annual leafy-stemmed herbs, some species slightly woody; stem grooved, mostly branched; leaves entire or undulate, flat or crisped; sheaths usually cylindric, brittle, soon falling away; inflorescence of simple or compound often panicled racemes; flowers green or reddish, perfect, dioecious or polygamomonoecious, whorled, on jointed pedicels; calyx 6-parted, the three outer sepals unchanged in fruit, the three inner ones mostly developed into valves which are entire, dentate or fringed with bristle-like teeth; stamens 6; stigmas tufted; akene 3-angled, the angles more or less margined.

Flowers dioecious; leaves hastate; plant small.

R. acetosella.

Flowers not dioecious; leaves not hastate; plant coarse.

Outer sepals without tubercles; leaves crisped, oblong, truncate at base.

$R$. occidentalis.

Outer sepals, or some of them with tubercles; leaves neither crisped, nor oblong, nor truncate.

Sepals with slender teeth.

Annual; tubercles 3; pedicels very short.

Perennial; tubercle 1; pedicels long.

Sepals entire or nearly so.

Leaves flat, all lanceolate.

Leaves undulate, the lower cordate.

Valves 4-6 $\mathrm{mm}$. long; pedicels longer.

Valves $2 \mathrm{~mm}$. long; pedicels not longer.

R. maritimus,

$R$. obtusifolius.

R. mexicanus.

R. crispus.

$R$. conglomeratus.

Rumex acetosella L. Sheep Sorrel. Dioecious, widely spreading by $\% / 1 / 20 M+A 0$ creeping rootstocks; stems slender, $10-30 \mathrm{~cm}$. high simple or somewhat branched; leaves 3-10 cm. long, very acid, glabrous, mostly hastate, the basal lobes entire or toothed; sheaths scarious, becoming cut into lobes; panicle narrow, the branches ascending; bracts wanting; flowers small, on short jointed pedicels, clustered; sepals remaining small, much shorter than the 3 -angled akene.

A common and troublesome weed.

Rumex occidentalis Wats. Stout, $100-150 \mathrm{~cm}$. tall; leaves oblong-ovate, mostly obtuse, $15-40 \mathrm{~cm}$. long, entire or undulate, cordate at the base; petioles of the lower leaves long and slender, of the upper stout; panicles $30-60 \mathrm{~cm}$. long, dense, usually reddish; flowers on slender pedicels, $1 \mathrm{~cm}$. long; valves broadly ovate, obtuse, more or less toothed, 6-10 $\mathrm{mm}$. long, wholly without tubercles; akene brown, $4 \mathrm{~mm}$. long.

Common, especially in wet meadows near the seashore.

Rumex maritimus fueginus (Phil.) Dusen. Minutely pubescent; stems erect or procumbent, branched, $15-60 \mathrm{~cm}$. high; leaves linear-lanceolate, truncate or slightly cordate at base, 3-10 cm. long, wavy-margined; panicle dense, the flowers short-pedicelled in numerous close whorls; valves ovate, 
each bearing a linear-lanceolate tubercle on the back and 2 or 3 slender bristles on the margins.

Along the seashore, not common. This plant has generally been confused with $R$. persicarioides $\mathrm{L}$.

Rumex obtusifolius L. Bitter Dock. Stems $40-60 \mathrm{~cm}$. tall, erect; leaves oblong-ovate, all cordate, 15-30 cm. long; flowers long-pedicelled, in loose whorls; valves of the fruit ovate, fringed with a few bristly teeth, usually but one valve tubercle-bearing.

A troublesome weed, introduced from Europe.

Rumex mexicanus Meisn. Stems erect or decumbent, $40-90 \mathrm{~cm}$. long, slightly grooved, often branched below; leaves oblong-lanceolate or linearlanceolate, mostly acute, entire, rounded or cuneate at the base, $8-15 \mathrm{~cm}$. long; petioles rather short; panicle 10-12 cm. long, the branches short, leafy-bracted; valves triangular-ovate, slightly toothed, $3-4 \mathrm{~mm}$. long, each bearing a large oblong tubercle; akene broad, $2 \mathrm{~mm}$. long.

In wet places common., This species has been much confused with $R$. salicifolius Weinm.

Rumex crispus L. Yellow Dock. Stem stout, 50-100 cm. high, grooved, from an elongated fusiform root; leaves oblong, obtuse, truncate or rounded at the base, $15-30 \mathrm{~cm}$. long, the margin wavy and crisped; petiole short; panicle rather dense, $20-40 \mathrm{~cm}$. long, greenish; flowers on pedicels $5-10 \mathrm{~mm}$. long; valves 3-4 mm. long, broadly ovate or cordate, each bearing a tubercle; akene about 2-2.5 $\mathrm{mm}$. long, brown.

An introduced European weed.

Rumex conglomeratus Murr. Tall and slender; leaves ovate or lanceolate, the lower cordate; panicle elongated, leafy; flowers in dense whorls, the pedicels very short; valves of the fruit all tubercle-bearing.

A weed introduced from Europe.

\section{POLYGONUM.}

Annual or perennial, terrestrial or aquatic herbs, some species woody; stems erect, prostrate, climbing or floating; leaves alternate, sessile or petioled, continuous with or jointed to the cylindric funnelform or 2-lobed of ten lacerate or fringed sheaths; flowers small, perfect, green, white, pink or purple, variously clustered, the clusters terminal or axillary; pedicels jointed, subtended by the sheaths; calyx 4 or 5 -parted or cleft, the outer segments larger than the inner; stamens 3-9; stigmas capitate; akene lenticular or 3 -angled (rarely 4 -angled), invested by or exceeding the calyx.

Stems twining; leaves cordate.

Stems not twining; leaves not cordate.

$P$. convolvulus.

Leaves small, usually narrow; stems wiry.

Plant with woody rootstocks.

Plant without rootstocks; mostly annuals.

Plants prostrate.

Akenes not longer than the calyx.

Akenes protruding from the calyx.

Plants erect or ascending.

Flowers in rather de terminal brácteate

spikes; styles nearly obsolete.

Flowers axillary, or in loose or interrupted

P. paronychia. spikes; styles present.

$P$. aviculare.

$P$. fowleri.

P. kelloggii. 
Leaves rather broad, scarcely reduced upward.

Tall, branched throughout; style 3-cleft.

Low alpine plant; style 3 parted.

Leaves narrow, decidedly reduced upward.

Flowers in virgate much elongated loose spikes.

Flowers in interrupted but rather close spikes.

Style 3-cleft; filaments slender. $P$. spergulariaeforme. Style 3-parted; filaments dilated. $\quad P$. nuttallii.

Leaves comparatively large; flowers mainly terminal.

P. minimum.

P. douglasii.

Annuals; flowers in several spike-like racemes.

Ocreae naked; raceme drooping.

Ocreae bristly-ciliate.

Calyx not glandular; raceme dense.

Calyx glandular; racemes interrupted.

Racemes erect.

Racemes drooping.

Perennials.

Styles 3; plants with thick roots.

Flowers in racemes or panicles; styles short.

Flowers in a single dense spike-like raceme; styles long.

Raceme thick not bulbiferous; akenes smooth.

Raceme slender, often bulbiferous; akenes dull.

Styles 2; aquatic or swamp plants with flowers in spike-like racemes.

Leaves ovate or lanceolate, acuminate. $\quad P$. emersum.

Leaves oblong-elliptic, obtuse.

Sheaths without foliaceous border.

Sheaths with a spreading foliaceous border.

\section{P. lapathifolium.}

$P$. persicaria.

$P$. punctatum.

P. hydropiper.

P. newberryi.

P. bistortoides.

$P$. viviparum.

P. amphibium.

$P$. hartwrightii.

Polygonum convolvulus L. Annual; stems twining or prostrate, $50-100$ $\mathrm{cm}$. long, glabrous or pubescent, scurfy below; leaves heart-shaped or somewhat halberd-shaped, acuminate, $2-6 \mathrm{~cm}$. long, minutely scurfy beneath; petioles equalling or shorter than the blades; sheaths short; flowers in clusters on slender axillary leafy racemes; calyx 5-parted, closely investing the fruit; akene 3-angled, dull black, minutely roughened.

Introduced in cultivated or waste soil.

Polygonum paronychia Cham. \& Schlecht. Perennial, half shrubby, glabrous and somewhat glaucous; stems prostrate to ascending, irregularly branched, 20-80 cm. long; leaves sessile, lanceolate, revolute on the margins, strongly keeled beneath; sheaths silvery, lacerate, persistent on the old stems; flowers in small clusters, axillary in the upper leaves and crowded near the summit; calyx white or pinkish; stamens 8; akene 3-angled, black, smooth, shiny.

Along the ocean coast on sandy beaches.

Polygonum aviculare L. Knot-weed. Annual, glabrous; stems slender, 
prostrate, much branched, forming dense mats, the branches leafy to the top; leaves oblong or lanceolate, acute, $1-3 \mathrm{~cm}$. long, nearly sessile; sheaths scarious, cut into lobes; flowers 1 or few in the upper axils, pink, on very short pedicels which are included in the sheaths; akenes 3-angled, dull, minutely granular.

Everywhere a weed; much relished by stock.

Polygonum fowleri Robinson. Perennial, pale green; stems prostrate, branched, 10-50 cm. long, striate; leaves elliptic to oblong, short-petioled, 1-3 cm. long, about as long as the internodes; ocreae lacerate and scarious; flowers axillary; sepals oblong, green with the margins white or pink; akenes angular-ovoid, much longer than the calyx.

On sandy sea-beaches, Alaska to Washington; also on the Alantic coast.

Polygonum kelloggii Greene. Annual, branched from the base or simple, glabrous, $2-5 \mathrm{~cm}$. high, very leafy; leaves linear or lance-linear, sessile, acute, 5-10 mm. long; sheaths thin, lacerate; flowers in small clusters in the axils; calyx $2 \mathrm{~mm}$. long, green with white margins; akenes 3-angled, brown, dull, striate.

In open places in the mountains, rare in our limits.

Polygonum erectum L. Annual, yellowish green; stems erect or ascending, 20-60 cm. high, simple or branched; leaves elliptical or somewhat obovate, obtuse or acutish, 1-3 cm. long; flowers axillary, solitary or in twos; sepals yellowish-green, $3 \mathrm{~mm}$. long; akene triangular-ovoid, dull, enclosed by the calyx.

Native of Europe, sparingly introduced in waste places.

Polygonum minimum Wats. Annual, slightly scabrous, $5-30 \mathrm{~cm}$. high, usually branched from the base; stems wiry, red; leaves oblong-lanceolate, acute or apiculate, 5-12 mm. long; flowers axillary, crowded above, usually rose-colored, erect on short pedicels; stamens 5-8; akenes smooth, shiny, longer than the sepals.

In moist places at high altitudes, rare in our limits.

Mo Adams Polygonum douglasii. Greene. Annual; stems slender, $15-40 \mathrm{~cm}$. tall, erect, glabrous or nearly so; branches few, erect, angled; leaves lanceolate, acute at each end, sessile at the jointed base; sheaths cylindric, scarious, becoming cut into lobes; flowering branches slender; flowers 1-3, from the axils of the scattered bracts, soon becoming deflexed; calyx purple or whitish, with prominent green midribs; styles very short; akene 3-angled, black, shiny.

In gravelly soil, not common.

Polygonum spergulariaeforme Meisn. Annual, scurfy pubescent especially at the nodes; stems slender, wiry, loosely branched, erect, $15-30 \mathrm{~cm}$. high; leaves sessile, linear-lanceolate or oblanceolate, acute, $1-3 \mathrm{~cm}$. long, usually revolute on the margin, much reduced upward; sheaths lacerate; flowers in small clusters in the axils, more crowded toward the top; calyx $4 \mathrm{~mm}$. long, green with broad pinkish or white margin; stamens 8 ; filaments filiform; akene 3-angled, black, minutely roughened, shiny, included in the calyx.

In poor or gravelly soil, not common.

Polygonum nuttallii Small. Annual, glabrous; stems slender, angled, wiry, ascending, loosely branched, $5-15 \mathrm{~cm}$. high; leaves narrowly lanceolate or oblanceolate, acute at each end, sessile, 1-3 cm. long; sheaths at length lacerate; flowers axillary, crowded near the summit; calyx $2.5 \mathrm{~mm}$. long, pink margined; akene 3-angled, black, smooth, shiny.

British Columbia to Oregon, in open places, not common.

Polygonum lapathifolium L. Stems branched, $15-80 \mathrm{~cm}$. high, erect or ascending; leaves lanceolate, acuminate, scabrous on the midrib and margins, 10-20 cm. long; peduncles minutely glandular; spikes axillary and terminal, 
slender, 2-10 cm. long, erect or nodding; flowers white or pink; stamens 6; akene ovate, lenticular.

Sumas Prairie, Lyall; Vancouver Island, Macoun; rare in our limits.

Polygonum persicaria L. Lady's Thumb. Annual, erect or ascending, glabrous or puberulent; stems 15-90 cm. long; leaves lanceolate, acute or acuminate at each end, short-petioled, 5-25 cm. long, frequently with a brownpurple spot near the middle, glabrous or sparsely puberulent below and on the midrib margins and above; sheaths tubular, $10-15 \mathrm{~mm}$. long, coarsely fringed; spikes slender, 2-4 cm. long, slender peduncled, erect; calyx pink, 5-lobed; akene lenticular, black and shining.

Naturalized from Europe, very common.

Polygonum punctatum Elliott. Perennial or annual, nearly glabrous; stems erect or decumbent at base, often rooting at the nodes, $30-90 \mathrm{~cm}$. long; leaves lanceolate, acuminate, ciliate, $8-12 \mathrm{~cm}$. long; sheaths bristly ciliate; spikes erect, usually densely flowered; calyx greenish with white or pinkish margins; stamens 8; styles 2 or 3; akenes lenticular or 3-angled, smooth and shiny.

In wet places, not common in our limits.

Polygonum hydropiper L. Smartweed. Annual, glabrous; stems erect or ascending, 20-60 cm. high; leaves lanceolate, acute or acuminate, ciliate, 3-10 cm. long, very acrid; sheaths bristly-ciliate; spikes interrupted, nodding, $3-8 \mathrm{~cm}$. long; calyx green, dotted with dark glands; stamens 4 or 6 ; akenes minutely striate, dull.

In wet ground, not common, apparently introduced.

Polygonum newberryi Small. Perennial, dull green, somewhat puberulent $8 / 11 / 20 \mathrm{Mt}$ throughout; stems stout, rather fleshy, flexuous, mostly simple, $10-30 \mathrm{~cm}$. high; leaves ovate to ovate-oblong, obtusish, 1-4 cm. long, short-petioled; sheaths short, brown, scarious, entire; spikes axillary from the upper leaves, 1-2 cm. long, few-flowered; calyx greenish, 5 -parted, $3 \mathrm{~mm}$. long; stamens 8; akenes brown, 3 -angled, smooth and shiny.

In rocky soils in the Cascade Mountains at about $2000 \mathrm{~m}$. altitude.

Polygonum bistortoides Pursh. Perennial from a thick oblong tuber, glabrous throughout or sparsely puberulent; stem erect, simple, $30-60 \mathrm{~cm}$. tall; radical leaves oblong, acute or acuminate, 5-20 cm. long, 3-5 cm. broad, on slender usually shorter petioles; cauline leaves $3-4$, sessile, the uppermost much reduced, lanceolate; spikes oblong, 3-6 cm. long, dense; calyx white, deeply 5-cleft; akene chestnut-brown, 3-angled, smooth, shiny.

Moist meadows in the mountains at 1500 to $2000 \mathrm{~m}$. elevation.

Polygonum viviparum L. Petennial from a thick bulb-like base, glabrous; stems strictly erect, simple, $10-30 \mathrm{~cm}$. high; basal leaves oblong-lanceolate, acutish, truncate to subcordate at base, $5-20 \mathrm{~cm}$. long, long-petioled; cauline leaves lance-linear, sessile; spike terminal, erect, linear, the lower flowers often replaced by bulblets; calyx pink, 5-parted; stamens 8 ; styles long, exserted; akene triangular-ovoid.

A high alpine plant, collected in our limits only by Lyall, Cascade Mountains, latitude $49^{\circ}$.

Polygonum emersum (Michx.) Britt. Perennial, sparsely scabrous throughout; stems erect or decumbent, 1-2 m. long, rooting at the nodes; leaves oblong-lanceolate, acuminate, cuneate or rounded at the base, 8-16 cm. long, short-petioled; sheaths cylindric, loose, entire; spikes dense, $3-7 \mathrm{~cm}$. long, short-peduncled; calyx rose-red, 5-parted; akenes lenticular, black, shiny, slightly roughened.

In wet meadows; rare in our limits, common east of the Cascade Mountains; Sumas Prairie, Lyall. 
Polygonum amphibium L. Perennial, aquatic, glabrous or nearly so; leaves floating, elliptic or oblong, obtuse or acutish, smooth and shiny above, 5-12 cm. long, long-petioled; spikes dense, $2-3 \mathrm{~cm}$. long.

In ponds and lakes, common.

Polygonum hartwrightii Gray. Perennial, on muddy banks, more or less strigose-pubescent especially on the sheaths and bracts.

On the borders of ponds and lakes, not uncommon. Many botanists - consider this only a hairy terrestrial state of P. amphibium.

\section{Family 34. CHENOPODIACEAE. Goosefoot Family.}

Mostly annual or perennial herbs; stems angled, striate or terete; leaves alternate or sometimes opposite, simple, entire, toothed or lobed, mostly petioled, without stipules; flowers perfect, polygamous, monoecious or dioecious, small, greenish, regular or slightly irregular, commonly in panicled spikes, with or without bracts; calyx persistent, 2-5-lobed or parted, or rarely reduced to a single sepal or in some pistillate flowers wanting; petals none; stamens as many as the calyx lobes or fewer and opposite them; disk usually none; ovary mostly free from the calyx, 1-celled; ovule 1; fruit a utricle; endosperm mealy, fleshy or wanting.

Leaves nearly terete, fleshy.

Leaves flat, scale-like or subulate, not fleshy.

Leaves scale-like; flowers embedded in the fleshy axis.

161. Dondia, 132.

Leaves not scale-like; flowers not embedded in the axis.

Flowers unisexual; fruit enclosed by two bracts.

Flowers perfect; fruit bractless. Leaves becoming spiny. Leaves not spiny.

162. Salicornia, 132.

163. Atriplex, 133.

164. SAlsola, 133.

165. Chenopodium, 133.

\section{DONDIA.}

Fleshy plants growing in salty places; leaves alternate, fleshy, linear, nearly terete; flowers sessile in the axils of leafy bracts; calyx 5-parted, fleshy, enclosing the fruit; stamens 5 ; stigmas 2 or 3; embryo spirally coiled; endosperm scanty or none.

Dondia maritima (L.) Druce. Sea-blite. Stems 5-40 cm. high, with ascending or sometimes procumbent branches; leaves linear, plane above, convex beneath, glaucous, $3-5 \mathrm{~cm}$. long, those on the flowering branches reduced; flowers $1-4$, axillary, shorter than the subtending leaf; sepals convex or obscurely keeled; seed brown to black, $2 \mathrm{~mm}$. broad.

Salt marshes, rare in our limits. Coupeville, Gardner.

162. SALICORNIA.

Low plants growing in salty places; stems succulent, jointed; leaves reduced to opposite scales or teeth; flowers perfect, em- 
bedded three together in each hollow of the thickened upper joints forming a spike; the two lateral ones sometimes sterile; stamens 1 or 2 ; styles 2 , united at the base; embryo horseshoeshaped.

Salicornia ambigua Michx. Glasswort or Samphire. Stems erect or decumbent, 8-30 cm. high, from a somewhat woody base; spike $2-5 \mathrm{~cm}$. long, its scales short and acute; flowers subequal in size, as long as the joint.

Common in salt marshes.

\section{ATRIPLEX. Saltbush.}

Annual herbs, usually mealy or scurfy; flowers in leafy spikes, monoecious or dioecious; staminate with a 5-lobed calyx and mostly 5 stamens; pistillate of a naked pistil between 2 appressed foliaceous bracts, which are enlarged and sometimes united in fruit.

Bracts ovate to linear, without crest-like thickenings; leaves linear.

Bracts angular-ovate, usually with crest-like thickenings; leaves linear-lanceolate.

A. zosteraefolia.

Atriplex zosteraefolia (Hook.) Wats. Stems weak, decumbent, $20-30 \mathrm{~cm}$. long, glabrous or slightly scurfy; leaves fleshy, linear, mostly opposite, 3-10 $\mathrm{cm}$. long, 3-4 $\mathrm{mm}$. broad; flowers in axillary clusters; bracts ovate to linear.

Originally found on the shores of the Straits of San Juan de Fuca by Scouler; recently found by Dawson and Macoun at various points on the coast of Vancouver Island and adjacent British Columbia.

Atriplex littoralis L. Stems decumbent or sometimes erect, $30-60 \mathrm{~cm}$. long; leaves lanceolate or linear, sometimes hastate or few-toothed, darkgreen, somewhat scurfy; flowers in terminal panicles; bracts of the fruit deltoidtriangular, often tubercled or crested on the back, the margins thinner and green.

Common on the seashore.

164. SALSOLA.

Annual bushy-branched herbs; leaves rigid, subulate, pricklepointed; flowers sessile, perfect, 2-bracteolate, solitary in the axils, or sometimes several together; calyx 5-parted; stamens 5; utricle flattened, enclosed by the calyx, the segments of which are appendaged by a broad membranous horizontal wing in fruit; endosperm none.

Salsola kali tenuifolia G. F. W. Mey. Russian Thistle. Much branched from the base, forming hemispherical plants $30-90 \mathrm{~cm}$. or more in diameter; branches striate, often reddish below; leaves linear, bluish-green, sessile, tipped with a sharp point, fleshy at first but becoming dry and stiff, $1-3 \mathrm{~cm}$. long; wings of the calyx persistent, membranous.

Sparingly introduced but not troublesome as a weed in our limits.

165. CHENOPODIUM. GOOSEFOOT,

Annual or perennial, green and glabrous, white-mealy or glandular-pubescent herbs; leaves alternate, petioled, entire, 
sinuate-dentate or pinnately-lobed; flowers very small, green, perfect, sessile, bractless, clustered in axillary or terminal, of ten panicled or compound spikes; calyx 2-5-parted or lobed; stamens $1-5$; utricle embraced or enclosed by the calyx, the segments of which are herbaceous or slightly fleshy in fruit; endosperm mealy.
Calyx somewhat fleshy and often red in fruit; stamens 1 or 2.
C. humile.
Calyx not fleshy nor red;
Leaves mealy beneath.
Leaves green and glabrous or very slightly mealy.
Calyx-lobes keeled; teeth of the leaves few.
C. album.
C. hybridum.
Calyx-lobes not keeled; teeth of the leaves numerous.
Seeds dull; axillary flower clusters shorter than the leaves.
Seeds shiny; axillary flower clusters mostly longer than the leaves.
C. murale.
C. urbicum.

Chenopodium humile Hook. Stems usually decumbent, much branched, low; leaves ovate or lanceolate, often hastate, $2-5 \mathrm{~cm}$. long, dentate or entire, green; flower clusters in the axils of the upper leaves; seed small, $0.5 \mathrm{~mm}$. broad.

Along the seashore, not common.

Chenopodium album L. Lamb's Quarters. Pigweed. Erect, stout, 50$100 \mathrm{~cm}$. tall, usually simple below the inflorescence, more or less white-mealy throughout; leaves rhombic-ovate, sinuate or dentate, obtuse or acute, 2-4 $\mathrm{cm}$. long, greener above; petioles slender, nearly equalling the blade; uppermost leaves lanceolate and entire; panicle commonly $30 \mathrm{~cm}$. long; spikes axillary or terminal, rather dense; fruiting calyx $1 \mathrm{~mm}$. broad, the sepals keeled and arched over the lenticular fruit; seed black, minutely pitted.

A common introduced weed.

Chenopodium hybridum L. Green and glabrous throughout or the inflorescence a little mealy, erect, 60-120 cm. high; leaves triangular-ovate, acuminate, somewhat cordate at base, thin and rather large, 5-20 cm. long, with a few large teeth on each side; inflorescence a loose panicle; flowers in small clusters in leafless racemes; calyx-lobes keeled, shorter than the fruit.

In waste places, introduced from Europe.

Chenopodium murale L. Annual, green, slightly or not at all mealy; stems erect or nearly so, branched, $30-70 \mathrm{~cm}$. high; leaves rhombic-ovate, acute, truncate to cuneate at base, coarsely and unequally dentate, 5-10 cm. long; axillary flower clusters diverging, shorter than the leaves; seeds dull, sharp-edged.

A weed from Europe, occasionally found in waste places.

Chenopodium urbicum L. Annual, green and glabrous or slightly mealy; stems erect, usually branched, $30-80 \mathrm{~cm}$. tall; leaves triangular-ovate, acutish, mostly truncate at base, coarsely dentate, the larger ones 8-12 cm. long; axillary flower clusters narrow, erect, the upper ones longer than the leaves; seeds shiny, rounded on the edge.

Native of Europe, sparingly introduced as a weed in waste places.

\section{Family 35. AMARANTHACEAE. Amaranth Family.}

Weedy herbs; leaves thin, simple, mostly entire, alternate or opposite; flowers small, green or white, perfect, monoecious, polygamous or dioecious, bracteolate, usually in terminal spikes 
or axillary heads; calyx herbaceous or membranaceous, 2-5parted, the segments distinct or united at the base, equal, or the inner ones smaller; petals none; stamens 1-5, mostly opposite the calyx-segments, hypogynous; ovary 1-celled; ovule 1 (in ours); fruit a utricle, 1-seeded (in ours); endosperm mealy, usually copious.

\section{AMARANTHUS. AMARANTH.}

Annual branched erect or diffusely spreading, glabrous or pubescent herbs; leaves alternate, petioled, pinnately veined, entire, undulate or crisped; flowers small, green or purplish, mostly 3-bracteolate, in dense terminal spikes or axillary clusters; calyx of $2-5$ distinct sepals; stamens $2-5$; fruit an ovoid or oblong utricle, 2-3-beaked with the persistent style. Mostly pernicious weeds.

Flowers in dense terminal spikes.

Flowers in axillary clusters.

Plant erect, much branched; fruit rugose.

Plant prostrate; fruit not rugose.

A. retroflexus.

A. graecizans.

A. blitoides.

Amaranthus retroflexus L. Pigweed. Stem stout, 50-200 cm. tall, erect, pubescent, simple or branched; leaves ovate or rhombic-ovate, acute or obtuse, obscurely crenate or entire, minutely roughened, $3-10 \mathrm{~cm}$. long, slenderpetioled; spikes very dense, cylindric, erect, in large panicles; bracts subulate, 4-5 mm. long; sepals 5, oblong, acute, obtuse or emarginate.

Introduced in waste places.

Amaranthus graecizans L. Tumbleweed. Erect, pale green, much branched, glabrous or nearly so, 15-60 cm. tall; leaves oblong or narrowly obovate, obtuse or emarginate, $2-3 \mathrm{~cm}$. long, short-petioled; flowers in small axillary clusters; bracts subulate, spiny-pointed, much exceeding the sepals; sepals 3, oblong-lanceolate, membranous; fruit roughened.

Departure Bay, Vancouver Island, British Columbia, Macoun.

Amaranthus blitoides Wats. Very similar to A. graecizans but the branches prostrate, $30-60 \mathrm{~cm}$. long; bracts ovate-oblong, acuminate, little longer than the sepals; fruit smooth.

Departure Bay, Vancouver Island, British Columbia, Macoun.

\section{Family 36. NYCTAGINACEAE. Four O'Clock FAMILy.}

Herbs (in ours) with stems swollen at the joints; leaves opposite, entire; flowers in a terminal or axillary cluster subtended by an involucre; calyx tubular or funnelform, corolla-like; petals none; stamens 3-5, hypogynous; ovary 1-celled, 1-seeded, enclosed by the calyx-tube which is constricted above the ovary and is hardened in fruit into a nut-like pericarp. 


\section{ABRONIA.}

Annual or perennial herbs, with opposite petioled thick entire leaves; stems erect or prostrate; flowers sessile, conspicuous; calyx elongated, with 5 obcordate lobes; stamens $3-5$, unequal, on the calyx-tube; style filiform; fruit dry, with 1-5 net-veined wings.

Flowers rose-colored; wings of the fruit solid. Flowers yellow; wings of the fruit hollow.

A. acutalata. A. latifolia.

Abronia acutalata Standley. Stems prostrate; leaves oblong or ovate, obtuse, $2-4 \mathrm{~cm}$. long, slender-petioled; involucral bracts narrowly lanceolate; flowers rose-pink; wings of the fruit broad, thin, acute, prolonged beyond the body.

Along the ocean beach. Closely allied to A. umbellata Lam. to which our plant has usually been referred.

Abronia latifolia Esch. Prostrate, sticky-pubescent; root thick and fleshy; leaves ovate or reniform, thick, 2-4 cm. long; involucral bracts ovate to orbicular; flowers bright yellow.

Along the seashore. Herbage readily eaten by hogs and cows.

\section{Family 37. AIZOACEAE. Carpet WeEd Family.}

Soft herbs, sometimes fleshy or succulent; leaves whorled or opposite; stipules wanting; flowers small, regular, perfect, solitary, cymose or glomerate; calyx 4-5-cleft or parted; petals and stamens sometimes numerous, but petals often wanting; ovary usually free from the calyx, 2-several-celled; ovules numerous in each cell (in ours); fruit a capsule; endosperm scanty or copious.

\section{Mollugo. Carpet Weed.}

Mostly annual, much branched herbs; leaves whorled, sometimes basal or alternate; stipules scarious, membranaceous, deciduous; flowers small, whitish, cymose or axillary; sepals 5, white inside, scarious-margined, persistent; petals none; stamens hypogynous, 3 and alternate with the 3 cells of the ovary or 5 and alternate with the sepals; ovary and capsule usually 3 -celled.

Mollugo verticillata L. Carpet Weed. Annual, glabrous throughout, prostrate; stem slender, $10-30 \mathrm{~cm}$. long, branched; leaves spatulate or oblanceolate, acute or obtuse, entire, narrowed at the sessile base, 1-2 cm. long, 3-8 in a whorl; flowers small, solitary in the axils, on pedicels as long or longer; sepals oblong, shorter than the ovoid capsules; seeds shining, brown, curved.

On river banks, probably in our limits; common east of the Cascade Mountains.

Family 38. PORTUlaCACEAE. Purslane Family.

Annual or perennial usually succulent herbs; leaves entire, alternate or opposite; flowers regular, perfect; sepals 2 or 4-8; 
petals 4 or 5 , hypogynous, early withering; stamens as many as or more numerous than the petals and adherent to their bases; ovary 1-celled; ovules few to many; endosperm mealy.

Ovary half-inferior; sepals partly united.

169. Portulaca, 137.

Ovary superior.

Capsule circumscissile; sepals 4-8.

Capsule not circumscissile.

Style branches 2; capsule 2-valved; sepals scarious.

170. LeWisia, 137.

Style branches 3; capsule 3-valved; sepals not scarious.

Petals 3-7; stamens 3-12; leaves alternate, fleshy.

Petals 5; stamens 3 or 5 ; leaves opposite or alternate, not fleshy.

Corolla zygomorphic; styles short, cleft nearly to the base.

Corolla regular; styles elongated, united nearly to the top.

171. Spraguea, 138.

172. Calandrinia, 138.

173. Montia, 138.

174. Claytonia, 139.

\section{PORTULACA.}

Low fleshy herbs; leaves alternate or partly opposite; stipules scarious or none, or reduced to hairy tufts; flowers terminal and sessile, expanding in direct sunshine before mid-day, soon closing; sepals 2, coherent at the base in a tube and adnate to the ovary; stamens 7-20; ovules numerous.

Portulaca oleracea L. Purslane. Annual, prostrate, fleshy, forming mats $10-40 \mathrm{~cm}$. in diameter; leaves narrowly obovate, obtuse or truncate, narrowed at base, 1-2 cm. long, glabrous; calyx-lobes ovate, keeled; petals yellow, notched at the apex; stamens 7-12; capsule conical, acute, dehiscing below the middle.

Sparingly introduced as a weed.

\section{LEWISIA.}

Low acaulescent fleshy perennial herbs, with fleshy roots or a corm; flowers on short scapes, showy; sepals 4-8; petals 3-16; stamens numerous; capsule circumscissile; seeds many, black, shining.

Plant 10-20 cm. high; inflorescence a many-flowered panicle. Plant 2-8 cm. high; scapes 1-3-flowered.

L. columbiana. L. pygmaea.

Lewisia columbiana (Howell) Robinson. Roots fleshy, branched; leaves oblanceolate to spatulate, fleshy but flat, $2-5 \mathrm{~cm}$. long, green; scapes stout, 10-30 cm. high; bracts oblong, glandular-toothed; panicle loose, usually manyflowered; sepals nearly orbicular, the minute teeth gland-tipped; petals rosered, 8-10 $\mathrm{mm}$. long.

Abundant in the Olympic Mountains; also on Vancouver Island and most of the high peaks in the Cascade Mountains. Originally found in the Columbia River Gap, where it occurs nearly to the river level. 
Lewisia pygmaea (Gray) Robinson. Root fleshy; conical, simple; leaves linear to lanceolate or spatulate, $2-3 \mathrm{~cm}$. long, the petioles scarious-margined; scapes $2-5 \mathrm{~cm}$. high; sepals $4 \mathrm{~mm}$. long, orbicular, erose-dentate at the summit, the teeth glandular; petals 6-8, red, twice as long as the sepals; seeds 15-20.

At high altitudes in the Cascade Mountains, rare.

\section{SPRAGUEA.}

Glabrous fleshy herbs with mostly radical leaves; flowers in dense scorpioid spikes clustered in an umbel on a scape-like peduncle; sepals 2, orbicular-cordate, persistent; petals 4; stamens 3 ; style long, bifid at the apex; ovary 8-10-ovuled; capsule membranaceous, 2-valved; seeds black and shining.

Ut Adems. Spraguea multiceps Howell. Perennial with a thick fleshy root; crown re pink s simple or with several short branches, each bearing a rosulate tuft of leaves; leaves thick, spatulate, $5-8 \mathrm{~cm}$. long; peduncles spreading or nearly prostrate, 2-4 cm. long, usually with 1 or 2 scarious bracts; flowers rose-purple, in dense heads; sepals scarious, about as long as the petals; stamens and styles longer than the petals.

Common in sandy or gravelly soil in the Cascade Mountains, at 2500-3000 m. altitude. Not known in the Olympic Mountains.

\section{CALANDRINIA.}

Low succulent herbs with alternate or radical leaves; flowers purplish, in bracteate racemes or panicles or few on short scapelike stems; sepals 2, green, persistent; petals mostly 5 ; stamens 5-15; style 3-cleft, short; ovary free, many-ovuled; capsule globose or ovoid, membranaceous, 3-valved; seeds black, usually shining, smooth or minutely tuberculate.

Calandrinia caulescens HBK. Glabrous, branched from the base, decumbent, $5-15 \mathrm{~cm}$. high; leaves linear to oblanceolate, $2-6 \mathrm{~cm}$. long; flowers in racemes on erect or ascending peduncles; sepals ovate, acute, keeled; petals $3-5$, obovate, rose-colored, $4-8 \mathrm{~mm}$. long; capsule obovoid, acute; seeds lensshaped, minutely roughened.

Washington to Mexico, rare in our limits.

Calandrinia caulescens menziesii (Hook.) Gray. Flowers larger, the petals 8-12 mm. long.

Moist places, not common.

\section{MONTIA.}

Low branching glabrous succulent annual herbs; leaves mostly opposite; flowers small, white, nodding, axillary or racemose; sepals 2, ovate, herbaceous, persistent; petals 5, unlike, two larger and three smaller; stamens 3 , alternate with the smaller petals; style very short; stigmas 3.

Montia fontana L. (Claytonia hallii Gray.) Stems procumbent or ascending, rooting at the nodes, 3-10 cm. high or when aquatic often longer; leaves spatulate or obovate, $4-14 \mathrm{~mm}$. long; raceme terminal or axillary, few-flowered; petals white, $2 \mathrm{~mm}$. long, a little longer than the calyx.

In wet places and running water. 


\section{CLAYTONIA. (Mmtia-Sweetser)}

Low and glabrous succulent herbs, perennial from corms or thickened rootstocks or annual; basal leaves petioled, the cauline opposite or alternate; flowers small, white or rose-colored, in loose terminal racemes, lasting more than one day; sepals 2, ovate, herbaceous, persistent; petals 5, equal; stamens 5; style 3 -notched or cleft.

Perennials with thick roots or corms.

Corm globose; cauline leaves oblong. C. lanceolata.

Caudex elongate; cauline leaves linear-spatulate. C. megarrhiza.

Perennials or annuals; roots not cormose.

Stem bearing only two leaves, these opposite.

Cauline leaves not united.

Pedicels mostly bractless; perennial by rootstocks. C. asarifolia.

Pedicels mostly with bracts; roots fibrous. $\quad$ C. sibirica.

Cauline leaves united, at least at base.

United leaves not forming a disk, but linear or lanceolate.

United leaves forming a roundish disk.

Calyx $4 \mathrm{~mm}$. long; seeds $2 \mathrm{~mm}$. broad.

Calyx $2 \mathrm{~mm}$. long; seeds $1 \mathrm{~mm}$. broad.

Stems bearing more than two opposite leaves, or leaves alternate.

Cauline leaves of several pairs, opposite.

Cauline leaves alternate.

Perennial, producing slender stolons; leaves very fleshy.

Annual; not stoloniferous; leaves not very fleshy. Leaves broad, long-petioled; seeds striate.

Leaves narrow, sessile.

Seeds dull, less than $1 \mathrm{~mm}$. broad.

Seeds shining.

Petals $4 \mathrm{~mm}$. long; seeds $2 \mathrm{~mm}$. broad.

Petals minute or absent; seeds $1 \mathrm{~mm}$. broad.

C. spathulata.

C. perfoliata.

C. parviflora.

C. chamissoi.

C. parvifolia.

C. diffusa.

C. dichotoma.

C. linearis.

C. howellii.

Claytonia lanceolata Pursh. Stems simple, $8-15 \mathrm{~cm}$. tall, erect, from a globose tuber $1-4 \mathrm{~cm}$. in diameter; radical leaves few or wanting, lanceolate, acute, long-petioled; cauline a single pair, sessile, lanceolate or ovate-lanceolate, acute, $2-5 \mathrm{~cm}$. long; flowers $3-10$ in a short raceme which scarcely exceeds the cauline leaves; pedicels slender; petals pink, oblong or ovate, emarginate, 8-10 mm. long; seeds black, shiny, $2 \mathrm{~mm}$. broad.

In mountain meadows at about $1500 \mathrm{~m}$. altitude.

Claytonia megarrhiza (Gray) Parry. Root very large, fusiform, bearing from its crown several scapes and a cluster of leaves, these spatulate to cuneate, $5-15 \mathrm{~cm}$. long, the petioles broad and scarious-margined; scapes about as long as the leaves, bearing 2 or more opposite or alternate narrow bracts; racemes one-sided; sepals oblong; petals pink, 6-8 $\mathrm{mm}$. long.

High mountains, in the crevices of rocks. Mount Stuart, Elmer; Mount Jefferson, Oregon, Gorman.

Claytonia asarifolia Bong. Perennial, with short rootstocks, somewhat tufted; stems $15-30 \mathrm{~cm}$. tall, bearing a single pair of leaves below the inflorescence; leaves rather fleshy, broadly ovate, somewhat cordate, obtuse, $2-3 \mathrm{~cm}$. long, the cauline sessile, the radical slender-petioled; raceme peduncled, 3-12- 
flowered, with few or no bracts; pedicels slender; petals white, pellucid, 10-12 $\mathrm{mm}$. long; capsule longer than the sepals; seeds bright, shiny, $1-1.5 \mathrm{~mm}$. broad.

In cold woods along streams in the mountains.

le m RR Claytonia sibirica L. Stems simple, erect or ascending, 15-40 cm. high; basal leaves ovate, $2-6 \mathrm{~cm}$. long, contracted into long margined petioles; cauline pair ovate, sessile but not united; raceme bracteate, loose, the flowers on long pedicels; petals white or pink with red veins, about $6 \mathrm{~mm}$. long; seeds granulate.

In wet meadows and open moist woods, very common.

Claytonia spathulata Dougl. Annual, 2-10 cm. high, erect or spreading; basal leaves linear or somewhat spatulate, thickish; cauline leaves usually united on but one side or completely united and the disk narrower on one side, or rarely separate and sessile; racemes short, few-flowered; pedicels $6-8 \mathrm{~mm}$. long; sepals ovate; petals white or pink, $3-4 \mathrm{~mm}$. long, twice as long as the sepals; seeds black, shining, appearing minutely roughened under a lens.

In moist soil especially where somewhat saline; not common.

Claytonia spathulata exigua (Torr. \& Gr.) Piper. Basal leaves narrowly linear, $1-5 \mathrm{~cm}$. long; cauline linear, usually somewhat dilated at base and connate on one side.

In moist places, rare.

Claytonia perfoliata Donn. Annual, branched from the base, $10-50 \mathrm{~cm}$. high, erect; basal leaves long-petioled, the blades usually rhomboid-ovate, but varying to spatulate-linear; cauline leaves united, forming an orbicular or somewhat angled disk, $3-5 \mathrm{~cm}$. broad; racemes rather loose, one-sided; calyx $4 \mathrm{~mm}$. long; petals smaller, white; seeds smooth, shiny, lenticular, $2 \mathrm{~mm}$. broad.

Very common. A form with the cauline leaves distinct is $C$. perfoliata amplectens Greene.

Claytonia parviflora Dougl. Annual, branched from the base; stems usually 15-30 cm. high, erect; radical leaves long-petioled, linear, lanceolate or spatulate; cauline pair united into an orbicular somewhat angled disk, $1-4 \mathrm{~cm}$. in diameter; raceme usually loose, interrupted, somewhat one-sided; calyx $2 \mathrm{~mm}$. long; petals pink or white, about twice as long; seeds shiny, usually smooth, $1 \mathrm{~mm}$. broad.

In prairies or "burns."

Claytonia parviflora depressa Gray. Small and depressed, more fleshy; whole plant commonly reddish; cauline leaves sometimes nearly separate; radical leaves broadly ovate.

In open places.

Claytonia chamissoi Ledeb. Perennial, with slender elongate stolons, finally tuberiferous at the apex; flower stems mostly simple, $10-30 \mathrm{~cm}$. tall; leaves $3-7$ pairs, broadly spatulate, $2-4 \mathrm{~cm}$. long; raceme few-flowered; pedicels slender; petals pale or white, $6-8 \mathrm{~mm}$. long; stamens 5 ; capsule equaling the calyx; seeds kidney-shaped, minutely roughened.

Moist copses, rare in our limits. Comox, Vancouver Island, Macoun; Roy, Washington, Allen.

Claytonia parvifolia Moc. Fleshy perennial, producing slender creeping stolons, and propagating by leafy offsets produced in the axils of the cauline leaves; lower leaves obovate, acutish, short-petioled, 1-3 cm. long; cauline leaves reduced and narrower; racemes few-flowered; sepals suborbicular, 2 $\mathrm{mm}$. long; petals pink with darker veins, $8-10 \mathrm{~mm}$. long.

In moist places especially on rocks in the mountains. 
Claytonia diffusa Nutt. Annual, the whole plant usually reddish, much branched, 5-10 cm. high; leaves all alternate or a few of the lower ones opposite, the blades ovate, $1-2 \mathrm{~cm}$. long, abruptly narrowed into petioles of equal length; racemes numerous; pedicels of the lower flowers elongate, sometimes bracted; petals white or pale pink, emarginate, longer than the calyx; seeds sculptured with fine longitudinal and transverse striae.

In open coniferous woods, not common.

Claytonia dichotoma Nutt. Very similar to C. linearis but smaller in every way, $2-8 \mathrm{~cm}$. tall; calyx $2 \mathrm{~mm}$. long; petals scarcely exceeding the calyx; seeds $1 \mathrm{~mm}$. broad, dull.

Rare in our limits, but common east of the Cascade Mountains. First found by Nuttall at the mouth of the Willamette River.

Claytonia linearis Dougl. Annual, branched below, 5-15 cm. tall; leaves linear, succulent, all alternate, $2-5 \mathrm{~cm}$. long, scarious-margined at base; raceme 4-10-flowered, one-sided, the pedicels curving downward; sepals $4 \mathrm{~mm}$. long; capsule shorter than the sepals; seeds shiny, $2 \mathrm{~mm}$. broad.

In moist open places.

Claytonia howellii (Wats.) Piper. Annual, very small and slender, rooting at the nodes, $2-5 \mathrm{~cm}$. high; leaves linear-spatulate, $10-20 \mathrm{~mm}$. long, the foliar ones alternate; racemes few-flowered from the axils of ovate bract-like leaves opposite the foliar ones; pedicels reflexed in fruit; flowers very small, closepollinated; petals minute, white, $2-5$ or wanting.

In wet places in early spring. Victoria, Macoun; Seattle, Piper; Sauvies Island, Oregon, where first found by Howell.

\section{Family 39. CARYOPHYLLACEAE. PINK FAMILy.}

Annual or perennial herbs; stems often swollen at the nodes; leaves opposite, entire, with or without stipules; flowers regular and perfect; sepals 4 or 5 , separate or united into a calyx-tube; petals equal in number to the sepals or none; stamens not more than twice as many as the sepals, hypogynous or perigynous; styles 2-5; ovary 1-celled, rarely 3-5-celled; ovules several or many, basal or attached to a central column; fruit a capsule, akene or utricle; endosperm mealy.

Sepals united; petals long-clawed.

Styles 2; capsule with 4 teeth.

Styles more than 2; capsule not with 4 teeth.

Styles 3 , rarely 4 or 5 ; capsule with 3 or 6 teeth.

175. Dianthus, 142.

Styles always 5; capsule with 5 or 10 teeth. 177. Lychnis, 144.

Sepals free to the base or nearly so.

Stipules present, scarious.

Sepals spine-tipped; fruit a 1-seeded utricle. 178. Pentacaena, 144.

Sepals not spine-tipped; fruit a capsule.

Styles and valves of the capsule 3 .

Styles and valves of the capsule 5 .

Stipules wanting.

179. TISSA, 145.

180. SPERGULA, 145.

Petals none.

Styles as many as the sepals and alternate with them.

183. SAgina, 148. 
Styles fewer than the sepals or if as many Petals present. opposite them.

182. Stellaria, 146.

Petals 2-cleft or parted.

Capsule cylindric, usually curved. 181. Cerastium, 146.

Capsule ovoid or oblong not curved. 182. StellaRIA, 146.

Petals entire or notched.

Styles as many as the sepals and alternate with them.

Styles fewer than the sepals or if as many opposite them.

Disk of the receptacle conspicuous, 8-10-lobed.

183. SAgINA, 148.

Disk none.

Seeds without strophioles.

Seeds each with a strophiole.

184. Ammodenia, 148.

185. Arenaria, 149.

186. MOEHRINGIA, 150.

\section{Dianthus. Pink. Carnation.}

Annual or perennial ornamental herbs; flowers solitary or clustered, mostly pink, rose-colored, or white; calyx cylindrical, nerved or striate, 5 -toothed, subtended by 2 or more bractlets; stamens 10 ; styles 2 ; capsules 1 -celled, 4-toothed; seeds flattish on the back.

Dianthus armeria L. Deptford Pink. Annual, erect, 30-60 cm. high, somewhat pubescent; leaves linear; flowers in clusters of 2-4; bracts subulate, very pubescent; calyx tubular, $15 \mathrm{~mm}$. long, the teeth very acute; petals elliptic, crenate, rose-colored and with small white dots.

A native of Europe occasionally found in fields; introduced with grass seed.

\section{SILENE. CATCHFLy.}

Annual or perennial herbs; flowers clustered or solitary, mainly pink, red or white; calyx more or less inflated, tubular, ovoid or campanulate, 5-toothed, 10-many-nerved; petals 5, narrow, clawed, mostly crowned with a scale at the base of the blade; stamens 10 ; styles 3 , rarely 2,4 or 5 , if 5 opposite the calyxteeth; ovary 1-celled or incompletely 2-4-celled; ovules many; capsule 3 or 6 -toothed.

Calyx with 15 nerves or more.

Nerves $18-23$, prominent; calyx not inflated.

Nerves 15-20, obscure; calyx inflated.

S. multinervia.

Calyx with 5-10 nerves.

Plants annual or biennial.

Inflorescence a simple raceme.

Inflorescence a cyme or panicle.

Plant sticky-hairy.

Plant glabrous, except that the middle portion of each of the upper internodes is glutinous.

Plants perennial.

Acaulescent and densely matted.

S. latifolia.

Caulescent.

S. anglica.

Flowers solitary in the forks of leafy branches.

S. noctiflora.

S. antirrhina.

S. acaulis. 
Flowers small; petals white, bifid.

Flowers large; petals pink, 4-parted.

S. menziesii.

S. hookeri.

Flowers in terminal panicles, or occasionally solitary.

Calyx cylindric, narrowed at base; inflorescence a narrow panicle.

Calyx campanulate; inflorescence a few-flowered cyme.

Plants 5-10 cm. high; flowers 1-3.

Plants taller; flowers often numerous.

Blades of petals 2-lobed.

Blades of petals 4-lobed, the lateral lobes smaller.

S. scouleri.

S. suksdorfii.

S. douglasii.

S. macounii.

Silene multinervia Wats. Annual, erect, $20-30 \mathrm{~cm}$. high, pubescent and somewhat viscid in the inflorescence; leaves linear to narrowly oblong, acute; flowers irregularly cymose; calyx ovoid but narrowed above, with $18-23$ prominent nerves; petals small, purple.

Sparingly introduced from California.

Silene latifolia (Mill.) Britten \& Rendle. Bladder Campion. Perennial, glaucous; stems loosely branched, spreading or ascending, $20-40 \mathrm{~cm}$. high; leaves ovate to lanceolate, acute, the uppermost reduced to bracts; calyx glabrous, much inflated, thin, with $15-20$ veins connected by cross veinlets; petals white, 2 -cleft.

Introduced from Europe.

Silene anglica L. Annual, pubescent and somewhat viscid; stems erect, 15-30 cm. high; leaves oblanceolate, obtuse, mucronate, $2-3.5 \mathrm{~cm}$. long; flowers in a terminal one-sided raceme; calyx hairy, cylindric at first, becoming ovoid in fruit; petals small, pink or white, notched or entire.

Introduced from Europe.

Silene noctiflora L. Stems stout, erect, 30-80 cm. high; lower leaves oblanceolate or spatulate, the upper lanceolate, 5-8 cm. long; flowers white, few and long-peduncled, in a loose cyme; fruiting calyx ovoid, white with green veins, $25 \mathrm{~mm}$. long, the teeth subulate.

Sparingly introduced from Europe.

Silene antirrhina L. Annual, glabrous or puberulent; stem slender, mostly simple, the middle of each internode sticky-viscid; leaves linear or lanceolate, acute, $2-6 \mathrm{~cm}$. long, sessile; flowers in a forked compound cyme, long-pedicelled; calyx 10-nerved, ovoid, cylindrical in fruit, $6-10 \mathrm{~mm}$. long; petals white or pinkish, notched, little exceeding the calyx.

Sandy or gravelly soil, infrequent.

Silene acaulis L. Moss Campion. Perennial, densely tufted and mosslike, 2-5 cm. high; leaves numerous, linear, $8-12 \mathrm{~mm}$. long; flowers solitary, subsessile or short-peduncled; calyx glabrous, bell-shaped, the lobes obtuse; petals red-purple, notched or cleft at the apex, the lateral auricles very small.

Moist rocky places at high altitudes in the Cascade Mountains.

Silene menziesii Hook. Perennial, glandular-puberulent; stems weak, erect or decumbent, usually branched, $10-30 \mathrm{~cm}$. high, leafy; leaves ellipticlanceolate, acuminate or acute at each end, 2-6 cm. long; flowers small, solitary in the forks of leafy branches; calyx obconical, 5-6 mm. long, 5-toothed, nerves not prominent; petals white, 2 -cleft, $6-8 \mathrm{~mm}$. long, usually without a crown.

In open woods.

Silene hookeri Nutt. Leafy perennial with stout root; herbage grayish pubescent; stems 10-20 cm. high; leaves oblanceolate, acutish, 4-7 cm. long, 
or recurved, 8-12 mm. long; flowers sessile, in axillary clusters; calyx-lobes divergent, twice as long as the tube; petals minute.

On high sea-beaches along the ocean coast.

\section{TISSA.}

Low annual, biennial or perennial herbs; leaves fleshy, linear or setaceous, with scarious stipules; flowers in terminal racemose cymes; sepals 5 ; petals 5 (in ours), purplish or white; stamens $2-10$, commonly 10 ; styles 3 , very rarely 5 ; ovary 1 -celled; capsule-valves as many as the styles, when 5 , alternate with the sepals.

Plants not maritime; leaves not fleshy; stipules elongate, silvery.

Plants maritime; leaves very fleshy; stipules ovate.

Annual, fibrous-rooted; flowers 4-5 mm. long.

Perennial, large-rooted; flowers 6-7 mm. long.

T. rubra.

T. marina.

T. macrotheca.

Tissa rubra (L.) Britt. Annual, sometimes biennial or perennial, prostrate or decumbent; stems slender, 10-30 cm. long, smooth below, glandular above; leaves linear, cuspidate, $8-12 \mathrm{~mm}$. long; stipules silvery, attentuate-lanceolate, 4-5 $\mathrm{mm}$. long; flowers in a small cyme; pediceis filiform, exceeding the leaflike bracts; petals pink, hardly longer than the sepals.

Gravelly prairies, common.

Tissa marina (L. )Britt. More or less glandular pubescent, the branches spreading or procumbent; leaves fleshy; stipules ovate, acuminate; sepals ovate, obtuse, 4-5 $\mathrm{mm}$. long; petals pink; capsule acute, equalling or longer than the sepals.

On sandy or gravelly sea beaches.

Tissa macrotheca (Hornem.) Britt. Glandular-pubescent perennial with a stout fleshy root; stems decumbent to ascending, 10-30 cm. high; leaves fleshy, mucronate; sepals lanceolate, subacute; petals pink, nearly as long as the sepals; capsule ovoid, acute, as long as the calyx.

Sea beaches; much less common than $T$. marina.

180. SPERGULA. SPURREY.

Annual branched herbs; leaves subulate, fascicled, with scarious stipules; flowers in a cymose panicle; sepals 5 ; petals 5 , white; stamens 10 , rarely 5 ; ovary 1 -celled; capsule-valves 5 , opposite the sepals.

Seeds papillate; herbage nearly glabrous.

Seeds not papillate; herbage viscid.

S. arvensis.

S. sativa.

Spergula arvensis L. Annual, the decumbent stems $15-30 \mathrm{~cm}$. long; leaves whorled, filiform, $2-5 \mathrm{~cm}$. long; inflorescence naked, loosely cymose; pedicels often deflexed in fruit; sepals $4-5 \mathrm{~mm}$. long; petals white; seeds dark, minutely roughened with pale papillae.

Common weed in fields; introduced from Europe.

Spergula sativa Boenn. Very similar to $S$. arvensis but minutely viscid; flowers ill-scented; seeds not papillate.

Victoria, Macoun. 


\section{Cerastium. Mouse-ear Chickweed.}

Annual or perennial, generally pubescent or hirsute herbs; leaves flat, rarely subulate; stipules none; flowers in terminal bracted dichotomous cymes; sepals 5 ; petals 5 , retuse or bifid, very rarely subentire, white; stamens 10 , sometimes fewer; styles 5 , sometimes 4 or 3 , opposite the sepals; capsule cylindric, 1-celled, often curved, dehiscent by 10 , rarely 8 , apical teeth.

Petals decidedly longer than the sepals.

C. arvense.

Petals not longer than the sepals.

Pedicels longer than the calyx.

Pedicels not longer than the calyx.

C. vulgatum.

C. viscosum.

Cerastium arvense L. Perennial, tufted, pubescent throughout or sometimes nearly glabrous; stems weak, erect, $15-40 \mathrm{~cm}$. tall, nearly naked above; leaves linear or lanceolate, $2-3 \mathrm{~cm}$. long; flowers cymose, on slender pedicels; sepals oblong, acute, 5-6 mm. long; petals deeply notched, twice as long as the sepals.

In dry open ground; common and variable.

Cerastium vulgatum L. Perennial, viscid-pubescent throughout, tufted 10-30 cm. high; leaves oblong, obtuse, or the upper ones acutish, $10-25 \mathrm{~mm}$. long; inflorescence loose, the pedicels longer than the calyx; sepals obtuse, $4-5 \mathrm{~mm}$. long, as long as the 2-cleft petals; capsule somewhat curved, longer than the calyx.

A weed in lawns and pastures; introduced from Europe.

Cerastium viscosum L. Annual, viscid-pubescent, erect or nearly so, $10-20 \mathrm{~cm}$. high; leaves oval to ovate or obovate, very obtuse, the lowest narrowed into short-margined petioles; inflorescence rather close in flower, looser in fruit; sepals acute, $3-4 \mathrm{~mm}$. long; petals shorter than the sepals.

A weed introduced from Europe.

\section{STELlaRia. CHickweEd.}

Annual or perennial tufted generally diffuse herbs; leaves flat, rarely subulate; stipules none; flowers solitary or cymose, terminal or becoming lateral; sepals 5 or 4 ; petals 5 or 4 , rarely none, always more or less deeply bifid, often divided almost to the base, white; stamens $3-10$; styles 3 or 4 , rarely 5 ; capsules globose, ovoid or oblong, dehiscing by as many valves as there are styles.

Lowest leaves ovate, petiolate.

Stems pubescent with a line of hairs; leaves ovate. S. media.

Stems glabrous, except at base; leaves shiny, the upper linear-lanceolate.

Leaves all sessile.
S. nitens.

Bracts of the inflorescence small, scarious.

Pedicels erect; cyme few-flowered.

Pedicels spreading; cyme loosely many-flowered.

Leaves linear, acute at each end; seeds smooth.

Leaves lanceolate, broadest near the base; seeds rough.

Bracts of the inflorescence leafy.

Leaves lanceolate.

Leaves ovate.

Herbage glabrous.

Herbage finely puberulent.

S. longipes.

S. longifolia.

S. graminea.

S. borealis.

S. crispa.

S. washingtoniana. 
Stellaria media (L.) Cyrill. Annual, weak and spreading; stems weak, $10-30 \mathrm{~cm}$. long, glabrous except a line of hairs; lower leaves ovate, petioled, the upper narrower and sessile, all acute, 10-40 $\mathrm{mm}$. long; flowers solitary in the axils or somewhat cymose, on slender pedicels; calyx glandular-pubescent, nearly as long as the capsule; petals deeply 2-parted, shorter than the sepals; stamens 3,5 , or 10 .

A common weed introduced from Europe.

Stellaria nitens Nutt. Annual, somewhat tufted; stems erect, slender, shining, $8-15 \mathrm{~cm}$. tall, branched above, pubescent only at base; lowest pair of leaves ovate, acute, petioled, $4 \mathrm{~mm}$. long, the others linear-lanceolate and sessile, 5-10 $\mathrm{mm}$. long; cymes loose, few-flowered, the bracts scarious; pedicels thread-like, 1-5 cm. long; sepals 3 -nerved, very acute, scarious-margined, $4 \mathrm{~mm}$. long; petals deeply 2-cleft, half as long as the sepals or wanting.

In dry open places.

Stellaria longipes Goldie. Somewhat tufted, with creeping rootstocks, smooth and shining throughout; stems 4 -angled, erect, $15-40 \mathrm{~cm}$. high, branched above; leaves linear-lanceolate, tapering from the base to the acute apex, prominently 1 -nerved, $2-3 \mathrm{~cm}$. long; flowers solitary or in very loose cymes; bracts reduced and scarious or when the flowers are few or solitary foliaceous; pedicels slender, 2-10 cm. long; petals 2-cleft, exceeding the rather obtuse sepals; capsule longer than the calyx; seeds smooth, shining.

Moist places, not rare.

Stellaria longifolia Muhl. Erect or nearly so, the stem sharply 4-angled, glabrous, $20-40 \mathrm{~cm}$. high; leaves linear or oblong-linear, acute at each end, often ciliate near the base, $2-3 \mathrm{~cm}$. long; cyme open, long-peduncled, becoming lateral, many-flowered; pedicels spreading or at length deflexed; petals exceeding the sepals; capsule pale, longer than the calyx.

In wet meadows, rare.

Stellaria graminea L. Whole plant glabrous, shining; stems 4-angled, ascending, branched above, $35-60 \mathrm{~cm}$. high; leaves sessile, lanceolate, acute, $2-3 \mathrm{~cm}$. long; flowers in a loose much-forked cyme; bracts scarious, somewhat ciliate; pedicels slender, spreading or reflexed; sepals lanceolate, acute, 3nerved, nearly equalling the capsule; petals 2-cleft, as long as the sepals; seeds minutely roughened.

In wet places; introduced from Europe.

Stellaria borealis Bigel. ( $S$. calycantha Bong.) Perennial, glabrous throughout, the weak stems ascending, branched, 15-30 cm.long; leaves ovate to elliptic-lanceolate, 7-25 $\mathrm{mm}$. long; pedicels slender, sometimes deflexed, 15-30 mm. long; sepals ovate-lanceolate, acute, scarious-margined, 2-4 mm. long; petals wanting or if present shorter than the sepals; styles mostly 4; capsule ovoid, 3-5 $\mathrm{mm}$. long; seeds smooth.

Along rivulets in the mountains at high altitudes.

Stellaria borealis bongardiana Fernald. Larger; the stems often $60 \mathrm{~cm}$. long; leaves lanceolate, 3-8 cm. long, the upper gradually reduced; sepals 4-5.5 $\mathrm{mm}$. long; capsule 5-8 $\mathrm{mm}$. long.

Common in moist woods.

Stellaria borealis sitchana (Steud.) Fernald. Upper leaves reduced to scarious bracts, the flowers therefore loosely cymose. Otherwise like $S$. borealis bongardiana.

In marshes, especially near the seashore. While the lowland subspecies $S$. borealis bongardiana appears very different from the alpine or subalpine $S$. borealis, Fernald concludes that they are completely connected by Rocky Mountain forms. 
Stellaria crispa Cham. \& Schlecht. Perennial, glabrous; stems weak, decumbent or prostrate, $10-30 \mathrm{~cm}$. long, simple or with but few branches; leaves thin, ovate, acuminate, $8-12 \mathrm{~mm}$. long, entire or crisped on the margin, very short-petioled; pedicels slender, 6-20 mm. long; sepals lanceolate, 3nerved, very acute, with a narrow scarious margin; petals deeply cleft but usually wanting; capsule acutish, exceeding the sepals.

In moist woods, common.

Stellaria washingtoniana Robinson. Annual; stems slender, decumbent, leafy, not much branched, pubescent; leaves ovate, acute, very short-petioled, thin, about $8 \mathrm{~mm}$. long, glabrous or pubescent, 1-nerved, ciliate near the base; peduncles $1 \mathrm{~cm}$. long, spreading, 1-flowered; calyx pubescent, the sepals ovate, 2-3 mm. long, obtusish, faintly 3-nerved; petals none.

In deciduous woods; Nisqually River, Allen; Lake Cushman, Piper.

\section{SAGINA. PEARLWORT.}

Small matted herbs with thread-like or awl-shaped leaves; stipules none; flowers small, terminating the stem and the branches; sepals 4 or 5 ; petals 4 or 5 , or often none; stamens as many as or twice as many as the sepals; styles as many as the sepals and alternate with them; pod many-seeded, 4-5-valved. Species very difficult to define.

Herbage glandular-puberulent.

S. apetala.

Herbage glabrous.

Stems slender; leaves scarcely fleshy.

Stems rather stout; leaves fleshy.

S. occidentalis.

S. crassicaulis.

Sagina apetala barbata Fenzl. (S. ciliata (Greene) Piper.) Very slender, erect, $3-5 \mathrm{~cm}$. high, minutely glandular-pubescent; leaves linear, ciliolate at their broadened bases. .

In dry ground, rare.

Sagina occidentalis Wats. Glabrous, the slender decumbent stems 5-12 $\mathrm{cm}$. high; leaves linear, very acute, $6-10 \mathrm{~mm}$. long; peduncles $15-25 \mathrm{~mm}$. long; sepals subacute, $2.5 \mathrm{~mm}$. long, shorter than the capsule; petals shorter than the sepals.

Common in springy ground.

Sagina crassicaulis Wats. Distinctly fleshy; stems rather stout; leaves 5-20 mm. long; calyx $3 \mathrm{~mm}$. long, shorter than the capsule.

Along the seashore. Scarcely different from $S$. occidentalis.

\section{AMMODENIA.}

Stout fleshy perennial seashore plants with clasping thick leaves; flowers axillary; disk conspicuous, 10-lobed, glanduliferous; styles $3-5$; capsule globose, somewhat berry-like.

Ammodenia peploides (L.) Rupr. Perennial, very fleshy, glabrous, 10-30 $\mathrm{cm}$. high; leaves obovate or ovate, partly clasping; flower axillary, nearly sessile; sepals ovate-lanceolate, acuminate, $7 \mathrm{~mm}$. long; seeds smooth.

Along the seashore. Scarcely distinguishable is $A$. peploides major (Hook.) Piper, somewhat taller with larger somewhat apiculate leaves. 


\section{ARENARIA. SANDWORT.}

Annual or perennial mainly tufted herbs; leaves sessile, often subulate and more or less rigid; stipules none; flowers white, cymosely panicled or capitate, rarely solitary and axillary; sepals 5; petals 5, very rarely minute or wanting, entire or emarginate, white or nearly so; stamens 10 , or often fewer; styles generally 3 , rarely $2-5$; capsule globose or oblong, dehiscent at the apex by as many or twice as many valves as there are styles.

Leaves not narrowly linear nor rigid.

Perennial; leaves linear or lance-linear; stems and foliage weak and flaccid.

Annuals; leaves lanceolate or ovate; stems and foliage not weak and flaccid.

Leaves ovate; capsule flask-shaped.

Leaves lanceolate; capsule oblong.

A. paludicola.

es narrowly linear, firm or rigid.

Sepals obtuse.

Leaves glandular-hirsute; capsule-valves entire.

Leaves glabrous or nearly so; capsule-valves 2cleft.

A. serpyllifolia.

A. leptoclados.

Sepals acute or cuspidate.
Plants loosely or not at all matted; cymes dichot-
omously branched, several to many-flowered; low-
land plant.
Plants densely matted or tufted, alpine; cymes few-
flowered.
Sepals not strongly nerved; petals shorter than
the sepals.
Sepals strongly nerved; petals equalling the sepals.

Sepals acute or cuspidate.
Plants loosely or not at all matted; cymes dichot-
omously branched, several to many-flowered; low-
land plant.
Plants densely matted or tufted, alpine; cymes few-
flowered.
Sepals not strongly nerved; petals shorter than
the sepals.
Sepals strongly nerved; petals equalling the sepals.

Sepals acute or cuspidate.
Plants loosely or not at all matted; cymes dichot-
omously branched, several to many-flowered; low-
land plant.
Plants densely matted or tufted, alpine; cymes few-
flowered.
Sepals not strongly nerved; petals shorter than
the sepals.
Sepals strongly nerved; petals equalling the sepals.

Sepals acute or cuspidate.
Plants loosely or not at all matted; cymes dichot-
omously branched, several to many-flowered; low-
land plant.
Plants densely matted or tufted, alpine; cymes few-
flowered.
Sepals not strongly nerved; petals shorter than
the sepals.
Sepals strongly nerved; petals equalling the sepals.

Sepals acute or cuspidate.
Plants loosely or not at all matted; cymes dichot-
omously branched, several to many-flowered; low-
land plant.
Plants densely matted or tufted, alpine; cymes few-
flowered.
Sepals not strongly nerved; petals shorter than
the sepals.
Sepals strongly nerved; petals equalling the sepals.

Sepals acute or cuspidate.
Plants loosely or not at all matted; cymes dichot-
omously branched, several to many-flowered; low-
land plant.
Plants densely matted or tufted, alpine; cymes few-
flowered.
Sepals not strongly nerved; petals shorter than
the sepals.
Sepals strongly nerved; petals equalling the sepals.

Sepals acute or cuspidate.
Plants loosely or not at all matted; cymes dichot-
omously branched, several to many-flowered; low-
land plant.
Plants densely matted or tufted, alpine; cymes few-
flowered.
Sepals not strongly nerved; petals shorter than
the sepals.
Sepals strongly nerved; petals equalling the sepals.

Sepals acute or cuspidate.
Plants loosely or not at all matted; cymes dichot-
omously branched, several to many-flowered; low-
land plant.
Plants densely matted or tufted, alpine; cymes few-
flowered.
Sepals not strongly nerved; petals shorter than
the sepals.
Sepals strongly nerved; petals equalling the sepals.

A. sajanensis.

A. capillaris.

A. tenella.

Arenaria paludicola Robinson. Perennial, glabrous, the weak stems procumbent, shiny, angled, $15-30 \mathrm{~cm}$. long; leaves sessile, and somewhat connate, linear to linear-lanceolate, acute, 1-nerved, flat, $2-4 \mathrm{~cm}$. long, the upper not reduced; flowers solitary, axillary; sepals elliptic, subacute, 3-4 mm. long, nerveless; petals obovate, twice as long as the sepals; capsule oblong, shorter than the calyx.

In swamps near Tacoma, Flett; otherwise known only in California.

Arenaria serpyllifolia L. Annual, much branched, very leafy, puberulent throughout, 5-15 cm. high; leaves ovate, cuspidately acute, 10-15 $\mathrm{mm}$. long, sessile or nearly so; uppermost leaves but little reduced; pedicels longer than the calyx; sepals ovate-lanceolate, acute, 3-5-nerved; capsule flask-shaped.

In dry soil; introduced from Europe.

Arenaria leptoclados Guss. Very similar to A. serpyllifolia; stems slender, erect; leaves lanceolate, the uppermost reduced to bracts; capsule oblong.

Introduced from Europe.

Arenaria sajanensis Willd. Perennial, densely cespitose; stems decumbent, 2-6 cm. high, glandular-hirsute, the dead leaves persistent; leaves linear, firm, rather obtuse, 4-7 $\mathrm{mm}$. long, glabrous or minutely glandular; flowers mostly solitary; sepals narrowly oblong, obtuse, much longer than the spatulate obtuse petals; capsule oblong, longer than the calyx.

At high altitudes in the mountains.

Arenaria capillaris nardifolia (Ledeb.) Regel. Perennial from a branching $\% / 9$ / caudex, the stems $10-20 \mathrm{~cm}$. high; leaves mostly basal, crowded, linear, sharp- 
pointed, usually curved, glabrous, $15-25 \mathrm{~mm}$. long; inflorescence loose, glandular-puberulent; sepals ovate, obtuse, 3-nerved, scarious margined; petals obovate, longer than the sepals; capsule longer than the calyx.

Common in the mountains at about $2000 \mathrm{~m}$. altitude.

Arenaria tenella Nutt. Stems slender, loosely branched, 10-20 cm. high; leaves subulate, acute, $6-10 \mathrm{~mm}$. long, the broadened bases connate, the upper reduced; inflorescence glandular-puberulent; pedicels very slender, much longer than the calyx; sepals lanceolate, acuminate, strongly 3-nerved; petals oblong, as long as the sepals; capsule ovoid; seeds roughened.

In dry gravelly prairies.

Arenaria nuttallii Pax. Perennial, very leafy, densely branched from a stout vertical root, glandular throughout; leaves linear-subulate, rigid, sharppointed, spreading, 6-8 $\mathrm{mm}$. long, connate at base, the uppermost littlereduced; flowers numerous, in open cymes; sepals lanceolate, acuminate, faintly 3-nerved; petals acutish, not equalling the sepals; capsule ovoid, shorter than the calyx.

On the high peaks of the Cascade Mountains at about $2500 \mathrm{~m}$. altitude.

Arenaria verna L. Perennial, closely tufted, glandular-pubescent, $5-15 \mathrm{~cm}$. high; leaves linear-subulate, flat, strongly 3 -nerved; sepals ovate-lanceolate, acuminate, the margins scarious; petals narrowly obovate, obtuse, as long as the sepals; capsule longer than the calyx.

In rocky places, Cascade and Olympic Mountains, at about $2500 \mathrm{~m}$. altitude.

\section{MOEHRINGIA.}

Low perennial herbs, with lanceolate elliptic or oblong sessile or short-petioled soft leaves; flowers white, solitary in the axils of the leaves or in terminal cymes; sepals and petals 4 or 5 ; stamens 8 or 10 ; capsule oblong, few-seeded; seeds each with a membranous broad strophiole.

Petals longer than the obtusish sepals.

Petals shorter than the acuminate sepals.

M. lateriflora.

M. macrophylla.

Moehringia lateriflora (L.) Fenzl. Mostly puberulent throughout; stems slender, terete, erect or decumbent, simple or few-branched, $10-30 \mathrm{~cm}$. high; leaves elliptic or oblong, sessile, obtuse, $1-2 \mathrm{~cm}$. long; cymes few-flowered; sepals obtuse or acutish, $2 \mathrm{~mm}$. long, one half the length of the obovate petals.

In open woods, infrequent.

Moehringia macrophylla (Hook.) Torr. Minutely puberulent; stems erect or decumbent, angled, 5-10 cm. tall, mostly simple; leaves lanceolate, acute at each end, 2-6 cm. long; cymes few-flowered; sepals ovate-lanceolate, acuminate, $3 \mathrm{~mm}$. long, exceeding the petals.

In open woods, not rare.

\section{Family 40. NYMPhaEACEAE. Waterlily Family.}

Aquatic perennial herbs with horizontal rootstocks; leaves peltate or cordate, floating, submersed or rarely immersed; flowers perfect, solitary, axillary, on long peduncles; sepals 3, 4, 6 or more; petals 5-many, often grading into the sepals or stamens; stamens 5-many; carpels 3-many, indehiscent, free or immersed in a fleshy receptacle or more or less coalescent into a fleshy fruit; endosperm present or none. 
Leaves cordate; flowers large, yellow.

Leaves peltate; flowers small, purple.

187. Nymphaea, 151.

188. BRASENIA, 151.

\section{NYMPHAEA. Yellow POND Lilly.}

Acaulescent perennials from stout rootstocks, commonly slightly milky; leaves with united stipules which are sometimes adnate to the base of the petioles; calyx more showy than the corolla; sepals 5-12, concave, roundish, mostly yellow, and petallike; petals 10-20, hypogynous, small and thick, the innermost or sometimes all of them stamen-like; stamens numerous, hypogynous; stigmas radiate on the summit of the 10-25-celled ovary; ovules and seeds numerous.

Nymphaea polysepala (Engelm.) Greene. Wokas. Leaves orbicular or broadly oval, deeply cordate, $20-30 \mathrm{~cm}$. long, $12-20 \mathrm{~cm}$. broad; calyx subglobose, about $8 \mathrm{~cm}$. broad; sepals $8-12$, yellow, often red-tinged; petals 12-18, ovate-cuneate, truncate, $1-1.5 \mathrm{~cm}$. long; stamens very numerous; fruit subglobose, 4-5 cm. long.

Common in lakes. The seeds are used as food by some tribes of Indians

188. BRASENIA. WATERSHIELD.

Aquatic herbs with creeping rootstocks; leaves alternate, longpetioled, centrally peltate, oval, floating; flowers axillary, small; sepals 3 or 4 ; petals 3 or 4 , linear, sessile; stamens $12-18$; pistils 4-18, forming club-shaped indehiscent pods, each with 1-2 seeds.

Brasenia schreberi Gmel. Watershield. Leaves alternate, long-petioled, oval, entire or obscurely crenate, centrally peltate, $2-10 \mathrm{~cm}$. long; flowers dull purple; submerged parts of the plant coated with tough transparent jelly.

Common in lakes.

\section{Family 41. CERATOPHYLLACEAE. HoRnWORT FAMILY.}

Aquatic herbs, with whorled finely dissected leaves; flowers minute, sessile, monoecious, without calyx or corolla, but with an 8-12-cleft involucre in place of a calyx.

189. CERATOPHYLLUM. HORNWORT.

Herbs growing submerged; leaves sessile, cut into thriceforked, thread-like rigid divisions; sterile flowers of 10-20 stamens; fruit an akene.

Ceratophyllum demersum L. Stems 50-200 cm. long, sparingly branched; leaves rigid, $8-25 \mathrm{~mm}$. long; akene smooth, beaked with the persistent style and having a sharp tubercle on each side at the base.

Common in quiet streams and lakes. Very rarely found in flower or fruit.

Family 42. RANUNCULACEAE. ButTercup FAmily.

Annual or perennial herbs, or sometimes woody plants, with acrid sap; leaves usually alternate (opposite in Clematis), simple 
or compound; stipules none but the base of the petiole often clasping or sheathing; flowers regular or irregular; sepals 3-15, generally soon withering, of ten petal-like; petals 3-15, or wanting; stamens numerous or few, hypogynous; carpels numerous or few or rarely solitary, separate, 1-celled, 1-many-ovuled; endosperm present.

Carpels numerous, 1-ovuled; fruit an akene.

Leaves opposite.

Leaves alternate, whorled, or basal.

Cauline leaves three in a whorl.

Styles short, glabrous or pubescent. 191. ANEmone, 153.

Styles long, plumose.

190. Clematis, 152.

Cauline leaves alternate or none.

Petals none.

Leaves ternately decompound.

Leaves simple, palmately lobed.

Petals present.

Sepals spurred; akenes in a long slender spike.

192. Pulsatilla, 154.

Sepals not spurred; akenes in a head.

Petals white; akenes transversely wrinkled.

Petals yellow; akenes not transversely wrinkled.

Carpels few, 2-many-ovuled; fruit a follicle or

193. Thalictrum, 154.

194. Trautvetteria, 154.

195. Myosurus, 155.

196. BATRACHIUM, 155.

197. Ranunculus, 156.

berry.

Flowers irregular.

Upper sepal spurred; petals 4.

Upper sepal hood-like; petals 2.

Flowers regular.

Sepals spurred.

Sepals not spurred.

Petals large; flowers solitary.

Petals small or none; flowers solitary or in racemes or umbels.

Leaves simple.

Petals none; leaves crenate. 202. Caltha, 161.

Petals linear-spatulate; leaves palmately parted.

Leaves compound.

Carpels becoming berries.

Carpels becoming follicles.

Flowers in racemes.

Flowers not in racemes.

Petals none; follicles ses-

sile or short-stalked. 206. IsOPYRUM, 163.

Petals 5-6, linear; follicles long-stalked.

198. Delphinium, 159.

199. Aconitum, 160.

200. Aquilegia, 161.

201. Paeonia, 161.

203. Trollius, 162.

204. Actaea, 162.

205. Cimicifuga, 162.

207. Coptis, 163.

\section{CLEMATIS.}

Perennial herbs, low and erect, or more or less woody vines, climbing by the petioles; leaves opposite; sepals 4 , rarely 3 , or 
more than 4, petal-like; petals none or minute; stamens numerous; pistils numerous, 1 -ovuled; styles feathery or naked in fruit.

Clematis ligusticifolia Nutt. Half-woody climber, the stem 2-10 m. long; leaves pinnately compound, of 5-7 leaflets, or the lower pair ternate; leaflets ovate or lanceolate, sometimes 3-lobed, coarsely incised-dentate or subentire, 3-6 cm. long, sparsely pubescent, becoming glabrous; flowers dioecious, in large panicles, the staminate more showy; sepals white, oblong, densely hairy,

$2 \mathrm{~cm}$. long; akenes pubescent, the long tails plumose.

Reported from the Willamette Valley, Oregon, but not verified; common east of the Cascade Mountains and in the Umpqua Valley, Oregon.

\section{ANEMONE. ANEMONE. WINDFLOWER.}

Erect perennial herbs; leaves compound or divided, all radical, except 2 or 3 cauline which form an involucre usually remote from the flower; peduncles 1-flowered, solitary or in umbels; sepals 4-20, petal-like; petals none; stamens numerous; pistils numerous; akenes flattened, not ribbed; styles short, glabrous or pubescent, never plumose.

Akenes densely woolly; rootstock short and stout.

Leaves hairy, the lobes linear.

Leaves glabrate, the lobes usually cuneate.

Akenes not woolly; rootstocks slender.

Involucral leaves simple.

Involucral leaves 3-5-foliolate.

Flowers $8-12 \mathrm{~mm}$. in diameter, white.

Flowers $20-35 \mathrm{~mm}$. in diameter.

Sepals white.

Sepals blue.

A. hudsoniana.

A. drummondii.

A. deltoidea.

A. lyallii.

A. piperi.

A. oregana.

Anemone hudsoniana (DC.) Richards. More or less silky-villous; stems $20-40 \mathrm{~cm}$. high, 1-3-flowered; leaves ternate, cleft into linear divisions; sepals yellowish or dull red, about $1 \mathrm{~cm}$. long; head of akenes globose; styles about half as long as the akenes.

In the mountains, infrequent.

Anemone drummondii Wats. Glabrous or becoming so; stems $10-15 \mathrm{~cm}$. high; leaf-segments short; linear or narrowly cuneate; sepals bluish; styles slender, nearly as long as the akene.

In rock crevices in the mountains at high altitudes, rare.

Anemone deltoidea Hook. Stems $15-30 \mathrm{~cm}$. high from slender running rootstocks; radical leaves trifoliolate, the leaflets ovate, dentate, acute; sepals white, 1-2 cm. long; a kenes ovate, glabrous or nearly so.

In open woods from Pierce County, Washington, southward.

Anemone lyallii Britt. Stems very slender, 5-10 cm. high; leaves 3-foliolate, the leaflets lanceolate to ovate, obtusely toothed; flowers white, small, the sepals 4-6 $\mathrm{mm}$. long.

In moist mountain woods, fare.

Anemoné piperi Britt. Wood Anemone. Perennial from slender deepseated white rootstocks; stems erect, 1 -flowered, $10-20 \mathrm{~cm}$. tall, smooth or pubescent; radical leaf and the three of the involucre similar, ternate or often 5 -foliolate, petiolate, the leaflets or divisions oblong-cuneate or ovate, acute or acuminate, incisely toothed or lobed, 3-5 cm. long; sepals 4-7, oval, white; akenes puberulent, the style short. 
Moist woods, in the mountains. Scarcely distinct from the eastern $A$. quinquefolia L.

Anemone oregana Gray. Similar to A. piperi but larger; leaflets obovate to oval, obtusish, coarsely serrate or incised with but few teeth; sepals blue, 12-20 mm. long.

In the Cascade Mountains, mostly on the eastern slope.

\section{Pulsatilla. Pasque Flower.}

Perennial herbs with thick rootstocks, long-petioled palmately divided basal leaves and 3 cauline leaves in a whorl forming an involucre remote from the calyx; sepals petal-like; petals none; stamens numerous, the outer often sterile; pistils numerous; akenes with long persistent plumose styles.

Pulsatilla occidentalis (Wats.) Freyn. Whole plant covered with long hairs; stems stout, $30-60 \mathrm{~cm}$. high; basal leaves long-petioled, divided into numerous narrow segments; cauline leaves similar, sessile; flowers solitary, large; sepals whitish, tinged with purple, $15-20 \mathrm{~mm}$. long; akenes with tails $3-4 \mathrm{~cm}$. long.

Mountain meadows, abundant.

\section{THALICTRUM. MEAdOW RUE.}

Erect perennial herbs; leaves 2-3-ternately compound, radical and cauline, the latter alternate; flowers perfect, polygamous or dioecious, generally small, greenish-white, in corymbs, panicles or racemes; sepals 4 or 5, petal-like or greenish, dull-colored; petals none; stamens numerous; pistils 4-15, commonly few, 1-ovuled; akenes capitate, grooved or ribbed, inflated.

Akenes narrowly fusiform, 3-nerved on each face, in loose clusters.

Akenes falcate, compressed, obscurely veined, in dense clusters.

T. occidentale.

T. papyraceum.

Thalictrum occidentale Gray. Dioecious; stems 50-100 cm. tall; leaves ternately decompound; leaflets oblong, obovate or orbicular, mostly petioled, incisely dentate at the apex, glabrous, 1-2 cm. long; panicle loose; sepals elliptic-cuneate, grcenish; filaments very slender; anthers linear, slenderpointed; a kenes $6-12$, in loose clusters, stipitate, lanceolate, long-acuminate, 3-nerved on each side, the mid-nerve somewhat salient, 6-8 $\mathrm{mm}$. long.

In moist copses, especially in the mountains.

Thalictrum papyraceum Greene. Dioecious, glabrous throughout; stems stout, 1-3 m. tall; leaflets 3 , incisely 3 -lobed, the median lobe mucronate, the others obtuse; panicle loose, narrow; akenes 12-18, in dense globose clusters $2 \mathrm{~cm}$. broad, each falcate, strongly compressed, $1 \mathrm{~cm}$. long, the thin pericarp obscurely and irregularly veined.

Sauvies Island, Oregon, Howell.

\section{TRAUTVETTERIA.}

Tall erect perennial herbs; leaves palmately-lobed, the radical large and long-petioled; the cauline few, short-petioled or sessile; 
flowers white; in corymbs; sepals $3-5$, broad, concave; petals none; stamens numerous; pistils numerous, 1-ovuled; akenes capitate, sharply-angled, inflated; styles minute.

Trautvetteria grandis Nutt. Stems $30-50 \mathrm{~cm}$. tall, glabrous or nearly so; leaves broader than long, $8-30 \mathrm{~cm}$. across, 5-9-cleft, the lobes oblong or obovate, acute, incisely lobed and toothed; akenes smooth, ovate, three-angled, tipped with a slender recurved beak.

In mountain meadows and along mountain streams.

\section{MYOSURUS. MOUSE TAIL.}

Very small annual herbs; leaves entire, linear or at first spatulate, in a basal tuft; scapes simple, 1-flowered; sepals 5, spurred at the base; petals 5, greenish-yellow, with long nectariferous claws, or none; stamens 5-20; pistils numerous, borne on a central axis, the receptacle, which becomes greatly elongated in fruit; ovule 1.

Myosurus major Greene. Scapes several-many, 8-15 cm. high; fruiting spikes $2-4 \mathrm{~cm}$. long, rather stout; akenes with a short straight beak.

Vancouver Island to California.

\section{BATRACHIUM. WATER Buttercup.}

Perennial aquatic herbs with alternate dissected or palmately lobed leaves, the ultimate segments of the submersed leaves filiform; flowers solitary, rather small, white, borne on peduncles opposite the leaves; sepals and petals usually 5; petals oblong or oval, sometimes yellowish at base; stamens several or numerous; akenes compressed, not margined, nearly beakless, transversely wrinkled.

Receptacle glabrous; submersed leaves none, the floating ones 3-parted.

Receptacle hairy; submersed leaves capillary.

Floating leaves reniform or orbicular.

Floating leaves wanting.

\section{B. lobbii.}

B. aquatile.

B. aquatile pantothrix.

Batrachium lobbii (Gray) Howell. Stems slender, 15-30 cm. long; floating leaves orbicular in outline, 6-15 $\mathrm{mm}$. wide, 3 -parted into oblong lobes, the lateral ones notched at the apex; petals obovate, $4 \mathrm{~mm}$. long; styles slender, three times as long as the ovary; akenes rugose, each tipped with a short beak; receptacle glabrous.

Lost Lake, Vancouver Island, Macoun, and in western Oregon.

Batrachium aquatile (L.) Wimm. Water Crowfoot. Stems 5-40 cm. long, slender, growing in water; immersed leaves flaccid, all finely divided into filiform segments, $8-20 \mathrm{~mm}$. long; floating leaves $1-5$, reniform or orbicular, 3-5-lobed or parted; petals white, yellow at base, each bearing a naked nectariferous pit; akenes thick, transversely wrinkled, the style short; receptacle hairy.

In ponds, frequent.

Batrachium aquatile pantothrix (Brot.) Piper. All the leaves immersed and divided into filiform segments.

In ponds, often with $B$. aquatile. 


\section{RANUNCULUS. BUTTERCUP.}

Annual or perennial herbs; cauline leaves alternate; flowers solitary or corymbed; sepals usually 5, deciduous; petals as many or more, conspicuous or minute, with a nectariferous pit and a scale at the base of the blade; stamens numerous, occasionally few; pistils numerous, 1-ovuled; akenes capitate or spicate, generally flattened, each tipped with a minute or an elongated style.

Plants aquatic or subaquatic; leaves finely dissected when submersed, less so when aerial.

Plants terrestrial but often growing in very wet places; leaves never finely dissected.

Akenes thin-walled, the faces nerved; leaves crenate; the plant spreading by runners.

Akenes not thin-walled nor nerved.

Leaves entire or nearly so.

Stems creeping, rooting from the nodes.

Leaves lanceolate, $2-5 \mathrm{~cm}$. long.

Leaves linear-spatulate, $5-20 \mathrm{~mm}$. long.

Stems erect, not rooting from the nodes.

R. purshii.

Plants $30-60 \mathrm{~cm}$. high; leaves lanceolate or oblong.

Plants $10-25 \mathrm{~cm}$. high; leaves oblong-lanceolate.

Leaves or some of them lobed or divided.

Faces of the akenes scabrous or muricate; annuals.

Pubescent; akenes hispid with hooked hairs.

Nearly glabrous; akenes minutely spiny.

Faces of the akenes smooth or merely

$R$. flammula unalaschensis.

$R$. flammula reptans.

R. cymbalaria.

R. alismaefolius.

R. alismellus. pilose; mostly perennials.

Herbage glabrous or nearly so; low species.

Annual; leaves 3-5-lobed or parted, the lobes crenately in-

cised or cleft; akenes apiculate. $R$. sceleralus. Perennials.

Head of akenes globose; petals large, showy.

Head of akenes oblong.

Style straight; leaves ciliate, not cordate.

Style recurved; leaves cordate, not ciliate.

Herbage pubescent or hirsute; most-

\section{$R$. hebecarpus.}

$R$. muricatus.

R. suksdorfii.

R. eschscholtzii.

$R$. verecundus. ly tall and coarse species.

Beaks of the akenes hooked at tip.

Petals showy; pubescence villous.

Petals very small, pale; pube-

$R$. occidentalis. scence hirsute. 
Akenes hispid on the faces. $R$. bongardi.

Akenes smooth. Beaks of the akenes not hooked

$R$. bongardi douglasii. at the tip.

Akenes long beaked.

Akenes short beaked.

$R$. orthorhynchus.

Plants decumbent, creep-

ing by stolons; petals showy.

Plants erect or ascending, not stoloniferous.

Head of akenes oblong; petals not longer than the sepals.

Head of akenes globose; petals longer than the sepals.

$R$. repens.

$R$. pennsylvanicus.

$R$. oreganus.

Ranunculus purshii Richards. Aquatic and glabrous or more commonly terrestrial on muddy banks, and then pubescent; leaves orbicular, palmately 3-cleft, the segments 2-5-lobed; petals yellow, 4-5 mm. long, scarcely longer than the sepals; akenes without distinct border, tipped with a short straight beak.

Rare in our limits.

-Ranunculus cymbalaria saximontanus Fernald. Perennial, nearly glabrous; leaves clustered at the base and at the joints of the long slender stolons, ovate or ovate-cordate, coarsely crenate, thick, the petioles often pilose; scapes 1-7-flowered, 3-15 cm. high, commonly pilose; petals 5-8, pale yellow, 4-9 mm. long, exceeding the sepals; heads of akenes oblong, 6-12 $\mathrm{mm}$. long.

Moist soil especially where saline.

Ranunculus flammula unalaschensis (Bess.) Ledeb. Stems slender, creeping, rooting at the lower joints, $15-30 \mathrm{~cm}$. long; leaves narrowly-lanceolate, short-petioled, acute at each end, $2-5 \mathrm{~cm}$. long, shorter than the internodes; flowers small, yellow, mostly solitary on the ascending tips of the stems; akene small, smooth, short-beaked.

Gravelly borders of lakes and streams, common.

Ranunculus flammula reptans (L.) Schlecht. Stems very slender, rooting at all the joints; leaves linear to linear-spatulate, $10-25 \mathrm{~mm}$. long.

Gravelly or sandy shores of lakes and streams, especially in the mountains at low altitudes.

Ranunculus alismaefolius Geyer. Glabrous throughout, rather stout, 40-60 cm. tall, branched above; radical leaves long-petioled, lanceolate or ovate, obtuse, usually cuneate at the base, entire or obscurely denticulate, 5-10 cm. long; cauline leaves narrower, mostly sessile; peduncles elongated; sepals small; petals yellow, cuneate-obovate, strongly-nerved, $8 \mathrm{~mm}$. long; akenes turgid, smooth, short-beaked.

In wet places, Willamette Valley. Our plant is not typical of the species and may be distinct, possibly referrable to $R$. samolifolius Greene.

Ranunculus alismellus (Gray) Greene. Glabrous, 15-25 cm. high; stems solitary or few from a fascicle of fibrous roots, erect or nearly so; basal leaves lanceolate or oblong-lanceolate, entire, petioled, 2-5 cm. long, the cauline smaller; peduncles slender, axillary, longer than the subtending leaves; flowers yellow, small, $8-15 \mathrm{~mm}$. broad; petals 5 or 6 , obovate; akenes thick, shortbeaked, numerous in a globose cluster. 
Mount Adams and other high peaks of the Cascade Mountains, not definitely known from within our limits.

Ranunculus hebecarpus H. \& A. Annual; whole plant hairy; stems slender, mostly erect, $15-30 \mathrm{~cm}$. tall; leaves $2-3 \mathrm{~cm}$. broad, 3-parted, the lobes incisely 3-lobed; petioles of the leaves much longer than the blades; petals small, $2 \mathrm{~mm}$. long, about equalling the sepals; akenes flattened, with short hooked beaks, the sides roughened and covered with hooked hairs.

Eastern Washington to California. Introduced on Vancouver Island.

Ranunculus muricatus L. Annual, nearly glabrous; stems stout, rather succulent, 10-20 cm. high; basal leaves circular in outline, reniform, 3-lobed, coarsely crenate-dentate; cauline 3 -cleft, broadly cuneate; petals bright yellow, longer than the calyx; akenes flat, the sides armed with fine prickles, the beak stout, subulate.

Wet places, introduced from Europe.

Ranunculus sceleratus L. Annual, glabrous; stems erect, hollow, 15-40 $\mathrm{cm}$. high; leaves pale green, the basal ones reniform orbicular, deeply 3 -lobed, the cauline 3-5-lobed or parted and the divisions cleft or lobed; petals pale yellow, scarcely longer than the calyx; akenes short-beaked, smooth, numerous, in a cylindric head.

Rare in moist places but undoubtedly native.

Ranunculus suksdorfii Gray. Perennial, glabrous; leaves 1-2 cm. long, truncate to somewhat reniform at base, deeply 3-5-parted; segments of the basal leaves cuneate, 3-5-cleft, of the cauline linear and entire; petals suborbicular, retuse, $8-12 \mathrm{~mm}$. long, bright yellow; akenes in a globose cluster, glabrous, each tipped with a long slender style.

In moist places at about $2000 \mathrm{~m}$. altitude, Cascade and Olympic Mountains.

Ranunculus eschscholtzii Schlecht. Perennial, glabrous or nearly so, 10-20 cm. high; leaves ciliate, the basal orbicular, deeply 3-5-cleft or parted, the cuneate divisions again lobed or cleft; cauline mostly 3-parted, the lobes usually entire; flowers few; petals pale yellow, 6-10 $\mathrm{mm}$. long, exceeding the sepals; head of akenes oblong; akenes swollen, marginless, glabrous, tipped with a straight beak.

Along alpine rills at $1500-2000 \mathrm{~m}$. altitude. First found at Unalaska by Chamisso.

Ranunculus verecundus Robinson. Perennial, nearly glabrous; scems suberect or procumbent; basal leaves reniform to suborbicular, deeply cordate, 3parted, not ciliate, the segments 3-5-lobed or deeply crenate, the lobes obtuse; petiole $2-4 \mathrm{~cm}$. long, sparsely villose at the broadened base; cauline leaves $1-3$, 3-5-parted into narrow segments; peduncles 3-7 cm. long; petals obovate, bright-yellow, scarcely exceeding the sepals; akenes numerous in an ovoid to cylindric cluster, glabrous, compressed, $1.8 \mathrm{~mm}$. long; style recurved; receptacle villous at tip.

Mount Rainier, 2300 m. altitude, Flett; Mount Adams, 2000 m. altitude, Suksdorf.

Ranunculus occidentalis Nutt. Perennial, villous-hirsute; stems slender, $25-45 \mathrm{~cm}$. high, not much branched; basal leaves orbicular, cordate, deeply 3-5-cleft or sometimes parted, the segments cuneate and 2-7-lobed, the lobes acute; cauline leaves mostly parted into linear entire segments; petals bright yellow, 10-12 mm. long, twice as long as the reflexed sepals; akenes glabrous or sparingly bristly, flat, tipped with stout hooked beaks; cluster of akenes globose; receptacle glabrous.

Common in open prairies. 
Ranunculus bongardi Greene. Erect, $40-60 \mathrm{~cm}$. tall, glabrous or somewhat pubescent; leaves deeply 3-5-cleft, the lower cuneate-obovate, incisely 2-5toothed; petioles longer than the blades; flowers few, in open cymes, longpedicelled; petals 5 , very small, pale yellow; akenes much flattened, hispid on the faces, each with a slender circinate beak, aggregated into globose clusters.

Common in shady copses.

Ranunculus bongardi douglasii (Howell) Davis. Similar to $R$. bongardi but less pubescent or sometimes glabrous; akenes smooth, the beak shorter.

In moist places. All intergrades with the preceding occur.

Ranunculus orthorhynchus Hook. Perennial, glabrous or sparsely appressed-hairy; stems erect, $30-60 \mathrm{~cm}$. high, branched and nearly naked above; leaves pinnately divided into 5-7 narrow cleft or incised segments, the tips with white callous points; petals obovate, yellow, often purplish on the outside, strongly nerved, twice as long as the reflexed oval sepals; akenes few, glabrous, compressed, sharp-margined, the border shorter than the slender straight beak.

In wet meadows.

Ranunculus repens L. Pubescent or nearly glabrous; stems $30-60 \mathrm{~cm}$. long, creeping and rooting at the lower nodes; leaves often white-blotched, mostly 3-parted or 3-divided, the segments rhombic-ovate, 2-3-lobed and incisely toothed; petals obovate, about $1 \mathrm{~cm}$. long, much exceeding the spreading sepals; akenes obovate, tipped with a short recurved style.

In wet meadows, introduced from Europe.

Ranunculus pennsylvanicus L. f. Stout and tall, hirsute with spreading hairs, erect, $30-100 \mathrm{~cm}$. high, the root usually annual; leaves ternately compound, the leaflets ovate, acute, 3-cleft; flowers small; petals pale yellow, not longer than the sepals; akenes flat, obscurely margined, each tipped with a short siraight beak, crowded in a short cylindric head.

In damp meadows, rare in our limits.

Ranunculus oreganus (Gray) Howell. Sparsely bristly-hirsute; stems stout, erect or ascending, 30-90 cm. high; leaves ternately divided, the segments stalked, broadly ovate, 3 -cleft, the lobes incisely toothed; petals bright yellow, obovate, $6 \mathrm{~mm}$. long, twice as long as the reflexed sepals; akenes in an oblong or oval cluster, each with a stout straight flattened beak.

In wet places in open deciduous woods.

\section{DELPHINIUM. LARKSPUR.}

Annual or perennial erect branching herbs; leaves palmately lobed or divided; flowers showy, in a raceme or panicle; sepals 5 , petal-like, the upper one prolonged into a spur; petals 4 , sometimes 2, the two posterior ones spurred, the lateral, when present, small; stamens numerous; pistils $1-5$, sessile, many-ovuled, forming follicles at maturity.

Roots thickened, forming irregular tubers.

Pubescence minute, white, appressed.

Pubescence if any spreading, sometimes viscid.

D. menziesii.

Roots fasciculate, elongate, not tuber-like.

Pedicels shorter than the flowers and fruit; flowers pale blue.

Pedicels longer than the flowers and fruit; flowers deep blue.

Plant 1-2 m. high; leaves thin.

Plant $10-30 \mathrm{~cm}$. high; leaves thickish.

D. columbianum.

D. glaucum.

D. trolliifolium.

D. bicolor. 
Delphinium menziesii DC. Stems erect, simple or branched above, 30-70 cm. tall, appressed-puberulent at least above with white usually curved hairs; leaves 3-7-parted, the divisions usually deeply cleft into 2-4, usually 3 lobes, the segments linear or lanceolate; petioles mostly exceeding the blades; racemes loose, 5-25-flowered; pedicels spreading, mostly as long as or longer than the dark blue flowers; sepals pubescent on the outside, $2-2.5 \mathrm{~cm}$. long; spur as long, mostly acute and slender; follicles 3 , mostly diverging at maturity, pubescent, $1.4-3 \mathrm{~cm}$.long. Sound.

Originally collected by Menzies, probably at Nootka

Delphinium menziesii ochroleucum T. \& G. (D. leucophaeum Greene; D. willametense Suksdorf.) Sepals cream-colored; petals blue, bordered with white.

Willamette Valley, Nuttall, Howell, Suskdorf.

Delphinium columbianum Greene. (D. nuttallii Gray.) Very similar to $D$. menziesii; herbage somewhat glaucous, glabrous or nearly so below, finely villous and sometimes viscid in the inflorescence; follicles remaining erect or nearly so, villous-puberulent.

In prairies and open places, rare.

Delphinium glaucum Wats. Glabrous throughout; stems erect, stout, 1-2 m. high, smooth and glaucous; leaves orbicular, 5-7-parted, the lobes laciniately toothed and acuminate, dark green above, pale beneath; flowers pale, dull blue, in a dense raceme; pedicels short; sepals 10-12 $\mathrm{mm}$. long; follicles glabrous, veiny.

Along streams in the mountains.

Delphinium trolliifolium Gray. Roots stout, elongated, not tuber-like; herbage glabrous or the inflorescence sparsely villous, rarely somewhat viscid; stems erect, 1-2 m. high; leaves thin, orbicular in outline, 5-10 cm. broad, 5-7-cleft or parted, the lobes cuneate, incisely cleft into lanceolate acute lobes; raceme loosely many-flowered, the pedicels spreading; flowers dark blue; sepals 1.5-2 cm. long, ovate, acuminate; follicles glabrous, turgid, veiny, recurved when mature, $12-15 \mathrm{~mm}$. long.

In meadows along streams, Lewis County, Washington, to northern California. Commonly reputed to be very poisonous to cattle.

Delphinium bicolor Nutt. (D. glareosum Greene.) Roots stout, thick, elongated, not tuber-like; herbage sparsely villous, especially in the inflorescence, to nearly or quite glabrous; stems erect, $10-30 \mathrm{~cm}$. high; leaves succulent, orbicular in outline, 5-parted, the segments 3-5-cleft into narrow lobes; raceme loosely few to many-flowered; sepals blue, $1.5-2 \mathrm{~cm}$. long; petals white, veined with blue; follicles turgid, glabrous.

Rare in our limits; Olympic Mountains, Piper, Elmer, Flett; Goat Mountains, Allen.

\section{ACONITUM. Aconite. Monkshood.}

Tall erect perennial herbs; leaves palmately-lobed or divided; flowers large, showy, in terminal racemes or panicles; sepals 5, petal-like, very irregular, the upper one hooded or helmet-shaped; petals $2-5$, the upper two hooded, long clawed, concealed in the helmet; stamens numerous; pistils 3-5, many-ovuled, forming follicles at maturity.

Aconitum howellii A. Nelson. (A. bulbiferum Howell.) Stems slender weak and viny, $60-120 \mathrm{~cm}$. long, smooth below, tomentose above; leaves 
rather small, on short petioles, or the upper sessile, bearing bulblets in their axils, all laciniately cut into acute lobes; sepals pale blue; hood $12-16 \mathrm{~mm}$. long.

Near the base of Mount Hood, Oregon, Howell.

\section{AQUILEgIA. Columbine.}

Erect perennials with 2-3-ternately compound leaves; flowers regular, showy, on the ends of the branches; sepals 5, regular, petal-like; petals 5, all alike, each with a short lip and produced backward into a large hollow spur much longer than the calyx; pistils 5, with slender styles; pods erect, many-seeded.

Flowers scarlet and yellow.

A. formosa.

Flowers wholly yellow.

A. flavescens.

$5 / 20 / 10$ Aquilegia formosa Fisch. Usually sparingly pubescent; stems erect, ${ }_{28}^{27} 760-90 \mathrm{~cm}$. high; leaflets broadly cuneate, paler beneath, lobed; flowers nodding, s2.bright scarlet, yellow inside; sepals spreading; spurs nearly straight, about Fak twice as long as their blades.

fo. Common in moist places and in the mountains up to $2000 \mathrm{~m}$. altitude.

Aquilegia flavescens Wats. Like $A$. formosa but flowers wholly yellow. In the mountains, rare.

201. PAEONIA. Paeony.

Robust perennial herbs with ternately or pinnately compound leaves and showy flowers; sepals 5, herbaceous, persistent; petals 5-10: stamens numerous, inserted on a fleshy disk; pistils 2-5; fruit of 3-5 leathery several-seeded follicles.

Paeonia brownii Dougl. Whole plant glabrous and glaucous, $20-50 \mathrm{~cm}$. high, at first erect or ascending, in fruit decumbent; leaves thick, once or twice ternately divided or parted, the ultimate segments from narrowly oblong to obovate; sepals green, concave, unequal; petals dull brownish red, thick, scarcely longer than the sepals; follicles usually 5 , oblong, smooth, about $3 \mathrm{~cm}$. long; seeds black, shining.

In the Cascade Mountains at low elevations, principally on the eastern slope; also said to occur on Vancouver Island, but this is doubtful.

\section{CALTHA.}

Smooth succulent perennial marsh herbs with round and heart-shaped or reniform undivided leaves; sepals 5-15, petallike, regular; petals none; stamens numerous; pistils 5-15, several-ovuled, becoming in fruit several-seeded follicles.

Flowers yellow; stems decumbent, leafy.

Flowers white; stems erect, leafless or 1-leaved.

Leaves reniform-orbicular, broader than long.

Leaves cordate, longer than broad.

C. asarifolia.

C. biflora.

C. leptosepala.

Caltha asarifolia DC. Marsh Marigold. Stems decumbent, usually rooting at the nodes, one or few-flowered; leaves round-reniform; sepals 5-7, bright yellow; follicles sessile.

In bogs, Alaska to Oregon, along the coast; rare southward. 
$M+$ Adams Caltha biflora DC. Stems 10-20 cm. high; leaves crenate or repand, the flomen allgmbasal lobes usually overlapping; sepals 6-9, oval to oblong; follicles shortover fallen stalked.

of guhy $(\pi / 2)$ In wet alpine meadows, Alaska to California.

Caltha leptosepala DC. Stems $8-20 \mathrm{~cm}$. high; leaves cordate, crenate or repand; sepals $7-10$, oblong, often bluish beneath; follicles very short-stalked.

Wet mountain meadows, Alaska to Oregon and Colorado.

\section{TROLLIUS.}

Glabrous perennial herbs with palmately lobed or dissected leaves and yellow flowers; sepals 5-15, regular, petal-like, deciduous; petals 5-8, small, 1 -lipped, tubular at base; stamens and carpels numerous, the latter forming in fruit many-seeded follicles.

Trollius laxus Salisb. Globe Flower. Leaves 5-7-cleft; sepals white; petals numerous, shorter than the stamens, very small.

In wet places at low elevations in the mountains, rare.

\section{ACTAEA. BANEBERRY.}

Erect perennial herbs; leaves large, 2-3-ternately compound; flowers small, white, in a terminal raceme; sepals $3-5$, petal-like; petals 4-10, small, spatulate or narrow-clawed; stamens numerous; ovary 1-many-ovuled, in fruit forming a large somewhat poisonous berry.

Actaea spicata arguta (Nutt.) Torr. Stems $30-60 \mathrm{~cm}$. tall, erect; leaves triternately decompound; leaflets obliquely ovate or lanceolate, acuminate, coarsely incised-serrate or lobed, puberulent when young, 3-6 cm. long; racemes densely flowered, $2-3 \mathrm{~cm}$. long, becoming loose in age; berries bright red, rarely white.

In moist copses, frequent.

\section{CIMICIFUGA. BugBANE.}

Perennial herbs, with 2-3-ternately divided leaves and serrate leaflets; flowers white, in elongated racemes; sepals 4 or 5 , early falling; petals $1-8$, small, clawed, 2-lobed or none; stamens numerous; carpels 1-8, many-ovuled, becoming follicles at maturity.

Follicles stalked; petals usually present.

Follicles not stalked; petals none.

C. laciniata.

C. elata.

Cimicifuga laciniata Wats. Tall, $1 \mathrm{~m}$. or more high; leaflets oblong or ovate, lacinately toothed; follicles $3-5$, stalked, $12 \mathrm{~mm}$. long; secds flattened.

Woods about the base of Mount Hood, Oregon.

Cimicifuga elata Nutt. Tall, 1-2 m. high; leaflets broad, cordate, acute, coarsely serrate, mostly 3 -lobed; follicles $1-3$, sessile, $8-10 \mathrm{~mm}$. long; seeds not flattened.

In open woods, rare. 


\section{ISOPYRUM.}

Low glabrous perennials with 1-3 ternately compound leaves, their primary divisions long-petiolulate; flowers white; sepals 5 or 6 , broad, widely spreading; petals none (in ours); follicles 2-20, sessile, rarely short stipitate; ovules and seeds few (in ours).

Isopyrum hallii Gray. Stems erect, $30-80 \mathrm{~cm}$. high; leaflets $2-3 \mathrm{~cm}$. long, cuneate-obovate, incisely 3-lobed; flowers in leafy-bracted umbel-like cymes; sepals obovate; stamens numerous, as long as the sepals, the filaments clavate; follicles 3-5, ovate, turgid, sharp-beaked; seeds rugulose.

In woods along mountain streams, western Oregon, rare.

\section{COPTIS. Goldthread.}

Low glabrous perennials with slender rootstocks; leaves all radical, ternately compound; flowers on scapes, solitary, or in few-flowered umbels; sepals 5-7, petal-like; petals 5-6, small, linear, hood-shaped; stamens numerous; pistils $3-7$, on slender stalks, in fruit forming a cluster of divergent follicles.

Coptis laciniata Gray. Leaves trifoliolate, the ovate leaflets firm, shiny, 3-cleft or parted and the divisions incisely dentate; sepals whitish, linear, $8-10 \mathrm{~mm}$ long; petals filiform with a broader concave nectary below the middle; follicles longer than their stalk-like bases.

In mountain woods, Skamania County, Washington to northern California. C. trifoliata (L.) Salisb. has been reported to occur near Snohomish, Washington, but no specimens have been seen from farther south than Mount Mark, Vancouver Island, Macoun. The species is readily distinguished by the three undivided leaflets, oval sepals, and clavate petals.

\section{Family 43. BERBERIDACEAE. BARBERRY FAMILY.}

Shrubs or herbs; leaves alternate, mostly compound or divided, with stipules or dilated bases; flowers perfect, the bracts, sepals, petals and stamens all distinct and hypogynous; sepals and petals each usually in two rows of three; anthers opening by two valves or lids hinged at the top; pistil single; style short or none; fruit a berry or pod; seeds few or several; endosperm present.

Shrubs; leaves evergreen, pinnate, spiny.

Herbs; leaves deciduous, not pinnate nor spiny.

Leaves ternately compound; flowers in panicles. Leaves 3-parted; flowers in spikes.
208. Berberis, 163.

209. VANCOUVERIA, 164. 210. ACHLYS, 164.

\section{BERBERIS.}

Shrubs with yellow wood; leaves alternate, simple or compound, often spiny, evergreen (in ours); flowers yellow, in clustered racemes; bractlets $2-6$; sepals 6 , petal-like; petals 6 , in two rows, each with two basal glands; stamens 6 , short; stigma peltate; fruit a berry. 
Berberis nervosa Pursh. Oregon Grape. Stems erect, simple, 15-30 cm. high; leaves 30-75 cm. long, with 11-19 leaflets, these ovate or lanceolate, acuminate, spinulose-dentate; bud scales lanceolate, acuminate, $2-2.5 \mathrm{~cm}$. long, persistent, becoming dry and rigid; racemes terminal, one or several, 10-20 cm. long; pedicels shorter than the fruit; berries globose, purple-black with a white bloom, very acid.

Very common in coniferous woods.

Berberis aquifolium Pursh. Shrub often 1-2 m. high, erect or nearly so; leaflets 5-11, evergreen, shining, oblong or ovate, $4-10 \mathrm{~cm}$. long, with numerous spiny teeth; racemes usually clustered, subterminal; berries black with a bloom, usually pear-shaped.

In open places, not uncommon.

\section{VANCOUVERIA.}

Perennial herbs with triternate leaves; flowers in racemes or panicles; sepals 6 , in 2 series, obovate, petal-like, reflexed, subtended by 6 or 9 calyx-like bracts in 2 or 3 series; petals 6 , clawed, nectariferous; stamens 6; style slender; stigma terminal; ovary 2-9-ovuled; follicle oblong, membranaceous, 2-valved.

Vancouveria hexandra (Hook.) Morr. \& Dcne. Nearly glabrous with a few pilose hairs on the stem and petioles; leaves triternate, the petioles slender; leaflets thin, somewhat cordate at base, $2-5 \mathrm{~cm}$. long, angularly 3-lobed, or the margin repand or sub-entire; scape naked or bearing a single leaf, 10-30 $\mathrm{cm}$. high, exceeding the leaves; flowers white.

In deep woods; valley of the Nisqually River, Washington, and southward.

\section{ACHLYS.}

Herbs with creeping rootstocks; flowers in an erect spike; stamens 6-12; filaments elongated, filiform, or the outer dilated; ovary ovoid with a broad sessile stigma; ovule solitary; fruit at first somewhat fleshy, at length dry indehiscent, 1-seeded.

Achlys triphylla (Smith) DC. Vanilla-leaf. Rootstocks slender, scaly; leaves mostly solitary, glabrous, erect, the petiole about $30 \mathrm{~cm}$. long; leaflets 3 , spreading, broadly cuneate or fan-shaped, the outer margin coarsely sinuatedentate, the larger 5-10 cm. long; scape naked, as long as the leaf, the small white flowers in an erect spike $2-3 \mathrm{~cm}$. long.

Common in open coniferous woods. The plant contains cumarin which gives it a vanilla-like odor in drying.

\section{Family 44. PAPAVERACEAE. Poppy Family.}

Herbs with a milky or watery juice; leaves alternate, simple or compound, without stipules; flowers perfect, regular or irregular, the parts in twos or fours; sepals 2 ; petals $4-12$, separate or somewhat united; stamens 6 , diadelphous, or numerous and distinct; ovary 1 -celled with 2 or more parietal placentae; fruit a dry 1-celled pod with numerous seeds. 
Flowers regular.

Leaves alternate, lobed or dissected.

Leaves opposite, entire.

Flowers irregular.

Corolla 2-spurred at the base.

Corolla 1-spurred at the base.

211. Eschscholzia, 165.

212. Platystigma, 165.

213. Bikukulla, 165.

214. CAPNOIDES, 166.

\section{ESCHSCHOLZIA.}

Smooth glaucous slender annual herbs with colorless bitter juice; leaves alternate, petioled, lobed or dissected; flowers bright orange or yellow; sepals coherent into a narrow pointed hood; petals 4; stamens numerous, with short filaments and linear anthers; style short; stigma divided into 4-6 linear unequal lobes; ovary linear, with 2 placentae; capsule elongated, 1 -celled, 10-nerved, 2-valved, many-seeded.

Eschscholzia californica Cham. California Poppy. Perennial, glabrous and glaucous, the erect or decumbent branches $20-60 \mathrm{~cm}$. long; leaves ternately divided into linear acutish lobes; calyx conic; petals orange-yellow, fan-shaped, 3-5 cm. broad; capsule 5-8 cm. long; rim of the receptacle 3-6 $\mathrm{mm}$. broad.

In open prairies, Willamette Valley. E. californica is extremely variable and numerous species have been proposed for the variant forms. The northern forms have been named $E$. columbiana Greene and $E$. douglasii (Hook. \& Arn.) Walp., the former with a broad rim to the receptacle, the latter with a narrow rim, but this character is very variable. No species of Eschscholzia is known to be native north of the Columbia River and west of the Cascade Mountains, but cultivated forms commonly escape and become established for a time.

\section{PLATYSTIGMA.}

Low slender annual herbs; leaves pale-green, entire, opposite or whorled; flowers pale-yellow, long-peduncled; sepals 3 (rarely 2 ); petals 4-6; stamens few to many, with narrow filaments and oblong or linear-oblong anthers; stigmas 3 , distinct, ovate to linear; ovary 2-angled, oblong or linear; capsule 1-celled, 3-valved, many-seeded.

Platystigma oreganum (Nutt.) Benth. \& Hook. Glabrous, the spreading stems usually 5-20 cm. high; basal leaves spatulate to obovate, $15-20 \mathrm{~mm}$. long, the petioles margined; cauline spatulate to linear, sessile; flowers white, on long peduncles; petals white, 2-4 mm. long; anthers shorter than the filament; capsule linear, usually twisted when mature.

In open places, especially in gravelly or sandy soil. Rare in Washington but common southward.

\section{BIKUKULLA.}

Erect or diffuse glabrous perennial herbs; leaves ternately compound or dissected; flowers in racemes or panicles, irregular, nodding; pedicels 2-bracted; sepals 2, scale-like; petals slightly united into a 2-spurred or swollen nectariferous often witheringpersistent corolla; stamens 6 , in two sets, opposite the outer 
petals; placentae 2; style slender; capsule oblong or linear, 2-valved.

Bikukulla formosa (Andr.) Coville. Rootstocks thickish, creeping, the leaves and scapes arising at the tips of the branches; leaves two or three times ternate, $20-30 \mathrm{~cm}$. broad, the ultimate segments pinnately incised into narrow lobes, glaucous beneath; scapes exceeding the leaves; flowers bracted in panicles; corolla rose-colored, cordate with short rounded spurs, the outer petals with ovate spreading tips.

In moist woods, especially along streams.

\section{CAPNOIDES. Congffalis (Sweatren)}

Biennial erect pale or glaucous herbs; leaves radical and cauline, decompound; flowers in racemes; sepals 2, small; petals 4 , slight y united to a 1-spurred corolla; inner petals narrow, keeled; stamens 6 , in two sets, opposite the outer petals; placentae 2 ; style entire, dilated or lobed; capsule oblong or linear, 2 -valved.

Capnoides scouleri (Hook.) Kuntze. Perennial from thickened roots; stems scaly at base; basal leaves very large, pinnately decompound, the ultimate segments oblong, obtuse, entire or the terminal ones 3-lobed, 3-5 cm. long, glaucous beneath, blackening in drying; flowering stems with 1-3 smaller leaves; flowers pale pink, in a loose raceme; corolla $2-3 \mathrm{~cm}$. long, the spurs three times as long as the body.

In moist woods, not abundant, at $500-1000 \mathrm{~m}$. altitude; in some places at sea level.

\section{Family 45. CRUCIFERAE. Mustard FAMILy.}

Herbs, rarely somewhat woody, with watery sap; leaves alternate; stipules none; flowers perfect, regular, in usually bractless racemes, spikes or corymbs; sepals 4 , usually oblong; petals 4 rarely none, hypogynous, in the form of a cross, equal, generally clawed, alternate with the sepals; stamens 6, rarely fewer, hypogynous, of unequal length, the two shorter opposite the sepals, the four longer opposite the petals; pistil 1, of 2 united carpels; pod usually 2-celled, dehiscing by the separation of two valves from the central partition, or rarely indehiscent, either much longer than broad (a silique) or short (a silicle).

\section{Pods indehiscent.}

Pod elongated, transversely constricted.

Pod of 2 joints separating at maturity; fleshy seashore plants.

Pod constricted between the several seeds, not jointed; terrestrial plants, not fleshy.

215. CAKILE, 168.

Pod not elongated, not transversely constricted.

Pod broader than long, 2-celled.

216. Raphanus, 168.

217. Coronopus, 168. 
Pod orbicular, 1-celled.

Fruit wingless; pubescence branched. 218. Athysanus, 169.

Fruit winged; pubescence simple.

Pods dehiscent, 2-valved, either elongate (sili219. ThYSANOCARPUS, 169. ques) or short (silicles).

Pods elongate (siliques).

Siliques compressed parallel to the broad partition.

Valves 1-nerved; cauline leaves sessile.

Valves nerveless; leaves all petioled.

Flowers red; stem 2 or 3-leaved at or above the middle.

Flowers white; stem leafy below or throughout.

Siliques terete, not at all compressed.

Pods $4 \mathrm{~cm}$. or more long.

Flowers not yellow; stigmas entire or several-lobed, not 2-lobed.

Flowers cream-colored, often purple-tinged (in ours).

Flower 223. THELYPODIUM, 173.

Flowers yellow; stigmas 2-lobed.

Flowers large; leaves nearly entire.

Flowers small; leaves pinnatifid.

Pods less than $4 \mathrm{~cm}$. long.

220. ARABIS, 169.

221. Dentaria, 171.

222. Cardamine, 172.

224. Hesperis, 173.

225. Erysimum, 173.

228. Sisymbrium, 175.

Herbage canescent; flowers white. 226. SMELowskia, 174.

Herbage not canescent; flowers yellow or white.

Siliques beaked; seeds globose.

Siliques beakless; seeds oblong.

Valves of the pods nerveless.

Valves of the pods nerved.

Annuals; leaves pinnate or pinnatifid.

Perennials; leaves ly-

Pods short (silicles). rate.

227. Brassica, 174.

235. Radicula, 179.

228. Sisymbrium,175.

229. BARBAREA, 176.

Silicles compressed parallel to the partition.

Silicle turgid.

Silicle flat, not turgid.

Silicles orbicular.

Silicles ovate or oblong.

Silicles either not compressed or compressed at right angles to the partition.

Plant aquatic, submerged; leaves subulate.

Plant terrestrial; leaves not subulate.

Pods terete, not compressed.

Flowers white; plants maritime, fleshy.

Flowers yellow, or if white the

plants not maritime or fleshy. 235. Radicula, 179.

230. Lesquerella, 176.

231. Alyssum, 177.

232. Draba, 177.

233. Subularia, 178.

234. Cochlearia, 178. 


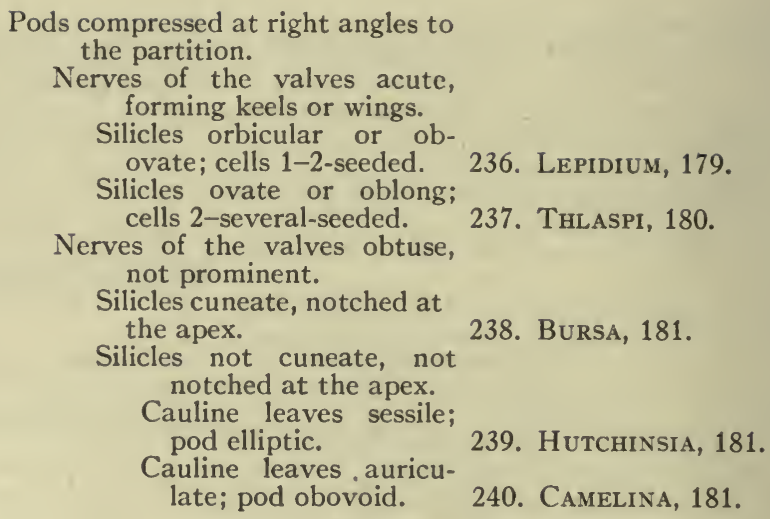

\section{CAKILE.}

Seaside annuals with fleshy stems; flowers purplish; pods short, 2-jointed, fleshy, the upper joint separating at maturity, each joint indehiscent, 1-celled and 1-seeded or the lower joint seedless.

Cakile edentula (Bigel.) Hook. Stems fleshy, leaves obovate, crenately or sinuately toothed; joints of the pod nearly equal in length, the upper ovoid, 4-angled at base, narrowed into a flattened beak.

Very rare along the seacoast. Long Beach near Ucluelet, Vancouver Island, British Columbia, Macoun; Port Angeles, Washington, Flett.

\section{RAPHANUS.}

Erect branching annual or biennial herbs with showy flowers; style long and slender; pod linear or oblong-cylindric, tapering upward, indehiscent, several-seeded, with a spongy pith between the seeds but no true partitions; seeds spherical.

Petals reddish, rarely white; pod not grooved.

$R$. sativus.

Petals yellowish, purple-veined; pod longitudinally grooved. $R$. raphanistrum.

Raphanus sativus L. Radish. Stems branched, 30-150 cm. high, glabrous or nearly so; basal leaves lyrate-pinnatifid, rough-hairy; petals purple; pods $10-12 \mathrm{~mm}$. thick, cylindric, tapering into a long pointed beak; seeds usually 2 or 3 .

Persisting in cultivated ground.

Raphanus raphanistrum L. Wild Radish. Stems 30-90 cm. high, loosely branched, hispid below, glabrous above; basal leaves lyrate-pinnatifid; petals yellow, strongly veined, turning white or purplish in age; pods $2-4 \mathrm{~mm}$. thick, moniliform, the beak slender; sceds 3-8.

A weed in fields and waste places.

\section{CORONOPUS.}

Annual or biennial diffused herbs with pinnatifid leaves; flowers small, whitish; pods flattened at right angles to the 
narrow partition, the 2 cells indehiscent, strongly wrinkled, each 1-seeded.

Pods notched at the apex, wrinkled.

Pods not notched at the apex, tubercled.

C. didymus.

C. coronopus.

Coronopus didymus (L.) Smith. Sparsely pubescent; stems branched, spreading, 5-30 cm. long; leaves pinnately parted into narrow entire or lobed segments, the lower ones petioled; pods $2 \mathrm{~mm}$. broad, about two thirds as long, notched at the apex, the surface finely wrinkled.

Sparingly introduced from Europe.

Coronopus coronopus (L.) Karst. Glabrous or a little pubescent; leaves similar to those of $C$. didymus, mostly less divided; pods coarsely rugose, not notched at the apex.

Native of Europe, introduced with ballast.

\section{ATHYSANUS.}

Slender annual herbs, usually branching at the base, with a pubescence of branched hairs; flowers minute, in racemes; petals small, white, or none; style short; ovules $3-4$, only one maturing; pod orbicular, indehiscent, not margined, nerveless, 1-celled, 1-seeded.

Athysanus pusillus (Hook.) Greene. Stems slender, branched from the base, 10-20 cm. tall, hirsute-pubescent throughout; leaves oblong-lanceolate, acute, usually coarsely dentate, rough-pubescent, $5-30 \mathrm{~mm}$. long; racemes loose, elongate; flowers very small, on curved pedicels; petals linear, minute or wanting; pods orbicular, about $2 \mathrm{~mm}$. in diameter, hirsute, on recurved longer pedicels.

Gravelly prairies and rocky slopes, rare west of the Cascade Mountains but common in the interior.

\section{THYSANOCARPUS.}

Erect and slender sparingly branched annual herbs, with a pubescence of simple hairs; flowers minute, white or rose-colored, in elongated racemes; pod mostly pendulous, on a slender pedicel, 1-celled, indehiscent, disk-shaped or concave, orbicular, winged, 1 -seeded; seed flattened but not winged.

Thysanocarpus curvipes Hook. More or less hirsute below, glabrous above; stem erect, usually branched above, $30-50 \mathrm{~cm}$. tall; radical leaves oblong, obtuse, dentate, $3-4 \mathrm{~cm}$. long, narrowed at base, with a petiole; cauline sagittate and clasping at base, acute, usually entire, commonly smaller; racemes elongated, loose; pedicels slender, recurved; pods orbicular, ovate or obovate, notched, apiculate by the persistent style, puberulent, 4- $6 \mathrm{~mm}$. long, the entire or crenulate wings as broad as the body.

In dry open ground, Victoria, British Columbia, Macoun; Willamette Valley, Oregon. Not known from western Washington.

220. ARABIS. ROCK CRESS.

Erect annual or perennial herbs; leaves seldom divided, the cauline sessile and usually clasping and auricled at the base; 
flowers white or purple; pod long-linear, compressed parallel to the partition; valves more or less 1-nerved; seeds flattened, usually winged, in one or two rows.

Seeds wingless; flowers white.

Basal leaves pinnately cleft into short and broad segments.

Basal leaves entire; cauline auriculate.

A. lyrata.

A. glabra.

Seeds winged or wing-margined.

Seeds arranged in a single row.

Cauline leaves cordate or auriculate at base.

Cauline leaves not cordate nor auricled.

Pubescence of very fine stellate hairs or none; pods broad.

Pubescence of simple or forked hairs; pods narrow. Petals small, not exceeding the sepals.

Petals much longer than the sepals.

Seeds more or less distinctly in two rows.

Pods reflexed.

Pods erect or ascending.

A. hirsuta.

Tall, $30-60 \mathrm{~cm}$. high; plant somewhat glaucous; pubescence of 2 -forked hairs.

Low, $10-30 \mathrm{~cm}$. high; plant glabrous or somewhat stellate-pubescent below.

A. platysperma.

A. olympica.

A. furcata.

A. patula.

A. drummondii.

A. lyallii.

Arabis lyrata occidentalis Wats. Pubescent at base, glabrous above stems branching from the base, ascending, $20-30 \mathrm{~cm}$. high; basal leaves lyratepinnatifid or sometimes nearly entire; cauline leaves spatulate to linear, mostly entire; petals white; pods ascending or spreading, very slender, flattened; stigma sessile or on a very short style; seeds oblong, wingless.

Nooksack River, Whatcom County, Washington, Suksdorf.

Arabis glabra (L.) Bernh. Biennial, pubescent near the base, glabrous and glaucous above; stems usually simple, $60-90 \mathrm{~cm}$. high; basal leaves oblanceolate, dentate or pinnatifid, pubescent, 5-8 $\mathrm{cm}$. long; cauline oblong-lanceolate, sessile, sagittate and auricled at base, all but the lower glabrous; flowers whitish, about $5 \mathrm{~mm}$. long; pods erect or ascending, linear, 4-10 cm. long, tipped with the large 2-lobed sessile stigma; pedicels $4-10 \mathrm{~mm}$. long.

Fields and open places, not rare.

Arabis hirsuta (L.) Scop. Biennial, usually rough-hairy, but shade plants often nearly glabrous; stems erect, $15-50 \mathrm{~cm}$. high; basal leaves clustered, oblanceolate, entire or somewhat dentate, usually $2-5 \mathrm{~cm}$. long; cauline oblong to lanceolate, entire or dentate, cordate or auriculate at base; flowers greenish white, small; pods on slender pedicels, erect, slender, $2-5 \mathrm{~cm}$. long, tipped with a very short stout style.

On rocky cliffs or gravelly bars, infrequent.

Arabis platysperma Gray. Perennial from a branched rootstock, finely stellate-pubescent to nearly glabrous, glaucous; leaves all entire, the basal oblanceolate and petiolate, 10-30 cm. high, the cauline oblong to lanceolate and sessile; flowers rose-colored or white; pods erect or ascending, flattened, the valves veiny, $3-6 \mathrm{~cm}$. long, $3-5 \mathrm{~mm}$. broad, tipped with a short style; seeds circular, broadly winged.

Mount Hood, Oregon, and southward in the mountains.

Arabis olympica Piper. Perennial, sparsely pubescent with simple or branched hairs; basal leaves obovate to oblanceolate, obscurely crenate, obtuse, petiolate, about $8 \mathrm{~mm}$. long; cauline sessile, oblong to lanceolate, obtuse, 
entire or nearly so; flowers corymbose; petals white, $2 \mathrm{~mm}$. long, as long as the sepals; pods erect, narrowly linear, glabrous, about $2 \mathrm{~cm}$. long, on stout glabrous pedicels.

Mount Olympus, Flett.

Arabis furcata Wats. Perennial from a branched rootstock; stems slender, 20-40 cm. high, glabrous; basal leaves oblong-ovate, entire or few-toothed, 3-5 cm. long, sparsely pubescent with forked hairs; cauline oblong to linear, sessile; petals white, spatulate, $12-15 \mathrm{~mm}$. long, twice as long as the calyx; pods slender, erect or ascending, 2-4 cm. long, attenuate at the apex.

On rocky bluffs in the gorge of the Columbia River.

Arabis patula Graham. (A. columbiana Macoun.) Biennial or perennial, somewhat pubescent below, glabrous above; basal leaves oblanceolate, entire or few-toothed, finally stellate pubescent, the petioles ciliate; cauline lanceolate, subentire, sessile, sagittate at base; flowers purple to nearly white; pods sharply reflexed, flattened, 4-6 cm. long; seeds in 2 rows.

On rocks and gravel bars in the mountains at low altitudes; not common.

Arabis drummondii Gray. Biennial, nearly glabrous and somewhat glaucous; stems mostly simple, 30-90 cm. high; basal leaves spatulate, sparingly dentate; cauline oblong to lanceolate, somewhat auriculate; pods erect or ascending, 4-10 cm. long; seeds oblong, winged, in two indistinct rows.

In rocky places in the mountains at low altitudes.

Arabis lyallii Wats. Perennial from a branched base, green or somewhat glaucous, glabrous or sparingly pubescent below; stems usually several, 5-10 $\mathrm{cm}$. high; radical leaves oblanceolate, acute, with slender petioles; pods straight, erect, $2-5 \mathrm{~cm}$. long; valves 1 -nerved below the middle and with some smaller veins.

Common in the mountains at $1500-2000 \mathrm{~m}$. altitude.

\section{DENTARIA.}

Perennial herbs with long fleshy rootstocks which have a pleasant pungent taste; stems leafless below, with 2 or 3 petioled compound leaves about or above the middle; flowers white or purple in a corymb or raceme; style elongated; pod lanceolate, compressed parallel to the partition; seeds in 1 row, wingless.

Basal leaves cordate-orbicular, crenately or sinuately lobed. Basal leaves mostly parted or divided into 3-5 segments.

D. tenella.

D. macrocarpa.

Dentaria tenella Pursh. Glabrous; rootstocks tuberiferous; stems 10-40 $\mathrm{cm}$. high; basal leaves simple, cordate-orbicular, coarsely crenate or lobed, 1-3 cm. long, their petioles often bulbiferous below; cauline leaves 3-parted, the narrow segments entire, $1-4 \mathrm{~cm}$. long; raceme short; petals rose-purple; pods $2-3 \mathrm{~cm}$. long, $2 \mathrm{~mm}$. broad, tipped with a slender style and a 2 -lobed stigma.

In moist woods.

Dentaria macrocarpa Nutt. Glabrous or slightly pubescent; rootstock tuberiferous, the tubers subglobose, 1-2 cm. in diameter; basal leaves 3-5lobed, cleft or divided, the segments linear, entire or toothed; peduncle short; flowers rose-purple; pods $3-5 \mathrm{~cm}$. long, $2 \mathrm{~mm}$. broad; stigma entire.

A variable species of which several forms have been described as subspecies, based mainly on differences in leaf contour. Most frequent on the eastern slope of the Cascade Mountains but occurring locally in the Willamette Valley. 


\section{CARDAMine. Bitter Cress.}

Mostly glabrous leafy-stemmed perennial herbs, growing in moist places; leaves entire, lobed or divided, all petioled; flowers white (in ours); pod elongated, compressed parallel to the partition; valves nerveless; seeds in 1 row, wingless.

Leaves all simple, entire or nearly so.

Leaves, or some of them, pinnate.

Basal leaves simple; cauline 3-5-foliolate.

Basal leaves pinnate.

Leaves all 3 -foliolate, sometimes 5 -foliolate; leaflets coarsely 3-5-toothed.

Leaves 3-13-foliolate.

Petals $4 \mathrm{~mm}$. long; leaflets 7-13, orbicular.

Petals 2-4 mm. long; leaflets 3-7.

Flowers subumbellate; leaflets orbicular.

Flowers racemose; leaflets oblong or roundish.

Capsules 8-20-seeded; leaflets mostly roundish.

Capsules 20-30-seeded; leaflets mostly oblong.
C. bellidifolia.

C. breweri.

C. angulata.

C. occidentalis.

C. kamischatica.

C. oligosperma.

C. pennsylvanica.

Cardamine bellidifolia L. Tufted from a branched caudex; stems $2-3 \mathrm{~cm}$. high; leaves ovate to elliptical, entire or with one or two lateral teeth, mostly obtuse, slender-petioled; flowers $1-5$, white; pods erect, 15-20 mm. long; style very short and stout.

At high altitudes in the mountains, not definitely known from our limits. Mount Adams, Suksdorf.

Cardamine breweri Wats. Perennial from slender rootstocks, glabrous or a little pubescent; stems erect or nearly so, mostly branched, $20-30 \mathrm{~cm}$. high; basal leaves simple and cordate-orbicular, entire or sinuate, sometimes pinnate with a pair of laieral leaflets; cauline pinnate, the leaflets orbicular to oblong, usually sinuate, sometimes lobed; flowers white, the petals $4 \mathrm{~mm}$. long; pods erect or ascending, 15-25 mm. long; style short and thick.

Mostly in the mountains along streams.

Cardamine angulata Hook. Perennial from running rootstocks, glabrous or sparsely hirsute; stems erect, mostly simple, $30-60 \mathrm{~cm}$. high; leaves 3-5foliolate; leaflets subequal, ovate to oblong, mostly cuneate, the terminal one 3-5-toothed; petals white, 8-10 cm. long; pods spreading, 2-25 mm. long; style stout, $2 \mathrm{~mm}$. long.

In wet places in woods, mostly near the ocean coast.

Cardamine occidentalis (Wats.) Howell. Perennial from a short somewhat tuberous rootstock, glabrous or pubescent below; stems erect, $20-40 \mathrm{~cm}$. high; leaves all pinnate with 3-6 pairs of leaflets; leaflets subentire, those of the basal leaves rounded, of the cauline obovate to oblong or linear; petals white, $4 \mathrm{~mm}$. long; pods $2-2.5 \mathrm{~cm}$. long, very slender, erect or nearly so; stigma nearly sessile.

In wet places, infrequent.

Cardamine kamtschatica (Regel) Schulz. Perennial from slender rootstocks, glabrous or nearly so; stems several, erect, $15-30 \mathrm{~cm}$. high; leaves pinnate, the basal with 3-5 rounded or oval, the cauline with 5-7 oblong subentire leaflets; flowers few, in a short corymb; pods crowded, erect, 2-2.5 cm. long, slender, prominently beaked.

Along rills at high altitudes in the mountains. 
Cardamine oligosperma Nutt. Annual, erect, usually simple-stemmed, $15-30 \mathrm{~cm}$. high, sparsely hirsute throughout or nearly glabrous; leaflets small, orbicular, petiolulate, 3-5-lobed or toothed; raceme few-flowered; flowers 2 $\mathrm{mm}$. long; pods erect, 8-20-seeded, 12-20 $\mathrm{mm}$. long.

Very common in moist upland soil in open woods.

Cardamine pennsylvanica Muhl. Annual or biennial, glabrous or nearly so, $30-60 \mathrm{~cm}$. high, simple or branched; leaflets $7-13$, sessile, mostly oblong, but those of the lowermost leaves suborbicular; pods suberect on spreading pedicels.

In wet places, common. Ambiguous forms seem to connect with $C$. oligosperma.

\section{THELYPODIUM.}

Stout biennial herbs, of ten succulent; leaves simple, entire, toothed or pinnatifid, often auricled at the base; flowers usually in rather dense racemes; sepals oblong to linear, rather short; style short; stigma entire; pods slender, terete or 4-angled; seeds oblong, in 1 row in each cell.

Thelypodium lasiophyllum (Hook. \& Arn.) Greene. Annual, erect, 30-90 $\mathrm{cm}$. high, hispid below, glabrous above; leaves oblong to oblanceolate, 5-15 $\mathrm{cm}$. long, irregularly dentate or incised, the spreading lobes entire or dentate, the cauline sessile; flowers in a close usually simple raceme; petals creamcolored, often purple-tinged, spatulate, $5 \mathrm{~mm}$. long, twice as long as the oblong sepals; pods slender, usually curved downwards, attenuate at apex, 5-7 cm. long.

Sandy or rocky soil; rare in our limits.

\section{HESPERIS.}

Erect perennial or biennial herbs with some branched hairs; flowers large, showy, pink-purple (in ours); sepals erect, oblong, the lateral ones saccate at base; petals with long and slender claws and broad obovate to orbicular blades; pods very long, spreading, torulose, beaked.

Hesperis matronalis L. Rocket. Perennial herb, the numerous stems erect, $30-90 \mathrm{~cm}$. high; leaves broadly lanceolate, serrate, acuminate, $5-10 \mathrm{~cm}$. long, the lower ones long-petioled; flowers pink-purple; pods slender, spreading, 5-10 cm. long.

A common garden plant, occasionally found escaped from cultivation.

\section{ERYSIMUM.}

Biennial or perennial herbs; leaves rather narrow, entire or toothed, not clasping; flowers of ten large, usually yellow; pod linear, 4-angled or rarely flattened, not stipitate; valves keeled by the prominent midrib; seeds oblong, marginless, in one row in each cell.

Pods flattened.

E. arenicola.

Pods terete.

Seeds quadrangular.

E. asperum.

Seeds lenticular.

E. capitatum. 
Erysimum arenicola Wats. Perennial, several-stemmed from a loosely branched base, $15-20 \mathrm{~cm}$. high; leaves mostly basal, oblanceolate, sparsely denticulate, $3-4 \mathrm{~cm}$. long, sparingly pubescent with appressed hairs; flowers bright yellow; pod somewhat flattened, very gradually attentuate into a long beak; valves 1-nerved.

In sandy soil at high altitudes in the Olympic Mountains.

Mr Adamo Erysimum asperum (Nutt.) DC. Whitish throughout with appressed pubescence; stems simple, stout, $15-40 \mathrm{~cm}$. tall, erect; leaves lanceolate or oblanceolate, entire or somewhat dentate, rarely lobed, mostly petioled, 6-10 $\mathrm{cm}$. long; flowers bright yellow; petals $15-25 \mathrm{~mm}$. long; pods stout, somewhat 4 -angled, about $8 \mathrm{~cm}$. long, tipped with a short stout beak and a large 2-lobed stigma; pedicels stout, $1 \mathrm{~cm}$. long.

In open places, in our limits only at high altitudes, $1500-2000 \mathrm{~m}$., in the mountains.

Erysimum capitatum (Hook.) Greene. (E. elatum Nutt.). Very similar to $E$. asperum; taller, usually $30-90 \mathrm{~cm}$. high, more leafy, the leaves greener and subentire, acuminate; pods 5-10 cm. long, the stigmas not deeply lobed; seeds lenticular, thin and scarious-winged at one end.

On rocky cliffs, along the lower Columbia River and northward.

\section{SMELOWSKIA.}

Low cespitose canescent perennials with pinnatifid leaves; flowers small, in terminal racemes; petals entire, obovate or spatulate; style short or none; pods lanceolate-oblong, compressed at right angles to the partition; valves sharply keeled so that the pod is 4 -angled.

Capsule lanceolate, attenuate at each end. Capsule ovate, nearly subcordate at base.

S. calycina. S. ovalis.

Smelowskia calycina C. A. Mey. Densely cespitose from a stout branched caudex covered with the bases of old leaves; herbage densely canescent with stellate and a few longer simple hairs; stems $5-15 \mathrm{~cm}$. high; leaves pinnate or deeply pinnatifid, the segments linear to oblong, obtuse; flowers white, often pink-tinged; pods lanceolate, attenuate at each end, 6-10 mm. long.

Rocky places in the mountains at 2000-2500 m. altitude.

Smelowskia ovalis Jones. Very similar to $S$. calycina but more densely pubescent; pods ovate, truncate or subcordate at base.

Olympic Mountains and Cascade Mountains at high altitudes.

\section{BRASSICA.}

Erect annual or biennial herbs; lower leaves mostly pinnate or lyrate, with a large terminal lobe; flowers yellow; pod terete or nearly so, tipped with a slender conical or somewhat flattened beak; seeds globose, in 1 row or rarely in 2 rows in each cell.

Cauline leaves auricled at base and clasping.

B. campestris.

Cauline leaves not auricled nor clasping.

Beak of the pod very short, less than one fourth the fertile portion.

Beak of the pod long, about equaling the fertile portion. Herbage hispid; upper leaves sessile.

Herbage nearly glabrous; upper leaves short-petioled.

B. nigra.

B. arvensis.

B. juncea. 
Brassica campestris L. Turnip. Smooth or nearly so, often glaucous, $30-90 \mathrm{~cm}$. high; lower leaves petioled, somewhat lobed or toothed; upper entire or nearly so, sessile and clasping by auricled bases; flowers yellow; pedicels spreading; petals $6-10 \mathrm{~mm}$. long; pods terete, $3-5 \mathrm{~cm}$. long, narrowed into a beak about $1 \mathrm{~cm}$. long.

A weed in fields. A cultivated form of this plant is the rutabaga.

Brassica nigra (L.) Koch. Black Mustard. Erect, 30-80 cm. high, sparsely hirsute; leaves green, slender-petioled, the terminal lobe large and coarsely toothed, the few lateral lobes small; pods $15-18 \mathrm{~mm}$. long, erect, on very short pedicels, only the lower fourth seed-bearing; seeds dark-colored.

In waste places.

Brassica arvensis (L.) Kuntze. Charlock. Stout, annual, 30-90 cm. high, hispid with scattered hairs; lower leaves pinnately parted, consisting of a large ovate-oblong terminal segment and 1 or 2 pairs of much smaller ones, all dentate; uppermost leaves sessile, none clasping; pods 2-4 cm. long, erect or ascending, the fertile portion torulose, tipped with a flat and stout beak half as long.

A weed in waste ground.

Brassica juncea (L.) Cosson. Stout, $30-100 \mathrm{~cm}$. high, the herbage somewhat glaucous and nearly glabrous; basal leaves lyrately lobed; cauline oblong, entire or nearly so, narrowed at base and short-petiolate; pods spreading, terete, $2.5-3.5 \mathrm{~cm}$. long, the empty beak long and slender.

A weed in fields; native of Asia.

\section{SISYMBRIUM.}

Mostly annual or biennial herbs; leaves neither clasping nor auriculate at the base, rarely entire, often finely dissected; flowers small, usually yellow or yellowish; style short or none; stigma 2-cleft; pod linear, short or long, flat or terete; seeds oblong.

Flowers white; leaves subentire, mostly basal.

\section{S. thalianum.}

Flowers yellow; leaves pinnate or pinnatifid.

Stigma simple; pubescence of branched hairs.

Stigma 2-lobed; pubescence of simple hairs.

Pods short, subulate.

Pods long, linear.

S. hartwegianum.

S. officinale.

S. altissimum.

Sisymbrium thalianum (L.) Gay. Mouse-ear Cress. Slender annual, $10-20 \mathrm{~cm}$. high, pubescent below; leaves mostly in a basal rosette, obovate to oblanceolate, obtuse, entire or sparingly toothed, $2-5 \mathrm{~cm}$. long; flowers usually white; pods terete, somewhat 4 -sided, usually purplish, about $1 \mathrm{~cm}$. long, scarcely longer than the slender pedicels.

In dry ground, introduced from Europe.

Sisymbrium hartwegianum Fourn. Loosely branched, 20-40 cm. high; leaves pinnate with narrow lanceolate to oblong leaflets, these obtuse and more or less toothed; pods crowded, erect, 5-7 mm. long, on suberect pedicels nearly as long.

Rare west of the Cascade Mountains; Charleston, Kitsap County, Washington, Piper.

Sisymbrium officinale L. Hedge Mustard. Erect, sparsely hirsute with simple hairs or glabrous, $30-90 \mathrm{~cm}$. high, divaricately branched above; leaves pinnatifid into 5-13 lobes, the terminal longest, all more or less dentate; upper 
cauline leaves sessile, the others petioled; flowers yellow, $3 \mathrm{~mm}$. broad; pods pubescent, tapering from the base to the apex, 1-2 cm. long, erect on short pedicels.

A weed in waste places; native of Europe.

Sisymbrium officinale leiocarpum DC. Pods glabrous.

A very common weed in waste ground.

Sisymbrium altissimum L. Tumbling Mustard. Erect, much branched, 60-150 cm. tall, glabrous or sparsely hirsute with simple hairs; basal leaves petioled, pinnatifid into linear or lanceolate entire or dentate lobes; upper leaves reduced, sessile; flowers pale yellow, $5 \mathrm{~mm}$. broad; pods spreading, linear, 6-10 $\mathrm{cm}$. long, on short stout pedicels.

Introduced from Europe. Locally called "Jim Hill Mustard."

\section{BARBAREA.}

Somewhat succulent perennials; stems angled; leaves entire or pinnatifid; flowers yellow, in racemes; pod linear, terete, or somewhat 4-angled, tipped with the short slender style; seeds flat, in 1 row.

Pods 1-1.5 $\mathrm{cm}$. long, the beak slender, 2-3 mm. long; uppermost leaves rarely pinnatifid.

Pods $2-4 \mathrm{~cm}$. long, the beak thick and short; uppermost leaves pinnatifid.

B. barbarea.

Barbarea barbarea brachycarpa (Rouy \& Foucaud) Piper. n. comb. ( $B$. vulgaris brachycarpa Rouy \& Foucaud). Perennial, glabrous; stems simple or branched above, $30-60 \mathrm{~cm}$. high; lower leaves pinnatifid, the terminal segment oblong to orbicular, larger than the 2-4 lateral pairs; upper cauline leaves obovate to oblong, coarsely toothed, or toward the base lobed; flowers deep yellow; pods $1-1.5 \mathrm{~cm}$. long, ascending to spreading, terete, the slender beak 2-3 $\mathrm{mm}$. long.

Introduced from Europe; Seattle, Piper.

Barbarea orthoceras dolichocarpa Fernald. Bitter Cress. Perennial, glabrous; stems simple or branched above, $30-90 \mathrm{~cm}$. high; lower leaves from entire to pinnately cleft or divided, the terminal segment large, orbicular or ovate, entire or nearly so; lateral segments 1-5 pairs, smaller, oblong, entire or toothed; petioles short, auricled at base; upper cauline leaves obovate, clasping, the lower part pinnately-cleft; raceme dense; petals yellow, $4 \mathrm{~mm}$. long, twice as long as the sepals; pods ascending or spreading, at length curved, $2-4 \mathrm{~cm}$. long, beaked by the stout style; pedicels short and stout.

In wet places, not common but clearly native.

\section{LESQUERELLA.}

Low annual or perennial herbs with stellate pubescence; flowers usually yellow; sepals oblong or elliptical, rather short; petals longer, spatulate to oblong-obovate, entire; stamens 6 ; style slender; stigma entire or nearly so; pod a turgid sub-globose silicle with a broad suborbicular partition, 2-celled, each cell 2-16-seeded.

Lesquerella occidentalis Wats. Pcrennial, from a stout caudex; herbage canescent with fine appressed silvery pubescence; stems $10-30 \mathrm{~cm}$. high, erect or ascending; basal leaves oblanceolate, coarsely toothed; cauline spatulate, 
entire; flowers yellow, the petals $8-10 \mathrm{~mm}$. long; pods oval in outline, half as thick as broad, 6-8 $\mathrm{mm}$. long, acutish, finely pubescent.

Stony places mostly on the eastern slope of the Cascade Mountains, Multnomah County, Oregon, Howell; Mount Adams, Washington, Flett.

\section{ALYSSUM.}

Low branching annual herbs; leaves mostly simple; flowers yellow; style slender; pod ovoid or orbicular, compressed; valves convex, nerveless; seeds one or two in each cell.

Alyssum alyssoides (L.) Gouan. Annual, 10-30 cm. high, stellatepubescent throughout, usually branched from the base; leaves entire, spatulate, 1-2 cm. long; flowers in racemes, $5-15 \mathrm{~cm}$. long; petals pale yellow, cuneate, scarcely exceeding the sepals; pods orbicular, margined, notched at the apex, minutely pubescent, $3 \mathrm{~mm}$. broad, on spreading pedicels.

Introduced and becoming common.

\section{DRABA.}

Low annual or perennial herbs; leaves entire or toothed; flowers white or yellow, mainly in racemes; pod oval to oblong or linear, compressed parallel to the partition; valves nearly flat, nerveless or faintly nerved; seeds few to many, in two rows in the cell, wingless.

Perennials.

Midrib of leaves becoming prominent; flowers yellow. D. glacialis.

Midrib of leaves not prominent; flowers white or yellow. Stems scapose; flowers white.

Annuals.

Stems very leafy; flowers yellow.

D. lonchocarpa.

D. aureola.

Flowers white; petals deeply 2-cleft.

Flowers yellow or yellowish; petals emarginate.

Pods $4 \mathrm{~mm}$. long, crowded.

Pods longer, not crowded.

Pods $6-8 \mathrm{~mm}$. long, much shorter than the pedicels.

D. verna.

D. brachycarpa.

Pods $8-15 \mathrm{~mm}$. long, about equalling the pedicels.

D. nemorosa.

D. stenoloba.

Draba glacialis Adams. Perennial with many short clustered leafy branches, the old leaves persistent on the stems; leaves linear, entire, ciliate at base, stellate-pubescent, $5-15 \mathrm{~mm}$. long, rigid in age and with a prominent midrib; scapes 5-15 cm. long; flowers yellow; pods ovate or oblong-ovate, acute, pubescent, $2-8 \mathrm{~mm}$. long, on pedicels a little longer.

On rock cliffs in the mountains.

Draba lonchocarpa Rydb. Perennial, from a branched caudex; leaves all or mostly in basal rosettes, oblanceolate, entire, minutely and densely stellate-canescent, not ciliate, the midrib prominent; scapes very slender, pubescent, $3-8 \mathrm{~cm}$. high; flowers white; pods lanceolate, glabrous, pointed at each end, 8-15 $\mathrm{mm}$. long, on shorter pedicels.

In gravelly or rocky soil in the mountains at about $2000 \mathrm{~m}$. altitude.

Draba aureola Wats. Perennial from a stout root, densely stellate-pubescent throughout, very leafy; basal leaves oblanceolate, entire, obtuse, 8-12 
$\mathrm{mm}$. long; cauline oblong; raceme dense; flowers yellow; calyx glabrous; pods oblong, obtuse, pubescent, $8-10 \mathrm{~mm}$. long.

In loose rocky soil, on Mount Rainier at $3000 \mathrm{~m}$. altitude, an elevation reached by only one other plant, namely Smelowskia ovalis. Known also from the Three Sisters, Oregon, and from Lassen's Peak, California.

Draba verna L. Annual; stems several, leafless, $5-10 \mathrm{~cm}$. high, simple, nearly glabrous; leaves in a rosette, oblong or oval, toothed or entire, obtuse, 4-8 $\mathrm{mm}$. long, pubescent with branched hairs; flowers white, in a loose raceme; petals deeply 2-cleft; pods oblong, glabrous, $4-8 \mathrm{~mm}$. long, shorter than the spreading pedicels.

In sandy soil. A very variable species composed of many forms which on account of close-pollination breed true.

Draba brachycarpa Nutt. Annual, the herbage pubescent; stems simple or branched, $5-20 \mathrm{~cm}$. high, leafy to the inflorescence; leaves ovate to oblong, entire or nearly so, 4-8 mm. long; pods oblong, acutish, glabrous, $4 \mathrm{~mm}$. long, about equalling the pedicels, crowded in a strict raceme.

Coburg, Oregon, Howell.

Draba nemorosa L. Annual, the simple stems $5-40 \mathrm{~cm}$. high, leafy and pubescent below; leaves sessile, oblong or ovate, usually dentate, acutish, 1-2 cm. long, stellate-pubescent; raceme loose, 3-many-flowered; flowers small, $4 \mathrm{~mm}$. broad; petals yellow becoming whitish, notched, a little longer than the villous sepals; pod oblong, acute, appressed-pubescent or glabrous, about $1 \mathrm{~cm}$. long, much shorter than the spreading pedicels.

In sandy soil. Pods usually pubescent. The form with glabrous pods is D. nemorosa leiocarpa Lindbl. (D. lutea Gilib.)

Draba stenoloba Ledeb. Annual, the slender stems $10-40 \mathrm{~cm}$. high, the leaves mostly in a basal rosette; leaves obovate to oblanceolate, mostly acute, more or less pubescent; sepals glabrous or with a few hairs; pods linear, glabrous, $10-15 \mathrm{~mm}$. long, equalling or longer than the pedicels.

Warm exposures, in the mountains.

\section{SUBULARIA. AwLWort.}

Small stemless aquatic glabrous perennials with tufted awlshaped leaves; flowers few, minute, white, on a naked scape 2-8 cm. high; style none; pod ovoid or spherical with a broad partition; valves turgid, 1-nerved; seeds several.

Subularia aquatica L. Submersed in shallow water or on muddy shores; leaves 12-20, unequal, erect, $3-6 \mathrm{~cm}$. long.

Sproat Lake, Vancouver Island, British Columbia, Macoun; Whatcom Lake, Whatcom County, Washington, Suksdorf. Infrequent, but usually abundant where found, sometimes forming extensive colonies like a grecnsward.

\section{COCHLEARIA.}

Maritime fleshy glabrous herbs with lobed or entire alternate leaves; flowers small, white; sepals short and broad, rounded at the apex; petals obovate, cuneate; style slender; stigma simple or nearly so; pod a very turgid globose silicle; seeds 2 -several, in 2 rows.

Cochlearia officinalis L. Succulent herb with decumbent branched stems about $30 \mathrm{~cm}$. long; basal leaves petioled, broadly ovate to orbicular, subcordate, 
somewhat lobed or subentire; upper cauline more deeply lobed or toothed, sessile and auriculate at base; pods globose, smooth or faintly reticulated.

Along the seacoast, Alaska to Oregon. Cape Elizabeth and Port Granville, Washington, A. S. Foster; Oregon, Howell; Vancouver Island, British Columbia, Macoun.

\section{RADICULA.}

Aquatic or marsh herbs; leaves usually lyrately or pinnately parted or toothed, auricled at base; flowers small, yellow or white; style short or slender; pods terete or nearly so; seeds turgid, minute, in two rows in each cell.

Flowers white; leaves pinnately divided.

Flowers yellow; leaves variously margined, mostly

R. nasturtium-aquatica. pinnate.

Pedicels short, 2-4 mm. long; stems diffuse.

Pods curved; leaf-lobes acute.

Pods straight; leaf-lobes obtuse.

Pedicels longer, 6-8 mm. long; stems erect.

Pods 4-8 mm. long.

Pods 8-12 mm. long.

R. curvisiliqua.

R. obtusa.

$R$. palustris.

$R$. pacifica.

Radicula nasturtium-aquatica (L.) Britten \& Rendle. Perennial, aquatic, smooth; stems procumbent, rooting at the lower nodes, $10-30 \mathrm{~cm}$. high; leaves pinnate; leaflets $3-11$, orbicular or oblong, sinuate, or the lower ones sometimes reduced to the terminal leaflet; petals white, 3-4 $\mathrm{mm}$. long; pods linear, 12-20 mm. long, acute at each end, a little longer than the spreading pedicels.

Cultivated under the name of Water Cress, and often escaping.

Radicula curvisiliqua (Hook.) Greene. Annual or biennial, glabrous or slightly pubescent, erect or decumbent, $15-40 \mathrm{~cm}$. high; leaves oblanceolate, sinuate-dentate or pinnately cleft into oblong dentate lobes; flowers small, pale yellow; petals $2 \mathrm{~mm}$. long, exceeding the sepals; pods linear-oblong, 4-16 $\mathrm{mm}$. long; style stout or none.

In dried-up ponds and swales, common and variable.

Radicula obtusa (Nutt.) Greene. Annual or biennial, glabrous or nearly so, branching from the base, spreading; leaves pinnately parted or divided, or the upper often subentire and oblong; pedicels $2-4 \mathrm{~mm}$. long, ascending or spreading; flowers yellow; pods usually long, straight; style very short and thick.

Reported from Vancouver Island, British Columbia, Macoun.

Radicula palustris (L.) Moench. Annual or biennial, glabrous or nearly so, erect, $30-90 \mathrm{~cm}$. high; leaves lanceolate, pinnately cleft or parted, petioled, 5-15 cm. long, the segments toothed; pods 4-8 mm. long, short-cylindric or ovoid, mostly shorter than the pedicels.

Wet places, sometimes in shallow water.

Radicula pacifica (Howell) Greene. Very similar to $R$. palustris; pods larger, 8-12 $\mathrm{mm}$. long, as long as the pedicels.

In wet places. Probably only a subspecies of $R$. palustris.

236. LEPIDIUM. PEPPERGRASS.

Erect or diffuse annual or biennial herbs; leaves pinnatifid, toothed or entire; flowers small, white or greenish, in racemes; 
pod orbicular to obovate, much flattened at right angles to the partition, 2-winged at the summit, each valve with one acute nerve forming a keel; seeds flattened, solitary in each cell.

Cauline leaves clasping at base.

L. draba.

Cauline leaves not clasping at base.

Apex of the pods bidentate, the valves reticulated.

Teeth of pods widely divergent.

Teeth of pods not widely divergent.

L. oxycarpum.

L. strictum.

Apex of the pods merely emarginate, the valves not reticulated.

Petals wanting or very minute; pods puberulent.

Petals present; pods usually glabrous.

Basal leaves pinnately parted, pubescent.

Basal leaves dentate, glabrous.

L. lasiocarpum.

L. menziesii.

L. medium.

Lepidium draba L. Perennials, $20-40 \mathrm{~cm}$. high, the herbage pubescent; leaves oval to oblong, obtuse, denticulate, the upper broadly auricled and clasping at base; racemes short; pods ovate, subcordate at base, tipped with the conspicuous style.

Sparingly introduced from Europe; Victoria, British Columbia, Anderson.

Lepidium oxycarpum T. \& G. Annual, glabrous or nearly so; stems branched from the base, slender, ascending, 10-15 cm. high; leaves narrow, pinnately cleft with a few acute lobes, or entire; raceme loose; petals none; pods glabrous, nearly orbicular, about $3 \mathrm{~mm}$. broad, with the teeth short and widely divergent.

Vancouver Island, British Columbia, Macoun, and California; mostly in saline soil.

Lepidium strictum Rattan. Annual, the herbage finely pubescent; stems branched, erect or ascending, $8-15 \mathrm{~cm}$. high; leaves pinnately cleft into narrow lobes; raceme crowded; petals none; pods ovate, glabrous, $2-2.5 \mathrm{~mm}$. long, the teeth short and subacute, not widely divergent.

In saline soil, Cadboro Bay, Vancouver Island, Macoun; otherwise known only from California and southwestern Oregon.

Lepidium lasiocarpum Nutt. Annual, usually with several decumbent stems; herbage pubescent; lower leaves pinnately parted, the obtuse segments toothed or entire; petals wanting or minute; capsule lenticular, retuse, thinner at apex, minutely pubescent.

Rare, probably only introduced in our limits.

Lepidium menziesii DC. Biennial, erect or sometimes decumbent, much branched above, $30-90 \mathrm{~cm}$. high; stems puberulent; lower leaves pinnately parted, more or less hairy, petioled, the segments toothed or entire; upper leaves incisely dentate to entire; petals present; stamens 2 or 4 ; pods lenticular, retuse, glabrous, about $3 \mathrm{~mm}$. broad, on longer spreading pedicels.

Common on high sea beaches.

Lepidium medium Greene. Much like L. menziesii but root annual; leaves serrate-dentate, seldom lobed, glabrous; stamens usually 6 , sometimes only 2 ; pods glabrous or puberulent.

In sandy soil, common in the interior but only occasional west of the Cascade Mountains.

\section{THLASPI.}

Glabrous annual or perennial herbs; basal leaves entire or toothed; cauline oblong, auricled and clasping; flowers white or 
purplish; pod more or less compressed at right angles to the partition, the valves often winged at the apex; seeds $2-4$ in each cell.

Pods large, winged, deeply notched; annual.

Pods small, scarcely winged or notched; perennial.

T. arvense.

T. alpestre.

Thlaspi arvense L. Penny Cress. Annual, erect, glabrous, simple or branched, 15-40 $\mathrm{cm}$. high; radical leaves oblanceolate, petioled; cauline oblong, obtuse, sagittate and half-clasping; petals white, spatulate, exceeding the sepals; pod orbicular, 8-12 $\mathrm{mm}$. long, broadly winged, deeply notched.

A weed, sparingly introduced.

Thlaspi alpestre L. Perennial, glabrous and green; stems usually several from a branched base, $10-20 \mathrm{~cm}$. high; basal leaves obovate or elliptic, petioled, entire or toothed; cauline oblong, entire, sessile and somewhat auriculate; flowers white; pods obovate, emarginate at apex, $4-8 \mathrm{~mm}$. long.

At high altitudes in the Cascade Mountains.

\section{BURSA.}

Slender and mostly smooth annual herbs; radical leaves tufted; flowers small, white, in racemes; pods cuneate, notched at apex, compressed at right angles to the partition, many-seeded.

Bursa bursa-pastoris (L.) Weber. Shepherd's Purse. Stellate-pubescent below, glabrous above, $30-60 \mathrm{~cm}$. tall, sparingly branched; basal leaves in a rosette, lanceolate or oblanceolate, pinnately-lobed, $2-8 \mathrm{~cm}$. long, dentate or entire; flowers white, about $2 \mathrm{~mm}$. long; pods triangular, cuneate, with a broad shallow notch at the apex.

A common weed.

\section{HUTCHINSIA.}

Low spreading annual with entire or pinnately-lobed leaves; flowers minute, white, in crowded racemes which elongate in fruit; stigma sessile or nearly so; silicle oval, compressed at right angles to the partition, not cuneate, not notched at the apex; each valve conspicuously 1-nerved.

Hutchinsia procumbens (L.) DC. Branched from the base, glabrous or sparsely pubescent, $5-15 \mathrm{~cm}$. high; stems decumbent or ascending; basal leaves pinnately lobed or entire; petioles $1-2 \mathrm{~cm}$. long; cauline leaves spatulate or oblanceolate, sessile, entire or with a few lobes; petals white, about as long as the sepals, $1 \mathrm{~mm}$. long; pods smooth, elliptic, 3-4 mm. long, on slender pedicels.

In moist ground, rare in our limits.

\section{Camelina. False flax.}

Erect annual herbs; leaves entire, toothed or pinnatifid; flowers small, yellowish; style slender; pod obovoid or pearshaped, slightly flattened parallel to the partition, many-seeded. 
Camelina microcarpa Andrz. Stems erect, mostly simple, 30-90 cm. tall, hirsute below, glabrous above; leaves lanceolate, acute, sagittate at base, half-clasping, erect, entire or nearly so, stellate-pubescent; flowers pale yellow; pods obovate, 4-5 $\mathrm{mm}$. wide, 6-8 $\mathrm{mm}$. long, beaked by the persistent style, glabrous, on slender pedicels, $8-18 \mathrm{~mm}$. long.

Sparingly introduced from Europe.

Camelina sativa (L.) Crantz. Very similar to $C$. microcarpa; pods larger, 6-7 $\mathrm{mm}$. broad, 6-8 $\mathrm{mm}$. long, on longer pedicels, $12-30 \mathrm{~mm}$. long.

Sparingly introduced from Europe.

\section{Family 46. DROSERACEAE. SUNDEW FAMILY.}

Small biennial or perennial mostly glandular-pubescent insectivorous herbs, living in bogs; leaves with circinate vernation; flowers regular, hypogynous, 5-merous, with all the parts persistent; anthers versatile; styles 1-5; ovary 1-3-celled; capsule with twice as many styles as there are parietal placentae; seeds numerous.

\section{DROSERA. SUNDEW.}

Low biennial or perennial herbs with a basal tuft of leaves covered with sensitive motile glandular hairs which act as insect traps; flowers usually in a simple 1-sided raceme on a naked scape; stamens 5 ; styles 3 or 5 , each deeply 2 -parted, stigmatic on the inner face near the tip.

Leaf blade nearly orbicular, abruptly narrowed into the petiole.

Leaf blade spatulate-oblanceolate, not abruptly narrowed into the petiole.

D. rotundifolia.

D. anglica.

Drosera rotundifolia $\mathrm{L}$. Leaves in a spreading rosette, the blade orbicular, abruptly narrowed into a much longer hairy petiole; scape slender, $10-30 \mathrm{~cm}$. high, the raceme usually 5-15-flowered; petals oblong, white, $3 \mathrm{~mm}$. long; capsule oblong; seeds narrowly spindle-form.

In sphagnum bogs, common.

Drosera anglica Huds. Leaves nearly erect, linear-spatulate, the naked or slightly hairy petiole scarcely longer than the blade; scape $6-20 \mathrm{~cm}$. high, 1-8-flowered; petals oblanceolate, white, $6 \mathrm{~mm}$. long; capsule oblong; seeds narrowly spindle-shaped.

In bogs in the mountains, rare. Horne Lake, Vancouver Island, Macoun; Mount Adams, Washington, Henderson.

\section{Family 47. CRASSUlaCEAE. Stonecrop Family.}

Succulent or fleshy plants, mostly herbs; stipules none; flowers regular and symmetrical, in cymes or rarely solitary; calyx hypogynous, mostly 4 or 5-parted or lobed; petals of the same number as the calyx-lobes, distinct or slightly united at the base, 
rarely wanting; stamens of the same number or twice as many as the petals; carpels of the same number as the sepals, distinct or united below; ovules numerous; follicles 1-celled; seeds minute; endosperm fleshy.

Flowers solitary axillary; annuals.

Flowers cymose; perennials or biennials.

Petals free to the base.

Petals united below the middle.

242. Tillaea, 183.

243. SEDUM, 183.

244. Gormania, 184.

\section{TILLAEA.}

Small and slender somewhat succulent glabrous annual herbs; leaves opposite, entire; flowers minute, solitary axillary, white; sepals and petals $3-5$, distinct or united at the base; stamens as many as the petals; carpels distinct; styles short-subulate; ovules 1-many.

Tillaea aquatica L. ( $T$. angustifolia Nutt.) Stems branching, rooting at base, $2-5 \mathrm{~cm}$. high; leaves linear, acute, the pairs somewhat connate; flowers mostly solitary, nearly sessile; petals ovate, obtuse, twice as long as the sepals; carpels obtuse; seeds many, oblong-linear.

On muddy river banks, rare.

\section{SEDUM. STONECROP.}

Fleshy mostly glabrous herbs, erect or decumbent; leaves alternate, entire or dentate, fleshy; flowers perfect, in terminal often 1 -sided cymes; calyx 4 or 5 -lobed or parted; petals 4 or 5 , distinct; stamens 8 or 10 , perigynous, the alternate ones usually attached to the petals; carpels 4 or 5 , distinct or united at the base; ovules numerous; follicles few-many-seeded.

Leaves spatulate, very glaucous.

S. spathulifolium.

Leaves not spatulate nor glaucous.

Leaves subglobose.

Leaves lanceolate, broadest at base.

Leaves becoming scarious; carpels divergent.

Leaves not becoming scarious; carpels erect.

S. divergens.

S. douglasii.

S. stenopetalum.

Sedum spathulifolium Hook. Herbage very glaucous; stems decumbent, 10-20 cm. long, curved upward near the tips; leaves broadly spatulate, flat, 15-20 mm. long; flowers pale yellow, nearly sessile, in a rather compact compound cyme; petals lanceolate, acute, $6 \mathrm{~mm}$. long, much longer than the sepals.

On rocks, common.

Sedum divergens Wats. Glabrous and bright green; stems decumbent, 5-10 cm. long; leaves oval in outline, subglobose, nearly as thick as broad, sessile, $7-8 \mathrm{~mm}$. long, mostly in rosettes at the ends of the branches; flowers yellow, in a compact cyme; petals three times as long as the sepals; carpels widely divergent when mature.

In the mountains at moderate elevations.

Sedum douglasii Hook. Stems erect, branched at base, from a stout rootstock, $15-20 \mathrm{~cm}$. high; leaves lanceolate, attenuate at the apex, $6-12 \mathrm{~mm}$. 
long, becoming white-scarious when old; axils of the cauline leaves commonly bearing short deciduous leafy branches by which the plant is propagated; flowers yellow, sessile, in an open cyme; petals lanceolate, acuminate, 5-6 mm. long, longer than the stamens; follicles diverging from their united bases.

On rocks, rather rare west of the Cascade Mountains, but common in the interior. A form occurring at Elk Rock near Portland, Oregon, has solitary terminal flowers, the others being replaced by propagula. This has been described as a distinct species under the name $S$. uniflorum Howell.

Sedum stenopetalum Pursh. Perennial from branched rootstocks, glabrous or minutely puberulent, green; stems erect, $6-15 \mathrm{~cm}$. high; leaves lanceolate. broadest at base, acute, sessile, 4-8 $\mathrm{mm}$. long; flowers bright yellow, nearly sessile, in a close cyme; petals lanceolate, acuminate, twice as long as the sepals; carpels $4 \mathrm{~mm}$. long, divergent only at the tips.

On cliffs in the mountains at moderate altitudes.

\section{GORMANIA.}

Low perennial herbs with horizontal root-stocks; leaves spatulate to obovate, the cauline similar to but smaller than the basal ones; flowers yellow to red, in compound cymes; calyx mostly deeply 5 -lobed, the lobes acute or obtuse; petals 5 , united below the middle, acute to acuminate, spreading above; stamens 10 , epipetalous; carpels many-ovuled, erect or nearly so in fruit.

This genus is very feebly separable from Sedum.

Gormania oregana (Nutt.) Britt. Glabrous, bright green; stems decumbent, 10-20 cm. long; leaves broadly spatulate, scattered rather equally; flowers yellow, becoming pink in age, in a compound cyme; petals linearlanceolate, attenuate-acuminate, somewhat united at base; stamens only half as long as the petals.

On rocks, especially at low altitudes in the mountains.

\section{Family 48. SAXIFRAGACEAE. SAXIfrage Family.}

Herbs or shrubs; leaves alternate or opposite; stipules usually none; flowers perfect or polygamo-dioecious; calyx usually 5lobed, free or adherent to the ovary; petals usually 4 or 5 , perigynous, rarely none; stamens usually definite in number and not more than twice the number of the calyx-lobes; pistil formed by the partial or complete union of 2-5 carpels; placentae axile or parietal; seeds usually numerous; endosperm present; embryo small.

\section{Shrubs.}

Low and spreading or trailing; stamens usually 10 or 12 .

Erect; stamens 5 or many.

Herbs.

Leaves alternate.

Leaves opposite.

Staminodia present; carpels 3 or 4 , united.

Staminodia none; carpels 2, distinct above.
245. Whipplea, 185.

246. Ribes, 185.

247. Philadelphus, 188.

248. Parnassia, 188. 
Placentae axial.

Carpels distinct; leaves coriaceous, without stipules.

Carpels united, at least below; leaves

249. Leptarrhena, 188. mostly not coriaceous.

Stamens 10.

Stamens 5.

Ovary superior.

Ovary not superior.

Rootstocks bearing bulblets; ovary almost wholly inferior.

252. Hemieva, 192.

Rootstocks not bearing bulblets; ovary halfinferior.

Seeds winged; petals persisting.

Seeds wingless; petals promptly deciduous.

Placentae parietal or nearly basal.

Stamens 8 or 10 .

Petals none; stamens 8 .

Petals present; stamens 10 .

Carpels unequal; petals entire. 256. TIARELLA, 193.

Carpels equal; petals laciniate. 257. Tellima, 194.

Stamens 5 or 3 .

Petals pinnatifid.

Petals entire or wanting, at least not pinnatifid.

Stamens 3; calyx tubular.

Stamens 5; calyx campanulate or turbinate.

Inflorescence a raceme.

Inflorescence a panicle.

250. Saxifraga, 189.

251. Bolandra, 191.

254. Therofon, 192.

255. Chrysosplenium, 193.

258. Mitella, 194.

259. Leptaxis, 195.

260. Elmera, 196.

261. Heuchera, 196.

\section{5. "WHIPPLEA.}

Low diffuse shrubs, pubescent with simple hairs; leaves opposite, short-petioled, without stipules; flowers white, in cymose clusters on a naked terminal peduncle; calyx 5-cleft, whitish, the tube adherent to the lower part of the ovary; petals 5 , ovate or oblong, contraçted at base; stamens usually 10 ; styles distinct, subulate; ovary 3 -5-celled, each cell 1 -ovuled; capsule septicidally dehiscent into 3-5 1-seeded parts.

Whipplea modesta Torr. Stems trailing, $20-60 \mathrm{~cm}$. long; leaves oval to ovate, acutish, pubescent, sessile or nearly so, entire or few-toothed, $1-3 \mathrm{~cm}$. long; cymes few-flowered; calyx campanulate, its lobes ovate; petals white, about $3 \mathrm{~mm}$. long, exceeding the calyx-lobes; capsule globose.

Lake Crescent, Clallam County, Washington, Webster, and southwards to California.

246. Ribes. Currant. Gooseberry.

Low sometimes prickly shrubs; leaves alternate, often fascicled, palmately-veined and lobed; flowers small, solitary or 
racemose, mostly terminating short and 1-2-leaved axillary shoots; calyx-tube adherent to the globose ovary and more or less extended beyond it, 5-, rarely 4-cleft, commonly colored or petal-like; petals 4 or 5 , small, perigynous; stamens as many as the petals and alternate with them; styles 2, more or less united; ovary 1-celled; ovules few or numerous; berry globose, fleshy, usually many-seeded.

Stems usually armed with spines and frequently with prickles.

Peduncles with numerous flowers in a raceme; calyx tube saucer-shaped.

Peduncles 1-4-flowered; calyx tube campanulate or cylindric.

Flowers about $2 \mathrm{~cm}$. long, dark purple.

Flowers much smaller, greenish or purplish.

Stems not thorny nor prickly.

Calyx tube cylindric or campanulate.

Flowers red; raceme many-flowered.

Flowers white or greenish; inflorescence few-flowered.

Berries red or orange, glabrous or slightly glandular; leaves resinous-dotted; inflorescence a raceme.

R. lacustre.

Berries black, glandular; leaves viscid-pubescent; inflorescence corymbose.

Calyx tube rotate.

Berries red, smooth.

Berries black, glandular.

Racemes pendent.

Racemes erect or ascending.

Glands sessile.

Glands stalked.

R. lobbii.

$R$. divaricatum.

R. sanguineum.

\section{$R$. cereum.}

$R$. viscosissimum.

R. ciliosum.

R. howellii.

R. bracteosum.

$R$. laxiflorum.

Ribes lacustre (Pers.) Poir. Stout, 1-2 m. high, armed with short 3-5branched spines and very numerous bristly prickles; leaves orbicular, cordate, deeply 5-lobed, incisely dentate, minutely glandular, $2-4 \mathrm{~cm}$. long; racemes loose, drooping; flowers greenish or purplish, slender-petioled; calyx short, saucer-shaped, the obtuse lobes spreading; stamens very short; berries nearly black, bristly glandular.

Moist woods, common.

Ribes lobbii Gray. Stems 1-2 m. high, the branchlets not bristly; subaxillary spines 3 , stout; leaves orbicular, cordate or subcordate at base, about $2 \mathrm{~cm}$. broad, 3-5-cleft, the lobes serrate, somewhat glandular-pubescent; flowers solitary or in threes, drooping, $2 \mathrm{~cm}$. long; calyx purple, campanulate, pubescent, shorter than the narrow spreading or reflexed segments; petals wedge-shaped, obtuse, white; berries globose, $10-12 \mathrm{~mm}$. in diameter, warty-glandular.

Vancouver Island to northern California, but occurring only locally. Ribes divaricatum Dougl. Shrub, 2-4 m. high; branchlets often with
cattered bristles; subaxillary spines $1-3$, stout, mostly dark colored, often deflexed; leaves orbicular, 3-5-lobed, incisely toothed, slightly pubescent beneath, 2-3 cm. broad; flowers 1-4, in small corymbs; calyx pale green or its lobes dark purplish, the tube campanulate, shorter than the spreading oblong lobes; petals wedge-shaped, white, erect, half as long as the calyx lobes; style villous; berries globose, black, 3-5 $\mathrm{mm}$. in diameter. 
In wet open places, common. The fruit of this wild gooseberry is of excellent flavor.

Ribes sanguineum Pursh. Red-flowering Currant. Shrub 2-3 m. high, with a balsamic odor; branchlets glandular; leaves orbicular in outline, cordate, 3-5-lobed, doubly serrate, glabrous above, canescent beneath, 3-10 cm. long, short-petioled; racemes drooping, 3-10 cm. long; bracts erose, about as long as the pedicels; calyx dark to light red, tubular-campanulate, the obovate segments spreading; petals white to pink, erect, spatulate, nearly as long as the calyx segments; berry black, densely glaucous and sparsely hirsute, sweetish but insipid.

Common in open dry woods, very showy when in bloom, the flowers spicyscented.

Ribes cereum Dougl. About $1 \mathrm{~m}$. high, with numerous short branches, $9 / 1 / 20 M^{\dagger}$ the young shoots commonly resinous-dotted and glutinous; shoots and under sides of the leaves puberulent; leaves orbicular, somewhat 3-5-lobed, crenatedentate, rounded or subcordate at base, about $1 \mathrm{~cm}$. long; petioles mostly shorter than the leaves; pedicels very short; racemes short, dense, 3-5-flowered, drooping; calyx white, cylindric, 6-8 $\mathrm{mm}$. long, glandular, the short lobes obtuse; petals orbicular; berry orange-red, insipid.

Common east of the summit of the Cascade Mountains, but very rare on the western slope; Mount Jefferson, Oregon.

Ribes viscosissimum Pursh. Unarmed, about $1 \mathrm{~m}$. high, pubescent throughout and somewhat glandular; leaves cordate-orbicular, obtusely 5-lobed, somewhat doubly dentate, soft-pubescent, especially beneath, 2-5 $\mathrm{cm}$. broad; petioles about as long as the blades, hirsute-glandular; racemes ascending, shorter than the leaves; bracts oblong or obovate, obtuse, conspicuous; flowers whitish or purplish, about $10 \mathrm{~mm}$. long, on short pedicels which become slender and elongate in fruit; calyx-tube campanulate, becoming cylindric, the erect lobes acute, shorter; petals small, white; berry black, rather dry.

Common in mountain woods on the eastern slope of the Cascade Mountains. Reported on the west slope at the head of Skagit River, British Columbia, Macoun.

Ribes ciliosum Howell. Stems prostrate or decumbent, about $1 \mathrm{~m}$. long; leaves orbicular, cordate, $2-5 \mathrm{~cm}$. broad, glabrous above, pubescent on the veins beneath, 3-5-lobed, the lobes acute, serrate, ciliolate; racemes pendent; bracts ovate, half as long as the pedicel; calyx reddish, saucer-shaped, its lobes rounded; petals wedge-shaped, $1 \mathrm{~mm}$. long; berries globose, bright red.

In the Cascade Mountains, rare. The berries are very similar to those of the cúltivated red currant, to which our species is closely related.

Ribes howellii Greene. Stems erect or ascending, 1-2 m. high; leaves orbicular, cordate or truncate at base, 3-5-lobed, the rounded lobes doubly serrate or incised, glabrous above, resinous-dotted beneath, $5-8 \mathrm{~cm}$. broad; petioles about as long as the blades; racemes pendent; bracts linear-lanceolate, equalling the pedicels; calyx green, the tube saucer-shaped, the lobes broad and obtuse; petals spatulate, dark purple; fruit black, glandular-bristly.

Abundant at the limit of trees in the mountains. The berries are not edible.

Ribes bracteosum Dougl. Stems 1-2 m. high; branchlets glabrous; leaves large, 15-20 cm. broad, punctate beneath with resiniferous glands, orbicular in outline, cordate, deeply 5-7-lobed, the lobes acuminate and coarsely doubly serrate; petioles slender; racemes erect, 10-25 cm. long; flowers many, greenish; bracts spatulate, about as long as the pedicels; calyx glabrous, saucer-shaped, the lobes oblong; petals wedge-shaped, obtuse, about $2 \mathrm{~mm}$. long; fruits black, sprinkled with resin dots, unpleasantly flavored. 
Common along streams in woods, often forming dense thickets, the herbage strongly scented on which account the plant is locally known as "Stink Currant." The berries are scarcely eatable.

Ribes laxiflorum Pursh. Stems 1-3 m. long, ascending; branchlets coppercolored, smooth; leaves orbicular, deeply cordate, glabrous, shiny above, 5-8 cm. broad, 5-7-lobed, the lobes acute, doubly serrate or somewhat incised; racemes erect, pubescent; bracts narrow, shorter than the glandular pedicels; calyx saucer-shaped, the lobes orbicular; petals fan-shaped; fruit globose, glandular-bristly, wine-colored.

Near the coast, Alaska to the mouth of the Columbia River.

\section{PHILADELPHUS.}

Shrubs; leaves opposite, petioled, entire or toothed, ovate or oblong, without stipules; flowers large, showy, white, solitary or cymose-clustered; calyx-tube top-shaped, 4- or 5-lobed, adherent to the ovary nearly or quite to its summit; petals 4 or 5 , large, obovate or roundish; stamens 20-40, on the disk; styles 3-5, more or less united; ovary 3-5-celled, inferior; ovules numerous; capsule 3-5-valved; seeds very numerous.

Philadelphus gordonianus Lindl. Syringa. Shrub 2-4 m. high, much branched above; bark pale, flaky; leaves ovate, acute or acuminate, dentate or nearly entire, pubescent on the under surface, $2-5 \mathrm{~cm}$. long; petioles short; panicle 4-10-flowered, the lower bracts leafy; calyx-lobes triangular-ovate, acute or acuminate, less than twice as long as the tube; petals white, oblong, 1.5-2 cm. long; styles united for two-thirds their length; stigmas dilated.

Common in moist open places. The odorous flowers are very showy.

\section{PARNASSIA.}

Glabrous perennial herbs with entire leaves; flower solitary, on a long scape-like stem which often bears a single sessile leaf; sepals 5, slightly united, persistent; petals 5, white with greenish or yellowish veins and a gland-bearing scale (really a cluster of sterile stamens or staminodia) at the base of each; stamens 5 , alternate with the petals, persistent; stigmas 4 , sessile; ovary 1-celled, with 4 parietal placentae; capsule 4 -valved, separating between the placentae.

Parnassia fimbriata Koenig. Leaves cordate to reniform, 3-4 cm. broad, slender petioled; stems $20-40 \mathrm{~cm}$. high, bearing a single cordate sessile leaf above the middle; sepals oblong; petals oblong, unguiculate, fringed near the base, white, 8-12 mm. long; scales fleshy, keeled, each usually bearing 5-9 teeth.

Common in bogs in the mountains.

\section{LEPTARRHENA.}

Perennial herbs with alternate coriaceous leaves; flowers in panicles; sepals 5 , erect, slightly adherent to the ovary; petals 5 , white, narrow, persistent; stamens 10 ; carpels 2 , united only at the base; follicles erect, slightly spreading at the tips. 
Leptarrhena amplexifolia (Sternb.) Ser. Rootstock stout, covered with the old brownish leaf-bases; basal leaves oblong to obovate, serrate above the middle, coriaceous, glabrous, green and shining above, pale beneath, 3-12 cm. long; petiole stout and broad; stems $20-40 \mathrm{~cm}$. high, bearing 1 or 2 small leaves; inflorescence paniculate, glandular; sepals ovate; petals white, narrow, about $2 \mathrm{~mm}$. long; carpels $8-10 \mathrm{~mm}$. long, not diverging, usually purple.

Common along alpine rivulets at about $1700 \mathrm{~m}$. altitude in Washington and northward to Alaska.

\section{SAXIFRAGA. SAXIFRAGE.}

Chiefly perennial herbs; stem short or none; radical leaves tufted; cauline mostly alternate; flowers perfect, solitary or in cymes or cymose panicles; calyx 5-lobed, free or adhering to the base of the ovary; petals 5, entire, perigynous; stamens 10 , perigynous; carpels 2, nearly distinct or united into a 2-celled ovary; placentae axile; styles distinct; capsules 2-beaked, 2celled, sometimes forming two almost separate follicles.

By some botanists divided into ten or more genera.

Stems producing perennial branches, these densely beset with small leaves.

Leaves coriaceous and evergreen, entire.

Filaments clavate; leaves spatulate, obtuse, not ciliate.

Filaments subulate; leaves lanceolate, ciliate.

Leaves not coriaceous, thin, 3-5-lobed or cleft.

Calyx united only at base; leaves cleft.

Calyx united to the middle; leaves lobed.

Stems not producing perennial leafy branches.

Calyx campanulate; stems leafy.

Leaves mostly 5-lobed; sepals obtuse.

Leaves entire or 3-toothed; sepals acute.

Calyx rotate; leaves all or mostly basal.

Leaves serrate or coarsely dentate.

Petals dissimilar; leaves spatulate, serrate, shortpetioled.

Petals similar; leaves cordate or reniform, coarsely toothed, long-petioled.

Caudex bulbous; herbage somewhat glandular; leaves usually doubly dentate.

Caudex not bulbous; leaves glabrous, simply dentate.

Petals orbicular, clawed.

Petals elliptic, not clawed.

S. tolmiei.

S. bronchialis.

S. cespitosa.

S. adscendens.

S. debilis.

S. nuttallii.

S. bongardi.

S. mertensiana.

S. odontoloma.

S. nelsoniana.

Leaves entire or merely crenate, all basal.

Leaves ovate or obiong, petioled, usually coarsely crenate.

Filaments subulate.

Filaments clavate.

S. rufidula.

S. marshallii.

Leaves entire or nearly so, oblong-spatulate to ovate.

Stems 30-60 cm. tall; flowers 7-9 mm. broad; leaves without petioles.

S. oregana.

Stems $10-30 \mathrm{~cm}$. high; flowers $6-8 \mathrm{~mm}$. broad; leaves more or less distinctly petioled.

S. integrifolia. 
\& / 20 Saxifraga tolmiei T. \& G. Densely tufted, the leafy stems short and branched, nearly prostrate; leaves glabrous, crowded, succulent, spatulate, 6-10 $\mathrm{mm}$. long, the margins entire and revolute; peduncles erect, scape-like, 5-10 cm. high, glandular, 1-6-flowered; sepals ovate, obtuse; petals oblong, unguiculate, white, twice as long as the sepals; filaments dilated; carpels often 3 or 4 , united only at base, $8-10 \mathrm{~mm}$. long.

Abundant in the mountains along rivulets at about $2000 \mathrm{~m}$. altitude. First collected by Tolmie, probably on Mount Rainier.

Saxifraga bronchialis austromontana (Wiegand) Piper. Stems tufted, densely leafy, erect or ascending, 10-20 cm. high; leaves coriaceous, subulatelanceolate, 5-10 cm. high; flowers cymose; sepals ovate, obtuse; petals white with a few yellow spots, oblong, 5-6 $\mathrm{mm}$. long.

\& Common in the mountains on rock cliffs at 1500-2000 m. altitude.

Saxifraga bronchialis vespertina (Small) Rosendahl. Differs from $S$. bronchialis austromontana in having the leaves oblong-spatulate, obtuse or obtusish, and the cymes larger and looser.

On rock cliffs at low altitudes.

Saxifraga cespitosa L. Densely tufted, glandular-pubescent, 5-15 cm. high; leaves crowded, spatulate, 6-20 mm. long, mostly 3-lobed or 3-cleft, with linear obtuse lobes; peduncles leafy-bracted, glandular, 1-6-flowered; sepals ovate, obtuse; petals white, oblong, often retuse, 5-6 $\mathrm{mm}$. long.

Rocky slopes and cliffs. Two forms occur in our limits, one high alpine, densely cespitose, the leaves with short obtuse lobes and obscure veins; the other from cliffs along the Columbia River and the San Juan Islands, with thinner prominently veined leaves and a taller looser habit. The latter approaches closely $S$. cespitosa laxa Koch. The former is scarcely matched in European material. This has recently been proposed as a new species by Small under the name Muscaria emarginata, the type being Elmer No. 2649 collected in the Olympic Mountains. This plant is, however, much nearer to true $S$. cespitosa than is the thin-leaved form.

Saxifraga adscendens L. Glandular-pubescent, $3-10 \mathrm{~cm}$. high; leaves mostly basal, cuneate to spatulate, mostly 3 -toothed, ciliate, $5-10 \mathrm{~mm}$. long; flowers few, in a compact cyme; sepals ovate, glandular; petals white, cuneateoblong, clawed, 3 -nerved, $3 \mathrm{~mm}$. long. Flett.

On rocks in the mountains, known in our limits only from Mount Baker,

Saxifraga debilis Engelm. Loosely tufted, somewhat glandular-pubescent; stems $3-10 \mathrm{~cm}$. high, ascending; basal leaves roundish, thin, crenately lobed, 5-15 $\mathrm{mm}$. long, petioled, the cauline few-lobed or entire; sepals ovate, obtuse; petals white, oblong, clawed, 3-7 $\mathrm{mm}$. long.

In rock crevices in the mountains. In our limits known only from Mount Rainier, Allen.

Saxifraga nuttallii Small. (S. elegans Nutt.) Glabrous, 5-30 cm. high; stems slender, branched, leafy; leaves oval to ovate, entire or 3-toothed at apex, 4-10 $\mathrm{mm}$. long, the lower ones petiolate; flowers white, on slender pedicels; sepals triangular, acute or acuminate; petals oblong, obtuse, 4-5 mm. long; follicles united below, diverging above.

On wet banks and cliffs, western Oregon; rare and local.

Saxifraga bongardi Presl. Pubescent and somewhat glandular; stems $10-30 \mathrm{~cm}$. high; leaves mostly in a basal rosette, oblanceolate or spatulate, toothed above the middle, $2-6 \mathrm{~cm}$. long, the petiole broad and short; inflorescence loosely paniculate; flowers white, some of them often replaced by leafy bulblets; sepals ovate, reflexed; petals lanceolate, clawed, unequal, white with two yellowish spots at base, $4-6 \mathrm{~mm}$. long.

Common along alpine rills. 
Saxifraga mertensiana Bong. Leaves nearly all basal, the blades orbicular-reniform, incisely many lobed, the lobes mostly 3-toothed at apex; stems $10-30 \mathrm{~cm}$. high; panicle loose, the branches flowering at the tips and usually bearing bulblets below; sepals reflexed; petals white, oblong or obovate, short-clawed; filaments broadest at top.

On moist cliffs, especially in the mountains.

Saxifraga odontoloma Piper. Glabrous below the inflorescence; leaves all basal, reniform-orbicular, coarsely and evenly dentate, $2-8 \mathrm{~cm}$. broad; petioles 2-3 times as long as the blade; scapes $10-40 \mathrm{~cm}$. high; flowers white, in a loose panicle; calyx lobes oval, obtuse, reflexed, $2 \mathrm{~mm}$. long; petals orbicular, unguiculate, longer than the calyx; filaments spatulate; carpels 7-8 $\mathrm{mm}$. long, becoming divaricate.

Common along streams in the mountains. Formerly confused with the European S. punctata L.

Saxifraga nelsoniana D. Don. Very similar to S. odontoloma; petals oblong to ovate, unguiculate at base, $3-4.5 \mathrm{~mm}$. long.

Along mountain rivulets at $1500-2000 \mathrm{~m}$. altitude, Alaska to Washington. Except for the form of the petals it is scarcely distinguishable from $S$. odontoloma.

Saxifraga rufidula (Small) Piper n. comb. (Micranthes rufidula Small.) Leaves in a basal rosette, thickish, ovate to oval, crenate, bright green and nearly glabrous above, densely red-tomentose beneath at least when young, 1-4 cm. long, short-petioled; scapes 5-10 cm. high, pubescent; cyme fewflowered; sepals ovate, obtuse; petals white, $4-5 \mathrm{~mm}$. long, nearly orbicular, clawed; filaments subulate.

In rock crevices mostly in the mountains.

Saxifraga marshallii Greene. Very similar to $S$. rufidula, but the leaves larger, 4-9 cm. long, not so thick and usually less pubescent; filaments clavate or spatulate.

Rock crevices in the mountains at about $2000 \mathrm{~m}$. altitude.

Saxifraga oregana Howell. Leaves spreading in a basal rosette, oblong to oblanceolate, obscurely denticulate, obtuse, nearly glabrous, $5-20 \mathrm{~cm}$. long; scapes stout, erect, glandular, $30-90 \mathrm{~cm}$. tall; inflorescence paniculate, usually pyramidal, rather dense; sepals ovate, obtuse, at length reflexed; petals white, oblong to oval, short-clawed, $4 \mathrm{~mm}$. long; filaments subulate.

In marshes, Washington to California; rather local.

Saxifraga integrifolia Hook. Leaves all basal in a rosette, oblong to ovate, entire or obscurely denticulate, viscidly-pubescent or glabrate, 4-8 cm. long; scapes glandular, erect, $15-40 \mathrm{~cm}$. high; inflorescence paniculate; sepals ovate, becoming reflexed; petals white, obovate, $2-3 \mathrm{~mm}$. long; filaments subulate,

Prairies, rare. First found near the mouth of the Columbia River by Scouler.

\section{BOLANDRA.}

Perennial herbs with creeping rootstocks; leaves alternate; flowers in loose few-flowered panicles; calyx broadly campanulate, 5-lobed, the tube free from the ovary; petals 5 , on the throat of the calyx, small, subulate, persistent, recurved; stamens 5 , short, alternate with the petals; ovary enclosed by the dilated calyx, ovate with a broad 2-celled base, deeply cleft above into two tapering horns, each tipped by a truncate nearly sessile stigma; capsule membranaceous. 
Bolandra oregana Wats. Flowering stems $10-40 \mathrm{~cm}$. high, the inflorescence glandular-pubescent; leaves reniform, angularly lobed, dentate, glabrous, 2-6 cm. broad; calyx large, campanulate, green or purple, the tube $5 \mathrm{~mm}$. long, the lanceolate lobes shorter; petals purple, lanceolate-attenuate, about $1 \mathrm{~cm}$. long; carpèls scarcely diverging, conical, $1 \mathrm{~cm}$. long.

On wet cliffs in the gorge of the Columbia River and at the falls of the Willamette, Oregon. The plant bears bulbils near the base.

\section{HEMIEVA.}

Glandular-puberulent perennial herbs with short bulbiferous rootstocks; basal leaves ternately divided; cauline leaves with more or less developed stipules; flowers in a cyme; calyx-tube campanulate, adherent to the lower half of the ovary; sepals 5 , triangular-lanceolate; petals 5 , obovate; stamens 5 , opposite the sepals, erect, on the outer margin of the disk; styles distinct; ovary 2 -celled, with axile placentae.

Hemieva ranunculifolia (Hook.) Raf. Glandular-pubescent; stems 10-30 $\mathrm{cm}$. high; basal leaves long-petioled, reniform, 3-parted, the segments cuneate and incisely 3 - or 4-lobed; middle cauline leaves similar but the petiole short and broad; uppermost leaves sessile, 3-lobed, passing into the oblong bracts; flowers white, in a compact cyme; calyx campanulate, its ovate lobes as long; petals obovate, $6-7 \mathrm{~mm}$. long.

In the Cascade Mountains in rocky places at about $1700 \mathrm{~m}$. altitude. Bulblets are produced in the axils of some of the leaves.

\section{SULLIVANTIA.}

Slender acaulescent perennial herbs with small_rootstocks and scape-like stems; leaves alternate, all but one basal, reniform to orbicular in outline, shallowly lobed and coarsely toothed, cordate, long-petioled; flowers in panicled cymes; calyx-tube campanulate, longer than the calyx; sepals 5 , erect; corolla whitish, regular, of 5 persistent clawed petals; stamens 5 ; ovary half-inferior; follicles erect, enclosed in the calyx-tube.

Sullivantia oregana Wats. Glandular-pubescent above; stems $10-20 \mathrm{~cm}$. high; leaves orbicular, cordate, obscurely lobed, incisely toothed, $2-5 \mathrm{~cm}$. broad, the slender petioles dilated at base; calyx campanulate with ovate lobes; petals obovate, unguiculate, white, $1.5 \mathrm{~mm}$. long; carpels thin, $4 \mathrm{~mm}$. long.

On wet cliffs; Multnomah Falls and Elk Rock, Oregon.

\section{THEROFON.}

Glandular-pubescent perennial herbs with scaly rootstocks; leaves reniform, cleft or lobed and dentate or crenate; stipules foliaceous or bristle-like; flowers perfect, in panicles on leafy lateral shoots; calyx-tube campanulate, urn-shaped or turbinate, adnate to the lower half of the ovary; sepals 5, lanceolate or ovate-lanceolate; petals 5 , white, obovate or spatulate; stamens 5 , opposite the sepals; styles 2 , distinct, in fruit forming 2 diver- 
gent beaks; ovary and capsule usually 2-celled with axile placentae; seeds numerous.

Stipules scarious or foliaceous.

Stipules represented by bristles.

T. intermedium.

T. elatum.

Therofon intermedium (Piper) Heller. Sparsely pubescent, glandular in the inflorescence; stems rather stout, $40-50 \mathrm{~cm}$. high, few-leaved; basal leaves orbicular, cuneate at base, subreniform with a broad sinus, 5-7-cleft, the lobes incisely toothed, 5-9 cm. broad; cauline similar but smaller and with stipules; peduncles axillary, 6-12-flowered; calyx campanulate, its lobes triangular; petals obovate, white, $4-5 \mathrm{~mm}$. long.

Chehalis County, Washington, Lamb. Very closely allied to T. majus (Gray) Wheelock which occurs in Idaho, southern Oregon and California.

Therofon elatum (Nutt.) Greene. Sparsely hirsute with reddish hairs; stems slender, 40-70 $\mathrm{cm}$. high, few-leaved; basal leaves reniform cordate, 5-9-1obed, incisely serrate, slender-petioled, $2-5 \mathrm{~cm}$. broad; cauline similar but smaller; inflorescence a long loose panicle; calyx deeply campanulate, its lobes acute; petals spatulate-oblong, white, 4-6 mm. long.

Rocky banks of streams, Vancouver Island to California.

\section{CHRYSOSPLENIUM.}

Low and small glabrous herbs with tender succulent leaves; flowers small, solitary or in leafy cymes; calyx-lobes 4 or 5, yellow within; stamens 8 or 10, very short, inserted on a conspicuous disk; styles 2 ; capsule obcordate or 2-lobed, flattened, very short, 1-celled with 2 parietal placentae, 2-valved at the top, many-seeded.

Chrysosplenium scouleri (Hook.) Rose. (C. glechomaefolium Nutt.) Perennial, glabrous; stems creeping or ascending, 5-15 cm. long, rooting at the joints; flowering branches ascending, $5-10 \mathrm{~cm}$. high; leaves opposite, or those of the flowering stems alternate, orbicular, crenate, 5-20 mm. broad, nearly sessile; flowers solitary, axillary; sepals $4 \mathrm{~mm}$. long, obtuse; stamens 8 .

In muddy places in the mountains at low altitudes.

\section{TIARELLA.}

Slender perennial herbs; leaves palmately lobed, sometimes with small stipules; flowers small, white, in a terminal raceme or panicle; calyx-tube campanulate, 5-parted, nearly free from the ovary; petals 5 , entire, small, short clawed; stamens 10 ; filaments long and slender; styles 2; ovary 1-celled, 2-horned; placentae parietal, becoming almost basal in fruit; ovules numerous; capsule 1 -celled, 2 -valved, the valves usually unequal; seeds usually few.

Leaves merely lobed.

T. unifoliata.

Leaves trifoliolate.

Leaflets coarsely dentate.

Leaflets deeply lobed or cleft.

T. trifoliata.

T. laciniata.

Tiarella unifoliata Hook. Pubescent throughout or nearly glabrous; stems simple, $15-40 \mathrm{~cm}$. high, erect or ascending; radical leaves ovate or 
orbicular, cordate, long-petioled, 3-7-lobed, the lobes crenate-dentate; cauline 1-3, similar but smaller, short-petioled; panicle narrow, loose, 5-15 cm. long; flowers white; petals small, thread-like.

Common in woods at low altitudes in the mountains.

Tiarella trifoliata L. Sparsely hirsute, the inflorescence glandular; stems slender, erect or áscending, 15-40 cm. high; basal leaves long-petioled, trifoliolate, the middle leaflet cuneate-obovate, 3 -lobed and toothed; lateral leaflets oblique; cauline leaves similar, smaller, short-petioled; panicle narrow; sepals oblong, acute; petals filiform, white, twice as long as the sepals; carpels unequal, membranaceous, the larger 6-7 mm. long.

ICommon in moist woods.

Tiarella laciniata Hook. Similar in size and habit to $T$. trifoliata; leaves trifoliolate, the middle leaflet 3-cleft, the segments deeply incised; lateral leaflets oblique, 2-cleft, the segments incised.

A rare species, known from Vancouver Island, British Columbia, Mount Constitution and Skamania County, Washington.

\section{TELLIMA.}

Perennial herbs; stem simple or branched at the base; leaves few, round-cordate, toothed or palmately-divided, chiefly alternate; petioles with stipule-like dilations at the base; flowers in a single terminal raceme; calyx 5-lobed, campanulate or turbinate, the base adhering to the base or lower half of the ovary; petals 5 , white, whitish or pink, on the throat or in the sinuses of the calyx, cleft or lobed; stamens 10, short, included; styles 2 or 3 , very short; ovary short, 1-celled, with 2 or 3 parietal placentae; capsule conical, slightly 3 -beaked; seeds very numerous.

Calyx campanulate; petals sessile, pinnately parted; plant not producing bulblets.

Calyx obconic; petals clawed, palmately cleft; plant producing bulblets.

T. grandiflora.

Tellima grandiflora (Pursh) Dougl. Hirsutely pubescent, the inflorescence glandular; stems erect, $30-60 \mathrm{~cm}$. high, bearing 2 or 3 nearly sessile smaller leaves; basal leaves cordate-orbicular, shallowly 3-9-lobed, dentate with broad teeth, 5-10 cm. broad, the hairy petioles 10-20 cm. long; raceme somewhat one-sided; calyx campanulate, $8 \mathrm{~mm}$. long, the lobes triangular; petals pinnately divided into filiform segments, greenish at first, gradually changing to bright red.

Common in moist woods. $T$. odorata Howell and T. breviflora Rydberg, each based mainly on slight calyx characters, are scarcely distinct.

Tellima parviflora Hook. Perennial, propagating by bulblets; herbage rough-pubescent; stems slender, $15-30 \mathrm{~cm}$. high; leaves palmately $3-5$-parted; segments cuneate, 3 -cleft, the lobes sometimes again cleft; pedicels erect, mostly as long as or longer than the calyx; calyx 4-6 mm. long, obconic or clubshaped; petals pink, deeply 3-cleft; ovary half-inferior.

In gravelly or rocky soil in open places. Bulblets are sometimes formed in the inflorescence.

258. MITELLA. MitrEwORT.

Low slender perennial herbs; leaves simple, mostly radical, long-petioled, ovate or orbicular; cauline rarely few, usually 
none; flowers small, white or greenish, in a simple raceme; calyx short, the broad tube 5-lobed, adherent to the base of the ovary and dilated beyond it; petals 5, slender, pinnatifid or 3-cleft into thread-like lobes; stamens 10 or 5 , very short; styles 2 , short; ovary globose, 1-celled, with 2 parietal almost basal placentae, partly superior; capsule globular or depressed, hardly at all lobed; seeds several to each placenta.

Stems bearing 1-3 leaves.

Stems leafless.

Petals mostly 3-cleft at apex.

Petals pinnately 3-5-parted.

Stamens opposite the petals.

Stamens alternate with the petals.

Leaves broadly reniform.

Leaves oblong-cordate.

M. caulescens.

M. trifida.

M. pentandra.

M. breweri.

M. ovalis.

Mitella caulescens Nutt. Stems slender, $25-40 \mathrm{~cm}$. high, bearing 1-3 petioled alternate leaves; basal leaves broadly ovate, cordate, 5-7-lobed, crenate-dentate, sparsely hairy; flowers greenish, in a loose raceme; petals pinnately cleft into $7-9$ filiform lobes; plants producing runners in summer.

In moist woods, not common.

Mitella trifida Graham. (Ozomelis pacifica Rydb.) Leaves all basal, their petioles hairy, slender, 5-7 cm. long, their blades reniform, obscurely 7-9lobed, crenate-dentate, sparsely pubescent, $2-4 \mathrm{~cm}$. broad; scapes $15-30 \mathrm{~cm}$. high; raceme often 1-sided; calyx campanulate; petals cuneate, deeply 3 -cleft.

In the mountains at about $2000 \mathrm{~m}$. altitude, rare.

Mitella pentandra Hook. Scapes $10-30 \mathrm{~cm}$. high, puberulent; leaves all basal, broadly cordate, coarsely crenate, sparsely pubescent, petioled; raceme loose; calyx saucer-shaped, the lobes short and obtuse; petals pinnately divided into 7-9 filiform lobes.

In moist woods in the mountains.

Mitella breweri Gray. Rootstock horizontal; leaves all basal, few, the slender petioles sparsely hairy, the blades reniform-orbicular, obscurely 3-5lobed, crenate-serrate, somewhat shiny above, nearly glabrous, $3-8 \mathrm{~cm}$. wide; scapes about as long as the leaves; calyx saucer-shaped, $3-4 \mathrm{~mm}$. in diameter; petals greenish, pinnately $3-5$-parted into filiform segments.

Common in the mountains at about the limit of trees.

Mitella ovalis Greene. ( $M$. hallii Howell.) Rootstock short, creeping; leaves all basal, their blades oval, cordate or reniform, obscurely 5-9-lobed, crenate-dentate, sparsely hirsute, $2-4 \mathrm{~cm}$. long, on slender hairy petioles 4-10 $\mathrm{cm}$. long; scapes exceeding the leaves; calyx saucer-shaped, $2-3 \mathrm{~mm}$. broad; petals pinnate with 3-5 filiform segments.

In moist ground near the coast, Vancouver Island to California.

\section{LEPTAXIS.}

Perennial herbs with scaly rootstocks and lateral leafy flowering branches; stipules membranaceous; calyx-tube funnelform, free from the ovary; sepals 5, ascending; petals 4, subulate, persistent; stamens 3 , opposite the upper 3 sepals; ovary 1-celled, many-seeded, with parietal placentae, attenuate and slightly stipitate at the base, each carpel long beaked. 
Leptaxis menziesii (Pursh) Raf. Sparsely hirsute throughout; stems clustered, 40-60 cm. high, simple, erect, 3-5-leaved; basal leaves ovate, cordate, acute, obscurely 5-7-lobed, serrate-dentate, 5-15 cm. long, slenderpetioled; cauline leaves smaller, shorter-petioled; racemes $10-30 \mathrm{~cm}$. long; pedicels shorter than the flowers; calyx cylindric, dark purple, the lobes unequal; petals filiform, twice as long as the calyx lobes; stamens exserted.

Common in rich woods; the plant propagates itself vegetatively by means of an adventitious bud formed at the tip of the petiole on many of the leaves.

\section{ELMERA.}

Low glandular-pubescent perennial herb with a thick scaly rootstock and lateral leafy flowering branches; cauline leaves with conspicuous membranous stipules; inflorescence racemose; calyx-tube deeply campanulate, adnate to the lower half of the ovary; sepals 5, ovate, erect; petals 5, spatulate, erect, 3-5-cleft at the apex or entire; stamens 5, opposite the sepals; ovary 1-celled, many-ovuled, with 2 parietal placentae.

Elmera racemosa (Wats.) Rydb. (Heuchera racemosa Wats.) Somewhat pubescent and the inflorescence glandular; basal leaves reniform-cordate, obscurely lobed, crenate, $2-4 \mathrm{~cm}$. broad, long-petioled; stems $10-40 \mathrm{~cm}$. high, bearing 1-3 small leaves; flowers white; calyx $4 \mathrm{~mm}$. long, campanulate, its lobes ovate; petals spatulate, entire or somewhat incised, slightly longer than the calyx-lobes.

Rock cliffs or rock talus in the mountains at $1500-3000 \mathrm{~m}$. altitude. Most abundant in the Olympic Mountains. Known only from Washington.

\section{HEUCHERA. Alum Root.}

Perennial herbs; leaves mostly basal, long-petioled, rounded, mostly cordate; cauline, if any, alternate; petioles with dilated margins or adherent stipules; flowers greenish or purple, in clusters which form a long narrow panicle; calyx tube campanulate, 5-lobed, coherent with the lower half of the ovary; lobes sometimes unequal; petals 5 , small, entire, sometimes minute or wanting, or early deciduous; stamens 5 ; styles 2 , slender; ovary 1 -celled, with 2 parietal placentae; capsule 1 -celled, more or less 2-beaked; seeds numerous.

Stamens exserted; flowers in loose panicles.

Leaf lobes triangular, acute; herbage glabrous. $\quad H$. glabra.

Leaf lobes rounded; herbage pubescent, at least the under leaf surface.

Stamens included; flowers in a spike or spike-like panicle.

Pubescence villous or hirsute.

Pubescence glandular.

H. micrantha.

Heuchera glabra Willd. Glabrous; stems erect or curved, 30-60 cm. high, bearing 1-3 leaves; basal leaves cordate-orbicular, 5-7-lobed, doubly serrate, thin, shining above, 4-10 cm. broad, slender-petioled; cauline similar, shortpetioled; panicles loose; calyx turbinate, puberulent, the oblong obtuse lobes as long as the tube; petals white, ovate, clawed, 2-3 $\mathrm{mm}$. long.

Rocky cliffs and slopes in the mountains, Alaska to Oregon. 
Heuchera micrantha Dougl. More or less villous; stems erect, $30-60 \mathrm{~cm}$. high, bearing 1-3 leaves or scapiform; basal leaves cordate-orbicular, obtusely lobed, crenate with cuspidate teeth, usually pubescent beneath, ciliate, 2-6 $\mathrm{cm}$. broad, the slender petioles usually pilose with reddish hairs; panicle loose, glandular-puberulent; calyx turbinate, the ovate lobes of equal length; petals white, oblanceolate, clawed, becoming twisted.

Common on rocky cliffs. The less pubescent or nearly glabrous form is considered by some botanists distinct under the name $H$. nuttallii Rydb.

Heuchera chlorantha Piper. Tufted from a branching caudex; leaves all basal, orbicular to reniform, cordate, 7-9-lobed, the lobes broadly rounded and dentate, glabrous except on the veins beneath; petioles slender, sparsely pilose with brownish hairs; scapes $50-100 \mathrm{~cm}$. high, villous; inflorescence a dense narrow panicle $5-10 \mathrm{~cm}$. long; bracts ovate to lanceolate, fimbriate, the lower ones 3-cleft; calyx greenish, turbinate-campanulate, the lobes oblong; petals minute or wanting.

In damp meadows, not rare. This species has generally been confused with $H$. cylindrica Dougl. of the interior.

Heuchera ovalifolia Nutt. Densely and minutely glandular-pubescent throughout; leaves all basal, broadly oval or ovate, slightly cordate, shallowly 5-lobed, crenate-dentate; stems erect, $10-30 \mathrm{~cm}$. high; inflorescence dense, 2-6 $\mathrm{cm}$. long; calyx greenish, 6-7 $\mathrm{mm}$. long.

In rocky places, mostly on the east slope of the Cascade Mountains and in the interior, but known from Mount Hood, Oregon.

\section{Family 49. ROSACEAE. Rose Family.}

Herbs shrubs or trees; leaves alternate, simple or compound, usually with evident stipules which are often quickly deciduous; flowers regular, mostly perfect, rarely polygamo-dioecious; calyx of 5 , rarely 3-8, sepals, united at the base, often surrounded by a row of bractlets; calyx-tube lined by the disk; petals as many as the sepals, rarely wanting, on the edge of the calyx-tube; stamens usually numerous or few and coherent with the calyxtube; carpels 1-many, distinct and free, or few and coherent with the calyx-tube into a 2 -several-celled inferior ovary; seeds few or solitary; endosperm none, scanty or rarely copious.

The so-called "calyx-tube" in this family is partly or wholly a hollowed-out receptacle, sometimes called the hypanthium.

Pistil one.

Fruit a drupe; petals present, white.

Flowers perfect; carpel one.

Flowers dioecious; carpels 5.

Fruit an akene; petals none, or if present, yellow.

Petals 5, yellow; calyx prickly.

262. Prunus, 199.

263. Osmaronia, 199.

Petals none; calyx not prickly.

Leaves palmately-lobed; flowers axillary.

Leaves pinnately-lobed; flowers in a spike.

274. Agrimonia, 205.

275. Alchemilla, 206.

276. SANGUisorba, 206. 
Pistils more than one.

Pistils 2-5, united with each other and with the lower part of the receptacle and calyx-tube with which in fruit they form a pome.

Flowers in racemes; locules of mature pomes 10.

Flowers in corymbs or cymes; locules 1-5.

Carpels stony in fruit.

Carpels papery in fruit.

Pistils few or many, free.

Fruit of few 2-several-seeded follicles.

Leaves palmately-lobed.

Leaves not palmately-lobed.

Stamens united at base; flowers in racemes.

Stamens not united at base; flowers in panicles or corymbs.

Stamineal disk adherent, entire; ovules 2.

Stamineal disk free at the edge, not entire; ovules 5 or more. Shrubs with simple leaves; flowers perfect.

Herbs with compound leaves; flowers dioecious.

Fruit of numerous 1-2-seeded akenes or drupelets.

Fruit of drupelets, usually united.

Fruit of akenes.

Receptacle urn-shaped or bell-shaped, enclosing the akenes.

Receptacle fleshy; akenes numerous.

Receptacle dry; akenes 1-4.

264. Amelanchier, 200.

265. Crataegus, 200.

266. Pyrus, 200.

267. Opulaster, 201.

268. Lutkea, 201.

269. Holodiscus, 202.

270. Spiraea, 202.

271. Aruncus, 203.

Petals 5, yellow; calyx prickly. 274. Agrimonia, 205.

Petals none; calyx not prickly.

Leaves palmately-lobed; flowers axillary.

Leaves pinnately-lobed; flowers in a spike.

Receptacle convex, flat or but slightly concave.

Styles persistent, mostly plumose or geniculate.

Calyx-lobes and petals 8 or 9. 277. Dryas, 206.

Calyx-lobes and petals 5 .

Styles jointed, the upper part deciduous.

Styles not jointed, plumose or naked.

Styles deciduous, naked.

275. Alchemilla, 206.

276. Sanguisorba, 206.

272. Rubus, 203.

273. Rosa, 204.

\author{
77. Dryas, 206.
}

278. Geum, 207.

279. Sieversia, 207.

Styles terminal.

Styles lateral.

Shrubs; carpels hairy.

280. Potentilla, 208.

Herbs; carpels glabrous.

Stamens 5; carpels 10 -

281. DASIPHORA, 210.

282. Sibbaldia, 210. 
ROSACEAE.

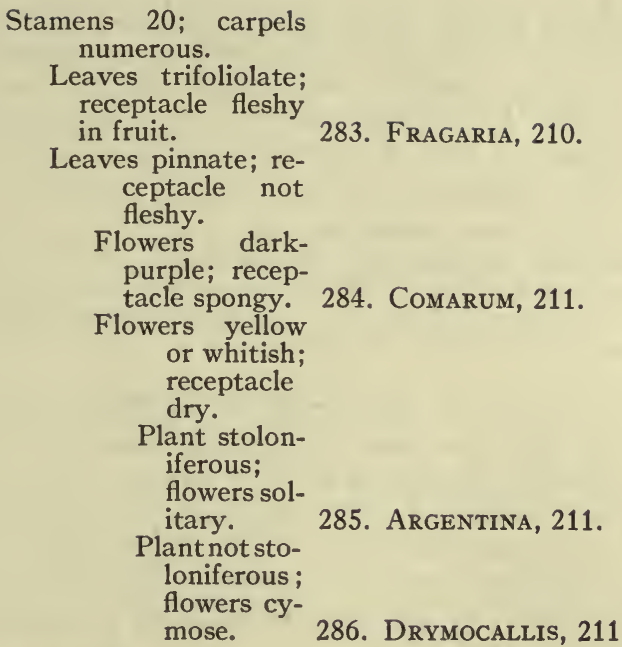

262. PRUNUS. Plum. Cherry.

Small trees or shrubs, many with edible fruits; leaves alternate, simple, usually serrulate; flowers white or rose-colored, solitary or fascicled in the axils or in terminal racemes or corymbs; calyx 5 -lobed, free from the ovary; petals 5, on the calyx-tube; stamens numerous; pistil 1 ; style 1 ; ovary 1 -celled, 2 -ovuled; fruit a drupe; seed 1 , rarely 2 ; endosperm none.

Flowers in corymbs.

Flowers in racemes.

$P$. emarginata.

P. demissa.

Prunus emarginata erecta (Presl) Piper n. comb. (Cerasus erecta Presl; Prunus emarginata villosa Sudw.) Wild Cherry. Small tree, 10-20 m. high; branches and bark chestnut brown, with prominent lenticels; leaves narrow, ovate, elliptical or obovate, obtuse or acute, cuneate at base, minutely serrate, tomentose beneath, 3-8 cm. long, short-petioled; corymbs few-flowered, appearing with the leaves, the pedicels pubescent; flowers about $1 \mathrm{~cm}$. broad; fruit oblong, bright red, bitter; stone with a grooved ridge on one side.

In open woods, common. The trees reach a maximum diameter of about $50 \mathrm{~cm}$. and a height of $20 \mathrm{~m}$.

Prunus demissa (Nutt.) Dietr. Chokecherry. Shrub or small tree, 2-8 m. high; leaves ovate or oblong-ovate, cuneate, rounded or cordate at the base, sharply serrate, $5-10 \mathrm{~cm}$. long, sometimes somewhat pubescent beneath; petioles $1-2 \mathrm{~cm}$. long, appearing after the leaves; calyx somewhat glandular; petals nearly orbicular; fruit globose, dark purple, 5-6 $\mathrm{mm}$. in diameter, not edible; stone globose.

In open prairies. First collected by Nuttall near the mouth of the Willamette River.

263. OSMARONIA.

Shrubs with alternate simple entire leaves; stipules none; flowers polygamo-dioecious, white, in loose nodding racemes, 
which appear with the branchlets from the same buds; calyx turbinate-campanulate, 5-lobed, deciduous; petals 5 , broadly spatulate, erect; stamens 15 , in two rows; styles short, lateral; carpels 5 , on the base of the calyx-tube, free, glabrous; fruit consisting of 1-4 oblong-ovoid 1-seeded drupes, with thin pulp and a smooth bony stone.

Osmaronia cerasiformis (T. \& G.) Greene. Indian Plum. Shrub, 2-4 $\mathrm{m}$. high; leaves broadly oblanceolate, acute, $5-10 \mathrm{~cm}$. long, glabrous, entire; racemes nodding; petals white, spatulate; drupes purple-black, oblong.

In wet soil, common. The young leaves and flowers have a peculiar rather unpleasant odor. The fruits are somewhat bitter.

\section{AMELANCHIER. SERvice Berry.}

Shrubs or small trees, not thorny; leaves alternate, simple, petioled, serrate or entire; flowers white, in racemes; calyx-tube campanulate, 5-lobed, more or less adherent to the ovary; petals 5 ; stamens numerous, on the calyx-tube; styles $2-5$, united below or distinct; ovary 5-celled, each cell 2-ovuled; berry-like pome 10-celled, by the growth of a false partition in each cell of the ovary; ovules 10 .

Amelanchier florida Lindl. Shrub or small tree, 2-5 m. high; leaves broadly oblong, rounded or subcordate at base, obtuse, tomentose when young especially beneath, glabrate, toothed above the middle or rarely entire, 2-4 cm. long; petioles pubescent, 1-2 cm. long; racemes 4-8 cm. long; calyx pubescent, the triangular acute lobes not longer than the tube; petals oblanceolate, obtuse, about $1 \mathrm{~cm}$. long.

In open woods, common.

265. CRATAEGUS. THORN. HAWthorn.

Shrubs or small trees, mostly thorny; leaves alternate, petioled, entire, serrate, lobed or pinnatifid; flowers white, rarely rosecolored, in terminal corymbs; calyx-tube cup-shaped or campanulate, adherent to the carpels, the limb 5-lobed; petals 5, roundish, on the calyx-tube; stamens many, or only 5 or 10 ; styles $1-5$, separate; ovary inferior, or its summit free; ovules one to each carpel; pome small, drupe-like, with 1-5 bony carpels, each 1 -seeded.

Crataegus douglasii Lindl. (C. brevispina (Dougl.) Heller.) Shrub, 2-6 m. high; spines stout, $2-3 \mathrm{~cm}$. long; leaves obovate, broadly cuncate at base, coarsely doubly dentate above the middle, acute or obtuse, sparsely pubescent on both sides when young, paler beneath, $2-5 \mathrm{~cm}$. long; petioles short, glandless; corymbs usually many-flowered; flowers about $12 \mathrm{~mm}$. broad; calyx-tube glabrous, the lanceolate lobes pubescent; anthers pink; fruit black, smooth; nutlets with cavities on the ventral faces.

Along streams and rivers, not common west of the Cascade Mountains.

266. PYRUS.

Trees or shrubs; leaves simple or compound; flowers in corymbed cymes; calyx urn-shaped, 5-cleft; petals roundish or obovate; 
stamens numerous; styles 2-5; pome fleshy or berry-like, the 2-5 carpels or cells of a papery or cartilaginous texture, 2-seeded,

Leaves simple; cyme simple.

Leaves pinnate; cyme compound.

Leaflets acute, serrate the whole length.

Leaflets obtuse, serrate only at the apex.
P. diversifolia.

P. sitchensis.

P. occidentalis.

Pyrus diversifolia Bong. Wild Crab-apple. Small tree, 5-10 m. high, somewhat spiny; leaves ovate-lanceolate, acute or acuminate, sometimes 3-lobed, serrate, pubescent beneath; flowers white, in a simple cyme; fruit oblong, green or purplish, depressed at each end.

In swamps, common.

Pyrus sitchensis (Roem.) Piper. Mountain Ash. Shrub, $2-5 \mathrm{~m}$. high, with $9 / 2 / 20$ / $/ 78$, smooth bark; young branches pubescent; leaves pinnate, $12-20 \mathrm{~cm}$. long; leaflets 4-6 pairs, mostly oblong, acute or acuminate, simply or doubly serrate, glabrous or nearly so, shiny above, $2-6 \mathrm{~cm}$. long, $1-2 \mathrm{~cm}$. broad; cymes dense, compound, $8-12 \mathrm{~cm}$. broad; flowers white, $8 \mathrm{~mm}$. broad; calyx and pedicels loosely woolly-pubescent; fruit bright-red, about $6 \mathrm{~mm}$. in diameter.

In the mountains at low altitudes.

Pyrus occidentalis Wats. Low shrub, about $1 \mathrm{~m}$. high; leaflets $7-11,8 / 22 / 20 \mathrm{M}$ oblong, obtuse, serrate near the tip, dull above, paler beneath; cymes rather small; fruit purplish with a bloom.

In the mountains, at about the limit of trees.

\section{OPULASTER. NINEBARK.}

Branching shrubs; leaves petioled, simple, palmately-lobed; flowers in umbel-like corymbs; calyx 5-lobed; petals 5, round, on the calyx-tube; stamens many, distinct, on the calyx-tube; pistils 1-5, more or less united; follicles 1-5, 2-valved; seeds 2-4; endosperm copious.

Opulaster opulifolius (L.) Kuntze. Shrub, 2-5 m. high, the branches spreading and covered with a thin flaky brownish bark; leaves broadly ovate to orbicular, cordate, palmately 3-5-lobed, somewhat doubly dentate, nearly glabrous above, stellate pubescent beneath, $2-8 \mathrm{~cm}$. long; petioles $1-2 \mathrm{~cm}$. long; inflorescence a dense corymb; petals white, obovate, longer than the blunt calyx-lobes; carpels membranaceous, glabrous, a half longer than the calyx.

On stream banks. The western form is by some authors considered distinct under the name O. capitatus (Pursh) Kuntze.

\section{LUTKEA.}

Low cespitose shrubs with decumbent stoloniferous branches; leaves 2-3 times ternately dissected; flowers perfect, in racemes; disk thickened, 10-lobed; calyx-tube hemispheric; sepals 5; petals 5 ; stamens numerous; pistils usually 5 , distinct; styles terminal, deciduous; stigmas truncate; ovules several; follicles coriaceous; seeds linear-lanceolate.

Lutkea pectinata (Pursh) Kuntze. Densely matted; stems creeping, $\% / 20 \mathrm{Nt}$ slender, woody; leaves twice or thrice cleft into narrow acute spreading lobes, $600 \mathrm{ft}$ glabrous; flowering stems $5-10 \mathrm{~cm}$. high; racemes $2-3 \mathrm{~cm}$. long.

In alpine meadows, abundant, often forming extensive mats. 


\section{HOLODISCUS.}

Thornless shrubs; leaves alternate, simply pinnately toothed or lobed, without stipules; flowers numerous, white, in terminal panicles; calyx deeply 5-lobed; petals 5, as long as the calyx lobes, rounded; stamens 20 , on a perigynous entire ring-like adherent disk, scarcely exserted; pistils 5 , each with 2 ovules, becoming 1-seeded hairy carpels almost indehiscent.

Holodiscus discolor (Pursh) Maxim. Ocean Spray. Iron-wood. Large shrub, 2-5 m. high; young twigs pubescent; leaves triangular-ovate, mostly obtuse, truncate or cuneate at base, woolly-pubescent beneath, glabrous above, 2-5 $\mathrm{cm}$. long; panicle broadly pyramidal, much branched, $10-20 \mathrm{~cm}$. long; flowers small, white, becoming yellowish; calyx densely short-pubescent, the lobes acute, spreading.

In open woods, abundant.

\section{SPIRAEA.}

Shrubs; leaves alternate, simple, without stipules; flowers white or pink, perfect, in racemes, cymes, corymbs, or panicles; calyx 4- or 5-lobed; petals 4 or 5, exceeding the calyx and inserted on the calyx-tube; stamens numerous, distinct, on a disk which is free at the edge and crenate or glandular-toothed; filaments much exserted; pistils commonly 5 , superior, alternate with the calyxlobes; ovules 5-11; follicles usually 5 , not inflated, 1 -valved; seeds few to several.

Low depressed shrubs with entire leaves.

S. hendersoni.

Taller shrubs with serrate or incised leaves.

Flowers white.

Flowers red.

Flowers in flat corymbs.

Flowers in elongate panicles.

Leaves tomentose beneath.

Leaves glabrous beneath.

S. lucida.

S. densiflora.

S. douglasii.

S. menziesii.

Spiraea hendersoni (Canby) Piper. Densely matted low shrub with the leaves in rosettes; leaves oblanceolate, glabrous or nearly so, thick, pale green; flowering stem $5-10 \mathrm{~cm}$. high; raceme dense, $2-3 \mathrm{~cm}$. long.

In rock crevices on high peaks in the Olympic Mountains.

Spiraea lucida Dougl. Low shrub, 30-60 cm. high, branched below; leaves elliptic or ovate, rounded at base, $2-6 \mathrm{~cm}$. long, coarsely and unevenly serrate or incised above the middle, green and glabrous on both sides; petioles short; inflorescence a flat-topped dense corymb, 5-12 cm. across; flowers small, white; carpels 5 , glabrous.

At low altitudes in the mountains. Very feebly distinguishable from the eastern $S$. corymbosa Raf.

$M+$ Adam Spiraea densifiora Nutt. Stems erect, 30-100 cm. high; leaves ovate or elliptic, serrate near the apex, usually obtuse; flowers in dense corymbs; petals rose-colored.

In the mountains at 1500-2000 m. elevation, near the limit of trees.

Spiraea douglasii Hook. Stems erect, 1-2 m. high; leaves oblong, serrate 
toward the apex, tomentose beneath; flowers in dense panicles, $8-20 \mathrm{~cm}$. long; petals rose-colored.

In swamps and on the margins of lakes, common.

Spiraea menziesii Hook. Erect shrub, 1-1.5 m. high, not much branched, $9 / 2 / 20$ Mt minutely pubescent on the young twigs and under side of the leaves; leaves Cfore in oblong, acute or. obtuse, rounded or cuneate at base, green on both sides, delta of Bu coarsely serrate above the middle, rarely entire, $3-6 \mathrm{~cm}$. long; petioles short; panicles dense, pyramidal or oblong, 5-20 cm. long; flowers rose-colored; calyx-lobes becoming reflexed; carpels 5 , glabrous.

In wet places, rare west of the Cascade Mountains. Common in the interior.

\section{ARUNCUS. GOAT'S BEARD.}

Tall dioecious herbs; leaves 2-3-pinnate, the leaflets rather large, ovate-oblong; flowers sessile or nearly so, on long spike-like branches in a large open panicle; petals small, narrow, white; carpels 3 or 4 .

Aruncus aruncus (L.) Karst. Glabrous; stems erect, 1-2 m. high; leaflets ovate or lanceolate, acuminate, doubly dentate, 5-10 cm. long; panicle large; flowers white.

On moist cliffs and banks, not rare.

\section{RUBUS.}

Perennial herbs or shrubs or vines, often prickly; leaves alternate, simple, or pinnately 3-7-foliolate, with stipules adherent to the petiole; flowers white or red, solitary or in racemes or corymbs; calyx 5-lobed, without bractlets; petals 5, conspicuous; stamens numerous, on the calyx-tube; styles nearly terminal; carpels numerous, on the convex receptacle, ripening into 1seeded drupelets forming an aggregate fruit.

Herbs.

Leaves palmately lobed; carpels tomentose. Shrubs.

Leaves palmately compound; carpels glabrous.

Stems trailing.

Leaves mostly compound; berries black.

Leaves mostly simple; berries red.

Stems erect or ascending.

Leaves palmately lobed; not prickly.

Leaves compound; prickly.

Stems perennial; berry cylindric.

Stems biennial; berry hemispheric.

Flowers red; berries yellow or orange.

Flowers white; berries black.
$R$. lasiococcus.

$R$. pedatus.

R. macropetalus.

$R$. nivalis.

R. parviflorus.

R. laciniatus.

R. spectabilis.

$R$. leucodermis.

Rubus lasiococcus Gray. Herbaceous with trailing stems; leaves broadly ovate, 3-5-lobed or rarely 3-foliolate, the lobes or leaflets serrate; flowers white, solitary, on slender peduncles; fruit composed of few-several large red fuzzy drupelets.

In shaded mountain woods, common.

Rubus pedatus Smith. Much like $R$. lasiococcus but the leaves palmate with 3-5 leaflets; fruit red, not fuzzy.

In mountain woods, often growing with $R$. lasiococcus. 
Rubus macropetalus Dougl. (R. helleri Rydb.) Dewberry. Stems slightly woody, biennial, prickly, trailing, $1-8 \mathrm{~m}$. long, usually unbranched the first year, but bearing numerous short flowering branches the second year; leaves 3 -foliolate, rarely 5 -foliolate; leaflets ovate, mostly acute, rounded or cordate at base, doubly and somewhat incisely dentate, pubescent especially beneath, $2-5 \mathrm{~cm}$. long; calyx glandular and prickly; petals white, 1-2 times as long as the acute somewhat foliaceous tipped sepals; fruit black when ripe, cylindrical, $1-3 \mathrm{~cm}$. long, finely flavored.

Abundant, especially in "burns"; commonly known as "blackberry."

Rubus nivalis Dougl. Stems trailing, armed with weak prickles; leaves ovate-cordate, 3 -lobed or rarely 3 -foliolate, serrate, shining; petals "lurid red"; fruit bright red, hemispherical, acid.

In mountain woods, rarely blooming.

(O) Adams Rubus parviflorus Nutt. Thimble Berry. Stems wholly unarmed, perennial, $1-1.5 \mathrm{~m}$. high; bark brownish, becoming shreddy, usually glandularpubescent when young; leaves palmately and acutely 5-lobed, irregularly serrate, cordate at base, soft-pubescent or nearly glabrous, $10-30 \mathrm{~cm}$. broad; petioles about as long as the blades, with stipules; corymbs few-flowered; calyx glandular and woolly; petals white, about $2 \mathrm{~cm}$. long; fruit red, flatconvex, juicy, about $2 \mathrm{~cm}$. broad.

In open woods, abundant.

Rubus laciniatus Willd. Evergreen Blackberry. Stems climbing, 3-5 m. long, armed with numerous stout recurved prickles; leaflets 3 , pinnately cleft or parted and laciniately incised, sparsely pubescent beneath; petioles prickly; flowers in small corymbs; sepals pubescent and armed with straight prickles; petals white or pinkish, often incisely cleft; fruit a blackberry.

Cultivated and commonly established as an escape making dense thickets.

Rubus spectabilis Pursh. Salmon-berry. Stems 1-3 m. high, armed with weak prickles; leaves mostly 3 -foliolate; leaflets ovate, acute or acuminate, coarsely serrate, often lobed; flowers red, mostly solitary; fruit a raspberry, yellow or dark-red.

In swamps and along streams. Two varieties occur, one the betterflavored with salmon-yellow fruits, the other with reddish-black fruits. The latter is also distinguishable by the purple color of the twigs. The young fleshy shoots are sweet and are often eaten by children and were formerly used as food by the Indians.

Rubus leucodermis Dougl. Blackcap. Erect shrubs, the biennial stems 1-2 m. high, very glaucous, armed with stout straight or curved prickles; leaves 3 -foliolate, rarely 5 -foliolate; leaflets ovate, acuminate, doubly serrulate, whitc-pubescent beneath, the lateral ones oblique and frequently with one or two lobes; petioles and midveins prickly; flowers small, in few-flowered corymbs; petals white, small, erect, shorter than the reflexed sepals; fruit nearly black when mature, hemispherical, glaucous or tomentose, about $1 \mathrm{~cm}$. broad.

In open woods. Young shoots sweet and edible.

\section{ROSA. ROSE.}

Erect or climbing shrubs, usually with prickly stems; leaves alternate, odd-pinnate, with adherent stipules; leaflets mostly serrate; flowers solitary or in corymbs; calyx-tube cup- or urnshaped, becoming fleshy in fruit, usually 5-lobed, without bractlets; petals 5 , large, obcordate; stamens numerous, on the calyx-tube; 
styles distinct or united; carpels numerous, sessile, within the calyx-tube; akenes numerous, enclosed in the berry-like calyxtube.

Leaves very glandular beneath.

R. rubiginosa.

Leaves not very glandular.

Flowers small, about $2 \mathrm{~cm}$. in diameter; calyx-lobes deciduous from the fruit.

Flowers large, $3 \mathrm{~cm}$. or more in diameter; calyx-lobes persistent.

Flowers mostly solitary; fruit globose, $2 \mathrm{~cm}$. broad.

Flowers in corymbs; fruit ovoid or oblong, not more than $1 \mathrm{~cm}$. broad.

R. gymnocarpa.

R. nutkana.

R. pisocarpa.

Rosa rubiginosa L. Sweetbrier. Stems slender, 1-2 m. high, armed with stout recurved prickles; calyx-lobes lanceolate, not foliaceous at the tips; fruit oval, 1-2 cm. long.

A sweet-scented species introduced from Europe and now abundant.

Rosa gymnocarpa Nutt. Small shrub, about $1 \mathrm{~m}$. high, armed with numerous slender straight prickles; leaflets 5-9, elliptic, cuneate at base, serrate, nearly glabrous, $5-20^{\circ} \mathrm{mm}$. long; serratures and petioles glandular; flowers mostly solitary, about $2 \mathrm{~cm}$. in diameter; calyx-lobes acuminate, not foliaceous appendaged, deciduous from the fruit; fruit oblong or pear-shaped, about $1 \mathrm{~cm}$. long.

Dry woods, common.

Rosa nutkana Presl. Stout, 1-2 m. high, armed with few but stout prickles; leaflets $5-7$, ovate or elliptic, obtuse, coarsely usually doubly serrate, $1-3 \mathrm{~cm}$. long, glabrous or somewhat pubescent, usually glandular on the petioles and serratures; flowers mostly solitary, 4-8 cm. broad; calyx-lobes glandular, foliaceous appendaged, persistent; calyx-tube globose, smooth; fruit globose but varying to ovoid or pyriform, about $2 \mathrm{~cm}$. in diameter; seeds large.

In springy places. Usually the leaves are sprinkled with minute glands beneath, but in one form they are sparsely pubescent, becoming glabrate.

Rosa pisocarpa Gray. Very similar to $R$. nutkana, the leaves usually finely pubescent; flowers smaller, about $3 \mathrm{~cm}$. in diameter, usually in corymbs; fruit ovoid or oblong, $5-10 \mathrm{~mm}$. in diameter.

Usually growing with $R$. nutkana.

\section{AGRIMONIA.}

Perennial herbs; leaves interruptedly pinnate with crenateserrate leaflets; flowers small, in spike-like racemes with 3 -cleft bracts; calyx-tube top-shaped or hemispherical, the throat beset with hooked bristles, hardened in fruit and enclosing the akenes; petals 5, yellow; stamens 5-15; styles terminal.

Agrimonia gryposepala Wallr. Hirsute and somewhat glandular; stems erect, branched, $90-120 \mathrm{~cm}$. high; principal leaflets 7 , unequal, oblong or the terminal one obovate, coarsely serrate, pubescent especially on the nerves beneath, usually with small leaflets between the principal ones; stipules coarsely toothed; flowers $8-10 \mathrm{~mm}$. broad; fruit reflexed, turbinate, its bristles mostly spreading, the outer reflexed.

Sumas Prairie, Lyall. 


\section{ALCHEMILLA.}

Low annual or perennial herbs; leaves palmately lobed or compound, with sheathing stipules; flowers perfect, small, greenish, in corymbs; calyx 4-or 5-lobed, with as many minute bractlets; petals none; stamens 1-4, very small; styles basal or lateral; carpels 1-4, distinct, free from the calyx-tube; akenes $1-4$, enclosed in the calyx-tube.

Alchemilla occidentalis Nutt. Annual, 2-8 cm. high, simple or branched below, sparsely hairy; leaves short-petioled, fan-shaped, 3-parted, the lobes acutely 2-3-cleft; stipules conspicuous, cleft; calyx 1-1.5 mm. long, acutely 4-cleft, the bractlets minute; akenes ovoid, pale, $1 \mathrm{~mm}$. long.

In dry fields, very inconspicuous.

\section{SANGUISORBA.}

Annual or perennial herbs; leaves alternate, odd-pinnate; stipules adherent to the petiole; flowers small, perfect (in ours), in dense terminal spikes or heads; calyx 4-lobed; petals none; stamens 4-many; styles terminal, filiform; carpels $1-3$, free from the calyx-tube; akenes usually 1 , enclosed in the 4 -angled dry closed calyx-tube.

Annual; flowers greenish.

S. occidentale.

Perennial; flowers not greenish.

Flowers white.

Flowers purple.

S. latifolia.

S. microcephala.

Sanguisorba occidentale Nutt. Annual, erect, glabrous, 15-40 cm. high, usually simple below; leaflets $4-6$ pairs, $1-2 \mathrm{~cm}$. long, ovate or oblong, deeply pinnatifid into linear obtusish lobes; flowers perfect, greenish, in short oblong spikes, 1-3 cm. long; bracts ovate, scarious-margined, persistent; calyx-lobes broadly ovate, scarious; stamens 4 , rarely 2 , somewhat exserted.

In open prairies; scarcely separable from $S$. annua Nutt.

Sanguisorba latifolia (Hook.) Coville. (S. sitchensis C. A. Mey.) Perennial, glabrous; stems $30-90 \mathrm{~cm}$. high, simple or branched above; leaflets 5-10 pairs, oval, about three times as long as broad, coarsely serrate, more or less cordate; stipules serrate; spikes $3-10 \mathrm{~cm}$. long; flowers white.

Wet places in the mountains, rare southward; Alaska to Oregon and Idaho.

Sanguisorba microcephala Presl. Glabrous; stems erect, 20-60 cm. high, sparingly branched above, not much longer than the leaves; leaflets 9-13, oblong-ovate, cordate, coarsely serrate-dentate, $1-4 \mathrm{~cm}$. long, firm, paler beneath; spikes dark purple, dense, oblong, $1.5-2.5 \mathrm{~cm}$. long; sepals oval; stamens short, not much exserted.

In bogs near the ocean coast, Alaska to northern California.

\section{DRYAS.}

Low tufted shrubs; leaves simple, petioled, white-canescent beneath; stipules present; flowers rather large, perfect, solitary on slender scapes; calyx persistent, not bracted, glandularhirsute, 8-9-lobed; petals 8 or 9 , obovate, larger than the calyxlobes; stamens numerous, on the throat of the calyx; carpels 
numerous, sessile on the dry receptacle; style terminal, persistent, elongated and plumose in fruit.

Dryas octopetala L. Somewhat shrubby, densely matted; leaves oblongovate, obtuse, crenate, bright green above, white beneath; flowers white.

At high altitudes on Mount Rainier and northward.

\section{GEUM.}

Perennial herbs; leaves pinnate, with stipules, the radical clustered; cauline smaller; flowers rather large, solitary or in corymbs; calyx 5-lobed with 5 alternate bractlets; petals 5 , obovate, usually longer than the calyx-lobes; stamens many, on the throat of the calyx; styles terminal, elongated in fruit, usually plumose or jointed, the upper part deciduous; akenes 2-6, pubescent.

Receptacle downy; terminal leaflet cuneate-obovate to oblanceolate, deeply cleft into acute lobes.

Receptacle nearly naked.

Terminal leaflet broadly ovate to suborbicular, not cordate, crenately cleft into mostly obtuse lobes.

Terminal leaflet suborbicular, cordate, finely crenatedentate.

G. strictum.

G. oregonense.

G. macrophyllum.

Geum strictum Ait. Stems $60-120 \mathrm{~cm}$. high, hirsute; radical leaves pinnate; cauline 3-5-foliolate; leaflets cuneate-obovate, incisely and acutely lobed and toothed, pubescent; petioles hirsute; flowers rather large; petals golden yellow; receptacle densely pubescent; styles hairy at top, the lower portion not glandular.

Victoria, British Columbia, common, Macoun. Not elsewhere reported from west of the Cascade Mountains.

Geum oregonense Scheutz. Intermediate between $G$. strictum and $G$. macrophyllum; leaflets obtuse, the terminal one broadly ovate or suborbicullar, cuneate or truncate at base, deeply lobed and toothed; inflorescence open; receptacle glabrous; petals pale yellow; styles puberulent.

Reported from Vancouver Island, Macoun.

Geum macrophyllum Willd. Stout, erect, $30-80 \mathrm{~cm}$. high, bristly-hairy; radical leaves pinnate, the terminal leaflet much larger than the 3-8 lateral ones, broadly ovate or suborbicular, 3-7-lobed, dentate, $5-10 \mathrm{~cm}$. long; lateral leaflets ovate or elliptic, dentate, $2-3 \mathrm{~cm}$. long, usually with smaller ones interspersed; cauline leaves similar, but nearly sessile, with 1-3 leaflets or segments; stipules ovate, toothed, $1-2 \mathrm{~cm}$. long; flowers yellow, about $1 \mathrm{~cm}$. broad, several in a loose cyme; petals obovate, deep yellow, longer than the reflexed acute calyx-lobes; fruiting head globose, $1.5 \mathrm{~cm}$. long; akenes hispid; styles jointed and twisted near the tip, the lower portion glandular.

In fields and meadows.

\section{SIEVERSIA.}

Low perennial herbs with simple stems; radical leaves pinnate; flowers in terminal cymes; sepals 5 , erect or spreading, with 5 bractlets; petals 5 ; carpels sessile; styles not jointed, persistent, erect, plumose or naked.

Petals shorter than the sepals. 
Sieversia ciliata (Pursh) G. Don. Erect, from stout rootstocks, 30-50 $\mathrm{cm}$. high, soft hairy throughout; radical leaves tufted, oblanceolate in outline, 10-15 cm. long, pinnate with numerous leaflets, these cuneate, obovate, incisely cleft into acute narrow lobes; cauline leaves 1 or 2 , much reduced; flowers long-peduncled, 3-5 in a cyme; calyx purplish, the linear bractlets scarcely exceeding the triangular acute calyx-lobes; petals oblong, erect, yellowish with purple veins, shorter than the calyx; akenes with straight plumose tails, $2-3 \mathrm{~cm}$. long.

In open prairies, rare west of the Cascade Mountains.

Sieversia campanulata (Greene) Rydb. Very similar to S. ciliata; stems not so tall, $15-25 \mathrm{~cm}$. high, mostly 2 -flowered; calyx-tube hemispheric, the lobes obtusish; petals broadly obovate, reddish-purple, much exceeding the calyx.

Olympic Mountains, Clallam County, Washington, Elmer, Grant; Saddle Mountain, Oregon, Gorman.

\section{POTENTILLA.}

Annual or perennial herbs; leaves alternate, pinnate or palmate, with stipules; flowers perfect, solitary or in cymes; sepals 5 , rarely 4 , with 5 , rarely 4 , alternate bractlets; petals 5 , seldom 4 , rounded, mostly yellow; stamens usually 20 , in two or three rows on the calyx-tube; style small, terminal or nearly so, not elongating in fruit, neither jointed nor plumose; carpels usually numerous; ovules pendulous, anatropous; receptacles and akenes dry in fruit.

Flowers solitary, long peduncled.

Flowers cymose.

P. longipedunculata.

Cymes leafy; annuals or biennials with small flowers and ternate leaves.

- Petals as long as the sepals.

Petals much shorter than the sepals.

Cymes loose, rather broad; leaflets oblanceo-

P. monspeliensis. late.

Cymes narrow, elongated; leaflets obovate.

P. millegrana.

$P$. biennis.

Cymes not leafy; perennials, with digitate leaves.

Leaflets 3.

Plant densely silky-villous.

Plant glabrous or nearly so.

Leaflets 5-9.

Low alpine plants, $20-30 \mathrm{~cm}$. high; cymes fewflowered.

Leaves green, pubescent.

Leaves glaucous, nearly glabrous.

Taller lowland plants, $40-80 \mathrm{~cm}$. high; cymes many-flowered.

Leaflets white-tomentose beneath.

Leaflets green on both sides.
$P$. villosa.

P. flabellifolia.
$P$. diversifolia.

$P$. glaucophylla.
$P$. gracilis.

P. macropetala.

Potentilla longipedunculata Rydb. Perennial with creeping rootstocks, villous; stems ascending, 40-50 cm. long, dichotomously branched; leaves digitately 3-5-foliolate; leaflets oblanceolate, 3-5 cm. long, deeply incisedserrate, green above, white tomentose beneath; peduncles villous, 1-flowered, about $10 \mathrm{~cm}$. long; flowers $2 \mathrm{~cm}$. broad; petals broadly cuneate, retuse, yellow; stamens about 20 .

Known by a single specimen from Monmouth, Oregon; possibly abnormal. 
Potentilla monspeliensis L. Annual or biennial, stout, leafy, erect, 30-80 $\mathrm{cm}$. high, hairy; leaves 3 -foliolate, or the lowest sometimes 5-foliolate, green; leaflets obovate to oblanceolate, serrate, $3-10 \mathrm{~cm}$. long; cyme rather dense, leafy; calyx hairy; petals pale yellow, obovate; stamens usually 20; akenes glabrous, rough.

In open places, not common.

Potentilla millegrana Engelm. Annual or biennial, pubescent; stems erect or ascending, branched, $20-60 \mathrm{~cm}$. high; leaves all trifoliolate; leaflets cuneateoblong, incisely serrate, the middle one lobed, $2-5 \mathrm{~cm}$. long; cyme loose, the bracts leaf-like; sepals acute; petals pale-yellow, half as long as the sepals; stamens mostly 10, 3-4 mm. long; akenes pale.

Prairies and river banks, rare in our limits.

Potentilla biennis Greene. Very similar to $P$. millegrana, usually somewhat glandular; leaflets broadly cuneate-obovate; inflorescence somewhat elongate.

Prairies, not common.

Potentilla villosa Pall. Perennial from a thick caudex, densely silvery pubescent; stems 10-20 cm. high, 1-2-leaved; leaves 3-foliolate; leaflets cuneate-obovate, coarsely toothed, silky above, tomentose beneath, $2-4 \mathrm{~cm}$. long; cyme few-flowered; sepals ovate; petals obcordate, 8-12 mm. long; stamens about 20.

In rocky places in the mountains at about $2000 \mathrm{~m}$. altitude. Washington northward to Alaska.

Potentilla flabellifolia Hook. Perennial from a short rootstock, green, $\$ / \pi / 20$ Mt Ad nearly glabrous; leaves 3 -foliolate, thin; leaflets cuneate-obovate, incisely toothed, minutely pubescent, $2-3 \mathrm{~cm}$. long, the median one petiolulate; petals obcordate, $8-10 \mathrm{~mm}$. long, bright yellow, longer than the sepals; stamens about 20 .

Common in the moist mountain meadows; first found on Mount Rainier by Douglas, according to Hooker but this is an error, as Douglas was never on this mountain.

Potentilla diversifolia Lehm. Perennial, somewhat silky-pubescent; stems ascending, 10-20 cm. high; basal leaves 5-7-foliolate, pinnate or digitate; leaflets cuneate-oblanceolate, incisely toothed, unequal, silky beneath; cyme few-flowered; petals obovate, emarginate, 6-7 mm. long, one half longer than the sepals; stamens about 20.

In the mountains at about $1500 \mathrm{~m}$. altitude.

Potentilla glaucophylla Lehm. Very similar to $P$. diversifolia, but less pubescent and somewhat glaucous; leaves apparently always digitate.

Mount Rainier, Piper, and widely distributed in the Rocky Mountains.

Potentilla gracilis Dougl. Perennial; stems erect, $30-60 \mathrm{~cm}$. high, white villous; leaves digitate; leaflets $5-7$, oblanceolate, pinnately incised half way to the midrib into acute teeth, dark green above, densely white tomentose beneath, 3-6 cm. long; petiole of basal leaves long, of the cauline short; cyme flat topped, rather loose; petals bright yellow, obcordate, about $1 \mathrm{~cm}$. long, much longer than the lanceolate sepals.

Prairies, Vancouver Island to southern Oregon.

Potentilla macropetala Rydb. Perennial, somewhat pubescent; stems ascending or decumbent at base, $20-40 \mathrm{~cm}$. high, sparsely hairy; leaves digitate, the basal mostly 5-foliolate and long-petioled, the upper ternate and subsessile; leaflets cuneate, coarsely toothed, grcen, appressed pubescent on both sides; cyme few-flowered; sepals lanceolate to ovate-lanceolate; petals broadly obcordate, about $1 \mathrm{~cm}$. long; stamens about 20 .

Tillamook, Oregon, and southward. 
281. DASIPHORA.

Small shrubs with pinnate leathery leaves; stipules sheathing, scarious; flowers axillary, yellow; calyx-tube saucer-shaped; bractlets, sepals and petals 5, the petals nearly orbicular; stamens numerous; pistils numerous; styles club-shaped, thick and glandular upward, inserted near or below the middle of the ovary; stigmas large, 4-lobed; akenes densely covered with long straight hairs.

Dasiphora fruticosa (L.) Rydb. Much branched, 30-100 cm. high; leaves numerous, pinnate with 5-7 leaflets; leaflets linear to lanceolate-oblong, acute, somewhat involute, silky, paler beneath, $1-2 \mathrm{~cm}$. long; petals bright yellow, orbicular, twice as long as the sepals.

In rocky places in the mountains at about $1500 \mathrm{~m}$. altitude.

\section{SIBBALDIA.}

Depressed somewhat woody alpine plants with alternate trifoliolate leaves; flowers in cymes on nearly leafless peduncles; calyx persistent, slightly concave, 5-lobed, with 5 bracts; petals 5, yellow, much smaller than the calyx-lobes; stamens 5, on the margin of the villous disk; carpels $5-10$, on short pubescent stipes; styles lateral.

Sibbaldia procumbens L. Perennial, sparsely villous, 5-15 cm. high; leaflets 3 , rather thick, cuneate, 3-5-toothed at the truncate apex, $1-2 \mathrm{~cm}$. long; peduncles usually shorter than the leaves; petals yellow, acute.

At high altitudes in the mountains.

\section{FRAGARIA. STRAWBERRY.}

Acaulescent perennial herbs, propagating by runners; leaves alternate, basal, tufted, 3 -foliolate, with obovate serrate leaflets; flowers polygamo-dioecious, white, few, in corymbs or racemes, on naked scapes; calyx deeply 5-lobed, with 5 alternate bractlets; petals 5 , obovate, short-clawed; stamens numerous, in 1 row; style lateral; carpels numerous; receptacle much enlarged and fleshy in fruit, conical, scarlet or white, bearing the small turgid akenes on the surface.

Leaves thick, silky and tomentulose beneath.

Leaflets strongly reticulate; pubescence close.

Leaflets not strongly reticulate; pubescence loose.

Leaves thin, not at all tomentulose beneath.

Flowers white.

Flowers pink.

F. chiloensis. F. crinita.

F. bracteata. $F$. helleri.

Fragaria chiloensis (L.) Duch. Rootstock stout; leaves usually $3-10 \mathrm{~cm}$. long, the petioles villous; leaflets obovate, the lateral ones oblique, coarsely toothed, firm, nearly glabrous above, densely silky beneath, reticulated, $2-5 \mathrm{~cm}$. long, all with short petiolules; scape villous, usually longer than the leaves, the cyme few-flowered; calyx silky-villous, the lobes lanceolate, acute, longer than the bractlets; petals nearly orbicular; fruit hemispherical, sweet and juicy, the akenes nearly superficial. 
Very common in open places. $F$. cuneifolia Nutt. is probably indistinguishable. It is usually characterized by having narrower more cuneate longer-stalked thinner less-reticulated leaflets and slightly smaller flowers; but all of these characters are decidedly variable in $F$. chiloensis.

Fragaria crinita Rydb. Very similar to $F$. chiloensis but more hairy, not reticulated, some of the pubescence loose and spreading; petioles densely hirsute.

Infrequent, British Columbia to California.

Fragaria bracteata Heller. Rootstocks stout; scapes 10-20 cm. high, usually exceeding the leaves; whole plant sparsely silky-villous; leaflets broadly obovate, cuneate at base, coarsely dentate; lateral leaflets oblique; flowers $1.5-2 \mathrm{~cm}$. broad; petals nearly orbicular, somewhat longer than the spreading sepals; fruit oblong, the akenes on the surface.

In prairies and open woods, common.

Fragaria helleri Holzinger. Very similar to $F$. bracteata; petals pink; flowers more often nodding.

Known from only a few localities, namely Olympia, Olga, and Woodlawn; Washington, and Latah County, Idaho. Probably not distinct from $F$. bracteata.

\section{COMARUM.}

Stout dark green nearly glabrous perennial herbs; leaves alternate, pinnate, with large stipules; flowers large, cymose or solitary, terminal or also axillary; calyx deeply 5-lobed and with 5 narrow bractlets; petals shorter than the calyx-lobes, acute, purple; stamens numerous on the large pubescent disk; pistils numerous on the pubescent receptacle which becomes spongy in fruit; styles lateral; akenes glabrous.

Comarum palustre L. Perennial; stems decumbent, rooting below, 30-90 $\mathrm{cm}$. long; leaves pinnately 5-7-foliolate; leaflets elliptic or oblong, serrate, obtuse, more or less pubescent beneath, 5-8 cm. long; cyme few-flowered; flowers dark-purple.

In swampy places or shallow water especially along lake shores, common.

\section{ARGENTINA.}

Stoloniferous creeping herbs with pinnately compound leaves; flowers axillary solitary; calyx deeply 5-lobed and with 5 alternate bractlets; petals yellow; stamens 20 or more; carpels numerous on a small villous receptacle; style filiform, lateral; akenes glabrous.

Argentina grandis (T. \& G.) Piper n. comb. (Potentilla anserina grandis T. \& G.; P. pacifica Howell; Argentina occidentalis Rydb.) Leaves $30-40 \mathrm{~cm}$. long, with 7-31 principal leaflets, bright green above, white tomentose beneath; leaflets oblong to obovate, coarsely serrate, the larger 4-6 cm. long; peduncles $10-30 \mathrm{~cm}$. long, nearly glabrous; akenes firm, laterally compressed, rounded on the back.

Abundant along the seashore, rare elsewhere.

286. DRYMOCALLIS.

Very similar to Potentilla; leaves pinnate; flowers yellow or whitish; stamens in groups on a thick fleshy disk; anthers flat; styles lateral, nearly basal; seeds ascending, orthotropous. 
Sepals broadly ovate.

D. wrangeliana.

Sepals lanceolate to ovate.
Petals small, slightly if at all exceeding the sepals.
Petals large, much exceeding the sepals.
D. glandulosa.
D. valida.

Drymocallis wrangeliana (Fisch. \& Lall.) Rydb. (D. oregana (Nutt.) Rydb.) Villous and glandular; stems erect, $60-90 \mathrm{~cm}$. high; basal leaves with 7-9 leaflets, these cuneate-obovate, doubly serrate-dentate, pubescent on both sides, 3-4 cm. long; petioles hairy; cauline leaves gradually reduced upwards; cyme rather loose; calyx glandular-hairy, the sepals ovate, the bractlets lanceolate and smaller; petals yellow, oval, 5-7 mm. long.

In open places mostly at low altitudes in the mountains.

Drymocallis glandulosa (Lindl.) Rydb. Perennial; stems erect, 40-50 cm. high, sparsely villous and glandular, loosely branched above; basal leaves with 7-9 leaflets, these obovate or orbicular, simply or doubly dentate, sparsely pubescent, 1-3 cm. long; cauline leaves usually with fewer leaflets; flowers $10-15 \mathrm{~mm}$. broad, in loose open cymes; calyx somewhat glandular; bractlets shorter than the ovate acute or acuminate calyx-lobes; petals oval or obovate, about as long as the sepals.

Prairies and open places.

Drymocallis valida (Greene) Piper. Similar in habit to $D$. glandulosa; glandular-pubescent throughout; leaflets 7-11, mostly obovate to orbicular, incisely serrate, $3-6 \mathrm{~cm}$. long; cyme rather loose and flat-topped; petals elliptic to suborbicular, one third longer than the sepals.

Open places in the mountains.

\section{Family 50. LEGUMINOSAE. PUlse FAMILy.}

Herbs, shrubs or trees; leaves alternate, mostly compound, with stipules; flowers irregular (papilionaceous) (in ours), perfect or sometimes polygamous, in spikes, heads, racemes or panicles; calyx 4-5-toothed or cleft; lobes equal or unequal, sometimes in 2 lips; petals more or less united or separate, perigynous or hypogynous, usually papilionaceous, that is, with the upper or odd petal (standard) larger than the others and usually turned backward or spreading; the two lateral ones (wings) oblique and exterior to the two lower; the last pair connivent and commonly more or less coherent by their anterior edges, forming the keel, which usually encloses the stamens and pistil; stamens 10 , rarely 5 or many, monadelphous, diadelphous or sometimes distinct; pistil 1, 1-celled or several-celled by the intrusion of partitions, free; ovules 1-many; fruit a legume; endosperm mostly none.

Stamens distinct.

287. THERMOPSIS, 213.

Stamens monadelphous or diadelphous.

Anthers of two forms, round and oblong.

Leaves palmate with 5-11 leälèts; ; plänt not spiny.

Leaves with solitary leaflets; plant spiny. 289 . ULEX, 217. 
Anthers all alike.

Leaves palmate or trifoliolate.

Foliage glandular-dotted.

Foliage not glandular-dotted.

Flowers in heads.

Flowers in racemes.

Racemes close, spike-like; pods curved or twisted.

290. Psoralea, 218.

291. TRIFOliUM, 218.

Racemes loose, long; pods straight. 293. Melilotus, 222.

Leaves pinnate.

Leaves abruptly pinnate, usually with tendrils.

Style filiform, hairy near the tip only.

Style flattened, hairy on the inner side.

Leaves odd pinnate, without tendrils.

Pod a loment.

Pod not a loment.

Flowers in umbels or solitary; pods linear.

Flowers in spikes or racemes, rarely

294. ViCiA, 222.

295. LATHYRUS, 223.

296. Hedysarum, 225. solitary, then the pods not linear.

Keel of the corolla acute or subulate at the apex.

Keel of the corolla obtuse at the apex.

297. Hosackia, 225.

\section{THERMOPSIS.}

Perennial herbs; leaves alternate, palmately 3-foliolate, with large foliaceous stipules; flowers large, yellow, in terminal or axillary racemes; calyx campanulate, the lobes equal and separate or the two upper united; standard nearly orbicular, equalling the oblong wings and about equalling the keel; stamens 10, distinct; ovary sessile or short-stipitate; ovules numerous; pod sessile or short-stipitate in the calyx, flat, linear, straight or curved.

Thermopsis gracilis Howell. (T. montana ovata Robinson.) Stout, 60-100 $\mathrm{cm}$. high, the glabrous somewhat glaucous stems slightly branched above; leaflets oval, ovate or obovate, mostly obtuse, cuneate at base, 3-6 cm. long, glabrous above, pubescent beneath; stipules ovate or lanceolate, large; petioles about as long as the leaflets; raceme terminal, short-peduncled, $8-16 \mathrm{~cm}$. long; flowers yellow, somewhat whorled, stout-pedicelled; calyx pubescent, its teeth triangular, shorter than the tube; corolla nearly $2 \mathrm{~cm}$. long; pods pubescent, dark-colored, linear, slender-beaked, 5-10 cm. long, erect or ascending, 8-12seeded.

In open woods, Chehalis County, Washington, Lamb, and southwards; scarcely more than a subspecies of $T$. montana Nutt.

\section{LUPINUS. LUPINE.}

Annuals or herbaceous or shrubby perennials; leaves alternate or basal, palmately 5-13-foliolate; flowers showy, of ten whorled, 
in terminal spikes or racemes; calyx 2-lipped, the upper lip of ten bifid, the lower sometimes 3-toothed; standard orbicular with reflexed sides; wings obovate, united at the summit and enclosing the falcate keel; stamens united into a closed tube; ovary sessile; pod more or less flattish, leathery and hairy.

Annuals.

Corolla $15 \mathrm{~mm}$. long; pod short, ovate, villous, 1 or 2 seeded.

Corolla 6-8 mm. long; pods linear, silky, 4-6-seeded.

Bracts equalling or exceeding the calyx; plant succulent.

Bracts much shorter than the calyx; plants not succulent.

Flowers subsessile, $6 \mathrm{~mm}$. long.

Perennials.

Flowers distinctly pedicelled, $8 \mathrm{~mm}$. long. $\quad L$. bicolor.

L. microcarpus.

L. carnosulus.

Calyx saccate or spurred at base.

Calyx symmetrical or nearly so.

Pubescence thin, never silky or villous; leaves glabrous above.

Leaflets 10-16, very large, 6-14 cm. long; stems usually simple; pods loosely villous.

Leaflets 6-9, 4-9 cm. long; stems usually branched; pods thinly pubescent.

Pubescence either silky or villous.

Herbage more or less villous with loose hairs, never silky.

Keel ciliate; corolla 8-10 mm. long; alpine plant, $10-20 \mathrm{~cm}$. high.

Keel naked; corolla larger.

Corolla 15-18 $\mathrm{mm}$. long; pubescence long villous; somewhat fleshy plant of the seacoast.

Corolla 12-16 mm. long; pubescence thin, short-villous; subalpine plant.

Herbage silky, of ten silvery.

Stems dwarf, 7-15 cm. high; racemes short; high alpine species.

Leaflets 5-8, acutish; standard elliptical.

Leaflets 7-10, obtuse; standard orbicular.

Stems taller; racemes usually elongate.

Leaves mostly basal and the stems scapelike.

Pubescence very silky and silvery; pods not villous.

Pubescence somewhat loose and shaggy, not silvery; pods villous.

Leaves not mostly basal, the stems leafy.

L. laxiflorus.

L. micranthus.

L. volcanicus.

L. polyphyllus.

L. columbianus.

Keel narrow, bent at nearly a right angle, early exposed for much of its length; pubescence thin.

Stems tall, branched, $50-90 \mathrm{~cm}$. high; root not much thickened.

Stems usually simple, $20 \mathrm{~cm}$. high; root much thickened.

L. nootkatensis.

L. subalpinus.

L. lyallii.

L. breweri. 
Keel broader, only moderately falcate, only the tip exposed.

Stems woody at base; herbage very silvery.

L. holosericeus.

Stems wholly herbaceous; herbage not very silvery.

Leaflets $1-2.5 \mathrm{~cm}$. long; procumbent seashore species.

\section{L. littoralis.}

Leaflets 2.5-3.5 cm. long; erect subalpine plants.

L. alpicola.

Lupinus microcarpus Sims. Annual, villous with long hairs; stems erect, 10-60 cm. high; leaves mostly basal; stipules very slender; leaflets $7-11$, oblong, cuneate at base, obtuse, acute or emarginate, smooth above, villous beneath, 2-5 cm. long; flowers in whorls, short-pedicelled; bracts subulate, persisting; calyx villous, 2-lipped, the upper lip 2-toothed, the lower 3-toothed; corolla cream-colored, more or less deeply tinged with purple, $12-15 \mathrm{~mm}$. long; keel ciliate; pod villous.

In sandy ground, Vancouver Island to California; rare northward.

Lupinus carnosulus Greene. Annual, somewhat succulent; stems erect, 30-60 cm. high, usually simple; pubescence thin, appressed; leaflets 5-7, oblanceolate, obtuse, mucronate, pubescent on both sides, $2-3 \mathrm{~cm}$. long, on longer petioles; flowers verticillate, in a loose raceme; bracts mostly exceeding the calyx; corolla deep blue, 6-10 $\mathrm{mm}$. long; keel ciliate.

Willamette Valley, Howell, to Middle California.

Lupinus micranthus Dougl. Annual; herbage villous; stems erect, $15-30 \mathrm{~cm}$. high; leaflets $5-7$, linear or narrowly lanceolate, glabrous above, $8-20 \mathrm{~mm}$. long; petioles as long as the leaflets; racemes short; flowers nearly sessile; bracts shorter than the calyx; calyx bilabiate, the upper lip 2-toothed, the lower entire; corolla blue, 5-6 mm. long; keel ciliate; pods linear, pubescent, 5-7-seeded; seeds gray.

In dry open ground, Washington to California.

Lupinus bicolor Lindl. Very similar to L. micranthus; leaflets silky on both sides; flowers on pedicels $4 \mathrm{~mm}$. long; corolla larger, $8 \mathrm{~mm}$. long; seeds brown.

Fort Vancouver, Douglas, to California.

Lupinus laxiflorus Dougl. Rather slender, about $60 \mathrm{~cm}$. high; pubescence finely silky, but the plant green; leaflets 6-11, oblanceolate, obtuse or acute, silky on both sides, 3-4 cm. long; petioles slender, usually twice as long as the leaflets; racemes loose, $10-15 \mathrm{~cm}$. long; pedicels slender, 5-6 mm. long; calyx short, spurred at base; corolla about $1 \mathrm{~cm}$. long; standard glabrous or pubescent.

Open pine woods, rare in our limits.

Lupinus polyphyllus Lindl. Perennial; herbage green, sparsely pubescent; stems erect, $1-2 \mathrm{~m}$. high, one to several arising from the same root; leaflets of the lower leaves 10-16, lanceolate, 6-14 cm. long, glabrous above, silky pubescent beneath; stipules triangular-subulate, large; petioles long; racemes 20-40 $\mathrm{cm}$. long, densely flowered; flowers long-pedicelled; calyx silky, the lips entire; corolla violet-blue, $12-14 \mathrm{~mm}$. long; keel not ciliate; pods dark, loosely hairy.

In wet meadows, Vancouver Island to Oregon. A very showy plant, often cultivated.

Lupinus columbianus Heller. Perennial, with several stems usually arising from the same crown; pubescence thin, short and appressed; stems branched, $60-80 \mathrm{~cm}$. high; leaflets $6-9$, oblanceolate, mostly acute, 4-5 cm. 
long, about half as long as the petioles; principal racemes elongated and long peduncled; bracts subulate, longer than the calyx; upper calyx-lip entire or 2-toothed; corolla purplish-blue; keel ciliate; pods sparsely pubescent.

Common in open woods. This species has been much confused with the very different $L$. rivularis Dougl. of California.

Lupinus volcanicus Greene. Perennial, with villous pubescence; stems simple, leafy, 10-20 cm. high, erect; leaflets 7-9, oblanceolate, acute or obtuse, $2-2.5 \mathrm{~cm}$. long, about one half as long as the petioles; stipules subulate; racemes short; corolla blue, 8-10 mm. long; keel ciliate.

In volcanic sand on Mount Rainier at $2600 \mathrm{~m}$. altitude.

Lupinus nootkatensis Donn. Perennial; pubescence villous with long spreading hairs, but herbage green; stems stout, leafy, 50-60 cm. high; leaflets $6-8$, obovate-oblong, obtuse or glabrous above, shorter than the petioles; stipules lanceolate, large; flowers long-pedicelled, in loose racemes; calyx large, the upper lip 2-toothed, the lower 3-cleft; corolla blue-purple, $1.5 \mathrm{~cm}$. long; keel not ciliate; pods $4 \mathrm{~cm}$. long, appressed pubescent.

Near the sea coast, Alaska to Vancouver Island, British Columbia (Victoria, Macoun), and to be expected in Washington.

Lupinus subalpinus Piper \& Robinson. Erect or somewhat decumbent, sparsely villous; stems simple, $25-40 \mathrm{~cm}$. high, leafy; leaflets spatulate-oblanceolate, rounded or obtuse at the apex, villous beneath, sparsely so or rarely quite glabrous above, 3-4.2 cm. long; raceme terminal $10-15 \mathrm{~cm}$. long, manyflowered, borne on a stoutish peduncle $3-5 \mathrm{~cm}$. in length; pedicels slender, 4-8 $\mathrm{mm}$. long, spreading-pubescent; flowers large and showy; petals 12-16 $\mathrm{mm}$. long; standard glabrous; keel entirely glabrous or with traces of ciliation; pods linear-oblong, about $3.5 \mathrm{~cm}$. long, obliquely sharp-pointed, 7-9-seeded.

In mountain meadows, at about $1700 \mathrm{~m}$. altitude.

Lupinus lyallii Gray. Perennial from a stout woody caudex; herbage densely silvery silky; stems short, the leaves mostly basal; leaflets 5-6, oblanceolate to obovate, acute, $6-10 \mathrm{~mm}$. long; petioles 2-4 times as long as the leaflets; flowering stems erect or ascending, 10-20 cm. high, exceeding the leaves; racemes short and dense; calyx bilabiate, the upper lip 2-cleft, the lower 3-cleft; corolla deep blue, $10 \mathrm{~mm}$. long; keel ciliate; standard elliptical; pods silky.

At high altitudes in the Cascade Mountains, British Columbia to Oregon. First collected by Lyall on the 49th parallel of latitude.

Lupinus breweri Gray. Perennial from a branched woody base; herbage silvery silky with appressed hairs; leaves mostly basal; leaflets $7-10$, narrowly obovate, obtuse, $8-12 \mathrm{~mm}$. long; peduncles equalling or exceeding the leaves; racemes very short; calyx bilabiate, the upper lip 2-cleft, the lower 3-toothed; corolla blue, 6-8 mm. long; standard orbicular; keetciliate; pod oblong, silky.

Mount Hood, Howell, and south through the Cascade and Sierra Nevada Mountains at high altitudes.

Lupinus lepidus Dougl. Perennial from a stout taproot; pubescence very silvery and silky; leaves chiefly basal; leaflets $7-9$, narrowly oblanceolate, acute, $2-4 \mathrm{~cm}$. long, about one-third as long as the petiole; stems erect, 40-60 $\mathrm{cm}$. high, the narrow raceme elongated; bracts shorter than the calyx; calyx bilabiate, the upper lip 2-cleft, the lower entire; corolla purplish-blue, $10 \mathrm{~mm}$. long; keel ciliate; pods silky.

In dry prairies, British Columbia to California.

Lupinus aridus Dougl. Perennial, with a stout vertical root; pubescence coarse, loose, white or somewhat yellowish; leaves mostly basal; leaflets 5-7, oblanceolate, acute, 1-2 cm. long, about one-third as long as the petioles; flowering stems erect, $20-40 \mathrm{~cm}$. high, the raceme dense, rather conical; bracts 
subulate, shorter than the calyx; calyx bilabiate, the upper lip 2-cleft, the lower entire; corolla purple-blue, 6-10 mm. long; keel ciliate; standard glabrous, oblong-obovate; pods villous.

In dry prairies, Washington to California.

Lupinus albicaulis Dougl. Perennial, with several to many stems arising $8 / 2 / 20 \mathrm{Mt}$ Ad from a stout crown; pubescence mostly thin and appressed, somewhat velvety; 6000 of $E$ \& f stems leafy, branched, $50-90 \mathrm{~cm}$. high; leaflets 5-9, oblanceolate, acute, thinly silky on both sides, $3-5 \mathrm{~cm}$. long, about as long as the petioles; principal raceme elongated, often $30 \mathrm{~cm}$. long, the others short; bracts subulate, 4-6 $\mathrm{mm}$. long, equalling the pedicels; calyx silky, the upper lip 2-cleft, the lower entire; corolla purple, about $12 \mathrm{~mm}$. long; keel much elongated, bent at right angles and early exposed, not ciliate; pods linear, villous.

Dry ground, Washington to California.
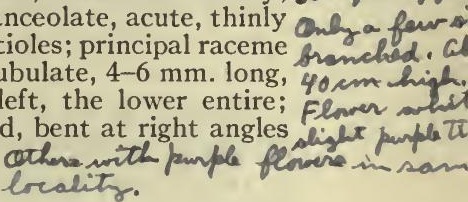

Lupinus gormani Piper. Perennial with a very large woody root; herbage silvery-pubescent; stems erect, $20 \mathrm{~cm}$. high; leaflets $5-7$, oblanceolate, obtuse or acute, $2-2.5 \mathrm{~cm}$. long, thinly sericeous on both sides; petioles shorter than the leaflets; stipules subulate; racemes few-Hlowered; pedicels $3-4 \mathrm{~mm}$. long; calyx pubescent, bilabiate, the upper lip 2-toothed, the lower entire; corolla violet, $10 \mathrm{~mm}$. long; standard orbicular, glabrous; keel strongly falcate, not ciliate; ovary hairy, 6-ovuled.

Known only from the Three Sisters, Oregon, where it was collected by Gorman.

Lupinus holosericeus Nutt. Stems much branched, decumbent and shrubby at base, $30-50 \mathrm{~cm}$. high, leafy; pubescence very silvery and silky; leaflets 5-9, lanceolate, acute, $2-5 \mathrm{~cm}$. long, usually shorter than the petiole; stipules subulate; flowers pedicelled, in racemes $10-30 \mathrm{~cm}$. long; calyx silky, the upper lip 2-cleft, the lower entire; corolla blue, 10-12 mm. long; keel ciliate; pods silky, 3-5-seeded.

Rocks near the falls of the Willamette River, where it was first found by Nuttall, and southward. A very handsome species on account of its silvery foliage and deep blue flowers.

Lupinus littoralis Dougl. Perennial; pubescence mostly silky and appressed; stems decumbent, $30-90 \mathrm{~cm}$. long; leaflets $5-8$, obovate, acute, silky on both sides, $10-25 \mathrm{~mm}$. long, shorter than the petioles; stipules subulate; racemes short; pedicels 5-6 mm. long; calyx without bractlets, the lip entire or nearly so; corolla blue, $12 \mathrm{~mm}$. long; keel ciliate; pods linear, 10-12-seeded.

Common on high sandy beaches along the ocean coast, Vancouver Island to California. The roots are said to have been used by the Indians for food.

Lupinus alpicola Henderson. Stems several from a thickish caudex, scaly at the base, erect, $30-50 \mathrm{~cm}$. high, simple or nearly so, leafy, covered by a fine short closely appressed pubescence; petioles slender, erect, all but the upper exceeding the 7 or 8 leaflets, these linear-oblanceolate, acute, finely sericeouspubescent on both surfaces, $2.6-3.6 \mathrm{~cm}$. long, $2-5 \mathrm{~mm}$. broad; racemes mostly terminal on the stems, shortly peduncled, loosely flowered, 7-10 cm. long; bracts lanceolate, sericeous-pubescent, rather short, when persisting not equalling the tomentulose pedicels; petals purplish blue; standard suborbicular, sparingly villous near the middle dorsally; keel strongly ciliated; pods lanceoblong, acute, silky, $2.4-3 \mathrm{~cm}$. long, 4 or 5-seeded.

Mount Adams, Henderson, Suksdorf; north side of Mount Hood, Oregon; Howell.

\section{ULEX.}

Low densely branched shrubs with leaves mostly reduced to phyllodes and spine-like; calyx deeply 2-lipped; standard ovate; 
wings and keel oblong, of about equal length; stamens monadelphous; pod short-oblong.

Ulex europaeus L. Gorse. Whin. A spiny much-branched shrub, about $1 \mathrm{~m}$. high; leaves mostly spiny, the lowest sometimes foliaceous, lanceolate; flowers bright yellow, solitary.

A European plant established in a few places.

\section{PSORALEA.}

Perennial herbs, usually glandular-dotted; leaves mostly 3-5foliolate, with stipules; flowers in spikes or racemes; calyx-lobes 5 , the lower longest; corolla papilionaceous; stamens 10, diadelphous or sometimes monadelphous; anthers of two kinds; ovary sessile or short-stalked, 1-ovuled; pod seldom longer than the calyx, thick, of ten wrinkled, indehiscent, 1-seeded.

Psoralea physodes Dougl. Erect or ascending, bushy, $30-50 \mathrm{~cm}$. high, sparsely hairy; leaflets ovate, acute, $3-4 \mathrm{~cm}$. long, somewhat glandular; peduncles as long as or longer than the leaves; flowers in dense short racemes; bracts small; calyx black-hairy, $8-10 \mathrm{~mm}$. long, in age becoming larger and inflated; corolla dirty-white, the keel tipped with purple; pod membranaceous, pubescent, suborbicular, enclosed in the calyx.

In dry open woods, common. The dried leaves are sometimes used for tea.

\section{TRIFOLIUM. Clover.}

Tufted or diffuse herbs; leaves mostly palmately, sometimes pinnately, 3-foliolate; stipules united with the petiole; flowers in heads or in umbel-like heads; calyx-teeth 5 , nearly equal; petals more or less persistent, the claws of all but the standard united more or less below the stamen-tube; stamens 10, diadelphous or the tenth only partly separate; pod small and membranous, 1-6-seeded, included in the calyx.

Head subtended by an involucre.

Corolla becoming conspicuously inflated, yellowish.

Corolla not becoming inflated.

Involucre not deeply cleft, its lobes serrate or entire; flowers white or pale pink; annuals.

Glabrous; calyx teeth slender and branched.

Villous; calyx teeth scarious-margined.

Involucre merely basal.

Involucre nearly enclosing the head.

T. flavulum.

ucre deeply cleft, the lobes laciniately toothed; flowers purple.

Perennial with creeping rootstocks.

Annuals.

Stems erect; calyx lobes of ten 3-toothed. T. tridentatum.

Stems decumbent; calyx lobes usually entire.

Leaflets linear.

Leaflets obovate or obcordate.

T. cyathiferum.

T. microcephalum.

T. microdon.

T. fimbriatum.

T. oliganthum.

T. variegatum.

Head not subtended by an involucre.

Perennials with thick roots or creeping rootstocks. 
Heads on axillary peduncles; flowers pedicelled.

Flowers white; stems creeping.

Flowers pink; stems procumbent.

Heads on terminal peduncles; flowers sessile.

Calyx-teeth plumose.

Calyx-teeth not plumose.

Flowers red; stipules aristate.

Flowers whitish; stipules not aristate.

Annual; roots fibrous.

Calyx-teeth plumose.

Heads ovate; flowers dark purple. T. albopurpureum.

Heads oblong; flowers pink.

Calyx-teeth not plumose.

Corollas yellow, becoming papery in age.

Heads 20-40-flowered; standard distinctly striate.

Heads 3-15-flowered; standard faintly striate.

Corollas pink, not becoming papery.

Teeth of the calyx scarious-margined and ciliate.

Teeth of the calyx not scarious-margined nor ciliate.

Leaflets shallowly notched at apex; calyx glabrous.

T. arvense.

T. repens.

T. hybridum.

$T$. eriocephalum.

$T$. pratense.

$T$. longipes. Leaflets deeply notched at apex; calyx hairy.

\section{T. procumbens.}

T. dubium.

T. ciliolatum.

T. gracilentum.

T. hallii.

Trifolium flavulum Greene. Annual, glabrous and somewhat fleshy; stems $20-40 \mathrm{~cm}$. high; leaflets obovate, obtuse, denticulate; stipules ovate, entire; heads globose, large, the involucre cleft into entire acuminate lobes; flowers large, reddish or yellowish, $2-2.5 \mathrm{~cm}$. long; calyx-teeth triangular, acute.

Sparingly introduced from California. Perhaps not specifically distinct from $T$. fucatum Lindl.

Trifolium cyathiferum Lindl. Annual, glabrous; stems weak, ascending, 10-30 cm. high; leaflets oblanceolate or obovate, serrulate, acute, obtuse or truncate, cuneate at base, $1-2 \mathrm{~cm}$. long; petioles slender; stipules ovate or lanceolate, laciniate; peduncles longer than the leaves; heads commonly 1.5 $\mathrm{cm}$. broad; involucre large and conspicuous, whitish with green margin, many-nerved, with short sharply-toothed lobes; flowers whitish; calyx membranous, prominently 5 -nerved, the nerves prolonged and branched, equalling the corolla; pod 2-seeded.

Very rare in our limits but common east of the Cascade Mountains; Lake Crescent, Webster; Vancouver Island, British Columbia, Macoun.

Trifolium microcephalum Pursh. Annual, erect or spreading, soft villous; stems $5-30 \mathrm{~cm}$. long; leaflets obovate, usually retuse, serrulate, $8-12 \mathrm{~mm}$. long; petioles slender; stipules entire, acuminate; heads small, many-flowered; involucre membranaceous, about 9-lobed, the lobes 3-nerved, entire; calyx hairy, the teeth subulate; corollas pale pink; pods glabrous, 1 -seeded.

In sandy soil, common.

Trifolium microdon Hook. \& Arn. Very much like T. microcephalum but the cup-shaped involucre nearly enclosing the head; calyx glabrous. Sandy soil, near the seacoast.

Trifolium fimbriatum Lindl. ( $T$. spinulosum Dougl.) Perennial by creeping rootstocks, glabrous throughout; branches prostrate or ascending, 
$20-40 \mathrm{~cm}$. long; leaflets oblong-obovate to oblanceolate, spinulose-denticulate, the lower obtuse or even retuse, the upper acute or acuminate, mostly 1-3 $\mathrm{cm}$. long; stipules triangular, acuminate, with a few teeth; heads subglobose, 1-2 cm. broad; involucre short, laciniately parted; calyx lobes unequal, subulate, somewhat spiny, 2-3 times as long as the tube; petals purple with paler or white tips.

In wet places, especially near the seashore.

Trifolium tridentatum Lindl. Annual, glabrous; stems erect, very slender, $10-40 \mathrm{~cm}$. high; leaflets lance-linear, acute, spinulose-serrulate, $2-5 \mathrm{~cm}$. long; stipules lanceolate, acuminate, the upper ones laciniate; heads globose, the largest $2 \mathrm{~cm}$. broad; involucre laciniately cleft, shorter than the head; calyxlobes subulate with a tooth on each side near the base; corolla purple and white.

In dry open ground, British Columbia to California. First collected by Douglas on the Columbia River.

Trifolium oliganthum Steud. Annual, glabrous; stems very slender, erect or ascending, usually branched from the base; stipules laciniately cleft; leaflets serrulate, the lower obovate or oblanceolate, obtuse or retuse, the upper linear or linear-lanceolate, acute or acuminate; stipules laciniately cleft; heads very small, 5-7-flowered; involucre small, deeply cleft; calyx-teeth subulate, rigid, entire; corolla purple and white.

In moist places, common. First collected by Nuttall at the mouth of the Willamette River.

Trifolium variegatum Nutt. Annual, glabrous throughout; stems decumbent, $10-30 \mathrm{~cm}$. long, branching, leafy; leaflets obovate to obcordate, minutely and sharply serrulate, veiny, 6-12 mm. long; stipules broad, fringed-toothed; peduncles very slender, longer than the leaves; heads small, 4-12-flowered; involucre shorter than the flowers, campanulate, fringe-toothed; calyx glabrous, its teeth subequal, subulate, longer than the tube; petals purple with white tips, pods 2-seeded.

In moist ground, common.

Trifolium repens L. White Clover. Perennial, glabrous or sparsely pubescent, with creeping stems $10-30 \mathrm{~cm}$. long, which root at the nodes; leaflets obovate, obtuse or notched at apex, cuneate at base, denticulate, 1-2 $\mathrm{cm}$. long; petioles elongated; stipules narrow, acute; peduncles longer than the leaves; head globose; flowers white, 6-10 $\mathrm{mm}$. long, pedicelled, at length reflexed; calyx-teeth acuminate, shorter than the tube.

Introduced from Europe, common.

Trifolium hybridum L. Alsike Clover. Perennial, erect or decumbent, not creeping, glabrous or nearly so, the stem $30-60 \mathrm{~cm}$. long; leaflets obovate, obtuse or notched, cuneate at base, sharply serrulate, 1-2.5 cm. long; petioles about as long as the leaflets; stipules membranous, ovate-lanceolate, acuminate; peduncles elongated; heads globose; flowers pink or pinkish, 6-8 $\mathrm{mm}$. long, on slender pedicels, at length reflexed; calyx-teeth subulate, about as long as the tube, much shorter than the corolla.

Introduced from Europe, common.

Trifolium eriocephalum Nutt. Perennial, villous-pubescent; root stout, fusiform; stems erect, 15-20 cm. high; leaflets oblong to oblong-lanceolate, serrulate, 2-5 cm. long; stipules lanceolate, acuminate; heads dense, ovoid to subglobose; flowers whitish, at length reflexed; calyx-teeth very plumose.

In gravelly soil, in prairies.

Trifolium pratense L. Red Clover. Perennial, erect or decumbent, rarely branched, $20-40 \mathrm{~cm}$. high, somewhat pubescent throughout; leaflets elliptic 
or obovate, obtuse or rarely emarginate, denticulate, $1-4 \mathrm{~cm}$. long, frequently dark-spotted near the middle; petioles short; heads globose or ovoid, sessile or nearly so, $2 \mathrm{~cm}$. long; flowers red, $10-12 \mathrm{~mm}$. long; calyx-teeth subulate, shorter than the corolla.

Introduced and common. Native of Europe.

Trifolium longipes Nutt. Perennial, glabrous or nearly so; root stout, fusiform; stems erect or ascending, $10-30 \mathrm{~cm}$. high; leaflets ovate to lanceolate, entire or minutely denticulate, obtuse; stipules ovate to lanceolate, acute, entire; peduncles exceeding the leaves; heads ovoid to subglobose, dense, 25-40-flowered, the flowers not becoming reflexed; calyx hairy, the teeth subulate, not plumose; corolla white; ovules $2-5$.

In moist places in the mountains.

Trifolium albopurpureum T.\& G. Annual, villous-pubescent; stems slender, $10-30 \mathrm{~cm}$. high, erect or ascending; stipules ovate-lanceolate, acuminate, entire; leaflets oblong, cuneate at base, obtuse or emarginate, denticulate, $5-12 \mathrm{~mm}$. long; heads ovoid, dense, long-peduncled, the flowers not becoming reflexed; calyx-teeth slender, plumose, the lowest one longest and exceeding the dark purple corolla; pod 1 -seeded.

In dry ground, Vancouver Island, British Columbia, to California.

Trifolium arvense L. Rabbit's Ear Clover. Annual, erect, somewhat silky-pubescent throughout, $10-30 \mathrm{~cm}$. high; leaflets linear or oblanceolate, obtuse or notched, denticulate near the apex, $1-2 \mathrm{~cm}$. long; petioles mostly shorter than the leaflets; stipules narrow, with long subulate tips; peduncles $2-4 \mathrm{~cm}$. long; head oblong, dense, $10-25 \mathrm{~mm}$. long, without an involucre; calyx plumose, the subulate lobes longer than the tube and the pink or whitish corolla.

Sparingly introduced from Europe.

Trifolium procumbens L. Hop Clover. Annual, pubescent; stems slender, spreading or ascending, 8-60 cm. long; leaflets cuneate-obovate, emarginate, denticulate; stipules ovate, ciliate; flowers yellow, at length reflexed, persistent and papery, $4 \mathrm{~mm}$. long; standard not becoming folded over the pod at maturity.

Common in fields and along roadsides, introduced from Europe.

Trifolium dubium Smith. Very similar to $T$. procumbens, but smaller in all its parts; flowers $3 \mathrm{~mm}$. long; standard persistent and folded over the pod.

In fields, introduced from Europe.

Trifolium ciliolatum Benth. Annual, glabrous or nearly so; stems erect, of ten branched from the base, 10-40 cm. high; stipules lanceolate, acuminate; leaflets oblong to obovate, obtuse or emarginate, serrulate, 1-2 cm. long; heads axillary, globose, $5-10 \mathrm{~mm}$. in diameter; flowers pedicelled, reflexed at maturity; calyx teeth unequal, lanceolate, acuminate, ciliolate on the scarious margins; corolla pink or purplish, $6 \mathrm{~mm}$. long.

Prairies, Washington to California.

Trifolium gracilentum T. \& G. Annual, glabrous or nearly so; stems slender, erect, $10-30 \mathrm{~cm}$. high; leaflets cuneate-oblong to obovate, serrulate, 5-20 mm. long; stipules lanceolate, the upper ones broader, acuminate; heads axillary, globose, small; flowers pedicelled, reflexed in age; calyx glabrous, the teeth subulate; corolla pink.

Prairies and open places. Vancouver Island, British Columbia, to California.

Trifolium hallii Howell. Very similar to $T$. gracilentum but somewhat pubescent and slightly glaucous; leaflets linear to oblong or cuneate, obcordate, denticulate; heads 10-30-flowered; calyx hairy.

In dry or sandy soil, Washington to California. 
292. MEDICAGO.

Annual or perennial herbs with small trifoliolate leaves; leaflets toothed; flowers small, yellow or violet, in axillary spikes or heads; pods 1-several-seeded, curved or coiled.

Perennial; flowers violet.

M. sativa.

Annual; flowers yellow.

Pod 1-seeded, curved, not spiny.

Pod several-seeded, coiled, spiny on the edge.

M. lupulina.

M. hispida.

Medicago sativa L. Alfalfa. Erect smooth much branched perennial; leaflets obovate-oblong, toothed especially near the apex; flowers violet or blue, in spike-like racemes; pods coiled.

Sparingly introduced in waste places.

Medicago lupulina L. Black Medick. Yellow Trefoil. Low pubescent decumbent branched annual; leaflets cuneate-obovate, toothed at the apex; flowers yellow, in short spikes; pods curved, black, slightly hirsute, 1-seeded.

Abundantly introduced in waste places.

Medicago hispida denticulata (Willd.) Urban. Bur Clover. Annual, glabrous; stems prostrate; leaflets obovate, notched; flowers yellow, in 3-5flowered heads; pods loosely coiled, deeply reticulated, the edge with śpines as long as one-half the width of the windings.

Roadsides and fields, common. The prickles on the pod vary greatly in length and in one form, $M$. hispida apiculata (Willd.) Urban, are only as long as the thickness of the windings.

\section{MELILOTUS.}

Annual or biennial sweet-scented herbs; leaves pinnately 3 -foliolate; leaflets denticulate; flowers in racemes; calyx campanulate, with short equal teeth; corolla deciduous, free from the stamen-tube; stamens diadelphous; anthers all alike; ovary sessile or stipitate, few-ovuled; pod coriaceous, 1-2-seeded.

Melilotus alba Desr. Sweet Clover. Biennial, stout, erect, branching, 1-2 m. high, finely puberulent or nearly glabrous; leaves slender-petioled; leaflets oblong or obovate, denticulate, mostly truncate at apex, 1-2 cm. long; stipules subulate; racemes slender, 10-20 cm. long; flowers white, sweetscented, 4-5 $\mathrm{mm}$. long, reflexed on short pedicels; calyx-teeth subulate, as long as the tube; pod ovoid, $2-3 \mathrm{~mm}$. long.

Introduced in waste ground.

294. VICIA. VETCH.

Climbing or trailing herbaceous vines; leaves pinnate, tendrilbearing, with half-sagittate or entire stipules; flowers solitary or in loose peduncled axillary racemes; calyx 5-cleft or toothed, unequal, the two upper teeth often shorter or the lowest longer; wings adherent to the short keel; stamens diadelphous or nearly so; style filiform, hairy near the tip only ; ovary 2-many-ovuled; pod flat, 2-valved, 2-several-seeded.

Flowers axillary, solitary or in twos, nearly sessile.

Leaflets oblong to ovate; pods brown.

Leaflets linear to linear-oblong; pods black.

V. sativa.

$V$. angustifolia. 
Flowers in spikes or racemes on axillary peduncles.

Annuals; peduncles few-flowered.

Perennials; peduncles mostly many-flowered.

Flowers ochroleucous or tawny.

Flowers violet or bluish-purple, rarely white.

Raceme 1-sided, densely 15-40-flowered.

Raceme loosely 5-20-flowered, not 1 -sided.

V. hirsuta.

$V$. gigantea.

V. cracca.

V. americana.

Vicia sativa L. Common Vetch. Tares. Pubescent or glabrous; stems erect, $30-60 \mathrm{~cm}$. high; leaflets 5-7 pairs, variable in form, obovate, oblong or oblanceolate, usually notched and mucronate; flowers violet-purple, $2-3 \mathrm{~cm}$. long; pods brown, $4-8 \mathrm{~cm}$. long; seeds somewhat compressed.

Introduced in waste places and cultivated.

Vicia angustifolia (L.) Roth. Much like V. sativa, but the leaflets narrow, linear; flowers 1-1.8 cm. long; pods black, 4-6 cm. long; seeds globose.

Introduced from Europe.

Vicia hirsuta (L.) Koch. Annual, glabrous or nearly so; stems very slender, 30-60 cm. high; leaflets 6-8 pairs, oblong or linear, obtuse; flowers very small, $3 \mathrm{~mm}$. long, whitish or bluish, in small racemes.

Sparingly introduced.

Vicia gigantea Hook. Somewhat pubescent, rather succulent, drying black; stems about $1 \mathrm{~m}$. high; leaflets $10-15$ pairs, oblong, obtuse, mucronate; racemes close, 5-20-flowered; corolla ochroleucous.

In moist woods, common. First found on the Columbia River by Douglas and by Scouler.

Vicia cracca L. Perennial, soft pubescent; stems stout, $30-90 \mathrm{~cm}$. high; leaflets 20-24, oblong or lanceolate, mucronate; racemes dense, one-sided; flowers blue or purplish.

Whatcom County, Washington, Gardner, Suksdorf.

Vicia americana Muhl. Perennial, stout or slender, 30-100 cm. high, nearly glabrous; leaflets 4-8 pairs, usually elliptic or ovate, obtuse or truncate, mucronulate, entire or toothed above, glabrous above, minutely puberulent beneath, about $2 \mathrm{~cm}$. long; tendrils well developed; stipules deeply toothed; peduncles usually shorter than the leaves, 4-8-flowered; flowers purple-violet, $15-20 \mathrm{~mm}$. long, short-pedicelled; calyx-tube campanulate with short broad unequal teeth, somewhat pubescent; pods glabrous, $2-4 \mathrm{~cm}$. long, 6-8 $\mathrm{mm}$. broad.

In thickets, common.

Vicia americana minor Hook. ( $V$. americana linearis Wats.) Leaflets linear, acute.

In dry ground, infrequent.

295. LATHYRUS. VETCHLING.

Mostly smooth perennial herbaceous vines or erect herbs; leaves pinnate, mostly with tendrils or tendrils much reduced or wanting; flowers in racemes or sometimes solitary; peduncles usually equalling or exceeding the leaves and several-flowered; calyx-teeth nearly equal or the upper ones somewhat shorter than the lower; corolla rather larger than in Vicia; stamens diadelphous or monadelphous below; style dorsally flattened near the top, hairy on the inner side; ovules generally numerous; pod flat or terete, 2-valved. 
Herbage densely silky-villous; tendrils none.

L. littoralis.

Herbage glabrous or if pubescent not villous.

Plants erect; tendril wanting or much reduced.

Flowers solitary, rarely 2 .

Flowers 5-7 to each raceme.

L. torreyi.

L. nuttallii.

Plants climbing by simple or 3-forked tendrils.

Stems wing-margined.

Stems wingless.

L. paluster.

Stipules narrow, semi-sagittate; leaves coriaceous.

Leaflets cuspidate, glabrous.

Leaflets not cuspidate, pubescent.

L. pauciflorus.

Stipules large, broad, semi-hastate; leaves membranaceous.

Flowers yellowish, becoming ochraceous.

Flowers blue-purple.

Leaflets thin, 5-8 pairs.

Leaflets thickish, 3-5 pairs.

L. coriaceus.

L. sulphureus.

L. polyphyllus.

L. maritimus.

Lathyrus littoralis (Nutt.) Endl. Herbage densely silky-villous; stems terete, weak and decumbent, 15-60 cm. long; leaflets 1-3 pairs, the lateral ones oblong, cuneate at base, 10-12 $\mathrm{mm}$. long, the terminal one linear and much smaller; stipules entire, longer than the leaflets; tendrils none; peduncles 2-7-flowered; calyx-teeth subequal, lanceolate, acute, as long as the tube; corolla violet-purple; pods villous, $3-4 \mathrm{~cm}$. long.

Common along the ocean coast; first collected and described by $N$ uttall from the mouth of the Columbia River.

Lathyrus torreyi Gray. Herbage sparsely villous; stems terete, erect, 15-40 cm. high; leaflets 4-7 pairs, oblong or ovate, mucronate, 5-12 mm. long, the terminal one often wanting; stipules semi-sagittate, narrow, entire, acuminate; peduncles 1 -flowered or rarely 2 -flowered, much shorter than the leaves; calyx-teeth subulate, the three lower ones longer than the tube; corolla $15 \mathrm{~mm}$. long; standard bluish-purple, the other petals whitish; pods narrow, pubescent.

In open woods, Washington to northern California, rather local.

Lathyrus nuttallii.Wats. Somewhat pubescent; stems slender, angled, 30-90 cm. high, ascending or erect; tendrils oblong to ovate, thin, cuspidate, pubescent beneath; stipules semi-sagittate; peduncles 5-7-flowered, about as long as the leaves; calyx pubescent, its teeth unequal, the lower one longest; corolla purple, $12-15 \mathrm{~mm}$. long; pods glabrous.

In open woods, rather scarce.

Lathyrus paluster L. Glabrous or nearly so; stems slender, wing-margined, erect or ascending, 30-90 cm. high; tendrils well developed; leaflets $2-4$ pairs, linear to narrowly oblong, firm, acute, $2-4 \mathrm{~cm}$. long; stipules sagittate, narrow, acuminate; peduncles 3-6-flowered; calyx-teeth unequal, the longer lower ones about as long as the tube; corolla purple, $2-2.5 \mathrm{~cm}$. long; pods glabrous, 5 cm. long.

In marshes near the seashore, not common.

Lathyrus pauciflorus Fernald. Glabrous throughout, $60-90 \mathrm{~cm}$. high; stems angled; leaflets 3-6 pairs, oblong-elliptic, thickish, prominently veined, paler beneath, acute and cuspidate, rounded at base, $2-4 \mathrm{~cm}$. long; stipules about half as long as the adjacent leaflets; tendrils simple or branched; peduncles exceeding the leaves, 3-5-flowered; flowers violet, about $2 \mathrm{~cm}$. long; calyx-teeth slightly pubescent, about as long as the tube; pods smooth, 4-6 cm. long.

Rare in our limits; Nisqually Valley, Washington, Allen; Vancouver Island, British Columbia, Macoun. 
Lathyrus coriaceus White. Perennial, glabrous, pale green; stems $10-30$ $\mathrm{cm}$. high, terete; stipules semi-sagittate, acuminate, not more than half as long as the leaflets; leaflets $6-12$, elliptical, obtuse, firm, 3-6 cm. long; raceme shorter than its leaf, 3-10-flowered; calyx-teeth subequal, acute, shorter than the tube; corolla violet-purple.

Seattle, $O$. A. Piper. A characteristic species of the sagebrush region, whose occurrence at Seattle is remarkable.

Lathyrus sulphureus Brewer. Glabrous, glaucescent; stems short, angled, $60-120 \mathrm{~cm}$. high, erect or ascending; leaflets 3-5 pairs, ovate to oblong, acutish, 2-4 cm. long; stipules broad, somewhat dentate; peduncles 6-15-flowered, about as long as the leaves; calyx-teeth very unequal, the lower ones largest; corolla at first pinkish-yellow, quickly fading to ochraceous; pods glabrous.

In open coniferous woods, not rare. In contrast to $L$. polyphyllus which grows in similar locations this fruits abundantly. The flowers are never "sulphur-yellow."

Lathyrus polyphyllus Nutt. Glabrous; stems stout, angled, erect or nearly so, $60-100 \mathrm{~cm}$. high; tendrils small; leaflets 5-8 pairs, thin, oblong to ovate, obtuse, paler beneath, $2-5 \mathrm{~cm}$. long; stipules broad, nearly as large as the leaflets, more or less dentate; peduncles $6-10$-flowered, shorter than the leaves; calyx-teeth ciliate, the two upper triangular and shorter than the subulate lower ones; corolla purple, $12-15 \mathrm{~mm}$. long; pods glabrous.

Very abundant in open coniferous woods. Few of the pods develop to maturity.

Lathyrus maritimus (L.) Bigel. Beach Pea. Pale and usually glabrous; stems short, 30-90 cm. long, decumbent; leaflets 3-5 pairs, thick, oblong to ovate, mostly obtuse, $2-5 \mathrm{~cm}$. long; stipules ovate, nearly as large as the adjacent leaflets, acute, the lower lobe of ten dentate; peduncles 6-10-flowered; calyx-teeth unequal, the upper two triangular, the others broadly subulate; corolla purple, $2-2.5 \mathrm{~cm}$. long; pods $4-5 \mathrm{~cm}$. long, nearly glabrous.

Common on seabeaches, the green seeds sometimes eaten like green peas.

\section{HEDYSARUM.}

Perennial herbs with odd-pinnate leaves; calyx 5-cleft, the lobes awl-shaped and nearly equal; keel nearly straight, obliquely truncate, not appendaged, longer than the wings; stamens diadelphous, 9 and 1; pod a loment, flattened, composed of several symmetrical separable roundish joints connected in the middle.

Hedysarum occidentale Greene. Glabrous; stems 30-60 cm. high; leaflets 13-21, oblong or lanceolate; stipules scaly; flowers purple, deflexed.

Abundant in the Olympic Mountains. Scarcely different from the eastern H. americanum (Michx.) Britt.

\section{HOSACKIA.}

Herbs or shrubs; leaves pinnate, 1-many-foliolate; stipules minute and gland-like or spine-like; flowers yellow or reddish, solitary or in umbels; calyx-teeth nearly equal; petals free from the diadelphous stamens; standard ovate or roundish; pod linear, compressed or somewhat terete, sessile, several-seeded. 
Annuals; flowers solitary or sometimes two on the peduncles.

Peduncles very short, the flowers nearly sessile.

H. denticulata.

Peduncles usually exceeding the leaves.

Flowers 3-4 mm. long; leaflets oblong to ovate, usually glabrous.

Flowers 5-6 mm. long; leaflets ovate to lanceolate, usually villous.

H. parviflora.

H. americana.

Perennials; flowers in umbels.

Pods curved, pubescent, 1 or 2 -seeded; flowers yellow.

Pods straight, glabrous, many-seeded; flowers at least in part not yellow.

Leaflets 9-15; flowers purple.

Leaflets 5-9, glabrous or nearly so.

Peduncles usually naked; corolla with yellow standard and white wings.

Peduncles with a bract at the umbel; corolla with yellow standard and purple wings.

H. decumbens.

H. crassifolia.

H. bicolor.

H. gracilis.

Hosackia denticulata Drew. Nearly glabrous; stems erect, $15-40 \mathrm{~cm}$. high; leaflets 2-6, obovate or oblanceolate, thick; peduncles shorter than the leaves; flowers solitary; calyx-lobes denticulate; petals yellow or reddish.

In low ground, not common.

Hosackia parviflora Benth. Glabrous; stems slender, 10-20 cm. high, erect or ascending; leaflets 3-5, mostly oblong, $12-15 \mathrm{~mm}$. long; flowers very small, $4 \mathrm{~mm}$. long, solitary or in twos; petals yellow or the standard pinkish.

In dry soil, common.

Hosackia americana (Nutt.) Piper. Annual, erect, usually branched, 30-60 $\mathrm{cm}$. high; leaves 3 -foliolate, or the upper 1 -foliolate, nearly sessile; leaflets ovate or lanceolate, silky-pubescent, acuminate, stalked, 6-20 mm. long; stipules gland-like, dark; peduncles as long as or longer than the leaves; flowers pink, 4-6 mm. long; calyx villous, the slender lobes twice as long as the tube, nearly equalling the corolla; pod linear, narrow, often reflexed, glabrous and shining, 2-3 cm. long.

Common and very variable.

Hosackia decumbens Benth. Perennial, many-stemmed from a thick woody root, villous and more or less tomentose; stems decumbent, branched, 30-60 cm. long; leaflets 5-7, oblong to obovate, cuneate at base, mostly acute, 6-10 mm. long; stipules minute, spine-like, deciduous; peduncles scarcely longer than the leaves; flowers yellow, in 5-10-flowered umbels, each umbel with a 1-3-foliolate bract; calyx silky, the teeth as long as the tube; pods falcate, pubescent, mostly 2-seeded.

In dry prairies.

Hosackia crassifolia Benth. Glabrous; stems erect, $30-60 \mathrm{~cm}$. high; leaflets $9-15$, oblong or obovate; flowers dull purple, in umbels; pods thick, $5 \mathrm{~cm}$. long.

In open pine woods, Mason County, Washington, and southward.

Hosackia bicolor Dougl. Perennial, glabrous or nearly so throughout, erect or decumbent, 30-50 cm. high, stout; leaflets 5-9, obovate, mostly obtuse, cuneate at base, $1.5-2 \mathrm{~cm}$. long; stipules broad, scarious; peduncles exceeding the leaves; flowers nearly sessile, spreading, 3-7 in an umbel; calyx about $6 \mathrm{~mm}$. long, the teeth shorter than the campanulate tube; corolla yellow, the wings white, 2-2.5 cm. long; pod linear, narrow, glabrous, 4-6 cm. long.

In wet ground, not rare.

Hosackia gracilis Benth. Glabrous; stems weak, decumbent, $15-30 \mathrm{~cm}$. 
long; leaflets 5-7, obovate or oblong-obovate; flowers in umbels; calyx-teeth as long as the tube; standard yellow, the wings and keel rose-colored; pod short.

In moist soil, near the seacoast, infrequent.

\section{OXYTROPIS.}

Low tufted perennials with very short stems and a thick root or rootstock; leaves pinnate, of many leaflets; flowers in a head or short spike on a scape-like peduncle; keel tipped with a sharp point or appendage; otherwise similar to Astragalus; pod often more or less 2-celled by the intrusion of the ventral suture.

Leaflets 6-8 mm. long, crowded, densely appressed canescent on both sides.

Leaflets $8-12 \mathrm{~mm}$. long, not crowded, thinly appressed canescent becoming glabrate above.

O. luteolus.

O. cusickii.

Oxytropis luteolus (Greene) Piper n. comb. (Aragallus luteolus Greene.) Loosely appressed canescent; leaflets close together, in 8-12 pairs, ellipticlanceolate, acutish, 4-6 mm. long; stipules scarious, ovate, acute; flowering stems $10-20 \mathrm{~cm}$. high, erect, bearing spikes $1-3 \mathrm{~cm}$. long; bracts oval, half as long as the calyx; corolla short-cylindric, canescent or with a few black hairs intermixed; corolla pale yellow, $15 \mathrm{~mm}$. long.

Olympic Mountains, head of Elwha River, Elmer.

Oxytropis cusickii Greenman. Loosely appressed villous; leaflets in 8-15 pairs, oblong-lanceolate, acute, $7-15 \mathrm{~mm}$. long; stipules scarious, ciliate; scapes exceeding the leaves, $10-20 \mathrm{~cm}$. high; spike dense, $2-5 \mathrm{~cm}$. long; bracts lanceolate, obtusish, half as long as the calyx; flowers nearly sessile; calyx cylindric, appressed pubescent with white hairs intermixed with black ones; corolla whitish, 12-15 mm. long; pods cylindric, 1-1.5 cm. long, 2-celled.

In the Olympic, Cascade and Blue Mountains, rare.

\section{ASTRAGALUS.}

Chiefly perennial herbs; leaves odd-pinnate, with stipules; flowers in spikes or racemes; calyx with 5 nearly equal teeth; corolla and its slender-clawed petals usually narrow, spreading, equalling or exceeding the wings and blunt keel; stamens diadelphous; anthers all alike; ovary sessile or stipitate; ovules numerous; pod sometimes inflated, 1-celled, or 2-celled by a false partition; seeds few or many.

Astragalus hookerianus (T. \& G.) Gray. Herbage pale, silky or villous with a fine whitish pubescence; stems ascending, 10-30 cm. long, usually much branched at base; leaflets 7-9 pairs, oblong, petiolulate, 4-6 mm. long; stipules lanceolate, the lower ones sheathing; peduncles shorter than the leaves, the racemes few-flowered; bracts setaceous, about as long as the pedicels; calyx pubescent with black and white hairs, the teeth subulate, shorter than the tube; corolla whitish, the tip of the keel purple tinged; pods short-stipitate, much inflated, thin, ovoid, $1-3 \mathrm{~cm}$. long, pale, mottled with purple splotches.

Olympic Mountains, Elmer. 


\section{Family 51. GeraniaceaE, Geranium Family.}

Annual or perennial herbs; leaves mostly basal, alternate or opposite, often with stipules; flowers solitary or clustered, perfect, regular, commonly symmetrical, the parts in fives; sepals persistent; stamens usually twice as many as the petals, mostly in two sets, those alternate with the petals sometimes sterile; ovary 1, deeply 3-5-lobed and 3-5-celled; ovules 2 in each cavity; fruit a capsule; carpels 1 -seeded, separating when mature from the axis.

Leaves palmate, variously cleft or divided.

Leaves pinnately compound (in ours).

300. Geranium, 228. 301. ERODIUM, 228.

\section{GERANIUM. WiLd GERANIUM.}

Annual or perennial herbs; leaves palmately-lobed, cleft or divided, with stipules; flowers regular, on axillary 1-2-flowered peduncles; sepals 5 ; petals 5 , hypogynous; stamens 10 , rarely 5 , generally 5 longer and 5 shorter; ovary 5 -lobed, 5 -celled, beaked with a compound style; capsule 5-celled, each 1-seeded, and longtailed, at maturity separating from the long beak of the receptacle, splitting from below upward.

Perennials; flowers large.

G. oreganum.

Annuals; flowers small.

Seeds smooth or nearly so.

Carpels canescent, not rugose.

Carpels glabrous, rugose.

G. pusillum.

Seeds reticulate or pitted.

Flowers deep purple; seeds pitted.

Flowers pale purple; seeds reticulately ridged.

Peduncles short; inflorescence compact.

Peduncles long; inflorescence loose.

Style-branches 4-6 $\mathrm{mm}$. long.

Style-branches $3 \mathrm{~mm}$. long.

G. molle.

G. dissectum.

G. carolinianum.

G. bicknellii.

G. laxum.

Geranium oreganum Howell. Perennial with a stout crown; stems 30-60 $\mathrm{cm}$. high, sparsely retrorse pubescent; leaf blades 5-7-parted, the segments cuneate and irregularly toothed, sparsely appressed pubescent especially on the nerves; petioles long, retrorsely pubescent; inflorescence glandular; sepals oblong-ovate, aristate; petals obovate, $12-15 \mathrm{~mm}$. long, purple; carpels puberulent.

In open places, Willamette Valley, Oregon.

Geranium pusillum Burm. f. Annual, spreading, finely-pubescent, the weak stems $15-30 \mathrm{~cm}$. long; leaves $1-3 \mathrm{~cm}$. broad, 7-9-cleft into equal cuneateoblong lobes, these 3-toothed at apex; peduncles scattered, 2 -flowered; flowers pink or violet, $4-5 \mathrm{~mm}$. broad; sepals acute, not awned; petals notched; anther-bearing stamens only 5; carpels canescent, small, including the tails about $1 \mathrm{~cm}$. long; seeds smooth.

A weed in lawns and waste places. 
Geranium molle L. Annual, pubescent with white hairs; stems spreading, $15-30 \mathrm{~cm}$. long; leaves orbicular, $2-3 \mathrm{~cm}$. broad, deeply cleft, the lobes crenately toothed, obtuse; sepals ovate-oblong, villous, not aristate; petals pink-purple, notched at apex, scarcely longer than the sepals; stamens 10; carpels transversely rugose, glabrous; seeds striate.

Introduced from Europe, common.

Geranium dissectum L. Annual, somewhat pubescent; stems decumbent, or ascendent, 15-45 cm. long; leaves 5-7-parted, the segments deeply cleft into narrow very acute usually curved divisions; sepals ovate, acuminate; petals purple; carpels pubescent.

Abundantly introduced from Europe.

Geranium carolinianum L. Annual, erect, branched, $15-30 \mathrm{~cm}$. high, pubescent throughout and somewhat glandular; leaves orbicular, $3-6 \mathrm{~cm}$. broad, deeply 5-9-cleft; lobes cuneate-oblong, acutely and incisely toothed or lobed; petioles slender; peduncles short, 2-flowered, the inflorescence rather compact; flowers pink, $8-10 \mathrm{~mm}$. broad; sepals ovate, acuminate, short-awned, ciliate; carpels hispid, the beaks $2 \mathrm{~cm}$. long, tipped with a short slender style; seeds reticulated.

Common in sandy soil.

Geranium bicknellii Britt. Similar to G. carolinianum; peduncles scattered, elongate; flowers in pairs, the pedicels much longer than the calyx; petals rose-colored; beak of the fruit tipped with a long slender style 4-6 $\mathrm{mm}$. long.

In open woods.

Geranium laxum Hanks. Annual; stems procumbent, 30-60 cm. long, retrorsely pubescent; leaves reniform in outline, $2.5-5 \mathrm{~cm}$. broad, parted into linear segments; pedicels glandular-hirsute; sepals ovate, aristate, glandularpubescent, the outer 7-8 $\mathrm{mm}$. long; petals purple; carpels hirsute; seeds reticulate.

Oyhut, Chehalis County, Washington, Lamb, and south to California.

301. ERODIUM.

Herbs, generally with jointed nodes; leaves opposite or alternate, with stipules; flowers regular, in axillary umbels; sepals 5; petals 5 , hypogynous; anthers 5 , the 5 shorter stamens sterile or wanting; ovary 5-lobed, 5-celled, beaked by the united styles; tails of the carpels bearded on the inner side, becoming twisted.

Erodium cicutarium (L.) L'Her. Alfilaria. Filaree. Branched and spreading from the base, hairy-pubescent, the weak stems $10-60 \mathrm{~cm}$. long; leaves pinnate, $3-15 \mathrm{~cm}$. long, the leaflets pinnatifid into narrow acute lobes; peduncles generally longer than the leaves, bearing 2-10 pink flowers; sepals acute, nearly as long as the entire petals, these $4 \mathrm{~mm}$. long; carpels puberulent, the tails $5-7 \mathrm{~cm}$. long, spirally-twisted when ripe.

Introduced from Europe; very common.

Family 52. OXALIDACEAE. WoOd Sorrel Family.

Annual or perennial low herbs (in ours) with sour watery juice; leaves delicate, palmate, usually trifoliolate, alternate or radical; flowers perfect, regular, 5-merous, but with 10 or 15 stamens; ovary superior, 5-celled, the carpels 2-many-ovuled, usually distinct above. 


\section{OXALIS, WOOD SORREL.}

Annual or perennial, short-stemmed or stemless herbs with alternate or basal trifoliolate leaves (in ours) and axillary or basal 1-several-flowered peduncles, sometimes also with small self-pollinating flowers; styles 5, separate, persistent; capsule subglobose, ovoid or columnar.

Caulescent; flowers yellow.

Acaulescent; flowers white.

O. suksdorfii.

Scapes 1-flowered; capsule ovoid.

Scapes several-flowered; capsule linear.

O. oregana.

O. trilliifolia.

Oxalis suksdorfii Trelease. (O. pumila Nutt. not Urv.) Rootstocks creeping; stems slender, $10-30 \mathrm{~cm}$. high, sparsely villous; leaflets obcordate, 10-15 mm. long; stipules wanting; peduncles about as long as the subtending leaf; flowers yellow, solitary or in pairs on slender pedicels; sepals oblong, villous; petals three times as long as the sepals, obtuse; capsule a little longer than the sepals.

In dry open woods, Clarke County, Washington, and southwards.

Oxalis oregana Nutt. Acaulescent, sparsely villous; petioles $5-20 \mathrm{~cm}$. long; leaflets obcordate, $2-4 \mathrm{~cm}$. long, glabrous above; scapes shorter than the leaves, 2-bracted above the middle; flower solitary; sepals oblong; petals white with purple veins, oblong, $15-25 \mathrm{~mm}$. long; capsule subglobose, $10 \mathrm{~mm}$. long.

In deep woods, especially at low altitudes in the mountains.

Oxalis trilliifolia Hook. Acaulescent, nearly glabrous; petioles 10-30 $\mathrm{cm}$. long; leaflets $3-5 \mathrm{~cm}$. long, broadly obcordate; scapes as long as the leaves; umbels 3-8-flowered; bracts lanceolate, acute; sepals ovate-lanceolate, acute, $4 \mathrm{~mm}$. long; petals white, oblanceolate, deeply notched and twice as long as the sepals; capsule linear, $2-3 \mathrm{~cm}$. long.

In deep woods, often growing with $O$. oregana.

\section{Family 53. EUPHORBIACEAE. SPURge FAmily.}

Herbs (in ours), with milky juice; leaves opposite, alternate or whorled, entire or toothed, sessile or petioled; stipules present or wanting; flowers monoecious or dioecious, often much reduced and subtended by an involucre which resembles a calyx; parts of flowers various, often different in staminate and pistillate flowers; calyx none or minute; petals often wanting; stamens 1-many, free or united; ovary usually 3-celled; fruit a 3-lobed capsule; endosperm copious.

Flowers surrounded by an involucre; capsule 3-celled. 303. EupHorbia, 230. Flowers without an involucre; capsule 1-celled. 304. PISCARIa, 231.

\section{EUPHORBIA. SPURGE.}

Perennial or annual herbs (in ours); flowers monoecious, included in a cup-shaped 4- or 5-lobed involucre resembling a calyx or corolla and usually bearing large thick glands at its sinuses; 
glands rounded or often petal-like or crescent-shaped; staminate flowers numerous, of a single naked stamen, jointed upon a short pedicel which usually has a minute bract at its base; pistillate flowers solitary in the center of the involucre, pedicelled, and soon exserted; calyx none, or rarely present and minute; styles 3, 2-cleft; stigmas 6 ; ovary 3 -celled, 3 -ovuled.

Glands of the involucre bearing petal-like appendages; plants prostrate or nearly so; seeds pitted and wrinkled.

Glands of the involucre not bearing petal-like appendages; stems erect; seeds pitted.

E. serpyllifolia.

Euphorbia serpyllifolia L. Annual, glabrous; stems prostrate, much branched from the base, 5-20 cm. long; leaves opposite, narrowly obovate, cuneate at base, serrulate, 4-10 mm. long; stipules fringed; involucres solitary-axillary, campanulate, $1 \mathrm{~mm}$. long; glands 4 , disc-shaped, each with a lobed appendage; seeds whitish, slightly ridged and pitted.

In dry soils, often in dried-up ponds.

Euphorbia peplus L. Annual or biennial; stems erect, 10-30 cm. high; leaves entire, alternate, obovate or the uppermost ovate; flowers umbellate; umbels 3-rayed, then dichotomous; glands of the involucre crescent-shaped, the horns elongated; carpels each with 2 wing-like crests on the back; seeds pale, pitted on the back, grooved on the inner face.

Sparingly introduced.

\section{PISCARIA.}

Low heavy-scented annual herbs; leaves alternate, entire, 3-nerved, petioled, without stipules; flowers monoecious, in axillary cymose fascicles, without an involucre, all apetalous, the pistillate without a calyx; calyx of the staminate flower 3-6-parted; stamens 6 or 7, central on the hairy receptacle; style simple, filiform; ovary with 4 or 5 small glands at its base, 1celled, 1-ovuled; capsule obovate-oblong, 1-celled, 2-valved.

Piscaria setigera (Hook.) Piper. Turkey Mullein. Grayish pubescent with stellate hairs and hispid bristles; stem much branched from near the base, the branches mostly procumbent, $15-60 \mathrm{~cm}$. long; leaves ovate, obtuse, $1-5 \mathrm{~cm}$. long, crowded near the tips of the branches; calyx of staminate flower with oblong obtuse lobes; pistillate flowers often in clusters of 2 or 3; ovary and style pubescent; seed shiny, $4 \mathrm{~mm}$. long.

In dry ground, Columbia River to southern California. The plant was formerly used by the Indians to stupefy fish by throwing quantities of it in the streams.

\section{Family 54. CALlitrichaceaE. Water Starwort Family.}

Aquatic or rarely terrestrial usually tufted herbs; leaves opposite, entire, spatulate or linear, without stipules; flowers minute, perfect or monoecious, axillary; perianth none; bracts two, sac-like, or none; stamen 1; pistil 1; styles 2, filiform; ovary 4-celled; ovule 1 in each cell; fruit nutlike, compressed, 4-lobed, 4-celled, more or less winged or keeled; endosperm oily. 
305. CALlitriche. WATER Starwort.

Low slender usually tufted herbs; leaves spatulate or linear or both, entire; flowers monoecious, solitary or 2 or 3 in the axil of a leaf, with or without a pair of membranaceous bracts; staminate flower a single stamen; pistillate flower a single 4-celled ovary, sessile or pedicelled, with 2 distinct sessile stigmas.

Leaves all submersed, linear, 1-nerved.

Floating leaves obovate-spatulate, 3-nerved.

Styles about as long as the fruit.

Styles twice as long as the fruit.

C. autumnalis.

Callitriche autumnalis L. Leaves all submersed, linear, 1-nerved, retuse or bifid at apex; fruit orbicular, retuse, the two carpels separate nearly to the axis.

In flowing water, rare.

Callitriche palustris L. Aquatic or growing in the mud; floating leaves obovate, obtuse or emarginate, the others linear or spatulate, 1 -nerved, $1-2 \mathrm{~cm}$. long; when terrestrial, leaves all linear; bracts 2, as long as or longer than the fruit or wanting; fruit oval, emarginate, $1 \mathrm{~mm}$. long, the edges grooved and narrowly winged; styles erect, shorter than the fruit.

Not rare, in ponds and pools.

Callitriche bolanderi Hegelm. Floating leaves rhombic-obovate; fruit orbicular, usually obcordate, tipped with the much longer styles.

In still ponds, common.

\section{Family 55. EMPETRACEAE. CROWBERry FAMILY.}

Low evergreen heath-like shrubs; flowers small, dioecious or polygamous, axillary or in terminal heads; sepals 3 ; petals 2 or 3 or none; stamens 3 ; style short; ovary 2-several-celled, sessile, the style cleft into as many stigma-bearing segments as there are cells of the ovary; ovules 1 in each cell; fruit a berry-like drupe with 2 -several seed-like nutlets.

\section{EMPETRUM. CROWBERRY.}

Low spreading shrubs; flowers polygamous, scattered and solitary in the leaf-axils, inconspicuous, scaly-bracted; calyx of 3 spreading somewhat petal-like sepals; style very short; stigmas 6-9-rayed; fruit a berry-like drupe.

Empetrum nigrum L. Crowberry. Branches procumbent, 5-25 cm. long; leaves linear, obtuse, thick, 4-7 mm. long; berry black.

Mount Rainier, Piper; Copalis, Conard; Vancouver Island, British Columbia, Macoun.

\section{Family 56. LIMNANTHACEAE. False Mermaid Family.}

Low annual herbs with alternate pinnate leaves, without stipules; flowers perfect, regular, 3-6-merous, slightly peri- 
gynous; sepals persistent; glands alternating with the petals; stamens distinct; style one; carpels nearly distinct, 1-ovuled, in fruit fleshy and indehiscent, not beaked, separating from a very short axis.

Flower parts in fours, fives or sixes; stigmas capitate. 307. Limnanthes, 233. Flower parts in threes; stigmas not capitate. 308. FloerKEA, 233.

\section{LIMNANTHES.}

Tender annual herbs; leaves alternate, pinnately dissected, without stipules; flowers solitary, regular, symmetrical, on naked axillary straight peduncles; petals longer than the sepals, persistent, stamens twice as many as the petals; carpels nearly distinct, each 1-ovuled, becoming a half-fleshy nutlet in fruit; stigmas capitate.

Limnanthes macounii Trelease. Glabrous; stems much branched, decumbent, 5-10 cm. high; leaves pinnately 5-9-parted, the ovate, entire or 3 -cleft divisions remote; sepals mostly 4, lanceolate, acute; petals cuneateoblong, 3-4 $\mathrm{mm}$. long, cream-colored; carpels obovoid, tuberculate.

Victoria, Vancouver Island, British Columbia, Macoun; not known from any other locality.

\section{FLOERKEA.}

Tender low annuals, with alternate leaves lacking stipules; flowers regular, symmetrical, the parts in threes, solitary axillary, on curved peduncles; petals small, shorter than the sepals; stamens 6 ; carpels 3 , united at base; style 1 ; stigmas 3 , not capitate; fruit of 3 akenes with half-fleshy walls.

Floerkea proserpinacoides Willd. ( $F$.occidentalis Rydb.) Small glabrous herb, branched from the base, the branches $5-20 \mathrm{~cm}$. long; leaves pinnate with 3-5 leaflets, these lanceolate or the upper ones linear, sometimes 2-3cleft; sepals ovate, acute; petals white, about $2 \mathrm{~mm}$. long; carpels tuberculate.

In moist places, rare in our limits.

\section{Family 57. ANACARDIACEAE. CASHEW FAMILy.}

Trees or shrubs with resinous or milky acrid juice; leaves alternate, usually compound, without stipules, not punctate; flowers regular, small, polygamo-dioecious or perfect; calyx 5lobed; petals 5 ; stamens as many or twice as many as the petals, rarely fewer or more; styles 3 ; ovary 1 -celled, 1 -ovuled; fruit generally a small drupe; endosperm scanty or none.

\section{RHUS.}

Trees or shrubs, some of them poisonous to the skin; flowers polygamous or dioecious, seldom truly perfect, small, greenish or 
rarely yellow or rose-colored; calyx small, 5-parted; petals 5; stamens 5; fruit drupe-like; ovule basal.

Rhus diversiloba T. \& G. Poison Oak. Shrub with erect stems 1-2 m. high or under favorable circumstances clinging upon trees up to $3-8 \mathrm{~m}$.; leaves 3 -foliolate; leaflets oblong to obovate, obtuse, mostly coarsely toothed, rarely entire or pinnatifid, $2-7 \mathrm{~cm}$. long; flowers green, in small loose axillary panicles, usually shorter than the leaves; drupes white, globose, about $5 \mathrm{~mm}$. in diameter.

Common in gravelly or rocky soil.

Family 58. CELASTRACEAE. Stafftree Family.

Shrubs, often climbing; leaves simple and undivided, alternate or opposite; stipules none or small and early withering; flowers regular, usually perfect, small; pedicels commonly jointed; calyx 4- or 5-lobed, the lobes imbricated; petals 4 or 5, spreading: stamens 4 or 5 , perigynous on a disk, alternate with the petals; ovary sessile, free from or confluent with the disk; fruit a somewhat fleshy dehiscent pod; endosperm fleshy.

Deciduous shrub; flowers 5-merous. Evergreen shrub; flowers 4-merous.

310. Euonymus, 234. 311. Pachistima, 234.

\section{EUONYMUS.}

Deciduous shrubs with 4-sided branchlets and opposite serrate leaves; flowers small, on axillary peduncles, in loose cymes, perfect, 5-merous (in ours); stamens short; style short or none; pod 3-5-lobed, 3-5-valved; seeds 1-4 in each cell.

Euonymus occidentalis Nutt. Glabrous shrub, 2-5 m. high, the slender branches pale green; leaves ovate to elliptic-lanceolate, mostly acute at base, acute or acuminate, serrulate, 5-10 cm. long, on petioles 4-10 mm. long; peduncles $5 \mathrm{~cm}$. long, 1-4-flowered; flowers 5-merous, dark purple, about $10 \mathrm{~mm}$. broad; fruit smooth.

In deep woods along streams; Clarke County, Washington, and southward.

\section{PACHISTIMA.}

Low evergreen shrubs; leaves opposite, smooth, serrulate, coriaceous; flowers perfect, very small, green or purplish, solitary or fascicled in the axils; calyx-lobes 4, broad; petals 4 ; stamens 4 , on the edge of the disk; style very short; ovary free; pod small, oblong, 2-celled; seeds 1 or 2, enclosed in a white membranous many-cleft aril.

Pachistima myrsinites (Pursh) Raf. Evergreen glabrous shrub, much branched, 30-60 cm. high; leaves oblong, lanceolate or obovate, acute or obtuse, cuneate at base, serrulate, nearly sessile, $1-3 \mathrm{~cm}$. long, the margin somewhat revolute; flowers yellowish or purplish, $3 \mathrm{~mm}$. broad; peduncles and pedicels short, 2-3 mm. long; capsule oblong, acute, 5-6 mm. long.

In woods, especially in the mountains but occurring at sea level along Puget Sound. 


\section{Family 59. ACERACEAE. Maple Family.}

Trees or shrubs; leaves simple or pinnately or palmately compound, opposite, without stipules (in ours); flowers small, regular (in ours), polygamous or dioecious; sepals 4-5; petals of ten none (in ours); stamens $3-12$, inserted on the fleshy disk; ovary 2celled and lobed (in ours), with 2 ovules in each cell (in ours); endosperm none.

\section{ACER. MAPLE.}

Trees or shrubs; leaves opposite, palmately-lobed, without stipules; flowers small, polygamo-dioecious, in clusters; calyx colored, usually 5-lobed; petals 5 and equal or none; stamens $3-12$; styles 2; ovary 2-lobed, 2-celled; ovules 2 in each cell; fruit a double samara, 2-winged above, separable at maturity, each 1 -seeded.

Flowers in racemes; fruit hispid.

A. macrophyllum.

Flowers in corymbs; fruit glabrous.

Leaves 3-5-lobed; fruit wings somewhat spreading.

Leaves 7-9-lobed; fruit wings widely spreading.

A. douglasii.

A. circinatum.

Acer macrophyllum Pursh. Broadleaf Maple. Large tree reaching a height of $10-30 \mathrm{~m}$. and a diameter of $1-2 \mathrm{~m}$.; bark longitudinally sulcate; leaves $15-30 \mathrm{~cm}$. long and broad, deeply 3-5-lobed, the lobes entire or more commonly 3-5-cleft into acute sinuously-margined lobes, shiny above, paler and somewhat pubescent beneath especially on the ribs; flowers greenishyellow, in pendent racemes $8-15 \mathrm{~cm}$. long, the lower flowers infertile; calyx campanulate; petals obovate, as long as the sepals; fruit very hispid, the oblong slightly spreading wings $4-5 \mathrm{~cm}$. long.

Abundant in alluvial land; northward in Alaska to about latitude $55^{\circ}$ and southward in the mountains through California. First collected by Captain Meriwether Lewis.

Acer douglasii Hook. Dwarf Maple. Small tree, 3-10 m. high, with smooth light-gray bark; leaves simple, rarely 3 -foliolate, orbicular, acutish, 5 -lobed, coarsely serrate, truncate or subcordate at base, glabrous, dark-green above, paler beneath, 5-10 cm. long; petiole slender; flowers polygamous, in small corymbs; petals narrow, spatulate-oblong, veiny, about as long as the similar sepals; fruit glabrous, roughened, the wings diverging at less than a right angle, $2.5-3 \mathrm{~cm}$. long.

Along mountain streams, only rarely found at sea-level in our limits. Extends northward to Lynn Canal, Alaska.

Acer circinatum Pursh. Vine Maple. Shrub or small tree, the trunk 3-10 m. high, rarely erect; bark smooth, gray; leaves $6-12 \mathrm{~cm}$. long, nearly orbicular, more or less cordate at base, cleft nearly to the middle into 7-9 acute scrrate lobes, nearly glabrous when mature, somewhat villous when young; flowers loosely corymbose; sepals oblong, acute, spreading; petals hood-like, acutish, shorter than the sepals; fruit becoming glabrous, the wings diverging nearly $180^{\circ}$.

Abundant in alluvial soil; found only west of the Cascade Mountains. Northern limit near latitude $51^{\circ}$; southern limit Mendocino and Trinity Counties, California. The leaves become purple-colored after midsummer and gorgeously crimson in the fall. 
Family 60. BALSAMINACEAE. Balsam Family.

Usually glaucous succulent herbs with watery juice; leaves alternate, simple, without stipules; flowers irregular with a petal-like imbricated usually spurred calyx; petals 4 , united in two pairs; stamens 5 , with short filaments and more or less united anthers; ovary 5-celled; seeds without endosperm.

\section{IMPATIENS. JEWELWEED.}

Delicate herbs with translucent stems; leaves coarsely toothed, petioled; flowers axillary or panicled, often of two kinds, large sterile ones and smaller cleistogamous ones which ripen good seed; sepals apparently four, the posterior ones usually spurred; petals 4 , united in two pairs; filaments 5 , each with a scale-like appendage; appendages united and covering the stigma; pod with evanescent partitions, opening suddenly when touched and projecting the seeds.

Impatiens nolitangere L. (I. occidentalis Rydb.) Touch-me-not. Annual, glabrous, 60-90 cm. high, pale green, slightly glaucous; leaves oval to elliptical, coarsely crenate-serrate, rounded or subcordate at base, paler beneath, 5-10 $\mathrm{cm}$. long, on shorter petioles; flowers pale yellow; saccate sepal much longer than broad, gradually tapering into a long recurved spur.

In moist woods, Whatcom County, Washington, and northward.

\section{Family 61. RHAMNACEAE. BUCKTHORN FAMILY.}

Erect shrubs or small trees; leaves simple; stipules small and early deciduous or none; flowers small and regular, sometimes polygamo-dioecious; disk fleshy; calyx 4- or 5-toothed; petals 4 or 5 , on the disk, or sometimes none; stamens 4 or 5 , perigynous, alternate with the sepals and opposite the petals; ovary sessile; fruit a drupe or pod, with 1 seed in each cell; endosperm sparingly fleshy.

Fruit a drupe; flowers solitary or in umbels.

Fruit a dry capsule; flowers in panicles.

314. Rhamnus, 236.

315. Ceanothus, 237.

\section{RHAMNUS. BUCKTHORN.}

Shrubs or small trees; leaves alternate, petioled, pinnatelyveined, with small deciduous stipules; flowers greenish, polygamous or dioecious, in axillary clusters; calyx 4- or 5-cleft; calyxtube bell-shaped, lined with the disk, both free from the ovary; petals 5, small, oblong, sessile, acute or none; stamens 4 or 5; ovary $2-4$-celled; fruit a berry-like drupe, with $2-4$ separate seedlike nutlets. 
Rhamnus purshiana DC. Bearberry. Small tree, 3-12 m. high, with nearly smooth dark-gray bark; young twigs pubescent; leaves elliptic, obtuse or acuminate, rounded at base, somewhat undulate, denticulate, pubescent especially beneath, $5-15 \mathrm{~cm}$. long; petioles $1-2 \mathrm{~cm}$. long, downy; umbels stoutpeduncled, 8-15-flowered; flowers $3-5 \mathrm{~mm}$. long; sepals 5; petals minute, hood-shaped; fruit black, obovoid, as large as a pea, 3 -seeded, insipid.

Common in moist or wet places. Bark used medicinally under the name Cascara sagrada.

\section{CEANOTHUS.}

Shrubs, sometimes evergreen; leaves alternate, petioled; flowers perfect, in small umbel-like clusters, forming dense terminal panicles often on naked branches; calyx 5-lobed; calyx and disk adherent to the ovary; petals hooded, spreading; stamens 5 ; ovary 3-lobed; fruit 3-lobed, dry and very oily, the three carpels splitting apart when ripe.

Leaves opposite, tridentate at apex.

C. cuneatus.

Leaves alternate.

Plant gummy; leaves thick, evergreen.

Leaves pubescent beneath.

Leaves glabrous beneath.

Plant not gummy; leaves thin, deciduous.

Leaves mostly entire; flowers blue or white.

Leaves serrate or dentate.

Flowers white; twigs terete; leaves large.

Flowers blue; twigs angled; leaves small.

C. velutinus.

C. velutinus laevigatus.

C. peduncularis.

C. sanguineus.

C. thyrsiflorus.

L Fok Ceanothus cuneatus (Hook.) Nutt. Stems erect, rigid, much branched, $1-4 \mathrm{~m}$. high; twigs gray, tomentulose when young; leaves opposite, cuneateobovate or spatulate, obtuse or retuse at apex, denticulate to entire, 5-10 $\mathrm{mm}$. long, short-petioled, minutely tomentose beneath; flowers white or rarely bluish, in axillary umbels; capsules oblong, each carpel with a horn-like crest near the top.

In dry or rocky ground, from the Columbia River southwards.

Ceanothus velutinus Dougl. Sticky Laurel. Stout shrub, 1-2 m. high, much branched; branchlets puberulent; leaves oval, obtuse, subcordate at base, prominently 3-nerved, finely denticulate, thick and firm, glabrous and gummy above, puberulent beneath, 5-8 cm. long; petioles stout; flowers white, in terminal panicles $5-10 \mathrm{~cm}$. long; peduncles stout, puberulent; pedicels slender; carpels subglobose, 3-lobed above, nearly smooth.

In open woods, rather common. The plant has a pleasant aromatic odor.

\section{beneath.}

Ceanothus velutinus laevigatus (Dougl.) T. \& G. Leaves glabrous

Known from Vancouver Island, Menzies, Macoun, Harstine Island, Mason County, Washington, southwestern Oregon and northern California.

Ceanothus peduncularis Greene. Stems 1-2 m. high, loosely branched; leaves oval-oblong, rounded at base, acute and mucronate at apex, 3-nerved, pubescent on both faces, 3-6 cm. long; panicle 5-8 cm. long; peduncle elongated, pubescent, its bracts oblong, acute, pubescent; bractlets ovate to lanceolate, acuminate, villous.

Washington to California.

is $5 \tau$ Ceanothus sanguineus Pursh. Buckbrush. Shrub, 1-3 m. high, with '/8 slender smooth usually reddish branchlets; leaves thin, elliptical or ovate, 
obtuse, rounded at base, finely serrate, glabrate above, paler and puberulent beneath, 5-8 cm. long; petioles slender; panicles lateral, 6-10 cm. long, their peduncles villous; flowers white; capsules smooth, 3-lobed.

In open woods, not common in our limits.

Ceanothus thyrsiflorus Esch. California Lilac. Loosely branched shrub, $1-5 \mathrm{~m}$. high; twigs angled, brownish, glabrous or nearly so; leaves elliptic, acute at base, obtuse at apex, finely dentate, 3-nerved, glabrous except on the veins beneath, $2-5 \mathrm{~cm}$. long, on short hairy petioles; flowers usually blue, in dense compound terminal panicles; capsule globose, smooth.

Western Oregon and California, on rocky slopes. Very showy when in bloom.

\section{Family 62. MALVACEAE. MALLOW FAMILy.}

Herbs or shrubs; leaves alternate, palmately-veined, with stipules; flowers regular, showy; peduncles axillary, jointed; calyx valvate; sepals 5 , united at base, often subtended by an involucre of numerous bractlets; corolla convolute; petals 5, their bases united with each other and with the stamen-column; stamens numerous, monadelphous, in a column; pistils several, the ovaries united in a ring or forming a several-celled pod; endosperm scanty.

Bractlets none; stamens in two series.

Bractlets 3; stamens monadelphous.

316. SidAlCEA, 238.

317. MaLva, 239.

\section{SIDALCEA.}

Herbs (ours all perennials); leaves rounded, mostly lobed or parted; flowers pink or red, in a narrow terminal raceme or spike; involucre none; stamen-column double, the filaments of the outer series united usually into 5 sets opposite the petals; styles filiform, stigmatic on the inner surface; carpels 5-9,1-ovuled, separating at maturity from the short axis, indehiscent.

Flowers red; mature carpels smooth.

S. hendersonii.

Flowers pink; mature carpels rugose.

Stems hirsute.

Stems stellate-pubescent.

S. campestris.

S. virgata.

Sidalcea hendersonii Wats. Perennial, glabrous or nearly so and bright green; stems erect, $60-90 \mathrm{~cm}$. high, nearly simple; leaves orbicular, deeply 5-7-cleft, the segments merely lobed or toothed; flowers deep rose-colored, in terminal racemes; bracts linear, exceeding the pedicels; calyx-lobes ovate, acuminate, $12-15 \mathrm{~mm}$. long; petals $2.5 \mathrm{~cm}$. long; carpels glabrous, not rugose.

In marshes near the sea shore, Vancouver Island, British Columbia, to Oregon. Abundant near Everett, Washington.

Sidalcea campestris Greene. Perennial, pale green, pubescent with both simple and stellate hairs; stems $30-90 \mathrm{~cm}$. high, of ten branched above, bristlyhirsute; leaves orbicular, the leaves 5-9-lobed or cleft, the upper deeply 5-9. parted, the segments divided into narrow lobes; petioles longer than the blades; racemes erect, rather dense; calyx usually canescent, $8-10 \mathrm{~mm}$. long; petals 
pink, emarginate or erose at apex, about $2 \mathrm{~cm}$. long; carpels rugose and pubescent.

In moist meadows, Willamette Valley, Oregon. S. asplenifolia Greene found at Seattle in hay meadows is apparently the same and perhaps was introduced with grass seed.

Sidalcea virgata Howell. Perennial, green, thinly stellate puberulent throughout, not at all pilose; stems erect, slender, 30-90 cm. high; basal leaves long-petioled, orbicular, with 5-7 oblong obtuse toothed lobes, 5-15 $\mathrm{cm}$. broad, puberulent beneath with stellate hairs, above mostly with simple appressed hairs; cauline similar, more deeply lobed or even parted into narrow subentire segments; racemes erect, loosely flowered; calyx densely puberulent, the lobes ovate, acuminate, $6-8 \mathrm{~mm}$. long; petals $1.5-2 \mathrm{~cm}$. long, somewhat erose, purple; carpels pale, puberulent.

In open places, Willamette Valley, Oregon, and southward.

\section{MALVA. Mallow.}

Pubescent or glabrous herbs; leaves dentate, lobed or dissected; flowers perfect, axillary or terminal, solitary or clustered; involucre 3-leaved; calyx 5-cleft; petals 5, obcordate; styles numerous, stigmatic down the inner side; fruit depressed, separating at maturity into as many 1 -seeded indehiscent carpels as there are styles.

Flowers large, only in the upper axils; cauline leaves dissected; carpels very hairy.

Flowers small, fascicled in the axils; leaves 5-9-lobed.

Carpels puberulent, not reticulated.

Carpels glabrous, reticulated.

M. moschata.

M. rotundifolia. M. parviflora.

Malva moschata L. Musk Mallow. Perennial, somewhat musk-scented, pubescent with simple hairs; stems erect or ascending, 30-60 cm. high; leaves orbicular, the basal ones incisely cleft, the cauline 5-parted, the divisions cleft or parted into narrow segments; flowers only from the upper axils, the peduncles exceeding the leaves; petals rose-colored or white, much longer than the sepals; carpels very hairy.

Introduced and locally abundant.

Malva rotundifolia L. Mallow. Cheeses. Annual or biennial, pubescent or glabrous; stems prostrate, branched near the base, $20-60 \mathrm{~cm}$. long; leaves round-reniform, 5-7-lobed, crenate-dentate, $2-5 \mathrm{~cm}$. broad; petioles long and slender; flowers whitish, about $1 \mathrm{~cm}$. broad, clustered in the axils; pedicels slender, 1-2 cm. long; carpels $12-15$, puberulent, not reticulated.

A native of Europe, introduced in waste places.

Malva parviflora L. Annual, glabrous or nearly so; stems ascending to erect, $15-60 \mathrm{~cm}$. high; leaves orbicular, cordate, crenate, somewhat angularly lobed; flowers axillary, solitary or clustered; pedicels short; flowers small; carpels glabrous, rough and netted on the back, somewhat wing-margined.

A weed in waste land.

\section{Family 63. HYPERICACEAE. St. JOHnswort FAMILY.}

Herbs or shrubs; leaves opposite, entire, mostly sessile, with translucent or dark-colored glandular dots; stipules wanting; 
flowers perfect, regular; sepals 4 or 5 ; petals 4 or 5 , hypogynous; stamens commonly in three or more clusters; styles $2-5$, usually distinct or nearly so; capsule 1 -celled, with 2-5 parietal'placentae, or 3-5-celled; endosperm none.

\section{HYPERICUM. ST. JOHNSWORT.}

Perennial herbs; leaves sessile, entire, punctate; flowers yellow, in cymes; sepals 5 ; petals 5 ; stamens numerous; ovary 1-celled, with 3-5 parietal placentae, rarely 3-5-celled.

Plants low, forming dense mats.

Alpine; leaves crowded; flowers mostly solitary.

Not alpine; leaves not crowded; flowers of ten several.

Plants erect, simple or nearly so.

Stamens 5-10; stems about $30 \mathrm{~cm}$. high.

Stamens numerous; stems tall.

Sepals acuminate; capsule not lobed.

Sepals obtuse; capsule 3-lobed.

H. bryophytum.

H. anagalloides.

H. majus.

$H$. perforatum.

H. scouleri.

Hypericum bryophytum Elmer. Annual, glabrous, often forming dense pure growths; stems very leafy, $2-5 \mathrm{~cm}$. high, weak, procumbent, branched at base; leaves broadly ovate or obovate, obtuse, sessile, $3-5 \mathrm{~mm}$. long, longer than the internodes, glabrous and somewhat glaucous; flowers solitary, rarely few in a cyme, very short peduncled, often 4-merous; sepals $3 \mathrm{~mm}$. long; petals equalling the sepals, ciliate; seeds brown, longitudinally striate.

In the mountains at about $2000 \mathrm{~m}$. altitude.

Hypericum anagalloides Cham. \& Schlecht. Stems weak, procumbent, much branched, $2-5 \mathrm{~cm}$. high; leaves pale, ovate, obtuse, somewhat clasping, $1 \mathrm{~cm}$. or less long; cymes peduncled, loose, the branches elongated; flowers small, not dotted, 6-8 mm. broad, dark yellow; sepals unequal, la nceolate, acuminate, in fruit much longer than the capsule; stamens 15-20.

Forming loose mats in springy places, common.

Hypericum majus (Gray) Britt. Annual or perennial; stems erect, 10-60 $\mathrm{cm}$. high; leaves lanceolate, subcordate, sessile or half-clasping, 5-7-nerved, 2-4 cm. long; cymes naked, rather dense; sepals lanceolate, long-acuminate, longer than the pale yellow petals and nearly as long as the capsule.

Green Lake, Seattle, Washington, Piper, evidently native.

Hypericum perforatum L. Tipton-weed. Perennial, stoloniferous; stems 30-90 $\mathrm{cm}$. high, erect, much branched; leaves elliptic to linear-oblong, obtuse, narrowed at base, conspicuously punctate with pellucid dots; flowers numerous, in leafy cymes; sepals lanceolate, acuminate; petals deep yellow, specked with black, twice as long as the sepals; capsule ovate-conical, reddish. to horses.

Introduced from Europe. Very troublesome as a weed, and poisonous

Hypericum scouleri Hook. Stems erect, simple or branched above, 15-60 $\mathrm{cm}$. high; leaves oblong-ovate, obtuse, half-clasping at base, $2-3 \mathrm{~cm}$. long, black-dotted on the margin; inflorescence a corymb, loose or rather dense; sepals ovate-lanceolate, obtuse or acute; petals bright yellow, black dotted on the margin, $1 \mathrm{~cm}$. or less long; stamens numerous, in three fascicles.

In wet places, common. 
Family 64. ELATINACEAE. WATERWort FAMILy.

Low annual marsh herbs; leaves opposite, not punctate, with membranous stipules; flowers minute, axillary, regular, symmetrical; sepals $2-5$, free; petals $2-5$, hypogynous; stamens as many or twice as many as the petals; ovary $2-5$-celled, with a many-ovuled axile placenta; fruit a capsule.

Plants glabrous; flower parts 2-4.

Plants pubescent; flower parts 5.

319. Elatine, 241.

320. Bergia, 241.

\section{ELATINE.}

Dwarf glabrous plants growing in or near the water, often rooting at the nodes; sepals $2-4$, obtuse; petals $2-4$, hypogynous; stamens as many or twice as many as the petals; styles or sessile stigmas 2-4; pod membranaceous, 2-4-celled, several-manyseeded.

Elatine americana (Pursh) Arn. Mostly branched from the base, spreading to erect, 2-4 cm. high; leaves obovate, obtuse, 2-5 $\mathrm{mm}$. long; flowers sessile, the parts mostly in twos, rarely in threes; capsule globose; seeds subcylindric, slightly curved, marked with 9 or 10 longitudinal lines and 20-30 cross lines.

Moist banks of the Columbia River, according to Howell.

\section{BERGIA.}

Diffuse or ascending herbs, branching, of ten pubescent; leaves entire or serrate; flowers axillary, solitary or clustered; parts of the flowers in fives; sepals acute, each with a prominent midrib; capsule crustaceous, ovoid, 5 -valved; seeds numerous.

Bergia texana (Hook.) Seubert. Annual, branched from the base, 4-20 $\mathrm{cm}$. high; stems erect or ascending, glandular-pubescent; leaves lanceolate, obovate or spatulate, serrate, 1-2 cm. long, petioled; flowers in small axillary fascicles; sepals acuminate, $3 \mathrm{~mm}$. long, equalling the white or pinkish petals; stamens 5 or 10 .

Banks of the Columbia River, perhaps reaching our limits.

Family 65. Violaceae. Violet Family.

Herbs with alternate or basal leaves, with stipules; flowers perfect, axillary, nodding; sepals 5 , hypogynous; corolla somewhat irregular, 1-spurred, of 5 petals; stamens 5 , hypogynous; anthers adnate, united over the pistil; ovary 1-celled, with 3 parietal several-ovuled placentae; capsule 3-valved; endosperm copious.

\section{VIOLA. VIOLET.}

Mostly perennial herbs; leaves alternate, with foliaceous stipules; peduncles 1-flowered, axillary; flowers usually of two 
kinds, the earlier ones perfect and conspicuous, but of ten sterile, the later (near the ground in stemless species) with small and rudimentary petals, cleistogamous and producing numerous seeds; sepals unequal, more or less auricled; petals unequal, the lower spurred; the two lower stamens spurred.

Acaulescent.

Flowers small, white.

Flowers larger, violet.

Rootstocks long and slender; petals pale violet.

Rootstocks thick; petals dark violet.

Plants not stoloniferous; stipules small.

Caulescent.

Plants stoloniferous; stipules large.

V. macloskeyi.

$V$. palustris.

V. nephrophylla.

$V$. langsdorfii.

Flowers yellow, or violet and yellow.

Stems prostrate, stolon-like; leaves evergreen.

Stems erect, not stoloniferous; leaves not evergreen.

Leaves dissected into linear lobes; flowers violet and yellow.

Leaves not dissected; flowers yellow.

Herbage pubescent; leaves lanceolate to ovate.

Herbage glabrous; leaves cordate to reniform.

V. sempervirens.

V. hallii.

V. nuttallii.

Flowers blue or violet.

Stipules scarious, entire.

Stipules herbaceous, at least some of them serrate or incised.

Leaves dotless; cauline stipules entire.

Leaves usually brown-dotted, at least beneath; stipules all serrate or laciniate.

Herbage glabrous or nearly so.

Herbage pubescent, the pubescence retrorse.

V. glabella.

V. flettii.

V. howellii.

V. adunca.

V. montanensis.

Viola macloskeyi Lloyd. Glabrous; rootstocks slender, creeping; leaves few, reniform, obscurely crenate; petioles slender; stipules ovate, acute; peduncles 3-7 cm. high, 2-bracted; petals white, the lateral ones bearded, the spur very short and saccate.

In sphagnum bogs.

Viola palustris L. Glabrous; rootstocks slender, at length producing runners; leaves cordate-orbicular, crenulate, $2-4 \mathrm{~cm}$. broad; stipules ovate, acuminate; flowers pale-violet, the lateral petals bearded; spur short, saccate; sepals obtuse.

In swamps, common, flowering in early spring.

Viola nephrophylla Greene. Glabrous or nearly so; leaves thickish, reniform to cordate, faintly crenate, obtuse, $2-6 \mathrm{~cm}$. long, rather pale; flowers violet, on peduncles $10-20 \mathrm{~cm}$. long, exceeding the leaves; lateral petals bearded, the spurred one villous; sepals ovate-lanceolate, obtuse; capsules oblong, glabrous.

In springy places, rare in our limits. Admiralty Head, Oscar A. Piper.

Viola langsdorfii Fisch. Glabrous; rootstocks stout, scaly, creeping; stems decumbent or ascending, 5-30 cm. long; leaves cordate-orbicular, crenulate, long-petioled; stipules large, lanceolate, the lowest often incised; corolla pale violet; lateral petals bearded; spur short.

In swamps near the ocean coast, from northern California to Alaska. 
Viola sempervirens Greene. ( $V$. sarmentosa Dougl.) Nearly glabrous; rootstocks scaly with the old stipules; stems creeping or ascending, slender; leaves cordate-orbicular, crenate, punctate with brownish dots, $2-3 \mathrm{~cm}$. broad; stipules ovate, scarious; peduncles about as long as the leaves; petals yellow, brown veined, the lateral ones bearded; spur short and blunt.

In open woods, common, blooming in early spring. The leaves remain green over winter.

Viola hallii Gray. Glabrous; stems from a deep-seated caudex, 10-15 cm. high; leaves deeply 3-parted, the divisions mostly 3-5-cleft or parted, the ultimate segments narrowly lanceolate or linear, obtuse, callus-tipped; petiole slender; upper stipules foliaceous, laciniate or entire; upper petals dark violet, the lower three lemon yellow, the lateral ones bearded at base, $10-15 \mathrm{~mm}$. long; spur short; capsule acute.

Prairies, Willamette Valley, Oregon, to northern California.

Viola nuttallii praemorsa (Dougl.) Wats. Stems very short from a thick caudex with fleshy roots; leaves broadly ovate to lanceolate, crenate or subentire, pubescent with white hairs, $2-4 \mathrm{~cm}$. long; petioles hairy, longer than the blades; stipules narrow, entire, acuminate; flowers yellow, the peduncles usually longer than the leaves; petals obovate, about $10 \mathrm{~mm}$. long.

Open prairies from near Tacoma southward.

Viola glabella Nutt. Whole plant glabrous or nearly so; rootstock rather stout, creeping; stem leafy above, $10-20 \mathrm{~cm}$. tall; radical leaves reniform, acuminate, crenate-serrate, $1-5 \mathrm{~cm}$. broad, long-petioled; cauline similar, short-petioled; stipules thin, membranous, ovate or lanceolate, entire; peduncles 2-6 cm. long; petals yellow, purple-veined, 10-12 mm. long; spur short and broad.

In moist woods in the mountains.

Viola flettii Piper. Glabrous; rootstocks stout, horizontal; stems 10-15 $\mathrm{cm}$. high, bearing 2-4 leaves near the summit; leaves broadly reniform, serrate, obtuse, firm, 3-4 cm. wide; petioles slender; stipules scarious, lanceolate, entire; peduncle axillary, exceeding the subtending leaf; sepals lanceolate, obtuse, minutely puberulent; petals violet, yellow at base, $12-14 \mathrm{~mm}$. long, the lateral ones bearded.

In rock crevices in the Olympic Mountains at about $1500 \mathrm{~m}$. altitude.

Viola howellii Gray. Glabrous or nearly so; stems short, 10-20 cm. long; leaves reniform-cordate, crenate-serrate, ciliate, $3-5 \mathrm{~cm}$. broad, the slender petioles 10-20 cm. long; stipules laciniate or the upper ones entire; peduncles about as long as the leaves; flowers violet; lateral petals bearded; spur short and blunt.

Prairies and open woods, Vancouver Island to Oregon.

Viola adunca Smith. Stems leafy, short or at length elongated, from creeping rootstocks, nearly glabrous throughout; leaves ovate, obtuse, slightly. cordate at base, crenate, usually brown dotted, 1-3 cm. long, on slender petioles 5-8 cm. long; stipules foliaceous, lanceolate, fringe-toothed; flowers violetpurple, rarely white; petals $6-12 \mathrm{~mm}$. long, the lateral ones bearded; spurs nearly straight, as long as the petals.

In open places, common and variable. Typical Viola adunca has puberulent leaves. The glabrous or nearly glabrous form is Viola adunca glabra Brainerd.

Viola montanensis Rydb. ( $V$. retroscabra Greene.) Caudex short, branched; stems 10-20 cm. high; leaves ovate-cordate, unevenly crenate, 2-5 cm. long, puberulent; petioles slender, 5-8 cm. long, retrorsely pubescent; stipules narrow, fimbriate; peduncles pubescent; sepals lanceolate, acute; petals pale violet, with a short blunt spur.

In mountain meadows. 
Family 66. CACTACEAE. Cactus Family.

Fleshy and thickened plants; stems-flattened, terete, ridged or tubercled, continuous or jointed, leafless or with small leaves, generally spiny; spines from cushions of minute bristles; flowers solitary, sessile, perfect, regular, showy; sepals and petals numerous, in several rows, the bases adherent to the ovary; stamens numerous, on the calyx-tube; style 1; ovary 1-celled, with several parietal placentae; ovules numerous; fruit a 1-celled berry; endosperm scanty or copious.

\section{OPUNTIA. Prickly Pear.}

Jointed, much-branched plants; leaves small, terete, subulate, early deciduous from the young branches; flowers usually lateral, large; calyx-tube not prolonged beyond the ovary; sepals numerous, spreading; petals numerous, slightly united; stamens very numerous, in several rows; fruit a berry, often prickly.

Opuntia polyacantha borealis Coult. Prostrate, frequently in large tufts; joints of the stem flattened, orbicular or oblong, 5-12 cm. long, pale-green; leaves minute, 3-4 mm. long; cushions pale, bristly; spines 4-8, whitish, usually red-tipped, 5-20 mm. long, mostly deflexed; flowers yellow, 4-5 cm. broad; fruit ovoid, dry, $2.5 \mathrm{~cm}$. long, with a shallow saucer-like apex; seeds $4 \mathrm{~mm}$. long, acutely margined.

In rocky places on the islands in the northern part of Puget Sound, known definitely from Whidby and Sucia Islands. This is the only cactus known from west of the Cascade Mountains. While Coulter has referred it to the above subspecies, it is probably distinct.

\section{Family 67. elaeAgnaceae. Oleaster Family.}

Shrubs or small trees with silvery-scaly leaves; flowers perfect or dioecious, clustered in the leaf-axils or at the nodes of the one year old twigs; calyx of staminate flowers 4-parted (in ours); calyx of pistillate or perfect flowers 4-lobed or 4-cleft (in ours); corolla none; stamens 4 or 8 , in perfect flowers on the throat of the perianth; ovary 1-celled, sessile; ovule 1; fruit drupe-like, formed from the pulpy calyx, inclosing the akene.

\section{LEPARGYREA.}

Silvery shrubs; leaves opposite, entire, deciduous; flowers small, nearly sessile in the leaf axils, clustered or the fertile solitary, dioecious; the staminate with a 4-parted calyx and 8 stamens, alternating with 8 processes of the thick disk; the pistillate with an urn-shaped 4-cleft calyx inclosing the ovary and becoming berry-like in fruit. 
Lepargyrea canadensis (L.) Greene. Shrub 1-2 m. high; young branches and leaves scurfy with rusty brown stellate scales; leaves ovate or oval, entire, obtuse, $2-4 \mathrm{~cm}$. long, petioled, nearly glabrous above, scurfy beneath; flowers small, clustered in the axils; fruit ovoid, orange-red; nutlet smooth.

Vancouver Island, British Columbia; common in Whatcom and Island Counties, Washington.

\section{Family 68. LYTHRACEAE. LOOSESTRIfE FAMILY.}

Herbs; leaves mostly opposite and entire, with no stipules; flowers axillary or whorled, perfect; calyx enclosing but free from the ovary; petals $4-7$, as many as the calyx-teeth, perigynous, or none; stamens $4-14$, on the calyx; style 1 ; ovary $2-4$-celled; ovules numerous, rarely few; fruit a membranous capsule; endosperm none.

Calyx tubular, cylindrical; petals usually 6 .

Calyx short, campanulate or globular; petals usually 4

324. Lythrum, 245. or none.

Flowers mostly more than one in the axils; capsule bursting irregularly.

Flowers mostly solitary in the axils; capsule septicidally dehiscent.

325. Ammannia, 245.

326. Rotala, 246.

\section{LYTHRUM.}

Slender herbs with 4-angled stems; calyx cylindrical, 8-12ribbed, 5-7-toothed, with as many secondary teeth in their sinuses; petals 5-7; stamens as many or twice as many as the petals, inserted near the base of the calyx; capsule subcylindric, 2-celled.

Lythrum hyssopifolia L. Annual, stems procumbent or ascending, 10-20 $\mathrm{cm}$. long; leaves numerous, oblong, obtuse, pale green, glabrous; flowers solitary in the upper axils, nearly sessile; calyx-lobes subulate, the intermediate processes broader; petals pale pink.

In dried-up ponds; common and apparently native.

\section{AMMANNIA.}

Low and inconspicuous smooth herbs; leaves opposite, narrow; flowers small, 1-several in the axils; calyx bell-shaped, usually 4-angled, 4-toothed and with 4 intermediate short tooth-like appendages in the sinuses; petals 4, small, early deciduous, or wanting; stamens 4-8; capsule globular, enclosed in the calyx, mostly 4-celled, bursting irregularly.

Ammannia coccinea Rottb. Erect or ascending, glabrous, $\dot{5}-30 \mathrm{~cm}$. high, branched below; leaves oblong-linear, acute or obtuse, auriculate-clasping at the sessile base, entire, $2-4 \mathrm{~cm}$. long; flowers $1-5$ in the axils, sessile or nearly so; petals broadly spatulate, truncate; style slender, about one-half as long as the capsule.

Moist river banks; not certainly known from within our limits but to be expected on the lower Columbia as it occurs near the mouth of Hood River, Oregon. 


\section{ROTALA.}

Low annual mostly glabrous herbs; stems 4-angled; leaves opposite, sessile or sometimes petioled; flowers small, axillary, mostly solitary; calyx 4 -lobed; petals 4 ; stamens 4 , short; ovary free from the calyx, globose, 4 -celled; capsule globose, enclosed by the membranous calyx, 4-celled, septicidally dehiscent.

Rotala ramosior (L.) Koehne. Annual, glabrous, simple or branched below, 5-15 cm. high, erect or ascending; leaves entire, oblong or spatulate, obtuse or acute, $1-2 \mathrm{~cm}$. long, narrowed into a short petiole at base, not auricled; flowers mostly solitary in the axils; calyx 2-3 mm. long; petals minute; style very short.

Moist places, especially lake shores and stream banks, rare.

\section{Family 69. ONAGRACEAE. Evening Primrose Family.}

Herbs with simple alternate or opposite leaves; stipules none; flowers perfect, symmetrical, the parts in twos or fours; calyxtube adherent to the ovary; petals on the throat of the calyx or rarely wanting; stamens as many or twice as many as the petals or calyx-lobes, on the calyx-tube; style single, slender; stigma-lobes as many as the cells of the ovary; fruit a capsule or small nut; endosperm none.

Parts of the flower in twos.

Parts of the flower in fours.

Calyx-limb persistent; petals minute or wanting.

Calyx-limb deciduous; petals conspicuous.

Seeds silky-hairy; lower leaves mostly opposite.

Seeds not hairy; leaves all alternate.

Anthers attached at or near the base, erect.

Calyx-lobes reflexed; petals entire.

Calyx-lobes erect; petals 2-lobed.

327. Circaea, 246.

Anthers attached near the middle, versatile.

Stamens unequal, the outer ones longer.

Stamens equal.

Stigmas deeply 4-cleft, the lobes linear.

Stigmas entire or nearly so.

328. ISNARDIA, 247.

329. Eilobium, 247.

330. Godetia, 250.

331. Boisduvalia, 252.

327. CIRCAEA. Enchanter's Nightshade.

Delicate perennial herbs with opposite leaves on slender petioles; flowers white, in terminal or axillary racemes; parts of the flower in twos; calyx-tube prolonged, deciduous; lobes reflexed; fruit indehiscent, small, bur-like, 1-2-celled, with hooked hairs; cells 1 -seeded. 
Leaves denticulate; racemes bractless.

Leaves dentate; racemes with minute bracts.

C. pacifica.

C. alpina.

Circaea pacifica Asch. \& Magn. Nearly glabrous but pilose with white hairs on the upper part of the stem, $12-50 \mathrm{~cm}$. high; stem usually simple, from a small tuber; leaves ovate-orbicular, nearly entire or slightly denticulate, $3.5-6 \mathrm{~cm}$. long, truncate or rarely cordate at base, acute or sometimes obtuse at apex; petioles one third as long to as long as the blade; bracts of the inflorescence foliaceous or setaceous or none; flowers $2.5-3 \mathrm{~mm}$. long, rarely pinkish in the buds; fruit mostly white-hairy.

In moist shady woods, common.

Circaea alpina L. Much like $C$. pacifica but more delicate, the leaves prominently toothed; racemes bractless; flowers pinkish.

In springy places in the mountains.

\section{ISNARDIA.}

Annual or perennial succulent herbs with prostrate creeping or floating stems; leaves opposite, fleshy, narrowed into petioles shorter than the blades; flowers perfect, axillary, sessile; calyx turbinate, with 4 segments, persistent; petals 4 and small, or none; stamens 4; filaments short; stigma 4-lobed, often nearly sessile; ovary 4-celled, very short; ovules numerous; capsule 4angled, septicidal; seeds numerous.

Isnardia palustris L. Glabrous; stems creeping or sometimes floating, 15-30 cm. long; leaves all opposite, ovate or oval, 1-2 cm. long, acute, petioled; flowers sessile, axillary; petals very small and reddish, or none; capsules shortoblong, 4-sided, sessile, not attenuate at base.

Borders of lakes and ponds, not rare.

\section{EPILOBIUM. WILLOW Herb.}

Mostly perennial herbs; leaves nearly sessile, denticulate or entire, alternate or opposite; flowers axillary or terminal, solitary or clustered; calyx-tube scarcely prolonged beyond the ovary, 4-cleft; petals 4, spreading or somewhat erect; stamens 8 , the alternate ones shorter; fruit a dehiscent capsule; seeds numerous, each with a tuft of silky hairs at the end.

Calyx-tube not prolonged beyond the ovary; flowers large.

Stems 1-2 m. tall; bracts small; style pubescent at base.

Stems $15-50 \mathrm{~cm}$. high; bracts leaf-like; style glabrous.

Calyx-tube prolonged beyond the ovary; flowers mostly small.

Flowers pale yellow; stigmas 4-cleft.

Flowers white or pink; stigmas 4-cleft or subentire. Annuals; leaves narrow; stigmas mostly 4 -cleft.

Stems simple or but little branched, $8-20 \mathrm{~cm}$. high; herbage crisp-puberulent.

Stems usually much branched, 30-90 cm. high; herbage glabrous or glandular. Perennials; stigmas subentire.

E. angustifolium.

E. latifolium.

E. luteum.

E. minutum.

E. paniculatum. 
Stems tall, $30-90 \mathrm{~cm}$. high.

Petals $6-10 \mathrm{~mm}$. long; herbage canescentpuberulent.

Petals 3-5 $\mathrm{mm}$. long; herbage not canescent-puberulent.

Capsule sessile; leaves ovate or elliptic, sessile.

Capsule pedicelled; leaves ovate- or oblong-lanceolate.

Pedicels shorter than the capsules; leaves ovate-lanceolate, petiolate.

Pedicels equalling the capsules; leaves oblong-lanceolate, sessile.

Stems low; species mostly alpine or subalpine.

E. franciscanum.

E. brevistylum.

E. adenocaulon.

E. halleanum.

Seeds smooth; plants creeping or stoloniferous.

Leaves or some of them toothed, thin.

Leaves entire.

Stems ascending, usually curved; leaves spreading, oval or oblong, thick.

Stems erect; leaves ascending, linSeeds papillate. ear or oblong-lanceolate.

Foliage glaucous and glabrous.

Foliage not glaucous.

Plants producing stolons.

Matted; leaves firm, pale, green, sessile.

Not matted; leaves thin, bright green, petiolate.

Plants not producing stolons.

Stems simple.

Stems branched.

E. anagallidifolium.

E. oregonense.

E. fastigiatum.

E. clavatum.

E. alpinum.

E. delicatum.

Seeds $2 \mathrm{~mm}$. long; stems pubescent but not in lines; pedicels much shorter than the capsules.

Seeds $1 \mathrm{~mm}$. long; stems pubescent in lines; pedicels about as long as the cap(s. sules.)

E. mirabile.

Epilobium angustifolium L. Fireweed. Perennial, erect, about $1 \mathrm{~m}$. high, glabrous or puberulent; leaves numerous, lanceolate, acute, entire, or denticulate, nearly sessile, $8-16 \mathrm{~cm}$. long; lateral veins confluent at the margin; raceme erect, many-flowered, $20-40 \mathrm{~cm}$. long; flowers rose-colored, $2-3 \mathrm{~cm}$. broad; pedicels slender, exceeding the narrow bracts; petals obovate, entire, clawed; stigma 4-lobed; capsules spreading, linear, canescent, 5-10 cm. long. In open woods, abundant, especially in "burns."

Epilobium latifolium L. Stems $10-20 \mathrm{~cm}$. high; leaves alternate, ovatelanceolate, usually entire, thick; flowers large, purple, in a short raceme.

In the mountains in wet places, at about $2000 \mathrm{~m}$. altitude.

Epilobium luteum Pursh. Ncarly glabrous; stems $20-40 \mathrm{~cm}$. high; leaves opposite, elliptic or ovate, dentate, mostly sessile; flowers rather large, pale yellow.

Common along mountain streams. 
Epilobium minutum Lindl. Annual, simple or branched, puberulent, 10-30 cm. high; leaves lanceolate, acute, undulate or denticulate, mostly alternate, 1-2 cm. long, narrowed at base; calyx-tube funnelform; petals pinkish, obcordate, 3-4 $\mathrm{mm}$. long; stigma deeply 4-lobed; capsules shortstalked, curved, ascending or erect, $2-2.5 \mathrm{~cm}$. long.

In open woods, not plentiful.

Quk Epilobium paniculatum Nutt. Annual, glabrous or minutely pubescent,
much-branched above, $30-60 \mathrm{~cm}$. high; bark becoming loose and papery at much-branched above, $30-60 \mathrm{~cm}$. high; bark becoming loose and papery at
base; leaves linear or linear-lanceolate, often curved and folded, acute, denticulate, $2-5 \mathrm{~cm}$. long, attenuate to a short petiole; flowers pink or whitish, variable in size, usually $4-10 \mathrm{~mm}$. broad, in loose racemes terminating the almost naked branches; petals notched; capsules lanceolate-linear, $1-1.5 \mathrm{~cm}$. long, on pedicels about as long.

In open woods, abundant.

Epilobium franciscanum Barbey. Very similar to $E$. adenocaulon, but canescent-puberulent throughout or somewhat pilose above; leaves mostly sessile.

Vancouver Island and British Columbia to California; rare northward.

Epilobium brevistylum Barbey. Puberulent; stems about $30 \mathrm{~cm}$. high, at their bases usually bearing bulb-like rosettes; leaves mostly opposite, ovate or broadly lanceolate, minutely toothed, sessile; flowers small, purple; seeds roughened.

In moist alpine meadows at moderate elevations.

Elipobium adenocaulon Haussk. Perennial by short stolons which produce fleshy rosettes in the fall; stems erect, $30-60 \mathrm{~cm}$. high, usually simple, leafy, glabrous or puberulent, sometimes glandular above; leaves mostly opposite, lanceolate, acutish, closely denticulate, glabrous or puberulent, 5-7 cm. long, mostly short petioled; inflorescence terminal, becoming loose; petals notched, about $4 \mathrm{~mm}$. long, pink; capsules linear, nearly sessile, $6-8 \mathrm{~cm}$. long, usually puberulent; seeds minutely papillate.

Very common in open places. Very variable.

Epilobium halleanum Haussk. Glandular-pubescent; stems tall and slender, 60-90 cm. high; leaves opposite, oblong or ovate-lanceolate, serrulate, sessile or partly clasping at base; flowers purple, $10-12 \mathrm{~mm}$. broad; seeds rather smooth, pale beaked.

In low meadows, rare.

Epilobium alpinum L. (E. hornemanni Reichenb.) Perennial, aften tufted, $10-30 \mathrm{~cm}$. high, erect, usually puberulent or glandular in the inflorescence; leaves ovate, entire or denticulate, $2-4 \mathrm{~cm}$. long, narrowed at base to a short petiole; petals pink or purple, $5-8 \mathrm{~mm}$. long; capsule pedicellate; seeds smooth or minutely roughened.

Common in wet places in the mountains. A form with smaller white or pale pink flowers is $E$. lactiflorum Haussk. but it intergrades completely with E. alpinum L.

Epilobium anagallidifolium Lam. Stems low, simple, commonly densely clustered, usually sharply curved and strongly nodding at apex; leaves mostly obtuse; flowers few; petals purple, $5 \mathrm{~mm}$. long; hairs on the seeds dingy.

Along alpine rivulcts, common.

Epilobium oregonense Haussk. Glabrous, except the glandular inflorescence; stems slender, $15-20 \mathrm{~cm}$. high; petals deep purple, 7-8 $\mathrm{mm}$. long.

In alpine bogs, rare.

Epilobium fastigiatum (Nutt.) Piper. Perennial, glabrous and glaucous, usually tufted, the stems mostly simple, $10-20 \mathrm{~cm}$. high; leaves sessile, all 
opposite, ovate or ovate-lanceolate, serrulate, or nearly entire, 1-2 cm. long; petals usually pink, 4-8 $\mathrm{mm}$. long; stigma clavate; capsules $6-7 \mathrm{~cm}$. long; seeds minutely roughened.

In the mountains at low elevations, not common.

Epilobium clavatum Trelease. Tufted, somewhat glandular throughout; stems simple, ascending, 10-15 cm. high; leaves ovate, obtuse; petals purple, about $5 \mathrm{~mm}$. long; seeds large, $1.5-2 \mathrm{~mm}$. long, the tuft of hairs dingy.

Moist rocky slopes in the mountains.

Epilobium delicatum tenue Trelease. Nearly glabrous, erect, $10-20 \mathrm{~cm}$. high; leaves ascending, lanceolate, thin and pale; petals pink, 5-8 mm. long. Along rivulets in the mountains, rare.

Epilobium mirabile Trelease. Erect, $20-30 \mathrm{~cm}$. high; stems and leaves crisp-pubescent; leaves ovate-lanceolate, obtuse, ascending; petals pale, about $5 \mathrm{~mm}$. long; capsule short-stalked.

Olympic Mountains near Mount Steele,.Piper.

Epilobium leptocarpum Haussk. Much branched, glabrous except the puberulent stems; leaves lanceolate, obtusish; flowers rather numerous, white or pinkish; seeds less than $1 \mathrm{~mm}$. long, the tuft of hairs pale brown.

Cascade Mountains, Oregon.

Epilobium leptocarpum macounii Trelease. Whole plant, even to the flowers and capsules pubescent; leaves ovate-lanceolate.

Olympic Mountains, Piper; Mount Adams, Suksdorf; and north to Alaska. Probably a distinct species.

\section{GODETIA.}

Annuals, mostly erect; leaves alternate, sessile or nearly so; flowers showy, mostly red, in racemes or spikes or on starved plants solitary; calyx tube obconic, the limb splitting only on one side or into 4 lobes; petals broad, obovate, entire or notched; stamens 8, in two series, the ones opposite the petals shorter; stigma capitate or 4-lobed; capsule linear or narrowly-oblong, terete or 4-angled, 4-valved; seeds in 1 or 2 rows.

Stigmas linear; capsules pedicelled; calyx splitting on one side only.

Anthers hairy, the empty tips becoming hooked.

Anthers glabrous, the tips not empty.

Stigmas short and broad; capsules sessile; calyx-lobes becoming free (except $G$. gracilis).

Ovary and capsule villous.

Ovary and capsule puberulent or glabrous.

G. amoena.

G. caurina.

Capsule not prominently ribbed.

Style and stigmas very short, only half as long as the stamens.

G. quadrivulnera.

Style and stigmas nearly as long as the stamens. Capsule prominently ribbed.

Petals large, 2-3 cm. long, each with a dark blotch; capsules $1.5-3.5 \mathrm{~cm}$. long.

Petals $1-1.5 \mathrm{~cm}$. long; capsules $1-1.5 \mathrm{~cm}$. long.

G. romanzovii.

G. gracilis.
G. viminea.

G. arnottii.

Godetia amoena (Lehm.) Lilja. Puberulent; stems 30-60 cm. high; leaves linear to lanceolate, short petioled, $1-5 \mathrm{~cm}$. long; buds erect or but little nodding; calyx tube 5-10 mm. long; calyx tips united, splitting on one side in 
flowering; petals pink or rose-purple, $15-30 \mathrm{~mm}$. long; anthers purple, yellow and curved at the tip; stigmas yellow; capsule terete, broadest in the middle, puberulent, short-pedicelled, $3.5-4.5 \mathrm{~cm}$. long.

On dry plains, infrequent.

Godetia amoena lindleyi (Dougl.) Jepson. Petals pink, each with a dark purple central blotch.

Prairies; first collected by Douglas at Fort Vancouver, Washington.

Godetia caurina Abrams. Puberulent; leaves linear-lanceolate, entire; flower buds mostly erect, obtuse or acute; calyx tube $2 \mathrm{~mm}$. long; petals obovate, each purple with a darker central blotch, $1.5-2 \mathrm{~cm}$. long; anthers $3 \mathrm{~mm}$. long, glabrous; stigmas linear; capsule stoutly beaked, terete, puberulent, $2.5 \mathrm{~cm}$. long, on a pedicel half as long.

Vancouver Island and adjacent Washington.

Godetia quadrivulnera (Dougl.) Spach. Puberulent; stems slender, 30-60 $\mathrm{cm}$. high, simple or with few branches; lower leaves oblong to narrowly obovate, the upper linear or linear-lanceolate, sessile, entire or nearly so, $2-3 \mathrm{~cm}$. long; calyx lobes mostly separate and reflexed; calyx-tube $2-3 \mathrm{~mm}$. long; petals deep purple, each with a darker spot near the apex, 6-12 mm. long; stigmas purple, oblong, short; capsule sessile, 4 -sided, villous, $1.5-2.5 \mathrm{~cm}$. long.

Dry prairies, quite common; first collected at Fort Vancouver, Washington, by Douglas.

Godetia romanzovii (Ledeb.) Spach. Densely white puberulent throughout; stems slender, often branched from the base, $20-30 \mathrm{~cm}$. high; leaves linear, sessile, 1-3 cm. long; buds ovoid, acuminate, erect; sepals at length separate and reflexed; petals about $1 \mathrm{~cm}$. long, purple; stigma ovate, purple, as long as the style, both together $3 \mathrm{~mm}$. long, half as long as the stamens; ovary densely white puberulent, 8-ribbed; capsules sessile, somewhat 4 -sided, abruptly beaked, 10-14 $\mathrm{mm}$. long.

Port Angeles, Elmer, No. 2567. G. romanzovii was found by Chamisso on the "Northwest Coast" and is known only from garden specimens. Elmer's plant described above agrees in the very short style and stigmas but differs in other respects and may represent a distinct species.

Godetia gracilis Piper n. sp. Stems slender, erect, mostly simple, 30-60 $\mathrm{cm}$. high; herbage appressed-puberulent; leaves few, sessile, linear, $2-5 \mathrm{~cm}$. long; buds lance-ovoid, acute, somewhat nodding; calyx-tube turbinate, 4-5 mm. long; calyx splitting on one side in anthesis, the tips remaining united; corolla rose-colored, the obovate petals $1-2 \mathrm{~cm}$. long; filaments subulate, glabrous; anthers sparsely hairy, becoming curved, filled with pollen to the tip; stigmas yellow, short and broad; pods sessile, puberulent, terete, $2-3 \mathrm{~cm}$. long; seeds brown, the ends oblique, minutely crested on the margin of the top.

Dry prairies from Vancouver Island southward, the type collected at Silverton, Oregon, Elihu Hall, No. 192, in 1871. The species has been much confused with G. tenella Cav. and G. quadrivulnera Dougl. It is very closely allied to G. dudleyana Abrams, but differs in its bud being acute and not acuminate; pods terete, not 2 -ribbed on each face, abruptly tipped not distinctly beaked, and much more puberulent; it also closely resembles small flowered specimens of G. amoena but is at once separated by the short stigmas.

Godetia viminea (Dougl.) Spach. Glabrous to finely puberulent, rather stout, erect, $30-80 \mathrm{~cm}$. high; leaves linear to lanceolate, entire, $1-5 \mathrm{~cm}$. long; calyx-tube narrowly campanulate, membranous, 6-10 mm. long; calyx-lobes free at tip in the bud, at length separate and reflexed; petals purplish, usually paler at base and with a dark blotch in the center; stigmas oblong, purple; capsule sessile, puberulent, straight, 4 -sided, with a stout rib on each face, short, $1.5-3.5 \mathrm{~cm}$. long. 
Fields and prairies, western Oregon to California; first found in the Umpqua Valley, Oregon, by Douglas.

Godetia arnottii (T. \& G.) Walp. Glabrous, leafy especially near the top; stems $20-40 \mathrm{~cm}$. high; leaves thickish, oblong to oblong-lanceolate, entire, 2-4 cm. long; flowers crowded; petals purple; capsules glabrous, 8ribbed, $1-1.5 \mathrm{~cm}$. long.

Open places, Willamette Valley, Oregon, and southward.

\section{BOISDUVALIA.}

Erect leafy annual herbs; leaves alternate, sessile, simple; flowers small, in leafy simple or compound spikes; calyx-tube funnelform above the ovary, 4-lobed; petals 4, 2-lobed, purple or white; stamens 8, those opposite the petals shorter; anthers attached near their bases, erect; ovary 4-celled, several-ovuled; capsule membranaceous, ovate-oblong to linear, nearly terete, acute, sessile, dehiscent to the base; seeds $3-8$, in one row in each cell.

Leaves of the inflorescence broad; capsule septifragal.

Leaves of the inflorescence narrow; capsule loculicidal.

B. densiflora. B. stricta.

Boisduvalia densiflora (Lindl.) Wats. Erect, simple or with a few branches below, hoary-puberulent throughout or nearly glabrous, $30-90 \mathrm{~cm}$. high; lower leaves lanceolate, acuminate, denticulate, $2-6 \mathrm{~cm}$. long; upper leaves gradually shorter and sometimes broader, ovate, acuminate, nearly entire, crowded; spikes dense; corolla 6-8 mm. broad, purplish; capsules oblong, 5-8 $\mathrm{mm}$. long, the partitions not adherent to the valves in dehiscence; seeds 3-6 in each cell.

In low meadows.

Boisduvalia stricta (Gray) Greene. Erect, simple or rarely branched below, villous throughout, $30-40 \mathrm{~cm}$. high; leaves all alike, lanceolate, acute, entire or denticulate, $2-3 \mathrm{~cm}$. long; flowers in the axils of the upper leaves and occasionally of the lower also; corolla $2-3 \mathrm{~mm}$. long, purplish; capsules slender, acuminate, $8-10 \mathrm{~mm}$. long; partitions adherent to the valves; seeds $6-8$ in each cell.

In dried-up ponds and swales, rare.

\section{GAYOPHYTUM.}

Very slender caulescent branching annuals; leaves alternate, linear, entire; flowers axillary; calyx-tube not prolonged beyond the ovary, 4-parted; petals 4 , white or rose-colored, very small, obovate or oval, with a very short claw; stamens 8 ; anthers broad or rounded, attached by the middle, those opposite the petals on shorter filaments and usually sterile; ovary 2-celled; fruit a dehiscent capsule; seeds few-many, naked, in one row.

Gayophytum ramosissimum T. \& G. Erect, with usually many slender branches, glabrous below, puberulent above, 15-40 cm. high; leaves linear or linear-lanceolate, $1-4 \mathrm{~cm}$. long, acute, attenuate at the sessile base; flowers pink, small, $2-4 \mathrm{~mm}$. broad, pedicelled; capsules oblong or somewhat clubshaped, of ten torulose, $6-12 \mathrm{~mm}$. long, spreading, on slender pedicels, sometimes deflexed; seeds not hairy.

Dry soil, especially in open woods. 


\section{Oenothera. Evening Ppimrose.}

Annual, biennial or perennial herbs with prostrate or erect stems; leaves alternate, entire, toothed or pinnatifid; buds erect or drooping; flowers white, pink or yellow, blooming by night or by day; flowers axillary or in terminal spikes; calyx-tube elongated, terete, filiform or enlarged upward; segments narrow, tips free or united in bud, finally reflexed; stamens 8, equal, with filiform filaments and linear anthers; ovary 4-celled, the united styles filiform; stigma 4-cleft; ovules numerous in one, two or more rows, horizontal or ascending; capsule 4-celled, 4-angled, loculicidal; seeds numerous, angled or terete, with or without a tubercle.

Oenothera biennis L. Biennial, stout, erect, simple or little branched above, $30-100 \mathrm{~cm}$. high, sparsely hirsute throughout; leaves green, oblonglanceolate to lanceolate, acute or acuminate, repandly denticulate, $5-15 \mathrm{~cm}$. long, all but the basal ones sessile; bracts lanceolate; calyx-tube $2.5-3.5 \mathrm{~cm}$. long; petals obovate, bright yellow, about $2 \mathrm{~cm}$. long; capsule broadest at or near the base.

Infrequent in open places, especially near the seashore. O. biennis L. consists of numerous forms or very closely related species at present the subject of much investigation by students of heredity. Our form was called O. muricata L. in the Flora of Washington, but is not that plant.

\section{SPHAEROSTIGMA.}

Annual or biennial caulescent herbs; flowers axillary or in spikes; calyx-tube obconical or shortly funnelform; stamens 8, equal in length; anthers attached near the middle, versatile; stigma entire; capsule 4-celled, terete or angled; seeds in one row in each cell.

Sphaerostigma contortum (Dougl.) Walp. Slender annual, usually branched from the base, $10-15 \mathrm{~cm}$. high, sparsely puberulent or glabrous; leaves narrowly linear, entire or denticulate, $2-3 \mathrm{~cm}$. long, sessile; flowers sessile in the axils, somewhat shorter than the leaves; petals reddish-yellow, $2 \mathrm{~mm}$. long, as long as the reflexed calyx-lobes; capsules sessile, linear, somewhat 4 -sided, usually twisted or bent at the base, $2-3 \mathrm{~cm}$. long. tains.

Victoria, British Columbia, Macoun; common east of the Cascade Moun-

\section{Family 70. HALORAGIDACEAE WAter Milfoil FAmily.}

Aquatic or marsh or alpine perennial herbs with inconspicuous symmetrical flowers sessile in the axils of leaves or bracts; calyxtube adherent to the ovary; calyx-limb very short or none; petals small or none; stamens $1-8$; pistil of $1-4$ carpels, if more than one, more or less united; styles or sessile stigmas distinct; fruit indehiscent, 1-4-celled with one seed in each cell. 


\section{HIPPURIS.}

Perennial herbs, with simple erect stems and whorled simple entire leaves; flowers small, perfect or polygamous; calyx entire; style thread-shaped with the stigma on one side lying in a groove between the lobes of the single large anther: fruit nut-like, 1celled, 1-seeded.

Leaves 8-12 in each whorl; tall aquatic plant.

Leaves 5-6 in each whorl; minute alpine plant.

H. vulgaris.

H. montana.

Hippuris vulgaris L. Mare's Tail. Aquatic; stems simple, $30-90 \mathrm{~cm}$. high; leaves usually $2-4 \mathrm{~cm}$. long, linear, acute, in whorls of $6-12$, rather rigid or the submersed ones flaccid.

Borders of lakes and ponds, not common.

Hippuris montana Ledeb. Terrestrial; stems $2-8 \mathrm{~cm}$. high; leaves in whorls of 5 or $6,8-12 \mathrm{~mm}$. long.

In wet places in alpine meadows, often forming extensive colonies.

\section{MYRIOPHYLLUM. WATER Milfoil.}

Perennial aquatics; leaves crowded, often whorled; submersed ones pinnately parted into capillary lobes; flowers monoecious or polygamous, sessile in the axils of the upper leaves, usually above water; calyx of the staminate flowers 4-parted, of the fertile 4 -toothed; petals 4 or none; stamens 4 or 8 ; fruit nut-like, 4 -celled, deeply 4-lobed.

Stamens 4; petals persistent; floral leaves linear, sparingly denticulate.

Stamens 8; petals deciduous.

Floral leaves ovate, entire or toothed, shorter than the

flowers.
Floral leaves pinnatifid, much longer than the flowers.

M. hippuroides.

Myriophyllum hippuroides Nutt. Lower leaves pinnate, the divisions filiform; upper linear, acute, remotely dentate or nearly entirc; petals white, obovate; fruit $2 \mathrm{~mm}$. long.

In ponds, rare.

Myriophyllum spicatum L. Leaves $2-3 \mathrm{~cm}$. long, rather rigid, pinnately parted into filiform segments, the rachis equally narrow; bracts ovate, entire or dentate, about equalling the flowers; petals greenish.

In lakes and ponds, not rare.

Myriophyllum verticillatum pectinatum Wallr. Leaves flaccid, all dissected into filiform segments; rachis flattened and broader than the segments; bracts pinnatifid, shorter than or barely exceeding the flowers.

In quiet lakes, infrequent. In typical $M$. verticillatum $L$., not known from our limits, the bracts are much longer than the flowers.

\section{Family 71. ARALIACEAE. Ginseng FAMily.}

Perennial herbs, shrubs, or trees; leaves simple or compound, with dilated petioles; flowers umbellate, paniculate or racemose; 
calyx adherent to the ovary, the limb entire or toothed; petals 5, epigynous; stamens 5 , epigynous, alternate with the petals; styles 2 or more; ovary 2 or more celled, crowned with a disk; fruit a few-celled drupe.

\section{ECHINOPANAX.}

Stout shrubs, ours very prickly; leaves simple, long-petioled, suborbicular, palmately-lobed; flowers perfect or polygamous, in numerous umbels which are in racemes or panicles; calyx-margin narrow or obsolete, obscurely crenate-lobed; carpels (in ours) 2 .

Evek Echinopanax horridum (Smith) Dcne. \& Planch. Devil's Club. Shrub; stems 1-4 m. long, mostly decumbent below, armed with pale prickles; leaves all at the summit of the stem, 10-30 $\mathrm{cm}$. broad, palmately 5-13-lobed; lobes acute and serrate; petioles and principal veins prickly beneath; flowers greenish-yellow; fruit scarlet.

Abundant in wet places. The prickles make painful wounds and are therefore but erroneously supposed to be poisonous. The whole plant has a rank odor.

\section{Family 72. UMBELLIFERAE. PARSLey FAmily.}

Herbs; stems usually hollow; leaves compound or simple; petioles often dilated at the base; flowers small, in umbels or rarely heads, the umbels often subtended by primary bracts (the involucre); in compound umbels, the secondary rays of ten subtended by secondary bracts (the involucels); calyx entirely adherent to the ovary; petals and stamens on the calyx-tube; base of the style (stylopodium), often expanded; ovary 2-celled, 2ovuled; fruit of 2 seed-like dry carpels with contiguous inner surfaces (the commissure), each carpel marked lengthwise with 5 primary ribs and often with 4 intermediate secondary ones, in the intervals between which oil-tubes are commonly found; carpels often separating from each other, supported on the summit of a slender axis (the carpophore).

Mature fruits are absolutely necessary for accurate determinations in this family.

Flowers in dense heads; fruit scaly or tuberculate.

338. ERyngium, 257.

Flowers in umbels.

Fruit more or less bristly.

Bristles hooked, covering the whole fruit surface.

339. Sanicula, 257.

Bristles only on the ribs of the fruit.

Stylopodium obsolete; bristles barbed at tip.

340. Daucus, 258. 
Stylopodium conical; bristles not barbed.

Carpels oblong or ovate.

Carpels linear.

Fruit glabrous, not at all bristly.

341. Caucalis, 258.

342. OSMORHIZA, 259.

Carpels strongly flattened dorsally.

Stylopodium conical; petals obcordate. 343. HeraCleum, 260.

Stylopodium flat or obsolete.

Plants acaulescent.

Plants caulescent.

Flowers white; dorsal ribs of fruit prominent.

Ultimate segments of leaves large.

Ultimate segments of leaves small.

Flowers yellow or purple; dorsal ribs of fruit filiform.

Flowers yellow.

Flowers brownish-purple.

Carpels not dorsally flattened.

Oil-tubes obsolete or very obscure.

Leaves ternately decompound.

Leaves simple, peltate.

344. Cogswellia, 260.

Oil-tubes present; leaves not peltate.

Fruit with a single oil-tube in each interval.

Stylopodium conical.

Leaflets lanceolate to ovate.

Leaflets linear.

Involucre wanting.

Involucre present.

Stylopodium flat or obsolete.

Flowers yellow; leaves simple or trifoliolate.

Flowers white.

Leaves decompound.

Leaves reduced to hollow petioles.

Fruit with more than one oil-tube

345. Angelica, 261.

346. Conioselinum, 262.

347. Pastinaca, 262.

348. LePtotaenia, 263.

342. OSMORHIZA, 259.

349. HYDROCOTYLE, 263.

350. Cicuta, 263.

351. CoRIANDRUM, 264.

352. Carum, 264.

353. Zizia, 265.

354. Oenanthe, 265.

355. Lilaeopsis, 265. in each interval.

Stylopodium conical.

Fruit globose.

Fruit oblong.

Stylopodium flat or obsolcte.

Ribs of the fruit wing-like.

Ribs of the fruit not winglike.

Plants acaulescent.

Fruit with all the ribs filiform; root not tuberous.

Fruit with the dorsal ribs filiform, the lateral ones corky; root tuberous.

356. BERULA, 266.

357. Ligusticum, 266.

358. Glehnia, 267.

Plants caulescent; ribs

359. Hesperogenia, 267.

360. Orogenia, 267. 
of the fruit all thick and corky.

Leaflets linear or narrowly lanceolate. Leaflets ovate.

361. SiUm, 267.

362. Coelopleurum, 268.

\section{ERYNGIUM.}

Glabrous perennials; leaves often rigid, coriaceous, entire, spinosely toothed or divided; flowers white or blue, sessile, in dense bracteate heads; sepals very prominent, rigid and persistent; stylopodium wanting; styles short or long, of ten rigid; fruit ovoid, compressed laterally, covered with hyaline scales or tubercles; carpel with ribs obsolete; oil-tubes mostly 5, 3 dorsal and 2 commissural; seed face plane.

Eryngium petiolatum Hook. Stems erect, $30-40 \mathrm{~cm}$. high; lower leaves reduced to long nodose petioles, sometimes with small lanceolate remotely spinulose blades; upper leaves opposite, narrow, spinulose-serrate; heads globose, about $8 \mathrm{~mm}$. wide; bracts and bractlets subulate, ciliate-spinulose, twice as long as the heads.

In swales, rare, western Oregon. First collected by Douglas.

\section{SANicUla. Sanicle.}

Perennial tall rather glabrous herbs, with ternate or palmate leaves; flowers perfect and staminate mixed in heads in few-rayed umbels, yellow or green; involucral bracts few; calyx-teeth evident, persistent; fruit globular, the carpels not separating, ribless, the whole surface covered with hooked bristles.

Fruit 6-7 mm. long; styles much exceeding the bristles. Fruit $4 \mathrm{~mm}$. long or less; styles not exceeding the bristles.

Mature fruit stipitate; leaves palmately divided.

Mature fruit sessile, not stipitate.

Leaves pinnately parted, the segments incised.

Leaves palmately divided.

Principal leaf divisions confluent at base.

Principal leaf divisions distinct at base.
S. marilandica.

S. menziesii.

S. bipinnatifida.

S. howellii.

S. septentrionalis.

Sanicula marilandica L. Stems erect, 30-120 cm. high; leaves 5-7-parted, the divisions incisely serrate and cleft; umbels 3-7-rayed; sterile flowers numerous, sometimes in separate umbellets; fruit sessile, 6-7 $\mathrm{mm}$. long, its bristles bulbous-based.

Vancouver Island, British Columbia, Macoun, and eastward.

Sanicula menziesii Hook. \& Arn. Stems erect, 30-100 cm. high, branched above; leaves mostly basal, cordate-orbicular, palmately $3-5-l o b e d, 5-10 \mathrm{~cm}$. broad, the lobes incisely cleft and toothed, the teeth bristle-tipped; umbel 3 - or 4-rayed; involucral bracts leaf-like; involucels 6-8, linear, entire; flowers yellow; fruit sessile, stipitate, obovate, $2-4 \mathrm{~mm}$. long, very bristly.

Common especially on bluffs along the seashore. The northern plant is feebly distinguishable from the typical plant of California by having the leaflobes obtuse or obtusish instead of acute. It has been named $S$. tripartita Suksdorf. 
Sanicula bipinnatifida Dougl. Stems $20-40 \mathrm{~cm}$. high, stout; leaves mostly basal, pinnately 3-7-parted, the divisions incisely toothed or lobed, decurrent on the rachis forming a wing; umbel 3-4-rayed; involucral bracts leaf-like; involucels narrow, acute; flowers purple or yellow, in dense umbellets, the sterile ones pedicelled; fruit $3 \mathrm{~mm}$. long.

Prairies, Vancouver Island to California. First collected by Douglas at Fort Vancouver.

Sanicula howellii Coult. \& Rose. Stems stout, $20-30 \mathrm{~cm}$. high, sometimes tufted; leaves thick, orbicular, palmately 3-5-lobed, incisely toothed and cleft, the teeth mucronate; umbels few-rayed, the involucral bracts leaf-like; involucels large, equalling or exceeding the dense umbellets; flowers yellow; fruit $3-4 \mathrm{~mm}$. long, bristly all over.

In drifting sand, often half buried, Vancouver Island, British Columbia, to Oregon. First collected by Howell at Tillamook Bay, Oregon.

Sanicula septentrionalis Greene. Erect, slender, 10-35 cm. high; basal leaves few, small, ternate or biternate, the obovate segments cleft or toothed; cauline leaves few, more sharply toothed; peduncles arising singly along the stem; umbels with 3-5 rays; involucre of pinnatifid leaf-like bracts; fruiting rays $1.5-3.5 \mathrm{~cm}$. long; flowers yellow; fruit $4 \mathrm{~mm}$. long.

Prairies, Vancouver Island, British Columbia, to northern California.

\section{DAUCUS. CARROT.}

Annual or biennial herbs; leaves pinnately decompound; bracts of the involucre foliaceous and cleft; flowers white; calyx-teeth obsolete; fruit oblong, flattened dorsally; primary ribs of the carpel 5, slender and bristly, the secondary 5-winged, each bearing a single row of barbed prickles; stylopodium depressed or none; oil-tubes solitary in the intervals.

Annual, 10-60 cm. high; umbel small.

Biennial, 60-90 cm. high; umbel large.

D. pusillus.

D. carota.

Daucus pusillus Michx. Annual; herbage bristly pubescent; stems slender, $10-30 \mathrm{~cm}$. high; leaves pinnately decompound, the ultimate segments narrowly linear; umbels small, $2-5 \mathrm{~cm}$. broad; fruit $3-5 \mathrm{~mm}$. long.

Dry fields and prairies, common.

Daucus carota L. Wild Carrot. Biennial; herbage bristly; stem stout, 60-90 cm. high; leaves pinnately decompound, the ultimate segments lanceolate, cuspidate; umbel $5-12 \mathrm{~cm}$. broad; fruit 3-4 mm. long.

The wild form of the cultivated carrot, very troublesome as a weed. The flowers are usually white, rarely rose-colored or purple.

\section{CAUCALIS.}

Mostly hispid annuals; leaves pinnately dissected with very small segments; flowers white; calyx-teeth prominent; fruit short, ovate or oblong, compressed laterally; carpel with 5 filiform primary ribs with spreading bristles and 4 prominently winged secondary ones with barbed or hooked prickles; stylopodium thick, conical; oil-tubes solitary in the intervals.

Caucalis microcarpa Hook. \& Arn. Annual, erect, branched, 8-20 cm. tall, more or less hairy, leaves pinnately much dissected, the ultimate segments 
linear-oblong, $2.5 \mathrm{~mm}$. long; umbels unequally 3-6-rayed; involucral bracts resembling the leaves; involucels usually entire; fruit oblong, armed with rows of hooked prickles.

In fields and prairies, Vancouver Island, British Columbia, and adjacent Washington. Not otherwise known west of the Cascade Mountains but common in the interior and southward into California.

\section{OSMORHizA. Sweet Cicely.}

Glabrous to hirsute perennials, $30-90 \mathrm{~cm}$. high; roots thick, aromatic; leaves ternately decompound; leaflets broad, ovate to lanceolate, variously toothed; involucre and involucels fewleaved or wanting; flowers white or purple, in few-rayed and few-fruited umbels; calyx-teeth obsolete; stylopodium conical, sometimes depressed; styles mostly short; fruit linear to linearoblong, more or less attenuate at base, obtuse, acute or beaked at apex, glabrous or bristly on the ribs; carpels slightly flattened dorsally or not at all, nearly pentagonal in section, with equal ribs and thin pericarps, of ten tapering into a long tail-like attenuation at the base; oil-tubes obsolete in the mature fruit (often numerous in young fruit); seed face from slightly concave to deeply sulcate.

Fruit glabrous.

Fruit with bristly ribs.

O. ambigua.

Flowers purple; fruit short-beaked.

Flowers white.

Foliage strigose-pubescent; fruit beaked.

Foliage glabrous or nearly so.

Fruit with a conspicuous sharp beak.

Fruit constricted below the apex and with a truncate tip.

O. purpurea.

O. brevipes.

O. divaricata.

O. leibergii.

Osmorhiza ambigua (Gray) Coult. \& Rose. Glabrous except the pubescent nodes; stems branched, $30-60 \mathrm{~cm}$. high; leaves twice or thrice ternate; leaflets ovate, acute, incisely toothed and cleft, thin, 3-6 cm. long; umbel of 4-8 rays, without bracts; rays $3-6 \mathrm{~cm}$. long, widely spreading; fruit $12-18 \mathrm{~mm}$. long, beaked, attenuate at base.

In the mountains at about $1500 \mathrm{~m}$. altitude, rare. Goat Mountains, Allen.

Osmorhiza purpurea (Coult. \& Rose) Suksdorf. Nearly glabrous; stems $10-60 \mathrm{~cm}$. high; leaves once or twice ternate; leaflets ovate to lanceolate, acute to acuminate, incisely lobed and toothed, $2-7 \mathrm{~cm}$. long; umbel with $2-4$ rays, these 5-7 cm. long; fruit hispid at base, 10-12 mm. long, slightly beaked at apex.

Mount Hood, Oregon, Henderson; Olympic Mountains, Washington, Lamb; and northward to Alaska.

Osmorhiza brevipes (Coult. \& Rose) Suksdorf. (Washingtonia brevipes Coult. \& Rose.) Similar to $O$. divaricata but pubescent with white hairs; pedicels shorter, $4-12 \mathrm{~mm}$. long, decidedly shorter than the fruit, which is 14-16 $\mathrm{mm}$. long.

In open woods, Washington to California.

Osmorhiza divaricata Nutt. Glabrous or nearly so, 30-60 cm. tall; leaves biternate; leaflets ovate or lanceolate, acute or acuminate, thin, coarsely 
serrate and more or less incised; umbels 2-9-rayed; pedicels mostly $1-2 \mathrm{~cm}$. long; involucels none; fruit 16-20 mm. long, bristly-hairy on the ribs, the carpels distinctly beaked, much narrowed at the base.

In woods, common.

Osmorhiza leibergii (Coult. \& Rose) Suksdorf. Very similar to O. divaricata; pedicels 10-15 mm. long, longer than the fruit; fruit slightly hispid at base, otherwise nearly glabrous, blunt at the tip.

In the Cascade and Olympic Mountains.

\section{HERACLEUM.}

Tall stout perennials; leaves large, ternately compound; involucres deciduous; involucels of numerous bractlets; flowers white, in large many-rayed umbels; calyx-teeth small or obsolete; petals obcordate, the outer ones often dilated and 2-cleft; stylopodium thick conical; fruit broadly ovate, very much flattened dorsally, somewhat pubescent; carpel with dorsal and intermediate ribs filiform, the broad lateral wings contiguous to those of the other carpel, strongly nerved toward the outer margin; oil-tubes solitary in the intervals, conspicuous, about half as long as the carpel, 2-4 on the commissural side; seed very much flattened dorsally.

Heracleum lanatum Michx. Cow Parsnip. Very stout, 1-2 m. tall, pubescent throughout; leaves ternate or biternate; petioles much dilated; leaflets round-cordate, $10-25 \mathrm{~cm}$. broad, irregularly lobed and dentate; rays 5-15 cm. long; fruit obcordate, $8-12 \mathrm{~mm}$. broad, the oil-tubes conspicuous. Abundant in wet places, the young shoots used as food by the Indians.

344. COGSWELLIA.

Acaulescent or short caulescent dry ground perennials; roots fusiform or tuberous; leaves ternate to dissected, sometimes pinnate; involucre none; involucels mostly present; flowers yellow, white or purple; calyx-teeth obsolete or very rarely evident; stylopodium wanting; fruit strongly flattened dorsally, oblong to orbicular; carpel with filiform and approximate dorsal and intermediate ribs and winged laterals coherent till maturity with those of the other carpel; pericarp thin; oil-tubes 1-several in the intervals (rarely obsolete), 2-10 on the commissural side; seed dorsally flattened, with plane face (rarely slightly concave).

Peduncles stout, usually swollen at top; herbage glaucous. C. nudicaulis.

Peduncles slender, never swollen at top; herbage green.

Bractlets conspicuous.

Bractlets small or wanting.

Leaves ternate.

C. utriculata.

Leaves pinnate.

C. triternata.

Oil-tubes 3 in each interval.

C. hallii.

Oil-tubes 1 in each interval.

Fruit with wings as broad as body.

C. martindalei.

Fruit with wings narrower than body.

C. angustata. 
Cogswellia nudicaulis (Pursh) Jones. Glabrous and somewhat glaucous, root cylindric, thick and fleshy; leaves all basal, mostly biternate or ternate; and then quinate; leaflets ovate to narrowly lanceolate, entire or with a few teeth at the apex, 3-5 cm. long, thickish; peduncles stout, 10-30 cm. high; rays unequal, 4-20 cm. long; flowers yellow; fruit smooth, oblong, 9-14 $\mathrm{mm}$. long.

In sandy or gravelly soil, Vancouver Island, British Columbia, to California.

Cogswellia utriculata (Nutt.) Jones. Glabrous or merely puberulent; leaves mostly basal, 1 or 2 cauline, ternately or pinnately decompound, the ultimate segments narrowly linear, 6-12 $\mathrm{mm}$. long; petioles dilated at base; peduncles or stems $20-30 \mathrm{~cm}$. high; rays unequal, $2-5 \mathrm{~cm}$. long; flowers yellow; fruit elliptical, glabrous, $2-7 \mathrm{~mm}$. long.

Prairies, Vancouver Island, British Columbia, to California. Root tuberous, said to have been used by the Indians for food. First collected by Nuttall near the mouth of the Willamette River.

Cogswellia triternata (Pursh) Jones. Peduncles $\cdot 30-70 \mathrm{~cm}$. tall; leaves bipinnate or triternate, puberulent; leaflets linear-lanceolate, $5-15 \mathrm{~cm}$. long; umbel unequally 5-18-rayed, the rays $1-5 \mathrm{~cm}$. long; fruit oblong, glabrous, 6-12 mm. long; oil-tubes large, solitary between the ribs; two on the inner side.

Prairies from near the head of Puget Sound, southward.

Cogswellia hallii (Wats.) Jones. Glabrous; leaves mostly basal, a few cauline, pinnate, oblong in outline, the segments ovate, deeply toothed or pinnatifid, about $1 \mathrm{~cm}$. long; umbel 3-6-rayed; flowers yellow; fruit elliptical, glabrous, $6 \mathrm{~mm}$. long, with 3 oil-tubes in the intervals between the ribs and 4 on the inner side.

Mount Hood, Oregon, Howell; Mount Saint Helens, Washington, Mrs. Biggs, à doubtful specimen; not otherwise known.

Cogswellia martindalei (Coult.\& Rose) Jones. Glabrous, somewhat glaucous, leaves rather thick, bipinnate, the ultimate segments ovate, toothed or pinnatifid, $10-12 \mathrm{~mm}$. long; stems bearing 1 or 2 leaves, $15-40 \mathrm{~cm}$. high; fruit glabrous, $8-16 \mathrm{~mm}$. long, the wings as broad as or broader than the body; oiltubes solitary in the intervals between the ribs, two on the inner side.

Bluffs of the Columbia River at Bridal Veil, Oregon, and southward.

Cogswellia angustata Coult. \& Rose. Very similar to $C$. hallii, but fruit with one oil-tube in each interval and two on the inner side.

Common in rocky places in the mountains at about $1500-2000 \mathrm{~m}$. altitude. Probably only a form of $C$. hallii.

\section{ANGELICA.}

Stout perennial herbs; leaves ternate, then pinnate, rarely simply pinnately compound; involucre scanty or none; involucels of small bractlets or none; flowers in large terminal umbels; calyx-teeth mostly obsolete; stylopodium conical; fruit flattened dorsally, ovate or oblong, glabrous or pubescent; calyx-tube prominent, crenulate; carpels with strong ribs, the lateral ribs usually broadly winged, distinct from those of the other carpel, forming a double-winged margin to the fruit; oil-tubes 1-several in the intervals, or indefinite, $2-10$ on the commissural side; seed face plane or somewhat concave. 
Involucels of numerous bractlets.

Involucels usually wanting.

A. genuflexa.

Fruit 4-6 mm. long, the lateral wings not thick and corky.

Fruit 6-8 mm. long, the lateral wings thick and corky.

A. lyallii.

A. arguta.

Angelica hendersoni Coult. \& Rose. Herbage densely tomentose; stems stout, 1-2 m. high; leaves quinate, then pinnate; leaflets thick, broadly ovate, obtuse, cuneate or rounded at base, serrate, 7-10 cm. long; umbel 10-12 cm. broad; fruit oblong, pubescent, $6-9 \mathrm{~mm}$. long, the lateral wings thick and corky, as broad as the body.

On the ocean coast, Washington to California. First collected at Ilwaco by Henderson.

Angelica genuflexa Nutt. Glabrous below the inflorescence; stems stout, 90-150 cm. high; leaves once or twice pinnate, the divisions more or less deflexed; leaflets ovate to lanceolate, acuminate, sharply serrate or incised; umbel many-rayed, $10-15 \mathrm{~cm}$. broad; bractlets of the umbellets linear; fruit 3-4 mm. long, glabrous, emargina te at base and apcx, the lateral wings broader than the body.

Very common in swamps. First collected by Nuttall on Sauvies Island, Oregon, and near Fort Vancouver, Washington.

Ut Cdams Angelica lyallii Wats. Stout, $60-150 \mathrm{~cm}$. tall, glabrous or the inflorescence sometimes puberulent; leaves ternate, then once or twice pinnate; leaflets ovate or lanceolate, acute, serrate or dentate, 2-10 cm. long; umbel manyrayed; involucre and involucels wanting; fruit oblong, 4-6 mm. long, the lateral wings about as broad as the body; oil-tubes solitary in all the intervals.

Wet places in the mountains at moderate elevations.

Angelica arguta Nutt. Very similar to A. lyallii but the fruit larger, 6-8 $\mathrm{mm}$. long, the lateral wings thick and corky.

Known only from the type specimen collected by Nuttall in 1835 on Sauvies Island, Oregon, and near Fort Vancouver, Washington. The rediscovery and better understanding of this species is much to be desired.

\section{CONIOSELINUM.}

Perennial herbs, glabrous below the inflorescence; leaves ternate then pinnately decompound; flowers white; calyx-teeth obsolete; fruit oblong, dorsally flattened, glabrous; carpel with prominent dorsal and intermediate ribs, the lateral ribs broadly winged and thickish; stylopodium slightly conical; oil-tubes usually solitary in the dorsal intervals, 1 -several in the lateral intervals, and $2-8$ on the commissural side.

Conioselinum gmelini (Cham. \& Schlecht.) Coult. \& Rose. Glabrous below the inflorescence; stems erect, 1-1.5 m. high; leaves large, ternate, then pinnately decompound, the ultimate segments ovate to linear-oblong, mostly incisely cleft, $1-2.5 \mathrm{~cm}$. long; umbel $10-25$-rayed, the rays $2-3 \mathrm{~cm}$. long; bracts and bractlets narrowly linear; fruit $4-5 \mathrm{~mm}$. long, with prominent ribs and broad wings.

High sea-beaches and on the borders of tidal marshes. Foliage handsome, fern-like.

347. PASTINACA. PARSNIP.

Tall stout glabrous biennial with pinnately compound leaves; flowers yellow; calyx-teeth obsolete; fruit oval, very much flat- 
tened dorsally; stylopodium flattened; dorsal ribs filiform, the lateral extended into broad wings; oil-tubes small, solitary in in the intervals, $2-4$ on the commissural side.

Pastinaca sativa L. Glabrous; stems $60-90 \mathrm{~cm}$. high; leaves pinnately compound, the leaflets ovate to oblong, incisely serrate; flowers yellow; fruit oval.

The common parsnip of the garden frequently becomes wild.

\section{LEPTOTAENIA.}

Usually tall or stout, glabrous, nearly acaulescent; roots thick, fusiform, often very large; leaves usually large, pinnately decompound; involucre of few bracts or none; involucels of numerous small bractlets; flowers yellow or purple; calyx-teeth obsolete or sometimes evident; stypolodium wanting; fruit flattened dorsally, oblong-elliptical, glabrous; carpel with dorsal and intermediate ribs filiform or obscure; lateral wings very thick and corky; commissural face with a prominent central longitudinal ridge left after separation from the carpophore; oil-tubes 3-6 in the intervals, 4-6 on the commissural side, mostly small, sometimes obsolete; seeds very flat, with plane or slightly concave face.

Leptotaenia dissecta Nutt. Nearly glabrous and somewhat glaucous; stems stout, 30-90 cm. high; leaves mostly basal, large, ternate then thrice pinnate; ultimate segments ovate to oblong, incisely pinnatifid, puberulent on the veins beneath, 1-2.5 cm. long; peduncle elongated; umbel 8-20-rayed; bracts linear; flowers brownish-purple; fruits 10-18 mm. long.

Vancouver Island, British Columbia to California, first collected by Nuttall near the mouth of the Willamette River.

\section{HYDROCOTYLE.}

Low perennial herbs growing in or near water, with slender creeping stems; leaves orbicular-peltate or reniform; flowers small, white, in simple or proliferous umbels without an involucre; calyx teeth minute or obsolete; fruit more or less orbicular, strongly compressed laterally; carpel with 5 primary ribs, the dorsal marginal, broad or filiform; intermediate ribs filiform, usually curved; lateral ribs filiform or broad; oil-bearing layer prominent beneath the epidermis, occasionally with small tubes.

Hydrocotyle ranunculoides L.f. Floating or creeping in mud; leaves round-reniform, thick, crenately 3-7-cleft; peduncles $3-7 \mathrm{~cm}$. long, shorter than the petioles, reflexed in fruit; umbel 5-10-flowered; fruit 2-3 mm. broad.

Ponds and muddy banks, not rare.

\section{0. cicuta. Water Hemlock.}

Smooth poisonous marsh perennials; leaves pinnately compound; leaflets serrate; involucre of few bracts or none; involucels of several slender bractlets; flowers white; calyx-teeth rather prominent; stylopodium low, sometimes low-conical; 
fruit compressed laterally, oblong to orbicular, glabrous; carpels with strong flattish corky ribs, the lateral largest at least in section; oil-tubes solitary in the intervals, two on the commissural side; seed nearly terete or somewhat dorsally flattened, the commissural face plane or slightly concave.

Leaflets thickish, lanceolate to ovate-lanceolate, closely and sharply serrate or even cleft, strongly reticulate beneath.

Leaflets thinner, linear-lanceolate, not so closely or sharply serrate, not strongly reticulate beneath.

C. douglasii.

Cicuta douglasii (DC.) Coult. \& Rose. Glabrous and somewhat glaucous; stems stout, 60-90 cm. high, loosely branched; leaves twice pinnate; leaflets lanceolate to ovate-lanceolate, closely and sharply serrate or more or less incised, 5-10 cm. long; fruit orbicular, $2 \mathrm{~mm}$. long.

In swamps, common. First collected by Douglas at the mouth of the Columbia River. Root very poisonous.

Cicuta vagans Greene. Very similar to $C$. douglasii; leaflets narrower, linear-lanceolate, thin in texture, and less strongly reticulate beneath.

In swamps, probably only a form of $C$. douglasii.

\section{CORIANDRUM. CORIANDER.}

Annual herbs; leaves bipinnately divided; flowers white, in spreading umbels; calyx 5-toothed; fruit globose, not constricted, 10 -ribbed, the primary ribs inconspicuous.

Coriandrum sativum L. Glabrous; stems slender, $60-90 \mathrm{~cm}$. high; lower leaves pinnate, the leaflets fan-shaped, many-cleft, the upper leaves more dissected with linear ultimate segments; flowers white; fruit globose, smooth.

In waste places, an escape from gardens.

\section{CARUM. Caraway.}

Smooth erect slender herbs; roots fascicled, tuberous or fusiform; leaves pinnate, with few linear leaflets; involucels of few to many bracts; flowers white; calyx-teeth prominent for the size of the fruit; stylopodium conical; fruit compressed laterally, orbicular to oblong, glabrous; carpels with filiform or inconspicuous ribs; oil-tubes large and solitary in the intervals, 2-6 on the commissural side; seeds dorsally flattened, more or less longitudinally grooved beneath the oil-tubes, the face plane or slightly concave.

Fruit orbicular, $2 \mathrm{~mm}$. long.

Fruit oblong, 3-4 mm. long.

C. gairdneri:

C. oreganum.

Carum gairdneri (Hook. \& Arn.) Gray. Roots fusiform, clustered; stems erect, slender, $30-100 \mathrm{~cm}$. tall, simple or branched above; leaves few, mostly pinnate, with 3-7 linear leaflets, 5-15 cm. long, the lowermost rarely bipinnate, the upper simple; umbels $6-15$-rayed, the rays $2-4 \mathrm{~cm}$. long; involucels linear, acuminate; fruit subglobose, flattened, 1-2 mm. long, with small calyx-teeth.

Common in low meadows. Roots edible, a favorite food of the Indians. 
Carum oreganum Wats. Very similar to $C$. gairdneri but the lower leaves more divided, and with shorter linear lobes; involucels broader and more scarious; fruit oblong, 3-4 mm. long.

Willamette Valley, Oregon, south to northern California. First found by Nuttall on Wappatoo or Sauvies Island; doubtfully distinct from $C$. gairdneri.

\section{ZIZIA.}

Smooth perennials with simple to ternately compound leaves; involucre none; involucels of small bractlets; flowers yellow; calyx-teeth prominent; stylopodium wanting; styles long; fruit compressed laterally, ovate to oblong, glapbrous; central fruit of each umbellet sessile; carpel with filiform ribs; oil-tubes large and solitary in the broad intervals, 2 on the commissural side and a small one in each rib; seed terete, longitudinally grooved beneath the oil-tubes.

Zizia cordata (Walt.) Koch. Glabrous, 30-80 cm. tall; lower leaves simple, cordate, crenately toothed, $2-8 \mathrm{~cm}$. long, sometimes lobed or even ternate, mostly long-petioled; upper leaves short-petioled, palmately compound, of 3-5 leaflets, ovate or lanceolate, incised and serrate; fruit ovate, 3 $\mathrm{mm}$. long.

Said to occur in the Willamette Valley; abundant east of the Cascade Mountains.

\section{OENANTHE.}

Aquatic glabrous herbs with succulent stems; leaves pinnate or decompound; flowers white, in involucrate umbels; calyx-teeth rather prominent; fruit glabrous, globose or but slightly laterally compressed; carpel with broad obtuse corky ribs; stylopodium very short, conical; styles elongated; oil-tubes solitary in the intervals, 2 on the commissural side.

Oenanthe sarmentosa Presl. Glabrous; stems weak, decumbent, somewhat succulent, 30-60 $\mathrm{cm}$. long; leaves ternate, then bipinnate, the leaflets ovate, acuminate, coarsely serrate, sometimes lobed at base, $1-2.5 \mathrm{~cm}$. long; umbels $3-5 \mathrm{~cm}$. broad; involucral bracts few, linear; fruit oblong-cylindrical, $4 \mathrm{~mm}$. long.

Very common in wet places; first found at Nootka Sound by Haenke. Sometimes called Water Parsley.

\section{LILAEOPSIS.}

Small glabrous perennials, creeping and rooting in the mud; leaves reduced to hollow cylindrical or awl-shaped jointed petioles; flowers white, in few-flowered umbels which are subtended by minute bracts; calyx-teeth small; fruit glabrous, globose or but slightly compressed laterally; carpel with filiform dorsal and intermediate ribs, the lateral ribs thick and corky next to the commissure; stylopodium flat; oil-tubes solitary in the intervals, 2 on the commissural side. 
Lilaeopsis occidentalis Coult. \& Rose. Leaves linear-attenuate, $3-18 \mathrm{~cm}$. long; peduncles much shorter than the leaves; fruit $2 \mathrm{~mm}$. long, the lateral ribs corky-thickened.

Muddy shores of lakes, Alaska to Oregon, of ten abundant enough to make a dense sward.

\section{BERULA.}

Smooth aquatic perennials, with simply pinnate leaves; involucre and involucels of conspicuous narrow bracts; flowers white; calyx-teeth minute; fruit compressed laterally, nearly round, glabrous; carpels nearly globose with slender inconspicuous ribs; stylopodium conical; oil tubes numerous and contiguous, closely surrounding the seed cavity.

Berula erecta (Huds.) Coville. Stems erect, 20-90 cm. high; leaflets 5-9 pairs, linear to oblong or ovate, serrate or incised or somewhat laciniately lobed, 2-8 cm. long; peduncles $2-5 \mathrm{~cm}$. long; fruit barely $2 \mathrm{~mm}$. long.

In wet places, very rare in our limits; near Tacoma, Flett.

\section{LIGUSTICUM. LOVAGE.}

Smooth perennials from large aromatic roots; leaves usually large, ternately or ternately-pinnately compound; flowers white or pinkish, in large many rayed umbels; involucre usually none; involucels narrow; calyx teeth small or obsolete; fruit oblong or ovoid, compressed laterally if at all, glabrous; carpels with prominent and equal ribs; stylopodium conical; oil tubes $2-6$ in the intervals, $6-10$ on the commissural side.

Stems naked, the leaves mostly basal; flowers purplish. Stems leafy; flowers white.

Leaflets coarsely toothed or lobed.

Leaflets deeply cleft into linear lobes.

L. purpureum.

L. apiodorum.

L. apiifolium.

Ligusticum purpurem Coult. \& Rose. Nearly glabrous; stems 40-60 cm. high; leaves nearly all basal, once or twice ternate, then pinnate; leaflets ovate, obtuse, incisely toothed or lobed, 1-2.5 cm. long; flowers purple-tinged; rays of the umbel few, $2-3 \mathrm{~cm}$. long; fruit $4 \mathrm{~mm}$. long.

In alpine meadows, at about the limit of trees, in the Cascade Mountains.

Ligusticum apiodorum (Gray) Coult. \& Rose. Glabrous, except the puberulent inflorescence and the scabrous leaf margins; stems $60-90 \mathrm{~cm}$. high; leaves ternately decompound; leaflets distinct or somewhat confluent, cuneateoblong, incised, paler beneath; umbels $6-15$-rayed, the rays $3-5 \mathrm{~cm}$. long; involucels linear-setaceous; flowers white or pinkish; fruit 3-4 $\mathrm{mm}$. long.

Portland, Oregon, Henderson, and south to San Francisco, California.

Ligusticum apiifolium (Nutt.) Gray. Nearly glabrous up to the puberulent inflorescence; stems $60-120 \mathrm{~cm}$. high; leaves twice to thrice ternate, then pinnate, ultimate segments ovate, deeply cleft into linear mostly entire acute lobes; umbel many-rayed, the rays $5-10 \mathrm{~cm}$. long; flowers white; fruit $4 \mathrm{~mm}$. long.

In open woods and prairies, not common. First collected by Nuttall near the mouth of the Willamette River. 


\section{GLEHNIA.}

Low villous-tomentose herbs growing in drifting sands along the seashore; leaves thickish, densely white-tomentose beneath, once or twice ternate or ternate-pinnate, with ovate or roundish leaflets; flowers whitish; bracts subulate; calyx-teeth small; fruit globose, glabrous; carpel somewhat flattened dorsally with 5 equal broad and corky thickened wings; stylopodium flat; oil-tubes $2-3$ in the intervals, 4-6 on the commissural side.

Glehnia littoralis (Gray) Schmidt. Herbage villous-tomentose; stems very short; leaves twice-ternate and then pinnate, the leaflets rather fleshy, ovate to orbicular, serrate to dentate, densely white tomentose beneath, $2-5$ $\mathrm{cm}$. long; stems shorter than the leaves; rays of the umbel 10-12; fruits 8-10 $\mathrm{mm}$. broad, with wings $3 \mathrm{~mm}$. wide.

Common in drifting sand along the ocean coast, Oregon to Alaska; first collected by Cooper at Shoalwater Bay or Willapa Harbor.

\section{HESPEROGENIA.}

Low acaulescent plants; leaves once or twice ternate; flowers yellow, in umbels with a few unequal rays, with one or two bractlets and no involucre; calyx-teeth obsolete; fruit glabrous, nearly orbicular or short-oblong, compressed laterally, rounded at base and apex; carpel with indistinct filiform ribs; stylopodium none; oil-tubes 2 or 3 in the intervals.

Hesperogenia stricklandi Coult. \& Rose. Glabrous, pale green; root stout; leaves all basal, ternate or biternate, long-petioled, the segments lanceolate, acutish, rather thick, $8-12 \mathrm{~mm}$. long; stems $8-10 \mathrm{~cm}$. high, naked, with a single reduced leaf; rays $3-6$, unequal; flowers yellow; fruit $2 \mathrm{~mm}$. long.

Known only from Mount Rainier, Allen, Flett.

\section{OROGENIA.}

Dwarf glabrous acaulescent plants from tuberous or fusiform roots; leaves ternate with linear segments; flowers white, in a subcompound umbel with a few linear bractlets and no involucre; calyx-teeth minute; fruit glabrous, oblong, very slightly compressed laterally; carpels with filiform dorsal and intermediate ribs and excessively thickened lateral ones; stylopodium flattened; oiltubes very small, 3 in the intervals, $2-4$ on the commissural side.

Orogenia linearifolia Wats. Tuber globose; scape slender, $2-12 \mathrm{~cm}$. high; leaves 2 or 3 , ternate or biternate, glabrous, the leaflets linear, obtuse, entire, $2-5 \mathrm{~cm}$. long; umbels 2-10-rayed; flowers white, nearly sessile; fruit 3-4 $\mathrm{mm}$. long.

Willamette Valley, Oregon, to Idaho, Utah and California.

\section{SIUM.}

Perennial, growing in water or in wet places; leaflets serrate or pinnatifid; involucres and involucels of numerous narrow bracts; flowers white; calyx-teeth minute; stylopodium depressed; 
styles short; fruit compressed laterally, ovate to oblong, glabrous; carpels with prominent corky nearly equal ribs; oil-tubes 1-3 in the intervals, never solitary in all the intervals, $2-7$ on the commissural side; seed subangular, with plane commissural face.

Sium suave Walt. (S. cicutaefolium Schrank.) Stout, $60-80 \mathrm{~cm}$. tall; leaves pinnate, with 7-17 linear or lanceolate serrate acuminate leaflets, these $5-12 \mathrm{~cm}$. long; umbel many-rayed, the rays $2.5-4 \mathrm{~cm}$. long; fruit $3 \mathrm{~mm}$. long, with prominent ribs.

Margins of lakes and ponds, common. When growing in water the leaflets are finely dissected.

\section{COELOPLEURUM.}

Stout glabrous seacoast perennial herbs; leaves 2-3-ternate on very large inflated petioles; flowers greenish-white, in many-rayed umbels with a few-leaved deciduous involucre and numerous small linear-lanceolate involucels; calyx-teeth obsolete; fruit oblong, slightly flattened laternally if at all, glabrous; carpels with very thick and prominent corky ribs which become hollow, all equal or the lateral ones broadest; oil tubes small, 2-4 on the commissural side and 1 or 2 under each rib.

Leaflets acute or acuminate, not thick.

Leaflets obtuse, very thick.

C. longipes.

C. maritimum.

Coelopleurum longipes Coult. \& Rose. Glabrous below the inflorescence; stems stout, 1-1.5 m. high, loosely branched above; leaflets ovate, acute to acuminate, cuneate at base, mostly sharply serrate, $3-5 \mathrm{~cm}$. long; inflorescence puberulent; umbel large, flat-topped, $10-15 \mathrm{~cm}$. broad; fruit oblong, $3 \mathrm{~mm}$. broad, 4-6 $\mathrm{mm}$. long.

Along the seacoast of Washington and British Columbia. Scarcely distinct from the Alaska C. gmelini (DC.) Ledeb.

Coelopleurum maritimum Coult. \& Rose. Very similar to C. longipes; leaflets broadly ovate, often subcordate, obtuse, $6-7 \mathrm{~cm}$. long; fruit $6-7 \mathrm{~cm}$. long.

On ocean bluffs near the mouth of the Columbia River; Ilwaco, Washington, Henderson, Piper; Astoria, Oregon, Cooper.

\section{Family 73. CORNACEAE. Dogwood Family.}

Trees or shrubs, rarely herbs; leaves simple, alternate or opposite; flowers regular, perfect, polygamous or dioecious, in cymes or heads; calyx-tube adherent to the ovary; petals and stamens 4 , on the margin of an epigynous disk in the perfect flowers; style 1; ovary 1-2-celled, with one ovule in each cell; fruit a 1-2-seeded drupe.

Flowers perfect, in loose or head-like cymes.

Flowers dioecious, in spikes. 


\section{CORNUS. DOGWOOD.}

Herbs, shrubs or trees; leaves opposite, sometimes apparently whorled, entire; flowers perfect, in a cymose or capitate cluster; calyx minutely 4-toothed; petals 4, oblong or ovate; stamens 4 , with slender filaments; style 1 ; drupe ovoid or oblong, with a 2 -celled 2 -seeded stone,

Flowers in loose cymes, not involucrate; fruit white.

C. occidentalis.

Flowers in head-like cymes, surrounded by a conspicuous involucre; fruit red.

Tree, $10-20 \mathrm{~m}$. high; bracts $4-8 \mathrm{~cm}$. long.

Herb, 8-20 cm. high; bracts $1-2 \mathrm{~cm}$. long.

C. nuttallii.

C. canadensis.

Cornus occidentalis (T. \& G.) Coville. Much branched shrub, 2-5 m. high, with red twigs, these hairy when young; leaves ovate to oval, acute to acuminate, mostly cuneate at base, glabrous above, loose pubescent beneath, 4-8 cm. long; petiole 1-2 cm. long; cymes short-peduncled, 2-6 cm. broad, pubescent; flowers cream-colored, 6-8 $\mathrm{mm}$. broad; fruit globose, white; stone oblique, compressed, the edge furrowed.

In wet ground, especially on stream banks, common.

Cornus nuttallii Audubon. Tree 6-12, rarely $20 \mathrm{~m}$. high; bark gray-brown, smooth or on very old trunks flaky; young twigs pubescent; wood fine-grained, white; winter buds sharp-pointed; leaves obovate, acute or acuminate, cuneate at base, puberulent above, pubescent beneath, 8-12 cm. long; petioles 6-20 $\mathrm{mm}$. long; heads hemispheric, $1-2 \mathrm{~cm}$. broad, surrounded by an involucre of $4-8$, usually $5-6$, obovate cream-colored or sometimes pink bracts, $4-5 \mathrm{~cm}$. long; drupes bright shiny orange-red, 25-40 in each cluster, each tipped with the persistent calyx; stone nearly as broad as long.

British Columbia to California. Under cultivation the dogwood frequently blooms a second time in the fall and under such conditions the involucral bracts are oftener pink tinged.

i2 $5 t$ Cornus canadensis L. Perennial herb, 10-20 cm. high, the rootstocks woody; stems scaly below, bearing 2 or 3 pairs of leaves above, forming a false whorl and sometimes a pair near the middle; leaves ovate or oblong, acute or acuminate, narrowed at base, sessile, entire, sparsely puberulent, 2-4 cm. long; peduncle solitary, 4-5 cm. long; involucral bracts 4-6, white, ovate, 8-16 mm. long; flowers greenish, small, in dense heads; fruit bright red, globular, $4 \mathrm{~mm}$. in diameter.

In rich woods, especially in the mountains.

\section{GARRYA.}

Evergreen shrubs, with 4-angled branchlets; leaves opposite, entire, coriaceous, with short connate petioles; flowers dioecious, in axillary aments; petals none; staminate flowers with a 4-parted calyx; stamens 4; filaments distinct; disk and ovary none; pistillate flowers with a 2-lobed or obsolete calyx-limb; stamens and disk none; styles 2, stigmatic on the inner side, persistent; ovary 1-celled; berry blue or purple, ovoid, 1-2-seeded.

Garrya elliptica Dougl. Shrub, 2-3 m. tall; leaves elliptical or oval, mucronate, undulate-margined, dark-green and shiny above, densely tomentose beneath, 5-10 cm. long; staminate aments 5-20 cm. long, the silky bracts 
acute to truncate; pistillate aments $3-8 \mathrm{~cm}$. long, the bracts acute or acuminate; fruit globose, sessile, densely tomentose, $6-9 \mathrm{~mm}$. in diameter.

Douglas reports this shrub " plentiful on the shore, in rocky situations, on the south side of the Columbia, near its confluence with the sea." No recent specimens seem to have been collected north of the Rogue River.

\section{Family 74. PYROLACEAE. Pyrola Family.}

Perennial green herbs or chlorophyll-less and leafless rootparasites or saprophytes; flowers solitary, racemose or corymbose, often on a scape, perfect, nearly regular; calyx 2-6-lobed or parted, free from the ovary; corolla gamopetalous and 5toothed or of 5 separate petals; stamens 10 , with one- or twohorned anthers; ovary superior, 4- or 5-celled; style short or slender, often declined; capsule globose, 4- or 5-lobed, loculicidally 4- or 5-valved.

Ovary 1-celled.

Petals united; sepals 2 or 4 , entire.

Petals distinct; sepals 4 or 5 .

Sepals and petals fimbriate; anthers long.

Sepals and petals entire; anthers short. Ovary 4 - or 5-celled.

Petals none; flowers in a spike.

Petals present; flowers solitary or in racemes or corymbs.

Petals united almost to the tips.

Petals free almost or quite to the base.

White, tawny or red (sometimes turning black on drying) chlorophyll-less parasites or saprophytes.

Flowers solitary.

Flowers in a 1 -sided raceme.

Green chlorophyll-bearing herbs.

Flowers solitary.

Flowers in racemes or corymbs.

365. NEWBERRYA, 270.

366. Pleuricospora, 271.

367. Pityopus, 271.

368. Allotropa, 271.

369. Pterospora, 272.

Inflorescence a corymb; style short.

Inflorescence a raceme; style mostly long.
370. MoNotropa, 272.

371. HyPOPITYS, 272.

372. MONESES, 273.

373. Chimaphila, 273.

374. Pyrola, 274.

\section{NEWBERRYA.}

Stout simple stemmed fleshy white herbs without chlorophyll and with flowers in a dense spike; leaves scale-like; calyx of 2 , rarely 3 or 4 sepals; corolla tubular-urceolate, $4-5$-lobed; stamens normally 8 or 10 , sometimes fewer; filaments pubescent above the middle with long hairs; disk of short and deflexed glands alternating with the stamens; ovary ovate; style long; stigma depressed-capitate; placentae of $4-8$ broad lamellae bearing ovules on both surfaces. 
Newberrya congesta (Gray) Torr. (Hemitomes congestum Gray; Newberrya longiloba Small.) Whole plant white or brownish, glabrous, 10-20 cm. high; scale-like leaves imbricated, oval to oblong, obtuse, rather thin, obscurely erose, passing into the similar bracts; flowers in a short crowded raceme; corolla-lobes ovate, obtuse to acute, hairy within.

In deep woods, British Columbia to Oregon, rare.

\section{PLEURICOSPORA.}

Stout fleshy white herbs without chlorophyll and with the flowers crowded into a dense spike; leaves scale-like; calyx of $4-5$ sepals; corolla of $4-5$ plane petals; stamens 8 or 10 ; filaments glabrous; anthers introrse, the cells opening longitudinally from base to apex; ovary ovoid; style columnar; stigma depressed capitate to funnelform; placentae parietal, commonly 8 .

Petals oblong or oblong-lanceolate, as long as the sepals; lower scales entire.

Petals spatulate, much longer than the sepals; lower scales laciniate.

P. fimbriolata.

Pleuricospora fimbriolata Gray. Whole plant white, fleshy, glabrous, stout, 5-20 cm. high; scale-like leaves numerous, the lower ovate and entire, the upper narrower and fringed; flowers in a dense corymb; bracts fringed, as long as the corolla.

In deep coniferous woods in the mountains, rare; British Columbia to California.

Pleuricospora longipetala Howell. Stem slender, 10-15 cm. high; scalelike leaves well-imbricated, lanceolate, acuminate, laciniately toothed; flowers white or yellowish, numerous, in a dense oblong raceme; sepals lanceolate, acute or acuminate, laciniately toothed, about as long as the bracts; petals narrowly spatulate, $12 \mathrm{~mm}$. long, much longer than the sepals, the obtuse apex fimbriate.

In dense woods, near the hot springs in Clackamas County, Oregon, Howell.

\section{PITYOPUS.}

White herb, glabrous or nearly so; leaves scale-like; inflorescence a dense bracteate spike; sepals 4 or 5 , distinct, persistent; petals as many, pubescent; stamens 8 or 10 ; filaments pubescent; anthers short; ovary 1-celled, ovoid, 4-5-lobed, each lobe 2ribbed; style stout; stigma truncate, annular; ovules many.

Pityopus oregona Small. Whole plant white and glabrous; stem stout, about $10 \mathrm{~cm}$. high; scales triangular or the upper lanceolate, acute, entire or erose, 1-2 cm. long; bracts lanceolate to spatulate; sepals rhomboid-lanceolate, $12 \mathrm{~mm}$. long; petals oblong, obtuse, pubescent within, as long as the sepals.

In dense woods, north of Mount Hood, Oregon, Howell; and the same or a very similar species (Monotropa californica Eastwood) in Marin County, California.

\section{ALLOTROPA.}

Reddish chlorophyll-less herbs with numerous scale-like leaves; flowers in a spike; sepals 5, roundish, persistent; petals none; stamens 10, glabrous; style at first short, at length longer; 
stigma large, capitate; ovary globose, 5-celled; seeds numerous, on the thick axillary placenta.

Allotropa virgata T. \& G. Whole plant dark reddish; stem simple, stout, erect, $30-50 \mathrm{~cm}$. high, $1 \mathrm{~cm}$. or more in diameter, swollen at base; scale-like leaves numerous, especially near the base, the lower ones ovate, the upper lanceolate, attenuate, acuminate; spike dense; bracts linear; sepals erosely dentate.

In open rather dry coniferous woods, British Columbia to California. A plant of remarkable appearance.

\section{PTEROSPORA.}

Stout simple purplish-brown clammy-pubescent root-parasitic herbs without chlorophyll; stem wand-like, with scattered lanceolate scales toward the base, in place of leaves; flowers many, nodding, white, in a long bracted raceme; corolla gamopetalous, ovate, urn-shaped, 5-toothed; stamens 10; anthers 2-celled, awned on the back; stigma 5-lobed; capsule globose, flattened, 5-lobed, 5-celled; seeds very numerous.

Pterospora andromedea Nutt. A reddish purple glandular-hairy herb, with straight simple flowering stems, 30-90 cm. high; roots coral-like, much branched; scale-like leaves brownish, scarious, attenuate-lanceolate, largest and most numerous below, 1-3 cm. long; raceme elongated, the flowers nodding on pedicels 1-2 cm. long; bracts small, narrow; flowers white or pinkish, 4-5 $\mathrm{mm}$. broad; capsules flattened, globose, $1 \mathrm{~cm}$. wide.

Coniferous woods in the mountains, usually occurring in colonies. The plants die after blooming.

\section{MONOTROPA.}

White chlorophyll-less herbs which turn black on drying; stems clustered; flowers solitary, nodding, on scapes; sepals 2-4, deciduous; petals 5 or 6 oblong, not saccate, tardily deciduous; stamens 10-12; anthers short, peltate; disk 10-12-toothed, united to the base of the ovary; style short, thick; stigma funnelform, with obscurely crenate margin; ovary 5 -celled; seeds minute.

Monotropa uniflora L. Whole plant bluish-white, rarely pinkish, drying black, glabrous; stems $10-30 \mathrm{~cm}$. high, usually clustered; scale-like leaves scattered, broadly lanceolate, entire; flower nodding; fruit erect.

Rich woods, rather common.

\section{HYPOPITYS.}

Whitish tawny or reddish chlorophyll-less herbs; roots a dense mass of fleshy fibers; flowers in a nodding one-sided raceme on a slender scape; sepals and petals 5 in the terminal flower, $3-4$ in the lateral ones; petals saccate at the base; stamens 6-10; filaments subulate-filiform; anthers horizontal; disk 8-10-toothed, united to the base of the ovary; style slender; stigma funnelform, its margin glandular-ciliate; ovary 3 -5-celled.

Bracts and sepals merely ciliate.

Bracts and sepals fimbriate. 
Hypopitys hypopitys (L.) Small. Whole plant reddish or yellowish, somewhat pubescent, $10-40 \mathrm{~cm}$. high; scale-like leaves lance-ovate, entire or slightly erose, scattered above, densely arranged below; flowers 3-20, racemose, nodding at first, erect in fruit; terminal flower 5-merous, the lateral ones 3-4-merous; style terete; stigma disk-like; pod subglobose.

In coniferous woods, especially in the mountains at low altitudes, common. $H$. brevis Small described from specimens collected at Independence Valley, Oregon, by Craig, is said to differ by having the style much dilated upward and the stigma funnelform.

Hypopitys fimbriata (Gray) Howell. Very similar to $H$. hypopitys but the upper scales, the bracts and the sepals laciniate or fimbriate.

In coniferous woods, rare. Reported from Mount Arrowsmith, Vancouver Island, and Chilliwack, British Columbia, Macoun; Cascade Mountains of Oregon; not yet known to occur in Washington.

\section{MONESES.}

Low perennial glabrous herbs; flowers solitary on a slender scape, drooping, white or pink; petals 5, distinct, widely spreading, orbicular; stamens 10; filaments not enlarged in the middle, naked; anthers conspicuously 2-horned; style exserted; stigma large, peltate, with 5 short radiating lobes; ovary globose, 4-5celled; ovules numerous; capsule subglobose, 4-5-celled, 4-5valved; seeds numerous, minute.

Moneses uniflora (L.) Gray. Rootstock very slender; stems erect, bearing 2-4 pairs or whorls of leaves; leaves obovate or orbicular, obtuse, finely crenate or dentate, $8-20 \mathrm{~mm}$. long, narrowed at the base, the petioles shorter; scapes $5-12 \mathrm{~cm}$. high, 1-flowered, usually bearing a solitary bract; flowers white, nodding, $12-20 \mathrm{~mm}$. broad; capsules erect, 6-8 mm. broad.

Coniferous woods in the mountains. The Pacific Coast plant has by some botanists been considered distinct under the name $M$. reticulata Nutt.

\section{CHIMAPHILA. PIPSISSEWA.}

Low nearly herbaceous perennials; leaves irregularly opposite, whorled or scattered, coriaceous, short-petioled, serrate; flowers in corymbs on a leafy stem; petals 5 , widely spreading, orbicular; anthers 2-horned; stigma large, peltate, with 5 narrow and conspicuous radiating lobes; valves of the capsule naked.

Flowers many; leaves cuneate-oblanceolate, numerous. Flowers few; leaves ovate or oblong-lanceolate, few.

C. umbellata.

C. menziesii.

Chimaphila umbellata (L.) Nutt. (C. occidentalis Rydb.) Stems 15-30 $\mathrm{cm}$. high, erect from horizontal rootstocks; leaves evergreen, leathery, cuneateoblanceolate, acute, serrate, $2-4 \mathrm{~cm}$. long, short-petioled, glabrous or minutely puberulent; flowers 4-8, pink, about $1 \mathrm{~cm}$. broad, in terminal corymbs; filaments bearded on the margins; capsule 6-8 $\mathrm{mm}$. broad.

Deep coniferous woods, common.

Chimaphila menziesii (R. Br.) Spreng. Stems 10-15 cm. high; leaves few, ovate or oblong-lanceolate, acute at each end, serrulate, 1-2.5 cm. long, the principal veins bordered with white; peduncle 1-3-flowered; petals white or pinkish; bracts ovate or orbicular; filaments expanded and hairy in the middle.

In deep coniferous woods especially in the mountains. 


\section{PYROLA.}

Low and smooth perennial herbs; leaves roundish, petioled, evergreen, basal or nearly so; flowers nodding, in a simple raceme, on a more or less scaly-bracted scape; corolla of 5 concave more or less converging petals; stamens 10; ovary 4- or 5-celled; ovules very numerous; fruit a flattened globose 5-lobed 5-celled capsule.

Style straight.

P. secunda.

Style curved downward.

Green leaves none, or very rudimentary.

Flowers red.

Flowers white.

P. aphylla.

$P$. dentata.

Green leaves present.

Calyx lobes obtuse, very short; flowers greenish.

P. chlorantha.

Calyx lobes acute.

Flowers white or whitish.

Veins of leaves white-bordered.

Veins of leaves not white-bordered.

Flowers red or pink.

Leaves coriaceous, shiny, acute.

Leaves thin, dull, obtuse.

P. picta.

$P$. dentata.

P. bracteata.

P. elata.

Mr Atame Pyrola secunda L. Rootstocks slender, usually much branched; stems erect or ascending; leaves somewhat clustered at the base, ovate, obtuse or acute, crenate, $1-3 \mathrm{~cm}$. long, on slender petioles $1 \mathrm{~cm}$. long; scapes $10-25 \mathrm{~cm}$. high, with few scale-like bracts, which also occur between the leaves; raceme one-sided, 3-8 cm. long; flowers white, on short pedicels, soon nodding; corolla regular; petals oblong, $4 \mathrm{~mm}$. long, each with a pair of tubercles at base; anthers obtuse; stigmas large, 5-lobed.

Deep coniferous woods, especially in the mountains.

Pyrola aphylla Smith. Stems $20-40 \mathrm{~cm}$. high, erect, the whole plant red or very rarely with one or two small green leaves; rootstock stout, scaly, branched; leaves reduced to lanceolate or subulate bracts; raceme loose, 10-30flowered; calyx-lobes ovate, acute; petals obovate, pink; anthers beaked; style nearly straight, declined.

In coniferous woods. The rare form with small green leaves has been called P. aphylla paucifolia Howell.

Pyrola chlorantha Sw. Leaves orbicular, often retuse, thick, not shiny, small, mostly $2-3 \mathrm{~cm}$. long, shorter than the petioles; scapes 10-20 cm. high, bractless or with solitary bracts; raceme 3-10-flowered; petals greenish-white, rounded; calyx-lobes very short and obtuse; anthers beaked.

In deep coniferous woods.

Pyrola picta Smith. Rootstocks creeping; leaves tufted at base, oblong, ovate or orbicular, obtuse or acute, mucronate, obscurely denticulate or entire, green, variegated with white along the veins, often purple beneath, $2-6 \mathrm{~cm}$. long; petioles margined, $1-3 \mathrm{~cm}$. long; scapes erect, $15-30 \mathrm{~cm}$. high, with few bracts, 10-20-flowered; calyx-lobes short, ovate, about one-fourth as long as the petals; corolla irregular; petals white, $6-7 \mathrm{~mm}$. long; anthers constricted at the apex; style deflexed, with a projecting collar at the base of the stigma.

Open coniferous woods, common.

Pyrola dentata Smith. Loosely tufted; leaf blades mostly oblong to oblanceolate, remotely dentate to subentire, obtuse or acute, dull green or glaucous, not mottled, $2-6 \mathrm{~cm}$. long, tapering at base into petioles nearly as long; scapes $10-25 \mathrm{~cm}$. high, naked or with 1-3 scales; raceme 5-15-flowered; bracts 
triangular-lanceolate; calyx-lobes deltoid-ovate, scarcely longer than broad; petals cream-colored, obovate; style deflexed.

In dry soil, in open pine woods. Allied to $P$. dentata and $P$. picta is a group of puzzling forms which represent different degrees of saprophytism rather than specific distinctions. $P$. pallida Greene has very glaucous leaves and usually grows in dense shade. $P$. sparsifolia Suksdorf and $P$. dentata integra Gray are apparently the same as $P$. pallida but with the leaves smaller in size and number or even reduced to scales.

$P$. septentrionalis Andres may be a good species distinguished by having deltoid-lanceolate calyx-lobes longer than broad. $P$. blanda Andres and $P$. conardiana Andres are apparently not different from $P$. septentrionalis. There is need of much field study and more copious material of all of these forms before their real relationships can be made clear.

Pyrola bracteata Hook. Leaves all basal, green, coriaceous, ovate, acute, rounded at base, crenulate, 3-6 cm. long; petioles margined, as long as the blades; scapes $20-40 \mathrm{~cm}$. high, with several brownish scarious lanceolate bracts; racemes many-flowered; calyx-lobes triangular-lanceolate, acute, about half as long as the petals; corolla irregular, dull-red, about $1 \mathrm{~cm}$. broad; anthers slightly constricted at apex; style declined, with a collar-like ring at the base of the stigma.

Coniferous woods, common.

Pyrola elata Nutt. Very similar to $P$. bracteata; but leaves broadly obovate or orbicular, obtuse, thinner, not shiny; flowers paler.

In wet places in woods. Probably not distinct from the more eastern P. uliginosa Torr. \& Gr.

\section{Family 75. ERICACEAE. Heather Family.}

Perennial herbs or shrubs; leaves simple, commonly alternate, articulated to the stem, without stipules; flowers regular, or nearly so; corolla generally gamopetalous, 4- or 5-lobed; stamens as many or twice as many as the corolla lobes, hypogynous; style single; ovary with as many cells as the corolla-lobes, or rarely less; seeds small; endosperm fleshy.

Calyx-tube adherent to the ovary.

Erect shrubs; corolla cylindric or urn-shaped. 375. VACCINIUM, 276.

Trailing vines; corolla deeply 4 -cleft, the lobes spreading.

Calyx-tube free from the ovary.

Fruit a berry or drupe.

Calyx becoming large and fleshy; bark not red.

Calyx small; bark red.

Tree; fruit a many-seeded berry.

Shrub; fruit a 5-10-seeded drupe.

Fruit a dry capsule.

Anther-cells each tipped with a recurved awn.

Corolla 5-lobed; peduncles lateral.

Corolla 5-cleft; peduncles terminal.

376. Oxycoccus, 277.

ther-cells not appendaged.

Petals not united; bracts deciduous.

377. Gaultheria, 278.

378. Arbutus, 278.

379. ARCTOStAPHYLOS, 279.
380. CASsiope, 280.

381. Harrimanella, 280. 
Flowers white, umbelled; leaves evergreen.

Flowers coppery, solitary; leaves deciduous.

Petals united.

382. Ledum, 280.

383. Cladothamnus, 281.

Bracts firm, persistent; leaf-buds not scaly.

Leaves heath-like; corolla without pouches.

Leaves lanceolate; corolla with 10 pouches which hold the anthers.

Bracts thin, deciduous; leaf-buds scaly.

Corolla funnelform, 5-lobed. Corolla globose, 4 -toothed.

384. Phyllodoce, 281

385. KaLMia, 282.

386. RHODODENDRON, 282.

387. Menziesia, 282.

\section{VACCINIUM. HUCKLEBERRY.}

Branching shrubs with alternate leaves sometimes coriaceous; flowers small, solitary or in racemes or clusters; corolla various in shape, epigynous, 4 - or 5 -cleft: stamens 8 or 10 ; anthers sometimes 2-awned on the back; fruit a 4- or 5-celled or sometimes 8-10celled berry; seeds numerous.

Leaves evergreen; filaments hairy.

V. ovatum.

Leaves deciduous; filaments glabrous.

Flowers in clusters of 2-4; corolla mostly 4-lobed; calyx deeply 4 - or 5 -parted.

Leaves thick, prominently veiny, obtuse or retuse. V. uliginosum.

Leaves thinner, obscurely veiny, obtuse or acute. $V$. occidentale.

Flowers solitary; corollas mostly 5-lobed; calyx obscurely lobed.

Tall shrubs, 1-3 m. high.

Leaves serrate; berries blackish without bloom. V. macrophyllum.

Leaves entire.

Berries blue with a bloom.

Berries red.

Low shrubs, less than one-half $\mathrm{m}$. high.

V. ovalifolium.

$V$. parvifolium.

Branches sharply angled; berries red or winecolored.

Branches terete; berries blue with a bloom.

Leaves rather thin, bright green on both sides; corolla ovate or oblong.

Leaves thicker, pale and glaucescent; corolla globose.

V. scoparium.

V. caespitosum.

V. deliciosum.

Vaccinium ovatum Pursh. Evergreen; stems much branched, 1-1.5 m. high, very leafy; leaves ovate to oblong-lanceolate, somewhat revolute, acute, serrate, short-petioled, dark green, shiny above, $1-2.5 \mathrm{~cm}$. long; flowers in short crowded axillary racemes; corolla pink, $4 \mathrm{~mm}$. long; berries black, with or without a bloom.

Common in open woods, the berries much gathered by the Indians. First found by Lewis at the mouth of the Columbia River.

Vaccinium uliginosum L. Stems $15-60 \mathrm{~cm}$. high, branched and spreading; leaves oblong to obovate, obtuse or retuse, entire, dull, pale and slightly 
pubescent beneath, $1-2 \mathrm{~cm}$. long; flowers solitary or in fascicles of $2-3$, nearly sessile; corolla urceolate; berries black with a bloom, sweet.

Rare in our limits; Mount Constitution, Henderson; Vancouver Island, Macoun.

Vaccinium occidentale Gray. Stems about $30 \mathrm{~cm}$. high; leaves oval to obovate and oblanceolate, obtuse or acutish, entire, pale, 1-2 cm. long; flowers mostly solitary; corolla oblong-ovoid, 3-4 $\mathrm{mm}$. long; berry black with a bloom.

In wet places, Vancouver Island, British Columbia, Macoun, and through the Cascade Mountains mostly on the eastern side southward to California.

Vaccinium macrophyllum (Hook.) Piper. Huckleberry. Shrub, 1-2 m. high, glabrous throughout or nearly so; leaves oval or ovate, acute, rarely obtuse, cuneate at base, finely serrate, paler beneath, 1-4 cm. long, shortpetioled; pedicels slender; calyx-limb entire; corolla nearly globose, yellowish, 4-5 $\mathrm{mm}$. long; fruiting pedicels erect; fruit without a bloom, dark wine-colored or nearly black.

In forests in the mountains at 1000-1200 m. altitude. The excellent fruit is gathered in large quantities.

Vaccinium ovalifolium Smith. Stems $2-3 \mathrm{~m}$. high, with somewhat angled branchlets; leaves oval to oblong, obtuse, minutely serrulate to nearly entire, thin, glabrous, pale beneath, $2-5 \mathrm{~cm}$. long; flowers solitary, axillary, the pedicels recurved; corolla urceolate, pinkish; berries globose, black with a bloom, acidulous.

Common in deep woods at low altitudes in the mountains, rarely found at sea-level.

Vaccinium parvifolium Smith. Stems 1-2 m. tall, with green sharp-angled branchlets; leaves oblong to oval, obtuse, nearly entire, 6-20 mm. long; flowers solitary, axillary; pedicels recurved; corolla globose, pink-tinged, 10-12 $\mathrm{mm}$. long; berries clear red, acid and agreeable.

In woods, very common. The leaves of young plants are evergreen.

Vaccinium scoparium Leiberg. Low bushy glabrous shrub, $15-40 \mathrm{~cm}$. high, with numerous erect branches, green, all sharply angled; leaves very small, oval to ovate, serrate, bright green; corolla ovoid, $2 \mathrm{~mm}$. long; berries $6000 \mathrm{ft}$. light red, 2-4 $\mathrm{mm}$. in diameter.

In the mountains at $1500-2000 \mathrm{~m}$. altitude.

Vaccinium caespitosum Michx. Low bushy shrub, 10-30 cm. high, glabrous or minutely puberulent; leaves obovate, obtuse or acute, crenulateserrulate, cuneate at base, very short-petioled, $1-2 \mathrm{~cm}$. long; flowers solitary in the axils, longer than the drooping pedicels; calyx-lobes very short; corolla pink, ovoid, 5-6 $\mathrm{mm}$. long; berry blue, with a bloom, sweet, 3-5 mm. in diameter.

In moist ground, not common in our limits.

Vaccinium deliciosum Piper. Much branched, $10-30 \mathrm{~cm}$. high, the branches tercte; leaves pale green, glaucescent, glabrous, obovate to elliptic, acute, crenulate-serrulate, cuneate at base, $2-3 \mathrm{~cm}$. long; flowers solitary in the axils, nodding; corollas pinkish, subglobose, $5 \mathrm{~mm}$. long; berries globose, black with a bloom, sweet.

Abundant in alpine meadows at about the limit of trees in the Cascade and Olympic Mountains.

376. OXYCoccus. Cranberry.

Trailing woody vines (in ours) with alternate leaves; flowers solitary or few, axillary or terminal, nodding on slender pedicels; 
calyx adherent to the ovary, 4-5-cleft; corolla deeply 4-cleft, with spreading lobes; stamens 8 or 10 ; filaments separate; anthers connivent; ovary 4-celled; fruit an oblong or globose many-seeded 4 -celled juicy red berry.

Oxycoccus oxycoccus intermedius (Gray) Piper. Glabrous; stems slender, creeping, 15-40 cm. long; leaves oblong to ovate, acute or obtuse, dark green and shiny above, pale beneath, 6-15 mm. long; pedicels slender, erect, 2-10 together, each bearing a nodding flower; corolla pale rose color, 4 -parted, the segments 6-8 mm. long; berry dark red, globose.

Common in sphagnum bogs.

\section{GAULTHERIA.}

Shrubs or low and almost herbaceous plants with alternate broad evergreen leaves, shining above; flowers axillary, white or rose-colored, nodding; calyx 5-cleft; corolla urn-shaped to campanulate; stamens 10 , on the base of the corolla; stigma truncate or obtuse, entire; ovary 5-celled, 5-lobed; fruit berry-like, formed of the fleshy calyx enclosing the capsule.

Corolla urceolate; filaments hairy; shrub $0.5-2 \mathrm{~m}$. high. Corolla campanulate; filaments glabrous; shrub $5-20 \mathrm{~cm}$. high.

Leaves ovate or subcordate, $2-4 \mathrm{~cm}$. long.

Leaves oval, about $1 \mathrm{~cm}$. long.

G. shallon.

G. ovatifolia.

G. humifusa.

Gaultheria shallon Pursh. Salal. Shrub; stems .5-2 m. high, crooked, often somewhat decumbent; leaves ovate-oblong, rounded or subcordate at base, acuminate, serrulate, 3-10 cm. long; inflorescence glandular-pubescent; racemes many-flowered, 1 -sided, axillary and terminal; corolla white, ovoid, 6-10 mm. long; fruit black or dark-purple, very variable in size, shape and amount of glandular pubescence.

A very characteristic shrub of the Douglas spruce forests. Berries edible. First collected by Captain Meriwether Lewis at the mouth of the Columbia River.

Gaultheria ovatifolia Gray. Stems procumbent with erect or somewhat ascending branches, $10-15 \mathrm{~cm}$. high, sparsely pubescent; leaves ovate, acute, serrulate, $2-4 \mathrm{~cm}$. long; flowers solitary in the axils; corolla white, campanulate, 5-lobed; fruit scarlet, globose.

In open forests in the Cascade and Olympic Mountains at about $1200 \mathrm{~m}$. altitude. Fruit very spicy and delicious.

Gaultheria humifusa (Graham) Rydb. Stems spreading on the ground in tufts, the flowering branches $2-10 \mathrm{~cm}$. long; leaves oval to orbicular, serrulate, $1-2 \mathrm{~cm}$. long; flowers solitary in the axils; corolla white, campanulate, 5-lobed; berry globose, scarlet, spicy-flavored.

In the Cascade and Olympic Mountains at about $2000 \mathrm{~m}$. altitude.

\section{ARBUTUS.}

Trees or shrubs with evergreen leathery alternate petiolate leaves; flowers small, white or flesh-colored, in a terminal cluster of racemes or panicles, with scaly bracts and bractlets; calyx small, 5-parted; corollà globular or ovoid; style long; stigma obtuse; ovary on a hypogynous disk; ovules crowded on a fleshy placenta in the inner angle of each cell. 
Arbutus menziesii Pursh. Madroña. Evergreen tree, $10-30 \mathrm{~m}$. high, $20-80 \mathrm{~cm}$. in diameter; bark dark red, smooth, exfoliating each year, or on the oldest trunks becoming thicker, roughened and scaly; leaves oval, entire or on young shoots serrulate, obtuse, coriaceous, petioled, 6-12 cm. long, shiny above; inflorescence a panicle, its branches pubescent; calyx-lobes ovate; corolla white, 6-10 mm. long; berries globose, bright orange-red, maturing in autumn, scarcely edible.

British Columbia to California. Northward it occurs mainly on bluffs along lake or sea shores.

\section{ARCTOSTAPHYLOS. MANZANITA.}

Low shrubs; leaves alternate, coriaceous, persistent, entire or with a few irregular teeth; flowers small, nodding, pink or white, in terminal racemes or clusters; calyx free from the ovary; corolla ovate and urn-shaped, with 5 short teeth; stamens 10 ; anthers with two reflexed awns on the back; drupe berry-like with 5-10 seed-like nutlets.

Erect shrubs 1-2 m. high.

Prostrate creeping shrubs.

Leaves retuse at apex.

Leaves cuspidate at apex.

A. columbiana.

A. uva-ursi.

A. nevadensis.

Arctostaphylos columbiana Piper n. sp. A much-branched shrub, 1-3 m. high, the young twigs densely pubescent and setose with white hairs; leaves pale-green, oblong to oblong-ovate, cuspidately acute, $2-6 \mathrm{~cm}$. long, densely tomentulose on both surfaces but becoming glabrous above in age; petioles short, tomentose and somewhat setose; bracts lanceolate, tomentulose, sparsely setose-ciliate; racemes clustered; corolla white, ovoid; ovary tomentose; fruit depressed-globose, red-cheeked.

This is the common northern manzanita that has usually been referred to A. tomentosa Lindl. but the type specimens of that species are, according to Miss Alice Eastwood, from Monterey Bay, California, and are identical with A. vestita Eastwood. A. columbiana is common in gravelly soil from Vancouver Island to Oregon and in varying forms throughout much of California. As typical of the species I would designate Piper No. 898 from near Union City, Mason County, Washington. It may be that one or more of Howell's proposed species from southwest Oregon are conspecific with $A$. columbiana but this is doubtful.

Arctostaphylos uva-ursi (L.) Spreng. Kinnikinnick. Prostrate or trailing shrub with red bark, the much branched stems $20-80 \mathrm{~cm}$. long, forming dense mats, glabrous throughout or minutely puberulent; leaves evergreen, leathery, spatulate-obovate, obtuse or notched, cuneate at base, 1-3 cm. long, shortpetioled; flowers in short racemes; corolla pink, ovoid, 4-5 $\mathrm{mm}$. long; filaments hairy; fruit bright red, glabrous, $5-8 \mathrm{~mm}$. in diameter.

In open woods, common. A natural hybrid with the preceding is $A$. media Greene.

Arctostaphylos nevadensis Gray. Prostrate or decumbent shrub, much branched, the branches $30-60 \mathrm{~cm}$. long; leaves bright green, firm and rigid, ovate to oval, sharply cuspidate, short-petioled, 1-2 cm. long; flowers few, in racemes; corolla white, oblong-ovoid, 6-8 $\mathrm{mm}$. long; fruit globose, red.

In the Cascade Mountains at about $2500 \mathrm{~m}$. altitude. 


\section{CASSIOPE.}

Low tufted evergreen branched heath-like shrubs; leaves small, veinless, imbricated, of ten opposite or whorled; flowers solitary, nodding at the tip of an erect naked pedicel; sepals 4 or 5 , ovate; corolla white or rose-colored; stamens 8-10, included; style thickened at the base; ovary 4- or 5-celled, many-ovuled; capsule globose or ovoid, 4- or 5-valved.

Leaves not dorsally furrowed.

Leaves with a deep dorsal furrow.

C. mertensiana.

C. tetragona.

Mt Adams Cassiope mertensiana (Bong.) G. Don. Stems much branched, 20-40 cm. fot. flowere high, the branches erect; leaves oblong, thick, glabrous, 3-4 mm. long, closely appressed, 4-ranked, not furrowed on the back; pedicels slender; corolla $6 \mathrm{~mm}$. long.

Very common in the mountains at about the limit of trees, often occupying large areas.

Mt Adama Cassiope tetragona (L.) D. Don. Very similar to C. mertensiana but lo Termina ptouter; leaves puberulent when young, deeply furrowed on the back.

Cascade Mountains, 49th parallel, Lyall, northward to Alaska. Lyall's

lam specimens were probably from east of the Cascade divide as the plant was

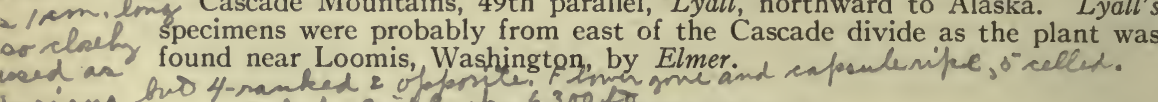
insiana on weso fork Bind Geck 381 . 300 HARRIMANELLA.

Low matted shrubs; leaves small, numerous, alternate, persistent, sessile or nearly so, linear to oblong; flowers solitary at the ends of the branches; calyx deeply 5-lobed; corolla campanulate, white or pink; stamens 10 , included; anther-sacs awnpointed; ovary 5-celled; fruit a subglobose, 5-lobed, 5-valved, many-seeded capsule.

Harrimanella stelleriana (Pall.) Coville. Stems very slender, spreading and matted; leaves linear-oblong, obtuse or acutish, serrulate, $2-4 \mathrm{~mm}$. long; pedicels equalling or excceding the leaves; calyx-lobes oblong-oval, obtuse; corolla white, 6-7 mm. long; capsules subglobose.

Mount Rainier, on moist slopes at about the limit of trees and northward to Alaska.

\section{LEDUM. LABRAdOR TEA.}

Erect branching shrubs; leaves alternate, evergreen, entire, more or less resinous-dotted, slightly fragrant when bruised; flowers white, in terminal bracted corymbs; calyx small, 5-toothed, persistent; petals 5 , obovate or oval, obtuse; stamens 5 or 10 , exserted; style filiform, exserted; stigma 5-lobed; ovary ovoid, 5-celled; capsule oblong, 5-celled, 5-valved.

Leaves glaucous beneath.

Leaves rusty-tomentose beneath.
L. columbianum.

L. groenlandicum.

Ledum columbianum Piper. Erect with erect branches, $60-90 \mathrm{~cm}$. high; bark becoming smooth and brown; leaves oblong, reticulate, $4-6 \mathrm{~cm}$. long, rather obtuse but apiculate, strongly revolute, dark green and glabrous above, 
whitish and resinous-dotted beneath, the midrib and short petiole minutely puberulent as well; corymbs terminal, convex, $3-5 \mathrm{~cm}$. broad; pedicels slender, puberulent and resinous-dotted, recurved in fruit, $1.5-3 \mathrm{~cm}$. long; lobes of the calyx very small, broadly rounded; petals white, oval, 5-6 mm. long, obtuse; stamens 5-7, the filaments sparsely hirsute at base; ovary minutely canescent and resinous-dotted; capsules oblong, acutish.

In sphagnum bogs, near the mouth of the Columbia River.

Ledum groenlandicum Oeder. Very similar to L. columbianum but less glandular and leaves rusty-woolly beneath.

Common in sphagnum bogs.

\section{CLADOTHAMNUS.}

Shrubs with erect branching stems; leaves alternate, narrow, entire, with obscure alternate lateral veins, petioled; flowers perfect, solitary-axillary or in few-flowered corymbose clusters; calyx rotate, with 5 narrow lobes which are much longer than the tube; corolla copper-colored; petals narrow; stamens 10 , shorter than the petals; filaments subulate; style elongated, enlarged at the apex; stigma capitate, somewhat lobed; ovary 5-6-celled, lobed; capsule depressed-globose.

Cladothamnus pyrolaeflorus Bong. Erect shrub about $2 \mathrm{~m}$. high; leaves membranaceous, obovate-lanceolate, obtuse or acutish, usually mucronate, ciliolate when young, 2-4 cm. long, paler beneath; flowers short-peduncled; calyx-lobes oblong-linear, more or less ciliolate; petals coppery-red, $10-15 \mathrm{~mm}$. long.

Saddle Mountain, near Astoria, Oregon, Gorman; Baldy Peak, Jefferson County, Washington, Lamb; Cascade Mountains, 49th parallel, Lyall, and northward to Alaska.

\section{PHYLLODOCE.}

Low alpine heath-like evergreen undershrubs; leaves numerous, linear, obtuse, serrulate; flowers solitary or in umbels at the ends of the branches; calyx free from the ovary; corolla 5-toothed; stamens 10; anthers pointless, shorter than the filaments; fruit a 5-celled 5-valved, many-seeded dry capsule.

Corolla ovoid, yellowish, glandular.

Corolla campanulate, red, glabrous.
P. glanduliflora.

$P$. empetriformis.

Phyllodoce glanduliflora (Hook.) Coville. Stems erect, with erect branches, $8 / 11 / 20 M+1$ $20-40 \mathrm{~cm}$. high; leaves linear-oblong, obtuse, thick, serrulate, 5-10 $\mathrm{mm}$. long; inflorescence glandular; corolla glandular, pale yellow, ovoid, $6-8 \mathrm{~mm}$. long the tube very short.

Cascade and Olympic Mountains at about $2500 \mathrm{~m}$. altitude, rarely found growing with $P$. empetriformis.

Phyllodoce empetriformis (Smith) D. Don. Much branched, $15-50 \mathrm{~cm}$. high; flowers in umbels; corolla rose-colored, campanulate, 4-5 $\mathrm{mm}$. long, the lobes shorter than the tube.

Abundant in the mountains at the limit of trees. Very showy when in bloom and locally called "heather." 


\section{KALMIA.}

Evergreen mostly smooth shrubs with alternate or opposite entire coriaceous leaves; flowers showy, solitary or in corymbs; calyx 5-parted; corolla 5-lobed; filaments long and filiform; capsule globose, 5-celled, many-seeded.

Kalmia polifolia Wang. (K. glauca Ait.) Shrub, 30-60 cm. high, not much branched; leaves oblong, the margin revolute, shiny green above, glaucous beneath, $2-3 \mathrm{~cm}$. long; flowers in simple flat-topped corymbs; sepals ovate; corolla purple, $12-18 \mathrm{~mm}$. broad.

In sphagnum bogs, very showy when in bloom. The western plant is considered by Small to be distinct from the eastern species, under the name $K$. occidentalis Small.

Kalmia polifolia microphylla (Hook.) Piper n. comb. ( $K$. glauca microphylla Hook.) Smaller; stems $15-20 \mathrm{~cm}$. high; leaves $1-2 \mathrm{~cm}$. long; corolla 8-12 mm. broad.

In swamps at high altitudes in the Cascade Mountains.

\section{RHODODENDRON.}

Shrubs or small trees; leaves mostly alternate, entire; flowers large and showy, in umbelled clusters from terminal buds; calyx small; corolla bell-shaped or funnelform, with 5 lobes, regular or irregular; stamens as many or twice as many as the corolla-lobes; capsule 5-celled, 5-valved, many-seeded.

Leaves evergreen; inflorescence terminal; flowers pink. Leaves deciduous; inflorescence lateral; flowers white.

R. californicum. $R$. albiflorum.

Rhododendron californicum Hook. Shrub 2-3 or rarely 5-6 m. high; leaves coriaceous, oblong, slightly revolute, shiny green above, pale beneath, obtuse and mucronate, acute at base, $10-15 \mathrm{~cm}$. long; flowers numerous; calyx-lobes very short, obtuse; corolla turbinate-campanulate, rose-colored, $3 \mathrm{~cm}$. long, with broad rounded lobes.

In open woods, British Columbia to California. Very local in distribution but usually abundant where found. $R$. macrophyllum Don is an older name which probably applies to our plant. It was collected by Menzies on the "Northwest Coast" and described, probably erroneously, as having white flowers.

Rhododendron albiflorum Hook. (Azaleastrum albiflorum Rydb.) Shrub, 1-2 m. high, with erect or clustered branches; herbage strigose-pubescent and somewhat glandular; leaves membranaceous, oblong, undulate, acute, 3-6 cm. long; flowers in small lateral clusters of $1-3$, nodding; sepals ovate, glandular-ciliate; corolla creamy-white, open campanulate, 5 -lobed, $2 \mathrm{~cm}$. long.

Common in the mountains at the limit of trees.

\section{MENZIESIA.}

Shrubs with alternate hairy deciduous leaves; flowers small, nodding, greenish-purple, in terminal corymbs or umbels, developed with the leaves; calyx small or minute, flattish, 4-toothed or lobed; corolla cylindrical to urn-shaped, 4 -lobed; stamens 8 ; capsule ovoid, woody, 4-celled, 4-valved, many-seeded. 
Menziesia ferruginea Smith. Erect shrub, 1-2 m. high, the branches inclined to be falsely whorled, the young branchlets strigose; leaves thin, oblong or obovate, mostly acute, short-mucronate, cuneate at base, serrulate and ciliate, strigose above, paler beneath, $2-5 \mathrm{~cm}$. long; petioles short; pedicels slender, 2-4 cm. long, glandular-puberulent; corolla oblong- or ovoid-campanulate, reddish-yellow, 7-9 mm. long; filaments ciliate at base; capsules oblong or obovoid, glabrous; seeds tailed at each end.

Along the ocean coast and in the Olympic Mountains in the typical Alaska form. The form in the Cascade Mountains differs in having less pubescent leaves. $M$. glabella Gray does not occur in our limits.

Family 76. PRIMULACEAE. PRIMrose FAMILy.

Herbs; leaves simple, mostly entire, alternate, opposite or in a basal cluster, without stipules; flowers regular, perfect; corolla gamopetalous, 4-8-, usually 5-lobed or cleft; stamens as many as and opposite the corolla-lobes, epipetalous; ovary superior, 1celled, with a free central placenta rising from the base; fruit a capsule; seeds several or many; endosperm fleshy.

Stems short; leaves in a basal rosette.

Corolla-lobes reflexed; stamens exserted.

Corolla-lobes erect or spreading; stamens included.

Corolla-tube equalling or exceeding the calyx.

Corolla-tube shorter than the calyx.

389. Douglasia, 284.

390. ANDrosace, 284.

Stems elongated, leaf-bearing.

Leaves mostly clustered near the summit of the stem.

Leaves not clustered near the summit of the stem, mostly opposite or whorled.

Corolla none, the calyx petal-like; leaves fleshy; flowers sessile, solitary-axillary.

Corolla present; leaves not fleshy; flowers in spikes or racemes, or if solitaryaxillary then peduncled.

Capsule circumscissile; flowers reddish, solitary-axillary.

Capsule dehiscent by valves or irregu388. Dodecatheon, 283.

391. Trientalis, 285.

392. Glaux, 285. larly; flowers yellow.

Flowers in racemes or solitary; filaments somewhat united at base.

Flowers in spikes; filaments distinct. 395. NAUMBURGIA, 286.

388. Dodecatheon. Shooting Star. Bird Bill.

Perennial smooth or viscid-puberulent stemless herbs; leaves all in a basal cluster, oblong or spatulate; flowers showy, nodding, solitary or in an umbel, on a scape, with an involucre; calyx deeply 5-cleft; corolla with a very short tube, 5-parted, purple or white; filaments distinct and short or united into a tube; capsule ovoid or oblong, many-seeded. 
Capsule dehiscing by valves from the apex.

Filaments united into a yellow tube half as long as the anthers; flowers purple; leaves entire.

Filaments free; flowers white; leaves dentate.

D. vulgare.

Capsule circumscissile; filaments free or nearly so, black.

Leaves broadly elliptic to obovate.

Leaves oblong-lanceolate, crenate.

D. dentatum.

D. latifolium.

D. jeffreyi.

Dodecatheon vulgare (Hook.) Piper. (D. pauciflorum (Durand) Greene.) Glabrous throughout, $15-45 \mathrm{~cm}$. high; leaves spatulate-oblanceolate, obtuse, entire or rarely denticulate, $5-10 \mathrm{~cm}$. long, narrowed into a winged petiole as long; umbels 5-20-flowered; bracts of the involucre triangular-lanceolate, acute, 6-20 mm. long; pedicels 1-6 cm. long; calyx-lobes broadly lanceolate, acute or acuminate, not much longer than the tube; petals purple, $1 \mathrm{~cm}$. long; stamineal tube yellow, half as long as the purple anthers; capsules ovoid, $6-9 \mathrm{~mm}$. long, splitting into 5 teeth at the apex when mature.

In dry open ground.

Dodecatheon dentatum Hook. Glabrous; leaves ovate to oval, thin, irregularly dentate, 5-10 cm. long, the petiole about as long as the blade; scape 20-30 $\mathrm{cm}$. high; calyx-lobes ovate or triangular-ovate, acuminate, about as long as the tube; corolla white with two purple spots at the base of each lobe; capsule cylindric, opening at the tip by teeth.

On wet banks in the Cascade Mountains and along the gorge of the Columbia River.

Dodecatheon latifolium (Hook.) Piper. (D. hendersoni Gray.) Leaves broad, elliptic or obovate, narrowed at base, entire; scape 10-30 cm. high; corolla dark-purple with yellow center; stamens dark purple, the tube $1-2 \mathrm{~mm}$. long; capsule opening by a lid, then splitting.

In open fields and prairies. First found at Fort Vancouver by Douglas.

Mt Adams Dodecatheon jeffreyi Van Houtte. (D. viviparum Greene.) Leaves fenera oblong-lanceolate, acute or obtuse, $15-25 \mathrm{~cm}$. long, crenate with a minute callus in each notch; scapes $25-50 \mathrm{~cm}$. high; flowers deep purple; stamens ong pantradistinct to the base, dark purple; capsule opening by a lid.

Common in wet alpine meadows.

\section{DOUGLASIA.}

Low tufted herbs, often somewhat woody; leaves in a basal rosette; flowers solitary or in small umbels; calyx campanulate, 5-lobed, persistent; corolla-lobes spreading, the tube equalling or exceeding the calyx, the throat contracted and 5 -crested beneath the sinuses; stamens distinct, included; style filiform; ovary 5-ovuled; capsule turbinate, 1 or 2 -seeded.

Douglasia laevigata Gray. Nearly glabrous; leaves oblong-lanceolate, mostly entire, obtuse, 4-6 mm. long; flowers blood-red, in small umbels.

In the mountains. First found on Mount Hood, Oregon, by Howell; very common in the Olympic Mountains; Goat Mountains near Mount Rainier, Allen.

\section{ANDROSACE.}

Small herbs; leaves in a basal rosette; flowers very small, solitary or in umbels; calyx 5-cleft, with a short tube; corolla salver-shaped or funnelform, 5-parted, the lobes erect or spreading, the tube shorter than the calyx; capsule 5-valved. 
Androsace filiformis Retz. Glabrous annual; leaves basal in a rosette, ovate, obtuse, entire or denticulate; scapes $2-10 \mathrm{~cm}$. high; bracts of the involucre subulate; pedicels capillary, $1-2 \mathrm{~cm}$. long; calyx globose in fruit, the lobes triangular; corolla white, longer than the calyx; capsule globose.

In wet places, Forest Grove, Oregon, Marsh.

\section{TRIENTALIS. STAR-FLOWER.}

Low smooth perennials, with simple erect stems; leaves few, alternate, mostly clustered at the summit of the stem, the lower ones reduced to scales; peduncles several, slender, each bearing a solitary flower; corolla rotate, 7-parted, rarely 5-, 6- or 8parted; filaments slender, united at the base; anthers oblong, recurved after dehiscing; style filiform; ovary free; capsule fewseeded.

Leaves acute, clustered at top.

Leaves obtuse, scattered along the stem.

T. latifolia.

T. arctica.

$25 t$ Trientalis latifolia Hook. Stems $10-30 \mathrm{~cm}$. high, from small rather deepseated tubers; leaves 4-7, whorled near the top, lanceolate to oblong-oval, acute, 3-8 cm. long, short-petioled; pedicels very slender, shorter than the leaves; corolla lobes pink, lanceolate, acuminate.

In woods, very common.

Trientalis arctica Fisch. Stems $5-10 \mathrm{~cm}$. high, with scattered obtuse or retuse leaves; corolla nearly white.

In cranberry bogs, not rare.

\section{GLAUX.}

Low leafy fleshy perennials; leaves opposite, entire, sessile; flowers sessile, solitary-axillary; calyx bell-shaped, 5-cleft, the lobes ovate or oblong, petal-like; corolla none; stamens 5 , on the base of the calyx, alternate with its lobes; capsule 5-valved, fewseeded.

Glaux maritima L. Glabrous and glaucous, $8-20 \mathrm{~cm}$. high, usually erect; leaves oblong or ovatc, fleshy, mostly opposite, $4-12 \mathrm{~mm}$. long; flowers in the axils, pink.

On the seashore, common.

\section{ANAGALLIS. Pimpernel.}

Low spreading annual herbs; leaves opposite or whorled, entire; flowers solitary-axillary, peduncled; corolla rotate, with a very short tube, the lobes broad; stamens 5 ; filaments bearded; capsule circumscissile, many-seeded.

Anagallis arvensis L. Annual, glabrous; stems decumbent or ascending, 10-20 cm. high; leaves ovate, sessile; peduncles exceeding the leaves; flowers orange-scarlet, sometimes white; petals obovate, minutely glandular-ciliate.

Introduced from Europe in fields and waste places. 


\section{LYSIMACHIA. LOOSESTRIFE.}

Leafy-stemmed perennial herbs; leaves mostly opposite or whorled, usually glandular-dotted; flowers yellow, in racemes or solitary-axillary; calyx 5-6-parted; corolla rotate, the lobes entire, bearing no teeth between the lobes; stamens slightly united at base, often unequal; capsule few to several-seeded.

Flowers in a raceme; corolla with dark dots. Flowers solitary, axillary; corolla not dotted.

L. terrestris.

L. nummularia.

Lysimachia terrestris (L.) BSP. Glabrous; stems erect, $30-80 \mathrm{~cm}$. high, sometimes bulbiferous in the leaf-axils; leaves lanceolate, acute at each end, mostly opposite, the upper reduced to linear or subulate floral bracts; flowers racemose, on slender pedicels; corolla yellow with dark dots, the lobes oblonglanceolate.

In cranberry bogs, Willapa Harbor, Washington, Cora B. Eaton. Doubtless introduced with cranberry plants from the eastern states.

Lysimachia nummularia L. Moneywort. Stems creeping, 10-30 cm. long; herbage glabrous; leaves numerous, orbicular, short petioled; flowers solitary, axillary; calyx-lobes ovate-lanceolate; corolla $2-3 \mathrm{~cm}$. broad, not dotted, the lobes ovate, obtuse; filaments broadened and slightly united at base.

Portland, Oregon, Gorman. Introduced from Europe.

\section{NAUMBURGIA.}

Erect perennial leafy herbs with slender rootstocks; leaves opposite, sessile, punctate; flowers in axillary spikes; calyx 5-7divided, the segments linear; corolla deeply 5-7-parted, the tube very short and the segments narrow, with or without a small tooth in each sinus; stamens 5-7, distinct, equal; capsule 5-7valved, few-seeded.

Naumburgia thyrsiflora (L.) Duby. Glabrous or nearly so; stems simple, 20-60 cm. high, erect, from creeping rootstocks; leaves lanceolate, sessile, $3-5 \mathrm{~cm}$. long, the lower ones reduced and scale-like; peduncles axillary from the 1-4 middle pairs of leaves; flowers small, in a dense oblong spike, pale yellow; calyx-lobes linear-lanceolate, acute; capsule glandular-dotted.

In swamps, rare in our limits.

\section{Family 77. PLUMBAGINACEAE. LeAdwort FAmily.}

Herbs with regular flower's; calyx gamosepalous, of 5 plaited lobes; corolla of 5 nearly distinct or united petals; stamens 5 , opposite the corolla-lobes, hypogynous or adnate to their bases; anthers 2-celled; styles 5, distinct or united; ovary superior, 1 -celled, with one ovule on a slender stalk rising from the base of the cavity; fruit a 1-seeded utricle.

\section{STATICE.}

Stemless densely tufted perennial herbs; leaves narrow, linear broad and petioled, persistent; flowers rose-colored, in a head 
on a naked scape but subtended by a reversed sheath; calyx scarious, funnelform; corolla of 5 nearly distinct long-clawed petals; stamens 5 , on the bases of the petals; styles 5 , filiform, free or united only at the base, glabrous or delicately plumose below, stigmatic on the inner side; fruit a utricle.

Statice armeria L. Thrift. Perennial, tufted; leaves numerous, narrow, linear, 3-6 cm. long; scapes $10-30 \mathrm{~cm}$. high; bracts scarious, obtuse; calyx-tube 10-nerved, pubescent, the lobes cuspidate; corolla pink.

In sandy or gravelly soil, British Columbia to California.

\section{Family 78. OLEACEAE. Olive Family.}

Trees or shrubs with opposite pinnate or simple leaves; flowers usually in racemes or panicles; calyx gamosepalous and 4-cleft, toothed, or entire, or none; corolla 4-merous, gamopetalous or polypetalous, or none; stamens usually 2 ; ovary 2 -celled, with 2 ovules in each cell.

\section{FRAXINUS. AsH.}

Large trees with petioled pinnate leaves; flowers in crowded panicles or racemes from the axils of leaves of the previous season, dioecious, polygamous or monoecious; calyx small and 4-cleft, or entire, or none; petals none; stamens usually 2; anthers large; style 1 ; stigma 2 -cleft; fruit 1-2-celled flattened, 1-2-seeded.

Fraxinus oregana Nutt. Oregon Ash. Tree, 20-40 m. high; bark pale, longitudinally ridged; leaflets $5-7$, oval or oblong-lanceolate, acuminate; entire, 5-10 cm. long; flowers dioecious, appearing with the leaves; fruit oblanceolate, $2-3 \mathrm{~cm}$. long.

In low ground, common.

\section{Family 79. GENTIANACEAE. Gentian Family.}

Mostly herbs; leaves entire, opposite, sessile, without stipules; flowers perfect, regular, solitary or clustered; corolla gamopetalous, 4-12-parted; stamens as many as the corolla-lobes and alternate with them, epipetalous; ovary 1-celled, with 2 parietal placentae; fruit a capsule, usually 2 -valved; seeds numerous; endosperm copious.

Style filiform, usually decidous; anthers oblong to linear, mostly twisting or curving with age.

398. Centaurium, 287.

Style stout and persistent or none; anthers remaining straight.

399. Gentiana, 288.

\section{CENTAURIUM.}

Low branching annual herbs; leaves sessile or clasping; flowers white or reddish; calyx 4- or 5-parted; corolla funnel or salver- 
form, 4- or 5-parted, the tube slender; anthers exserted, erect, oblong to linear, twisting spirally with age; style filiform, usually deciduous; stigmas capitate or 2-lipped.

Basal leaves in a rosette.

C. centaurium.

Basal leaves not in a rosette.

C. minimum.

Centaurium centaurium (L.) W. F. Wight. Glabrous; stems $15-30 \mathrm{~cm}$. high; leaves oblong, acutish, $2-5 \mathrm{~cm}$. long, the cauline sessile, the basal petioled and forming a rosette; flowers numerous, in a compound flat-topped cyme; corolla red, $10 \mathrm{~mm}$. long, its lobes obtuse.

In waste places, introduced from Europe.

Centaurium minimum (Howell) Piper n. comb. (Erythraea minima Howell.) Stems filiform, simple or sparingly branched, 1-2 inches high; leaves lanceolate, acute, 2-6 mm. long; flowers racemosely disposed, all pedicellate; lobes of the pink or white corolla lanceolate, acute, $4 \mathrm{~mm}$. long, more than half as long as the tube; anthers oblong; lobes of the style fanshaped; seeds globular, strongly pitted.

"In wet places, throughout western Oregon." From the description the plant is very closely allied to $C$. muhlenbergii (Griseb.) W. F. Wight.

\section{GENTIANA. Gentian.}

Herbs; leaves opposite; flowers solitary or in cymes, showy, in late summer or autumn; calyx 4- or 5-cleft; corolla funnelform or bell-shaped, 4- or 5-lobed, regular, without glands, often with intermediate plaited folds which bear appendages at the sinuses; anthers remaining straight with age; style stout, persistent or none; stigmas 2.

Annuals; corollas small, less than $2 \mathrm{~cm}$. long.

Corolla without appendages between the lobes.

Corolla with bifid appendages between the lobes.

Perennials; corollas $3 \mathrm{~cm}$. or more long, with appendages between the lobes.

Stems $15-30 \mathrm{~cm}$. high, clustered, mostly 1 -flowered.

Stems taller, mostly solitary, several-many-flowered.

G. acuta.

G. douglasiana.

Gentiana acuta Michx. Annual, erect, simple, or with few erect branches, glabrous, 5-40 cm. high; leaves rather few, the basal spatulate-oblanceolate, obtuse, petioled; cauline oblong-lanceolate, acute or obtuse, sessile, 5-30 mm. long; peduncles from the axils of most of the leaves, $1-4 \mathrm{~cm}$. long; calyx cleft below the middle, the lobes acute, usually very unequal; corolla $5-15 \mathrm{~mm}$. long, without folds in the sinuses, the acutish lobes with a fringe of bristles on their bases within.

In open woods, rare in our limits.

Gentiana douglasiana Bong. Annual; stems slender, cymosely branched, $10-20 \mathrm{~cm}$. high; leaves ovate, the basal ones in a rosette, the cauline several pairs, 4-8 mm. long; flowers white, in a loose cyme; calyx 5-cleft; corolla $8 \mathrm{~mm}$. long, funnelform, with oblong lobes shorter than the tube, the accessory lobes 2-cleft; capsule stalked.

In bogs, Alaska to Vancouver Island, British Columbia; Port Renfrew, British Columbia, Rosendahl \& Brand. Said to have been collected near Snohomish, Washington, and reported by Hooker from Fort Vancouver, Washington. 
Gentiana calycosa Griseb. Stems tufted, simple, 10-20 cm. high; leaves several pairs, ovate, the uppermost involucrate about the usually solitary flower; corolla deep blue, bell-shaped, 3-4 cm. long.

Common along rills in the mountains at about $2000 \mathrm{~m}$. elevation.

Gentiana sceptrum Griseb. Perennial, erect, 60-90 cm. high, pale green, simple or branched above; leaves oblong-lanceolate to ovate, mostly acute, 4-8 cm. long; flowers clustered, sometimes dense; calyx-lobes unequal, lanceolate or narrowly oblong, sometimes as long as the tube; corolla bell-shaped, blue, usually dark spotted within, 3-5 cm. long.

In bogs. Very variable as to calyx-lobes; forms with narrow lance-linear leaves have been referred to $G$. menziesii Griseb.

\section{Family 80. MENYANTHACEAE. Buckbean Family.}

Perennial aquatic or marsh herbs, with basal or alternate entire crenate or trifoliolate leaves; flowers clustered, regular, perfect; calyx deeply 5-parted, persistent; corolla funnelform to rotate, 5-lobed or 5-cleft; stamens 5, epipetalous, alternate with the corolla-lobes; style long, short, or none; ovary 1-celled with two parietal placentae; fruit dehiscent or indehiscent.

Leaves trifoliolate; corolla lobes fimbriate.

400. Menyanthes, 289.

Leaves simple, reniform; corolla lobes entire. 401. NePHrophyLlidium, 289.

\section{MENYANTHES. BUCKBEAN.}

Perennial herbs with thick creeping rootstocks sheathed by the membranous bases of the petioles; leaves trifoliolate; calyx 5-parted; corolla funnelform, 5-cleft; style slender, persistent; stigma 2-lobed; capsule bursting irregularly, many-seeded.

Menyanthes trifoliata L. Buckbean. Perennial from scaly rootstocks; leaves trifoliolate, the petioles sheathing at base; leaflets oblong to obovate, entire, obtuse; peduncles stout; racemes 10-20-flowered; corolla white or rose-tinged, its lobes bearded above; capsule ovoid.

In sphagnum bogs and shallow lakes.

\section{NEPHROPHYLLIDIUM.}

Perennial marsh herbs with creeping rootstocks; basal leaves reniform, deeply and coarsely crenate, 7 -nerved at the base, long petioled; flowers white, in short panicled cymes on scapes; calyx deeply parted into 5 elongated lanceolate lobes; corolla short funnelform, divided above the middle into 5 ovate obtuse lobes, not bearded but with a median crest; stamens 5 , on the corolla, alternate with the lobes; style short or none; stigma large, shield-shaped; ovary 1 -celled with 2 parietal placentae, surrounded at the base by 5 glands; capsule more or less spherical, opening irregularly at the tip.

Nephrophyllidium crista-galli (Menzies) Gilg. Leaves reniform, crenate, 
5-12 cm. broad, sometimes notched at the apex; scapes 30-60 cm. high; flowers white, in a cyme; corolla lobes not bearded but with a median crest.

In bogs, Alaska to British Columbia and Granville, Washington, where it was collected by Conard.

\section{Family 81. APOCYNACEAE. Dogbane Family.}

Herbs (in ours) with acrid milky juice; leaves entire, opposite, without stipules; flowers regular; calyx free from the ovaries; corolla gamopetalous, 5-lobed; stamens 5, alternate with the corolla-lobes, epipetalous; pistils of two carpels, the ovaries separate (in ours), the styles or stigmas united; fruit a pair of follicles; seeds many, often downy-tufted at the apex; endosperm not copious.

\section{APOCYNUM. DOGBANE.}

Perennial herbs; leaves opposite, mucronate-pointed; flowers small, in cymes, on short pedicels; calyx 5-parted, the lobes acute; corolla bell-shaped, 5-cleft, bearing 5 triangular appendages below the throat, opposite the lobes; stamens 5, on the very base of the corolla; fruit of two long and slender follicles; seed with a tuft of long silky down at the apex.

Corolla lobes erect; leaves oval or oblong.

Corolla lobes spreading or recurved; leaves ovate.

A. cannabinum.

A. androsaemifolium.

Apocynum cannabinum L. Glabrous throughout or sometimes puberulent, pale green; stems erect, branched above, $60-100 \mathrm{~cm}$. high; leaves oblongelliptic or somewhat lanceolate, cuspidate-acuminate, rounded or cuneate at base, the margin slightly revolute, $2-6 \mathrm{~cm}$. long; petioles 5-8 $\mathrm{mm}$. long; calyxlobes lanceolate-acuminate, $2-3$ times as long as the tube; corolla white, 3-5 $\mathrm{mm}$. long, the lobes erect; pods reflexed, linear, tapering at each end, $6-8 \mathrm{~cm}$. long.

The common form in our region with corolla $3 \mathrm{~mm}$. long and flowers in a small terminal cyme surrounded by leafy branches has been considered a distinct species, A. suksdorfii Greene.

Apocynum androsaemifolium L. Stems $30-90 \mathrm{~cm}$. high; branches erect or ascending, glabrous throughout or rarely puberulent, usually very floriferous; leaves ovate, cuspidate, $1-4 \mathrm{~cm}$. long, dark-green above, pale beneath, short-petioled; flowers rose-colored; calyx-lobes about equalling the tube; corolla 5-6 mm. long, the lobes recurved; pod 6-8 cm. long, spreading or reflexed.

In dry open woods.

\section{Family 82. CONVOlvUlaceae. Morning Glory Family.}

Mostly twining or trailing herbs, often with milky juice; leaves alternate; flowers regular, perfect, mostly showy; calyx 5-lobed; corolla gamopetalous, 5-plaited or lobed, convolute or twisted in the bud; ovary 2-celled; ovules 2 in each cell, the cells 
sometimes becoming 4 in the fruit by false partitions; fruit a globular, 2-6-seeded capsule; endosperm mucilaginous.

\section{CONVOLVULUS. MORNING GLORY.}

Herbs or somewhat woody plants, twining, erect or prostrate; flowers 1 or 2 in the axils of the leaves; corolla funnelform to campanulate; stamens included; style undivided, or 2-cleft only at the apex; capsules globose, 2-celled or imperfectly 4-celled by false partitions between the 2 seeds or by abortion 1-celled.

Calyx without bracts; stigma filiform.

Calyx enclosed by two bracts; stigmas oblong to ovate.

Stigmas ovate; leaves fleshy.

Stigmas oblong; leaves thin.

Bracts ovate, acute.

Bracts oval, obtuse.
C. arvensis.

C. soldanella.

C. sepium.

C. nyctagineus.

Convolvulus arvensis L. Whole plant pubescent; stems prostrate, trailing, $30-120 \mathrm{~cm}$. long; leaves oblong or ovate, obtuse or acute, $1-4 \mathrm{~cm}$. long, sagittate or hastate or auricled at base; petioles 1-2 cm. long; peduncles longer than the leaves, mostly 1- or 2-flowered; pedicels each with two small bracts; corolla pinkish, 1-2 cm. long; stigmas thread-like.

A troublesome weed, native of Europe.

Convolvulus soldanella L. Stems trailing, $15-30 \mathrm{~cm}$. long; leaves thick, reniform, usually entire, glabrous, $2-5 \mathrm{~cm}$. broad; bracts ovate, cordate, about as long as the sepals; corolla purplish, $2-5 \mathrm{~cm}$. long.

On the sandy seashore.

Convolvulus sepium L. Usually glabrous, climbing over shrubs to a height of 2-3 m.; leaves sagittate or somewhat hastate, acuminate, $2-5 \mathrm{~cm}$. long; basal lobes entire or angularly 2-lobed; peduncles nearly as long as the leaves; calyx enclosed by two large ovate bracts; corolla white, sometimes pink, 4-6 $\mathrm{cm}$. long; stigmas capitate, oval or oblong.

Banks of streams, reported from the Willamette Valley.

Convolvulus nyctagineus Greene. Pubescent; stems slender, 5-30 cm. long; leaves ovate or deltoid ovate, acute or obtuse, sometimes angularly lobed at base, truncate or cuneate at base, $2-5 \mathrm{~cm}$. long, on longer petioles; flowers axillary, peduncled; bracts oval, obtuse, about as long as the calyx; sepals obtuse, mucronate; corolla white, about $3 \mathrm{~cm}$. broad.

Willamette Valley, Oregon, and southward.

\section{Family 83. CUSCUTACEAE. Dodder FAMILy.}

Whitish or yellowish parasitic twining vines with leaves reduced to minute alternate scales; sepals 5 , separate or united into a 5-lobed or parted calyx; corolla gamopetalous, urn-shaped or bell-shaped, 5-lobed, usually with fimbriate or crenulate scales on the tube alternating with the lobes; stamens 5 , alternate with the corolla-lobes; ovary globose to oblong, 2-celled; ovules 2 in each cell; capsule circumscissile or indehiscent, 1-4-seeded. 


\section{CUSCUTA. DODder.}

Leafless annual herbs with yellow or reddish stems twining and parasitic on the plants to which they cling; flowers small, clustered; calyx 4- or 5-cleft or of 5 sepals; corolla urn- or bell-shaped, 4- or 5-cleft; stamens with a scale-like appendage at the base; ovary 2 -celled, 4-ovuled; capsule usually 4 -seeded.

Stigmas filiform; corolla scales crenulate.

Stigmas capitate; corolla scales fringed.

Capsule pointed; flowers subsessile.

Capsule globose.

Flowers sessile; style shorter than the ovary.

Flowers pedicelled; style as long as the ovary.

C. epithymum.

C. squamigera.

C. arvensis.

C. cephalanthi.

Cuscuta epithymum Murr. Stems very slender, reddish; flowers in dense clusters; calyx 4-5-lobed, the lobes acute; corolla white or pinkish, 4-5-lobed, the lobes erect, acute, persisting on the capsule; scales crenulate, margined.

Parasitic on clover, thyme and other plants. Introduced from Europe.

Cuscuta squamigera (Engelm.) Piper. Stems slender, short; flowers 3-5 $\mathrm{mm}$. long; calyx-lobes acute; corolla-lobes acute, denticulate, as long as the tube; style not longer than the ovary; capsule pointed.

On herbaceous plants, in salt marshes.

Cuscuta arvensis Beyrich. Stems fine, pale yellow; flowers 1.5-2 mm. long, in dense clusters; calyx-lobes obtuse, broad; corolla-lobes ovate-lanceolate, acuminate, slightly longer than the tube; .scales large, oval, fringed; seeds 4 .

Parasitic on clover and other low plants; introduced from the eastern states.

Cuscuta cephalanthi Engelm. Stems coarse, dark yellow; flowers $2 \mathrm{~mm}$. long, on thick pedicels, in loose clusters; calyx-lobes oblong, obtuse, about as long as the tube; corolla-lobes oblong, obtuse, shorter than the tube; scales fringed.

Parasitic on shrubs or tall herbs; rare in our limits.

\section{Family 84. POLEMONIACEAE. Phlox FAMily.}

Herbs; leaves alternate or opposite, simple or divided, without stipules; flowers regular, perfect, 5-merous, except the pistils; corolla gamopetalous, convolute in the bud; lobes not plaited; stamens epipetalous, alternate with the corolla-lobes, distinct; style 3-lobed; ovary 3-celled; capsule 3-celled, 3-valved, the valves usually breaking away from the triangular central column; seeds few-many; seed-coats when wetted commonly becoming mucilaginous and developing spiricles.

Calyx distended and at length burst by the capsule.

Corolla large, salverform; leaves all opposite, entire; seeds not becoming mucilaginous when wetted; ours all suffruticose perennials.

Corolla tubular, funnelform or salverform, usu405. Phlox, 293. ally small; leaves mostly alternate, usually not entire. 
Calyx not distended nor burst by the capsule.

Corolla rotate (in ours); leaves pinnate, the leaflets entire.

Corolla not rotate.

Calyx-lobes spine-tipped; leaves pinnatifid. 408. NAvarretia, 294.

Calyx-lobes not spine-tipped; leaves entire or pinnatifid.

407. Polemonium, 294.

409. Collomia, 296.

\section{PHLOX,}

Perennial herbs or half shrubby plants; leaves opposite, sessile, entire; flowers in cymes, terminal or in the upper axils, mostly bracted; calyx narrow, 5 -cleft, at length distended and burst by the capsule; corolla salverform with a long tube, a narrow opening and broad or rounded lobes; stamens included, very unequally inserted on the upper part of the corolla-tube; ovules 1 or sometimes 2 ; capsules ovoid, with but one seed in each cell.

Loosely tufted, the leaves not crowded; flowers in cymes.

Densely tufted with crowded leaves; flowers solitary.

Calyx woolly; leaves not ciliate.

Calyx glabrous; leaves hispid-ciliate.
$P$. adsurgens.

$P$. diffusa.

$P$. condensata.

Phlox adsurgens Torr. Glabrous except the inflorescence; stems spreading or ascending, $15-40 \mathrm{~cm}$. high; leaves ovate-lanceolate to ovate, acute, $1-2 \mathrm{~cm}$. long; calyx scarious between the angles, glandular-pubescent, the teeth shorter than the tube; corolla pink, its tube twice as long as the calyx, its lobes ovate, sometimes retuse.

In open woods, western Oregon, perhaps not in our limits.

Phlox diffusa Hook. Stems prostrate; leaves clustered, linear, sharppointed, glabrous, 6-12 mm. long; calyx-teeth as long as the tube; corolla pale violet or nearly white, the obovate lobes $6-9 \mathrm{~mm}$. long.

In the mountains, above timber line, often forming large mats.

Phlox condensata (Gray) E. Nelson. Minutely glandular, densely tufted; leaves much crowded, oblong-linear, rigid, longitudinally grooved, ciliatemargined, 5-6 mm. long; calyx $5 \mathrm{~mm}$. long, its teeth linear, apiculate; corolla white, the tube nearly twice the calyx, the rounded lobes 4-5 mm. long; style short.

Olympic and Cascade Mountains at high altitudes, growing on rocks.

\section{GILIA.}

Herbs or half-shrubby plants; leaves alternate or opposite; calyx narrow, the lobes acute, the tube scarious below the sinuses, becoming distended and finally burst by the capsule; corolla tubular-funnelform, the limb little spreading (in ours); stamens equally or unequally inserted; capsules with 1-many seeds.

Perennials.

\section{G. nuttallii.}

\section{Annuals.}

Leaves or some of them opposite.

Leaves all opposite, dissected into filiform segments.

Lower leaves opposite, the upper alternate, all entire.

Leaves all alternate.

Calyx glabrous; corolla 8-10 mm. long.

Calyx woolly; corolla 10-12 mm. long.
G. bicolor.
G. gracilis.
G. capitata.
G. achilleaefolia. 
Gilia nuttallii Gray. Perennial, tufted from a woody base, somewhat puberulent; stems erect, $10-30 \mathrm{~cm}$. high, mostly simple; leaves sessile, opposite, palmately parted into 3-7 segments, these linear, somewhat rigid, mucronate, scabrous, 1-2 cm. long; flowers in a terminal dense cluster; calyx-lobes subulatelanceolate, rigid; corolla white, with yellow throat, the tube puberulent on the outside, not exceeding the calyx, the lobes obovate, $6-7 \mathrm{~mm}$. long; ovules 2 in each cell.

Mount Rainier, at 2000 m. elevation, E. C. Smith; Goat Mountains, Allen.

Gilia bicolor (Nutt.) Piper. Annual, pubescent; stems slender, 5-10 cm. high, mostly simple; leaves palmately parted into thread-like sharp-pointed divisions, 4-10 $\mathrm{mm}$. long; corolla with a very slender yellow tube, $12-20 \mathrm{~mm}$. long, the small pink limb $6 \mathrm{~mm}$. broad.

In dry soil, common.

Gilia gracilis (Dougl.) Hook. Annual; erect, usually simple, 10-30 cm. high, branched above, glabrous below, pubescent and glandular above; leaves sessile, entire, the lower opposite, oblong or obovate, 1-2 cm. long, the upper alternate, lanceolate, acute, $2-4 \mathrm{~cm}$. long; flowers solitary in the forks or axils, short-pedicelled, somewhat cymose through the reduction of the leaves; calyxlobes subulate, mucronate, twice as long as the campanulate tube, this at length splitting to the base; corolla tubular-salverform, $8-10 \mathrm{~mm}$. long, the tube yellow, not longer than the calyx-lobes, the limb purple-pink; stamens unequally inserted; ovules and seeds solitary in each cell; seed-coats without spiricles.

\section{Common in open ground.}

Gilia capitata Hook. Annual, glabrous or nearly so; stems slender, erect, loosely branched, 20-60 cm. high; leaves alternate, once or twice pinnately divided into very narrow segments; flowers pale blue, in dense globose clusters terminating long naked peduncles; calyx-lobes lanceolate-acuminate, about as long as the tube; corolla $8-10 \mathrm{~mm}$. long, the oblong or linear lobes as long as the tube, which is but little dilated in the throat; seeds developing mucilage and spiricles when wetted.

In sandy or gravelly soil, in open places.

Gilia achilleaefolia Benth. Very similar to $G$. capitata; herbage slightly pubescent; heads only moderately compact; calyx somewhat tomentose, pubescent, its lobes ovate, spine-tipped, longer than the tube; corolla pale blue, dilated in the throat, the lobes obovate or broadly oblong.

Vancouver Island, British Columbia, to California, in sandy soil, not common.

\section{POLEMONIUM. JACOB'S LADDER.}

Annual or perennial herbs; leaves alternate, pinnate, with entire leaflets; flowers in corymbs, nearly bractless; calyx rotate or campanulate, the tube very short; stamens equally inserted at the summit of the corolla-tube; capsule few-several-seeded.

Annual; corolla white, nearly rotate.

P. micranthum.

Perennial; corolla campanulate.

Densely cespitose, 5-10 cm. high; herbage glandular.

Viscid-glandular throughout; flowers violet with yellow eye.

Less viscid, sparsely pilose throughout; flowers white or pale blue.

Loosely cespitose, $15-30 \mathrm{~cm}$. high, scarcely glandular.

Lobes of the calyx as long as the tube.

Lobes of the calyx twice as long as the tube.

P. elegans.

$P$. viscosum.

P. humile.

$P$. carneum. 
Polemonium micranthum Benth. Annual, branched from the base, spreading, $6-20 \mathrm{~cm}$. high, somewhat viscidly pubescent throughout; leaves mostly petioled, $1-4 \mathrm{~cm}$. long; leaflets $5-13$, obovate or lanceolate, acute or obtuse, $3-8 \mathrm{~mm}$. long; peduncles solitary, opposite the leaves; calyx-lobes triangular, as long as the broadly campanulate tube; corolla white, rotate, not equalling the calyx; ovules 2 or 3 in each cell.

In dry open places, rare in our limits.

Polemonium elegans Greene. Perennial, viscid-pubescent; stem 5-12 cm. high; leaflets numerous, crowded, obovate or elliptical, $2-4 \mathrm{~mm}$. long; flowers in a dense cyme; corolla violet, with a broad yellow throat.

Cascade Mountains at 2000-3000 m. elevation.

Polemonium viscosum pilosum Greenman. Perennial, pilose-pubescent and somewhat viscid-glandular; stems $6-10 \mathrm{~cm}$. high; leaflets numerous, moderately crowded, thickish, ovate, $2-3 \mathrm{~mm}$. long; calyx campanulate, the lobes oblong-ovate to oblong, obtuse; corolla white or pale blue with a yellow center, $8-10 \mathrm{~mm}$. long; filaments naked at base.

Goat Mountains, Washington, Allen.

Polemonium humile R. \& S. Perennial, loosely tufted, viscid-puberulent; $8 / 8 / 2$ • Mt. stems $15-30 \mathrm{~cm}$. high, bearing 1-3 leaves; leaflets 15-21, oblong-lanceolate $6000 \mathrm{fo}$. 3 to oval, 10-15 mm. long; flowers blue, in open cymes; calyx-lobes triangular, lean on about as long as the tube; corolla campanulate-funnelform, the broad rounded lobes longer than the tube; filaments hairy at base; capsule $2-4$-seeded.

The plant has an unpleasant odor. At about the limit of trees in the mountains, common.

Polemonium carneum Gray. Perennial, nearly glabrous; stems ascending or erect, 15-60 cm. high, leafy; leaflets 11-21, lanceolate to oblong-ovate, acute, $1-5 \mathrm{~cm}$. long; cymes few-flowered; calyx campanulate, $1-2 \mathrm{~cm}$. long, more or less pubescent, the narrow acute lobes about twice as long as the tube; coroila salmon-colored or blue, the rounded lobes longer than the tube; filaments dilated and pilose at base; seeds $2-4$ in each cell.

Chehalis County, Washington, to middle California. As here delimited the species is quite variable in regard to the number and size of the leaflets, the amount of pubescence on the calyx, and especially the color of the corolla which in the original specimen is flesh-colored. $P$. amoenum Piper seems only a blue-flowered form, and $P$. luteum Howell is probably only a yellow-flowered variety.

\section{NAVARRETIA.}

Glabrous or viscid-pubescent annual herbs; leaves all alternate, pinnatifid, setaceous or spiny; flowers crowded in bracteate clusters on the ends of the branches; calyx-tube scarious, not becoming distended and not burst by the capsule, the ribs prolonged into unequal bristle-tipped lobes; corolla tubular; capsule 1-3-celled, 1-many-seeded.

Herbage glandular-viscid with a bad odor.

Herbage neither glandular nor with a bad odor.
N. squarrosa.

N. intertexta.

Navarretia squarrosa (Esch.) Hook. \& Arn. Skunk Weed. Annual, glandular, erect or spreading, simple or much branched, $10-30 \mathrm{~cm}$. high, very leafy; leaves mostly alternate, pinnately parted and the segments cleft or parted, the lobes sharp pointed, the upper ones and the bracts becoming spine-like; calyx-lobes subulate, spiny-tipped, usually entire, longer than the tube; corolla 
pale blue, 8-10 $\mathrm{mm}$. long, the tube shorter than the calyx, the limb small; stamens included; ovules 8-12 in each cell.

Common in open places, very ill-smelling.

Navarretia intertexta (Benth.) Hook. Annual; stems erect and simple below or more commonly much branched and spreading, 5-15 cm. high, pubescent; leaves all alternate, once or twice pinnately cleft into linear spinescent lobes, glabrous or nearly so; flowers crowded in head-like clusters, the bracts and calyx-tube villous with white hairs; calyx-lobes more or less cleft into spinose divisions; corolla tubular, funnelform, pale blue, equalling the calyx-lobes, 5-6 mm. long; stamens exserted; ovules and seeds 3 or 4 in each cell; seed-coats developing spiricles.

Vancouver Island, British Columbia, to California, in dry open places.

\section{COLLOMIA.}

Herbs with alternate entire leaves; calyx not distended by the capsule, obconical, the lobes not spine-tipped; corolla tubular funnelform, with open throat and a spreading limb of short obtuse lobes; stamens unequally inserted on the corolla tube; capsule narrowed at the base; seeds usually 1 in each cell, mucilaginous and forming spiricles when wetted.

\section{Leaves entire.}

Corolla salmon-colored, $2-3 \mathrm{~cm}$. long.

Corolla pink, $1 \mathrm{~cm}$. long.

Leaves more or less dissected.

Annual; leaves pinnate.

Perennial; leaves palmate.

C. grandiflora.

C. linearis.

C. heterophylla.

C. debilis.

Collomia grandiflora Dougl. Annual, erect, usually simple, $30-40 \mathrm{~cm}$. high, viscid-glandular below; leaves sessile, all alternate, lanceolate or linear, the upper broader, all entire, $2-6 \mathrm{~cm}$. long; flowers crowded in a terminal headlike cluster; calyx obconical, the lobes broad, obtuse, shorter than the tube; corolla salmon-color, narrowly funnelform, 15-25 mm. long; stamens unequally inserted; ovules and seeds solitary in the cells, the seed-coats developing spiricles when wetted.

In dry open woods.

Collomia linearis Nutt. Annual, erect, simple or branched above, 10-30 $\mathrm{cm}$. high, pubescent throughout or glabrous below, glandular above; leaves sessile, alternate, linear or lanceolate, acute, entire, 2-6 cm. long; flowers crowded in head-like clusters; calyx-lobes triangular, acute, as long as the obconic tube; corolla pink, 8-10 mm. long, slender-tubular, the lobes small; stamens unequally inserted; ovules and seeds solitary in each cell; seed-coats with spiricles.

In low ground, not rare.

Collomia heterophylla Hook. Annual, the stems usually decumbent, $10-20 \mathrm{~cm}$. long; leaves all alternate, pinnatifid with the lobes entire or again cleft, or the upper ones less lobed or even entire; flowers in a dense leafybracted cyme; corolla purplish, $10-12 \mathrm{~mm}$. long.

In moist open woods, common. First found at Fort Vancouver by Douglas.

Collomia debilis (Wats.) Greene. Perennial; stems loosely tufted; leaves oblong, 3-7-cleft or some entire; flowers crowded in a leafy head; corolla purplish, 12-16 mm. long.

Growing in loose rock at high altitudes in the Cascade Mountains. 


\section{Family 85. HYDROPHYLlaCEAE. Waterleaf Family.}

Herbs, commonly hairy; leaves mostly alternate; flowers perfect, regular, on naked 1-flowered scapes or in dense one-sided cymes or false racemes; calyx 5-parted or of 5 sepals; corolla gamopetalous, deeply 5-lobed; stamens on the corol'a-tube, alternate with its lobes; style 2-cleft, or styles 2 and separate; ovary entire, 1-celled, with 2 parietal placetae or 2-celled by the union of the placentae; fruit a 2-valved 4-many-seeded capsule; endosperm copious.

Styles entire.

Styles 2-cleft.

410. Romanzoffia, 297.

Corolla imbricated in bud; placentae narrow.

Corolla convolute in bud; placentae broad.

Perennials; stamens exserted.

Annuals; stamens included.

411. Phacelia, 297.

412. HydrophyLLum, 298.

413. NEMOPHILA, 299.

\section{ROMANZOFFIA.}

Low and delicate perennial herbs; leaves mainly radical, cordate or reniform, crenately 7-11-lobed, long-petioled; flowers on a scape, in a loose raceme or panicle; calyx deeply 5-parted; corolla white or pinkish, more or less funnelform, not appendaged within; stamens unequal, on the base of the corolla; style filiform; stigma small, entire; ovary and capsule 2-celled or nearly so; ovules and seeds numerous.

Herbage glabrous or nearly so; pedicels longer than the flowers in anthesis.

Herbage pubescent; pedicels shorter than the flowers in anthesis.

$R$. sitchensis.

R. unalaschensis.

Romanzoffia sitchensis Bong. Nearly glabrous; leaves thin, reniform, crenately 7-11-lobed, 1-2 cm. broad, long-petioled; scapes 6-15 cm. high, branched, loosely flowered; calyx much shorter than the corolla; corolla white, the lobes orbicular; style filiform: capsule retuse.

On moist cliffs in the mountains; rootstocks bearing small tubers.

Romanzoffia unalaschensis Cham. Pubescent especially the inflorescence, somewhat bulbous at base; leaves thick, reniform to orbicular, usually with 9 short lobes; scapes erect, rarely with a single leaf, $8-12 \mathrm{~cm}$. high; racemes short; pedicels erect; calyx-lobes nearly as long as the corolla; corolla white, somewhat funnelform; style short; capsule obtuse.

Cape Elizabeth, Washington, Foster, and north to Alaska.

\section{PHACELIA.}

Perennial or mostly annual herbs; leaves simple, lobed or divided, alternate, or the lowest opposite; flowers in one-sided raceme-like cymes; calyx deeply 5-parted, the lobes usually narrow and similar; corolla from almost rotate to narrow-funnel- 
form, commonly with appendages inside of the tube, consisting of 10 vertical plaits in pairs between the bases of the filaments; stamens equally inserted at or near the base of the corolla; ovary with narrow parietal placentae; ovules and seeds 4numerous.

Leaves with many lobes.

P. sericea.

Leaves entire or with few lobes or divisions.

Flowers bright blue, rather large.

Flowers whitish, rather small.

$P$. linearis.

$P$. nemoralis.

Phacelia sericea (Graham) Gray. Perennial; stems 15-20 cm. high, leafy; leaves silky-pubescent, pinnate, with numerous narrow lobes; flowers in a dense spike-like cyme; corolla violet.

In the Cascade and Olympic Mountains, at high elevations. A very handsome species.

Phacelia linearis (Pursh) Holzinger. Annual, 10-50 cm. high, simple below the inflorescence; whole plant rough-hairy, usually with some shorter white pubescence; leaves sessile, linear or lanceolate, entire or cleft into 2-5 narrow lobes; inflorescence usually branched, consisting of spike-like racemes; pedicels short; calyx-lobes linear, hispid-ciliate; corolla violet-blue, nearly rotate, $12-15 \mathrm{~mm}$. broad; appendages 10 , narrow, free from the filaments; stamens equalling the corolla; filaments sparsely hairy; style 2-cleft; capsule shorter than the calyx; ovules 12-16; seeds pitted-reticulate.

Dry prairies, rare in our limits; Whidby Island, Gardner.

Phacelia nemoralis Greene. Hirsute-pubescent throughout but green, not hoary; leaves long-petioled, ovate-oblong, entire, simple or the lower ones with one or two pairs of small leaflets; flowers in dense spike-like cymes; corolla greenish-yellow.

Dry prairies, not common. Very closely related to $P$. heterophylla Pursh which differs mainly in the herbage being canescent.

\section{HYDROPHYLLUM. WATERLEAF.}

Perennial herbs; leaves long-petioled, mostly pinnately-parted; flowers white or violet, in cymose dense clusters; calyx 5-parted into narrow divisions; corolla bell-shaped, a nectariferous grooved appendage opposite each lobe; stamens and style exserted beyond the corolla-lobes; ovary lined with dilated and fleshy placentae; ovules 4 ; capsule 2 -valved, $1-4$-seeded.

Calyx-lobes smooth on the back; flowers pale violet; basal leaves with 5 approximate segments.

Calyx-lobes pubescent on the back; flowers white; leaves with

5-9 scattered segments, paler beneath.

H. tenuipes.

Hydrophyllum tenuipes Heller. Stems about $30 \mathrm{~cm}$. high; leaves longpetioled, nearly all 5-parted or divided; segments close together, acuminate, coarsely toothed or incised, somewhat paler beneath; calyx-lobes bristlymargined, otherwise smooth; corolla pale violet.

In moist woods, common. A form which occurs near Ilwaco has darker flowers and thicker doubly dentate leaves. It may be distinct.

Hydrophyllum albifrons Heller. Roots densely fascicled; stems $30-40 \mathrm{~cm}$. high, exceeded by the leaves, sparingly hairy; leaves $10-20 \mathrm{~cm}$. long, pinnately 
5-7-divided; divisions ovate, incisely and coarsely cleft and toothed, 3-6 cm. long; lower petioles elongated; inflorescence a rather dense cyme, exceeding the leaves; calyx soft-hispid, deeply 5-parted into lanceolate divisions, without appendages in the sinuses; corolla whitish.

In mountain meadows.

\section{NEMOPHILA.}

Diffuse and tender annual herbs; leaves opposite or partly alternate, pinnatifid or lobed; peduncles terminal or lateral, 1-flowered, slender; calyx enlarging more or less in fruit, 5-parted, with a reflexed appendage at each sinus; corolla rotate or nearly campanulate, deeply 5-lobed, the throat appendaged more or less with 10 internal scales or plaits; stamens and style shorter than the corolla; ovules 4 or many; capsule 2-valved, ripening $1-16$ seeds.

Flowers large, 10-20 mm. broad; peduncles mostly twice as long as the leaves.

N. atomaria.

Flowers small, 2-7 mm. broad; peduncles about as long as the leaves.

Corolla tubular; leaves ovate in outline, acutely 5 -lobed.

Corolla campanulate; leaves oblong in outline, obtusely 57-lobed.

N. parviflora.

N. sepulta.

Nemophila atomaria Fisch. \& Meyer. Nearly glabrous; leaves ovate or suborbicular, pinnately 5-9-lobed; peduncles twice as long as the leaves; calyx-lobes ovate-lanceolate; corolla white or pale blue, dotted or veined with black, hairy at the center.

Douglas County, Oregon, and southward.

Nemophila parviflora Dougl. Stems prostrate or procumbent, $5-15 \mathrm{~cm}$. long; leaves mostly opposite, ovate in outline, pinnately 5-lobed, the lobes acute; peduncles mostly shorter than the leaves, not deflexed in age; corolla short tubular, white, 2-5 $\mathrm{mm}$. broad.

Common in moist open places.

Nemophila sepulta Parish. ( $N$. densa Howell.) Prostrate or decumbent, the branches usually short, $2-5 \mathrm{~cm}$. long; leaves opposite, oblong, pinnately 5-7-lobed, the lobes mostly obtuse; peduncles about as long as the leaves, at length deflexed; calyx-lobes lanceolate, $2-5 \mathrm{~mm}$. long; corolla open-campanulate, white, often dotted with blue specks in the center, 3-7 $\mathrm{mm}$. broad.

Rare, Vancouver Island, British Columbia, to California.

\section{Family 86. BORAGINACEAE. Borage FAMILy.}

Mostly rough-hairy herbs; leaves alternate, entire, without stipules; flowers regular, perfect; calyx 5-parted; corolla 5-lobed, sometimes with projecting appendages or swellings (fornices) in the throat; stamens 5 , inserted on the corolla-tube; style 1 ; ovary usually deeply 4 -lobed, forming in fruit 4 seed-like nutlets, or separating into two 2 -seeded nutlets; nutlets attached by the base or inner angle or face to the receptacle, which is sometimes elongated (the gynobase); endosperm none. 
Mature fruits are necessary for accurate determinations in this family.

Nutlets armed with barbed prickles.

Nutlets erect, prickly on the margins and sometimes on the back.

Nutlets spreading, prickly all over.

Nutlets not armed with barbed prickles.

Corolla tubular or tubular-funnelform, blue.

Corolla funnelform or rotate.

Nutlets erect, attached by the very base.

Racemes bractless; corolla rotate; roots slender.

Racemes bracteate; corolla funnelform; roots thick.

414. Lappula, 300.

415. Cynoglossum, 301.

416. Mertensia, 301. ts erect or oblique, attached above the base, with a more or less prominent fruiting receptacle (gynobase).

Corolla yellow or orange, with a naked open throat.

Corolla white or blue with more or less prominent swellings in the throat.

Gynobase elongate, the nutlets attached by one-third their length or more.

Gynobase low.

Nutlets oblique or incurved, attached about the middle by a caruncle-like process; leaves all alternate.

Nutlets attached just inside the base; lower leaves opposite.

417. Myosotis, 302.

418. LithosPermum, 303.

419. Amsinckia, 303.

420. Cryptantha, 303.

421. Plagiobothrys, 304.

422. Allocarya, 304.

\section{LAPPULA.}

Annual, biennial or perennial rough-hairy herbs; flowers small, in racemes or spikes; calyx 5-parted, reflexed or open in fruit; corolla short-salverform or somewhat funnelform, white or blue, the throat closed with prominent appendages (fornices); nutlets attached by some part of the inner angle or face to the gynobase, armed either along a distinct margin or more or less over the whole back with backwardly-barbed prickles.

Lateral prickles of the fruit united.

Lateral prickles of the fruit free.

L. cupulata.

L. occidentalis.

Lappula cupulata (Gray) Rydb. Annual, erect, loosely branched, 15-50 $\mathrm{cm}$. high, hispid-pubescent throughout; leaves all sessile, linear, obtuse, 1-3 $\mathrm{cm}$. long; racemes becoming very loose and elongated, leafy-bracteate; pedicels stout, shorter than the calyx; corolla very small, white or blue, its tube barely as long as the calyx; nutlets convex on the back, granular-roughened, the margins with a border of united prickles, thus forming a shallow cup; ventral face convex, covered with whitish tubercles; scar long and narrow, nearly as long as the nutlet.

Victoria, British Columbia, Macoun. 
Lappula occidentalis (Wats.) Rydb. Very similar to L. cupulata; the flowers white or pale blue; marginal prickles of the nutlets separate or barely united at base.

Victoria, Macoun; common east of the Cascade Mountains.

\section{CYNOGLOSSUM. HOUND'S TONGUE.}

Coarse herbs with broad leaves, the lower ones large and longpetioled; flowers in bractless panicled racemes; calyx 5-parted, persistent, open in fruit; corolla short-salverform with conspicuous arching crests at the throat; stamens and styles included; nutlets 4 , armed all over the back with short stout glochidiate prickles, affixed by their inner angle to the pyramidal gynobase.

Cynoglossum grande Dougl. Pubescence villous; stems stout, 40-60 cm. high; lower leaves ovate-oblong, often subcordate, acute, $10-20 \mathrm{~cm}$. long, long-petioled; upper leaves smaller, tapering at base, the short petiole winged; racemes panicled; calyx-lobes ovate; corolla blue; nutlets ovoid, rough with glochidiate-tipped prickles. ward.

In open woods, Fort Vancouver, Clarke County, Washington, and south-

\section{MERTENSIA. BLUEBELL.}

Glabrous or pubescent perennial herbs; flowers blue or rarely white, mostly bractless, in panicled racemes or in corymbs; calyx deeply 5-cleft or parted; corolla tubular-funnelform or trumpetshaped to almost campanulate, the open throat bearing obvious or obsolete transverse folds or crests; filaments flattened or nearly filiform; style filiform; stigma entire; nutlets from somewhat fleshy to membranaceous, not armed with barbed prickles.

Leaves glabrous on both sides or merely papillose above; calyx smooth on the back, the lobes elongate, acute.

Leaves pilose beneath.

Upper leaf surface strigose; calyx-lobes pubescent on the back.

Upper leaf surface smooth or merely papillose.

Calyx-lobes pubescent on the back.

Calyx-lobes glabrous on the back.

M. laevigata.

M. denticulata.

M. subcordata.

M. leptophylla.

Mertensia laevigata Piper. Stems stout, erect, more or less glaucous, 40-90 cm. high; leaves pale or glaucescent, numerous, the cauline ovate, acuminate, glabrous or somewhat papillate above, glabrous beneath, ciliate on the margin, 5-7 cm. long, short-petioled; inflorescence loose, the pedicels appressed-pubescent or muriculate; calyx divided nearly to the base, its lobes lance-oblong, acute, ciliate, smooth on the back, over half as long as the corolla tube; corolla blue, $14 \mathrm{~mm}$. long, the somewhat ampliate limb as long as the tube; filaments dilated, shorter than the anthers; nutlets finely muriculate, pale, the scar of attachment central.

Cascade and Olympic Mountains at moderate elevations.

Mertensia denticulata (Lehm.) Piper n. comb. (Lithospermum denticulatum Lehm.; Mertensia platyphylla Heller.) Nearly glabrous; stems erect, 40$70 \mathrm{~cm}$. high; leaves ovate to ovate-lanceolate, acuminate, narrowed at base, 6-10 cm. long, the lower ones long-petioled, all strigosely pubescent and 
somewhat papillate above; pedicels appressed-pubescent; calyx-lobes linearlanceolate, pubescent on the back, ciliate; corblla bluc, 10-12 mm. long, much enlarged in the throat.

In woods near the ocean coast in Washington.

Mertensia subcordata Greene. Stems erect, $30-90 \mathrm{~cm}$. high; leaves ovate, acute or acuminate, rounded or subcordate at base, pilose beneath, smooth or papillose above, petioled, 5-8 $\mathrm{cm}$. long; petioles hairy; pedicels pubescent; calyx-lobes oblong-lanceolate, pubescent on the back; corolla blue, $10 \mathrm{~mm}$. long.

In open woods in the Cascade Mountains.

Mertensia leptophylla Piper. Stems glabrous, stout, erect, a meter or more high; leaves ovate, acute, pilose beneath, glabrous above, ciliate, very thin, the blades $6-10 \mathrm{~cm}$. long, all on margined petioles $1-3 \mathrm{~cm}$. long; inflorescence loose; pedicels with spreading pubescence; calyx parted nearly to the base, the lobes narrowly triangular-lanceolate, acute, ciliate, smooth $n$ n the back; corolla blue, about $12 \mathrm{~mm}$. long, the slightly enlarged throat as long as the tube; filaments dilated, shorter than the anthers.

Known only from the Olympic Mountains of Clallam County, Washington, Elmer, Lawrence. Perhaps not distinct from $M$. subcordata Greene.

\section{MYOSOTIS. FORGET-ME-NOT.}

Low spreading herbs, usually soft-hairy; cauline leaves sessile; flowers blue or white, in at length elongated racemes, without bracts; corolla short-salverform or almost rotate, its throat contracted by transverse crests, the rounded lobes convolute in the bud; anthers ovate or oblong; nutlets small, ovoid, smooth and shining, thin-crustaceous; scar small.

Annual; calyx hairs hooked; corolla white.

Perennial; calyx hairs straight; corolla blue.

Calyx-lobes shorter than the tube.

Calyx-lobes longer than the tube.

M. macrosperma.

M. scorpioides. M. laxa.

Myosotis macrosperma Engelm. Annual, erect, rough-hairy throughout, $10-40 \mathrm{~cm}$. tall, branched above or simple; leaves oblong-linear or oblanceolate, obtuse, sessile, 1-2 cm. long; racemes elongated and loose in fruit, leafy at the base; pedicels shorter than the calyx; fruiting calyx 4-5 $\mathrm{mm}$. long, deeply 5-cleft, the lobes lanceolate, unequal, hispid with hooked hairs; corolla small, white; nutlets oval, biconvex with a narrow margin, very smooth and shiny, silvery-gray, $1-1.5 \mathrm{~mm}$. long; scars minute.

In open ground, not common.

Myosotis scorpioides L. Forget-me-not. Perennial, rough-pubescent; stems decumbent and rooting at the lower nodes, 10-60 cm. long; leaves oblong-lanceolate to linear-oblong, obtuse, narrowed at base, $2-6 \mathrm{~cm}$. long, the lower ones petioled; calyx-lobes triangular, shorter than the tube, appressed pubescent; corolla $5-8 \mathrm{~mm}$. broad, blue with a yellow center; nutlets keeled on the ventral side. Europe.

In wet places, often abundant. The true Forget-me-not, a native of

Myosotis laxa Lehm. Perennial from slender rootstocks, appressedpubescent throughout; stems weak and slender, $10-30 \mathrm{~cm}$. long; leaves oblonglanceolate to spatulate, $2-3 \mathrm{~cm}$. long; racemes very loose; pedicels much longer than the calyx; calyx-lobes as long as or longer than the tube; corolla pale blue; 
nutlets oval, biconvex, with a narrow margin, very smooth and shiny, black, 1-1.5 mm. long; scar minute.

In wet ground, rare.

\section{LITHOSPERMUM. GROMWELL.}

Mostly herbs with reddish roots; leaves sessile; flowers leafybracted, axillary or subaxillary; calyx 5-parted; corolla salverform, funnelform or sometimes approaching campanulate; filaments mostly very short; anthers short, included; style slender; stigma mostly truncate, capitate or 2-lobed; nutlets ovoid, bony, either polished and white or dull and rough,

Lithospermum ruderale Dougl. Perennial, tufted, the stems simple, 15-30 cm. high, pubescent with long and short hairs; leaves numerous, lanceolate, rarely linear, attenuate-acute, sessile, 5-10 cm. long, minutely soft-hispid; flowers in a dense leafy cluster; corolla greenish-yellow, campanulate-funnelform, pubescent inside, nearly naked in the throat, 10-12 $\mathrm{mm}$. long; style slender; nutlets light-colored, ovoid, acute, hard and smooth, 3-4 mm. long.

Dry prairies; rare in our limits but common east of the Cascade Mountains.

\section{AMSINCKIA.}

Rough-hispid annuals; leaves oblong or linear; corolla salverform or tubular-funnelform with a slender tube and open throat, the limb sometimes plaited at the sinuses, yellow; style filiform; stigma capitate or 2-parted; nutlets crustaceous or coriaceous, unappendaged, ovate-triangular, attached below the middle to an oblong-pyramidal gynobase.

Stems decumbent; calyx sparsely bristly, the lobes ovate. Stems erect; calyx densely bristly, the lobes linear.

A. lycopsoides.

A. intermedia.

Amsinckia lycopsoides Lehm. Stems decumbent, 30-60 cm. long; leaves green, ovate or lanceolate, somewhat toothed, the sparse bristles with swollen bases; spike long and sparse, leafy-bracted; calyx-lobes oblong or ovate, obtuse, two or three of them often united; nutlets dark-colored, rough.

Common along the seashore, but also behaving as a weed in cultivated land.

Amsinckia intermedia Fisch. \& Meyer. Tar Weed. Erect, usually simple, $30-60 \mathrm{~cm}$. high, the bristly hairs mostly white; leaves lanceolate or linear, 5-12 cm. long, the upper somewhat broader at base; raceme becoming much elongated in fruit; calyx-lobes linear, acute, very bristly in fruit, 6-8 mm. long; corolla yellow, 5-6 mm. long; nutlets dark-colored, the back convex and somewhat keeled, obliquely ridged and roughened with tubercles.

Common in dry ground.

\section{CRYPTANTHA.}

Small annuals or perennials, mostly canescent and hispid; leaves narrow; flowers in terminal spikes or racemes; calyx erect or closed about the fruit and falling with it; corolla white, small, salverform; nutlets 4 , or less by abortion, smooth or roughened, each attached by one-third or more or its length by the central face or angle to a slender usually subulate gynobase. 
Calyx twice as long as the acuminate nutlets. Calyx little longer than the acute nutlets.

C. ambigua.

C. muriculata.

Cryptantha ambigua (Gray) Greene. Slender, 15-30 cm. high, shorthispid; leaves oblong-linear, $1-2 \mathrm{~cm}$. long; spike nearly bractless, rather fewflowered; fruiting calyx 6-8 mm. long, with rather small bristles, the lobes linear, twice as long as the fruit; nutlets all four maturing, ovoid, acute, rough, with papillae of two sizes; ventral groove forked at the very base.

Prairies, rare; first collected by the Wilkes Expedition at Fort Nisqually, Washington.

Cryptantha muriculata (A.DC.) Greene. Erect, branched from the base, 10-20 cm. high, hispid throughout; leaves oblong or linear, $1-3 \mathrm{~cm}$. long; spikes often in pairs or 3-5 in a cluster, bractless; fruiting calyx $5 \mathrm{~mm}$. long, short-bristly, with linear lobes which are a little longer than the fruit; corolla 5-6 $\mathrm{mm}$. broad, with prominent appendages in the throat; nutlets $2 \mathrm{~mm}$. long, usually all four present, ovoid-triangular, obtuse, roughened with minute papillae and some larger ones on the back and usually on the ventral face; ventral groove extending from the apex to near the base where it widens out into a triangular depression.

In dry prairies.

\section{PLAGIOBOTHRYS.}

Hispid annuals, the juice staining purple; basal leaves in a rosette; flowers small, in spikes or racemes; calyx campanulate; corolla small, white, short-funnelform; nutlets rough, rarely smooth, each attached by the middle of the somewhat concave inner face to a hemispherical or globular gynobase.

Nutlets somewhat cruciform, muriculate.

Nutlets ovoid, carinate, dull, roughened.

$P$. tenellus.

$P$. nothofulvus.

Plagiobothrys tenellus (Nutt.) Gray. Stems usually several, slender, 5-20 cm. high; leaves mostly in a basal rosette, oblong-linear or lanceolate, 5-20 mm. long; nutlets pale green, shining, keeled and papillate.

In dry ground, Vancouver Island, British Columbia, to California.

Plagiobothrys nothofulvus Gray. Stems erect, $30-60 \mathrm{~cm}$. high, branched; basal leaves oblong or lanceolate, $2-5 \mathrm{~cm}$. long, mostly in a rosette; calyx with long hairs, reddish when young, but becoming paler; nutlets ovoid, not shining, keeled on the back and roughened.

In dry fields and prairies, Willamette Valley, Oregon, and southward.

\section{ALLOCARYA.}

Small annuals or perennials, branched from the base; lower leaves mostly opposite, narrow; flowers small, white; calyx 5parted, erect or little spreading in fruit; corolla white, salverform, usually with appendages at the throat; nutlets not armed with barbed prickles, attached only at the inside of the base to a slightly elevated gynobase.

Corolla small, 2-3 mm. broad; branches prostrate.

Corolla large, 6-8 $\mathrm{mm}$. broad; stems erect or ascending.

Racemes leafy-bracted; pedicels $6 \mathrm{~mm}$. long; scar of the nutlets linear.

A. hispidula.

A. chorisiana. 
Racemes bractless or nearly so; pedicels 1-2 mm. long; scar of the nutlets oblong.

Nutlets not stipitate.

Nutlets stipitate.

A. scouleri.

A. stipitata.

Allocarya hispidula Greene. Annual, much branched from the base, spreading or ascending, 10-30 cm. high, sparingly hairy; leaves few, linear, obtuse, 1-3 cm. long; spikes slender, elongate, leafy-bracteate near the base; corolla white, small; fruiting calyx $2 \mathrm{~mm}$. long, hispid; nutlets ovate-oblong, with obliquely rough ridges on the three faces, keeled the whole length on the ventral face; scar nearly basal.

In moist places, not common in our limits.

Allocarya chorisiana (Cham. \& Schlecht.) Greene. Pubescence thin, appressed; stems branched, spreading or ascending, 30-60 cm. long; leaves linear, 5-10 cm. long; racemes loose, leafy-bracted below; pedicels slender, 6-8 $\mathrm{mm}$. long; corolla 6-8 mm. broad, the yellow appendages in the throat conspicuous; nutlets ovoid, keeled on the ventral side, tuberculate and granulate on the back, dark colored.

Vancouver Island, British Columbia, Macoun; and along the coast of California. Not known from any intermediate locality.

Allocarya scouleri (Hook. \& Arn.) Greene. Appressed pubescent; stems slender, loosely branched, erect or nearly so, $10-30 \mathrm{~cm}$. high; leaves linear, sessile, the lower ones opposite; flowers in slender mostly bractless racemes; pedicels $2 \mathrm{~mm}$. long; calyx erect in fruit, its pubescence rusty when young; corolla $6-8 \mathrm{~mm}$. broad, the appendages in the throat yellow and puberulent; nutlets ovoid, rugulose, granulate, dark colored.

In wet meadows, common.

Allocarya stipitata Greene. Very similar to A. scouleri; nutlets ovoidlanceolate, keeled on the ventral face, granulate and indistinctly rugulose on the back, the scar distinctly stipitate.

In moist places, Washington to California.

\section{Family 87. VERBENACEAE. Verbena FAmily.}

Herbs or shrubs, not aromatic; leaves opposite; flowers perfect; corolla either 2-lipped or irregular; stamens 4, didynamous; style single, terminal; stigma entire or 2-lobed; ovary not lobed; fruit 2-4-celled, dry or drupaceous, usually splitting when ripe into as many 1-seeded indehiscent nutlets; endosperm scant or none.

\section{VERBENA. Vervain.}

Herbs; flowers sessile, in single or panicled bracteolate spikes; calyx tubular, 5-toothed, one tooth often shorter; corolla salverform, more or less unequally 5-cleft; stamens included, the upper pair occasionally without anthers; style slender; stigma mostly 2-lobed; fruit splitting into 4 -seed-like nutlets. 
Verbena hastata L. Perennial, erect, 30-90 cm. high, simple below the inflorescence, rough-puberulent throughout; stems 4-sided; leaves oblong or broadly lanceolate, acute or acuminate, coarsely serrate, 6-12 cm. long, shortpetioled; spikes numerous, clustered at the summit of the stem, slender, 5-15 $\mathrm{cm}$. long; bracts shorter than the calyx; corolla blue, $3 \mathrm{~mm}$. broad.

In moist open places; Victoria, Macoun; common in the Willamette Valley, Oregon.

Verbena bracteosa Michx. Branches prostrate or spreading, $15-30 \mathrm{~cm}$. long, rough-hairy throughout, the root often becoming woody; leaves oblong or obovate, cuneate at base, pinnately 3 -cleft, coarsely dentate, $1-3 \mathrm{~cm}$. long; petiole short, margined; spikes terminal, 1-10 cm. long; upper bracts entire, lanceolate, acuminate, becoming rigid; the lower somewhat cleft, all exceeding the flowers; corolla blue, $4 \mathrm{~mm}$. long; anthers without appendages.

Banks of the Columbia River (Menzies Island, Douglas); rare in our limits, common in the interior.

\section{Family 88. LABIATAE. Mint Family.}

Mostly aromatic herbs with 4-sided stems; leaves simple, opposite; corolla more or less 2-lipped, the upper lip 2-lobed or sometimes entire, the lower 3-lobed; stamens on the corolla-tube, didynamous or diandrous; style usually 2-lobed at the apex; ovary deeply 4-lobed or parted; fruit of 4 seed-like nutlets or akenes, each with one erect seed; endosperm mostly none.

Ovary 4-lobed; corolla nearly regular, 5-cleft.

Ovary 4-parted; corolla nearly regular, 4-cleft, or distinctly bilabiate.

Corolla nearly regular, or when bilabiate, the upper lip plane.

Corolla regular or nearly so.

Antheriferous stamens 2.

Antheriferous stamens 4.

Corolla bilabiate.

Plant creeping; flowers axillary.

Plant erect; flowers capitate-verticillate.

Corolla distinctly bilabiate, the upper lip

424. Trichostema, 307. concave.

Calyx with a protuberance on the upper side.

425. LyCOPUS, 307.

426. Mentha, 308.

427. Micromeria, 309.

428. Madronella, 309.

Calyx without a protuberance.

Upper pair of stamens longer than the lower.

Calyx teeth unequal, the upper very large.

Calyx teeth subequal.

Flowers in rather dense and many-flowered cymose clusters forming interrupted spikes or racemes; upper floral leaves small and bractlike.

Flowers in loose few-flowered

429. Scutellaria, 309.

430. Dracocephalum, 310.

431. NepetA, 310. 
axillary clusters; leaves all alike.

432. GLeсhомa, 311.

Upper pair of stamens shorter than the lower.

Calyx bilabiate.

Calyx not bilabiate.

Teeth of the calyx 10 .

Teeth of the calyx 5 .

Calyx teeth spiny.

Calyx teeth not spiny.

433. Prunella, 311.

434. MARRUbium, 311.

435. LEONURUS, 312.

Flowers opposite; calyx

becoming inflated." 436. Physostegia, 312.

Flowers whorled; calyx not becoming inflated.

Throat of the corolla dilated.

Throat of the cor-

olla not dilated. 438. STACHYs, 313.

\section{TRICHOSTEMA.}

Low annual branched herbs or somewhat woody plants; leaves entire; calyx bell-shaped, oblique, deeply 5-cleft, the 3 upper teeth elongated and partly united, the 2 lower very short; corolla small, almost equally 5-parted, the 3 lower lobes more or less united; stamens 4, much exserted; anther-cells divergent and at length confluent.

Corolla tube not exceeding the calyx; leaves membranaceous, costate-veined.

Corolla tube slender, exserted; leaves crowded, strongly 3-

5-nervose.

T. oblongum.

T. lanceolatum.

Trichostema oblongum Benth. Annual, erect, branched, 10-30 cm. high, the stem soft-hairy; leaves oblong or oval, acute, entire, 1-3 cm. long, canescently pubescent, narrowed at base, short petioled; flowers in nearly sessile axillary dense cymes; pedicels short; calyx campanulate, hairy, equally 5-cleft, the narrow lobes much longer than the teeth, equalling the corollatube; corolla violet.

In moist open places, first collected at Fort Vancouver, Washington, by Douglas. Odor strong but not unpleasant.

Trichostema lanceolatum Benth. Bluecurls. Densely ashy-pubescent; stems simple or more often branched from the base, erect, $10-30 \mathrm{~cm}$. high; leaves numerous, lanceolate, sessile or nearly so, attenuate to an acute apex; flowers in dense axillary nearly sessile clusters; calyx-lobes ovate, acute, longer than the tube; corolla blue, very slender, $12 \mathrm{~mm}$. long.

From the Columbia River to California in dry ground. The original specimens of Douglas are said to have been collected at Fort Vancouver, Washington.

\section{LYCOPUS.}

Low perennial herbs, glabrous or puberulent, not aromatic; leaves sharply-toothed or pinnatifid; flowers small, mostly white, in dense axillary whorls; calyx bell-shaped, nearly equally 4 - or 5- 
lobed; anther-bearing stamens 2, distant; the upper pair either sterile or wanting.

Plants not stoloniferous; calyx-teeth triangular-cuspidate, longer than the nutlet.

Plants stoloniferous at base; calyx-teeth acute, shorter than the nutlet.

L. americanus.

Lycopus americanus Muhl. Glabrous or puberulent; stems erect, simple or little branched, $30-60 \mathrm{~cm}$. high, from creeping rootstocks; leaves lanceolate or ovate-lanceolate, acuminate or acute, cuneate at base, coarsely serrate or sinuately incised, $2-5 \mathrm{~cm}$. long; petioles short; flowers sessile, in dense axillary whorl-like clusters; bracts subulate; calyx-teeth triangular-cuspidate, stiff, nearly as long as the small white corolla, exceeding the nutlets; sterile stamens slender, with thickened tips.

In low moist ground, common.

Lycopus uniflorus Michx. Nearly glabrous; stems erect, $20-60 \mathrm{~cm}$. high, tuberous-thickened at base; stolons more or less tuberous; leaves oblonglanceolate or lanceolate, acute or acuminate, serrate, attenuate at base, sessile or nearly so, $6-15 \mathrm{~cm}$. long; flower clusters dense; calyx teeth triangular; corolla tubular, $3 \mathrm{~mm}$. long.

In moist ground, not rare.

\section{MENTHA. MINT.}

Aromatic fragrant perennial herbs; flowers very small, in dense clusters forming false whorls in the axils or in terminal spikes; calyx bell-shaped or tubular, 5-toothed, equal or nearly so; corolla with a short included tube, almost equally 4-cleft, the upper lobe broadest, entire or notched; anther-bearing stamens 4 , equal, erect, distant.

Whorls of flowers all axillary.

Whorls of flowers in terminal spikes, or some in the upper axils.

Leaves lanceolate, sessile or nearly so; spikes slender.

Leaves ovate, petioled; spikes thick.

M. canadensis.

Mentha canadensis borealis (Michx.) Piper. Wild Mint. Erect, simple or branched, $20-40 \mathrm{~cm}$. high; stems usually simple, glabrous except in the angles; leaves ovate or broadly lanceolate, mostly acute, rounded or cuneate at the base, sharply serrate, short-petioled, glabrous; flowers in dense sessile axillary clusters; calyx $2-3 \mathrm{~mm}$. long, the triangular acute teeth short; corolla paleviolet, rarely white, $5 \mathrm{~mm}$. long, its lobes rounded, its tube exceeding the calyx.

In low grounds, common.

Mentha spicata L. Spearmint. Green and glabrous throughout, the stems $30-60 \mathrm{~cm}$. high, simple below the inflorescence; leaves oblong-lanceolate, acute or acuminate, serrate, narrowed to a sessile or short-petioled base, $2-5 \mathrm{~cm}$. long; spikes terminal, narrow, the flowers in interrupted whorls; bracts lanceolate, usually ciliate; calyx hairy, the tube campanulate, little longer than the subulate teeth; corolla purple, its tube exceeding the calyx.

Common, introduced from Europe.

Mentha citrata Ehrh. Glabrous or nearly so; stems ascending or erect, $30-60 \mathrm{~cm}$. high; leaves ovate, the lower ones obtuse, serrate, petioled, about 
$2 \mathrm{~cm}$. long; heads of flowers roundish, peduncled, terminal and from the upper axils; calyx glabrous, its teeth triangular-subulate.

In wet places, introduced from Europe.

427. MICROMERIA.

Low sweet-odorous plants; flowers small, in the axils of the leaves; calyx oblong or tubular, about 10-nerved, terete not gibbous, about equally 5-toothed; corolla short, distinctly 2lipped; upper lip flattish, entire or notched, neither concave nor hooded, the lower spreading, 3-parted; stamens 4, the lower pair longer.

Micromeria chamissonis (Benth.) Greene. Yerba Buena. Perennial, somewhat pubescent, with slender trailing stems, $30-60 \mathrm{~cm}$. long; leaves orbicular or ovate, obtuse, rounded or subcordate at base, coarsely dentate or . subentire, 6-25 mm. long; petioles short; flowers solitary, axillary; pedicels slender, 2-bracted near the base; calyx $3-4 \mathrm{~mm}$. long, the teeth triangular; corolla white or purplish, $8 \mathrm{~mm}$. long, its tube exceeding the calyx.

Common in open woods; the balsamic odor pleasant.

\section{MADRONELLA.}

Erect woody perennials, with entire leaves and small purple or white flowers in terminal heads which are subtended by broad thin bracts; calyx tubular, 5-toothed, not 2-lipped; corolla 2lipped, the upper lip 2-cleft, the lower 3-cleft; stamens 4, the lower pair the longer; anther-cells at length divergent.

Madronella discolor Greene. Puberulent; stems woody, tufted, $20-40 \mathrm{~cm}$. high; leaves ovate, firm, green above, pale beneath, entire, $2-3 \mathrm{~cm}$. long, shortpetioled; inflorescence a dense head; bracts broadly ovate, thin, more or less purple tinged; calyx-teeth lanceolate, hairy; corolla pale violet, 6-8 $\mathrm{mm}$. long.

On warm slopes at the base of Mount Rainier.

\section{SCUTELlaria. SKULlCAP.}

Annual or perennial herbs, sometimes woody not aromatic; flowers in axillary or terminal racemes or solitary in the axils of leaves or bracts; calyx bell-shaped in flower, 2-lipped, with a gibbous protuberance on the upper side, splitting to the base at maturity, the upper lip at length usually falling away; corolla with an elongated curved ascending tube, dilated at the throat, 2-lipped, the upper erect, arched or galeate; stamens 4 , ascending under the upper corolla-lip, the lower pair longer.

Flowers small, in axillary or terminal racemes.

S. lateriflora.

Flowers larger, solitary in the leaf axils.

Lower lip of corolla not villous.

Lower lip of corolla villous within.

S. galericulata.

Corolla 14-20 mm. long; leaves oblong, obtuse at each end.

S. antirrhinoides.

Corolla 16-25 mm. long; upper leaves linear or narrow, acute at base.

S. angustifolia. 
Scutellaria lateriflora L. Perennial, glabrous; stems erect, branched, 20-60 cm. high; leaves thin, lanceolate-ovate to oblong-ovate, acuminate, coarsely serrate, rounded at base, $3-8 \mathrm{~cm}$. long, petioled; flowers blue, in axillary or sometimes terminal, one-sided racemes; corolla 5-8 $\mathrm{mm}$. long, the lips short, subequal; nutlets smooth.

In moist places, common.

Scutellaria galericulata L. Perennial, glabrous or slightly pubescent; stems erect, $20-80 \mathrm{~cm}$. high, simple or loosely branched; leaves oblong to ovate-lanceolate, acute, serrate, subcordate at base, 2-6 cm. long, shortpetioled; flowers solitary in the axils; pedicels shorter than the calyx; corolla blue, puberulent, the lower lip longer than the upper; nutlets muriculate.

Rare in our limits; Mount Constitution, Henderson.

Scutellaria antirrhinoides Benth. Minutely puberulent; stems mostly branched, 15-30 cm. high; leaves oblong to oblong-lanceolate, obtuse, shortpetioled, entire, 10-20 cm. long; flowers solitary in each axil; calyx.puberulent; corolla dark blue, $2-2.5 \mathrm{~cm}$. long, puberulent.

From the Columbia River to California. The original specimens were collected at Fort Vancouver by Scouler but the plant has not since been found north of the Columbia River.

Scutellaria angustifolia Pursh. Perennial, with rather stout somewhat moniliform rootstocks, $15-20 \mathrm{~cm}$. high, puberulent or glabrous; stems simple or little branched; cauline leaves broadly linear or oblong, obtuse, entire, narrowed at base, sessile or nearly so, 1-2 cm. long; radical ovate, on longer petioles, sometimes toothed; flowers solitary in the axils; pedicels as long as the calyx; corolla violet-blue, $25 \mathrm{~mm}$. long, puberulent outside; lower lip villous within; nutlets minutely granulate.

Rare in our limits; Victoria, Macoun.

\section{DRACOCEPHalUm. Dragon Head.}

Coarse herbs with blue flowers in dense bracteate terminal clusters; calyx tubular, 15-nerved, 5-toothed; corolla 2-lipped, the upper lip erect, emarginate, the lower 3-lobed; stamens 4; anther-cells divergent; nutlets ovoid, smooth.

Dracocephalum parvifiorum Nutt. Stems stout, erect, 20-60 cm. high; leaves ovate-lanceolate, incisely dentate, $3-8 \mathrm{~cm}$. long, slender-petioled; inflorescence spike-like, the flowers densely crowded in whorls in the upper axils; bracts oblong to ovate, cut-toothed, the teeth bristle-tipped; calyx cylindric, puberulent, the upper tooth broadest, all acuminate; corolla pale blue, slightly exceeding the calyx.

Not definitely known from our limits but reported to occur in the Willamette Valley, Oregon.

\section{NEPETA.}

Perennial herbs; calyx tubular, often incurved, obliquely 5toothed; corolla 2-lipped, dilated in the throat; upper lip erect, rather concave, notched or 2-cleft; lower lip spreading, 3 -cleft, the middle lobe largest, notched or entire; stamens 4, ascending under the upper corolla-lip, the upper pair longer; anther-cells divergent.

Nepeta cataria L. Catnip. Perennial, erect, $30-90 \mathrm{~cm}$. high, finely canescent throughout; leaves ovate or oblong, acute, dentate, somewhat 
cordate at base, 2-6 cm. long, petioled, densely canescent; spike stout, dense, $2-10 \mathrm{~cm}$. long; calyx-teeth subulate, the longest one-half as long as the tube; corolla white or purplish, with dark dots, $10-12 \mathrm{~mm}$. long, its tube exceeding the calyx.

Introduced in waste places; native of Europe.

\section{GLECHOMA.}

Low diffuse perennial herbs; leaves all alike, nearly orbicular or reniform, crenate, long-petioled; flowers rather large, blue or violet, solitary or in few-flowered axillary clusters; calyx oblongtubular, 15-nerved, oblique at the throat, unequally 5-toothed, but not 2-lipped; corolla-tube exserted, enlarged in the throat, 2-lipped; upper lip erect 2-lobed or emarginate; lower lip spread ing, 3-lobed; stamens 4, didynamous, all anther-bearing, ascending under the upper corolla-lip; ovary deeply 4-parted; nutlets o void, smooth.

Glechoma hederacea L. Ground Ivy. Pubescent; stems creeping, 15-40 $\mathrm{cm}$. long, the branches erect or ascending; leaves numerous, cordate-orbicular, coarsely crenate, $1-4 \mathrm{~cm}$. broad, the petiole as long as or longer than the blades; flowers axillary, solitary or in few-flowered clusters; calyx puberulent, the lobes acute, about one-third as long as the tube; corolla violet, three times as long as the calyx.

Introduced from Europe.

\section{PRUNella. Heal AlL.}

Low perennials; flowers in terminal or axillary heads or spikes; calyx tubular-bell-shaped, about 10-nerved, 2-lipped, not gibbous on the upper side, closed in fruit; upper lip broad and flat, truncate, with 3 short teeth, the lower 2-cleft; corolla 2-lipped, slightly contracted at the throat and dilated at the lower side just beneath it; upper lip arched, erect, entire, the lower reflexedspreading, 3-cleft; stamens 4, ascending under the upper lip, the lower pair longer.

Prunella vulgaris lanceolata (Barton) Fernald. Glabrous or nearly so, erect or ascending, 15-40 cm. high; leaves ovate-oblong or oblong-lanceolate, acute or obtuse, rounded or cuneate at base, entire or crenate, $2-6 \mathrm{~cm}$. long; petioles slender, about half as long as the blades; spikes terminal, very dense, $2-5 \mathrm{~cm}$. long; bracts very broad, ovate or orbicular, cuspidate-acuminate, ciliate; calyx-teeth somewhat ciliate; corolla violet, $8-12 \mathrm{~mm}$. long, hardly twice as long as the purplish calyx.

Moist ground, common; ascends in the Olympic Mountains to about $5000 \mathrm{~m}$. altitude.

\section{MARRUBIUM.}

Bitter-aromatic, whitish-woolly perennials, branched at the base; leaves wrinkled; flowers small, much crowded in axillary whorls, calyx tubular, 5-10-nerved, nearly equally 10-toothed, the teeth spiny-pointed; corolla 2-lipped, the upper lip erect, notched, the lower spreading, 3-cleft, the middle lobe broadest; 
stamens 4 , short, included in the corolla-tube, the upper pair longer.

Marrubium vulgare L. Horehound. Stems tufted, erect, simple, about $30 \mathrm{~cm}$. high, densely white woolly, especially below; leaves broadly ovate, obtuse, coarsely crenate, thickish, rounded or cuneate at base, rough, woolly beneath, 1-3 cm. long, on petioles nearly as long; flower clusters dense, axillary; calyx-teeth 10 , subulate, hooked at the apex, hardened in fruit; corolla white.

Introduced in waste places; native of Europe.

\section{LEONURUS. MOTHERWORT.}

Erect herbs with cut-lobed leaves; flowers in axillary whorls; calyx 5-nerved, with 3 nearly equal teeth; corolla bilabiate, the upper lip oblong, entire, somewhat arched, the lower spreading, 3-lobed, the middle lobe larger, narrowly oblong-obovate, entire, the lateral ones oblong.

Leonurus cardiaca L. Perennial; somewhat puberulent; stems stout, erect, 1-1.5 m. high; leaves long-petioled, orbicular to oblong-lanceolate, palmately 3-5-cleft, the lobes acute; flower clusters dense; calyx-tceth subulate, as long as the tube; corolla purplish or white, $6-10 \mathrm{~mm}$. long, the upper lip bearded.

In waste places, introduced from Europe.

\section{PHYSOSTEGIA.}

Smooth erect perennial herbs; leaves sessile, lanceolate or oblong, mostly serrate; flowers large and showy, opposite, crowded in simple or panicled terminal leafless spikes; calyx obscurely 10-nerved, short-tubular or bell-shaped, more or less enlarged and slightly inflated in fruit; corolla funnelform, with a much inflated throat, bilabiate; upper lip erect, nearly entire;lower lip 3-parted, spreading, small, the middle lobe larger, broad and rounded, notched.

Physostegia parviflora Nutt. Glabrous; stems erect, 30-90 cm. high, mostly simple; leaves lanceolate to ovate-lanceolate, acute or the lower ones obtuse, sharply serrate, sessile or nearly so, $6-10 \mathrm{~cm}$. long; spikes manyflowered; bracts ovate, acute, shorter than the calyx; calyx-teeth short; corolla purple, $12 \mathrm{~mm}$. long.

In moist places, especially river-banks and lake shores, rare in our limits.

\section{Lamium. Dead Nettle.}

Decumbent herbs; calyx tubular-bell-shaped, about 5-nerved, with 5 nearly equal awl-pointed teeth; corolla 2-lipped, dilated at the throat, the tube longer than the calyx; upper lip arched, narrowed at the base, the middle lobe of the spreading lower lip broad, notched at the apex, contracted at the base; lateral lobes small, at the margin of the throat; stamens 4 , ascending under the upper lip; the lower pair longer. 
Lamium amplexicaule L. Biennial, branched from the base, sparingly pubescent; stems simple, erect, $15-20 \mathrm{~cm}$. high; lower leaves orbicular, coarsely crenate, truncate or cordate at base, 1-2 cm. long, on petioles as long or longer; upper sessile, half-clasping, rather distant; flowers sessile, in axillary and terminal clusters; calyx pubescent, the sharp teeth nearly as long as the tube; corolla purple, the lower lip spotted, $12-15 \mathrm{~mm}$. long.

A weed in cultivated ground; introduced from Europe.

Lamium maculatum L. Perennial, sparsely pubescent; stems ascending, 10-30 cm. high; leaves ovate, cordate, coarsely crenate, petioled, green with broad white splotches along the midrib; calyx pubescent, its lobes subulate, as long as the tube; corolla $1 \mathrm{~cm}$. long, purple-red, with a transverse ring of hairs within.

In waste ground; a weed introduced from Europe.

\section{STACHYS. Hedge Nettle.}

Herbs, rarely woody, not aromatic; calyx tubular-bell-shaped, 5-10-nerved, equally 5-toothed or the upper teeth united to form an upper lip; corolla not dilated at the throat, 2-lipped, the tube about equalling the calyx; upper lip concave, often arched, erect or rather spreading, entire or nearly so; lower lip usually longer and spreading, 3-lobed, the middle lobe largest and nearly entire; stamens 4 , ascending under the upper lip, the lower pair longer.

Upper leaves sessile, the lower short-petioled.

Upper leaves not sessile, the lower long-petioled.

Corolla-tube little longer than the calyx; calyx-lobes subulatearistulate.

Corolla-tube twice as long as the calyx.

Corolla $20 \mathrm{~mm}$. long; calyx glabrous or sparsely hirsute; leaves subcordate.

S. palustris.

Corolla $12 \mathrm{~mm}$. long; calyx soft-villous; leaves mostly cordate.

S. bullata.

S. ciliata.

S. pubens.

Stachys palustris L. Perennial, erect, $30-60 \mathrm{~cm}$. high, soft-pubescent throughout or the stem short-hairy; leaves oblong or ovate-lanceolate, mostly obtuse, crenate-serrate, rounded or cordate at the nearly sessile base, 5-10 $\mathrm{cm}$. long; spikes short-peduncled, the clusters rather close together, the lower with leafy bracts; upper bracts lanceolate; calyx hairy, the tube campanulate, little longer than the subulate teeth; corolla pink-purple, $1 \mathrm{~cm}$. long; the upper lip pubescent, the tube equalling the calyx.

In wet places, rare in our limits; Vancouver, Washington, Suksdorf.

Stachys bullata Benth. Pubescence hirsute or villous; stems erect, 30-70 $\mathrm{cm}$. high; leaves ovate to oblong, mostly obtuse, subcordate or rounded at base, crenate, more or less rugose, $2-5 \mathrm{~cm}$. long; calyx campanulate, the subulate cuspidate teeth half as long as the tube; corolla red, $12-14 \mathrm{~mm}$. long.

In moist places, Clarke County, Washington, and southward.

Stachys ciliata Dougl. Softly pilose to nearly glabrous; stems stout, 1-2 $\mathrm{m}$. high, mostly simple, harshly hispid on the angles; leaves all petioled, thin, ovate to oblong, acute, subcordate, coarsely crenate-dentate, 5-15 cm. long; bracts leaf-like, reduced; calyx tubular, $8 \mathrm{~mm}$. long, the short teeth triangular, cuspidate; corolla red, white-spotted on the lower lip.

Common in swamps; odor disagreeable. 
Stachys pubens (Gray) Heller. (S. emersoni Piper.) Sparsely pubescent; stems erect, about $1 \mathrm{~m}$. high, retrosely hispid on the angles; leaves thin, ovate, obtuse, cordate or subcordate at base, coarsely crenate, sparsely-pilose on both sides, 6-7 cm. long; petioles hirsute; flowers in a leafy-bracted spike, or the lower in the axils of ordinary leaves; calyx campanulate, the deltoid cuspidate teeth ciliate; corolla red, bearded in the throat, the lower lobes white-spotted.

In swampy places near the ocean coast.

\section{Family 89. SOlANACEAE. Nightshade Family.}

Herbs or shrubs, commonly rank-scented, with colorless juice; leaves alternate, without stipules; flowers regular, 5-merous, solitary or in cymes, on bractless pedicels; calyx mostly 5 -lobed; corolla gamopetalous, mostly 5 -lobed, usually plaited in the bud; stamens as many as the corolla-lobes and alternate with them; style 1 ; ovary entire, superior, 2-celled, becoming a many-seeded capsule or berry; endosperm fleshy.

Corolla rotate; fruit a berry.

439. Solanum, 314.

Corolla funnelform to salverform; fruit a capsule.

Flowers solitary.

Flowers in racemes or panicles.

440. Datura, 314

441. Nicotiana, 315 .

\section{SOLANUM. Nightshade.}

Herbs or shrubs; calyx and rotate corolla 5-parted or cleft, the latter plaited in the bud; stamens epipetalous, exserted; filaments very short; anthers converging; styles elongated; ovary 2-celled, rarely more; fruit a berry.

Solanum nigrum L. Nightshade. Annual, glabrous or somewhat pubescent, usually branched, $15-30 \mathrm{~cm}$. high; leaves ovate or triangular, acute or obtuse, cuneate at base, sinuately toothed or rarely entire, $1-4 \mathrm{~cm}$. long; petioles shorter than the blades; flowers in lateral peduncled small cymes; calyx-lobes obtuse; corolla white, deeply 5 -cleft, the lobes spreading; berries globose, black.

In waste places, introduced; but perhaps also native on lake and river banks.

440. DATURA.

Rank narcotic-poisonous annual or perennial weeds, erect, tall, branching; leaves alternate, petioled, ovate; flowers large, showy, solitary on short peduncles in the forks of the stems; calyx prismatic, 5-toothed, deciduous; corolla funnelform, with a 5-10-toothed plaited border; fruit a globular prickly 4 -valved 2-celled capsule; seeds rather large, flat.

Datura stramonium L. Jamestown or Jimson Weed. Annual, glabrous or nearly so, green, $30-90 \mathrm{~cm}$. high; leaves ovate, acuminate or acute, coarsely toothed or lobed, usually narrowed at base, petioled, 6-20 cm. long; calyx-tube 5-angled, not half as long as the white corolla, this $6-10 \mathrm{~cm}$. long; capsule ovoid, densely prickly, the lower prickles usually shorter.

Sparingly introduced. 
441. NICOTIANA. ToвACCo.

Rank acrid-narcotic herbs; leaves mostly entire; flowers in racemes or panicles, sometimes showy; calyx bell-shaped or oblong, 5-toothed or lobed, persistent; corolla commonly funnelform or salverform, the plaited border 5-lobed; stigma capitate, somewhat 2-lobed; fruit a smooth, 2-4-valved, 2-celled capsule; seeds numerous, small.

Nicotiana quadrivalvis Pursh. Viscid-pubescent; stems stout, branched from near the base, $30-60 \mathrm{~cm}$. high; basal leaves ovate-lanceolate, the cauline oblong to lanceolate, acute, narrowed at base, sessile or nearly so, 10-15 cm. long; flowers few; calyx-lobes shorter than the tube; corolla white, $3-4 \mathrm{~cm}$. broad, its lobes rounded; capsule globose.

Willamette Valley, Oregon, formerly cultivated by the Indians.

\section{Family 90. SCROPHULARIACEAE. FIGWORT FAMILY.}

Herbs or some shrubby; leaves alternate or opposite, without stipules; flowers perfect, mostly complete and irregular; corolla irregular, more or less 2-lipped, the upper lip 2-lobed, the lower 3 -lobed; stamens on the corolla-tube, the fertile 4 and didynamous or only 2 , rarely 5 present and all fertile; style single; stigma entire or 2-lobed; fruit a 2-celled usually many-seeded capsule, with axile placenta; seeds mostly small; endosperm copious.

Anther-bearing stamens 5; leaves alternate.

442. Verbascum, 316.

Anther-bearing stamens 2 or 4 ; leaves alternate, opposite or whorled.

Fifth sterile stamen present.

Corolla spurred at base.

Corolla not spurred.

Sterile stamen elongated, filament-like.

Seeds wingless; anthers woolly or glabrous.

Seeds winged; anthers woolly.

Sterile stamen represented by a gland or scale on the upper side of the corolla-tube.

Peduncles several-flowered.

Peduncles 1-flowered.

Corolla conspicuously 2 -lipped.

Corolla nearly rotate.

Fifth sterile stamen wanting.

Stamens 4, 2 anther-bearing, 2 sterile.

Sterile filaments 2 -forked, exserted.

Sterile filaments simple, included.

443. Linaria, 316.

Stamens all anther-bearing.

Stamens 2.

Calyx 5-parted.

Calyx 4 -parted.

444. Pentstemon, 317.

445. Chelone, 319.

446. Scrophularia, 319.

447. Collinsia, 319.

448. Tonella, 320.

449. Ilysanthes, 320 .

450. Gratiola, 320 .

450. Gratiola, 320.

Leaves alternate, mostly basal. $\quad$ 451. SyNTHYRIS, 321.

Leaves opposite, at least the lower.

452. VERONICA, 322. 
Stamens 4.

Corolla nearly regular; leaves entire. 453. LimoseLLA, 323.

- Corolla 2-lipped; leaves usually not entire.

Stamens not enclosed in the upper lip.

Leaves opposite; calyx prismatic.

Leaves alternate; calyx campanulate.

Stamens enclosed in the upper lip.

Anther cells equal, parallel.

Calyx inflated in fruit; leaves opposite.

Calyx not inflated; leaves alternate or whorled.

Anther cells unequal.

Lips of corolla unequal, the upper larger.

Lips of corolla subequal.

454. Mimulus, 323.

455. Digitalis, 325.
456. Rhinanthus, 326.

457. Pedicularis, 326.

458. Castilleja, 327.

459. ORTHOCARPUS, 329.

\section{VERBASCUM. MULLEIN.}

Tall and usually woolly biennial herbs; leaves alternate, the cauline sessile or decurrent; flowers in large terminal spikes or racemes; calyx 5-parted; corolla 5-lobed, rotate, the lobes slightly unequal; stamens 5, all anther-bearing; style flattened at the apex; capsule globular, many-seeded.

Flowers in a spike; leaves densely woolly.

Flowers in a raceme; leaves glabrous or nearly so.

V. thapsus.

V. blattaria.

mer easo of Verbascum thapsus L. Common Mullein. Densely woolly throughout, the stout erect stems $1-2 \mathrm{~m}$. high, somewhat wing-angled by the decurrent bases of the leaves; leaves thick, oblong, acute, entire or obscurely dentate, narrowed toward the base, $10-30 \mathrm{~cm}$. long, gradually reduced upwards; flowers yellow, 16-20 mm. broad, in a dense long spike; stamens unequal, the two lower and longer glabrous, the others with hairy filaments.

Introduced from Europe.

Verbascum blattaria L. Moth Mullein. Stems slender, erect, 30-60 $\mathrm{cm}$. high, not angled, glabrous below, glandular-pubescent above; leaves oblong, obtuse or the upper acute, crenate-dentate or cut-lobed, all but the lower sessile and partly clasping, 6-8 cm. long; raceme loose; pedicels spreading; calyx glandular; corolla yellow or white, $2-2.5 \mathrm{~cm}$. broad; stamens all with hairy filaments; capsules subglobose, 6-7 $\mathrm{mm}$. long.

Introduced from Europe.

443. LINARIA.

Herbs with alternate leaves or the lower opposite; flowers in terminal spikes or racemes; calyx 5-parted; corolla bilabiate, spurred on the lower side, the throat nearly closed; stamens didynamous; capsule thin, opening by pores beneath the summit.

Flowers yellow, 25-30 mm. long.

Flowers blue, $6-8 \mathrm{~mm}$. long.

L. linaria .

L. canadensis. 
Linaria linaria (L.) Karst. Butter and Eggs. Glabrous; stems erect, $30-100 \mathrm{~cm}$. high; leaves linear, sessile, pale or glaucous, very numerous, 1-3 $\mathrm{cm}$. long; inflorescence a dense raceme; calyx-lobes oblong, acute; corolla 2-3 $\mathrm{cm}$. long, yellow with an orange throat; seeds rough, winged.

Introduced along roadsides and in fields.

Linaria canadensis (L.) Dumort. Glabrous; flowering stems slender, 30-60 $\mathrm{cm}$. high, the sterile basal branches spreading; leaves oblong-linear, entire, flat, $2-4 \mathrm{~mm}$. wide; racemes slender; flowers blue; calyx-lobes lanceolate; corolla about $10 \mathrm{~mm}$. long, on pedicels of about the same length; spur slender, curved; seeds wingless.

In sandy soil, not common.

444. PENTSTEMON. BEARD-TONGUE.

Perennial herbs; leaves opposite, the upper sessile or partly clasping, the floral reduced to bracts; flowers showy, in a racemose panicle; calyx 5-parted; corolla tubular, more or less inflated or bell-shaped, either decidedly or slightly 2-lipped, the upper lip 2-lobed, the lower 3-cleft; anther-bearing stamens 4; sterile fifth filament about equalling the others; style long; stigma entire; capsule many-seeded.

Low half-shrubby plants, with leathery leaves; anthers woolly.

Leaves lanceolate, glabrous.

Leaves ovate or orbicular.

Flowers purple; leaves green, glabrous.

Flowers crimson; leaves glaucous, puberulent.

Taller herbaceous plants, with membranous leaves; anthers

P. fruticosus.

P. menziesii.

P. rupicola. not woolly.

Anthers opening only at the apex.

Corolla blue or bluish, 15-20 mm. long. $\quad P$. diffusus.

Corolla crimson, $20-25 \mathrm{~mm}$. long.

Anthers splitting open for nearly their whole length.

Leaves ovate, serrate; flowers purplish.

Leaves oblong, entire; flowers not purplish.

Flowers yellowish.

Flowers blue.

$P$. richardsoni.

P. ovatus.

P. confertus.

$P$. procerus.

Pentstemon fruticosus (Pursh) Greene. Stems simple, ascending from a branched woody base, $15-40 \mathrm{~cm}$. high; leaves coriaceous, glabrous, lanceolate, oblanceolate or ovate, mostly acute, entire or with a few teeth, narrow at base, the lower short-petioled, $1-4 \mathrm{~cm}$. long; inflorescence a raceme, rarely a panicle, 2-11-flowered, viscid-pubescent; bracts much reduced; sepals ovate-lanceolate, attenuate-acuminate, 8-12 mm. long; corolla tubular-funnelform, dullpurple, somewhat 2-lipped, 3-4 cm. long; anthers very woolly, dehiscing their whole length, sterile filament bearded.

Mount St. Helens and southward. A variable species first found by Lewis in the Bitter Root Mountains. P. crassifolius Lindl. is a form with entire leaves, a valueless character as both entire and serrate leaves often occur on the same plant; $P$. douglasii Hook. is a dwarfed high altitude form with relatively broad and short leaves; $P$. adamsianus Howell is a form from Mount Adams with larger and thinner leaves.

Pentstemon fruticosus cardwellii (Howell) Piper. Leaves thick, serrulate, mostly obtuse, otherwise as in $P$. fruticosus.

Mount Hood, Howell; Mount St. Helens, Goodwin. 
Pentstemon menziesii Hook. Stems shrubby, much branched, 5-15 cm. high; leaves oblong to ovate, serrulate, $0.5-2 \mathrm{~cm}$. long; inflorescence a raceme or narrow panicle, glandular; corolla dull purple-violet, $2-3 \mathrm{~cm}$. long.

On rocks in the mountains, above timber line, Vancouver Island, British Columbia, and Washington. First collected at Nootka Sound by Menzies.

Pentstemon menziesii davidsonii (Greene) Piper. Very similar to $P$. menziesii, but the leaves smaller and mostly entire.

Rocky places at about $2000 \mathrm{~m}$. altitude, Washington to California.

Pentstemon rupicola (Piper) Howell. Herbage very glaucous and somewhat puberulent but the inflorescence glandular; stems woody, much branched, making dense mats, $8-10 \mathrm{~cm}$. high; leaves firm, ovate to orbicular, dentate, 6-10 $\mathrm{mm}$. long; sepals ovate, acute; corolla deep rose-colored, $3-4 \mathrm{~cm}$. long, broadened in the throat, the lobes obtuse.

Rock cliffs in the mountains, first described from Mount Rainier.

Pentstemon diffusus Dougl. Glabrous or nearly so; stems herbaceous, erect, $30-60 \mathrm{~cm}$. high; leaves ovate or oblong, serrate, 3-10 cm. long; panicle leafy; corolla blue or violet, $2 \mathrm{~cm}$. long, glabrous within; sterile filament hairy above.

On the banks of mountain streams, common. First found by Douglas near the mouth of the Columbia River.

Pentstemon richardsonii Dougl. Glabrous; stems from a branched woody base, erect or ascending, $60-90 \mathrm{~cm}$. high, often branched; leaves lanceolate to ovate, mostly deeply toothed or pinnatifid, $3-8 \mathrm{~cm}$. long, those on the branches alternate; panicle loose, somewhat glandular; sepals ovate, acute; corolla red, somewhat funnelform, 20-25 mm. long; sterile filament with a few hairs near the tip.

On dry rocky cliffs along the Columbia River.

Pentstemon ovatus Dougl. Stems $15-30 \mathrm{~cm}$. high; leaves ovate, serrate, the upper ones sessile; corolla purplish-blue, 2-lipped, bearded in the throat, 16-20 mm. long; sterile filament bearded at the apex.

On rocky banks and cliffs, first collected by Douglas at the Cascades of the Columbia River. This species very closely resembles $P$. diffusus but is easily distinguished by the anthers.

Pentstemon confertus Dougl. Glabrous throughout but not glaucous; stems erect, commonly $30-40 \mathrm{~cm}$. high; leaves all entire, the radical oblong, lanceolate or oblanceolate, acute or obtuse, 3-6 cm. long, attenuate at the base into a petiole, the cauline similar, sessile, the upper of ten ovate, acuminate; panicle strict, narrow, leafy below, 14-40 cm. long, of 2-8 whorl-like clusters; flowers 6-10 mm. long; sepals glabrous, the scarious margin irregularly dentate or erose, about as long as the capsule; corolla yellow or nearly white, 2-lipped; lower lip bearded; anthers dehiscing their whole length; sterile filament bearded.

In mountain meadows, common. Except for the color of the flowers, this is indistinguishable from $P$. procerus Dougl.

nt Adams Pentstemon procerus Dougl. Stems 20-60 cm. or in alpine forms only $5-10 \mathrm{~cm}$. high; basal leaves oblong or oblong-lanceolate, acute or obtuse; cauline often ovate and acuminate; flowers blue, in dense whorl-like clusters; corolla 8-12 mm. long.

In mountain meadows. First collected by Douglas near Fort Vancouver, Washington; the high alpine dwarfed form common on Mount Rainier was named $P$. tolmiei by Hooker, but all possible intergrades occur. 


\section{CHELONE.}

Smooth perennial herbs with erect branching stems; leaves serrate; flowers large, white or purple, nearly sessile, in spikes or clusters, closely imbricated with round-ovate concave bracts and bractlets; calyx of 5 distinct imbricated sepals; upper lip of corrolla broad and arched, keeled in the middle, notched at the apex; lower lip woolly-bearded in the throat, 3-lobed at the apex, the middle lobe smallest; seeds many.

Chelone nemorosa Dougl. Stems erect, 30-60 cm. high; leaves ovate- $9 / 2 / 20 \mathrm{Mt}$ Ad lanceolate, acute, dentate, 5-8 cm. long, short-petioled; flowers purple, in a cibme crinal narrow panicle; corolla $2.5-3 \mathrm{~cm}$. long.

Common along mountain streams.

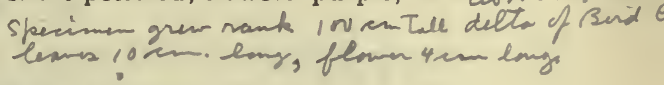

446. SCROPHULARIA. FIGWORT.

Perennial herbs; leaves opposite; flowers small, in loose cymes in a narrow terminal panicle; calyx deeply 5-cleft; corolla 5-lobed, the 4 upper lobes erect, the lower spreading; stamens 4 ; the fifth sterile one a scale-like rudiment at the summit of the corolla-tube; capsule many-seeded.

Scrophularia californica Cham. Puberulent; stems stout, simple, about $1 \mathrm{~m}$. high, somewhat 4-sided; leaves triangular-ovate, acute, coarsely and unevenly toothed or cleft, 5-12 cm. long, on petioles about half as long; panicle narrow, $20-40 \mathrm{~cm}$. long, somewhat glandular; bracts lanceolate-attenuate; flowers dull-purple or green; calyx-lobes rounded, as long as the tube; corolla 6-8 mm. long; rudimentary stamen broad, spatulate; capsules conicall, glandular.

In moist meadows. A variable species. Specimens from the ocean coast near the mouth of the Columbia River are somewhat fleshy.

\section{COLLINSIA.}

Annuals or biennials; leaves simple, opposite, sessile or the lowest petioled and the upper whorled; flowers solitary or clustered in the upper axils; calyx deeply 5-cleft; corolla with the tube saccate at the base on the upper side, deeply 2-lipped, the upper lip 2-cleft, the lower 3-cleft, the middle lobe keeled and sac-like; anther-bearing stamens 4 ; sterile stamen a gland-like structure; capsule 4-many-seeded.

Tube of corolla longer than the limb; corolla 5-7 $\mathrm{mm}$.

long.

Tube of corolla shorter than the limb; corolla $8-16 \mathrm{~mm}$.

C. tenella. long.

Corolla $12-16 \mathrm{~mm}$. long; pedicels deflexed in fruit. Corolla $8-10 \mathrm{~mm}$. long; pedicels erect in fruit.

C. grandiflora.

C. grandiflora pusilla.

Collinsia tenella (Pursh) Piper. ( $C$. parviflora Dougl.) Glabrous or minutely puberulent, branched from the base, erect or spreading, $10-20 \mathrm{~cm}$. high; lower leaves oblong or orbicular, petioled, often toothed; the upper nearly sessile, oblong or linear, acutish, 1-2 cm. long, of ten in whorls of 3-5; flowers slender-pedicelled, solitary or nearly so in the axils, even of the lower 
leaves; calyx-lobes lanceolate, acute, longer than the tube, not equalling the corolla; corolla violet or blue, 6-7 mm. long, 2-lipped for half its length.

Common on banks and in open prairies.

Collinsia grandiflora Dougl. Very similar to C. tenella but larger, 15-30 $\mathrm{cm}$. high; leaves larger, the cauline in whorls of 3-7; calyx-lobes triangularsubulate, very acute, longer than the tube; corolla blue-violet, 8-16 mm. long.

In open prairies, especially southward.

Collinsia grandiflora pusilla Gray. Plants $5-15 \mathrm{~cm}$. high; pedicels erect in fruit; corolla $8-10 \mathrm{~mm}$. long.

Perhaps only a starved form of $C$. grandiflora. Washington to California.

448. TONELLA.

Very similar to Collinsia but the cauline leaves mainly ternately divided or 3 -parted; corolla obscurely 2 -lipped, the 5 more or less unequal lobes somewhat rotately spreading, the tube somewhat gibbous above; ovules and seeds 1-4 in each cell.

Tonella collinsioides Nutt. Stems weak and slender, branched from the base; lower leaves ovate or roundish, entire or 3-lobed or sometimes parted, slender-petioled; upper sessile, mostly 3-parted, the lobes or divisions oblong or lanceolate; corolla blue.

Southern Washington to California. First collected by Nuttall near the mouth of the Willamette River.

\section{ILYSANTHeS. False Pimpernel.}

Small and smooth annual herbs; leaves opposite, sessile; peduncles axillary, 1-flowered, the upper becoming racemose; calyx becoming 5-parted, the divisions becoming narrow and nearly equal; upper lip of corolla short, erect, 2-lobed, the lower larger; spreading, 3-cleft; anther-bearing stamens 2 ; sterile filaments unequally 2 -forked, exserted; stigma 2-lobed; capsule manyseeded.

Ilysanthes dubia (L.) Barnhart. Glabrous, simple or branched from the base, $5-12 \mathrm{~cm}$. high; leaves sessile, ovate, acute or with a few teeth, 1-2 cm. long, the upper ones reduced; pedicels slender, twice as long as the leaves, spreading in fruit; flowers 6-8 mm. long; calyx-lobes linear, as long as the purple corolla; capsule ovoid-oblong, 4-6 mm. long.

Banks of streams and ponds, rare.

450. GRATIOLA. HEdGE Hyssop.

Low mostly perennial branching herbs; leaves opposite, sessile; peduncles axillary, 1-flowered; calyx 5-parted, the narrow divisions usually equal; upper lip of corolla entire or 2-cleft, the lower 3 -cleft; anther-bearing stamens 2 ; sterile filaments 2 , simple and included, or none; style dilated or 2-lipped at the apex; capsule 4-valved, many-seeded.

Herbage viscid-puberulent; calyx subtended by a pair of bractlets at the base.

Herbage glabrous; calyx without bractlets.

C. virginiana.

C. ebracteata. 
Gratiola virginiana L. Annual; stems erect, branched below, viscidpuberulent or pubescent above, nearly glabrous at base, $10-30 \mathrm{~cm}$. high; leaves sessile, oblong-lanceolate, acute, entire or toothed, usually narrowed at base, 1-2 cm. long, glabrous or nearly so; pedicels slender, equalling the leaves; calyx enclosed at base by 2 foliaceous bracts which equal the lobes; corolla $8-10 \mathrm{~mm}$. long, its yellow tube nearly twice as long as the calyx; lobes whitish, the two upper notched; capsule ovoid.

In muddy places, rare in our limits.

Gratiola ebracteata Benth. Very similar to G. virginiana but glabrous and the calyx bracts wanting; stems usually simple; leaves somewhat longer, lanceolate, mostly entire, tapering from near the base into a long slender apex; capsule subglobose, obscurely 4-angled.

Muddy banks of ponds and streams.

\section{SYNTHYRIS.}

Perennial herbs; leaves alternate, crenate or laciniately cleft, the radical roundish or cordate; flowers small, blue, purplish or green, in a spike or raceme; calyx 4-parted; corolla campanulate, with 4 more or less unequal lobes, or none; stamens 2 , from just below the upper sinuses, or in one apetalous species on the hypogynous disk, exserted; stigmas simple; capsule many-seeded.

Flowers in spikes; leaves cleft into narrow segments.

Flowers in racemes; leaves reniform-orbicular.

Petals and sepals laciniately incised.

S. pinnatifida.

Petals and sepals entire.

Scapes weak, usually shorter than the thin leaves.

Scapes stout, exceeding the thick leaves.

S. schizantha.

S. rotundifolia.

S. reniformis.

Synthyris pinnatifida lanuginosa Piper. Leaves white tomentose, palmately 3-7-parted or divided, the segments again cleft; spikes dense, bracteate; corolla whitish, cylindraceous, 4 -cleft.

Olympic Mountains, Flett, not otherwise known. S. pinnatifida Wats. occurs in the Rocky Mountains.

Synthyris schizantha Piper. Stems $20-30 \mathrm{~cm}$. high; basal leaves reniformorbicular, somewhat cut-toothed, glabrous above, long-petioled; cauline leaves 2 , ovate, sessile; raceme viscidly-pubescent; bracts and calyx-lobes as well as the blue petals cleft into narrow lobes.

Mount Baldy, Olympic Mountains, Conard, Lamb; near Elbe, Cascade Mountains, Flett. Not otherwise known.

Synthyris rotundifolia Gray. Leaves orbicular-reniform, crenate, somewhat pubescent; flowering stems leafless, $8-12 \mathrm{~cm}$. high, barely exceeding the leaves; sepals spatulate, entire; corolla blue, the petals entire.

In open dry woods, Chehalis County, Washington, and southward nearly to California.

Synthyris reniformis Benth. Leaves thickish, glabrous, orbicular-reniform, crenately many-lobed, the lobes coarsely crenate; petioles longer than the blades; stems stout, exceeding the leaves; flowers blue, on very short pedicels.

In the Columbia River gorge on the Oregon side, where it was first found by Douglas. 
452. VERONICA. SPEEDWELl.

Chiefly herbs; leaves opposite or whorled, or the upper alternate; flowers small, in racemes or spikes or sometimes solitary in the axils; calyx 4-parted; corolla rotate, 4-parted, the lower lobes and sometimes the lateral ones narrower; stamens 2, exserted; style entire; stigma single; capsule flattened, fewmany-seeded.

Annuals; flowers solitary in the axils.

Pubescent; petals blue; leaves crenate.

V. arvensis.

Glabrous or nearly so; petals white; leaves mostly entire. $V$. peregrina. Perennials; flowers in racemes.

Peduncles axillary.

Leaves linear or linear-lanceolate; capsule deeply notched.

Leaves oblong-lanceolate to ovate; capsule with a shallow notch.

V. scutellata.

Peduncles terminal.

Capsules orbicular, obcordate; lower leaves petioled.

Capsules elliptic, emarginate; leaves all sessile.

Leaves shorter than the internodes; corolla 5-6 mm. broad.

Leaves longer than the internodes; corolla 6-10 $\mathrm{mm}$. broad.

Corolla 8-10 mm. broad, blue.

Corolla 6-7 $\mathrm{mm}$. broad, white.

V. americana.

V. humifusa.

V. alpina.

V. cusickii.

V. allenii.

Veronica arvensis L. Annual, pubescent; stems simple or branched at base, $5-20 \mathrm{~cm}$. high, erect or nearly so; leaves ovate, crenate, the lower shortpetioled, the upper sessile; bracts lanceolate, entire; flowers small, shortpedicelled; corolla pale blue, shorter than the calyx; capsule obcordate.

A weed, introduced from Europe.

Veronica peregrina L. Annual, erect, branched from the base, glabrous or puberulent and glandular, $8-40 \mathrm{~cm}$. high; lower leaves opposite, petioled, oblong, obtuse, dentate; upper alternate, linear, obtuse or acute, entire or nearly so, 1-2 cm. long; flowers white, solitary in the axils; pedicels very short, not as long as the flowers; corolla 1-2 mm. broad; capsules orbicular, notched, about as long as the calyx.

Common in moist open places.

Veronica scutellata L. Perennial, glabrous or nearly so, rooting at the lower joints; stems $15-30 \mathrm{~cm}$. high; leaves all sessile, lanceolate or nearly linear, mostly denticulate or entire, attenuate-acute, 3-5 cm. long; racemes axillary from alternate axils, slender, few-flowered, as long as or exceeding the leaves; pedicels slender, spreading; corolla blue, $4-5 \mathrm{~mm}$. broad; capsule notched both at apex and base.

In swamps, not rare.

Veronica americana Schwcin. Perennial, glabrous throughout, rooting at the lower nodes; stems decumbent, usually branched, 30-60 cm. long; leaves all opposite, oblong, ovate or lanceolate, obtuse, serrate, rounded at the base, short-petioled; racemes opposite, in the upper axils, exceeding the leaves; pedicels spreading, longer than the bracts and flowers; flowers blue with darker stripes, $4 \mathrm{~mm}$. broad; capsule with a shallow notch at the apex, $4-5 \mathrm{~mm}$. broad.

Common in wet places. Forms of this species are sometimes mistaken for V. anagallis-aquatica L. which probably does not occur in our limits. 
Veronica humifusa Dickson. Perennial, glabrous or puberulent; stems erect or decumbent, $10-15 \mathrm{~cm}$. high; leaves opposite, oval, ovate or orbicular, crenate-dentate or subentire, short-petioled, about $1 \mathrm{~cm}$. long; racemes terminal; bracts oblong, alternate; pedicels erect, equalling or exceeding the calyx; corolla blue, dark-striped, $4 \mathrm{~mm}$. broad; capsule orbicular, notched at apex, as long as the calyx.

Common in moist fields and copses.

Veronica alpina L. Perennial, pubescent; stems simple, erect, $6-20 \mathrm{~cm} .8 \% / 20$ Mt A high; leaves ovate or oblong, entire or crenate; corolla blue, $4-6 \mathrm{~mm}$. broad. $6000 \mathrm{fo}$.

Common in alpine meadows.

Veronica cusickii Gray. Perennial, glabrous except the glandular inflorescence; leaves ovate or oblong, entire, thickish; corolla blue, $8-10 \mathrm{~mm}$. broad.

In the Cascade Mountains, at high elevations. First found by Cusick, in the Blue Mountains, in eastern Oregon.

Veronica allenii Greenman. Much like $V$. cusickii, but the white corolla smaller, 6-7 $\mathrm{mm}$. broad.

Mount Rainier, Allen; not otherwise known.

453. LIMOSELLA. MUDWORT.

Very small glabrous annual herbs, stoloniferous, rooting and creeping in the mud; leaves narrow, entire, fleshy, in dense clusters around the simple 1-flowered naked peduncles; flowers small; calyx campanulate, 5-toothed; corolla rotate-campanulate, 5-cleft, nearly regular; stamens 4 , all anther-bearing; style short; stigma thickish; capsule many-seeded.

Limosella tenuifolia Wolf. Tufted; leaves narrowly linear, not expanded at the tip, $2-5 \mathrm{~cm}$. long; peduncles shorter than the leaves; corolla white or pinkish, $2 \mathrm{~mm}$. broad, hardly longer than the calyx; capsules globose, obtuse, $2-2.5 \mathrm{~mm}$. long.

Muddy banks of streams, rare.

454. MIMULUS. MONKey Flower.

Herbs with mostly simple opposite leaves; flowers axillary, on simple peduncles or by the redcution of the upper leaves racemose; calyx prismatic, or rarely campanulate, usually 5-angled, 5-toothed, the upper tooth usually the largest; corolla irregular, 2-lipped; upper lip erect or reflexed, 2-lobed, the lower spreading, 3-lobed; stamens 4, all anther-bearing; stigma 2-lobed; seeds numerous.

Corolla reddish or purple.

Flowers very small, about $5 \mathrm{~mm}$. long, pale purple.

Flowers large, over $2 \mathrm{~cm}$. long.

Corolla scarlet; stamens exserted.

Corolla rose-purple; stamens included.

Corolla yellow; stigmas 2-lipped.

Calyx not angled, deeply 5-cleft.

Calyx 5-angled, 5-toothed.

Annuals.

Corolla rather large.

Corolla small.

M. breweri.

M. cardinalis.

M. lewisii.

M. pilosus. 
Perennials.

Leaves pinnately veined.

Herbage glabrous.

Herbage slimy-viscid, musk-scented.

Leaves palmately veined.

M. dentahus.

M. moschatus.

Rootstocks wanting.

Leaves ovate to orbicular.

Leaves oblong-lanceolate.

M. langsdorfii.

M. scouleri.

Rootstocks present.

Stems 2-4 cm. high, mostly 1-flowered; plants stoloniferous, densely matted, alpine.

Stems $10-20 \mathrm{~cm}$. high, mostly several-flowered, arising from slender matted rootstocks; herbage slimy-viscid.

M. alpinus.

M. implexus.

Mimulus breweri (Greene) Rydb. Annual, viscid-pubescent, 3-12 cm. high, simple or branched; leaves linear-lanceolate, sessile or nearly so, entire, 1-2 cm. long; peduncles as long as the calyx; calyx cylindric, the short teeth triangular-obtuse; corolla pale rose-colored, 5-10 mm. long.

On dry cliffs in the mountains.

Mimulus cardinalis Dougl. Perennial, somewhat villous, the inflorescence viscid; stems erect, $60-90 \mathrm{~cm}$. high; leaves mostly ovate, the upper pairs connate, erosely dentate, several-nerved, $5-10 \mathrm{~cm}$. long; calyx prismatic, its short teeth subequal; corolla scarlet, $3-5 \mathrm{~cm}$. long, the tube longer than the lips; stamens exserted; seeds wrinkled lengthwise.

In moist places, western Oregon, in the Umpqua Valley; perhaps not in our limits.

Mimulus lewisii Pursh. Perennial, viscid-pubescent; stems simple, erect, 30-50 cm. high; leaves oblong-ovate, denticulate, acute, 3-4 cm. long, the nerves conspicuous; peduncles exceeding the leaves; calyx angular-campanulate, the teeth triangular, sharp-pointed; corolla rose-red, $4 \mathrm{~cm}$. long, 2-lipped, the tube longer than the calyx, the lobes rounded and spreading.

Common along alpine streams.

Mimulus pilosus (Benth.) Wats. Annual, erect, usually much branched, villous throughout with soft somewhat viscid hairs, $10-30 \mathrm{~cm}$. high; leaves oblong or lanceolate, acute, entire, sessile, 1-3 cm. long; pedicels about equalling the leaves; calyx campanulate, not at all angled, deeply 5-cleft, oblique at the orifice; corolla yellow, shortly 2 -lipped, $6-8 \mathrm{~mm}$. long, the lobes nearly equal.

Reported from Vancouver Island, Macoun. Common east of the Cascade Mountains.

Mimulus nasutus Greene. Much like $M$. langsdorfi $i$ but strictly annual, the leaves usually orbicular; corolla $1-1.5 \mathrm{~cm}$. long, pale-yellow, the tube barely as long as the calyx, the lower lip usually with a large purple blotch.

Vancouver Island, British Columbia, to California, rare in our limits.

Mimulus alsinoides Dougl. Annual, glabrous; stems slender, $8-20 \mathrm{~cm}$. high; leaves ovate to orbicular, denticulate, petioled, $6-20 \mathrm{~mm}$. long; pedicels slender, spreading; calyx tubular, the teeth small, subequal; corolla 2-lipped, 10-12 $\mathrm{mm}$. long, yellow with a purple spot in the middle of the lower lip.

On wet rocks, Vancouver Island. British Columbia, to Oregon. The plant is slightly musk-scented.

Mimulus dentatus Nutt. Perennial with slender rootstocks, glabrous; stems erect, $20-40 \mathrm{~cm}$. high, simple; leaves ovate to oblong, acute, evenly and strongly serrate, $4-8 \mathrm{~cm}$. long; calyx-tecth acute, subequal, half as long as the tube; corolla $3 \mathrm{~cm}$. long, deep yellow with purple dots in the open throat. 
In moist places in woods, from the mouth of the Columbia River to California.

Mimulus moschatus Dougl. Musk Plant. Perennial, villous and shiny viscid, musk-scented; stems weak, spreading, ascending or erect, $10-40 \mathrm{~cm}$. high; leaves oblong-ovate, denticulate, $2-5 \mathrm{~cm}$. long, all petioled; peduncles shorter than the leaves; calyx tubular-prismatic, $8-12 \mathrm{~mm}$. long, the unequal teeth acute; corolla pale yellow, spotted in the throat, about $2 \mathrm{~cm}$. long.

Common in moist places.

efe Mimulus langsdorfii Donn. Perennial by short stolons, erect or decumbent, glabrous or puberulent, $15-60 \mathrm{~cm}$. high, or depauperate plants much smaller and dying after blooming; leaves several-nerved from the base, ovate, obtuse or acute, rounded or subcordate at base, the lower long-petioled and often with ragged lobes at base, the upper short-petioled or sessile; floral leaves often cuneate; flowers in a raceme, the pedicels as long as or shorter than the flowers; calyx in fruit 5-angled and inflated, the upper lobe longest, the others turned toward it, all much shorter than the tube; corolla yellow, hairy and often spotted in the throat, usually $2-3 \mathrm{~cm}$. long, the tube exceeding the calyx.

Very common in moist places and exceedingly variable. $M$. hirsutus Howell and $M$. grandifloruis Howell seem to lack any satisfactory differential characters.

Mimulus scouleri Hook. Perennial, stoloniferous, glabrous; stems erect, 30-60 cm. high; leaves oblong-lanceolate, obtuse, denticulate, shining, 2-5 $\mathrm{cm}$. long, the lower ones petioled, the upper broader, ovate, sessile; calyx campanulate, the teeth triangular, obtuse; corolla yellow, about $3 \mathrm{~cm}$. long.

Muddy banks of the Columbia River near its mouth.

d Mimulus alpinus (Gray) Piper. Glabrous or nearly so; stems weak and of ten densely matted, leafy to the top, $5-10 \mathrm{~cm}$. high, mostly 1-flowered; leaves ovate, nearly sessile, entire or slightly denticulate; corolla $2-3 \mathrm{~cm}$. long. tains.

Abundant on wet cliffs and along rivulets at high altitudes in the moun-

Mimulus implexus Greene. Tufted perennial with slender fleshy rootstocks, glabrous up to the inflorescence; stems $15-30 \mathrm{~cm}$. high; leaves all cauline, 3-5 pairs, ovate, sessile, sparsely dentate, 3 -nerved, 2-4 cm. long; inflorescence puberulent and viscid; calyx campanulate, angled, purple-dotted, the teeth triangular, the upper one largest; corolla pale yellow, bearded and purple-dotted in the throat.

Along alpine rivulets at about the limit of trees, rare in our limits.

\section{DIGITALIS.}

Tall herbs with alternate or scattered entire or toothed leaves; flowers showy, in racemes; calyx 5-parted, the lobes often foliaceous; corolla with a somewhat inflated tube and a short scarcely spreading limb, declined; stamens 4, didynamous, included in the corolla.

Digitalis purpurea L. Foxglove. Pubescent; stems stout, $60-120 \mathrm{~cm}$. high; leaves ovate or ovate-lanceolate, acute, dentate; flowers in a long raceme, drooping; corolla purple or white, 3-5 cm. long, spotted within.

Introduced from Europe. 


\section{RHINANTHUS.}

Annual erect herbs, with opposite leaves; flowers yellowish, in a one-sided spike; calyx membranaceous, 4 -toothed, inflated in fruit; corolla 2-lipped, the upper lip arched, ovate, obtuse, with two lateral teeth, the lower lip 3-lobed; stamens 4, all antherbearing, enclosed in the upper lip; anther-cells equal; capsule orbicular, compressed.

Rhinanthus kyrollae Chabert. Stems erect, 30-60 cm. high, simple or more commonly with ascending branches; leaves lanceolate, sessile, 2-5 cm. long, serrate, minutely scabrous; bracts pale green, ovate-lanceolate, with slender acuminate teeth; calyx $1.5 \mathrm{~cm}$. long; corolla pale yellow.

In open fields and prairies; rare in our limits.

\section{PEDICULARIS. LOUSEWORT.}

Perennial herbs; leaves toothed or pinnatifid, the floral bractlike; flowers rather large in a spike; calyx 2-5-toothed, irregular; corolla strongly 2-lipped, the upper lip (galea) arched, laterally compressed, sometimes beaked, the lower 3-lobed; stamens 4, enclosed by the upper lip; anthers equally 2-celled; capsule several seeded.

Leaves lanceolate, doubly-crenulate.

P. racemosa.

Leaves pinnately parted.

Flowers yellowish or whitish.

Corolla yellow, with a slender inrolled beak.

Corolla whitish, with a broad hood-like beak.

Flowers purple.

Corolla beakless; seashore plant.

Corolla beaked; alpine plant.

Beak long and filiform, curved.

Beak short and conical.

P. contorta.

P. bracteosa.

P. parviflora.

P. surrecta.

P. ornithorhyncha.

Pedicularis racemosa Dougl. Ascending or spreading, glabrous throughout or puberulent above, the stems simple or somewhat branched, $30-40 \mathrm{~cm}$. long; leaves alternate, lanceolate, acute or obtuse, doubly crenulate, 5-10 $\mathrm{cm}$. long; petioles short; flowers short-pedicelled, in racemes, with gradually reduced leaves or bracts; calyx 2-cleft in front, 2 -toothed behind; corolla white or reddish, the galea much incurved, nearly reaching the apex of the broad lip.

\section{Common in alpine woods.}

Pedicularis contorta Benth. Glabrous; stems simple, erect, $20-30 \mathrm{~cm}$. high; basal leaves petioled, 5-8 cm. long, pinnately parted into linear toothed segments; cauline leaves similar, sessile; spikes densely many-flowered, 5-10 $\mathrm{cm}$. long; calyx cleft before and behind, the lobes 2-toothed; corolla pale yellow, the galea slender, elongate and somewhat circinate, about as long as the lower lip.

In the mountains at high elevations. First collected by Tolmie on Mount Rainier.

NitAdams Pedicularis bracteosa Benth. Glabrous below, sparsely pubescent above; stem stout, erect, $30-100 \mathrm{~cm}$. high, with tuber-like roots; leaves ovate or oblong in outline, 5-12 cm. long, the basal petioled, the cauline nearly sessile, pinnately parted or divided into narrow lanceolate or linear, serrate or incised somes compond 
divisions, 1-5 cm. long; inflorescence an erect dense spike, 10-50 cm. long; bracts ovate, acuminate, entire or nearly so, exceeded by the flowers; calyx 5 -cleft, with narrow triangular lobes; corolla whitish, $2 \mathrm{~cm}$. long, the galea longer than the lip, curved, hooded at the apex, the orifice entire.

In wet alpine meadows.

Pedicularis parviflora Smith. Stems branched from the base, decumbent; leaves pinnately parted into narrow oblong incised segments; spike leafy, short; calyx-lobes crested; corolla purple, the galea nearly straight and bearing one or sometimes two pairs of small teeth.

Along the seashore, infrequent, Alaska to Washington.

Pedicularis surrecta Benth. Stem erect, strict, $30-60 \mathrm{~cm}$. high; leaves

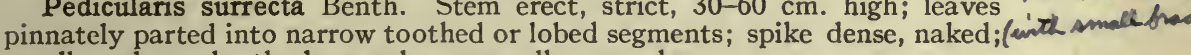
corolla red-purple, the long galea upwardly curved.

Common in alpine swamps.

Pedicularis ornithorhyncha Benth. Stems erect, 10-15 cm. high; leaves pinnately parted, the narrow segments rather scattered and dentately lobed; stem naked or bearing 1 or 2 reduced leaves; spike short, $1-3 \mathrm{~cm}$. long; corolla purple, the galea conical, turned downward.

In alpine meadows, in the Cascade Mountains at about $2000 \mathrm{~m}$. altitude. First collected on Mount Rainier by Tolmie.

458. Castilleja. Painted Cup, Indian Pink, or Indian Paint Brush.

Perennial herbs, sometimes woody at the base; leaves alternate, entire or cleft into linear lobes, the floral ones usually dilated, colored and more showy than the yellow, red or whitish spiked flowers; calyx tubular, flattened, 2-4-lobed; corollatube included; upper lip (galea) much longer than the lower, narrow, arched and keeled, enclosing the 4 unequal stamens; lower lip short, 3-lobed; anthers unequally 2-celled; capsule many-seeded.

Bracts whitish or yellowish; galea shorter than the tube of the corolla.

C. levisecta.

Bracts scarlet or crimson (occasionally yellow or white); galea as long as or longer than the corolla tube.

Leaves and bracts cleft into linear lobes.

Stems glabrous below; bracts crimson or white. $\quad$. oreopola.

Stems pilose to the base; bracts scarlet.

Galea much longer than the corolla tube. C. rupicola.

Galea about equalling the corolla tube. $\quad$ C. angustifolia.

Leaves and bracts entire, very rarely cleft.

Stems from slender rootstocks; bracts green, with scarlet tips.

Stems from a stout caudex; bracts scarlet.

Leaves puberulent, but not viscid; bracts or some of them lobed or toothed.

Leaves glabrous; bracts entire.

Plants erect; leaves rather thin.

Plants decumbent; leaves thick.

C. suksdorfii.

C. crispula.

C. miniata.

C. dixonii.

Castilleja levisecta Greenman. Erect, strict, soft-pubescent throughout; stem 15-30 cm. high; leaves oblong-lanceolate, mostly with 1-3 pairs of narrow lobes; bracts broad, yellow, lobed at the apex; galea shorter than the corollatube. 
In open meadows near the seacoast, Vancouver Island, British Columbia, and Washington.

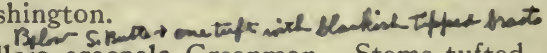

- Mt Adams Castilleja oreopola Greenman. Stems tufted, glabrous below, pubescent Bat th one tuft above, $15-30 \mathrm{~cm}$. high; leaves oblong-lanceolate, mostly cleft about half-way at afore dith into 3-5 narrow lobes; bracts rose-purple, rarely white, 3-cleft; galea about as long as the corolla-tube.

meck Abundant in alpine meadows, at 1500-2000 m. altitude.

Castilleja rupicola Piper. Stems tufted, sparsely pubescent, $10-20 \mathrm{~cm}$. high; leaves usually purplish, deeply cleft into 3-7 linear spreading lobes; bracts similar, scarlet-tinged; galea much longer than the corolla-tube.

On cliffs, Mount Rainier, Washington, to British Columbia. 6000 fo.
Mt Ademis Castilleja angustifolia (Nutt.) G. Don. Stems usually clustergd fromea , Salman, entire, the upper broader, cleft to about the middle into 3-5 narrow lobes; inflorescence short and dense, becoming elongate in fruit; bracts like the leaves but broader(and more deeply cleft) pilose below, the tips scarlet, rarely yellow; calyx 2-3 cm. long, with lanceolate lobes; corolla 2 ent. Tong, the upper lip hardly as long as the tube, much longer than the short 3-lobed lower lip. limits.

In dry or rocky ground. Very variable; three subspecies occur in our

Castilleja angustifolia abbreviata Fernald. Stems sparingly pilose; leaves oblong-ovate to obovate, short, $1-2.5 \mathrm{~cm}$. long.

Common in the Olympic Mountains and apparently of restricted range.

Castilleja angustifolia bradburii (Nutt.) Fernald. Stems sparingly pilose; leaves lanceolate to oblong-lanceolate, $2-5 \mathrm{~cm}$. long.

The commonest subspecies in our limits.

Castilleja angustifolia hispida (Benth.) Fernald. Stems densely pilose, 40-50 cm. high; leaves harshly pubescent, short, ascending.

In prairies; first found at Fort Vancouver, Washington, by Douglas.

M+Adams Castilleja suksdorfii Gray. Sparsely villous; stems $30-60 \mathrm{~cm}$. high, arising from slender creeping rootstocks; leaves lanceolate, $3-6 \mathrm{~cm}$. long, entire ○. U or the upper with a pair of narrow lobes; bracts broader, more or less scarlettipped, 3-lobed; corolla $3 \mathrm{~cm}$. long, the galea longer than the tube; lip 3-lobed.

Wet al pine meadows in the Cascade Mountains, rare.

Castilleja crispula Piper. Perennial from a stout woody crown; whole herbage sparsely crisp-puberulent; stems erect or nearly so, $20-30 \mathrm{~cm}$. high; leaves lanceolate, acute, broadest near the sessile base, 3-nerved, 2-4 cm. long, all entire or the uppermost with a few teeth; spike short and dense; bracts broader than the leaves, scarlet-tipped, all or at least the upper ones fewtoothed near the apex; calyx villous, about equally cleft before and behind, each lateral segment cleft about midway into 2 attenuate-lanceolate acute lobes; corolla about $3 \mathrm{~cm}$. long, the glandular puberulent galea green except a thin scarlet margin, nearly straight, as long as the sparsely pilose tube; lip small, the three teeth saccate-involute, acute; ovary elliptic-acuminate.

Mount St. Helens, Washington, Coville, Goodwin; Chilliwack Valley, British Columbia, Macoun. Very close to C. miniata Dougl. but differing in its puberulent herbage and the dentate bracts.

Castilleja miniata Dougl. Glabrous below the inflorescence; stems erect, simple or nearly so, $30-100 \mathrm{~cm}$. high; leaves lanceolate or linear-lanceolate, acute or acuminate, entire, sessile, $3-5 \mathrm{~cm}$. long; spikes dense, pubescent: 
bracts broad, mostly 3-5-toothed or cleft, scarlet-tipped, shorter than the flowers; calyx about equally cleft before and behind, the divisions 2-cleft; corolla yellowish, $3 \mathrm{~cm}$. long, the upper lip straight and slender, longer than the tube; lower lip very short; pod ovoid, 10-12 $\mathrm{mm}$. long, enclosed in the calyx.

From the sea level up to an altitude of $1600 \mathrm{~m}$.

Castilleja dixoni Fernald. Very similar to $C$. miniata but prostrate or decumbent; leaves thickish, turning black in drying.

Along the ocean seashore; perhaps only a form of C. miniata.

459. ORTHOCARPUS.

Low annuals, very similar to Castilleja; calyx 4-cleft; corolla tubular; the upper lip (galea) scarcely longer and usually much narrower than the inflated 1-3-saccate lower ones; anthers unequally 2-celled, or the smaller anther-cell rarely wanting.

Lobes of lower lip of corolla well developed.

Galea bearded on the back; filaments pubescent.

Galea naked; filaments smooth.

Spike short and dense; bracts with broad obtuse white lobes.

Spike slender; bracts with slender lobes.

O. purpurascens.

Lobes of lower lip of corolla very small.

Lip simply saccate, scarcely larger than the galea.

Bracts very different from the leaves, the upper ones entire.

Bracts less different from the leaves, all 3-5-lobed.

Lip with 3 conspicuous swellings, much larger than the

O. castilleoides.

O. attenuatus. galea.

Flowers very small, 4-6 mm. long, dull purple; leaves pinnatifid or bipinnatifid into filiform segments.

Flowers larger, 12-20 mm. long; leaves simply pin-

O. pusillus.

O. imbricatus.

O. bracteosus. nate with slender lobes or entire.

Corolla sulphur-yellow, 2-2.5 cm. long; anthers 1-celled.

Corolla white, about $1 \mathrm{~cm}$. long; anthers 2celled.

O. erianthus.

O. hispidus.

Orthocarpus purpurascens Benth. Hirsute-pubescent; stems erect, simple or branched from the base, 15-30 cm. high; leaves all 3-5-lobed or cleft, the lobes very narrow; flowers in a dense spike; bracts purplish or reddish, broader than the leaves, 3-5-lobed, as long as the flowers; calyx-lobes linear, as long as the tube; galea longer than the 3 -saccate lip, curved at tip.

Seattle, probably introduced, Piper. Common in prairies, Oregon to California.

Orthocarpus castilleoides Benth. Puberulent; stems usually branched from the base and decumbent; leaves oblong or lanceolate, cut into narrow lobes; flowers in a dense short thick spike; bracts broader than the leaves, white-tipped; corolla whitish.

In brackish marshes, along the seashore.

Orthocarpus attenuatus Gray. Minutely pubescent; stems erect, 10-20 $\mathrm{cm}$. high, pubescent above; leaves linear, long-attenuate, sometimes with narrow lobes; flowers scattered, in a narrow spike; bracts with attenuate lobes, sometimes white-tipped; corolla white; galea narrowly conical, straight.

In dry open places, British Columbia to California. 
Orthocarpus imbricatus Benth. Puberulent; stems slender, erect, 10-30 $\mathrm{cm}$. high; leaves linear-lanceolate, attenuate, puberulent; bracts somewhat papery, oval, net-veined, purplish at tip; spike dense; corolla purple; galea triangular, straight, as long as the lip.

Olympic Mountains, Elmer, and south to the mountains of northern California, rare.

Orthocarpus bracteosus Benth. Hirsute pubescent; stems erect, 10-30 $\mathrm{cm}$. high; leaves all deeply cleft into 3 acute lanceolate lobes, the lateral ones spreading; inflorescence a dense spike; bracts broader than the leaves, 3-5lobed, greenish; calyx-lobes subulate; corolla purple, 12-14 mm. long, the galea short and inflexed.

Open prairies, Vancouver Island to California. O. strictus Benth. is probably identical and if so has priority.

Orthocarpus pusillus Benth. Pubescent; plants low, usually purplish, $5-10 \mathrm{~cm}$. high; leaves pinnately dissected into thread-like divisions; bracts similar; flowers scattered, shorter than the bracts; corolla purplish, 4-5 $\mathrm{mm}$. long.

Common in dry gravelly soil.

Orthocarpus erianthus Benth. Minutely pubescent; stems slender, strictly erect, $10-20 \mathrm{~cm}$. high, simple or branched; leaves pinnately parted above the broader entire base into narrow segments; spike narrow; bracts similar to the leaves but small, the upper ones not longer than the calyx; corolla $2-2.5 \mathrm{~cm}$. long, yellow, the narrow falcate galea purple-tipped.

Washington, where perhaps introduced, to Oregon and California.

Orthocarpus hispidus Benth. Annual, slender, erect, simple or with few erect branches, rough-hairy throughout, $10-40 \mathrm{~cm}$. high; leaves linear or lanceolate, attenuate, entire or pinnately cleft into $3-5$ linear lobes, $2-6 \mathrm{~cm}$. long; spikes dense, narrow; bracts like the leaves, but shorter and broader; calyx-teeth subulate, shorter than the corolla-tube; corolla white, slender, 12-14 mm. long; lip with 3 sac-like swellings; galea straight, pointed.

Moist places in open ground, Willamette Valley.

Family 91. OROBANCHACEAE. Broomrape Family.

Root-parasitic herbs, destitute of foliage and green color, yellowish or brownish throughout; leaves reduced to alternate scales; flowers solitary, loosely clustered or spicate; calyx 4- or 5toothed or parted; corolla gamopetalous, tubular, more or less 2 -lipped, hypogynous; stamens 4, didynamous, epipetalous; style long; stigma large; ovary 1 -celled, with 2 or 4 parietal placentae; capsule 1-celled, 2-valved; seeds very numerous, minute.

Anther cells not separated, their bases rounded.

460. Boschniakia, 330.

Anther cells separated below, their bases mucronate.

- Bracts on the calyx or elongated peduncles none.

Bracts on the calyx or short pedicel one or two.

461. Thalesia, 331.

462. OROBANCHE, 331.

\section{BOSCHNIAKIA.}

Stout fleshy reddish simple-stemmed parasitic herbs; flowers sessile or subsessile in a dense scaly-bracted spike; bractlets 
linear, usually wanting; calyx short, cup-shaped, the teeth very variable; corolla swollen toward the base; upper lip entire or notched; lower lip 3-parted; stamens slightly exserted; anthercells parallel, blunt at base; stigmas 2-lobed or 4-lobed; capsules globose, 4-valved; seeds with a thin reticulated coat.

Boschniakia hookeri Walp. (B. strobilacea Gray.) Tuber-like underground stem globose, reticulated; stems stout, $10-30 \mathrm{~cm}$. high, reddish, flowering from near the ground; scale-like leaves rhomboidal, usually densely imbricated, more or less erose; flowers sessile or nearly so; calyx very variable, the teeth varying from subulate to broadly triangular, sometimes obsolete or nearly so; corolla ciliate; filaments bearded at base; capsule globose; seeds favose.

From Vancouver Island, British Columbia, to California; first found by Menzies at Nootka Sound. Northward the plant is parasitic on Gaultheria shallon or rarely on Arctostaphylos; southward the common host is Arctostaphylos but sometimes Arbutus menziesii. It seems impossible to maintain $B$. hookeri, the northern plant, and the usually stouter southern form, $B$. strobilacea, as distinct species.

\section{THALESIA.}

Yellowish, violet or nearly white herbs, parasitic on the roots of various plants; scale-leaves scattered; flowers solitary or in loose clusters; calyx 4- or 5-cleft; corolla 2-lipped, the upper lip erect, mostly 2-lobed or emarginate, the lower spreading; stamens included.

Calyx-lobes subulate, longer than the tube.

T. uniflora.

Calyx-lobes triangular, shorter than the tube.

T. fasciculata.

Thalesia uniflora (L.) Britt. Stem stout, 1-4 cm. long, mostly subterranean, with a few ovate obtuse scales and bearing 1-5 or more 1-flowered glandular-puberulent peduncles 5-12 cm. high; calyx glandular, the obconic or campanulate tube exceeded by the narrow subulate lobes; corolla violet or yellowish, 1-2.5 cm. long, glandular-puberulent without.

Rare in our limits.

Thalesia fasciculata (Nutt.) Britt. Stems elongated, 2-12 cm. long, bearing a cluster of 2-30 very glandular 1-flowered peduncles, $5-10 \mathrm{~cm}$. high; calyx-tube campanulate, about as long as the broad triangular lobes; corolla yellowish, $1-2 \mathrm{~cm}$. long.

Parasitic on various plants; not common.

462. OROBANCHE.

Parasitic herbs on the roots of various plants, usually yellowish or reddish; flowers in spikes, sessile or nearly so, with bracts; calyx deeply 2-lobed, the lobes often 2-cleft; corolla irregular, the tube slightly curved, the upper lip erect or incurved, the lower spreading; capsule 2-valved.

Flowers pedicellate; anthers woolly.

Flowers subsessile; anthers glabrous or nearly so.

O. grayana.

O. ludoviciana. 
Orobanche grayana Beck. (O. comosa Hook.) Stems stout, very short; flowers in a dense simple or branched corymb, all pedicelled; calyx-lobes narrow; corolla purplish; anthers woolly.

Parasitic on Grindelia; rare, in our limits known from Vancouver Island, British Columbia, and Whidby Island, Sucia Island, and Flattop Island, Washington.|1

JOrobanche ludoviciana Nutt. Whole plant reddish-yellow, viscid-pubescent; stem stout, erect, simple or with erect branches, scaly, $15-25 \mathrm{~cm}$. long; flowers 2-bracted at the base of the calyx, in dense spikes, looser below; calyx unequally 5-cleft, the lobes linear-lanceolate; corolla yellowish, 12-15 $\mathrm{mm}$. long, the lobes acute, hardly spreading.

Parasitic on Composite plants; known in our limits from Victoria, British Columbia, Macoun; Fort Vancouver, Washington, Douglas.

\section{Family 92. LENTIBULARIACEAE. Bladderwort FAmily.}

Small aquatic herbs with 1-few-flowered scapes; calyx 2lipped; corolla deeply 2-lipped, the lower lip larger, '3-lobed and with a prominent usually bearded palate, spurred at the base in front; stamens 2 , with confluently 1-celled anthers; style very short or none; stigma 1-2-lipped; ovary free, 1-celled, with a free central placenta; capsule of ten bursting irregularly.

Leaves entire; plant terrestrial.

Leaves dissected; plant aquatic.

463. Pinguicula, 332.

464. UTRICULARIA, 332.

463. PINGUICULA. BUtTERWORT.

Small stemless perennial herbs growing on damp rocks; leaves broad, entire, soft-fleshy, mostly greasy to the touch; flower solitary on a scape; upper lip of the calyx 3-cleft, the lower 2 -cleft; corolla with an open hairy or spotted palate, the lobes spreading.

Pinguicula vulgaris $L$. Leaves elliptic or ovate, obtuse, $2-5 \mathrm{~cm}$. long, short-petioled; scape 5-12 cm. high; corolla violet, the tube conical with a straight spur, the lower lip much longer than the upper.

Moist banks and rocks in the mountains.

464. UTRICULARIA. BLADDERWORT.

Aquatic submersed plants; leaves dissected into capillary segments and bearing little air-bladders which act as floats, or sometimes rooting in the mud and with few or no leaves or bladders; flowers on 1-few-flowered scapes; corolla bilabiate, with the throat closed by a prominent palate; anthers convergent.

Leaves $2-3$ times pinnately parted, crowded; flowers large. Leaves 2-4 times forked, scattered; flowers small.

U. vulgaris. U. minor.

Utricularia vulgaris L. Stems rather stout, immersed, thickly crowded with the finely parted pinnate leaves; corolla yellow, $12-16 \mathrm{~mm}$. broad, with reflexed sides; spur conical, shorter than the lower lip.

In still ponds, not common. 
Utricularia minor L. Stems floating; leaves forked 2-4 times, the threadlike divisions few; corolla yellow, 4-6 $\mathrm{mm}$. broad, the lips wide open; spur very short.

In ponds, scarce.

\section{Family 93. PlantaginaceaE. Plantain Family.}

Mostly stemless herbs; flowers regular, 4-merous, in spikes; corolla gamopetalous, dry and membranaceous, veinless; stamens 4 , or rarely 2 , on the corolla-tube, alternate with its lobes; ovary 2-, or falsely 3-4-celled; ovules 1-several in each cavity.

\section{Plantago. Plantain.}

Leaves nerved or ribbed, radical; flowers small, in bracted spikes, on naked scapes; calyx of 4 persistent sepals; corolla salverform or rotate, 4-parted; stamens 4 , or rarely 2 , in all or some flowers with long exserted filaments; ovary 2-celled; ovules 1 -several in each cell; capsule 2-celled, 2-several-seeded.

Leaves ovate or lanceolate.

Seeds numerous; leaves ovate.

Seeds only $2-4$; leaves lanceolate.

Leaves linear.

Corolla-lobes closed over the fruit.

Corolla-lobes spreading in fruit.

Leaves fleshy; seaside plants.

Leaves obtuse; capsule $4 \mathrm{~mm}$. long.

Leaves acute; capsule 6-8 $\mathrm{mm}$. long.

Leaves not fleshy; inland plants.

Spikes woolly; bracts short.

Spikes not woolly; bracts long.
P. major.

P. lanceolata.

P. bigelovii.

P. maritima. .

P. macrocarpa.

P. purshii.

P. aristata.

Plantago major L. Common Plantain. Perennial, pubescent or glabrous, the erect scapes mostly $10-30 \mathrm{~cm}$. high; leaves broadly ovate, 3-5-ribbed, obtuse or acute, rounded at base, entire or coarsely dentate, $3-20 \mathrm{~cm}$. long, on stout channeled petioles; spikes 5-20 cm. long; flowers all alike, perfect; sepals ovate or oblong, obtuse, shorter than the acutish capsule; seeds 6-15.

Introduced in waste places; also native, especially on lake and sea beaches.

Plantago lanceolata L. Buckhorn. Perennial, with a stout tap-root, erect, $30-45 \mathrm{~cm}$. high, more or less pubescent; leaves $5-20 \mathrm{~cm}$. long, sparsely pubescent, woolly at the base of the broad petiole; spikes dense, $1-3 \mathrm{~cm}$. long, a little thicker at the base; bracts and sepals scarious; flowers all alike, perfect; capsule oblong, obtuse, 2-seeded; seeds concave on the inner face.

Introduced; common in lawns and meadows.

Plantago bigelovii Gray. Annual, green and glabrous; leaves linear, obtuse, entire, $4-10 \mathrm{~cm}$. long; spikes dense, few-flowered, $2-3 \mathrm{~cm}$. long, exceeding the leaves; stamens 2; capsule ovoid-oblong, $4 \mathrm{~mm}$. long, 4-seeded.

In salt marshes, rare.

Plantago maritima L. Glabrous or nearly so, somewhat fleshy; leaves linear, obtuse, more or less woolly at base, $5-25 \mathrm{~cm}$. long; spikes dense, $2-10$ $\mathrm{cm}$. long; bracts obtuse, shorter than the calyx; sepals oval, keeled on the back; corolla-lobes acutish; stamens 4; seeds few, not concave on the face.

On the seashore, common. 
Plantago macrocarpa Cham. \& Schlecht. Perennial, fleshy; leaves lanceolate, acute, $10-30 \mathrm{~cm}$. long, tapering into a long margined petiole; scapes as long as or longer than the leaves; spike dense, cylindric, in fruit $4-5 \mathrm{~cm}$. long, its axis pubescent; bracts and sepals rather fleshy, scarious-margined; capsule ovoid-oblong, 4-seeded, 6-8 mm. long.

Common on the seacoast, Alaska to Vancouver Island, Bricish Columbia, and perhaps to Washington.

Plantago purshii R. \& S. Annual, 5-30 cm. high, white-hairy or woolly throughout; leaves 5-10 cm. long, 1-3-nerved, linear or lanccolate, acute, narrowed at the base into a petiole; spikes dense, 1-10 cm. long; bracts subulate, exceeding the flowers, becoming rigid; flowers perfect but of two kinds on separate plants, in one the four stamens being long and exserted, in the other short and included; sepals oblong, obtuse, with broad scarious margins; corolla white, the spreading lobes ovate.

Common in dry ground.

Plantago aristata Michx. Much like $P$. purshii but greener and less hairy; bracts of the spikes much longer than the flowers.

Sparingly introduced from the central states.

\section{Family 94. RUBIACEAE. MAdDER FAMILy.}

Herbs (in ours); leaves opposite, entire with intervening stipules or whorled without stipules; flowers generally perfect; calyx 4- or 5-lobed or toothed, coherent with the ovary; corolla gamopetalous, regular, 4- or 5-lobed or toothed; stamens on the corolla and alternate with its lobes; ovary inferior, 2-5-celled; endosperm hard, copious.

Corolla funnelform, 4- or 5-lobed; calyx-lobes present. 466. Sherardia, 334. Corolla wheel-shaped, 3- or 4-parted; calyx-teeth none. 467. Galium, 334.

466. SHERARDIA.

Slender procumbent herbs with 4 -sided stems; leaves lanceolate, pointed, in whorls of 4-6; flowers small, blue or pinkish, surrounded by a gamophyllous involucre; calyx-lobes lanceolate, persistent; corolla funnelform, the limb 4-5-lobed; style filiform, 2-cleft; stigmas capitate; fruit dry, twin, of 2 indehiscent 1seeded carpels.

Sherardia arvensis L. Scabrous; stems tufted, loosely branched, 10-20 $\mathrm{cm}$. high; leaves in whorls of 4,5 , or 6 , lanceolate or lance-linear, acute, 6-15 $\mathrm{mm}$. long; flowers capitate; involucre 6-8-lobed, the lobes lanceolate, acute; corolla pink, with spreading lobes; calyx-teeth persistent on the fruit.

Introduced from Europe.

467. Galium. Bedstraw. Cleavers.

Annual or perennial herbs with 4-angled stems; leaves whorled, without apparent stipules; flowers small, usually cymose; calyxteeth obsolete; corolla rotate, 4-parted, rarely 3-parted; stamens as many as the corolla-lobes, short; styles 2 , short; stigmas capi- 
tate; ovary 2-lobed, 2-celled; ovules solitary; fruit dry or fleshy, globular, separating when ripe into 2 closed 1 -seeded carpels.

Annuals; fruit hispid or hirsute.

Leaves mostly in fours; stems erect, smooth. G. bifolium.

Leaves 6-8 in each whorl; stems rough on the angles.

Perennials; fruit smooth, hispid or canescent.

Leaves 3-nerved, in whorls of four.

Fruit canescent, becoming smooth; leaves linear.

Fruit hispid; leaves wider than linear.

Leaves oblong-ovate, acutish. G. kamtschaticum.

Leaves obovate or orbicular, obtuse. G. kamtschaticum oreganum.

Leaves 1 -nerved.

Whorls containing 6 leaves; fruit hispid with hooked hairs.

Whorls containing 4,5 , or 6 leaves; fruit

G. triflorum. smooth.

Flowers cymose, the peduncles irregularly branching.

Flowers not cymose.

Flowers solitary. $\quad$ G. trifidum.

Flowers or many of them in twos. G. claytoni.

Galium bifolium Wats. Glabrous; stems erect, $10-20 \mathrm{~cm}$. high, simple or but little branched; leaves linear to oblanceolate, $8-15 \mathrm{~mm}$. long, the upper often in twos; peduncles 1 -flowered, about as long as the leaves; flowers white.

In moist places in the mountains at about $1500 \mathrm{~m}$. altitude. Known from Mount Adams and Mount Stuart and to be expected in our limits.

Galium aparine L. Stems weak and reclining, retrosely prickly on the angles, $30-120 \mathrm{~cm}$. long; leaves linear or linear-spatulate, mostly cuspidate, more or less retrorsely-hispid, especially on the margins and midribs, $5-8 \mathrm{~cm}$. long; pedicels from the upper axils or terminal, bearing solitary flowers; fruit on erect pedicels, densely hispid with somewhat hooked bristles, 3-4 $\mathrm{mm}$. broad.

Very abundant in open woods.

Galium boreale L. Glabrous or nearly so; stems rather slender, but erect, 30-60 cm. high, leafy; leaves 3-nerved, oblong-linear, lanceolate or linear, obtuse to acuminate, mostly $1-3 \mathrm{~cm}$. long; flowers white, in small cymes which form a large terminal panicle; bract-like leaves much reduced and in pairs; fruit globose, small, hispid, but becoming glabrous.

In moist meadows, not common.

Galium kamtschaticum Steller. Stems erect, $10-30 \mathrm{~cm}$. high; leaves in fours, obovate to orbicular, 3-nerved, obtuse, slightly pilose on the nerves and margins; flowers cream-colored, in small cymes; pedicels spreading; corollalobes acute; fruit hispid.

Stevens Pass, Washington, Sandberg \& Leiberg, north to Alaska and Kamtschatka.

Galium kamtschaticum oreganum (Britt.) Piper. Leaves oblong-ovate, acutish; otherwise like G. kamtschaticum.

Common in woods in the mountains at low altitudes, Vancouver Island, British Columbia, to Oregon.

Galium triflorum Michx. Stems weak, prostrate to ascending, $30-100 \mathrm{~cm}$ long, retrorsely hispid on the angles; leaves lanceolate, bristle-tipped, $2-8 \mathrm{~cm}$. 
long; peduncles 3-flowered, rarely 6-flowered; flowers greenish-white, all pedicelled; fruits covered with hooked bristles.

In moist woods, very common.

Galium cymosum Wiegand. Stems ascending, 30-80 cm. high, 4-angled, rough on the angles, loosely branched; leaves in fives and sixes, linear, obtuse, scabrous on the margins, $10-17 \mathrm{~mm}$. long; flowers numerous, in terminal and lateral cymes; pedicels short, divaricate; corolla $2 \mathrm{~mm}$. broad, 3-parted; fruit glabrous.

Washington and Oregon, near the coast; not common.

Galium trifidum pacificum Wiegand. Stems slender, 30-50 cm. high; leaves mostly in fours, unequal, oblong-spatulate, obtuse, cuneate at base, thin in texture, $15-25 \mathrm{~mm}$. long; peduncles lateral, capillary, scabrous or smooth, 1-flowered, not longer than the leaves; corolla 3-lobed; fruit smooth.

In wet places, common.

Galium claytoni subbiflorum Wiegand. Stems ascending, weak and slender. 15-20 cm. high, retrorsely scabrous on the angles; leaves linear, scabrous on the margins and midribs; peduncles axillary or terminal, recurved, often scabrous, some of them 1-flowered, others 2- or even 3-flowered; flowers very small, white, the parts often in threes; fruit glabrous.

In wet places, rare in our limits.

\section{Family 95. CAPRIFOLIACEAE. HoNeysuckle FAMILy.}

Shrubs or rarely herbs; leaves opposite, without genuine stipules; flowers perfect, generally in cymes; calyx-tube adherent to the ovary; corolla gamopetalous, tubular or rotate, 4 - or 5cleft, sometimes irregular; stamens distinct, as many as the corollalobes, rarely fewer; ovary 2-5-celled, or not rarely 1 -celled; ovules solitary or several; endosperm fleshy.

Corolla rotate or urn-shaped; flowers in compound cymes.

Leaves pinnate.

468. SAMBucus, 336.

Leaves simple.

Corolla tubular or bell-shaped; flowers not in compound cymes.

Creeping herbaceous vines; fruit dry.

Shrubs, erect or climbing; fruit a berry.

Corolla regular, bell-shaped.

Corolla more or less irregular, tubular, commonly 2-lipped.

469. VIBURNUM, 337.

470. LinNaEa, 338.

471. SYMPHORICARPOS, 338.

472. LONICERA, 338.

\section{SAMBUCUS. ELDER.}

Shrubs or trees; leaves opposite, pinnate; leaflets serrate or laciniate; flowers small, white, numerous, in compound cymes; calyx-lobes minute or obsolete; corolla gamopetalous, open urnshaped, 5-cleft; lobes broadly spreading; stamens 5, distinct; stigmas 3 ; fruits of berry-like drupes with 3-5 nutlets, each with one seed.

Inflorescence flat-topped; berries black, with a bloom.

S. glauca.

Inflorescence pyramidal; berries red, rarely yellow or brownish. S. callicarpa. 
Sambucus glauca Nutt. Shrub 2-5 m. high, or sometimes a tree 8-10 m. high, glabrous throughout, somewhat glaucous; young pith white; leaves pinnate; leaflets $5-9$, thickish, oblong or ovate-lanceolate, acuminate, sharply serrate, short-stalked, paler beneath, 8-12 cm. long; lower leaflets sometimes more or less divided; subulate stipels occasionally present; cymes usually 5-rayed, large, flat-topped; flowers white, $4-5 \mathrm{~mm}$. broad; fruit black, very glaucous; nutlets rugose.

In dry ground, Vancouver Island, British Columbia, to California and Idaho.

Pank Sambucus callicarpa Greene. Shrub 2-5 m. high; bark smooth, brown; young pith brownish-yellow; leaflets 5-7, oblong-lanceolate, serrate, acute or acuminate, $5-12 \mathrm{~cm}$. long, sparingly pubescent beneath; panicle pyramidal; flowers cream-colored; berries bright scarlet, sometimes chestnut-colored, rarely yellow.

In wet ground, very common. The form with chestnut-colored fruit is very abundant on the bluffs of Puget Sound between Seattle and Everett, Washington.

\section{VIBURNUM.}

Shrubs or small trees; leaves simple, commonly toothed, sometimes deeply lobed; flowers white, in flat compound cymes; calyx 5-toothed; corolla spreading, deeply 5-lobed; stamens 5, exserted; stigmas 1-3; fruit a 1-celled 1-seeded drupe with soft pulp and a thin crustaceous stone.

Cyme radiate, that is the outer flowers neutral and enlarged. V. opulus.

Cyme not radiate.

Leaves roundish, mostly 3 -lobed.

Leaves oval to elliptic, dentate.

V. pauciflorum. V. ellipticum.

Viburnum opulus americanum (Mill.) Ait. Erect shrub, 1-4 m. high, glabrous or nearly so; leaves orbicular in outline, rounded or cuneate at base, 3-5-ribbed, strongly 3-lobed, the triangular lobes acuminate, usually dentate; petioles bearing 2 or more round usually reddish excrescences at summit; stipules very slender; cymes flat, the outer flowers neutral and much enlarged; fruit red, acid.

Rare in our limits, Sumas Prairie, Lyall; Cape Horn, Piper. The cultivated snowball is a form of the true V.opulus L. of Europe.

Viburnum pauciflorum Pylaie. High-bush Cranberry. Shrub, 1-2 m. high, the branchlets glabrous; leaves orbicular or ovate, mostly 3-lobed, truncate or subcordate at base, pubescent beneath; cymes peduncled, on short 2-leaved branches, small, 1-2 cm. broad; flowers white, all perfect; drupes globose, red.

Along streams in the mountains, infrequent.

Viburnum ellipticum Hook. Shrub, 1-3 m. high, erect; leaves broadly oval or oblong, coarsely dentate above the middle, obtuse, firm in texture, somewhat pubescent, especially beneath, 3-5-nerved from the base; petioles slender; stipules subulate; cymes rather dense; flowers cream-colored; corolla $8 \mathrm{~mm}$. broad; fruit black.

Along both sides of the lower Columbia River, where first found by Douglas, and southward to California. 


\section{LINNAEA. TWIN-FLOWER.}

Creeping and trailing small evergreen herbs; leaves ovate or orbicular, opposite, petioled; flowers in pairs, on the summit of elongated terminal peduncles; calyx-teeth 5, awl-shaped, deciduous; corolla funnelform, almost equally 5-lobed, purple and whitish, hairy inside; stamens 4 , two shorter, all included and inserted near the base of the corolla; ovary and the small dry pod 3-celled, but one seed ripening, the other ovules abortive.

Linnaea borealis longiflora Torr. Twin-flower. Stem perennial, trailing, slender, pubescent, $30-100 \mathrm{~cm}$. long; leaves obovate or orbicular, obtuse, crenate above the middle, mostly cuneate at base, sparingly pubescent, 10-25 $\mathrm{mm}$. long, short-petioled; flowering branches erect, 8-10 cm. high, leafy below, forked above into two, very rarely more, glandular pedicels, each bearing a single nodding flower; calyx-lobes lanceolate, about twice as long as the very glandular tube; corolla pink, hairy inside, $1-1.5 \mathrm{~cm}$. long.

In woods, very common.

\section{SYMPHORICARPOS. SNOWBERRY.}

Low and branching shrubs; leaves oval or oblong, shortpetioled, entire or wavy-margined; flowers 2-bracteolate, in axillary and terminal spikes or clusters, rarely solitary; calyx-teeth 5 or 4 , short, persistent; corolla regular or nearly so, bell-shaped to salverform, white or pink, 5- or 4-lobed; stamens as many as the corolla-lobes, epipetalous; ovary 4-celled, two of these being 1 -ovuled and fertile, the two alternate several-ovuled and sterile; fruit globular and berry-like, containing 2 bony seed-like nutlets.

Erect shrub; leaves glabrous.

Trailing shrub; leaves pubescent.

S. albus.

S. mollis.

Symphoricarpos albus (L.) Blake. (S. racemosus Michx.) Erect much branched shrub, $30-90 \mathrm{~cm}$. high; leaves ovate or oval, acute or obtuse, rounded or cuneate at base, entire or on vigorous shoots sinuately-toothed or lobed, pubescent beneath, short-petioled, $1-4 \mathrm{~cm}$. long; flowers in terminal and axillary racemes; corolla pink, campanulate, $4-5 \mathrm{~mm}$. long, villous on the lobes within, these obtuse, shorter than the tube; stamens and style included; berries white.

Common in open woods.

Symphoricarpos mollis Nutt. Whole plant covered with a short dense pubescence; stems weak, reclining, 30-120 cm. long; leaves oblong to oval, 1-2 cm. long, entire or on vigorous shoots deeply and sinuately lobed, acute or obtuse; flowers in clusters of 1-6; corolla pink, campanulate, $4 \mathrm{~mm}$. long, slightly villous within, the lobes obtuse, as long as the tube; stamens and style included; berries white.

In dry open woods.

472. LONICERA. HONEYSUCKLE.

Erect or climbing shrubs; leaves opposite, mostly entire; flowers in spikes or pairs; calyx minutely 5-toothed; corolla tubular or funnelform, of ten gibbous at the base, more or less 
irregularly 5-lobed, commonly 2-lipped; stamens 5, epipetalous; ovary 2- or 3-celled, with numerous ovules in each cell; berry several-seeded.

Climbing shrubs; flowers in terminal clusters; upper leaves connate-perfoliate.

Flowers orange; stamens and style little exserted.

Flowers pink; stamens and style long-exserted.

Erect shrubs; flowers on axillary peduncles in pairs; upper leaves not connate.

Bracts large, foliaceous; flowers yellow; fruit black.

Bracts small and narrow; flowers whitish; fruit red.

L. ciliosa.

L. hispidula.

Lonicera ciliosa (Pursh) Poir. Stems slender, twining to a height of 3-7 m.; young parts glaucous; leaves oval, obtuse, glaucous beneath, ciliate, 2-6 cm. long, short-petioled; uppermost pairs on the flowering branches connate into oval or orbicular disks; peduncles terminal, rarely in the axils of the penultimate pair of leaves; flowers sessile, in whorls; corolla yellow or orange, sparsely hairy; tube narrow, gibbous near the base, $2-2.5 \mathrm{~cm}$. long; limb spreading, slightly 2-lipped; berries orange-red.

In open woods, common.

Lonicera hispidula Dougl. Stems slender, twining, 2-4 m. high, the young shoots hispid; leaves oval or ovate, often subcordate, glabrous and green above, pale and pubescent beneath, $1-3 \mathrm{~cm}$. long, the uppermost usually connate; flower clusters often panicled; corolla reddish without, yellowish within, 15-20 $\mathrm{mm}$. long, 2-lipped, the strongly gibbous tube not longer than the lips; filaments exserted, hairy at base; berries red.

On banks and cliffs. Common on the bluffs along Puget Sound.

Lonicera involucrata Banks. (L.ledebouri Esch.) Shrub, 1-3 m. tall, not twining; leaves oblong, ovate or obovate, mostly acuminate, rounded or cuneate at base, sparsely pubescent beneath or glabrate, $5-15 \mathrm{~cm}$. long, shortpetioled; peduncles axillary, shorter than the leaves; flowers yellow, a single pair surrounded at base by an involucre of 4- 6 bracts, the inner ones of which are united at base and become purple in fruit; corolla tubular, with short lobes, glandular-puberulent, $10-15 \mathrm{~mm}$. long; berries black, not united.

Along streams and in tidal marshes, common.

Lonicera utahensis Wats. Much branched shrubs, 1-2 m. high, not twining; leaves oblong, oval or ovate, obtuse, pubescent beneath, and somewhat ciliate, $1-5 \mathrm{~cm}$. long, short-petioled; flowers white or nearly so, in a pair at the apex of the peduncles, $1-2 \mathrm{~cm}$. long, with 2 small bracts at the base of ovary; corolla oblong-funnelform, $2 \mathrm{~cm}$. long, the 5 lobes nearly equal, the tube with a sac-like projection at base; berries red, not united.

Olympic Mountains, at about the limit of trees, Elmer, Flett. Common in the mountains of the interior.

\section{Family 96. VALERIANACEAE. VALERIAN FAMILY.}

Herbs; leaves opposite, without stipules; flowers perfect or dioecious, in panicled or clustered cymes; calyx-tube coherent with the ovary; corolla gamopetalous, tubular or funnelform, often irregular, 3-5-cleft; stamens distinct, 1-3, fewer than the corolla-lobes, epipetalous; ovary inferior, with one fertile 1-ovuled 
cell and two abortive or empty ones; fruit indehiscent; endosperm none.

Tall perennial herbs; calyx-limb of 5-15 plumose slender lobes, inrolled until fruiting.

473. VALERIANA, 340.

Low annual herbs; calyx-limb obsolete or nearly so. 474 . VALERIANELLA, 340.

\section{VALERIANA. VALERIAN.}

Tall perennial herbs, with strong-scented thickened roots; leaves simple or pinnate; calyx-lobes of several plumose bristles (pappus) which are rolled inward in flower but which unroll as the fruit matures; corolla commonly gibbous near the base, 5-lobed, nearly regular; stamens 3 ; abortive cell of the ovary small or obscure, obliterated in the akene-like fruit which is therefore 1-celled.

M†Adams Valeriana sitchensis Bong. Perennial from stout rootstocks, glabrous or nearly so; stems erect, $60-90 \mathrm{~cm}$. high; basal leaves simple or trifoliolate, the blades broadly ovate to orbicular; cauline 3-5-foliolate, the leaflets sessile, ovate to oblong, coarsely sinuate to sinuate-dentate; flowers whitish or pinkish, in dense umbels; calyx sparsely pilose; corolla funnelform, 6-7 $\mathrm{mm}$. long; stigma entire; fruit glabrous.

Abundant in the mountains at the limit of trees. Odor strong and rather unpleasant, especially when dry. First collected near Sitka by Mertens.

Valeriana sitchensis scouleri (Rydb.) Piper. Leaflets entire or merely undulate; otherwise like $V$. sitchensis.

Rocky stream banks at low altitudes.

\section{VALERIANELLA.}

Low annual dichotomously branched herbs; leaves tender, rather succulent; flowers small, bracted, whitish or pink, cymosely clustered; calyx merely toothed or teeth obsolete; corolla funnelform, manifestly or obscurely 2 -lipped; stamens 3 , rarely 2 ; fruit 1-celled, 1 -seeded.

Flowers rose-colored; fruit usually broadly winged. Flowers pale or white.

Corolla spurless; fruit winged.

Corolla spurred; fruit wingless.

V. congesta.

V. anomala.

V. samolifolia.

Valerianella congesta Lindl. Stems $10-40 \mathrm{~cm}$. high, erect, simple or with a few branches; leaves oblong, entire, obtuse, the cauline sessile; flowers rosecolored, in dense cymes; corolla 2-lipped, 6-8 $\mathrm{mm}$. long, spurred; fruit glabrous or puberulent, strongly keeled on the back.

In open ground, British Columbia to California. The fruit is usually broadly winged but in some forms the wings are narrow or even wanting.

Valerianella anomala Gray. Stems erect, $20-50 \mathrm{~cm}$. high; leaves oblong, acutish, $2-5 \mathrm{~cm}$. long; flowers white, in small terminal and axillary cymes; corolla white, funnelform, obscurely 2 -lipped, three lobes larger than the other two; spur wanting; fruit strongly keeled, $3 \mathrm{~mm}$. long, the wings usually broad.

In moist open places, rare. 
Valerianella samolifolia (DC.) Gray. Stems erect, 10-30 cm. high; leaves oblong or oblong-obovate, obtuse, $2-5 \mathrm{~cm}$. long; flowers in small cymes; bracts entire and subulate, or the upper ones palmately 3-parted; corolla white, obscurely 2-lipped; spur short; fruit wingless, 3 -angled, $2 \mathrm{~mm}$. long, glabrous or pubescent.

In moist ground, rare, Vancouver Island to California; also in Chile.

\section{Family 97. DIPSACACEAE. Teasel Family.}

Herbs; leaves opposite or whorled, without stipules; flowers in dense heads, surrounded by an involucre as in the Compositae; calyx-tube adherent to the ovary; corolla epigynous, 2-5-lobed; stamens $2-4$, distinct on the corolla-tube and alternate with its lobes; ovary inferior, 1-celled; ovule 1; fruit an akene with persistent calyx-lobes; endosperm fleshy.

\section{DIPSACUS. TEASEL.}

Rough-hairy or prickly tall biennial or perennial herbs; leaves large, opposite, the bases sometimes united into a cup; flowers in dense terminal peduncled oblong heads; bracts of the involucre and scales of the receptacle rigid or spiny-pointed; calyx 4toothed or lobed; corolla oblique, 2-lipped, 3-lobed; stamens 4; stigma oblique or lateral; akene free from or adherent to the involucel.

Dipsacus sylvestris Huds. Biennial, 1-2 m. high, the stems and midribs armed with stout prickles; lower leaves lanceolate, obtuse, crenate, rarely cleft at base, 15-30 cm. long; upper leaves sessile, of ten cuneate, acuminate, entire; heads ovoid, becoming cylindric, 5-10 cm. long; involucre of linear cuspidate prickly bracts, some of which are longer than the head; bracts of the receptacle ovate, armed with long straight awns; flowers lilac.

Sparingly introduced.

\section{Family 98. CUCURBITACEAE. Gourd FAmily.}

Mostly succulent herbs with tendrils; leaves alternate, palmately lobed or veined; flowers dioecious or monoecious; calyxtube adhering to the ovary; stamens 5 or usually 3 , then 2 with a 2-celled and 1 with a 1 -celled anther, usually united by their anthers, sometimes also by their filaments; stigmas 2 or 3 ; ovary 1-3-celled; fruit a pepo, fleshy or sometimes membranaceous.

\section{MICRAMPELIS.}

Tall climbing annual vines nearly smooth, with forked tendrils; leaves thin; flowers very numerous, small, greenish-white, monoecious, the staminate in compound racemes, the pistillate in small clusters or solitary from the same axils; petals 6 , lan- 
ceolate, united at the base and spreading; anthers more or less united; stigma broad; ovary 2-celled with 2 ovules in each cell; fruit fleshy, at length dry, with weak prickles, fibrous-netted within, 2-celled, 4-seeded.

Micrampelis oregana (T. \& G.) Greene. Glabrous or somewhat scabrous; stems climbing, 3-12 m. long; leaves reniform-cordate, $8-15 \mathrm{~cm}$. broad, deeply 5-7-lobed, the lobes triangular, acute and mucronate; staminate flowers in slender racemes; fruit subglobose, a little longer than thick, armed with soft green prickles, 2-4-celled; seeds orbicular, twice as broad as thick.

In rich soils, Washington to California. Root very large and fleshy, whence known as "Old Man Root."

\section{Family 99. CAMPANULACEAE. Bellflower Family.}

Herbs with milky juice; leaves alternate, without stipules; flowers regular, generally blue, showy, scattered; calyx adherent to the ovary; corolla 5-lobed, bell-shaped; stamens 5 , usually free from the corolla; anthers distinct or united; style 1, the upper portion provided with pollen-collecting hairs; stigmas 2 or more; ovary 2-5-celled, with axile placenta; capsule 2-severalcelled, many-seeded; endosperm fleshy.

Corolla irregular; anthers united.

Flowers axillary; submersed aquatic with linear elongate leaves.

477. Howellia, 342.

Flowers not axillary; terrestrial or subaquatic plants.

Tube of corolla cleft to the base on one side.

Tube of the corolla very long, not cleft.

Corolla regular; anthers separate.

478. RapUnTIUM, 343.

479. Bolelia, 343.

Ovary and capsule long and narrow.

Capsule opening at the top by a hole left by the falling away of the base of the style; flowers all alike.

480. Githopsis, 343.

Capsule opening on the sides by 2 or 3 little valves which leave small round perforations; flowers of two kinds.

Ovary and capsule short and broad or globular.

Calyx-lobes broad; flowers of two kinds.

Calyx-lobes narrow; flowers all alike.

481. Specularia, 344.

482. HETEROCODON 344.

483. Campanula, 344 .

\section{HOWELLIA.}

Aquatic herbs; flowers of 2 forms, the emersed with a corolla, the submersed with an undeveloped corolla; calyx-tube linearclavate, adnate for its whole length to the ovary, the limb of 5 nearly equal slender-subulate or filiform segments; corolla even in emersed flowers not exceeding the calyx, its short tube divided nearly to the base on one side; stamen-tube nearly free; anthers oval, the 2 smaller each with 3 hairs, the 3 larger naked; ovary 
strictly 1-celled, with 2 filiform parietal placentae each bearing 3-5 ovules; capsule clavate-oblong or fusiform, membranaceous.

Howellia aquatilis Gray. Annual, submersed or only the tips of the stems emersed; stems branched, $15-45 \mathrm{~cm}$. long; leaves narrowly linear, entire, 5-15 cm. long; emersed leaves broader, sparingly toothed; flowers axillary, short-peduncled; capsule linear-clavate.

In still ponds, Sauvies Island, near Portland, Oregon, and in north Idaho. Named after Mr. Thomas Howell and his brother by whom it was discovered.

\section{RAPUNTIUM.}

Herbs, rarely woody; flowers axillary or usually in bracted racemes; calyx with a short 5 -cleft tube; corolla with a straight tube split down on one side, somewhat 2-lipped, the upper lip of 2 rather erect lobes, the lower lip spreading and 3-cleft; two of the anthers bearded (in ours); pod 2-celled, many-seeded, opening at the top.

Rapuntium dortmanna (L.) Presl. Glabrous; leaves in a basal rosette, linear, obtuse, terete, $2-5 \mathrm{~cm}$. long, hollow and with a longitudinal partition; scapes slender, erect, $10-50 \mathrm{~cm}$. high, simple; flowers in a raceme; calyx-lobes subulate, as long as the tube; corolla pale blue, the lower lip slightly hairy.

Borders of lakes, often submersed, rare. Lake Crescent, Washington, Lawrence; Whatcom Lake, Washington, Suksdorf; Shawnigan Lake, Vancouver Island, British Columbia, Macoun.

\section{BOLELIA.}

Low and spreading glabrous annuals, rather succulent and tender; leaves sessile, narrow, entire, the upper reduced to bracts; flowers axillary, sessile; calyx-tube adherent to the ovary, very long and slender, 3-sided, usually twisted; corolla 2-lipped, with a very short tube; filaments and anthers both united into a tube; capsule long and slender, early becoming 1-celled.

Bolelia elegans (Dougl.) Greene. Stems erect, simple or branched near the base, $10-30 \mathrm{~cm}$. high, glabrous throughout or very minutely puberulent; leaves sessile, ovate or lanceolate, acute, $8-20 \mathrm{~mm}$. long; flowers blue, in a rather loose spike; bracts like the leaves but broader; calyx-tube very narrow, becoming 3-4 cm. long and appearing like a pedicel; calyx-lobes narrow, unequal; lower lip of the corolla sharply 3-lobed, $8-10 \mathrm{~mm}$. long and broad, blue with a large white and yellow center; divisions of the upper lip lanceolate.

Common on the margins of ponds, Chehalis County, Washington, and southward.

\section{GITHOPSIS.}

Low annual herbs; flowers all alike; calyx with a 10-ribbed tube and 5 long and narrow foliaceous lobes; corolla tubularcampanulate, 5-lobed; filaments short, dilated at the base; stigmas 3 ; ovary 3 -celled; capsule strongly ribbed, crowned with the rigid calyx-lobes about as long or longer, opening by a round orifice left by the falling away of the base of the style; seeds very numerous. 
Githopsis specularioides Nutt. Annual, erect, simple or branched from the base, hirsute-pubescent throughout, 5-20 cm. high; leaves sessile, linear or oblong, coarsely dentate, 3-12 $\mathrm{mm}$. long; flowers terminal on the stem or on axillary stout peduncles, erect; calyx-lobes linear, acuminate, glabrous above, 1-nerved, rigid, erect, as long as the narrowly-obconic tube; corolla blue, barely exceeding the calyx-lobes.

Prairies, Chehalis County, Washington, and southward. First collected by Nuttall near the mouth of the Willamette River.

\section{SPECULARIA.}

Annuals; cauline leaves sessile or clasping; flowers blue or purple, terminal or axillary, of two kinds, the earlier smaller, close-fertilized, with a rudimentary corolla which never opens, with mostly 3 or 4 calyx-lobes, the later with 5 calyx-lobes; corolla rotate, 5 -lobed; ovary 3 or sometimes 2 -celled; capsule more or less elongated, opening by 2 or 3 small lateral valves which leave round or oval perforations, usually over partitions.

Specularia perfoliata (L.) A. DC. Venus's Looking Glass. Stems slender, erect, leafy, $20-40 \mathrm{~cm}$. high, rough-hairy on the angles; leaves orbicular, cordate, crenate, clasping at base, 1-2 cm. long, scabrous on the margins and veins; flowers of 2 sorts, the earlier close-fertilized and with only rudimentary corollas, the later with showy violet corollas $4-10 \mathrm{~mm}$. broad, solitary or 2 or 3 in the axils; calyx of the close-fertilized flowers with 3 or 4 short lobes of the corollabearing flowers with subulate lobes slightly longer than the tube; capsule topshaped, opening near the middle.

In open places, not rare.

\section{HETEROCODON.}

A very delicate little annual; flowers of two sorts, the lower and earlier ones with merely rudimentary corollas and self-fertilized in the bud; calyx with an ovoid or inversely pyramidal tube much shorter than the foliaceous lobes, these broadly obovate, sharply toothed, veiny, 3 or 4 in the earlier, 5 in the later flowers; corolla short-campanulate, 5 -lobed; stamens and style as in Campanula; capsule 3-celled, 3-angled, bursting on the side; seeds numerous.

Heterocodon rariflorum Nutt. Annual, the slender stems simple or branched below, 8-20 cm. high, sparsely hairy; leaves ovate or orbicular, sessile and partly clasping, coarsely dentate, somewhat scabrous-ciliate, 3-10 $\mathrm{mm}$. long; earlier flowers without a corolla, the later ones with blue corollas, barely exceeding the calyx; calyx 5-8 mm. long, more or less hispid, the ovate acuminate usually toothed lobes a little longer than the tube.

Said to occur in the Willamete Valley; frequent in the interior.

\section{CAMPANULA. Bellflower.}

Chiefly perennial herbs; flowers all alike, showy; calyx-lobes narrow; corolla campanulate or nearly so, 5-lobed or cleft; stamens 5; filaments dilated at base; capsule short, 3-5-celled, opening on the side or near the base by 3-5 small uplifted valves leaving round perforations, many-seeded.

Ours all perennials. 
Style longer than the corolla; corolla-lobes spreading.

Corolla deep blue, twice as long as the calyx-lobes.

Corolla pale bluish, little longer than the calyx-lobes.

Style included; corolla lobes erect.

Herbage puberulent; leaves all entire.

Herbage glabrous; at least the basal leaves not entire.

Cauline leaves linear, entire; basal orbicular or cordate.

Cauline leaves spatulate-lanceolate, dentate; basal similar.

C. prenanthoides.

C. scouleri.

C. scabrella.

C. rotundifolia.

C. piperi.

Campanula prenanthoides Durand. Pubescent or glabrous; stems usually several, erect, 30-60 cm. high; leaves ovate-oblong to lanceolate, sharply and coarsely serrate, acute, 1-2 cm. long, the cauline sessile, the lower ones shortpetioled; flowers in a raceme, short-pedicelled; calyx-lobes subulate; corolla blue, narrowly campanulate, its lanceolate lobes 3 or 4 times as long as the tube.

In open places, southern Oregon, perhaps not reaching our limits.

Campanula scouleri Hook. Glabrous or nearly so; stems slender, 20-30 $\mathrm{cm}$. high, often with a few branches; leaves ovate to ovate-lanceolate or the upper lanceolate, acuminate, serrate, tapering at base, the petiole margined; flowers in a raceme or a few-branched panicle; calyx-lobes subulate; corolla 12-15 $\mathrm{mm}$. long, pale bluish, somewhat funnelshaped, the lance-ovate oblong lobes spreading, longer than the tube.

In open woods, common. First collected by Scouler at Fort Vancouver, Washington.

Campanula scabrella Engelm. Ashy puberulent, tufted, the numerous stems arising from a much branched base, $5-10 \mathrm{~cm}$. high; leaves entire, firm, spatulate to linear; corolla blue, campanulate, with lance-ovate lobes as long as the tube.

High alpine meadows, Mount Adams, and the mountains of northern California, probably occurring in our limits.

Campanula rotundifolia L. Glabrous, erect, branched at the very base, $10-40 \mathrm{~cm}$. high; basal and lower leaves broadly ovate or orbicular, cordate, dentate or entire, petioled; cauline linear, the lower somewhat spatulate, acute, sessile, $2-7 \mathrm{~cm}$. long; flowers solitary or racemose, erect; pedicels slender, nodding in the fruit; calyx-lobes subulate, longer than the tube, onehalf or one-third as long as the corolla; corolla campanulate, blue, 12-20 mm. long; capsule openings near the base.

Prairies and rock cliffs from sea level to $2000 \mathrm{~m}$. altitude.

Campanula piperi Howell. Glabrous; stems densely tufted from a much branched somewhat woody base, 4-10 cm. high, leafy; leaves thin, oblonglanceolate or spatulate, saliently dentate, acute, $1-3 \mathrm{~cm}$. long, narrowed at base into margined petioles; calyx-lobes subulate; corolla campanulate, bright blue, $1.5 \mathrm{~cm}$. long.

Abundant in rock crevices in the Olympic Mountains at about $2000 \mathrm{~m}$. altitude.

\section{Family 100. COMPOSITAE. Composite Family.}

Annual biennial or perennial herbs or undershrubs (in ours); leaves without stipules; flowers in a close head on a common receptacle, surrounded by one or more rows of bracts (tegules) 
forming the involucre; heads 1-many, discoid when all the flowers bear tubular corollas, ligulate when the corollas are all strapshaped, radiate when the outer corollas are strap-shaped and the inner tubular, in which case the outer are ray-flowers and the inner disk-flowers; receptacle often covered with bracts or scales (chaff), each subtending a flower; calyx gamosepalous, its tube wholly adherent to the ovary, its limb (pappus) none or cup-shaped or developed into teeth, scales, awns or capillary bristles; corollas alike in all the flowers of the head or dissimilar, either tubular or strap-shaped (ligulate), gamopetalous, epigynous; stamens 5, epipetalous, their anthers usually united into a tube (syngenesious); style 2-cleft at the apex or in sterile flowers usually entire; ovary bicarpellary, inferior, 1-celled, 1-ovuled, with basal placenta; fruit an akene, sometimes surmounted by the pappus, often compressed at right angles to the subtending chaff (laterally compressed) or compressed parallel to the chaff (obcompressed).

\section{SYNOPSIS OF THE TRIBES.}

Corollas strap-shaped in all the flowers of the head; plants with milky juice.

Corollas tubular in all the flowers of the head or strap-shaped in only the marginal ones; plants without milky juice.

Stamens distinct or nearly so.

Stamens united by their anthers into a tube Tribe I. Cichorieae. around the style (syngenesious).

Anthers caudate at base; style-branches neither truncate nor appendaged; heads not radiate.

Receptacle not bristly; corollas not deeply cleft.

Receptacle long bristly; corollas deeply cleft.

Anthers not caudate at base; style branches either truncate or tipped with an appendage.

Heads rayless; style branches clubshaped, obtuse; flowers all perfect, never yellow.

Heads radiate (rarely rayless).

Style branches of perfect flowers flat, or tipped with a distinct appendage; leaves mostly alternate.

Style branches of perfect flowers truncate or appendaged, not flattened; leaves often opposite. Involucre scarious; pappus not capillary.

Tribe 9. INUleaE.

Tribe 10. Cynareae.

Tribe 3. Eupatorieae.

Tribe 4. Astereae.

Tribe 7. Anthemideae. 
Involucre not scarious.

Pappus capillary.

Pappus never capillary.

Receptacle chaffy.

Receptacle not chaffy.

Tribe 8. Senecioneae.

Tribe 5. Heliantheae.

Tribe 6. Helenieae.

Tribe I. CichorieaE. Herbs, with milky juice; leaves alternate; corolla strap-shaped in all the flowers of the head and all the flowers perfect.

Genera nos. 484 to 496.

Tribe 2. Ambrosieae. Herbs, without milky juice, monoecious or dioecious; corollas tubular in the staminate flowers, reduced to a ring or none in the pistillate flowers, never strap-shaped. Genera nos. 497 and 498.

Tribe 3. Eupatorieae. Heads discoid, the flowers all alike, perfect and tubular, never yellow; style-branches thickened upward or club-shaped, obtuse, the stigmatic lines indistinct.

Genera nos. 499 and 500 .

Tribe 4. Astereae. Leaves alternate; heads discoid, the flowers all alike and tubular, or radiate and the outer ones strap-shaped and pistillate; receptacle naked (in ours); anthers not caudate at base; style-branches in the perfect flowers flat.

Genera nos. 501 to 510 .

Tribe 5. Heliantheae. Heads radiate or discoid; involucre not scarious; receptacle chaffy; pappus never capillary, sometimes none; anthers not caudate; style-branches truncate or hairy-appendaged.

Genera nos. 511 to 520 .

Tribe 6. Helenieae. Heads radiate or discoid; involucre little imbricated, not scarious; receptacle usually not chaffy; disk-flowers perfect and fertile; pappus a row of several chaffy scales.

Genera nos. 521 to 526 .

Tribe 7. Anthemideae. Mostly strong-scented; leaves alternate; heads radiate or discoid, the rays, when present, mostly white, the pistillate flowers rarely tubular, the perfect flowers sometimes sterile; tegules imbricated, more or less dry and scarious.

Genera nos. 527 to 533 .

Tribe 8. Senecioneae. Heads radiate or discoid, the involucre little or not at all imbricated, not scarious; receptacle naked; pappus capillary; anthers tail-less.

Genera nos. 534 to 539 .

Tribe 9. InUleat. Heads discoid, the pistillate flowers mostly filiform and truncate; pappus capillary or none; anthers sagittate, the basal lobes attenuate into tails; style-branches with unappendaged obtuse or truncate naked tips.

Genera nos. 540 to 545 .

Tribe ro. Cynareae. Leaves alternate; flowers all tubular and perfect, but the outer sometimes ray-like and neutral; involucre much imbricated; pappus mostly bristly; anthers caudate, long-appendaged at tip; stylebranches short or united, obtuse, unappendaged, smooth, often with a pubescent ring below.

Genera nos. 546 to 550 .

\section{ARTIFICIAL KEY TO THE GENERA.}

Corollas strap-shaped in all the flowers of the head; plants with milky juice.

Pappus none.

484. LAPSANA, 352.

Pappus present.

Pappus of scale-like or plumose bristles. 
Flowers not yellow.

Akenes long-beaked.

Akenes beakless, with a truncate summit.

Flowers yellow.

Receptacle chaffy.

Receptacle not chaffy.

Leafy-stemmed biennials or perennials.

Acaulescent annuals.

Pappus of capillary bristles, never

485. Tragopogon, 352.

486. Cichorium, 353.

487. HYPOCHAERIS, 353.

488. SCORZONELLA, 353.

489. MICROSERIS, 354.

plumose.

Heads solitary; leaves all basal.

Akenes muricate or spinulose at the apex.

Akenes smooth at the apex.

Heads several; leaves not all basal.

Akenes flattened.

Akenes beaked, if shortbeaked flowers not yellow.

Akenes beakless; flowers yellow.

Akenes terete, cylindric or prismatic.

Flowers purplish.

Flowers yellow or white.

Pappus copious, white and soft.

Pappus a single row of rough tawny bristles.

Corollas tubular in all the flowers of the head or

490. TARAXACUM, 355.

491. AGOSERIS, 355 .

495. Lactuca, 359.

496. Sonchus, 360 .

494. Nabalus, 359.

493. CREPIS, 358.

492. Hieracium, 356. strap-shaped in only the marginal ones; plants without milky juice.

Ray-flowers none; corollas all tubular.

Flowers of the head not all alike, some heads having imperfect flowers.

Perfect and imperfect flowers in the same head.

Marginal flowers neutral and sterile, often larger than the central ones, resembling ray flowers.

Marginal flowers perfect or pistil-

546. Centaurea, 393. late and fertile, not resembling ray flowers.

Pappus of capillary bristles.

Tegules in one row.

534. Petasites, 382

Tegules in several rows.

Pappus a short crown or none.

Leaves entire or nearly so, ovate.

Leaves incised, lobed or dissected, or if entire lanceolate.

Pistillate flowers apetalous.

Pistillate flowers with

531. Cotula, 381.

545. Adenocaulon, 393. tubular corollas. 
Heads in a corymb; pappus a short crown.

532. Tanacetum, 381.

Heads in a raceme or panicle; pappus none.

Staminate and pistillate flowers in 533. Artemisia, 381. different heads.

Pappus capillary; fertile involucre not bur-like.

Leaves prickly; heads large.

Leaves not prickly; heads small.

Pappus of staminate flowers either club-shaped or barbed at the apex.

Pappus of all the flowers alike and neither clubshaped nor barbed.

Pappus none; fertile involucre bur-like.

Bracts of staminate heads separate; bur large, with many tegules.

Bracts of staminate heads united; bur small, with 1-4 tegules.

541. Antennaria, 390.

548. Cirsium, 394.

542. Anaphalis, 392.

497. Xanthium, 361.

498. Gaertneria, 361.

Flowers of the heads all perfect and alike.

Pappus of separate capillary bristles.

Flowers whitish, cream-colored or purplish.

Leaves in whorls of 3 to 6 .

Leaves alternate or opposite. Heads about 10 -flowered. Heads about 40 -flowered. Flowers yellow or brownish.

Tegules in 3 or 4 rows.

Tegules in 1 row or nearly so. Involucre hemispheric to rotate.

Involucre campanulate or cylindric.

Heads many-flowered. 539. Senecio, 386.

Pappus not of separate capillary Heads 4-7-flowered. 536. RaINIERA, 383. bristles.

Pappus of numerous bristles united into a ring at the base.

Filaments monadelphous below.

Filaments distinct.

499. EUPATORIUM. 361.

535. LUiNA, 383.

500. Coleosanthus, 362.

503. HOORE BEKIA, 363.

506. ERIGERON, 366.

Leaves never prickly. 550. SAUSSUREA, 396.

Leaves more or less prickly.

548. Cirsium, 394.

Pappus not of bristles united in a ring. 
Pappus of rigid backwardlybarbed awns.

Pappus not of backwardly-

515. BIDENS, 374. barbed awns.

Pappus of numerous separate short rigid or chaffy bristles.

Pappus none or a minute crown.

Involucre scarious.

Involucre not scarious.

Heads solitary. Heads in clusters.

Disk-flowers 15.

Disk-flowers numerous.

Ray-flowers present, at least some of the

549. ARCTIUM, 395.

530. Matricaria, 380.

517. RUDBECKIA, 375.

511. M ADIA, 372 .

540. Psilocarphus, 390. marginal flowers having strap-shaped corollas.

Pappus none.

Involucre scarious.

Receptacle naked.

Receptacle chaffy.

529. Chrysanthemum, 380.

Involucre narrow; rays short. 527. ACHILLEA, 379.

Involucre broad; rays conspicuous.

528. ANTHEMis, 379.

Involucre not scarious.

Akenes all laterally compressed. 511. MAdIA, 372.

Akenes or at least part of them turgid or obcompressed.

Tegules not at all enclosing the ray akenes.

Tegules at least partly enclosing the ray akenes.

Ray akenes turgid, partly enclosed by the tegules.

Ray akenes usually obcompressed, wholly enclosed by the tegules.

Ray akenes straight, each enclosed by the basal part of the tegule.

Ray akenes curved, each enclosed by the whole tegule.

Pappus present, at least in the disk-

518. BALSAMORRHIZA, 376.

513. Hemizonia, 374.

514. LAgophyLla, 374.

512. Hemizonelia, 374.

flowers.

Pappus not of capillary bristles.

Receptacle chaffy.

Pappus of scales or awns.

Awns 2, or 4, retrorsely barbed.

Awns 2, barbless.

Pappus crown-like or of

515. Bidens, 374.

516. COREOPSIS, 375. 
short chaffy teeth or awns.

Rays pistillate and fertile.

Rays neutral.

Receptacle not chaffy.

Tegules in one row.

Akenes obpyramidal; receptacle naked.

Akenes linear, more or less 4-angled; receptacle beset with bristly points.

Tegules distinct.

Tegules united into a cup.

Tegules in more than one

519. Wyethia, 376.

520. Helianthus, 377. row.

Tegules in many rows.

Tegules in two or three rows.

Receptacle bristly; pappus present.

Receptacle naked; pappus present or none.

Pappus of 4 or 5 truncate scales, erose or lacerate at the tip or nearly entire.

526. Helenium, 379.

522. BAERIA, 377.

523. ERIOPHYLLUM, 378.

501. GRINDELIA, 362.

525. Gaillardia, 378.

Pappus of capillary bristles.

Pappus none.

524. Hulsea, 378.

521. JAUMea, 377.

Ray-flowers not yellow.

Tegules in 1 or 2 series, narrow; ray-flowers usually narrow and numerous.

Tegules in 2-5 series; rayflowers broader, less numerous.

Involucre narrow, with rigid bracts; ray-flowers white, 4 or 5 .

507. Sericocarpus, 369.

Involucre turbinate or hemispheric; rayflowers more than 5 . Stems scape-like. Stems leafy.

Tegules dry and chartaceous, closely appressed.

506. ERIGERON, 366.

Tegules more or less herbaceous and

Ray-flowers yellow. spreading.

508. Oreostemma, 370.

509. Eucephalus, 370.

Pappus double, the outer row very short.

510. Aster, 371.

502. Chrysopsis, 363. 
Pappus in one row.

Heads in panicles.

Panicle thyrsoid; receptacle alveolate.

Panicle flat-topped; receptacle fimbrillate.

Heads solitary or in cor-

504. Solidago, 364.

505. Euthamia, 366. ymbs.

Leaves all or mostly opposite.

538. ArNicA, 384.

Leaves alternate.

Heads large, $1.5 \mathrm{~cm}$.

or more

broad.

Heads $5 \mathrm{~cm}$. or

more broad.

Heads less than

$3 \mathrm{~cm}$. broad. 503. HoOREBEKIA, 363.

Heads small, $1 \mathrm{~cm}$. or less broad.

Involucre campanulate.

Involucre hem-

539. Senecio, 386. ispheric or broader.

Tegules 810, broad. 537. Crocidium, 383.

Tegules numerous, narrow.

506. ERIGERON, 366.

484. LAPSANA. NIPPLE-WORT.

Annuals with loosely branched leafy stems and milky juice; heads 8-12-flowered; involucre narrowly cylindrical, consisting of 8 principal tegules with smaller calyculate ones at the base; flowers yellow; receptacle naked; akenes oblong-obovoid; pappus none.

Lapsana communis L. Glabrous above, somewhat pubescent below; stem erect, branched at top, 30-100 cm. high; leaves thin, the lower ovate, somewhat dentate, petioled, of ten with 2-6 lobes at base, the upper oblong to lanceolate, acute, sessile, entire or subentire; heads numerous in a flat-topped inflorescence; involucre cylindric; principal tegules about 8 , linear, 4-5 mm. long, with several smaller ones at base.

Common in waste places; introduced from Europe.

\section{TRAGOPOGON.}

Stout leafy-stemmed and usually branching biennials or perennials, with milky juice; leaves entire, grass-like, clasping; flowers yellow or purple, in large solitary heads; involucre simple, of several equal bracts; pappus of numerous long-plumose bristles; corollas all ligulate; akenes narrowly fusiform, 5-10-ribbed, long-beaked. 
Tragopogon porrifolius L. Salsify. Oyster Plant. Biennial, glabrous throughout, the stout stems about $1 \mathrm{~m}$. high; leaves lanceolate, attenuate from the broader somewhat clasping base, 10-15 cm. long; peduncles long and stout, swollen under the head; involucral bracts lanceolate, acuminate, $4-5 \mathrm{~cm}$. long, exceeding the violet rays; outer akenes roughened, the inner smooth, $1 \mathrm{~cm}$. long, attenuate into a beak of equal length; pappus brownish, as long as the beak, plumose nearly to the tip.

Escaped from gardens and spreading.

486. CICHORIUM. CHICORY.

Perennials with thick fleshy roots, branched stems and milky juice; flowers blue, rarely purple or white; heads several-manyflowered; involucre double, herbaceous, the inner 8-10 tegules coriaceous at base, the outer 4 or 5 short and spreading; receptacle naked; akenes angled, striate; pappus crown-like, composed of numerous short blunt scales in 2 or more series.

Cichorium intybus L. Perennial, somewhat pubescent, especially below; stems stout, $60-120 \mathrm{~cm}$. high, stiffly branched; basal leaves lanceolate or spatulate, coarsely dentate or runcinately lobed, petioled, 8-15 cm. long; cauline leaves oblong to lanceolate, dentate, auricled and clasping at base; heads numerous, in small clusters, sessile or short-peduncled; principal tegules about 8; flowers bright blue.

A native of Europe, naturalized in fields.

\section{HYPOCHAERIS.}

Perennials with milky juice and slender sparingly branched stems; leaves mostly basal and rosulate; heads many-flowered; involucre campanulate, slightly imbricated; flowers yellow; receptacle chaffy, the bracts narrow and scarious; akenes 10ribbed, oblong to fusiform, at least 9 of the inner ones beaked; pappus composed of plumose bristles.

Leaves hirsute; akenes all beaked.

Leaves glabrous or nearly so; outer akenes beakless.

H. radicata. H. glabra.

Hypochaeris radicata L. Gosmore. Stems $20-40 \mathrm{~cm}$. high, erect, loosely branched above, glabrous or nearly so; leaves all basal, oblanceolate to obovate, coarscly toothed or lobed, hairy on both sides, $5-15 \mathrm{~cm}$. long; heads $2-3 \mathrm{~cm}$. broad; involucre cylindric, the tegules linear, acute; akenes all beaked, the beaks longer than the body.

A very troublesome weed in lawns and pastures; introduced from Europe.

Hypochaeris glabra L. Very similar to $H$. radicata; leaves glabrous or nearly so; heads smaller, the ligulate corollas but little longer than the involucre; outer akenes beakless but the inner ones beaked.

Sparingly established as a weed; introduced from Europe.

\section{SCORZONELLA.}

Perennials or biennials with fleshy fusiform root, milky juice, and mostly basal leaves; heads many-flowered, on long naked peduncles; involucre campanulate, loosely imbricated with 2 or 3 
series of tegules, the outer ones calyculate; flowers yellow; receptacle naked; akenes 8-10-ribbed, broadest at the truncate summit; pappus bristles 5 or 10 , broadened and scale-like at base, the long tip scabrous to plumose.

Leaves all basal, entire or nearly so.

Leaves mostly dentate or lobed, one or more cauline.

Pappus scales each attenuate into an awn-like tip.

Pappus scales abruptly awned.

S. borealis.

S. leptosepala.

S. laciniata.

Scorzonella borealis (Bong.) Greene. (Apargidium boreale (Bong.) T. \& G.) Glabrous; leaves all basal, linear-lanceolate, entire or obscurely denticulate, 6-15 cm. long, narrowed at each end; scapes 10-30 cm. high; involucre 12-15 mm. high; principal tegules $10-15$, lanceolate, acuminate, with as many shorter ones; akenes columnar; pappus barbellate, brownish.

Wet meadows, Alaska, southward in the mountains to northern California.

Scorzonella leptosepala Nutt. Glabrous; stems slender, $30-50 \mathrm{~cm}$. high; leaves linear to lanceolate, entire, dentate or variously pinnatifid; involucre 12 $16 \mathrm{~mm}$. high; tegules 6-12, lanceolate or the outer ovate-lanceolate, all gradually attenuate; akenes columnar; pappus scales 8 or 10, ovate-lanceolate to lanceolate, gradually tapering into the awn.

Washington to California in low meadows; first collected by Nuttall near the mouth of the Willamette River.

Scorzonella laciniata (Hook.) Nutt. Herbage glabrous, somewhat glaucous; stems $30-50 \mathrm{~cm}$. high, few-leaved, sparingly branched; leaves narrowly lanceolate, mostly incisely pinnatifid into narrow lobes, rarely only toothed or entire, $10-30 \mathrm{~cm}$. long; involucre $2-3 \mathrm{~cm}$. high; tegules lanceolate, broadest at base, abruptly acuminate; akenes columnar, $4 \mathrm{~mm}$. long; scales of the pappus $8-10$, entire, the body triangular ovate, tipped with a bristle 8 or 9 times longer.

Open prairies, Washington to California. S. procera (Gray) Greene has also been reported from within our limits but the specimens seen are immature and doubtful. It is similar to S. laciniata but stouter, the leaves most often entire or nearly so; heads larger; akenes $6 \mathrm{~mm}$. long with brownish pappus scales abruptly attenuate and long-awned.

\section{MICROSERIS.}

Acaulescent glabrous annuals with milky juice; leaves entire or variously lobed or cleft; heads nodding when in bud; involucre cylindric or hemispheric; tegules in 2 or 3 series, the outer very short, the inner thin, subequal, acuminate; receptacle flat, alveolate; ligulate corollas yellow; akenes cylindric, 8- or 10ribbed; scales of the pappus 5 or 10 , rarely 4 or 8 , broad at base, tapering and awn-like above, scabrous, never plumose.

Microseris bigelovii Gray. Annual; leaves lanceolate to linear, entire or dentate or pinnately lobed or parted, 3-6 cm. long; scapes 10-30 cm. high; involucre campanulate, $6 \mathrm{~mm}$. high, the principal tegules lanceolate, acute, the calyculate ones of two lengths; akenes $4-5 . \mathrm{mm}$. long, oblong, not contracted at the summit, the outer ones sometimes villous; pappus-scales brown, oblonglanceolate to ovate-lanceolate, the awns two or three times as long as the body.

Vancouver Island and Oregon to California; not known from Washington. 
490. TARAXACUM.

Acaulescent biennials or perennials, with milky juice; leaves radical, pinnatifid; heads large, on scapes; flowers yellow; receptacle flat, naked; involucre of 2 rows of tegules; pappus of copious and white capillary bristles which are not plumose; corollas all ligulate; akenes oblong or fusiform, angled, about 10 -ribbed, attenuate at base, with a long filiform beak at the apex.

Taraxacum taraxacum (L.) Karst. Dandelion. Glabrous or loosely pubescent when young; leaves oblong or oblanceolate, variously pinnatifid, the lobes usually toothed and turned backward, $10-20 \mathrm{~cm}$. long; peduncles 10-30 cm. high; involucre cylindric, the inner tegules either linear or linearlanceolate, the outer similar but shorter and recurved; heads many-flowered; ray-flowers yellow; akenes brownish, spinulose above, the pyramidal apex abruptly narrowed into a slender beak twice as long as the body; pappus white, copious.

A common weed, introduced from Europe.

\section{AGOSERIS.}

Acaulescent annuals or perennials, with milky juice; leaves radical, clustered; heads solitary, on scapes; flowers yellow, rarely orange or purplish; tegules in a few rows; receptacle flat, not chaffy; pappus of copious white capillary bristles, which are not plumose; corollas all ligulate; akenes oblong or linear, terete, 10 -ribbed, the apex contracted into a neck or prolonged into a beak.

Ours all perennials.

Akenes beakless; leaves glabrous; alpine plant.

A. alpestris.

Akenes beaked.

Leaves glaucous and thinly tomentose; beak of akene short, stout, nerved.

Leaves not glaucous; beak of akene slender, nerveless.

Beak much longer than the body of the akene.

Heads $2 \mathrm{~cm}$. high.

Heads $2.5-3 \mathrm{~cm}$. high.

Beak about as long as the body of the akene.

Flowers orange; leaves mostly entire.

Leaves lanceolate-spatulate; beak shorter than the body of the akene.

Leaves narrowly linear; beak longer than the body of the akene.

Flowers yellow; leaves mostly lobed.

A. glauca aspera.

A. laciniata.

A. grandiflora.

Akenes with beak $12-15 \mathrm{~mm}$. long; leaves mostly entire.

Akenes with beak 8-10 mm. long; leaves mostly lobed.

A. aurantiaca.

A. gracilenta.

A. elata.

A. apargioides.

Agoseris alpestris (Gray) Greene. Glabrous; leaves spatulate to lanceolate, pinnately lobed or cleft into broad lobes or parted into narrow divisions; scape erect, 4-10 cm. high; involucre campanulate, $15 \mathrm{~mm}$. high; tegules in 2 indistinct series, all acuminate, the outer ovate-lanceolate; flowers yellow; akenes columnar, 10-ribbed, beakless, as long as the capillary white pappus.

On the higher peaks of the Cascade Mountains; first found on Mount Adams by Suksdorf. 
Agoseris glauca aspera (Rydb.) Pipcr. Perennial, the whole plant thinly white tomentose; leaves linear to lanceolate, entire or sparsely denticulate, 5-10 cm. long; scapes $6-20 \mathrm{~cm}$. high; involucre campanulate, $2 \mathrm{~cm}$. high; tegules loosely imbricated in 2-3 series, the outer ones shorter, broadly lanceolate, acutish, tomentose, the inner glabrous and acute; ligulate corollas pale yellow; akenes fusiform, 10-12 $\mathrm{mm}$. long, tapering into a stout beak shorter than the body; pappus copious, white, the bristles scabrous.

In the Cascade Mountains at about $2000 \mathrm{~m}$. altitude.

Agoseris laciniata (Nutt.) Greene. Glabrous or sparsely pubescent; leaves lanceolate, saliently dentate or pinnatifid into linear lobes, $10-20 \mathrm{~cm}$. long; scapes $30-60 \mathrm{~cm}$. high; involucre somewhat tomentose at base or glabrate, 2-3 cm. long; flowers pale yellow; akenes about $15 \mathrm{~mm}$. long, the slender beak several times as long as the body; pappus shorter than the beak, bright white.

In dry open woods, common.

Agoseris grandiflora (Nutt.) Greene. Perennial, loosely pubescent or glabrate; leaves lanceolate or oblanceolate, attenuate-acuminate to obtuse, mostly pinnatifid into numerous lobes, $10-20 \mathrm{~cm}$. long; peduncles stout, 30-60 $\mathrm{cm}$. high; involucre campanulate, tomentose at base, 3-4 cm. high, the bracts in about 3 series; akenes fusiform, acutely 10 -ribbed, $6 \mathrm{~mm}$. long, attenuate into a slender beak, $20 \mathrm{~mm}$. long; pappus bright white, soft and capillary, much shorter than the beak.

In dry ground, Willamette Valley, where first collected by Nuttall; common east of the Cascade Mountains.

Agoseris aurantiaca (Hook.) Grcene. Sparsely pubescent to nearly glabrous; leaves spatulate to lanceolate, entire or denticulate, rarely toothed or incised, obtuse, short-petioled; scapes $20-40 \mathrm{~cm}$. high; involucre campanulate, $15-20 \mathrm{~mm}$. high; principal tegules lanceolate and acute, the outer ones oblong, obtuse; flowers orange, becoming purplish; akenes cylindraceous, tapering into a beak as long as the body.

Common in alpine meadows at about $2000 \mathrm{~m}$. altitude.

Agoseris gracilenta (Gray) Greene. Glabrous; leaves narrowly lanceolate or linear, mostly entire; scape slender, $30-50 \mathrm{~cm}$. high; involucre campanulate; tegules lanceolate, acute, glabrous except at base; flowers orange; akenes fusiform, the body $6-8 \mathrm{~mm}$. long, the beak $8-10 \mathrm{~mm}$. long.

Alpine meadows in the Olympic and Cascade Mountains.

Agoseris elata (Nutt.) Greene. Glabrous, somewhat glaucous; leaves spatulate to lanceolate, dentate to pinnatifid, $15-30 \mathrm{~cm}$. long, thickish in texture; scape $15-50 \mathrm{~cm}$. high; head $3 \mathrm{~cm}$. high; involucre hemispheric; tegules lanceolate, acute, pubescent; akenes 6-7 $\mathrm{mm}$. long, the beak as long as the body.

Prairies, not common. First found by Nuttall near the estuary of the Willamette River.

Agoseris apargioides (Less.) Greene. Sparsely pubescent, becoming glabrate; caudex stout; leaves spatulate, mucronate, somewhat dentate, 7-10 $\mathrm{cm}$. long; scapes exceeding the leaves, $10-15 \mathrm{~cm}$. high; heads $10-12 \mathrm{~mm}$. high; involucre campanulate; tegules green, the outer oblong, mucronate, pubescent, the inner lanceolate, acuminate; akenes $8-10 \mathrm{~mm}$. long, the beak as long as the body.

Sand dunes along the ocean coast. The northern form has been considered distinct from the California form under the name A. maritima Sheldon.

\section{HIERACIUM. HAWKWEED.}

Hispid and hirsute often glandular perennials with milky juice; leaves merely toothed or entire; heads small to medium, panicu- 
late or rarely solitary; flowers yellow or sometimes white; tegules in two rows; receptacle flat, naked; pappus of a single row of rough tawny bristles which are not plumose; corollas all ligulate; akenes oblong or columnar, terete or 4 - or 5-angled, mostly 10 -ribbed or striate, the apex truncate.

Stems many-leaved; involucre imbricated.

H. canadense.

Stems few-leaved; involucre a series of equal tegules and a few short calyculate ones.

Flowers white; involucre nearly glabrous.

Flowers yellow.

Heads small, black-hairy.

Heads larger, not black-hairy.

Involucre densely long-hairy.

Cauline leaves ample, half-clasping at the broad bases.

Cauline leaves much reduced.

Involucre with few or no long hairs.

Leaves nearly smooth.

Leaves hairy.

Leaves densely hirsute.

Leaves thinly white tomentose.

H. albiflorum.

H. gracile.

H. longiberbe.
H. scouleri.

H. cynoglossoides.

H. griseum.

H. cinereum.

Hieracium canadense Michx. Somewhat scabrous throughout; stems stout, $30-120 \mathrm{~cm}$. high; leaves numerous, lanceolate, entire or incisely serrate, sessile and somewhat clasping at base, gradually smaller upwards, $1-10 \mathrm{~cm}$. long, none clustered at base; heads corymbed, rarely solitary, on stout peduncles; involucre hemispheric, puberulent or glabrous, sometimes glandular, $1-2 \mathrm{~cm}$. broad; tegules in 2-3 series, the uppermost loose; akenes columnar; pappus brownish.

In open ground, very rare west of the Cascade Mountains; Coupeville, Gardner.

Hieracium albiflorum Hook. Stems slender, erect, 50-80 cm. high, villous $9 / 2 / 20$ Mt below; leaves oblong or oblong-spatulate, thin, entire or faintly toothed, the alme cmal lower tapering into broad petioles, the upper mostly sessile, all beset with delt of Bind sparse villous white hairs, especially the lowest; heads 15-30-flowered; involucre narrow, glabrous or with a few hairs, the tegules linear-lanceolate, pale; tegules guit akenes strongly striate.

Very common in dry open woods.

Hieracium gracile Hook. Tufted; stems usually several, $15-30 \mathrm{~cm}$. high; leaves mostly basal, oblong-spatulate, entire or nearly so, broadly petiolate, $3-8 \mathrm{~cm}$. long, glabrous or merely puberulent; heads several, racemose or corymbose; involucre $8 \mathrm{~mm}$. high, blackish with both hirsute and glandular hairs; akenes cylindric; pappus sordid or fuscous.

Common in alpine meadows at $1500-2000 \mathrm{~m}$. altitude.

Hieracium longiberbe Howell. Herbage sparingly hirsute with long white hairs; stems $30-50 \mathrm{~cm}$. high; leaves lanceolate, entire or denticulate, $6-15 \mathrm{~cm}$. long, the cauline scarcely reduced and half-clasping by the broad base; heads few in a cyme; involucre $12 \mathrm{~mm}$. high, densely shaggy with long white hairs, not glandular; principal tegules 10-20, lanceolate, acuminate.

On perpendicular cliffs along the Columbia River.

Hieracium scouleri Hook. Erect, $30-60 \mathrm{~cm}$. high, densely beset throughout with long soft white hairs swollen at the bases; basal leaves lanceolate or oblanceolate, entire, acute or obtuse, 10-20 cm. long, tapering into margined 
petioles; cauline similar, sessile, 5-12 $\mathrm{cm}$. long; inflorescence corymbose or paniculate, glandular; involucre $1 \mathrm{~cm}$. high, very glandular and long-villous; flowers yellow; akenes columnar; pappus fuscous.

In open prairies; first collected at the mouth of the Columbia River by Scouler; very variable in the amount and length of the pubescence. It is by no means clear that the three following species are really valid as different forms are not infrequently found growing close together. They deserve careful field study.

Hieracium cynoglossoides Arvet-Touv. Very similar to $H$. scouleri; lowermost leaves more or less setose-hairy, the upper ones nearly glabrous; involucre glandular and more or less hirsute with short black hairs.

In open prairies, British Columbia to Wyoming and Oregon.

Hieracium griseum Rydb. Very similar to $H$. cynoglossoides, differing only in the leaves being densely hirsute as in $H$. scouleri.

In open prairies, with the same range as $H$. cynoglossoides.

Mt Adams Hieracium cinereum Howell. Tufted from stout creeping rootstocks; herbage cinereous with a minute tomentum; stems $15-25 \mathrm{~cm}$. high, leafy only toward the base; leaves lanceolate, acute to acuminate, sparsely hirsute, denticulate, $7-10 \mathrm{~cm}$. long; petioles broad; heads in a close cyme; involucre 8-10 mm. high; principal tegules linear, scarious-margined, covered with a fine cinerous tomentum and bearing a row of short black bristles on the midnerve; outer tegules few and short; pappus sordid.

Table Rock, Clackamas County, Oregon, Howell.

\section{CREPIS.}

Annual, biennial or perennial plants with milky juice; heads several-many-flowered; flowers yellow; involucre usually double; receptacle flat, naked, sometimes alveolate; pappus simple, of copious and white capillary bristles which are not plumose; corollas all ligulate; akenes oblong, linear or fusiform, nearly terete or obtusely angled, 10-20-ribbed, generally contracted at base and more tapering at the apex, sometimes slightly beaked.

Akenes dilated at the insertion of the pappus; low glaucous plant with running rootstocks.

Akenes not dilated at the insertion of the pappus; plants without rootstocks.

Foliage mostly white-pubescent, scurfy; perennial. $\quad C$. occidentalis.

Foliage green, not canescent nor scurfy; annuals or biennials.

Involucres 6-8 $\mathrm{mm}$. high; akenes 10 -striate.

Involucres 8-12 $\mathrm{mm}$. high; akenes 13-striate.

C. nana.

C. capillaris.

C. biennis.

Crepis nana Richards. Glabrous and somewhat glaucous; stems tufted from creeping rootstocks, branched from the base, $3-5 \mathrm{~cm}$. high; leaves obovate to spatulate, entire, toothed or lyrately lobed, $2-5 \mathrm{~cm}$. long, long-petioled; heads solitary or few, on naked peduncles or stems; involucre cylindric; tegules $8-10$, linear, obtuse; flowers 8-14, yellow, turning pink; akenes linear, slightly fusiform, beakless, 10 -striate.

In rocky soil, at high altitudes in the mountains, rare; Olympic Mountains, Flett; Mount Adams, Suksdorf.

Crepis occidentalis Nutt. Perennial, erect, thinly white-tomentose through- 
out, 8-30 cm. high; stems usually with few erect branches; leaves broadly lanceolate, acute or acuminate, $5-10 \mathrm{~cm}$. long, pinnately toothed or cleft into narrow lobes, short-petioled or sessile; heads on stout peduncles; involucre oblong-cylindric, $12-18 \mathrm{~mm}$. long, tomentose and with a few large black glandular hairs, the principal tegules lanceolate, acuminate, the smaller basal tegules relatively broader; flowers 25-30; akenes brownish, fusiform, 8-10 mm. long, 10-18-ribbed, longer than the bright white pappus.

Very rare in our limits; Olympic Mountains, Flett. Common east of the Cascade Mountains.

Crepis capillaris (L.) Wallr. (C. virens L.) Nearly glabrous, somewhat hirsute below; stems erect, 30-90 cm. high; leaves spatulate-lanceolate, pinnatifid or simply toothed, 6-15 $\mathrm{cm}$. long, the basal ones short-petioled, the cauline sagittate-clasping at base; heads in loose cymes; involucre pubescent or glandular, $6-8 \mathrm{~mm}$. high.

A common weed in fields and waste places. Introduced from Europe.

- Crepis biennis L. Somewhat pubescent; stems erect, 60-90 cm. high; leaves oblong-spatulate, runcinately pinnatifid, 5-15 cm. long, the upper ones clasping at base; heads in cymes; involucre 8-12 mm. high, pubescent.

Vancouver Island, Macoun. Introduced from Europe.

\section{NABALUS.}

Perennial leafy-stemmed plants with fusiform tuberous roots and milky juice; inflorescence paniculate or racemose; heads 5-30-flowered, mostly nodding; involucre narrowly cylindric, of 5-14 linear tegules and a few calyculate ones at base; flowers cream-colored to purple; receptacle naked; akenes terete columnar or angled, striate; pappus of numerous whitish to brownish rather rigid capillary bristles.

Nabalus hastatus (Less.) Heller. (Prenanthes alata Gray.) Glabrous, stems 30-60 cm. high, simple or branched; leaves deltoid-triangular, acute; irregularly dentate, the lower with margined petioles, the upper sessile; heads in a loose corymb, 10-15-flowered; involucre campanulate, with 8-10 principal tegules; flowers purplish; akenes terete or tapering at summit.

Gravelly stream banks and on moist cliffs in the mountains.

\section{LACTUCA. WILd LetTUCE.}

Leafy-stemmed herbs, with milky juice; flowers yellow or blue or whitish, in paniculate few to many-flowered heads; tegules in 2 -few rows, the outer shorter; receptacle flat, naked; pappus of copious very short and fine capillary bristles which are not plumose; corollas all ligulate; akenes flat or flattish, narrowed at the summit or beaked.

Pappus brown; flowers whitish; leaves not spiny.

L. spicata.

Pappus white; flowers not whitish.

Flowers yellow; leaves spiny.

Flowers blue; leaves not spiny.

L. scariola.

L. pulchella.

Lactuca spicata (Lam.) Hitchc. Biennial, erect, 1-3 m. high, glabrous or nearly so, pale green, very leafy; leaves coarsely pinnatifid, the lobes irregularly toothed, the uppermost sessile and sometimes clasping; heads in a 
long narrow panicle; involucre $10 \mathrm{~mm}$. high; flowers bluish to whitish; akenes short-beaked.

In moist ground, in open woods, and on banks.

Lactuca scariola integrata Gren. \& Godr. Prickly Lettuce. Annual or biennial, erect, 1-2 m. high, glabrous and somewhat glaucous; leaves oblong or lanceolate, spiny on the margin and midrib, entire or irregularly toothed or cleft, sessile and usually auriculate-clasping at base, 5-20 cm. long, the uppermost much reduced; heads in large loose panicles; involucre narrowly cylindric, glabrous, $10-12 \mathrm{~mm}$. long, the outer tegules much shorter than the inner ones; flowers yellow; akenes flattened, narrowed into a beak longer than the body, as long as the bright white pappus.

A weed, introduced from Europe.

Lactuca pulchella (Pursh) DC. Blue-flowered Lettuce. Perennial, erect, leafy, 30-90 cm. high, puberulent or glabrate; leaves lanceolate, tapering at each end, acute or cuspidate, entire or sinuately toothed or lobed, $5-15 \mathrm{~cm}$. long; lower leaves petioled; heads loosely panicled; involucre cylindric, glabrous, 12-14 $\mathrm{mm}$. long, the outer tegules successively shorter, all lanceolate, acute; flowers blue or violet; akenes flat, not margined, $4 \mathrm{~mm}$. long, very short beaked; pappus copious, white.

Vancouver, Washington; rare in our limits.

\section{SONCHUS. SOW THISTLE.}

Leafy-stemmed mostly glabrous generally coarse herbs, with milky juice; flowers yellow, in corymbose or paniculate heads; tegules imbricated, the outer shorter; receptacle flat, naked; pappus of copious very fine and short capillary bristles, which are not plumose; corollas all ligulate; akenes flat or flattish, truncate, not beaked.

Heads large; involucre glandular-pubescent.

S. arvensis.

Heads medium-sized; involucre glabrous.

Leaves prickly-toothed; auricles rounded.

Leaves with soft teeth; auricles acute.

S. asper.

S. oleraceus.

Sonchus arvensis L. Perennial, glabrous to the inflorescence; stems 60-100 $\mathrm{cm}$. high, erect; lower leaves oblanceolate in outline, runcinately lobed, spinulose-denticulate, petioled, 10-30 $\mathrm{cm}$. long, the upper lanceolate, clasping at base; heads $3-5 \mathrm{~cm}$. broad; involucre glandular; ligulate corollas bright yellow; akenes longitudinally ribbed.

A weed, sparingly introduced from Europe.

Sonchus asper (L.) Hill. Annual, erect, $30-90 \mathrm{~cm}$. high, somewhat glaucous, glabrous below, glandular above; lower leaves ovate or broadly spatulate, obtuse or acute, rarely lobed, spinulose-dentate, the petioles margined; upper leaves oblong or oval, sessile and clasping at base, acuminate; heads cymosely arranged; involucre cylindric-campanulate, about $1 \mathrm{~cm}$. broad, glabrous; flowers yellow; akenes flat, margined, 3-nerved on each side.

A common weed, introduced from Europe.

Sonchus oleraceus L. Annual, glabrous, pale green; stems usually 60-90 $\mathrm{cm}$. high, erect, simple or but little branched; leaves pinnately cleft or parted, $10-20 \mathrm{~cm}$. long, the terminal segment large, triangular, denticulate, the lateral lobes much smaller; lower leaves petioled, the upper auriculate-clasping; involucre cylindric, glabrous; akenes flat, marked with longitudinal and cross ribs.

A weed, introduced from Europe. 


\section{XANTHIUM. COCKLEBUR.}

Annual herbs; leaves alternate, petioled; heads monoecious, in axillary or terminal clusters or short interrupted spikes, the pistillate heads 2 -flowered and below the several-flowered staminate ones; involucre of the staminate heads of several distinct narrow tegules; involucre of the pistillate heads bur-like, ovoid or oblong, closed, indurated, 2-celled, 2-flowered, armed all over with strongly hook-tipped spines; pappus none; corolla none; akenes obovoid thick.

Xanthium varians Greene. Stems simple or branched, $20-40 \mathrm{~cm}$. high, sparsely setose; leaves mostly ovate or rhombic-ovate, coarsely and doubly serrate-dentate, scabrous on both surfaces; fruiting burs ovoid, $15-20 \mathrm{~mm}$. long, armed with about 70 spines half as long as the diameter of the body; beaks stout, incurved at tip.

Sandy banks of the Columbia River.

498. GAERTNERIA.

Herbs (in ours) with mostly alternate leaves; sterile and fertile heads separate or sometimes mixed in the inflorescence; fertile involucre 1-4-celled, bur-like, armed with spines in more than one row; pistils solitary in each cell of the involucre.

Ours all seashore perennials.

Leaves 2-3 times pinnately parted.

Leaves cuneate-obovate, serrate or incised.
G. bipinnatifida.

G. chamissonis.

Gaertneria bipinnatifida (Nutt.) Kuntze. Herbage canescently hirsute; stems prostrate or procumbent, branched, $30-90 \mathrm{~cm}$. long; leaves ovate in outline, 3-5 cm. long, once or twice pinnatifid into oblong segments; staminate heads in a dense raceme; fruiting involucre ovoid-fusiform, nearly glabrous, armed with short subulate flattened spines.

Common on high sandy or gravelly sea-beaches.

Gaertneria chamissonis (Less.) Kuntze. Stems stout, prostrate or procumbent, $60-90 \mathrm{~cm}$. long, hirsutely pubescent; leaves oblong to oval, cuneate at base, obtusely serrate or the lower ones of ten incised, silvery-silky, petioled; fruiting involucre 2 -flowered, sparsely hirsute, armed with very short flat spines.

On the ocean coast, Vancouver Island to California.

\section{EUPATORIUM.}

Mostly perennial herbs; leaves whorled (in ours) mostly resiniferous-atomiferous; heads discoid, in cymes or panicles, rarely solitary; tegules few to numerous, receptacle naked; pappus of numerous scabrous capillary bristles, mostly in 1 row.

Eupatorium maculatum L. Perennial, stout, erect, 1-3 m. high, simple or branched near the top; herbage pubescent; leaves in whorls of $3-6$, ovate to oblong-ovate, incisely toothed, thickish and somewhat rugose, $10-30 \mathrm{~cm}$. long; heads numerous in a rather flat-topped cyme; involucre cylindric; tegules oblong, purplish, imbricated in 5 or 6 series, the outer shorter; flowers purple.

Sumas, Washington, Gorman; British Columbia eastward to Newfoundland and the Atlantic states. 


\section{COLEOSANTHUS.}

Herbs or undershrubs with opposite or alternate leaves; heads whitish; involucre campanulate, the tegules striate-nerved, imbricated, lanceolate or linear, the outer shorter, none herbaceous; receptacle flat, naked; pappus one row of separate capillary barbed or scabrous bristles.

Coleosanthus grandiflorus (Hook.) Kuntze. Glabrous or puberulent; stems erect, much branched, $60-90 \mathrm{~cm}$. high; leaves triangular-ovate, cordate or truncate at base, acuminate, crenate-dentate, $5-10 \mathrm{~cm}$. long; inflorescence cymose-paniculate: heads drooping, each about 40 -flowered; involucral bracts thin, the outer short and ovate, the inner oblong-linear; akenes minutely hispid, not glandular.

In rocky places along the Columbia River at Wyeth, Oregon, and probably in our limits. First collected by Douglas.

501. GRINDElia. Gum Plant.

Biennial or perennial herbs; leaves sessile or partly clasping; heads yellow, medium or rather large, solitary, terminating leafy branches or occasionally more or less corymbose, many-flowered, gummy; ray-flowers fertile, numerous, narrow, or rarely none; tegules numerous, narrow; receptacle flat or convex; pappus of 2-8 rigid and early-deciduous awns; style-branches tipped with an appendage; akenes compressed or turgid or the outermost somewhat 3-angled.

Heads 6-8 mm. high; tegules stiff, strongly recurved at tip.

Ray-flowers present.

Ray-flowers absent.

G. nana.

G. nana columbiana.

Heads $10-12 \mathrm{~mm}$. high; tegules softer, straight or moderately recurved at tip.

Cauline leaves broadest at base.

Cauline leaves not broadest at base.

Herbage wholly glabrous.

Herbage sparsely pubescent.

G. integrifolia.

G. oregana.

G. oregana wilkesiana.

I Grindelia nana Nutt. Stems erect, $15-60 \mathrm{~cm}$. high, simple or branched above; basal leaves spatulate, petioled, the upper sessile and partly clasping, entire or serrate, glabrous; heads hemispherical, $10-14 \mathrm{~mm}$. broad; bracts with slender revolute tips, sticky-viscid; ray-flowers $16-30,5-8 \mathrm{~cm}$. long; akenes narrow, somewhat 2-toothed at summit; pappus awns 2 or 3 .

In thin soils, usually abundant where found. First found near Fort Vancouver, Washington, by Nuttall. Common in the Willamette Valley.

Grindelia nana columbiana Piper. Ray-flowers wanting; otherwise the same as $G$. nana.

Near Portland, Oregon, and common east of the Cascade Mountains.

Grindelia integrifolia DC. Sparsely villous and pubescent, not glutinous; stems stout, about $50-90 \mathrm{~cm}$. high, of ten branched above; cauline leaves oblong-lanceolate to ovate, membranaceous, entire or sometimes serrate, acute or acuminate, $6-10 \mathrm{~cm}$. long, sessile and broadest at base, the radical petioled; involucre 10-12 $\mathrm{mm}$. high, surrounded by more or less foliaceous bracts; tegules subulate, setaceous. 
Dry prairies, Clarke County, Washington, and southwards. Common in the Willamette Valley.

Grindelia oregana Gray. (G. stricta DC. ?) Glabrous or nearly so and more or less varnished; stems stout, often tufted, $60-90 \mathrm{~cm}$. high; leaves subcoriaceous, oblong-spatulate or the upper lanceolate, mostly acute, entire to sharply denticulate, $6-10 \mathrm{~cm}$. long, the cauline sessile by a narrowed base, the radical petioled; involucre gummy, $10-15 \mathrm{~mm}$. high; tegules subulate; ray-flowers $12-20 \mathrm{~mm}$. long; a kenes truncate; pappus awns 2 or 3.

Common on high sea beaches; $G$. hendersoni Greene is apparently a mere form.

Grindelia oregana wilkesiana Piper n. subsp. Sparsely pubescent throughout with weak white hairs; otherwise like G. oregana.

Gray Harbor, Wilkes Expedition; Nisqually, Wilkes Expedition; Fraser River, Dr. Holmes; Queen Charlotte Islands, Osgood.

\section{CHRYSOPSIS.}

Low herbs; leaves numerous, alternate, sessile; heads solitary or in corymbs with yellow flowers; ray-flowers fertile or sometimes wanting; tegules narrow, acute, scarious-margined; receptacle flat; style-branches with appendages; pappus double, of two kinds, the interior of long copious capillary bristles, the exterior of short bristles or chaffy scales; akenes oblong-linear or ovateoblong, compressed, hairy.

Ray-flowers none; leaves green, hispid-hirsute.

Ray-flowers present; leaves canescent, strigose or hirsute.

C. oregana.

C. villosa.

Chrysopsis oregana (Nutt.) Gray. Herbage hispid-hirsute; stems tufted, 20-30 cm. high, mostly branched; leaves oblong to lanceolate, entire, acute, sessile, 3-5 cm. long; inflorescence corymbose-paniculate, glandular; involucre campanulate; tegules thin, linear to lanceolate, 1-nerved, in several series; akenes oblong; pappus white, capillary.

On gravel bars of streams, Washington to California.

Chrysopsis villosa (Pursh) Nutt. Perennial, the stems decumbent or suberect, $15-30 \mathrm{~cm}$. long, canescent throughout and more or less villous; leaves numerous, oblong or oblanceolate, mostly acute, sessile or nearly so, 2-3 cm. long; heads solitary or corymbed, terminating short leafy branches; involucre hemispherical, $10-15 \mathrm{~mm}$. broad; tegules canescent or nearly glabrous; ray-flowers golden-yellow; akenes obovate, pubescent; outer pappus very short.

Rare west of the Cascade Mountains; Coupeville, Washington, Gardner.

\section{HOOREBEKIA.}

Herbs or low undershrubs; leaves alternate, soft or rigid; heads solitary, terminal, or clustered, many-flowered; ray-flowers fertile or rarely none; involucre imbricated; tegules with or without foliaceous tips; receptacle flat or flattish; pappus tawny or reddish, of copious and unequal capillary bristles, somewhat rigid; style-branches with appendages; akenes turbinate and linear, terete, angled or more or less compressed. mattad

$$
\text { Cow shmbs stems proumbentor mearhy erects } 40-70 \text { cm hi }
$$


Tegules rigid; heads racemose.

H. racemosa.

Tegules not rigid; heads solitary.

H. lyallii.

Hoorebekia racemosa (Nutt.) Piper. Perennial; stems erect, $60-90 \mathrm{~cm}$. high, sparsely soft-hairy; leaves lanceolate, coriaceous, acute, entire, 5-15 $\mathrm{cm}$. long, the cauline sessile, the basal petioled, all somewhat scabrous on both surfaces and with sparse pubescence; heads racemosely or somewhat paniculately arranged, mostly long-peduncled; involucre turbinate or campanulate, $1-1.5 \mathrm{~cm}$. broad, the well-imbricated tegules linear, acute, pubescent, rigid and coriaceous, green-tipped; ray-flowers 6-8 $\mathrm{mm}$. long; akenes pubescent; style-branches filiform; pappus brownish.

In dry ground in the Willamette Valley, where first collected by Nuttall.

Hoorebekia lyallii (Gray) Piper. Viscid-puberulent; stems $10-20 \mathrm{~cm}$. high, leafy, arising from elongated branched rootstocks; leaves soft, oblongspatulate to oblanceolate, $1-5 \mathrm{~cm}$. long; heads solitary, 15-20-rayed; involucre hemispheric; tegules glandular, lanceolate, acute, a few outer ones loose and somewhat foliaceous; akenes glabrous.

In rocky places in the mountains at about $2500 \mathrm{~m}$. altitude, British Columbia to Oregon; rare and local.

\section{SOLIDAGO. GOLDENROD.}

Perennial herbs; leaves alternate; heads small, mostly in panicles or panicled racemose clusters, radiate, the ray-flowers fertile, yellow; involucre imbricated, the tegules usually without herbaceous tips; pappus simple, of a single series of mostly equal and slender scabrous capillary bristles; style-appendages lanceolate or triangular-subulate; akenes terete or angular, 5-12-ribbed.

Branches of the panicle racemiform.

Leaves thick and firm.

Leaves thin.

Heads small, 4-5 $\mathrm{mm}$. long, in very dense panicles.

Heads larger, 5-7 mm. long, in looser panicles.

Branches of the panicle not racemiform.

Tegules acutish; alpine plants.

Leaves mostly acute.

Leaves obtuse.

Tegules obtuse; lowland plants.

Panicle loose, raceme-like.

Panicle dense, branched.

S. tolmieana.

S. elongata.

S. serotina.

S. algida.

S. bellidifolia.

S. vespertina.

S. glutinosa.

Solidago tolmieana Gray. Nearly glabrous; stems $30-40 \mathrm{~cm}$. high, leafy; leaves firm and thick, linear to lanceolate, entire or sparingly serrate at tip, scabrous-ciliolate, $5-8 \mathrm{~cm}$. long; panicle narrowly pyramidal; heads $6 \mathrm{~mm}$. high; tegules thin, lanceolate, acutish.

Gravelly prairies, Washington and Oregon, rare; first collected by Tolmie at Fort Vancouver, Washington. Perhaps not distinct from S. missouriensis Nutt.

Solidago elongata Nutt. Stems mostly tufted, 60-100 cm. high, green, smooth; leaves lanceolate, acute or acuminate, serrate, obscurely 3-nerved, glabrous, smooth or scabrid on the nerves beneath, 6-12 cm. long; panicle pyramidal, very dense, $10-25 \mathrm{~cm}$. long; heads $4-5 \mathrm{~mm}$. high; tegules linear, acute or obtuse; ray-flowers yellow.

In moist meadows; the commonest species of the region. Nuttall's original specimens are from Sauvies Island, Oregon. The species is scarcely distinct from S. lepida DC. collected by Haenke at Nootka Sound. 
Solidago serotina salebrosa Piper. Stems tufted, stout and tall, 90-150 $\mathrm{cm}$. high; leaves lanceolate to oblong-lanceolate, acuminate, 3-nerved, serrate, harshly scabrous on both sides, $6-15 \mathrm{~cm}$. long; panicle somewhat pyramidal, moderately dense, 10-30 cm. long; heads 5-7 mm. high, crowded on the spreading often crowded branches; tegules thin, linear, obtuse; ray-flowers 7-14, yellow; akenes pubescent.

In moist places, not common in our limits.

Solidago algida Piper n. sp. Stems usually tufted, 10-30 cm. high, from a stout branched caudex, glabrous except the ciliation of the leaves and the branches of the panicle; basal leaf blades oblanceolate, entire to serrate or crenate-serrate, mostly acute, firm, glabrous except the ciliate margins, 3-10 $\mathrm{cm}$. long, the margined petioles nearly as long; cauline leaves similar, smaller; inflorescence a dense globose or oblong panicle, 3-7 cm. long; branches of the inflorescence puberulent; heads mostly solitary on the branches, manyflowered; involucre $6 \mathrm{~mm}$. high; tegules linear, thin, scarious and slightly erose at the margins, acute or acutish, glabrous, not glutinous; ray-flowers short, yellow.

The common alpine golden-rod of the Olympic and Cascade Mountains, very closely related to $S$. scopulorum (Gray) A. Nels. and S. ciliosa Greene of the Rocky Mountains but different from both. Olympic Mountains, Piper, 2200, 2199 (type); Elmer 2596; Lamb, 1313; Mount Rainier, Piper, 2158; Smith, 1064; Flett, July 12, 1890; Mount Stuart, Elmer, 1166; Whited, 767; Mount Baker, Stratton; Loomis, Elmer, 562.

Solidago bellidifolia Greene. Glabrous except the scabrous ciliate margin of $8 / 7 / 20 \mathrm{Mt} A$ the leaves; stems 10-30 cm. high; basal leaf-blades thickish, oblong to obovate, rounded at apex, crenate-dentate, $2-5 \mathrm{~cm}$. long, the margined petiole a little shorter; cauline similar, smaller; heads in a dense globose or oblong cluster, 2-10 cm. long; involucre $5 \mathrm{~mm}$. high; tegules linear, obtuse to acutish, rather thin, minutely erose on the margins, glabrous not glutinous; ray-flowers numerous, yellow.

Rocky places at high altitudes, Mount Hood, Mount Adams, and Mount Stuart.

Solidago vespertina Piper n. sp. Glabrous up to the minutely puberulent or sometimes resinous inflorescence; stems erect, $30-60 \mathrm{~cm}$. high; basal leaves spatulate to oblanceolate, thickish, obtuse or sometimes acute, serrate above the middle, narrowed into a margined petiole as long as the blade; cauline leaves similar, smaller, the upper ones sessile; inflorescence narrow, erect, racemose to subpaniculate, $10-15 \mathrm{~cm}$. long, sometimes leafy bracted near the base; heads $6 \mathrm{~mm}$. high, many-flowered; involucre campanulate; tegules oblong, obtuse, thin-margined, nearly glabrous, erect, in about 3 series, the outer successively shorter; ray-flowers few, pale yellow, 3-toothed at apex; akenes puberulent.

In open pine woods, Mason County, Washington, near Union City, Piper 886 (type). Flett 878 from Tacoma differs only in having the involucre varnished. In the Flora of Washington, this species was referred to S. purshii Porter (S. humilis Pursh).

Solidago glutinosa Nutt. Glabrous, but more or less varnished with resin, especially the inflorescence; stems erect, 30-90 cm. high; leaves oblong-lanceolate to oblanceolate, serrate toward the apex, the upper cauline sessile, the basal ones petioled and $8-10 \mathrm{~cm}$. long; heads numerous, in a dense compound virgate or pyramidal panicle, each 5-6 mm. high, 8-15-flowered; tegules oblonglinear, erect, in about 3 series; ray-flowers few, yellow.

Gravelly prairics, Vancouver Island to Oregon. First collected by Nuttall near the mouth of the Willamette River. 


\section{EUTHAMIA.}

Erect scabrous perennials with narrow alternate leaves; flowers in numerous small heads in terminal flat-topped corymbose panicles; heads many-flowered, the ray-flowers yellow, equalling and more numerous than the disk-flowers; receptacle fimbrillate; akenes villous.

Euthamia occidentalis Nutt. Glabrous; stems 90-120 cm. high, erect, branched above; leaves linear, entire, 3-nerved, the principal ones 5-10 cm. long; heads peduncled, in small corymbs; tegules narrow, acute; ray-flowers 16-20. tember.

Common in moist places especially along lake shores; flowering in Sep-

\section{ERIGERON. Fleabane.}

Herbs; very similar to Aster, but differing in the usually naked peduncled heads; involucre simpler, of narrow erect equal tegules, not coriaceous and without herbaceous tips; rays narrower and usually very numerous, often in more than one row, rarely wanting; pappus more scanty or fragile, sometimes with a conspicuous short outer row; style appendages very short and roundish or obtuse; akenes mostly 2-nerved.

Rays very short or wanting.

Leaves ternately cleft to parted; perennial.

Leaves entire; plants not perennial.

Heads paniculate; involucre glabrous; annual. E. canadensis.

Heads corymbose; involucre hirsute, at least at base; biennial.

Rays present, conspicuous.

Plants annual or biennial; stems erect, branched above; ray-flowers white.

Plants perennial; roots stout.

Leaves narrow or with narrow lobes; low alpine plants.

Ray-flowers golden yellow; involucre woolly.

Ray-flowers pink or violet, never yellow.

Leaves 3-5-cleft; involucre sparsely hirsute.

Leaves entire.

Involucre woolly; leaves spatulate. E. uniflorus.

Involucre hirsutulous; leaves linearlanceolate.

Leaves flat, rather large and broad, entire or

E. acris.

E. ramosus.

E. aureus.

E. compositus trifidus.

E. pacificus. toothed.

Stems low; leaves mostly basal.

Involucre loosely villous; fleshy seashore plant.

Involucre not villous.

Basal leaves dentate; plant producing rosulate offsets.

Basal leaves entire; plant not producing off sets.

Leaves glabrous.

E. glaucus.

E. oreganus.

E. spatulifolius. 
Leaves ciliate and sparsely pilose.

Stems tall, leafy.

E. leibergii.

E. speciosus.

E. philadelphicus.

Leaves entire; ray-flowers violet.

Ray-flowers broader, 30-60.

Cauline leaves half-clasping at base. E. howellii.

Cauline leaves sessile or shortpetioled.

Involucre sparsely pilose.

Involucre minutely glandular. E. salsuginosus.

Erigeron canadensis L. Annual, strictly erect, simple or with erect branches, usually $30-100 \mathrm{~cm}$. high, loosely hirsute throughout; leaves numerous, linear, entire, or the lower spatulate and incisely lobed or dentate; heads panicled, very numerous, small, 3-5 mm. high; involucres cylindric; rayflowers whitish, very small.

Native but weedy in habit and abundant in cultivated land.

Erigeron acris debilis Gray. Biennial, erect, glabrous or sparsely pubescent, $10-20 \mathrm{~cm}$. high; basal leaves spatulate-lanceolate; cauline lanceolate, sessile, all entire, acute or obtuse, 5-10 cm. long; heads few, paniculate or corymbose, 6-8 mm. broad; involucre puberulent and somewhat hirsute; rayflowers very narrow, pinkish, equalling the disk, within them a series of tubular filiform pistillate flowers; akenes smooth; pappus copious, brownish.

In the mountains at about $2000 \mathrm{~m}$. altitude.

Erigeron ramosus septentrionalis Fernald \& Wiegand. Annual or biennial, erect, branched above, sparsely hirsute, leafy to the top; lower leaves spatulatelanceolate, acute, entire or dentate, the blades 5-8 cm. long; upper cauline lanceolate, entire, sessile, smaller; heads loosely corymbed; involucre $3-4 \mathrm{~mm}$. high, glabrous or with a few bristly hairs; ray-flowers white, numerous, short, 4-6 mm. long; pappus of the disk-flowers double, the inner of few deciduous bristles, the outer of short persistent scales; ray-flowers with few or no bristles to the pappus.

Prairies, not uncommon.

Erigeron aureus Greene. (Aplopappus brandegei Gray.) Perennial from a stout crown; herbage ashy-puberulent; stems $6-12 \mathrm{~cm}$. high; leaves mostly basal, obovate to spatulate, entire, petioled; cauline oblong to lanceolate, few, small; heads solitary, $8-10 \mathrm{~mm}$. broad; involucre loose, woolly; tegules lanceolate; ray-flowers 15-20, bright yellow; akenes pubescent.

High peaks of the Cascade Mountains at about $2700 \mathrm{~m}$. altitude, British Columbia and Washington; first found on Mount Stuart.

Erigeron compositus trifidus (Hook.) Gray. Biennial, tufted from a woody crown; basal leaves petioled, the blade 3-cleft, the lateral lobes often again cleft; cauline sessile, often entire; flowering stems $5-10 \mathrm{~cm}$. high; heads solitary; ray-flowers 30-50, pink or white, 6-10 mm. long; akenes short-pubescent; pappus simple.

In rocky soil in the mountains at about $2500 \mathrm{~m}$. altitude.

Erigeron compositus discoideus Gray. Similar to E. compositus trifidus; ray-flowers absent.

Cascade Mountains, latitude $49^{\circ}$, Lyall.

Erigeron uniflorus L. Perennial; stems erect, simple, 4-20 cm. high, somewhat pubescent; basal leaves spatulate, obtuse, entire, $2-5 \mathrm{~cm}$. long, the blade as long as the petiole; cauline leaves lanceolate, acute, sessile; head 
solitary; involucre very woolly; tegules linear-lanceolate, acute; ray-flowers purple, numerous, $6-8 \mathrm{~mm}$. long.

Cascade Mountains, without exact locality, Dr. Cooper.

Erigeron pacificus Howell. Perennial from a woody rootstock, thinly canescent, hirsutulous throughout; stems leafy, erect or ascending, 5-10 cm. high; basal leaves linear-lanceolate, acute, petioled, $2-5 \mathrm{~cm}$. high, thinly pubescent with short stiff white hairs on both sides; cauline similar but smaller and short petioled; involucre hemispheric, $1 \mathrm{~cm}$. broad; tegules linear-oblong, acute, 4-5 mm. long, thinly hirsutulous; ray-flowers $20-40$, blue to purple, 10-12 $\mathrm{mm}$. long; akenes minutely pubescent; pappus double, the outer bristles very short, the inner equalling the disk-flowers.

On grassy slopes near Table Rock, Clackamas County, Oregon, Howell; not otherwise known.

Erigeron glaucus Ker. Somewhat viscid pubescent; stems 20-30 cm. high; leaves mostly in a basal tuft, pale green, hardly glaucous, somewhat fleshy, obovate or spatulate, entire or nearly so, $6-10 \mathrm{~cm}$. long; cauline spatulate-oblong, obtuse, sessile; heads mostly solitary, large, the disk $2.5 \mathrm{~cm}$. broad; involucre loose, villous with long hairs; ray-flowers 60-100, violet, broad, 10-12 $\mathrm{mm}$. long.

Along the seashore of Oregon and California.

Erigeron oreganus Gray. Perennial, pubescent; stems spreading or ascending, $15-30 \mathrm{~cm}$. long; leaves mostly in a basal rosette, cuneate-obovate, coarsely dentate or incised, $3-8 \mathrm{~cm}$. long; cauline spatulate, subentire, smaller; heads solitary or few; involucre $8-10 \mathrm{~mm}$. high; tegules linear, acuminate, the outer loose and passing into the leaves; ray-flowers 60-70, pink, 10-12 mm. long; pappus simple.

On perpendicular cliffs in the gorge of the Columbia River; not elsewhere known.

Erigeron spatulifolius Howell. Perennial from a very stout caudex, green and nearly glabrous; stems usually several, slender, sparsely hirsute, erect or ascending, 10-20 cm. high; basal leaves spatulate to oblanceolate, broadly obtuse, entire or with a few crenate teeth near the apex, glabrous on both sides, $2-4 \mathrm{~cm}$. long, including the margined petiole; cauline leaves oblong or ovate-oblong, acute, sessile, small, about $1 \mathrm{~cm}$. long; involucre hemispherical, $1 \mathrm{~cm}$. broad; tegules broadly linear, attenuate-acute, minutely granular; rayflowers $30-40$, purple; pappus bristles as long as the disk-flowers; akenes smooth.

On rocky banks, Pansy Camp, Cascade Mountains, Oregon, Howell.

Erigeron leibergii Piper. Perennial from a stout caudex, sparsely hirsute and glandular throughout; flowering stems $10-15 \mathrm{~cm}$. high, mostly simple and bearing a single head; basal leaves broad, spatulate to oblanceolate, obtuse, entire, ciliate, 4-9 cm. long; cauline oblong, sessile, mostly acute, $1-2 \mathrm{~cm}$. long; involucre viscid glandular and sparsely hirsute; tegules linear, acuminate; ray-flowers $20-25$, violet, $1 \mathrm{~cm}$. long.

Mount Stuart, Leiberg; Bear Creek, Okanogan County, Washington, Gorman; 25-mile Creek, Okanogan County, Gorman. E. leibergii differs from $E$. spatulifolius only in the herbage and involucre being somewhat pilose. It is not unlikely that the two constitute but one species, variable as to pubescence.

Erigeron speciosus DC. (E. glabellus mucronatus Hook.) Perennial tufted, sparingly hirsute or nearly glabrous; stems $30-50 \mathrm{~cm}$. high, leafy to the top, erect; leaves lanceolate, entire, acute or acuminate, usually ciliate at least at the base, the upper cauline sessile by a broad base, the lower and radical petioled, $5-15 \mathrm{~cm}$. long; heads few, in a loose cory $\mathrm{mb}$; involucre hirsute or 
nearly glabrous, 5-6 mm. high; ray-flowers about 100 , narrow, violet, about $1 \mathrm{~cm}$. long; akenes pubescent; pappus double, the outer bristles very short.

Gravelly soil, infrequent.

Erigeron philadelphicus L. Perennial, sparsely hairy; stems erect, branched above, $30-90 \mathrm{~cm}$. high; basal leaves oblong or oblong-obovate, obtuse, dentate, 3-6 cm. long, narrowed into a short petiole; cauline mostly entire, sessile and half-clasping; heads numerous in a corymb; involucre hemispheric; ray-flowers pink, numerous, very narrow; akenes puberulent.

Moist banks and meadows, common.

Erigeron howellii Gray. Perennial, glabrous except near the top; stems 30-50 cm. high, leafy; leaves entire or merely denticulate, thin in texture, glabrous; basal ones petioled, ovate to obovate; cauline half-clasping at base, ovate, mucronate, $2-5 \mathrm{~cm}$. long; heads solitary; involucre somewhat pubescent; tegules subulate; ray-flowers 30-35, white, 15-20 mm. long.

Perpendicular bluffs along the Columbia Gorge in moist places.

Erigeron amplifolius Howell. Green nearly glabrous; stems erect, $50-70$ $\mathrm{cm}$. high; leaves entire or with a few teeth, the basal ones lanceolate to ovatelanceolate, 5-10 cm. long, slender petioled, gradually reduced, the upper sessile; heads solitary or few, short-peduncled; involucre hemispheric, 10-12 $\mathrm{mm}$. broad; tegules linear, acute, minutely glandular and sparsely pilose along the midrib; ray-flowers 50-60, blue or violet, about $2 \mathrm{~cm}$. long; akenes pubescent.

On open hillsides near Table Rock, Clackamas County, Oregon, Howell.

Erigeron salsuginosus (Richards.) Gray. Perennial; stems erect, 30-60 $\mathrm{cm}$. high, pubescent toward the top; lower leaves petioled, spatulate to narrowly-obovate, entire or denticulate, green, glabrous, $5-20 \mathrm{~cm}$. long; cauline oblong-lanceolate, sessile; heads solitary or few; involucre loose, subulatelinear, viscid and minutely pubescent; ray-flowers 50-70, pink, $12-15 \mathrm{~mm}$. long, rather broad.

Abundant in alpine meadows at 1500 to $2000 \mathrm{~m}$. altitude, sometimes called "Mountain Daisy."

Erigeron salsuginosus angustifolius Gray. Stems $15-20 \mathrm{~cm}$. high; leaves narrower, spatulate to lanceolate.

This is merely a reduced high altitude form of E. salsuginosus.

\section{SERICOCARPUS.}

Perennial herbs, with many sessile alternate mostly entire leaves and small heads of whitish flowers in corymbs; heads $12-$ 20 -flowered, radiate; involucre cylindric or somewhat clavate; tegules appressed, closely imbricated, coriaceous but with spreading green tips; ray-flowers few, 4 or 5; receptacle foveolate; style branches lanceolate-subulate; akenes pubescent; pappus of numerous scabrous capillary bristles.

Sericocarpus rigidus Lindl. Herbage pale green and scabrous; stems 30-60 cm. high, leafy; leaves oblong-spatulate, obtuse and usually mucronate, entire, stiff but hardly rigid, 2-2.5 cm. long; inflorescence a rather dense corymb; involucre turbinate; tegules oblong to linear, 1-nerved; akenes canescent, half as long as the white pappus.

In dry ground, Vancouver Island to California. 


\section{OREOSTEMMA.}

Acaulescent perennial herbs with solitary heads on scapiform stems and entire leaves; heads broadly hemispheric; tegules herbaceous, narrow, subequal, rather loose, in about 2 series; receptacle flat; ray-flowers numerous, violet to purple; style branches slender, acute, hirsutulose; akenes prismatic, villous; pappus a single series of denticulate capillary bristles.

Oreostemma alpigena (T. \& G.) Greene. Caudex and root stout; stems spreading or ascending, 5-10 cm. high, scape-like, the leaves much reduced; basal leaves spatulate to linear, obtuse, entire, glabrous, 3-8 cm. long; involucre hemispheric, $12 \mathrm{~mm}$. high; tegules linear, acute, somewhat pubescent; ray-flowers violet, $12-15 \mathrm{~mm}$. long; a kenes hirsute at the summit.

At high altitudes in the Cascade Mountains. First collected on Mount Rainier by Tolmie in 1833.

\section{EUCEPHALUS.}

Perennial herbs; leaves alternate, all cauline, the lowermost much reduced; heads panicled, rarely solitary, radiate; involucre well imbricated, campanulate; tegules chartaceous, closely appressed, arranged in 3 or 4 series, the outer successively shorter; receptacle lacerate-alveolate; ray-flowers in a single series, violet or white; disk-flowers yellow; style branches lanceolate; akenes compressed; pappus copious, of numerous unequal bristles.

Ray-flowers white, becoming pink-tinged.

Ray-flowers purple or violet.

Leaves tomentose beneath.

Leaves glabrous on both sides.

E. paucicapitatus.

E. ledophyllus.

E. engelmanni.

Eucephalus paucicapitatus (Robinson) Greene. Stems tufted, erect, leafy, 30-50 $\mathrm{cm}$. high, somewhat pubescent; leaves elliptic-oblong, puberulent, 2-3 $\mathrm{cm}$. long, erect or ascending; heads mostly solitary, sometimes 3 or 4 , shortpeduncled, 3-3.5 $\mathrm{cm}$. broad; tegules lance-linear, pubescent, ciliolate, acute, purple at tip, loosely imbricated in 2-3 series, $8 \mathrm{~mm}$. long; ray-flowers $12-18$, white becoming pink.

Common in alpine meadows of the Olympic Mountains, but not known to occur elsewhere.

Eucephalus ledophyllus (Gray) Greene. Stems usually tufted, erect, 30-80 cm. high; leaves numerous, lanceolate, entire or sparsely denticulate, glabrous above, tomentose beneath, $2-5 \mathrm{~cm}$. long, the lower obtuse, the upper cuspidate; heads solitary or several in a loose cyme; tegules lance-linear, acute or acuminate; ray-flowers violet; akenes sparsely hirsute.

Alpine meadows in the Cascade Mountains, southern British Columbia to Oregon.

Eucephalus engelmanni (Gray) Greene. Nearly glabrous; stems $60-90$ $\mathrm{cm}$. tall, erect; leaves oblong-lanceolate to ovate-lanceolate, thin, entire or more or less serrulate, 5-10 $\mathrm{cm}$. long, the upper ones cuspidate; heads racemosely or paniculately cymose; involucre hemispheric; tegules ovate-lanceolate, acute or acuminate, the outer loose and partly foliaceous, the inner purplish; ray-flowers purple, 10-12 $\mathrm{mm}$. long; akenes oblong-obovoid.

Alpine meadows in the Cascade Mountains, mostly on the eastern slopes. 
Eucephalus macounii Greene. Sparsely rough pubescent; leaves oblonglanceolate to oblong, sessile, acute, half-clasping at base, sharply serrate with scattered teeth; heads few, corymbose; involucre turbinate; tegules lanceolate, acute, purple tinged, pubescent and ciliate, arranged in about 4 series; rayflowers 10-15, narrow, violet; akenes pubescent.

Victoria, Macoun; no specimens have been seen and the description is compiled.

\section{ASTER.}

Mostly perennial herbs; leaves alternate; heads solitary, corymbed or panicled, many-flowered, radiate; ray-flowers several or numerous, in one row, fertile or rarely sterile, white, purple or blue, never yellow; disk-flowers yellow, often turning purple; involucre imbricated; tegules commonly with herbaceous tips; receptacle flat or convex, naked; pappus tawny, simple, of copious slender scabrous capillary bristles; anthers tipped with an appendage; styles appendaged; akenes more or less compressed, rarely slender, 4-5-nerved.

Leaves coriaceous; involucre well imbricated, broadly turbinate, not glandular.

A. radulinus.

Leaves membranaceous; involucre hemispheric, not well imbricated.

Involucre viscid or pruinose-glandular.

Involucre not viscid or glandular.

Heads less than $1 \mathrm{~cm}$. broad.

Tegules acute.

Tegules obtuse.

Heads more than $1 \mathrm{~cm}$. broad.

Cauline leaves auriculate at base.

Cauline leaves not auriculate at base.

A. major.

A. oreganus.

A. hallii.

A. foliaceus.

A. douglasii.

Aster radulinus Gray. Herbage scabrous and pubescent; stems stout, 20-50 cm. high, mostly branched above; leaves firm, subcoriaceous, broadlylanceolate to obovate, sharply serrate, tapering at base, 5-10 cm. long, scabrous on both sides; heads corymbose; involucre turbinate or obconical, 6-8 $\mathrm{mm}$. high; tegules imbricated, firm, oblong-lanceolate, obtuse or abruptly acute, pubescent; ray-flowers violet or nearly white, short; akenes pubescent.

In dry ground, Vancouver Island to California.

Aster major (Hook.) Porter. (A. modesta Lindl.) Herbage sparsely pubescent, glandular in the inflorescence; stems $60-80 \mathrm{~cm}$. high, branched above, leafy; leaves thin, lanceolate to oblong-lanceolate, serrate or subentire, acute, sessile or partly clasping at the narrowed base, 5-10 cm. long; heads $15-20 \mathrm{~cm}$. broad, numerous in a leafy bracted corymb or panicle; involucre hemispheric; tegules green, loose, linear, acute, little imbricated, glandular; ray-flowers 30-50; dark violet, 10-12 $\mathrm{mm}$. long; akenes pubescent; pappus tawny.

Common along streams in the mountains.

Aster oreganus Nutt. Glabrous or nearly so; stems slender, $40-60 \mathrm{~cm}$. high, branched at top; leaves linear-lanceolate, entire, sessile, 4-6 cm. long; inflorescence subracemose, rather dense; heads 5-7 mm. high; involucre loose, the outer tegules herbaceous, lanceolate, acute, the inner ones thinner and narrower; ray-flowers white or purple, $4 \mathrm{~mm}$. long; akenes scaberulous.

In wet places, rare; first collected by Nuttall near the mouth of the Willamette River. 
Aster hallii Gray. Glabrous or nearly so; stems slender, erect, 30-60 cm. high, leafy to the top; leaves linear-lanceolate, entire, scabrous on the margin, 5-10 cm. long; inflorescence narrow, rather close, often raceme-like; heads small, 6-8 mm. high; involucre campanulate; tegules linear or somewhat spatulate, green-tipped, glabrous, obtuse, erect; ray-flowers white or nearly so, 8-10 $\mathrm{mm}$. long.

In dry ground, western Oregon.

Aster foliaceus frondeus Gray. Glabrous or sparsely pubescent; stems stout, erect or ascending, simple or usually with a few branches, 20-60 cm. high; leaves few, the lower large, $8-10 \mathrm{~cm}$. long, oblanceolate, tapering into winged petioles; cauline sessile, broadly half-clasping at the base; heads few, large, $1.5-2.5 \mathrm{~cm}$. broad, usually on naked peduncles; involucre $10-14 \mathrm{~mm}$. high, the tegules herbaceous, linear-lanceolate, loose, all about equalling the disk, the outer largest; ray-flowers dark-violet, about $1 \mathrm{~cm}$. long; akenes not glabrous.

In moist meadows in the mountains at low altitudes. First collected by Lyall on the Cascade Mountains, latitude $49^{\circ}$.

NtAdam Aster foliaceus apricus Gray. Very like $A$. foliaceus frondeus, but dwarf, -7200 fo $10-15 \mathrm{~cm}$. high; leaves thicker; heads solitary or few.

On the higher peaks of the Cascade Mountains at about 2500 m. altitude.

It Adama Aster douglasii Lindl. Glabrous or nearly so; stems erect, $30-120 \mathrm{~cm}$.
high; leaves mostly sessile, lanceolate and broadest near the middle, sometimes high; leaves mostly sessile, lanceolate and broadest near the middle, sometimes of the branches much smaller; heads usually numerous, panicled; involucre hemispheric, $10-12 \mathrm{~mm}$. high, the tegules green at tip, narrow, acute, the outer sometimes foliaceous and passing into the reduced leaves of the branchlets; ray-flowers pale violet, $10-12 \mathrm{~mm}$. long.

Common and very variable. Firsi collected by Douglas at the mouth of the Columbia River.

511. MADIA. TARWEED.

Annuals; leaves linear or lanceolate, entire or slightly toothed, at least the upper alternate; heads peduncled, clustered; flowers yellow; ray-flowers $1-20$ and pistillate, or rarely wanting; diskflowers 1-5, perfect; receptacle chaffy only at the margin; pappus none or of several small scales in the sterile flowers; rayakenes laterally compressed, enclosed in the infolded tegules; disk-akenes laterally compressed.

Heads small, long-peduncled; disk-flower one.

Heads larger, sessile or short-peduncled; disk-flowers several.

Leaves all or mostly opposite; perennial.

Leaves all or mostly alternate; annuals.

Involucre laterally compressed; ray-flowers 1-5.

Involucre campanulate; ray-flowers 5-12.

Ray-flowers 15-20 mm. long; receptacle bristly.

Ray-flowers 4-8 mm. long; receptacle glabrous or nearly so.

Heads scattered, 6-10 mm. high; herbage moderately glandular.

Heads clustered, 10-12 mm. high; herbage very glandular.

M. exigua.

M. madioides.

M. glomerata.

M. elegans.

M. racemosa.

M. sativa.

Madia exigua (Smith) Greene. Annual; stems slender, erect, usually branched above, hirsute-pubescent below, glandular above, 10-30 cm. high; 
leaves linear, 1-3 cm. long; heads $2-3 \mathrm{~mm}$. high, long-peduncled, loosely corymbed; tegules $4-8$, enclosing as many ray-flowers which are scarcely longer; disk-flowers solitary; akenes black, obovate but lop-sided, that of the disk-flower straight, those of the ray-flowers curved.

Dry ground, rather common. First collected by Menzies.

Madia madioides (Nutt.) Greene. Perennial, somewhat villous; stems slender, erect, 40-60 cm. high, loosely branched above; leaves linear-lanceolate, sparsely serrate, sessile, $5-10 \mathrm{~cm}$. long, all but the uppermost opposite; inflorescence a loose panicle; heads slender-peduncled, $8 \mathrm{~mm}$. high, manyflowered; tegules 8-12, glandular, each enclosing a fan-shaped ray-flower $8-10 \mathrm{~mm}$. long; disk-flowers sterile, with a pappus composed of oblong scales; akenes of the ray-flowers broad, curved, compressed.

Very common in open woods; first collected by Nuttall at the mouth of the Willamette River.

Madia glomerata Hook. Stems erect, simple or with erect branches, very leafy to the top, $30-100 \mathrm{~cm}$. high, hirsute, the inflorescence glandular; leaves linear or linear-lanceolate, ascending, $2-6 \mathrm{~cm}$. long, scabrous and hirsute; heads densely crowded, at length somewhat racemose; ray-flowers few or none, short; disk-flowers 2-5; corollas pubescent; akenes black, club-shaped, those of the ray-flowers flattened and 1-nerved on each face, those of the disk-flowers somewhat 4-angled; pappus wanting.

In dry open ground; Puyallup, Piper; common in the Willamette Valley.

Madia elegans Don. Annual, hirsutely pubescent and somewhat glandular; stems erect, $30-120 \mathrm{~cm}$. high; leaves lanceolate to linear, entire or nearly so, broadest at base, sessile, the lower ones much crowded, 5-10 cm. long; inflorescence corymbose; tegules 5-15, hirsute; ray-flowers $12-20$, acutely 3-lobed, $15-20 \mathrm{~mm}$. long, yellow or often brown at base; disk-flowers sterile; akenes much compressed, obliquely obovate.

Prairies, Willamette Valley and southward; said by Hooker to have been collected by Douglas and by Scouler at Fort Vancouver, Washington, but it is doubtful if it occurs north of the Columbia River.

Madia racemosa (Nutt.) T. \& G. Stems erect, 30-90 cm. high, simple or branched above, hirsute below, glandular above; leaves linear or lanceolate, acute, $2-8 \mathrm{~cm}$. long; heads $6-10 \mathrm{~mm}$. high, hemispherical or broadly ovoid, racemosely or corymbosely arranged, commonly peduncled; corolla pubescent; ray-flowers 5-8, rarely 10 ; disk-flowers few; akenes flattened and nerved on the broader faces or the nerve lacking; pappus none.

Very common in dry ground; first described from specimens collected by Nuttall at the estuary of the Willamette River. Very variable and as here described including $M$. dissitiflora T. \& G., whose supposed distinctions break down completely.

Madia sativa Molina. Annual, viscid pubescent and very glandular; stems stout, $30-90 \mathrm{~cm}$. high, erect, simple or with erect branches; leaves lanceolate or the upper linear, sessile, broadest at base, entire, 5-10 cm. long; inflorescence narrowly paniculate, the heads mostly in dense clusters; rayflowers 5-12, their corollas pale yellow; disk-flowers 4-8 $\mathrm{mm}$. long; rayakenes curved, obovoid, compressed, often 1-nerved on each face; disk-flowers fertile, their akenes cuneate-oblong, somewhat 4-angled.

In dry ground, Willamette Valley and southward.

Madia sativa capitata (Nutt.) Piper. Heads densely congested, the inflorescence capitate or short-oblong.

Vancouver Island to California. 


\section{HEMIZO NELLA.}

Small loosely branched annuals with linear opposite or the upper alternate leaves; heads with 4 or 5 ray flowers and 1-4 disk flowers; involucre of 4 or 5 obcompressed incurved tegules, each enclosing an akene; bracts of the receptacle 3-5, united into a cup; ligulate flowers minute, yellow; akenes obovoid, broad and convex on the back.

Hemizonella durandi Gray. Herbage more or less hirsute, glandular near the top; stems $5-15 \mathrm{~cm}$. high, loosely branched; leaves linear, $10-15 \mathrm{~mm}$. long; earliest heads in the forks of the branches, slender-peduncled, bractless, the later ones racemose, 2-bracted at base, or short-peduncled; akenes hairy, oblong-ovate or subfusiform, tipped with an inflexed beak.

In dry ground, not common, Vancouver Island to California.

\section{HEMIZONIA.}

Mostly annual herbs, usually more or less glandular and viscid and heavy-scented; leaves alternate or sometimes opposite; heads not large, many- or sometimes few-flowered; tegules rounded on the back, partly enclosing the turgid more or less oblique ray-akenes; disk-akenes abortive or infertile.

Hemizonia pungens (Hook. \& Arn.) Torr. \& Gr. Hairy, but only slightly glandular; stems $30-60 . \mathrm{cm}$. high; basal leaves bipinnatifid; cauline simply pinnatifid, the lobes lanceolate or linear-lanceolate, entire, very sharp-pointed; the leaves on the branchlets entire, small and crowded, rigid, spine-tipped; tegules lanceolate, spine-tipped; receptacle convex; rays short, narrow, toothed at the apex; pappus none.

Sparingly introduced; a native of California. Tacoma, Flett.

\section{LAGOPHYLLA.}

Annuals; stem slender, much-branched; leaves alternate or opposite, mostly entire; heads small, few-flowered; ray-flowers about 5 , pistillate, fertile; disk-flowers as many, perfect but sterile; involucre of as many tegules as the ray-flowers; receptacle small and flat; pappus none; ray-akenes obovate, much obcompressed, smooth, enclosed by the base of the tegule; diskakenes slender and abortive.

Lagophylla ramosissima Nutt. Erect, loosely branched, $15-70 \mathrm{~cm}$. high; stems light colored, puberulent; leaves all but the lowest attenuate, entire, linear-lanceolate or the lowest somewhat spatulate, 1-3 cm. long, all white villous; heads 5-6 mm. long, in small clusters on the leafy branches; tegules ciliate with long hairs, and usually bearing a few stalked glands on the back; ray-flowers yellow, small; akenes $3 \mathrm{~mm}$. long, club-shaped, with a ridge down the inner face.

Prairies, Willamette Valley and southward.

515. BIDENS. BEgGaR TICKS.

Annual or perennial herbs; leaves opposite; heads small or medium, yellow or sometimes white; ray-flowers $3-10$, sterile or 
none, in which case the flowers are all perfect and tubular; receptacle chaffy; pappus of 2-4 rigid backwardly-barbed awns; ray- and disk-akenes obcompressed.

Plant aquatic; submerged leaves capillary.

B. beckii.

Plants terrestrial; none of the leaves capillary.

Akenes 4-angled; leaves dentate.

Akenes flat; leaves more or less incised.

B. cernua.

B. elata.

Bidens beckii Torr. (Megalodonta remota Greene.) Aquatic, glabrous; stems simple or little branched, $30-100 \mathrm{~cm}$. long; submersed leaves $2-5 \mathrm{~cm}$. long, finely dissected into filiform segments; emersed leaves a few pairs, lanceolate, acute, serrate, $1-3 \mathrm{~cm}$. long; heads solitary, short-peduncled; tegules oblong, obtuse, glabrous; ray-flowers golden-yellow; akenes smooth, the stout awns barbed near the tip.

Green Lake, Seattle, Washington, Piper; not otherwise known in our limits.

Bidens cernua L. Annual, glabrous or minutely hispid; stems erect, simple or with few short branches, $30-60 \mathrm{~cm}$. high; leaves linear-lanceolate to lanceolate, coarsely and unequally serrate, acuminate, sessile and somewhat cuneate at base, 6-12 $\mathrm{cm}$. long; heads short-peduncled, 12-15 mm. broad; outer tegules foliaceous, much longer than the membranous inner ones; ray-flowers 6-12, bright yellow, or sometimes absent; akenes elongate, wedge-shaped, 4-angled and bearing 4 backwardly barbed awns half as long as the body.

A very variable species growing in wet places, blooming in autumn.

Bidens elata (T. \& G.) Sherff. (B. amplissima Greene.) Glabrous or nearly so; stems stout, $40-100 \mathrm{~cm}$. high; leaves lanceolate, oblanceolate or oval, acute, deeply serrate or incised, $8-18 \mathrm{~cm}$. long; heads $1-3$, nearly sessile, $2 \mathrm{~cm}$. broad; outer tegules linear to oblanceolate, larger than the head, often incised; ray-flowers pale yellow; akenes $8 \mathrm{~mm}$. long, glabrous, flat, broadly cuneate, the margins inwardly barbed; awns 4 , rarely 2 , about half as long as the akene, retrorsely barbed.

Sauvies Island, Oregon, Nuttall; Vancouver Island, Macoun.

\section{COREOPSIS.}

Annual or perennial herbs usually with opposite leaves; heads many-flowered, radiate; involucre of 2 rows of about 8 tegules each, the outer spreading and foliaceous, the inner appressed and nearly membranaceous; ray-flowers mostly 8 , neutral, yellow or purple, rarely wanting; receptacle flat with deciduous membranaceous chaff; akenes obcompressed, often winged, with 2 barbless subulate awns.

Coreopsis atkinsoniana Dougl. Glabrous; stems $30-100 \mathrm{~cm}$. high, erect, usually branched; leaves all opposite, the lowest bipinnately parted into linear lobes, the upper reduced to simple linear bracts; heads cymosely paniculate; tegules in two series, the outer short, the inner ovate, scarious-margined, 6-8 mm. long; ray-flowers yellow, with brown bases; akenes oblong, narrowly winged, bearing two short subulate teeth.

In wet places on river banks, rare in our limits.

517. RUDBECKIA.

Mostly perennial herbs; leaves alternate; heads many-flowered, mostly with sterile ray-flowers, sometimes rayless; disk-flowers 
perfect; receptacle elongated, becoming columnar; pappus a chaff-like cup or 4 chaffy teeth more or less united into a cup; akenes quadrangular and mostly laterally compressed.

Rudbeckia hirta L. Black Eyed Susan. Herbage hispid to hirsutepubescent; stems erect, $30-60 \mathrm{~cm}$. high; leaves lanceolate to oblong, entire or sparingly serrate, 3-5-nerved, the lower ones petioled, the cauline sessile; heads solitary or few, long-peduncled; ray-flowers 10-20, orange-yellow; disk ovoid, dark brown; chaff of the receptacle linear, acute; pappus none.

A native of the eastern states, sparingly introduced in fields.

\section{BALSAMORHIZA.}

Low perennials; leaves mostly radical; heads large, usually solitary; flowers yellow; receptacle flat or barely convex with linear-lanceolate chaff; pappus none; ray-akenes obcompressed; disk-akenes prismatic-quadrangular or laterally compressed.

Leaves entire or merely dentate; herbage green; involucre not woolly.

Leaves pinnately cleft, parted or divided; herbage canescent; involucre puberulent to lanate.

B. deltoidea.

B. balsamorhiza .

Balsamorhiza deltoidea Nutt. Herbage green, scabrous and sparsely pubescent or glabrate; stems erect, $20-40 \mathrm{~cm}$. high; radical leaves ovatelanceolate to deltoid, acute, cordate or subcordate at base, entire or irregularly serrate, green on both sides, 10-25 cm. long, long-petioled; cauline leaves two, small, lanceolate, near the middle of the stem; heads solitary or sometimes 3; tegules linear-lanceolate, the outer ones foliaceous and spreading; ray-flowers 2-4 cm. long.

Prairies, Vancouver Island to California. First collected by Nuttall near the mouth of the Willamette River.

Balsamorhiza balsamorhiza (Hook.) Heller. Herbage canescent with silky or more or less tomentose pubescence; stems $20-30 \mathrm{~cm}$. high, bearing a pair of small opposite leaves near the base; radical leaves oblong-lanceolate in outline, pinnately to bipinnately parted into linear segments or merely pinnatifid or incised; involucre woolly to merely pubescent; tegules lanceolate, the outer sometimes foliaceous.

Prairies, rare west of the Cascade Mountains; first collected at Fort Vancouver, Washington, by Douglas.

\section{WYETHIA.}

Perennial herbs; stems simple, rarely branching; leaves alternate, mostly entire and ample; heads many-flowered, solitary or few, medium or large; flowers yellow; ray-flowers elongated, pistillate or fertile; pappus a chaffy crown or cup; ray-akenes neither obcompressed nor laterally compressed.

Wyethia angustifolia (DC.) Nutt. Somewhat hirsute with short white hairs; stems 30-60 cm. high; basal leaves long-lanceolate, mostly entire, acuminate, 20-40 cm. long; cauline sessile, smaller and broader; head long-pedunculate; involucre campanulate, loose; tegules broadly lanceolate, green and herbaceous, ciliate, equalling the disk; ray-flowers $4 \mathrm{~cm}$. long; akenes pubescent at summit; pappus awns stout, subulate, minutely hirsute, 1-2 in the disk-flowers, 3-4 in the ray-flowers.

Moist places, Willamette Valley and southward. 


\section{HELIANTHUS.}

Coarse annuals or perennials; leaves entire or toothed, all or at least the lower ones opposite; heads solitary or corymbose, medium or large; ray-flowers yellow, sterile; disk-flowers yellow, brownish or dark-purple; receptacle flat or convex; pappus a pair of early-falling chaffy scales or awns; akenes neither very flat nor winged; ray-akenes laterally compressed; disk-akenes 4-angled, compressed.

Helianthus tuberosus L. Jerusalem Artichoke. Pubescent or hirsute; stems erect, 1-3 m. high; leaves ovate to oblong-lanceolate, subcordate, acuminate, serrate, scabrous above, pubescent beneath, the lower ones opposite; tegules loose, lanceolate, attenuate, hirsute-ciliate, spreading at the tips, as long as the disk; ray-flowers 12-20,3-4 cm. long; akenes pubescent.

Escaped from cultivation; native of the eastern states. The rootstocks bear edible tubers.

\section{JAUMEA.}

Perennial plants, herbaceous or suffrutescent, with opposite entire leaves and peduncled solitary heads of yellow flowers; involucre campanulate, the broad fleshy tegules imbricated in 2 series, the outer shorter; receptacle conical, naked; corollas glabrous; style branches papillose or hairy, truncate to shortconical; akenes 10-nerved; pappus (in ours) none.

Jaumea carnosa (Less.) Gray. Glabrous, somewhat fleshy; stems ascending, leafy, 20-40 cm. high; leaves spatulate-linear, nearly terete, sessile and cuneate at base, $2-3 \mathrm{~cm}$. long; head erect, short-peduncled; involucre campanulate; ray-corollas 6-10, linear, short; receptacle conical, smooth, fleshy; akenes glabrous, without pappus.

In salt marshes along the seashore, Vancouver Island to California.

\section{BAERIA.}

Mostly annual herbs with opposite entire or pinnately dissected leaves and yellow flowers; heads many-flowered, radiate; involucre herbaceous, campanulate to hemispheric, with 5-15 oblong to ovate plane or somewhat keeled tegules in a single series; receptacle subulate to conical, naked; corolla of the diskflowers with a slender tube as long as the 5-lobed campanulate limb; akenes slender somewhat clavate; pappus a crown of scales or sometimes wanting.

Baeria maritima Gray. Pubescent when young but becoming glabrous; stems diffusely spreading; leaves oblong-linear, entire or the lower sparingly laciniate-toothed, $2.5 \mathrm{~cm}$. long; tegules $6-8$; ray-corollas orbicular; akenes puberulent; pappus of 3-5 subulate awns and at least as many small narrow laciniate scales.

Bird Island, Barclay Sound, Vancouver Island, Nervcomb, and the Farallone Islands, California; not known to occur elsewhere. 


\section{ERIOPHYLLUM.}

Perennial herbs, sometimes shrubby at base; leaves usually alternate, entire or pinnately or ternately parted or lobed; ray-flowers present, fertile; involucre campanulate or obovoid; tegules erect, commonly united at base, oval or oblong; pappus of nerveless and mostly pointless scales; throat or limb of diskcorollas rather narrow; style-branches truncate or rarely minutely tipped; akenes narrow, mostly 4-angled.

Eriophyllum lanatum (Pursh) Forbes. Perennial, erect or decumbent at base, loosely white-woolly throughout; leaves spatulate or cuneate-obovate, the lowermost and upper ones often entire, the others 3-7-lobed or parted; heads long-peduncled; involucre lanate, campanulate, 10-12 $\mathrm{mm}$. high; tegules 8-12, oblong, obtuse; ray-flowers $6-15$, golden-yellow; disk-corollas glandular; akenes glabrous; pappus short.

In gravelly soil, common and variable.

524. HULSEA.

Perennial, viscid-pubescent, balsamic-odorous herbs with alternate sessile leaves and solitary or scattered large heads of many yellow flowers; involucre hemispheric, the herbaceous rather loose linear-lanceolate tegules in 2-3 series; receptacle flat, naked; ray-flowers numerous; disk flowers with the throat larger than the tube; style branches thickened at the obtuse tips; akenes linear-clavate, pubescent; pappus of 4 truncate entire or lacerate scales.

Hulsea nana Gray. Perennial with branched rootstocks; herbage viscid and villous and somewhat lanate; stems $10-20 \mathrm{~cm}$. high; leaves mostly basal, oblong-spatulate, pinnatifid or incised, narrowed into a margined petiole; head solitary, peduncled; involucre 10-12 $\mathrm{mm}$. high; tegules lanceolate; rayflowers yellow; pappus scales fimbriate, as long as the villous akene.

In loose volcanic rock at high altitudes, Mount Rainier and southward.

\section{GAILLARDIA.}

Pubescent herbs; leaves alternate, entire or incised or even pinnatifid; heads solitary and long-peduncled, large; ray-flowers yellow or partly dark-purple, sterile; disk-flowers usually purplish or brownish; tegules in 2-3 series, the outer larger and foliaceous; receptacle convex or hemispherical, with one or more awns among the flowers resembling chaff; pappus of 6-10 hyaline chaffy scales each with a prominent midrib which is prolonged into a naked awn, or in the sterile ray-flowers, scales awnless; akenes oblong, top-shaped, each surrounded by a tuft of hairs.

Gaillardia aristata Pursh. Perennial, erect, $30-60 \mathrm{~cm}$. high, rough-pubescent; lower leaves spatulate, long-petioled, the upper sessile, all entire or more or less pinnately lobed, 5-12 cm. long; heads long-peduncled; involucre hairy, the lanceolate acuminate tegules unequal, the longest about $1 \mathrm{~cm}$.; disk-flowers dark-purple; ray-flowers 10-18, yellow, purplish at base, 15-20 $\mathrm{mm}$. long; bristles of the receptacle as long as the akenes or longer.

Prairies, rare in our limits. 


\section{HELENIUM.}

Erect, simple or branching herbs; leaves all alternate and all but the lower sessile; heads small or large, many-flowered, on naked terminal peduncles; ray-flowers yellow, several or numerous, pistillate; disk-flowers yellow or turning brownish or purplish, small and very numerous, all fertile; tegules spreading or reflexed at maturity; pappus of 5-12 thin or hyaline chaffy scales with or without midribs; akenes top-shaped, striate-ribbed, hairy on the ribs.

Helenium autumnale grandiflorum (Nutt.) Gray. Perennial, erect, 30-90 $\mathrm{cm}$. high, glabrous or puberulent; leaves oblong or ovate-lanceolate, acute, dentate or nearly entire, 5-12 cm. long, decurrent on the stem forming wings; heads few or many, long-peduncled, $10-15 \mathrm{~mm}$. broad; involucre nearly flat, the tegules linear or linear-spatulate, pubescent; ray-flowers 10-16, yellow, somewhat drooping, 1-2 cm. long, all fertile; akenes pubescent; pappus scarious, the scales acuminate, awn-pointed.

River banks, not common.

\section{ACHILLEA.}

Perennial herbs, rather strong-scented; leaves alternate, serrate or pinnately dissected; heads small, in corymbs, manyflowered; flowers yellow, white or sometimes rose-colored, all fertile; ray-flowers few or several, mostly short or broad, pistillate; involucre narrow, the tegules imbricated in a few rows, appressed; receptacle flattish to conical, with thin chaff; pappus none; akenes oblong or ovate, obcompressed, surrounded by a narrow and cartilaginous margin. green; stems erect, usually tufted, $30-90 \mathrm{~cm}$. high; basal leaves short-petioled, oblong or oblong-lanceolate, $8-20 \mathrm{~cm}$. long, pinnately divided into very numerous segments which are once or twice pinnately-cleft or parted into linear acute lobes; heads small, numerous, in convex or flat-topped terminal corymbs; involucre ovoid or subglobose, $3-5 \mathrm{~mm}$. high; ray flowers 4 or 5 , white, $2-4$ $\mathrm{mm}$. long.

Abundant in open ground and clearly native. Alpine forms are much dwarfed, often only $15-20 \mathrm{~cm}$. high, and approach $A$. borealis Bong. of Alaska. $A$. lanulosa Nutt. with very!canescent herbage, common east of the Cascade Mountains, apparently does not occur in our limits.

\section{ANTHEMIS.}

Herbs; leaves alternate, mostly tripinnately divided; heads many-flowered; ray-flowers numerous, commonly conspicuous, pistillate or sometimes sterile; disk-flowers fertile; involucre broad, the tegules very numerous, imbricated and appressed; receptacle convex to oblong-conical, chaffy with mostly slender or thin scales or awns subtending at least the central flowers; pappus none or a short chaffy crown; akenes obovoid or oblong, 4 or 5angled, $8-10$-ribbed or many-striate, truncate at the apex. 
Ray-flowers yellow; leaves somewhat tomentose.

A. tinctoria.

Ray-flowers white; leaves not tomentose.

Leaves glabrous, ill-scented; ray-flowers neutral.

Leaves pubescent, not ill-scented; ray-flowers fertile.

A. cotula.

A. arvensis.

Anthemis tinctoria L. Perennial, herbage pubescent; stems erect, loosely branched, 30-60 cm. high; leaves sessile, oblong to ovate in outline, parted in narrow acute serrate lobes; heads long-peduncled, 3-4 cm. broad; ray flowers yellow, pistillate; tegules oblong, obtuse, pubescent; chaff of the receptacle lanceolate, acuminate; pappus crown-like.

In fields, sparingly introduced from Europe.

Anthemis cotula L. Dog Fennel. May-weed. Annual, much branched, puberulent or glabrate, $30-60 \mathrm{~cm}$. high; leaves 1-3 times pinnately-dissected into thread-like lobes; heads $2 \mathrm{~cm}$. broad; receptacle conical, with bristly bracts near the apex, none at the margin; tegules oblong, obtuse, pubescent; ray-flowers white, $10-18$, becoming reflexed in age; akenes 10 -ribbed, roughened; pappus none.

A very common weed, introduced from Europe.

Anthemis arvensis L. Corn Chamomile. Pubescent annual herb resembling $A$. cotula but not ill-scented; leaves less finely 1-2-pinnately parted; chaff lanceolate, pointed, subtending and exceeding all the disk-flowers; akenes smooth; pappus a minute border.

Native of Europe; introduced.

529. CHRYSA NTHEMUM.

Herbs; heads many-flowered; ray-flowers usually elongated, numerous, pistillate; disk-flowers usually all fertile; involucre hemispherical or flatter, the tegules more or less scarious, shortappressed, imbricated in several rows; receptacle flat or convex, naked; pappus none; disk-corollas often flattened or 2-winged below, 4 or 5-toothed; akenes short, nearly terete, several ribbed or angled, truncate at apex.

Chrysanthemum leucanthemum pinnatifidum Lecoq. \& Lemotte. Oxeye Daisy. Perennial, erect, $30-60 \mathrm{~cm}$. high, glabrous or nearly so, usually simple; basal leaves oblong or spatulate, incisely pinnatifid or toothed; cauline smaller, sessile and partly clasping, linear; heads $3-5 \mathrm{~cm}$. broad, on long naked peduncles; tegules oblong-lanceolate, obtuse, rusty at tip; ray-flowers $20-30$, white; akenes many-ribbed, pappus none.

Common in fields; introduced from Europe.

\section{MATRICARIA.}

Annual or biennial glabrous branching herbs; heads manyflowered, solitary or in corymbs; ray-flowers none (in ours); disk-flowers yellowish-green; involucre hemispherical or flatter, of numerous more or less scarious appressed tegules in few rows; receptacle conical at least in fruit, naked; pappus a minute crown or none; akenes 3-5-ribbed, wingless.

Matricaria matricarioides (Less.) Porter. Annual, 5-20 cm. high, simple or branched, sparsely pubescent or glabrous; leaves oblong, $1-3 \mathrm{~cm}$. long, once or twice pinnately dissected into small linear acute segments; heads 5-9 
$\mathrm{mm}$. high, terminating short stout peduncles; involucre saucer-shaped, the tegules oblong, obtuse, green, with scarious margins; ray-flowers none; diskflowers yellowish-green; receptacle conical; akenes oblong; pappus represented by a low sometimes $1-2$-toothed crown.

Dry ground, very common.

531. COTULA.

Annual or perennial strong-scented low herbs with alternate lobed or dissected leaves and slender-peduncled rayless heads with two kinds of flowers; heads many-flowered, hemispheric to globose; involucre of about 2 ranks of tegules; receptacle flat or convex, naked; outer one or two rows of flowers pistillate, apetalous or nearly so; disk flowers tubular, 4-toothed, fertile; mature akenes raised on short erect persistent stalks; pappus none.

Glabrous; leaves entire to pinnatifid.

Pubescent; leaves bipinnately dissected.

C. coronopifolia.

C. australis.

Cotula coronopifolia L. Glabrous or nearly so, somewhat fleshy; stems decumbent or ascending, 20-30 cm. long; leaves linear-oblong, pinnately incised or the upper entire, clasping and sheathing at base; heads subglobose, peduncled, $8-10 \mathrm{~mm}$. broad; pistillate flowers in a single marginal row, their akenes with thick spongy wings.

Common especially in marshes along the seashore; a native of South Africa.

Cotula australis Hook. Somewhat pubescent; stems slender, much branched, 15-30 cm. high; leaves bipinnately parted, the ultimate segments linear; heads small, 4-6 mm. broad; pistillate flowers in 2 or 3 rows, their akenes pedicelled.

Vancouver Island to California, sparingly introduced; a native of Australia.

532. TANACETUM. TANSY.

Perennial bitter strong-scented herbs with alternate pinnately dissected leaves and corymbed heads of yellow flowers; heads many-flowered; involucre hemispheric; tegules imbricated, chartaceous; receptacle naked, convex; flowers all fertile, the outer ones pistillate with tubular 3-5-toothed corollas; akenes angled or ribbed, truncate at top; pappus a short crown.

Tanacetum huronense Nutt. Soft hairy or woolly, especially in young plants; stems stout, 30-90 cm. high; leaves twice to thrice pinnately dissected, the ultimate segments oblong and crowded; heads $1-2 \mathrm{~cm}$. broad, on stout peduncles; corollas of the pistillate flower flattened, somewhat ray-like, 3-5cleft; pappus teeth present.

On sand dunes along the ocean coast.

533. ARTEMiSia. Sagebrush. Wormwood.

Herbs or undershrubs, bitter and odorous; leaves alternate, usually dissected; heads numerous, small, in racemes or panicles, several to many-flowered, discoid; flowers yellow, yellowish or brownish, all tubular, the outermost series pistillate or all alike, the more numerous perfect flowers either fertile or sterile; tegules dry, 
imbricated in a few rows, appressed; receptacle flattish to hemispherical, naked, sometimes hairy; pappus none; corollas of pistillate flowers slender and small, 2 or 3 -toothed, of the perfect flowers enlarged above, 5-toothed; akenes obovoid or oblong, almost always glabrous.

Ours all perennial herbs.

Disk-flowers perfect but sterile; marginal flowers pistillate and fertile; leaves pinnately or bipinnately divided into narnow lobes.

Heads very numerous, small, greenish.

Heads rather few, large, brownish.

Disk-flowers perfect, fertile; marginal flowers pistillate and fertile; leaves not finely dissected.

Heads campanulate.

Heads cylindric.

A. canadensis. A. borealis.

Artemisia canadensis Michx. Glabrous or canescently pubescent; stems $30-60 \mathrm{~cm}$. high; lower leaves bipinnately divided into narrowly linear segments, the cauline less divided; inflorescence a narrow panicle; heads 4-6 $\mathrm{mm}$. broad; involucre hemispheric, green, glabrous or rarely pubescent.

In rocky soil, rare in our limits; Coupeville, Washington, Gardner.

Artemisia borealis wormskioldii Bess. Silky pubescent; stems 20-40 $\mathrm{cm}$. high; lower leaves ternately or biternately divided into linear lobes; cauline leaves linear, entire or 3-parted; heads racemose; involucre brownish, pilose.

Rocky places in the mountains, rare; Mount Rainier, Flett; Olympic Mountains, Flett.

Artemisia tilesii Ledeb. Herbage canescent with a thin tomentum; stems erect or ascending, leafy, $60-90 \mathrm{~cm}$. high; leaves oblong-lanceolate, rarely entire, mostly incisely or laciniately cleft into narrow attenuate lobes, thinly tomentose, becoming glabrous above; panicle loose, pyramidal; heads hemispheric; involucre broadly campanulate, arachnoid when young, sometimes glabrate, more or less brownish.

In the mountains at low altitudes.

Artemisia suksdorfii Piper. Tufted; stems stiffly erect, $90-120 \mathrm{~cm}$. high; leaves numerous, oblong-lanceolate, acute, entire to sparingly dentate or rarely incised, 6-10 cm. long, bright green above, white-tomentose beneath; panicle pyramidal, dense, $30-60 \mathrm{~cm}$. long; heads cylindric, $3-4 \mathrm{~mm}$. high, 5-8-flowered; involucre pale green, glabrate, the tegules obtuse, hyalinemargined.

Abundant especially on bluffs along the seacoast.

\section{PETASITES. Sweet Coltsfoot.}

Perennial herbs with creeping rootstocks; leaves large, radical, the cauline reduced to bracts; heads numerous, in a raceme or corymb on the end of a scape-like stem; flowers whitish or purplish, some imperfect; tegules in one row; akenes narrow, 5-10-ribbed; pappus soft, white.

Leaves ovate or oblong, 5-7-lobed, 5-10 cm. long; alpine plant. $P$. frigida.

Leaves reniform-orbicular, 7-9-cleft, very large, often $30 \mathrm{~cm}$. or more broad; lowland plant. 
Petasites frigida (L.) Fries. ( $P$. nivalis Greene.) Flowering stems 10-20 $\mathrm{cm}$. high; leaves cordate-ovate or reniform-hastate in outline, 5-7-lobed with broad sinuses, 5-10 cm. long, green above, white tomentose beneath; lobes entire or with a few teeth.

Along alpine rivulets in the Olympic Mountains and in the Cascade Mountains from Mount Rainier northward.

Petasites speciosa (Nutt.) Piper. Flowers blooming before the leaves appear; stems $15-40 \mathrm{~cm}$. high, covered with scaly reduced leaves; foliage leaves reniform-orbicular, very large, $15-50 \mathrm{~cm}$. broad, 7-9-lobed beyond the middle, green and glabrous above, densely.white tomentose beneath; lobes oblong, coarsely dentate; flowers lavender-colored, with the odor of violets.

Common on moist bluffs. It has been confused with the eastern $P$. palmata (Ait.) Gray.

\section{LUINA.}

Perennial herbs with alternate entire sessile leaves; heads corymbose, each about 10-flowered; involucre campanulate; tegules 8-10, firm, carinate, arranged in a single series; receptacle flat, naked; corollas all alike, cream-colored, deeply 5-cleft; anthers sagittate at base; style branches linear, flattened, truncate; akenes 10-striate; pappus of soft white capillary bristles.

Luina hypoleuca Benth. White tomentose, except the upper surface of the leaves; stems tufted, $20-30 \mathrm{~cm}$. high, erect, leafy and simple to the inflorescence; leaves ovate or elliptical, obtuse, firm, shiny-green above, $2-3 \mathrm{~cm}$. long; heads corymbose; involucre $8 \mathrm{~mm}$. high; flowers cream-colored.

Common on rock cliffs and gravel bars in the mountains, at $1000-2000 \mathrm{~m}$. altitude. First collected by Lyall at Lake Chilukweyuk, near the 49th parallel.

\section{RAINIERA.}

Perennial herb with alternate sessile entire leaves and numerous heads in a panicle; heads 4-7-flowered; involucre cylindric, with 4-7 firm carinate tegules in a single series; receptacle flat, naked; corollas all tubular, pale yellow, deeply 5 -cleft; anthers not sagittate at base; style branches linear, truncate; akenes glabrous, prismatic; pappus capillary, copious, pale-tawny. Scarcely distinct from Luina.

Rainiera stricta Greene. (Luina piperi Robinson.) Glabrous or nearly so; stems stout, erect, leafy, $60-90 \mathrm{~cm}$. high; leaves oblong-lanceolate, petioled, $15-30 \mathrm{~cm}$. long, the cauline sessile or nearly so and smaller; heads 5-6-flowered, numerous, in an erect raceme, $15-30 \mathrm{~cm}$. long; involucre cylindric; tegules 5-7, linear or oblong, acute; flowers pale yellow; pappus tawny.

Alpine meadows on and about Mount Rainier.

\section{CROCIDIUM.}

Small annual herbs with alternate leaves; heads solitary, terminal, small, radiate, the flowers all fertile; involucre hemispheric, of 8-12 thin herbaceous tegules in one row; ray-flowers about 12, yellow; disk-flowers more numerous, yellow; style branches short and broad with large appendages; pappus of one 
row of deciduous equal white barbed bristles, but none in the ray-flowers.

Crocidium multicaule Hook. Woolly when young but soon glabrate; stems numerous, tufted, 5-25 cm. high; radical leaves in a basal tuft, obovate or spatulate, few-toothed, sessile or short-petioled; cauline leaves small, linear; heads slender-peduncled, small but showy; tegules oblong-ovate.

In open ground, Vancouver Island to California. First found at Fort Vancouver, Washington, by Douglas.

\section{ARNICA.}

Perennial herbs; stems mostly simple, from creeping rootstocks or a corm-like base; leaves all or some of them opposite, simple, entire, or merely toothed; heads rather large, solitary or few, usually long-peduncled, many-flowered; flowers yellow, all fertile; ray-flowers elongated, pistillate, or sometimes none; involucre broadly campanulate, the tegules in 1-2 rows; receptacle naked, flat; pappus a single series of rather rigid strongly scabrous or barbellate capillary bristles; akenes linear, 5-angled or 5-10ribbed, somewhat hirsute or nearly glabrous.

The species of this genus are of very unsatisfactory definition.

Basal leaves cordate, long-petioled.

Herbage pubescent, the stems hirsute or villous.

Herbage glabrous.

Akenes atomiferous-glandular; leaves often similarly glandular on both sides.

Akenes glabrous or nearly so.

Leaves large, usually dentate, thin.

Leaves small, crenate-dentate, firm.

Basal leaves not cordate, short-petioled.

Heads rayless.

A. cordifolia.

Heads radiate.

Pappus whitish, barbellate.

Herbage viscid-glandular; upper leaves much reduced.

Herbage atomiferous-glandular or glandless; upper leaves but little reduced.

Pappus fuscous, subplumose.

Upper surface of leaves glabrous, sticky. Stem leaves ovate or ovate-oblong. Stem leaves lanceolate or lance-oblong.

Upper surface of leaves pubescent. Pubescence sparse, pilose. Pubescence dense, short.

A. gracilis.

A. latifolia.

A. betonicaefolia.

A. eradiata.

$M+$ Adoms Arnica cordifolia Hook. Erect from horizontal rootstocks, $20-40 \mathrm{~cm}$. high, sparsely pubescent; basal leaves ovate or orbicular, deeply cordate, dentate, acute or obtuse, $5-10 \mathrm{~cm}$. long, on petioles about as long; cauline usually 2 pairs, less broad, the short petioles margined; heads long-peduncled; involucres turbinate-campanulate, 15-20 mm. high, viscid-pubescent, the linear-lanceolate tegules acute; ray-flowers $8-12$, yellow, $2-3 \mathrm{~cm}$. long; akenes pubescent.

In the mountains at low altitudes, rare in our limits, but common east of the Cascade Mountains; upper Nisqually Valley, Allen. 
Arnica gracilis Rydb. Herbage minutely atomiferous glandular; stems slender, 15-30 cm. high; basal leaves ovate, dentate, 3-ribbed, slender-petioled; cauline leaves in 2 pairs, similar, the upper sessile; heads 1-3; ray-corollas bright yellow, $15 \mathrm{~mm}$. long; akenes minutely glandular.

Olympic Mountains, Lamb, Piper.

Arnica latifolia Bong. Glabrous or nearly so; stems erect, $30-60 \mathrm{~cm}$. high, from slender rootstocks; leaves all opposite, the lower petioled, cordate or subcordate, coarsely dentate; cauline leaves 2 or 3 pairs, oval to ovate, sessile by a broad base; heads long-peduncled; involucre campanulate, sparsely pilose to nearly glabrous; tegules about 13 , oblong-obovate, acuminate, $1 \mathrm{~cm}$. long; ray-flowers dark yellow, $1.5-2 \mathrm{~cm}$. long; akenes glabrous.

Common along alpine streams.

Arnica betonicaefolia Greene. Nearly glabrous; stems slender, 6-15 cm. high; leaves oval to oval-lanceolate, obtuse, crenate-dentate, $2-3 \mathrm{~cm}$. long, the basal ones petioled, the $2-3$ pairs of cauline sessile; heads 1-3, long-peduncled; involucre $10 \mathrm{~mm}$. high, turbinate; tegules pubescent, acute; ray-flowers 1-1.5 cm. long; akenes sparsely hairy at top; pappus white.

In alpine meadows at about $2000 \mathrm{~m}$. altitude. The type specimens are from Mount Steele in the Olympic Mountains.

Arnica eradiata (Gray) Heller. (A. parryi Gray.) Hirsutely pubescent, gTandular toward the top; stems mostly simple, $30-50 \mathrm{~cm}$. high; leaves oval to ovate-oblong, denticulate, the basal ones petioled; cauline 1-3 pairs; heads rayless, solitary or often $3-5$; involucre $10-12 \mathrm{~mm}$. high; tegules hirsute and glandular; akenes glabrous or sparsely hirsute.

In alpine meadows at about $2000 \mathrm{~m}$. altitude.

Arnica fulgens Pursh. Erect, $30-60 \mathrm{~cm}$. high, the crown thickened and rusty-woolly, sometimes with creeping rootstocks; whole plant viscid-pubescent; basal leaves spatulate-lanceolate, 3-nerved, entire or nearly so, obtuse, 5-12 cm. long; cauline 2 or 3 pairs, sessile, the upper sometimes very small; heads 1-3, long-peduncled; involucres $10-12 \mathrm{~mm}$. high, densely glandularpubescent; ray-flowers yellow, $12-16 \mathrm{~mm}$. long; tubes of disk-corollas hairy; akenes pubescent.

A species of the interior, rare in our limits; Goat Mountains, Allen. The subterranean characters may vary according to soil; the form without rootstocks has been named as a species, $A$. pedunculata Rydb.

Arnica aurantiaca Greene. Tufted, 5-20 cm. high; stems erect, bearing 1-3 heads; cauline leaves 2 or 3 pairs, entire, the lowest oblong, obtuse, the upper oblong-lanceolate, acute, glabrous except the margins; peduncle sparsely glandular and pubescent; involucre turbinate-campanulate; tegules about 10, lanceolate, woolly at base, thinly ciliate; ray-flowers orange-yellow; akenes silky; pappus white.

Goat Mountains, Allen.

Arnica amplexicaulis Nutt. Nearly glabrous and somewhat gummy; stems $30-60 \mathrm{~cm}$. high, tufted; leaves ovate, acute, saliently dentate, glabrous and gummy above, 4-7 cm. long; basal ones petioled; cauline 4-7 pairs, halfclasping at base; heads mostly 3 or 5 ; ray-flowers $1-1.5 \mathrm{~cm}$. long; akenes hairy.

Along streams, especially in the mountains at low altitudes. First collected at Willamette Falls, Oregon, by Nuttall.

Arnica macounii Greene. Sparsely pubescent; stems tufted, $30-50 \mathrm{~cm}$. high; leaves lanceolate or oblong-lanceolate, acute, serrate-dentate, 5-10 cm. long, the basal ones petioled, the 4-7 cauline pairs sessile; heads cymose, usually 5-7, on small stems 1-3; involucre campanulate; tegules hispidulous, not glandular; akenes hispid and glandular; pappus fuscous. 
Along streams in the mountains at low altitudes. Differs from A. amplexicaulis Nutt. mainly in its narrower leaves.

Arnica aspera Greene. Sparsely pilose; stems tufted, 40-60 cm. high; leaves ovate-lanceolate, saliently dentate, hairy on both sides, the cauline sessile, 4-6 cm. long; heads mostly 3-5, slender-peduncled; involucres campanulate; tegules pustulate-hairy; akenes setose; pappus tawny.

Along alpine rivulets at $1700 \mathrm{~m}$. altitude, the type specimen from Mount Rainier.

Arnica mollis Hook. Herbage villous-pubescent, somewhat glandular above; stems $20-40 \mathrm{~cm}$. high; leaves oblong to oblong-lanceolate, entire or denticulate, mostly acute, the lower ones petioled, 5-10 cm. long; cauline leaves $3-5$ pairs, the upper ones remote, sessile; heads mostly 3 , rarely 5-9, 4-6 cm. broad; tegules glandular, lanceolate, acute; akenes hairy.

Along alpine rivulets at $1500-2000 \mathrm{~m}$. altitude.

\section{SENECIO.*}

Herbs (in ours) or shrubby plants; leaves all alternate; heads usually solitary or in corymbs, many-flowered; flowers yellow, all fertile; ray-flowers pistillate or occasionally none; tegules herbaceous, mostly narrow, equal, in one row, or with a few short outer (calyculate) ones; receptacle flat or merely convex, naked; pappus of very numerous and mostly white, fine and soft capillary and merely scabrous bristles; akenes terete or somewhat angled, usually 5-10-ribbed.

Annuals.

Heads discoid; short outer tegules black-tipped.

Heads with short rays; short outer tegules few, not black-tipped.

Biennials or perennials; heads usually radiate.

Leaves pinnately divided.

Stem $30-50 \mathrm{~cm}$. high.

Stem 10-20 cm. high.

Leaves all undivided or those of the stem pinnately lobed.

Heads discoid (except in subsp. fallax). Heads radiate.

Heads few, terminating the stem and branches.

Foliage glabrous.

Foliage tomentulose.

Heads usually numerous, in a terminal corymbose cyme.

Stem leafy to the inflorescence.

Stem leafy below, naked above.

Tegules black-tipped.

Herbage arachnoid tomentulose. S. lugens.

Herbage pubescent with coarse

S. vulgaris.

S. sylvaticus.

S. harfordii.

S. flettii.

S. pauciflorus. jointed hairs or glabrous.

Herbage glaucous, glabrous, fleshy; leaves mostly entire.

S. ductoris.

S. websteri.

S. triangularis.

S. hydrophilus.

* The account of this genus has been prepared with the assistance of Dr. J. M. Greenman. 
Herbage not glaucous nor fleshy, pubescent at least when young; leaves dentate or denticulate.

Leaves subcordate; rayflowers pale yellow.

Leaves not subcordate; ray-flowers darker yellow.

Tegules not black-tipped.

S. ochraceus.

S. exaltatus.

Herbage more or less permanently tomentulose.

Leaves entire or denticulate.

Leaves coarsely dentate.

Herbage glabrous or nearly so.

Lower leaves oblanceolate.

Lower leaves ovate or obovate.

Stem $30-50 \mathrm{~cm}$. high.

Stem 10-15 cm. high.

S. fastigiatus.

S. fastigiatus macounii.

S. multnomensis.

S. pauciflorus fallax.

S. suksdorfi.

- Senecio vulgaris L. Annual, sparsely pubescent or glabrous, usually branched, $15-30 \mathrm{~cm}$. high; leaves spatulate or oblong in outline, $1-3 \mathrm{~cm}$. long, half-clasping at base, pinnately-lobed, the lobes short and usually toothed; heads few to many, in corymbs; involucre 5-7 mm. high, the inner tegules linear, acute, often black-tipped, the outer few and short; ray-flowers wanting; akenes puberulent; pappus copious, white.

A common weed in waste ground; introduced from Europe.

Senecio sylvaticus L. Annual, erect, 10-60 cm. high, slightly pubescent; lower leaves oblong to lanceolate, lyrately pinnatifid, petioled; upper leaves unequally pinnatifid, sessile, sagittate at the clasping base; heads corymbed, slender-peduncled; involucre cylindrical; outer tegules few or wanting, if present not black-tipped; ray-flowers very short, yellow.

Introduced from Europe; Portland, Oregon, Gorman.

Senecio harfordii Greenman. Perennial, glabrous or essentially so throughout; stem erect or ascending from a slender rootstock, $20-50 \mathrm{~cm}$. high, somewhat glaucous, usually leafy; leaves mostly pinnately divided, with irregularly lobed divisions, and these in turn dentate, including the petiole $4-14 \mathrm{~cm}$. long, $1-5 \mathrm{~cm}$. broad, thin in texture, and drying pale green; the lowermost leaves often undivided, rotund and crenately lobed; uppermost leaves without petioles; inflorescence a terminal corymbose cyme, few-many-(2-30-) headed; heads mostly less than $1 \mathrm{~cm}$. high, including the ray-flowers $1.5-2 \mathrm{~cm}$. in diameter; involucre shorter than the disk-flowers; tegules about 13, narrowly lanceolate, 5-5.5 mm. long, acuminate, acute, glabrous; ray-flowers commonly 5, bright, yellow; disk-flowers 18-25; akenes 2.5-3.5 mm. long, glabrous.

Common in the gorge of the Columbia River, on moist rock cliffs.

Senecio flettii Wiegand. Perennial, glabrous; stems $15-20 \mathrm{~cm}$. high, tufted; leaves mostly basal, oblong, $8-12 \mathrm{~cm}$. long, petioled, pinnately parted into irregular oblong incisely-toothed angular divisions; cauline similar, smaller; heads $7 \mathrm{~mm}$. high, several in a rather close corymb; tegules 10-12, thin, acute; ray-flowers $2-4$, dark yellow; akenes glabrous.

In rocky soil in the Olympic Mountains, at about $2300 \mathrm{~m}$. altitude, abundant; Mount Rainier, near Cowlitz Cleavers, Miss Winona Bailey.

Senecio pauciflorus Pursh. Perennial, 10-30 cm. high, slightly floccose- 
tomentose at the base, in the axils of the leaves and in the inflorescence, otherwise glabrous; lower leaves petiolate, broadly ovate, 1-2 cm. long, 8-14 $\mathrm{mm}$. broad, subcordate to cuneate at the base, crenate-serrate, rather thick and firm in texture; petioles equalling or twice as long as the blade; upper leaves more or less pinnate; inflorescence usually a close compact umbel; heads discoid, about $1 \mathrm{~cm}$. high in anthesis; tegules glabrous, their tips tinged with purple; akenes glabrous.

Widely distributed; Labrador, Rocky Mountains, British Columbia to northern California. In our limits it has been collected on Mount Constitution, San Juan County, Washington, Henderson, and at Deming, Whatcom County, Washington, Flett.

Senecio pauciflorus fallax Greenman. Stem erect, about $50 \mathrm{~cm}$. high; lower stem-leaves $3-8 \mathrm{~cm}$. long, $1-2.5 \mathrm{~cm}$. broad, pinnately parted with deep broad sinuses between the lateral divisions, blackish or dark green in the dried state; segments narrowly oblong to subovate, obtusely toothed; upper leaves reduced to mere bracts; inflorescence cymose, few-headed; heads $8-10 \mathrm{~mm}$. high, radiate; involucre campanulate; tegules $18-21$, linear, acute, 6-8 mm. long, slightly purplish-tipped, glabrous; ray-flowers 10-12, yellow; diskflowers 50-60; akenes glabrous.

In partial shade, Deming, Whatcom County, Washington, Flett; not otherwise known.

Senecio ductoris Piper. (S. fremonti T. \& G.) Perennial, glabrous; stems tufted from a stout woody caudex, erect or ascending, $10-20 \mathrm{~cm}$. high; leaves broadly obovate to spatulate or oblong, obtuse, dentate or incised, thick in texture, 2-5 cm. long, the lower ones abruptly petioled, the uppermost sessile; heads solitary or few together, the peduncles exceeding the leaves; ray-flowers $8-12$.

Rocky places in the mountains at $2000-2500 \mathrm{~m}$. altitude.

Senecio websteri Greenman. Perennial, floccose-woolly to nearly glabrate; stems erect or ascending, 15-20 cm. high; basal leaves thick, ovate to oblong-obovate: acute, sinuate-dentate to denticulate, $8-12 \mathrm{~cm}$. long, narrowed into a wing-margined petiole; cauline lanceolate, sessile, irregularly dentate; heads solitary on peduncles $4-8 \mathrm{~cm}$. long; involucre campanulate and calyculate; principal tegules linear-lanceolate, acute, sparsely woolly, 13-15 mm. long; ray-flowers $12-15 \mathrm{~mm}$. long; akenes glabrous.

Known only from talus slopes on Mount Angeles, Olympic Mountains, Washington, Webster.

Senecio triangularis Hook. Perennial, glabrous throughout, $30-90 \mathrm{~cm}$. high; stem simple, leafy to the top; leaves narrowly or broadly triangular, acute or acuminate, evenly dentate, truncate at base or the lower often cordate and the upper cuneate, $5-15 \mathrm{~cm}$. long, on short petioles; heads corymbed; involucre 6-8 mm. high; tegules linear-lanceolate, acute, pubescent at tip; ray-flowers 6-12, yellow.

In moist places in the mountains, but occurring at sea-level near the mouth of the Columbia River.

Senecio lugens Richards. Perennial, floccose-tomentose in the early stages, more or less glabrate; stem $10-60 \mathrm{~cm}$. high, leafy below, nearly naked above; radical and lower leaves oblong-spatulate, $3-15 \mathrm{~cm}$. long, 1-3 cm. broad, obtuse or rounded at the apex, narrowed below into a winged petiole, repand-callous, denticulate to subentire, thin, membranous, sparingly tomentose or glabrous; stem leaves remote, gradually reduced, becoming bracteiform; inflorescence a few-headed corymbose cyme; heads radiate, $1-1.5 \mathrm{~cm}$. high; involucre campanulate, calyculate, glabrous or subtomentose particularly at the base; tegules about 13 and as well as the bracteoles conspicuously black-tipped; akenes glabrous. 
Arctic North America and Alaska, south to Wyoming and Washington; in our limits known only from the Olympic Mountains, Flett.

Senecio hydrophilus Nutt. Perennial, wholly glabrous and slightly glaucous; stems erect, $60-100 \mathrm{~cm}$. high, stout; leaves fleshy with obscure veins, entire or nearly so, the basal oblanceolate, short-petioled, $10-30 \mathrm{~cm}$. long; cauline sessile or half-clasping, lanceolate; heads numerous, in a dense cyme, short-peduncled; involucre cylindric, $6 \mathrm{~mm}$. high; tegules 8-12; ray-flowers small, few or sometimes wanting. limits.

Near the Cascades of the Columbia, Howell, perhaps not within our

Senecio ochraceus Piper n. comb. (S. exaltatus ochraceus Piper.) Perennial, sparingly white-tomentose; stems erect, $30-60 \mathrm{~cm}$. high; lower leaves broadly ovate, subcordate, crenate-dentate to subentire, 5-8 cm. long, petioled; upper leaves much reduced, sessile, lanceolate-attenuate; heads in a rather close corymb; involucres campanulate, tomentose; tegules about 13, linear, acute, black-tipped, 6-8 $\mathrm{mm}$. long; ray-flowers pale yellow.

British Columbia to Montana and northern California; Goat Mountains, Washington, Allen.

Senecio exaltatus Nutt. (S. oreganus Howell.) Perennial; stem simple, erect, $20-120 \mathrm{~cm}$. high, terete, striate, glabrous, or somewhat pubescent with long flaccid jointed white hairs; lower leaves petiolate, oblong-ovate to oblonglanceolate, 10-20 cm. long, 2-8 cm. broad, obtuse, unequally dentate to subentire, gradually narrowed to abruptly contracted at the base, glabrous or more or less crisp-hirsute; upper stem-leaves soon becoming sessile and much reduced; inflorescence terminating the stem in a few to many-headed corymbose cyme; heads about $1 \mathrm{~cm}$. high in anthesis, radiate; tegules about 13 , commonly penicillate and black-tipped; akenes glabrous.

British Columbia to Montana and Oregon; rare west of the Cascade Mountains, but first collected by Nuttall at the mouth of the Willamette River; Lake Labish, Howell (type of S. oreganus).

Senecio fastigiatus Nutt. Perennial; herbage thinly white tomentose; stems erect, $30-40 \mathrm{~cm}$. high; leaves mostly basal, lanceolate to spatulate, obtuse, obscurely crenulate or entire, firm in texture, 5-7 cm. long, the lower ones slender petioled, the cauline sessile and narrower; inflorescence a cyme with nearly erect branches; heads $8-10 \mathrm{~mm}$. high; ray-flowers yellow; akenes glabrous.

Gravelly prairies, Washington and Oregon, west of the Cascade Mountains.

Senecio fastigiatus macounii (Greene) Greenman. Stem $30-45 \mathrm{~cm}$. high, simple or branched; leaves entire to coarsely erose-dentate. Differs from $S$. fastigiatus chiefly in the dentate character of the leaves.

Mount Constitution, San Juan County, Washington, Flett; Columbia Valley, Lyall; Willamette Valley near Tangent, Oregon.

Senecio multnomensis Greenman. Perennial; stems flexuous, suberect, $30-70 \mathrm{~cm}$. high, glabrous, except in the leaf axils; lower leaves oblong-oblanceolate, 4-15 cm. long, obtuse, crenate-serrate, or more or less lyrately lobed, glabrous in age; upper sessile or half-clasping; inflorescence cymose, the peduncles elongate; heads $10-13 \mathrm{~mm}$. high, rayed; tegules about 21 , linear lanceolate, $8-10 \mathrm{~mm}$. long, acute, pale green, glabrous; ray-flowers yellow; akenes glabrous.

British Columbia to Oregon.

Senecio suksdorfii Greenman. (S. adamsi Howell.) Perennial, floccosewoolly, becoming more or less glabrate; stems $10-30 \mathrm{~cm}$. high; basal leaves obovate to suborbicular, crenate-dentate, slender petioled; cauline oblong- 
lanceolate, sessile, pinnately lobed or parted; heads in a rather dense cyme; involucre hemispheric; tegules linear-lanceolate, acute, $8-10 \mathrm{~mm}$. long; rayflowers $12-15$.

In talus at the base of cliffs, Mount Adams, Suksdorf, Howell; Mount Rainier in Indian Henry Park, Tarleton.

\section{PSILOCARPHUS.}

Low woolly annuals; leaves entire, mostly opposite; heads small, discoid, many-flowered, in terminal capitate clusters and in the forks of the branches, surrounded by the upper leaves; fertile flowers numerous, in several series on the globular chaffy receptacle; pappus none; akene loose in the bladder-like bract, oblong or narrower, slightly compressed.

Heads covered with long loose woolly hairs.

P. elatior.

Heads covered with short close wool.

Prostrate; leaves oblong or elliptic.

Ascending; leaves narrowly oblanceolate.

$P$. tenellus.

$P$. oreganus.

Psilocarphus elatior Gray. Erect and simple or more commonly branched from the base and spreading, $5-10 \mathrm{~cm}$. high, loosely white-woolly throughout; leaves lanceolate or linear-spatulate, $1-2 \mathrm{~cm}$. long; heads $6-8 \mathrm{~mm}$. broad, subtended by leaves; fruiting tegules appressed, tomentose; akenes cylindrical.

In low ground, especially in dried-up ponds, Vancouver Island to Idaho and Oregon. First found near Portland, Oregon.

Psilocarphus tenellus Nutt. Canescently tomentose with fine appressed wool; stems ascending, much branched from the base, 3-8 cm. high; leaves spatulate, 5-10 mm. long; heads small, numerous, in fruit 4-6 $\mathrm{mm}$. in diameter; akenes fusiform, oblong, $1 \mathrm{~mm}$. long.

Vancouver Island, Macoun; Fairhaven, Whatcom County, Washington, Suksdorf; not otherwise known north of California.

Psilocarphus oreganus Nutt. Stems ascending, 2-5 cm. high; leaves narrowly oblanceolate, $8-10 \mathrm{~mm}$. long; heads covered with close wool; bracts $2 \mathrm{~mm}$. long; akenes cylindric.

The original specimens were collected by Nuttall "near the Oregon and outlet of the Wahlamet." The plant has not since been found west of the Cascade Mountains, but it is not rare in the interior.

\section{ANTEN NARIA.}

Low white-woolly cespitose perennials; leaves alternate, entire; heads small, solitary or corymbose, completely dioecious; receptacle naked; staminate flowers with the pappus-bristles thickened or barbellate at the apex; pistillate with the slender pappusbristles united at base in to a ring.

Plants not stoloniferous; stems $5-10 \mathrm{~cm}$. high.

A. lanata.

Plants stoloniferous, growing in patches; stems usually 15 or more $\mathrm{cm}$. high.

Heads loosely racemose; inflorescence glandular.

Heads corymbose; inflorescence not glandular.

Leaves 3-5 cm. long, oblanceolate or narrowly obovate.

Green and glabrate above.

Tomentose on both surfaces.

A. racemosa.

A. howellii.

A. concolor. 
Leaves much smaller and narrower.

Tegules greenish brown.

Tegules pink.

Leaves obtuse, white tomentose.

Leaves acutish, grayish tomentose.

A. media.

A. concinna.

A. rosea.

Antennaria lanata (Hook.) Greene. Densely and rather coarsely woolly; stems erect, $10-15 \mathrm{~cm}$. high, not at all stoloniferous; basal leaves spatulatelanceolate, petioled, 2-6 cm. long; cauline linear; inflorescence dense; involucre 4-6 $\mathrm{mm}$. high, very woolly at base, the inner tegules with papery white tips.

Common in rocky soil in the mountains at $2000-2500 \mathrm{~m}$. altitude.

Antennaria racemosa Hook. Perennial by stout leafy stolons; stems slender, erect, $15-40 \mathrm{~cm}$. high, glabrous or nearly so; basal leaves oval or ovate, obtuse, green and glabrous or glabrate above, white-woolly beneath, 1-3 cm. long, cuneate at base, petioled; cauline sessile, lanceolate, mostly acute, 1-3 $\mathrm{cm}$. long; inflorescence glandular, racemose or somewhat paniculate; staminate heads always racemose, subglobose, 4-6 $\mathrm{mm}$. high, slender-peduncled, the tegules brownish, obtuse; pappus with thickened tips; pistillate heads usually corymbose, oblong, 6-8 mm. long, the tegules greenish, narrow-tipped; pappus simple.

Open woods in the mountains; rare west of the Cascade Mountains.

- Antennaria howellii Greene. Stems slender, 15-30 cm. high, grayish woolly; stolons prostrate, leafy, $5-10 \mathrm{~cm}$. long; basal leaves cuneate-oblanceolate, petioled, 1-nerved, acutish, 3-5 cm. long, becoming green above, persistently white-tomentose beneath; heads in a close cyme; involucre campanulate, $8 \mathrm{~mm}$. high; tegules linear-lanceolate, the tips white and scarious; akenes glandular.

In open coniferous woods, common.

Antennaria concolor Piper. Cespitose, the ligneous rootstocks and stolons slender; stems slender, erect, $20-30 \mathrm{~cm}$. high, sparsely tomentose; basal leaves thin, spatulate, $2.5-3.5 \mathrm{~cm}$. long, whitish, abruptly acuminate, concave on the lateral margins, the greener upper side becoming nearly glabrous the second season; cauline 7-9, linear or linear-lanceolate; inflorescence of 4-7 short-peduncled heads in a corymb; involucre $8-9 \mathrm{~mm}$. high; tegules in about 3 ranks, mostly acute, greenish below, fuscous in the middle, the tips paler or white.

In open places in fir woods near the suburb of Portland, Oregon, known as Mount Scott. Only pistillate plants are known.

Antennaria media Greene. Densely white tomentose; stems $4-6 \mathrm{~cm}$. high; stolons 1-3 cm. long; leaves spatulate-oblanceolate, acute, $12-15 \mathrm{~mm}$. long; heads in a dense cluster; involucre of the pistillate flowers $4 \mathrm{~mm}$. high, the tegule tips oblong, mostly obtuse, usually greenish brown; staminate involucre similar.

Common in the mountains at $2000-2500 \mathrm{~m}$. altitude.

Antennaria concinna E. Nelson. Densely white tomentose; stems leafy, $10-35 \mathrm{~cm}$. high; stolons $3-5 \mathrm{~cm}$. long; basal leaves spatulate, acute, whitetomentose on both sides, about $10 \mathrm{~mm}$. long; cauline linear-oblong to linear; inflorescence dense or moderately open, of 6-15 heads; involucre 6-7 mm. high; tegules obtuse, more or less rose-tinged.

Olympic Mountains, Elmer, Piper, Lawrence.

Antennaria rosea (D. C. Eaton) Greene. Densely white-tomentose throughout; stems slender, $20-30 \mathrm{~cm}$. high; stolons ascending; leaves narrowly oblanceolate, acute, $15-20 \mathrm{~mm}$. long; heads in rather close clusters; involucres 5-6 mm. high; pistillate tegules rose-colored, rarely white, obtuse, the staminate plant unknown.

In dry sandy or gravelly soil, in the mountains. 


\section{ANAPHALIS. EvERLASTING.}

White-woolly perennial herbs with erect leafy stems and entire leaves; heads numerous, small, discoid, dioecious but usually with a few perfect flowers in the center of the pistillate heads; involucre campanulate to oblong, its tegules scarious, numerous, closely imbricated; pappus bristles of staminate flowers little if at all thickened at the apex, that of the fertile flowers not at all united at the base.

Anaphalis margaritacea occidentalis Greene. Stems erect, $20-60 \mathrm{~cm}$. high; leaves broadly lanceolate, somewhat revolute, sessile, bright shining green above, white-woolly beneath; heads numerous, in a terminal corymb 4-15 cm. broad; involucre campanulate, subglobose; tegules ovate-lanceolate, obtuse, pearly white.

Very common in open places, especially in old "burns."

Anaphalis margaritacea subalpina Gray. Very similar to A. margaritacea occidentalis but usually not so tall; leaves permanently pubescent above; corymbs mostly smaller and denser.

Rather rare in moist meadows in the mountains at low elevations.

\section{GNAPHALIUM. CUdWEed.}

Woolly herbs; leaves alternate, entire; heads small, discoid; pistillate flowers very numerous in more than one row; flowers white or yellow; perfect flowers fewer in the center; staminate flowers none; pappus-bristles slender, not thickened above; akenes oblong or ovate.

Bristles of the pappus united at base; involucre brownish. G. purpureum.

Bristles of the pappus separate at base.

Plants low; flowers in dense leafy clusters; involucres very woolly.

Tegules white; plants loosely-woolly.

Tegules brownish; plants appressed-woolly.

Plants tall; flowers in looser leafless clusters; involucres woolly only at base.

Involucre white; cymes loose.

Involucre yellowish; cymes dense.

G. palustre.

G. uliginosum.

Gnaphalium purpureum L. Biennial or sometimes annual; herbage silvery canescent; stems erect, $20-30 \mathrm{~cm}$. high; basal leaves spatulate, obtuse, green above, appressed woolly beneath, short-petioled, $2-5 \mathrm{~cm}$. long; cauline narrower, mostly linear, sessile; heads in dense clusters in the axils of the upper leaves, making a spike-like inflorescence; tegules brownish or purplish, acute; akenes scabrous.

Very common in open places.

Gnaphalium palustre Nutt. Annual, much branched at base, 5-12 $\mathrm{cm}$. high, very woolly throughout; leaves lanceolate, oblong or spatulate, $1-2 \mathrm{~cm}$. long; heads $2-3 \mathrm{~mm}$. high, sessile, in small terminal or axillary clusters, which are very woolly and subtended by leaves; involucre of few tegules, these linear, acute or obtuse, brownish with white tips; akenes glabrous, the bristles falling separately.

Common in dried-up pond bottoms and on river banks. 
Gnaphalium uliginosum L. Annual, appressed-white-woolly; stems branched from the base, 5-20 $\mathrm{cm}$. high; leaves spatulate to linear, sessile, obtuse, 3-4 cm. long; heads sessile in dense leafy-bracted clusters; tegules brownish, oblong to oblong-lanceolate, the outer obtuse, the inner acute; pappus bristles distinct, falling separately.

Moist places, especially on river banks.

Gnaphalium microcephalum Nutt. Pubescence woolly, dense, white, close; stems several, slender, erect, 30-60 cm. high; leaves linear or the lower lanceolate, decurrent at base; heads in clusters of several, these paniculate; involucres turbinate to campanulate, woolly only at base, 3-4 mm. high; tegules bright white, scarious, obtuse.

In gravelly or sandy soil, not rare.

Gnaphalium chilense Spreng. Erect, very leafy, 30-60 cm. high, simple or branched below, persistently tomentose, not glandular; leaves linearlanceolate or somewhat spatulate, acute, $5-8 \mathrm{~cm}$. long, scarcely decurrent at base; heads $4-5 \mathrm{~mm}$. high, in one or few dense clusters; involucre hemispheric; tegules greenish-white, oblong, obtuse; akenes glandular.

Prairies and open woods.

\section{INULA. ELECAMPANE.}

- Tall coarse herbs with large heads of yellow flowers and simple alternate leaves; heads radiate, many-flowered; disk-flowers fertile; involucres hemispheric; tegules imbricated, the outer ones herbaceous; receptacle flat, naked; anthers caudate; style branches linear, rounded at apex; akenes 4-5-ribbed, pappus capillary, scabrous.

Inula helenium L. Elecampane. Pubescent, especially above; stems stout, 1-2 m. high, erect, branched above; leaves oblong to ovate, acute, denticulate, tomentose beneath, $20-30 \mathrm{~cm}$. long, the basal ones long-petioled, the cauline sessile or half-clasping; heads solitary or few, $5-10 \mathrm{~cm}$. broad; outer tegules ovate, foliaceous, the inner smaller, spatulate, obtuse; ray-flowers numerous, slender; akenes 4-sided, glabrous.

In fields and along roadways; introduced from Europe.

\section{ADENOCAULON.}

Slender perennial herbs with alternate petioled leaves, green above, white-woolly beneath; heads few, small, 5-10-flowered, glandular, in a loose panicle; tegules in one row; receptacle flat, naked; flowers all tubular, the marginal pistillate, fertile, the central perfect, but sterile; akenes elongated at maturity, clubshaped; pap'pus none.

Adenocaulon bicolor Hook. Stem 30-90 cm. high, floccose-woolly; leaves mostly basal, triangular-ovate, somewhat cordate, with angular toothed margins, bright green above, white-woolly beneath, 5-10 cm. long; petioles margined; inflorescence glandular; tegules ovate to lanceolate, acute, reflexed in fruit; akenes club-shaped, the top covered with stalked glands.

In open woods, very common.

\section{CENTAUREA.}

Herbs; heads many-flowered; flowers all with tubular and deeply 5-cleft corollas, some of the marginal ones commonly 
sterile, often much larger and conspicuous, the others perfect and fertile; involucre globular, the tegules tipped or margined with spines or scarious appendages; receptacle very bristly; pappus of numerous rigid or sometimes chaffy naked bristles; akenes mostly compressed, attached by one margin just above the base.

Tegules each tipped with a slender spine; ray-flowers yellow. C. melitensis.

Tegules spineless, all more or less fimbriate; ray-flowers red, blue, white or violet.

C. cyanus.

Centaurea melitensis L. Annual; herbage pubescent; stems $30-100 \mathrm{~cm}$. high, loosely branched; basal leaves petioled, lyrately lobed, the lobes obtuse or rounded; cauline leaves sessile, entire or merely toothed; heads short-peduncled, 10-12 mm. in diameter; tegules each tipped with a branched spine.

Introduced from Europe. Very troublesome as a weed in California where it is called "Napa Thistle."

Centaurea cyanus L. Bachelor's Button. Stems erect, slender, usually branched, 30-90 cm. high; heads solitary on slender branches; involucre ovoid; tegules in about four series, pale, the middle ones margined with a silvery scarious-toothed border; ray-flowers large, white, blue, pink or violet.

A common weed in fields and waysides.

547. Silybum. Milk Thistle.

Coarse prickly herb with pinnately lobed alternate mottled leaves and large solitary heads of purple flowers; involucre subglobose; tegules imbricated in a few series, large, rigid, the spiny tips spreading; receptacle flat, bristly; flowers all alike, tubular, perfect, fertile; akenes glabrous; pappus bristles numerous, flattish, scabrous or barbellate, united at base and falling together.

Silybum marianum (L.) Gaertn. Glabrous or slightly tomentose; stems 60-120 cm. high; leaves blotched with white, oblong-lanceolate, the lower ones unequally lobed, spinose-dentate, the cauline strongly clasping at base; heads globose, 5-6 cm. broad; flowers purple; pappus bristles white.

In waste places, adventive from Europe.

\section{CIRSIUM. Thistle.}

Biennial or perennial herbs; leaves alternate, sessile, mostly pinnatifid and prickly; heads usually large, terminal, manyflowered; flowers all tubular, perfect and all alike, rarely imperfectly dioecious; involucre ovoid or spherical; tegules imbricated, in many rows, the tips scarious or prickly; receptacle thickly clothed with soft bristles or hairs; pappus of numerous bristles united into a ring at the base, plumose, deciduous; akenes oblong, flattish, not ribbed.

Dioecious; heads $1-1.5 \mathrm{~cm}$. in diameter; perennial by spreading roots.

C. arvense.

Hermaphrodite; heads larger; biennials. 
Tegules all with dilated fringed tips.

Tegules or some of them with spiny tips.

Outer and inner tegules all with spiny tips.

C. americanum.

Outer tegules spine-tipped: inner ones unarmed.

\section{C. lanceolatum.}

Heads clustered, short-peduncled; flowers pink.

Heads few, long-peduncled; flowers cream-colored. C. remotifolium.

Cirsium arvense (L.) Scop. Canada Thistle. Perennial, with slender creeping rootstocks; whole plant green, thinly tomentose when young becoming glabrous, much branched, 1-2 m. high; leaves numerous, oblonglanceolate, pinnately-lobed, sessile and somewhat clasping at base, 10-20 cm. long; prickles numerous, rather weak; heads small, corymbed, dioecious; staminate heads globose, the flowers much exserted; pistillate heads oblongcampanulate, the flowers scarcely projecting; tegules well imbricated, somewhat ciliate, the short ovate outer ones spine-tipped, the inner ones lanceolate, soft-tipped; flowers pink-purple.

A weed in cultivated ground, introduced from Europe.

Cirsium americanum (Gray) Robinson. Stems erect, $30-90 \mathrm{~cm}$. high, sparingly branched above; leaves lanceolate, coarsely dentate to pinnatifid or even pinnately parted, weakly prickly, green above, white tomentose beneath, 6-12 cm. long; heads mostly solitary, terminating the branches; involucre $-\overline{2}-3 \mathrm{~cm}$. high; tegules with a dilated scarious tip, this lacerate and mucronate on the outer ones, entire on the inner; flowers cream-colored; some of the pappus bristles dilated at tip.

Washington to California; rare northward.

Cirsium lanceolatum (L.) Scop. Bull Thistle. Stems stout, somewhat woolly, usually branched, leafy to the top, $100-150 \mathrm{~cm}$. high; leaves lanceolate, deeply pinnatifid, hispid-pubescent but green above, white-tomentose beneath, decurrent at base, 6-15 cm. long, armed with numerous stout prickles; heads large, on stout leafy peduncles: involucre well imbricated, sparsely woolly; tegules lanceolate, acuminate, all tipped with stout erect spiny points; flowers purple.

A very common weed, introduced from Europe.

Cirsium edule Nutt. Stems usually tall and nearly simple, 1-2 m. high, thinly pubescent; leaves numerous, lanceolate, pinnately-lobed, pubescent above, woolly beneath, but soon green and glabrate on both sides, $5-20 \mathrm{~cm}$. long; prickles rather weak; heads large, usually clustered, short-peduncled, often surrounded by the upper leaves; involucre persistently white-woolly; tegules loose, each tapering to a slender rather weak spiny point, the outer broader and shorter, not glandular; corolla purple, the lobes thickened at the tips, shorter than the throat; pappus-bristles a little thickened at the tips.

In rich open woods and banks; the roots formerly used as food by the Indians.

Cirsium remotifolium (Hook.) DC. Woolly and cobwebby, especially when young; stems erect, 1-2 m. high; leaves oblong-lanceolate in outline, sinuately lobed to deeply pinnatifid, moderately prickly, white tomentose beneath; heads long-peduncled; involucre $3-4 \mathrm{~cm}$. high; tegules linear-attenuate, the outer spiny-pointed, the inner scarious and lanceolate at tip; flowers cream-colored; pappus bristles often thickened at tip.

Prairies and meadows, Washington to California.

549. ARCTIUM. BURDOCK.

Coarse biennial plants with large ovate to orbicular cordate leaves; heads many-flowered; involucre globose; tegules numerous, 
closely imbricated, slender, appressed at base, spreading and hooked at tip; flowers perfect, all tubular, purple; receptacle bristly; akenes oblong, transversely wrinkled; pappus of numerous short rough bristles.

Arctium minus Schk. Stems stout, branched, 1-2 m. high; leaves broadly ovate, mostly cordate, obtuse, entire or more or less dentate, floccose-woolly beneath, the basal ones $30-50 \mathrm{~cm}$. long; petioles channelled; heads subracemose, $15-30 \mathrm{~mm}$. broad; involucre glabrous or cobwebby; tegules arcuate, spreading.

Common in waste places.

\section{SAUSSUREA.}

Perennial leafy stemmed herbs with corymbosely clustered medium sized heads of purple flowers; heads many-flowered; involucre oblong to obovoid; tegules imbricated, appressed, obtuse; receptacle bristly; flowers all alike, tubular, perfect; style branches slender; akenes oblong; pappus double, the larger bristles numerous, plumose, united in a ring and falling together; outer bristles similar but smaller and less plumose or naked.

Saussurea americana D. C. Eaton. Sparsely arachnoid-tomentose; stems stout, erect, $30-120 \mathrm{~cm}$. high, leafy; basal leaves ovate to oblong-ovate, subcordate, acute to acuminate, mostly dentate, pubescent beneath, petioled; cauline similar, sessile by a narrow base or the uppermost lanceolate; heads 10-17-flowered, numerous, in panicled cymes; heads $12-15 \mathrm{~mm}$. high; involucre ovoid-cylindric, pubescent; tegules obtuse in 5 or 6 series; flowers blue-violet.

Alpine meadows at about $2000 \mathrm{~m}$. altitude. Especially abundant in the Olympic Mountains.

SUMMARY.

\begin{tabular}{|l|c|c|c|}
\hline & Families. & Genera. & $\begin{array}{c}\text { Species and Sub- } \\
\text { species. }\end{array}$ \\
\cline { 2 - 2 } \cline { 1 - 1 } Pteridophyta. & 7 & 22 & 61 \\
Gymnospermae. & 2 & 10 & 22 \\
Monocotyledones. & 15 & 111 & 412 \\
Dicotyledones. & 76 & 407 & 1122 \\
\hline \multicolumn{1}{|c|}{ Totals. } & 100 & 550 & 1617 \\
\hline
\end{tabular}




\section{NEW SPECIES, NEW SUBSPECIES, AND NEW COMBINATIONS.}

\section{NEW SPECIES.}

Arctostaphylos columbiana Piper........................p. 279

Godetia gracilis Piper.............................. 251

Panicularia occidentalis Piper .......................... 59

Populus vancouveriana Trelease......................... p. 118

Solidago algida Piper............................... p. 365

Solidago vespertina Piper............................. p. 365

NEW SUBSPECIES.

Grindelia oregana wilkesiana Piper....................... 363

\section{NEW COMBINATIONS.}

Argentina grandis (T. \& G.) Piper........................ 211

Barbarea barbarea brachycarpa (Rouy \& Foucaud) Piper............p. 176

Carex celsa (Bailey) Piper............................. p. 79

Centaurium minimum (Howell) Piper..................... 288

Juncoides campestre congestum (Thuill.) Piper................ p. 92

Juncoides majus (Hook.) Piper........................ p. 92

Juncoides subsessile (Wats.) Piper....................... p. 91

Kalmia polifolia microphylla (Hook.) Piper................... 282

Mertensia denticulata (Lehm.) Piper....................... 301

Oxytropis luteolus (Greene) Piper........................ 227

Panicularia leptostachya (Buckl.) Piper...................... 59

Prunus emarginata erecta (Presl) Piper.....................p. 199

Saxifraga rufidula (Small) Piper......................... 191

Senecio ochraceus Piper............................ p. 389 



\section{GLOSSARY .}

Abortive. Sterile; reproductive parts failing to develop.

Acaulescent. Stemless or apparently so, or with the stem underground.

Acerose. Needle-shaped; with a sharp rigid point.

Acrid. Sharp and harsh to the taste. Adnate. United, especially where different organs are fused.

Adventive. Coming from a different region and not thoroughly naturalized.

Akene. A dry, one-celled, one-seeded, indehiscent fruit.

Alveolate. Resembling a honeycomb.

Ament. A catkin; a scaly spike.

Amphitropous (ovule or seed). Halfinverted and straight but with a lateral hilum.

Ampliate. Abruptly expanded.

Anastomose. To connect by crossveins and form a network.

Anatropous (ovule or seed). Inverted and straight with the micropyle next to the hilum.

Androgynous. Having both staminate and pistillate flowers.

Annular. In the form of a ring.

Annulus. A ring, especially the ring of thick-walled cells on a fern sporangium.

Anthesis. The period of full bloom of a flower.

Apiculate. Ending in a short pointed tip.

Appressed. Lying close and flat against something.

Arachnoid. Cobwebby.

Arcuate. Curved in the form of a bow.

Aristate. Tipped with a stiff short bristle.

Atomiferous. Bearing minute scattered granules.

Auricle. An ear-shaped appendage. Awn. A bristle-like terminal or dorsal appendage.

Barbellate. Minutely barbed.

Bifid. Two-cleft.
Bilabiate. Two-lipped.

Biternate. Twice-ternate.

Bract. A modified reduced leaf occurring in the inflorescence.

Bracteate. Having bracts.

Bracteolate. Having small bracts.

Callosity. A hardened thickening.

Callus. A hard protuberance; in the grasses, the tough often hairy swelling at the base of the lemma or palea.

Calyculate. Having bracts around a flower or head which imitate or resemble a calyx.

Campanulate. Bell-shaped, that is cup-shaped with a broad base.

Canescent. Hoary with a grayish pubescence.

Capillary. Hair-like.

Capitate. Shaper like a head; collected into a head.

Carinate. With a keel.

Carpel. A simple pistil or one of the units of a compound pistil.

Carpophore. The slender prolongation of the axis which bears the ripe carpels in the Umbelliferae.

Cartilaginous. Firm and tough, cartilage-like.

Caryopsis. A grain, that is a seedlike fruit with a thin wall adherent to the single enclosed seed as in the grasses.

Caudex. The persistent base of an otherwise annual herbaceous stem.

Caudicula. The thread-like or strapshaped stalk of a pollinium.

Caulicle. The stem-like part of an embryo, the hypocotyl.

Cauline. Pertaining to the stem; on the stem.

Cernuous. Nodding; slightly drooping.

Cespitose. Growing in tufts; forming mats.

Chaff. A small thin bract becoming dry and membranous.

Chartaceous. Papery. 
Chlorophyll. The green coloring-matter found in plants.

Ciliate. Fringed with hairs on the margin.

Ciliolate. Minutely ciliate.

Circinate. Coiled from the tip downward, like fern leaves in the bud.

Circumscissile. Opening by the formation of a circular line of cleavage and the falling off of the top like a cap.

Clavate. Club-shaped, gradually thickened upwards.

Cleft. Margin indented half way to the midrib or more, especially if the incisions are sharp.

Cleistogamous. Pollinated in the bud, without the flowers opening.

Commissure. The surface by which one carpel joins another ( $U m$ belliferae).

Compressed. Flattened, especially laterally.

Connate. United.

Connivent. Converging.

Contiguous. Adjacent to each other.

Coriaceous. Leathery.

Corm. The enlarged fleshy base of a stem; like a bulb but solid.

Costate. Ribbed.

Cotyledon. The first leaves of the embryo plant already formed in the seed.

Crenulate. Finely crenate.

Crested. With an upraised crest-like appendage.

Crustaceous. Hard and brittle.

Cruciform. Cross-shaped; cruciate.

Culm. A hollow stem (Poaceae).

Cuneate. Wedge-shaped.

Cuspidate. Tipped with a cusp, that is a sharp rigid point.

Cymose. Bearing cymes, or cymelike.

Declined. Bent downward.

Decompound. More than once compound.

Decumbent. Reclining but with the apex ascending.

Decurrent. Extending down the stem below the point of insertion.

Dehiscence. The method of opening.

Deltoid. Triangular with the apex upward.

Denticulate. Minutely dentate.

Diadelphous. Stamens in two separate groups.
Diandrous. With two stamens.

Didynamous. Stamens in two pairs of unequal length.

Diffuse. Widely or loosely spreading.

Dimorphic. Occurring in two forms.

Dioecious. Stamens and pistils on different plants.

Discoid. Disk-like; in the Compositae, a discoid head is one without ray-flowers.

Disk-flowers. The flowers with tubular corollas which are in the center of the head in certain Compositae.

Dissected. Divided into numercus small segments.

Divaricate. Widely divergent.

Divergent. Spreading away from each other.

Divided. Margin indented to the midrib but the segments not quite distinct.

Dorsal. Relating to or attached to the back of an organ.

Drupaceous. Drupe-like.

Drupe. A fleshy fruit with the inner portion hard and stony, one-celled and containing but one seed.

Ebracteate. Without bracts.

Elaters. Thread-like appendages to spores which curl and uncurl with changes in the moisture conditions of the air.

Emarginate. Having a very shallow notch at the apex.

Embryo. The tiny plant as it rests partly grown in the seed.

Endosperm. The food cells in the seed surrounding the embryo and contained in the embryo sac.

Epicotyl. The growing point and young bud in the embryo in the seed.

Epigynous. Apparently growing on top of the ovary.

Equitant. Astride; as when leaves are alternately folded over each other in two ranks (Iris).

Erose. Irregularly toothed as if the margin were gnawed out.

Evanescent. Soon fading away.

Exserted. Projected beyond an envelope, as the stamens from the corolla.

Falcate. Scythe-shaped. 
Farinaceous. Containing $\mathrm{sta} \mathrm{rch}$; starch-like.

Fascicle. A close bundle or cluster.

Fasciculate. In close bundles (fascicles).

Favose. Resembling a honeycomb; alveolate.

Fertile. Capable of producing pollen or fruit.

Fibrillose. With fine fibers.

Fibrous. Compose of or resembling fibers.

Fimbriate. Fringed.

Fimbrillate. With a minute fringe.

Flexuous. Zigzag; bending alternately in opposite directions.

Floccose. With fleecy tufts of soft woolly hairs.

Foliaceous. Leaf-like.

Follicle. A fruit consisting of a single carpel dehiscing along the ventral suture.

Fornix. (plural-fornices). A swelling in the throat of the corolla.

Foveolate. With small pits or depressions.

Fugacious. Fading or falling very early.

Fuscous. Grayish-brown.

Fusiform. Spindle-shaped.

Galea. A helmet-shaped or beak-like upper lip of a corolla.

Galeate. Helmet-shaped; having a galea.

Gamophyllous. Composed of coalescent leaves or leaf-like organs.

Geniculate. Bent abruptly, like a knee.

Gibbous. With a protuberance or swelling on one side.

Glabrate. Nearly glabrous or becoming glabrous.

Gland. A secreting organ or a protuberance resembling one.

Glanduliferous. Bearing small glands. Glaurcscent. Somewhat glaucous.

Glaucous. Covered with a whitish bloom.

Glochidiate. Barbed at the tip.

Glomerate. In small compact clusters.

Glumaceous. Glume-like.

Glume. A chaff-like bract, especially the two empty bracts at the base of a grass spikelet.

Glutinous. Sticky, glue-like.
Grain. A one-celled one-seeded indehiscent seed-like fruit in which the wall of the fruit adheres to the seed, a caryopsis.

Granulate. Appearing as if covered with minute granules.

Gynobase. An enlargement or prolongation of the receptacle bearing the ovary or in the fruit the nutlets (Boraginaceae).

Hastate. Halberd-shaped.

Haustoria. Root-like organs which parasitic plants send into the cells of their hosts to absorb food.

Hermaphrodite. Having both sexes; in flowering plants, with both stamens and pistils.

Hilum. The attachment scar on the seed.

Hirsute. Pubescent with rather coarse stiff hairs.

Hispid. Covered with rigid hairs or bristles.

Hyaline. Transparent or translucent.

Hypanthium. An enlargement or special development of the receptacle and calyx-tube as in the Rosaceae.

Hypocotyl. The stem-like part of the embryo (caulicle).

Hypogynous. Attached to the receptacle below and entirely free from the ovary.

Imbricated. Overlapping and breaking joints like shingles.

Immersed. Growing wholly under water.

Incised. Cut sharply and irregularly more or less deeply.

Indehiscent. Not opening when ripe.

Indurated. Hardened.

Indusium. The protective membranous covering formed over the fruit-dot in many ferns.

Involucel. A secondary involucre enveloping an umbellet (Umbelliferae).

Involucrate. Having an involucre.

Involucre. A circle or cluster of bracts surrounding a flower or group of flowers.

Involute. Rolled inward.

Keel. A projecting midrib on the 
dorsal side of a leaf or scale; the two anterior united petals in a papilionaceous flower (Leguminosae).

Lacerate. Irregularly cleft as if torn.

Laciniate. Cut into narrow pointed lobes.

Lanate. Woolly.

Lemma. A bract in a grass spikelet which bears a flower in its axil.

Lenticel. One of the pores in the epidermis of a woody stem.

Lenticular. Lentil-shaped, that is with the shape of a double-convex lens.

Ligulate. Strap-shaped.

Ligule. A thin often scarious projection from the summit of the leafsheath in the grasses and similar plants.

Limb. The expanded part of a petal or sepal.

Lobed. Margin indented less than half way to the midrib.

Locule. One of the cavities or cells of an ovary.

Loculicidal. Dehiscing so that the clefts open into the cavities of the ovary.

Lodicule. One of the tiny scales sometimes found in a grass flower.

Loment. A jointed legume, usually constricted between the seeds.

Lunate. Crescent-shaped or halfmoon-shaped.

Lyrate. Pinnatifid with a large and rounded terminal lobe and the lower lobes small.

Marcescent. Withering but persistent.

Megasporangium. The case in which the megaspores are produced.

Megaspore. One of the large spores in certain fern allies and the seed plants, which is stored with food and which produces a female gametophyte.

Membranaceous. Membrane-like; thin, soft and more or less translucent.

Microsporangium. The case in which microspores are produced; a cell of an anther.

Microspore. One of the small spores in certain fern-allies and the seed- plants, which produce the male gametophyte; a pollen grain.

Monadelphous. Stamens united all in one cluster.

Moniliform. Appearing like a string of beads.

Monoecious. With stamens and pistils in separate flowers on the same plant.

Mucronate. Tipped with a short small abrupt tip.

Mucronulate. Slightly mucronate.

Muricate. Rough with short hard points.

Muriculate. Very finely muricate.

Narcotic. Numbing or sleep-producing.

Nectariferous. Producing nectar.

Nectary. An organ or spot where nectar is secreted.

Nerve. A small slender usually unbranched rib.

Neutral. Without stamens or pistils.

Node. The place in a stem where the woody bundles fuse and where the leaves and buds are normally produced.

Nodulose. With little knots or knobs.

Nut. A hard indehiscent one-celled and one-seeded fruit, though usually developing from a compound ovary.

Nutlet. A tiny nut.

Ob- Inverted.

Obcompressed. Compressed dorsoventrally instead of laterally.

Obsolete. Not evident.

Ochroleucous. Yellowish-white.

Ocrea. A tubular stipule (Polygonaceae).

Olivaceous. Olive-green.

Operculum. A lid; the cap of a circumscissile capsule.

Orthotropous (ovule or seed). Erect, with the micropyle at the apex opposite the hilum.

Palea. A delicate bract which encloses the grass flower and stands opposite the lemma.

Panicle. A loose irregularly compound inflorescence with pedicelled flowers.

Paniculate. Borne in panicles; resembling a panicle. 
Papilionaceous. Butterfly-like, that is having the upper petal enlarged and spreading, the two lateral ones small and oblique, and the two anterior ones connivent into a keel.

Papillate. Papillose.

Papillose. Having minute nipplelike projections.

Pappus. The modified calyx-limb in the Compositae, composed of a ring, a crown of hairs, chaff or scales.

Parasitic. Depending on another organism for its food-supply.

Parted. Margin indented nearly but not quite to the midrib.

Pectinate. Pinnatifid, with narrow close segments; comb-like.

Pellucid. Clear, transparent.

Peltate. Shield-shaped, with its stalk attached near the center of the dorsal surface.

Penicillate. In a pencil-shaped tuft.

Pentamerous (5-merous). Five in number.

Penultimate. The next to the last.

Pericarp. The matured ovary wall forming a protective coat in the fruit.

Perigynium. The inflated sac which encloses the ovary in Carex.

Perigynous. Around the ovary; that is, adnate to the perianth or to a receptacle-cup.

Petiolulate. Having a petiolule.

Petiolule. The stalk of a leaflet.

Phyllode. An expanded petiole serving as a leaf blade.

Pilose. With soft hairs.

Pinnule. One of the smaller subdivisions of the primary divisions of a pinnately compound leaf.

Pistil. The organ in the flower which produces the ovules and provides for their pollination.

Plaited. Folded into parallel folds.

Plumose. Having fine hairs like a plume.

Plumule. The growing point or bud of an embryo (epicotyl).

Pollinium. A mass of waxy pollen composed of coherent pollen-grains (Orchidaceae.)

Polygamo-dioecious. With perfect and staminate flowers on some plants and perfect and pistillate flowers on others.
Polygamous. Having both perfect and unisexual flowers on the same plant.

Precocious. Appearing before the leaves (said of the flowers in some willows).

Prismatic. Angular with flat sides, like a prism in shape.

Proliferous. Producing offsets.

Pruinose. Covered with a whitish powder.

Puberulent. Minutely pubescent.

Pubescence. Hairiness.

Pubescent. Covered with hairs, especially short soft ones.

Pulvinus. A cushion-like swelling.

Punctate. Dotted.

Puncticulate. Minutely punctate.

Pungent. Terminated in a rigid point; penetrating.

Pustulate. Covered with pustules.

Pyramidal. Pyramid-like.

Pyriform. Pear-shaped.

Quadrifoliolate. With four leaflets.

Raceme. A simple inflorescence of pedicelled flowers on a common more or less elongated axis.

Rachilla. The axis of a grass spikelet.

Rachis. The main axis of an inflorescence.

Radiate. Arranged radially from a center; having ray-flowers.

Radical. Pertaining to the root; occurring at the base of the stem.

Raphe. The ridge on a more or less inverted seed caused by the fusion of the stalk with the seed.

Ray. A branch of an umbel; a rayflower.

Ray-flower. One of the marginal ligulate flowers of a radiate head in the Compositae.

Receptacle. The modified axis on which the flower parts are borne.

Reniform. Kidney-shaped.

Resiniferous. Producing resin.

Reticulated. In the form of a network; net-veined.

Retrorse. Directed backward.

Rosulate. In the form of a rosette.

Rotate. Wheel-shaped; flat and circular in outline.

Rudiment. A partially developed functionless organ.

Rugose. Wrinkled. 
Rugulose. Slightly wrinkled.

Runcinate. Sharply incised with the segments directed backwards.

Rupestrine. Growing among rocks.

Saccate. Sac-shaped.

Sagittate. Arrow-shaped.

Salverform. Having a slender tube abruptly expanded into a flat limb.

Salient. Prominent.

Samara. An indehiscent winged fruit (Aceraceae).

Saprophytic. Depending on dead organic matter for its food.

Scaberulous. Minutely scabrous.

Scabrid. Minutely scabrous.

Scabrous. Covered with short hairs or points.

Scapose. Bearing or resembling a scape.

Scarious. Thin, dry, membranaceous, not green.

Scutellate. Plate-like.

Secund. One-sided.

Septicidal. Dehiscing through the partitions and between the cells.

Septifragal. Dehiscing into parts which break away from the partitions.

Serratures. Serrations.

Serrulate. Finely serrate.

Setaceous. Bristle-like.

Setose. Beset with bristles.

Sheath. A tubular envelope like the lower part of the leaf in the grasses.

Silicle. A short silique (Cruciferae).

Silique. A long 2-celled slender pod (Cruciferae).

Sinuate. Outline strongly wavy.

Sinus. The recess or indentation between two lobes.

Sordid. Dirty white.

Sorus. A cluster of spore-cases; a fruit-dot (Polypodiaceae).

Spathaceous. Spathe-like.

Spathe. A large petal-like bract enclosing an inflorescence.

Spatulate. Gradually narrowed downward from a rounded summit.

Spike. A simple inflorescence with the flowers sessile on a more or less elongated axis.

Spikelet. A small spike, especially the peculiarly specialized one in the grasses.

Spinescent. Becoming spiny.

Spinulose. With very small spines.
Spiricle. A minute coiled thread found on some seeds.

Sporangium. A spore-case.

Sporocarp. A pod-like structure enclosing the spore-cases (Marsileaceae).

Spur. A hollow-sac or tubular extension of the calyx or corolla or both, usually nectariferous.

Stellate-pubescent. With star-shaped hairs.

Sterile. Incapable of producing; as a flower without a pistil or a stamen without an anther.

Stipel. A stipule-like organ at the base of a leaflet.

Stipitate. With a stalk.

Stolon. A runner or basal branch that tends to strike root.

Stoloniferous. Having stolons.

Striae. Minute longitudinal lines.

Striate. Marked with longitudinal lines or ridges.

Strigose. Covered with short stiff appressed hairs.

Strophiole. An appendage near the hilum on certain seeds.

Stylopodium. A disk-like expansion at the base of the style (Umbelliferae).

Submersed. Growing under water.

Suffrutescent. Slightly or obscurely shrubby.

Sub- Somewhat or slightly.

Subulate. Awl-shaped.

Succulent. Juicy, fleshy.

Supra-axillary. Produced not in but above the leaf-axils.

Suture. The line of dehiscence.

Syngenesious. Stamens with united anthers but separate filaments.

Tawny. Dull yellowish brown.

Tegule. One of the sepal-like bracts surrounding the head in the Compositae.

Terete. Cylindrical or nearly so; not compressed.

Ternate. In threes.

Tetradynamous. With four long and two short stamens.

Thallus. A plant body not differentiated into root, stem and leaf.

Thyrsoid. Resembling a thyrsus.

Thyrsus. A contracted cylindrical or ovoid and usually compact panicle. 
Torulose. Cylindrical with contractions at intervals.

Tridentate. Having three teeth.

Trigonous. Having three angles or corners.

Truncate. Ending abruptly as if cut off squarely.

Tuberiferous. Bearing tubers.

Turbinate. Top-shaped; inversely conical.

Turgid. Swollen; distended by pressure from within.

Umbellate. In umbels or like an umbel.

Unguiculate. Contracted at the base into a claw.

Unisexual. Having but one sex; in flowering plants, with either but not both stamens or pistils.

Urceolate. Urn-shaped.

Utricle. A small bladder-like oneseeded fruit.
Vascular. Having woody bundles.

Velum. The membrane partly covering the sporangium in the leaf of Isoetes.

Ventral. Belonging to the anterior or inner face of an organ; the opposite of dorsal.

Verticillate. Arranged in a whorl.

Villous. With numerous long and soft hairs.

Virgate. Wand-shaped; slender, straight, erect.

Viscid. Glutinous, sticky.

Whorl. Leaves or other parts arranged in a circle of three or more at the same node.

Zygomorphic. Bilaterally symmetric$\mathrm{al}$; that is, capable of being divided symmetrically in but one plane. 


\section{INDEX.}

Abies.................. 20

Abronia................. 136

Acer................... 235

ACERACEAE . . . . . . . . . . 235

Achillea .................. 379

Achlys................. 164

Aconite................. 160

Aconitum ................. 160

Actaea ................... 162

Adder Tongue ................. 99

Adder's Tongue............. 97

Adder Tongue Family. ....... 8

Adenocaulon............. 393

Adiantum............... 4

Agoseris................. 355

Agrimonia................ 205

Agropyron............... 61

Agrostideae............. 33

Agrostis............... 42

Aira.................. 45

Aizoaceae . . . . . . . . . . . 136

Alchemilla . . . . . . . . . . . . . 206

Alder..................... 120

Red................ 120

Alfalfa.................. 222

Alfilaria................. 229

Alisma.................. 30

Alismaceae. . . . . . . . . 30

Allium................... 95

Allocarya................ 304

Allotropa . . . . . . . . . . . . 271

Alnus................... 120

Alopecurus............... 39

Alsike Clover. .............. 220

Alum Root. . .............. 196

Alyssum.................. 177

Amabilis Fir............. 21

Amaranth................ 135

Amaranthaceat............ 134

Amaranth Family. .......... 134

Amaranthus............... 135

Ambrosieae . . . . . . . . . . . 347

Amelanchier................ 200

Ammannia................ 245

Ammodenia............... 148

Amsinckia.............. 303

ANACARDIACEAE . . . . . . . 233

Anacharis............... 31

Anagallis.................. 285

Anaphalis................ 392
Anemone................. 153

Wood.................. 153

Androsace................ 284

Angelica................. 261

AngiospermaE ............ 23

Annual Blue-grass.......... 52

Antennaria............... 390

ANTHEMideaE . ............ 347

Anthemis.................. 379

Anthoxanthum.......... 37

A plopappus............... 367

Apocynaceae . . . . . . . . . 290

Apocynum............... 290

Apple, Wild Crab........... 201

Aquilegia . . . . . . . . . . . . 161

Arabis..................... 169

AraceaE ................. 85

AraliaceaE.............. 254

Arbor Vitae............... 18

Arbutus................ 278

Arctium............... 395

Arctostaphylos........... 279

Arenaria.................. 149

Argentina................. 211

Aristolochiaceae . . . . . . . . . 124

Arnica................. 384

Arrhenatherum.......... 45

Arrow Grass............... 29

Arrow Grass Family........... 29

Arrowhead................ 30

Artemisia ................ 381

Artichoke, Jerusalem. . . . . . . 377

Arum Family............. 85

Aruncus................ 203

Asarum................. 125

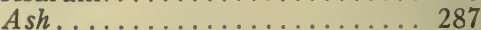

Mountain............ 201

Oregon................ 287

Asparagus............... 99

Asplenium............... 6

Aster................... 371

Astereae................ 347

Astragalus................. 227

Atriplex................ 133

Athyrium............... 6

Athysanus............... 169

Avena.................... 46

AvenEaE ................... 33

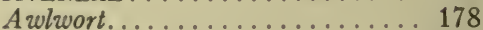

Azaleastrum............... 282 
Bachelor's Button............. 394

Baeria.................. 377

Balsam Family........... 236

BALSAMINACEAE........... 236

Balsamorhiza............ 376

Baneberry................ 162

Barbarea................ 176

Barberry Family. . . . . . . . . . . . 163

Barnyard Grass............. 35

Barley, Wall............... 64 Wild................ 63

Barnyard Grass........... 35

Batrachium............. 155

Bayberry..................... 119

Bearberry................ 237

Beard-tongue............. 317

Bear Grass. . . . . . . . . . . . . . 102

Beckmannia.............. 60

Bedstraw. .................. 334

Beech Family............. 121

Beech Fern.............. 3

Beggar Ticks............... 374

Bellflower............... 344

Bellflower Family........... 342

Bent-grass................ 42

BERBERIDACEAE . . . . . . . . . 165

Berberis. . . . . . . . . . . . . 163

Bergia................. 241

Bermuda-grass............. 61

Berula................. 266

Betula................. 119

Betulaceae . . . . . . . . . . 119

Bidens.................... 374

Bikukulla............... 165

Birch.................. 119

Birch Family............. 119

Bird Bill................ 283

Birthwort Family. ............ 124

Bitter Cress.............172, 176

Bitter Dock.................. 128

Blackberry, Evergreen......... 204

Blackcap................ 204

Black Eyed Susan........... 376

Black Hemlock............... 23

Black Medic................... 222

Black Mustard.............. 175

Bladder Campion............ 143

Bladder Fern.............. 8

Bladderwort............... 332

Bladderwort Family........... 332

Bluebell..................... 301

Bluecurls................. 307

Blue-eyed Grass. ............... 105

Blue-flowered Lettuce. . . . . . . . . 360

Blue-grass................ 52

Annual............... 52

Kentucky............... 54
Bluestem.............. 62

Bluetop.................. 41

Boisduvalia .............. 252

Bolandra................ 191

Bolelia................. 343

Borage Family............. 299

BORAGINACEAE . . ............. 299

Boschniakia............. 330

Botrychium ............. 9

Bracken.................. 4

Brake.................. 4

Brasenia............... 151

Brassica................ 174

Briza.................... 49

Broadleaf Maple............ 235

Brome-grass............. 50

Bromus............... 50

Broomrape Family.......... 330

Buckbean.................. 289

Buckbean Family............ 289

Buckbrush............... 237

Buckhorn................ 333

Buckthorn.............. 236

Buckthorn Family.......... 236

Buckwheat Family........... 125

Bugbane................. 162

Bull Pine................ 20

Bull Thistle............... 395

Bulrush, Western............ 84

Bur Clover............... 222

Burdock................ 395

Bur Reed................... 24

Bur-reed Family............... 24

Bursa................. 181

Butter and Eggs............ 317

Buttercup............... 156

Water.............. 155

Buttercup Family.......... 151

Butterwort.............. 332

Cactaceae.............. 244

Cactus Family. . . . . . . . . . 244

Cakile.................. 168

Calamagrostis........... 41

Calandrinia ............. 138

California Black Oak........ 122

California Lilac............. 238

California Poppy............ 165

CALlitrichaceaE.......... 231

Callitriche.............. 232

Calochortus................ 96

Caltha................. 161

Calypso................. 109

Camas................. 98

Death.................. 99

Camelina................. 181

Campanula.................. 344 
Campanulaceae........... 342

Canada Blue-grass........... 54

Canada Thistle.............. 395

Canary-grass.............. 37

Reed............... 36

Capnoides.............. 166

Caprifoliaceae........... 336

Caraway.................. 264

Cardamine............... 172

Carex.................... 66

Carnation................. 142

Carpet Weed............... 136

Carpet Weed Family......... 136

Carrot................... 258

Wild .............. 258

Carum.................. 264

Caryophyllaceae. . . . . . . . . 141

Cascara Sagrada............... 237

Cashew Family............. 233

Cassiope... . . . . . . . . . . . 280

Castanopsis.............. 121

Castilleja................ 327

Catchfly.................. 142

Catnip............... 310

Cat-tail.................. 24

Cat Tail Family........... 23

Caucalis................. 258

Ceanothus............... 237

Celastraceae............. 234

Centaurea................. 393

Centaurium ............... 287

Cephalanthera............. 108

Cerastium . . . . . . . . . . . . 146

Cerasus................... 199

Ceratophyllaceae. . . . . . . 151

Ceratophyllum . . . . . . . . . . 151

Ceropteris............... 2

Chaetochloa............... 35

Chamaecyparis............ 18

Charlock............... 175

Cheat................. 52

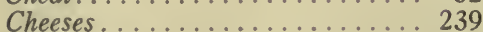

Cheilanthes.............. 5

Chelone... . . . . . . . . . . . . . 319

Chenopodiaceae . . . . . . . . 132

Chenopodium............. 133

Cherry.................... 199

Wild. . . . . . . . . . . . . 199

Chess.................. 52

Chickweed................. 146 Mouse-ear............ 146

Chicory................. 353

Chimaphila.............. 273

Chinquapin.............. 121

CHLORIDEAE................ 34

Chokecherry................. 199

Christmas Fern, Pacific....... 7
Chrysanthemum........... 380

Chrysopsis............... 363

Chrysosplenium.... . . . . . . . 193

Cicely, Sweet.............. 259

Cichorieae............. 347

Cichorium .............. 353

Cicuta.................. 263

Cimicifuga................ 162

Cinna................. 40

Circaea................... 246

Cirsium................... 394

Cladothamnus............. 281

Claytonia................. 139

Cleavers................... 334

Clematis................ 152

Clintonia................ 100

Clover.................... 218

Rabbit's Ear............ 221

Red................. 220

Sweet................. 222

White................ 220

Cochlearia................ 178

Cocklebur................. 361

Coelopleurum . . . . . . . . . . . 268

Cogswellia............... 260

Coleanthus................ 40

Coleosanthus.............. . 362

Collinsia ................. 319

Collomia................... 296

Coltsfoot, Sweet.............. 382

Columbine................. 161

Comandra............... 124

Comarum................ 211

Common Horsetail. . . . . . . . . . 11

Common Mullein............. 316

Common Plantain........... 333

Common Spleenwort.......... 6

Common Vetch.............. 223

Compositae.............. 345

Composite Family. . . . . . . . 345

Corallorhiza................ 108

Coral Root..... . . . . . . . . . . . . 108

Cord-grass................ 60

Coreopsis................. 375

Coriander................ 264

Coriandrum ............... 264

Cornaceae . . . . . . . . . . . . 268

Cornus................... 269

Coronopus . . . . . . . . . . . . . 168

Corylus................. 120

Cotton-grass............... 84

Cottonwood............... 118

Cotula.................... 381

Couch-grass................ 62

Cow Parsnip................. 260

Conioselinum............ 262

Convolvulaceae. . . . . . . . . 290 
Convolvulus.............. 291

Coptis................. 163

Corn Chamomile............... 380

Crab-apple, Wild............ 201

Cranberry................277

Crassulaceae............ 182

Crataegus................ 200

Crepis................... 358

Cress, Bitter...............172, 176

Mouse-ear............. 175

Penny............... 181

Rock................ 169

Crested Dogstail............ 48

Crocidium................ 383

Crowberry................. 232

Crowberry Family............ 232

Crowufoot, Water............ 155

Cruciferae.............. 166

Cryptantha.............. 303

Cryptogramma............ 4

Cucurbitaceae............ 341

Currant................... 185

Red-flowering. ......... 187

Cuscuta................. 292

Cuscutaceae . . .......... 291

Cynareae .............. 347

Cynodon................... 60

Cynoglossum ............... 301

Cynosurus................ 48

Cyperaceae............. 65

Cyperus................ 81

Cypripedium............ 107

Cytherea................ 108

Dactylis............... 52

Daisy, Mountain . . . . . . . . . 369

Oxeye............... 380

Dandelion................ 355

Danthonia................ 45

Darnel...................... 61

Dasiphora.................. 210

Datura................. 314

Daucus................. 258

Dead Nettle............... 312

Death Camas................ 99

Deer Fern................ 5

Delphinium................. 159

Dentaria................ 171

Deptford Pink............. 142

Deschampsia............. 46

Devil's Club............... 255

Dewberry.................... 204

Dianthus.................. 142

DicotyLEDONES........... 112

Digitalis................ 325

Dipsacaceae............. 341

Dipsacus................ 341
Disporum............... 102

Distichlis............... 56

Dock...................... 127

Bitter............... 128

Yellow.............. 128

Dodder.................. 292

Dodder Family............. 291

Dodecatheon............. 283

Dogbane................. 290

Dogbane Family............. 290

Dog Fennel............... 380

Dogwood.................. 269

Dogwood Family........... 268

Dondia................. 132

Douglasia................ 284

Douglas Spruce............. 22

Draba................. 177

Dracocephalum............ 310

Dragon Head.............. 310

Drosera................. 182

Droseraceae ............. 182

Dryas................. 206

Drymocallis.............. 211

Dryopteris.............. 7

Duckweed Family........... 86

Dulichium............... 82

Dwarf Maple................ 235

Echinochloa.............. 34

Echinopanax............ 255

Eel-grass.............. 28

ELAEAGNACEAE ........... 244

Elatinaceae............. 241

Elatine................... 241

Elder.................... 336

Elecampane.............. 393

Eleocharis............... 82

Eleusine................ 61

Elmera................. 196

Elodea................... 31

Elymus................ 62

EMPETRACEAE ........... 232

Empetrum............. 232

Enchanter's Nightshade........ 246

Engelmann Spruce........... 22

English Rye-grass............ 61

Epilobium................ 2467

Epipactis............... 112

EquisETACEAE............ 11

EquisetineaE............ 10

Equisetum.............. 11

Eragrostis............... 48

ERICACEAE.............. 275

Erigeron.................. 366

Eriogonum............. 125

Eriophorum............. 84

Eriophyllum............... 378 
INDEX.

Erodium................ 229

Eryngium............. 257

Erysimum.............. 173

Erythronium............ 97

Eschscholzia.............. 165

Eucarex............66, 68

Eucephalus............. 370

Euonymus................ 234

EUPATORIEAE............. 347

Eupatorium ................ 361

Euphorbia.............. 230

EUPHORBIACEAE . . . . . . . . . 230

Euthamia.............. 366

Evening Primrose........... 253

Evening Primrose Family...... 246

Evergreen Blackberry.......... 204

Everlasting............. 392

FAGACEAE............. 121

False Flax............... 181

False Hellebore............ 103

False Mermaid Family......... 232

False Pimpernel.............. 420

False Solomon's Seal.......... 103

Fern, Beech............... 3

Bladder.............. 8

Deer.

Gold-back . .

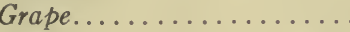

Holly................

Lace. .

Lady

Licorice-root

Maiden Hair.

Pacific Christmas

Rattlesnake...

Shield. .

Wood.

Fern Family.

Fern Plants.

Fescue.

Meadow.

Mouse-tail

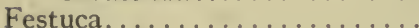

Festuceae .............. 33

Figwort................ 319

Figwort Family............ 315

Filaree................... 229

FILICINEAE.............. 1

Filix.................. 8

Fir.................. 20

Amabilis.............. 21

Noble............... 21

Red.................. 22

Subalpine............ 21

White................ 21

Fireweed............... 248
Flax, False............ 181

Fleabane................... 366

Floerkea................. 233

Forget-me-not........... 302

Four O'Clock Family.......... 135

Fowl Meadow-grass........... 54

Foxglove............... 325

Foxtail, Green.............. 35

Meadow.............. 40

Fragaria ............... 210

Fraxinus............... 287

Fritillaria............... 97

Frog's Bit Family.......... 30

Gaertneria............... 361

Gale, Sweet.................. 119

Gaillardia.............. 378

Galium.................. 334

Garrya.................. 269

Garry Oak............... 122

Gastridium............... 39

Gaultheria................. 278

Gayophytum.............. 252

Gentian................ 288

Gentiana................. 288

GentianAcEAE . . . . . . . 287

Gentian Family........... 287

GeraniacEaE . . . . . . . . 228

Geranium................. 228

Wild ............... 228

Geranium Family........... 228

Geum................. 207

Giant Cedar............... 18

Gilia . . ................ 293

Ginger, Wild................... 125

Ginseng Family............ 254

Githopsis............... 343

Glechoma................ 311

Glehnia................ 267

Globe Flower.............. 162

Glasswort.................... 133

Glaux.................. 285

Glyceria.................. 59

Gnaphalium............... 392

Goat's Beard. ............... 203

Godetia................ 250

Gold-back Fern............. 2

Goldenrod........................ 364

Goldthread...................... 163

Gooseberry................... 185

Goosefoot................. 133

Goosefoot Family............ 132

Goose-grass............... 61

Gormania............... 184

Gorse.................... 218

Gosmore................... 353

Gourd Family............. 341 
INDEX.

Grape Fern.

Grass, Barnyard.............. 35

Bear.................. 102

Bent................. 42

Bermuda............ 61

Blue................ 52

Blue-eyed............ 105

Brome.............. 50

Canary............... 37

Cord................ 60

Cotton.............. 84

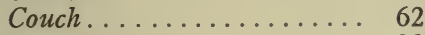

Eel.................. 28

English Rye.......... 61

Fowl Meadow........... 54

Goose.................. 61

Hair................. 45

Italian Rye........... 61

Kentucky Blue.......... 54

Orchard............... 52

Perennial Rye........... 61

- Quack............... 62

Reed Canary........... 36

Reed Meadow............ 59

Rough Meadow.......... 54

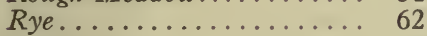

Salt................... 56

Slender Wheat.............. 62

Sweet Vernal........... 37

Tall Oat............. 45

Vanilla............. 37

Velvet................. 44

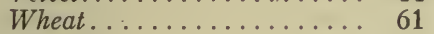

Grass Family................ 31

Gratiola............... 320

Green Foxtail.............. 35

Green Hellebore. . . . . . . . . . . . . . 103

Grindelia . . . . . . . . . . . . . 362

Gromwell. . . . . . . . . . . . . . . 303

Ground Ivy................ 311

Ground-pine................ 13

Gum Plant. . . . . . . . . . . . 362

Gymnogramme............ 2

Gymnospermae............ 16

Hair-grass............... 45

Haloragidaceae ............ 253

Harrimanella .............. 280

Hawkweed................. . . 356

Hawthorn . . . . . . . . . . . . . 200

Hazelnut. . . . . . . . . . . . . . 120

Heal All ..................... 311

Heather Family. . . . . . . . . . 275

Hedge Hyssop... . . . . . . . . . 320

Hedge Mustard.............. 175

Hedge Nettle.............. 313

Hedysarum ............. 225

Helenieae. . . . . . . . . . . 347

Helenium . . . . . . . . . . . . . 379

Heliantheae . . . . . . . . . . 347

Helianthus............. 377

Hellebore, False........... 103

Green................... 103

White............... 103

Hemieva............... 192

Hemitomes............... 271

Hemizonella.............. 374

Hemizonia . . . . . . . . . . . 374

Hemlock............... 22

Black................. 23

Mountain........... 23

Water.................. 263

Western............ 23

Heracleum.............. 260

Hesperis................ 173

Hesperogenia............ 267

Heteranthera............. 86

Heterocodon . . . . . . . . . . . . 344

Heterostylus.............. 28

Heuchera . . . . . . . . . . . . . 196

Hieracium . . . . . . . . . 356

Hierochloe............. 37

Hippuris. . . . . . . . . . . 254

Holcus................. 44

Holly Fern................ 7

Holodiscus... . . . . . . . . . . 202

Homalocenchrus........... 36

Honeysuckle.............. . 338

Honeysuckle Family. . . . . . . . 336

Hoorebekia................. . 363

Hookera................... 94

Hop Clover............... 221

Hordeae.............. 34

Hordeum.............. 63

Horehound................ . 312

Horned Pondweed........... 28

Hornwort. . . . . . . . . . . . . . 151

Hornwort Family. .......... 151

Horsetail. ................. 11

Common............... 11

Horsetail Family........... 11

Hosackia............... 225

Hound's Tongue.............. 301

Howellia................ 342

Huckleberry............... 276

Hulsea................. 378

Hutchinsia . . . . . . . . . . 181

Hyacinth, Wild............. 94

Hydastylus.............. 106

HYDROCHARITACEAE......... 30

Hydrocotyle............... 263

HYDROPHYLLACEAE. . . . . . . . . 297

Hydrophyllum . . . . . . . . . . . 298

HyPERICACEAE . . . . . . . . . . . 239 
Hypericum. . . . . . . . . . 240

Hypopitys.............. 272

Hypochaeris............... 353

Ibidium . . . . . . . . . . . . 111

Ilysanthes................ 320

Impatiens.

Incense Cedar.

Indian Paint Brush.

Indian Pink.

Indian Plum.

Inula.

INULEAE.

IRIDACEAE

Iris Family.

Iron-wood

Isnardia . .

ISOETACEAE

Isoetes. . .

Isopyrum

Italian Rye-grass

Ivy, Ground....

Jacob's Ladder.

Jamestown Weed..............

Jaumea.

Jerusalem Artichoke.

Jewelweed .

Jimson Weed

JUNCACEAE.

Juncoides

Juncus.

Juniper.

\section{Mountain}

Rocky Mountain

Juniperus

Kalmia

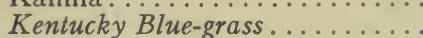

Kinnikinnick .

Knobcone Pine.

Knot-weed.

Kocleria .

Kruhsea

LABIATAE

Labrador Tea

Lace Fern

Lactuca

Lady-Fern.

Lady's Slipper.

Lady's Thumb.

Lagophylla.

Lamb's Quarters

Lamium

Lappula

Lapsana
320

19

327

327

200

393

347

104

104

202

247

15

15

163

61

311

294

314

377

377

236

314

87

91

87

17

18

18

17

282

54

279

20

129

48

101

306

280

5

359

6

107

131

374

134

312

300

352
Larkspur.................. 159

Lathyrus............... 223

Laurel, Sticky............... 237

Leadwort Family............ 286

Leather-leaf Polypody......... 3

Ledum.................... 280

LEGUMINOSAE . . . . . . . . . . 212

Lemna................ 86

LeMNACEAE .............. 86

LENTIBULARIACEAE. . . . . . . 332

Leonurus................. 312

Lepargyrea.................. 244

Lepidium.................. 179

Leptarrhena.............. 188

Leptaxis.................. 195

Leptotaenia .............. 263

Lesquerella............... 176

Lewisia.................... 137

Libocedrus............... 19

Licorice-root Fern............ 266

Lilac, California............ 238

Lilaea.................. 28

Lilaeopsis . . . . . . . . . . . . 265

LILIACEAE................ 92

Lilium...................... 96

Lily Family.............. 92

LiMNANTHACEAE . . . . . . . . . 2.32

Limnanthes............. 233

Limnorchis. . . . . . . . . . . . . . . 109

Limosella . . . . . . . . . . . . . . . 323

Linaria . . . . . . . . . . . . . 316

Linnaea..................... 338

Lithospermum. . . . . . . . . . . 303

Lloydia................ 98

Lodgepole Pine.............. 20

Lolium................... 61

Lonicera...................... 338

Loosestrife............... 286

Loosestrife Family............. 245

LORANTHACEAE ............ 122

Lousewort. . . . . . . . . . . . 326

Lovage................. 266

Luina................ 383

Lupine. . . . . . . . . . . . . 213

Lupinus................ 213

Lutkea................ 201

Lychnis................ 144

LYCOPODIACEAE............ 12

LYCOPODINEAE.............. 12

Lycopodium............... 13

Lycopus.................. 307

Lysias..... . . . . . . . . . . . . 111

Lysichiton . . . . . . . . . . . . 85

Lysimachia............... 286

LythracEaE . . . . . . . . . . . 245

Lythrum.................. 245 
Madder Family. . ........... 334

Madia.................. 372

Madroña.................. 279

Madronella............... 309

Maiden Hair Fern............ 4

Mallow................ 239

Musk.............. 239

Mallow Family............. 238

Malva................. 239

MaLvaceae.............. 238

Manzanita................. 279

Maple................... 235

Dwarf.............. 235

Vine.................. 235

Mare's Tail..................... 254

Mariposa Lily.................. 96

Marrubium.............. 311

Marsh Marigold............ 161

Marsilea................ 10

Marsileaceae ........... 10

Matricaria................. 380

-May-weed .................... 380

Meadow Fescue............. 58

Meadow Foxtail.............. 40

Meadow Rue.............. 154

Medicago................ 222

Megalodonta.............. 375

Melica.................... 49

Melilotus.................. 222

Mentha................ 308

Menyanthaceae . . . . . . . . . . 289

Menyanthes.............. 289

Menziesia................. 282

Mertensia................ 301

Mesquite................... 44

Micrampelis............. 341

Micranthes.............. 191

Micromeria............. 309

Microseris............... 354

Milfoil................... 379

Water................ 254

Milk Thistle............... 394

Mimulus................ 323

Mint................ 308

Wild................ 308

Mint Family.............. 306

Mistletoe Family........... 122

Mitella................... 194

Mitrewort................... 194

Moehringia............. 150

Mollugo.................. 136

Moneses................... 273

Monkey Flower. . . . . . . . . . . . 323

Moneywort................ 286

Monkshood............... 160

Monocotyledones......... 23

Monotropa.........271, 272
Montia................ 138

Moonwort............... 9

Morning Glory............ 291

Morning Glory Family. . . . . . . 290

Moss Campion................ 143

Motherwort............... 312

Moth Mullein................ 316

Mountain Ash............. 201

Mountain Daisy............. 369

Mountain Hemlock. ........... 23

Mountain Juniper........... 18

Mountain Sorrel............. 127

Mountain Timothy........... 39

Mouse-ear Chickweed......... 146

Mouse-ear Cress.............. 175

Mouse Tail.................. 154

Mouse-tail Fescue.......... 57

Mudwort................. 323

Muhlenbergia............ 37

Mullein................. 316

Common............... 316

Moth.............. 316

Mullein Pink.............. 144

Musk Mallow............... 239

Musk Plant............... 325

Mustard, Black............ 175

Hedge.............. 175

Tumbling............. 176

Nabalus.................. 359

NAJADACEAE . . . . . . . . 25

Najas................. 28

Napa Thistle............. 394

Naumburgia.............. 286

Navarretia................ 295

Nemophila................ 299

Nepeta................ 310

Nephrophyllidium.......... 289

Nettle.................... 122

Dead ................ 312

Hedge.................. 313

Nettle Family............. 122

Newberrya.............. 270

Nicotiana............... 315

Nightshade.............. 314

Nightshade Family........... 314

Ninebark.................. 201

Nipple-wort. . ............ 352

Noble Fir................. 21

Nyctaginaceae . . . . . . . 135

Nymphaea............... 151

NyMPHAEACEAE............ 150

Oak................... 121

California Black......... 122

Garry.................. 122

Poison................. 234 
Oat ................. 46

Smooth Wild........... 46

Oat grass, Tall............. 45

Ocean Spray. . . . . . . . . . . 202

Oenanthe............... 265

Oenothera............... 253

Old Man Root............... 342

Oleaceak................ 287

Oleaster Family. . . . . . . . . . 244

Olive Family... . . . . . . . . . . . 287

Olsynium................ 106

ONAGRACEAE............ 246

Onion.................. 95

Ophioglossaceae......... 8

Ophioglossum............. 9 9

Ophrys.................... 109

Opulaster............... 201

Opuntia................... 244

Orchard-grass............. 52

ORCHIDACEAE.............. 106

Orchid Family. . . . . . . . . . 106

Oregon Ash.............. 287

Oregon Grape. . . . . . . . . . . . . 164

Oreostemma............... 370

ORoBanchaceaE........... 330

Orobanche.............. 331

Orogenia................. 267

Orthocarpus. . . . . . . . . . . . . 329

OryzeaE............... 32

Osmaronia............... 199

Osmorhiza................ 259

Oxalidaceae............. 229

Oxalis................... 230

Oxeye Daisy. . . . . . . . . . . . . 380

Oxycoccus............... 277

Oxyria.................. 126

Oxytropis................ 227

Oyster Plant............. 353

Ozomelis................. 195

Pachistima.............. 234

Pacific Christmas Fern . . . . . . 7

Paeonia.................. 161

Paint Brush, Indian. . . . . . . . 327

Painted Cup.............. 327

Panicularia........... 58

Paniceae................ 32

Panicum............... 35

Papaveraceae . . . . . . . . . . 164

Parnassia............... 188

Parsley Family. . . . . . . . . . 255

Parsnip................. 262

Cow................. 260

Pasapalum............... 35

Pasque Flower. . . . . . . . . . . 154

Pastinaca................ 262

Pear, Prickly............. 244
Pearlwort................. 148

Pedicularis............... 326

Pellaea.................. 4

Penny Cress... . . . . . . . . . . 181

Pentacaena............... 144

Pentstemon.............. 317

Peony.................. 161

Peppergrass............... 179

Peramium . ............. 111

Perennial Rye-grass.......... 61

Petasites. . . . . . . . . . . . . 382

Phacelia............... . 297

Phal ARIdeaE ............ 32

Phalaris................ 36

Phegopteris............. 3

Philadelphus . . . . . . . . . . 188

Phleum.............. 38

Phlox.................. 293

Phlox Family. . . . . . . . . . . . 292

Phoradendron............ 123

Phyllodoce.............. 281

Phyllospadix............. 28

Physostegia ............. 312

Picea.................. 22

Pigweed..............134, 135

Pimpernel............... 285

False.............. 320

Pinaceae............... 17

Pine.................. 19

Bull................ 20

Ground................ 13

Knobcone............. 20

Lodgepole............ 20

Running............ 14

Sugar............... 20

Western White.......... 19

White-bark............. 19

Yellow............... 20

Pine Family.............. 17

Pine Lily. . . . . . . . . . . . . 102

Pinguicula.............. 332

Pink.................. 142

Deptford............... 142

Indian.............. 327

Mullein................ 144

Pink Family................ 141

Pinus..................... 19

Piperia............... 110

Pipes................... 12

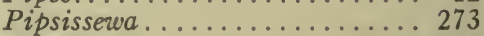

Piscaria................ 231

Pityopus............... 271

Plagiobothrys............. 304

Platystigma............... 165

Plantaginaceae.......... 333

Plantago................... 333

Plantain................ 333 
Plantain, Rattlesnake......... 112

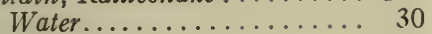

Plantain Family............. 333

Pleuricospora............ 271

Pleuropogon................ 49

Plum..................... 199

Indian............... 200

Plumbaginaceae . . . . . . . . . 286

Poa.................. 52

PoACEAE................. 31

Poison Oak................ 234

Polemoniaceae . . . . . . . . . . 292

Polemonium. . . . . . . . . . . . . 294

Polygonaceae............. 125

Polygonum............... 128

Polypodiaceae............ 1

Polypodium .............. 2

Polypody, Leather-leaf......... 3

Polypogon............... 39

Polystichum............... 6

Pond Lily, Yellow............ 151

Pondweed................. 25

Horned............... 28

Pondweed Family...........25, 86

Pontederiaceae........... 86

Poppy, California........... 165

Poppy Family. . . . . . . . . . . . . 164

Populus................. 118

Portulaca................ 137

Portulacaceae . . . . . . . . . 136

Potamogeton.............. 25

Potentilla................ 208

Prickly Lettuce. . . . . . . . . . . . . . . 360

Prickly Pear................. 244

Primocarex............... 66

Primrose, Evening. . . . . . . . . 253

Primrose Family. . . . . . . . . . 283

Primulaceae.............. 283

Prunella............... 311

Prunus. . . . . . . . . . . . . . . . . 199

Pseudotsuga.............. 21

Psilocarphus............... 390

Psoralea.................. 218

Pteridium.............. 4

Pteridophyta............ 1

Pterospora .............. 272

Puccinellia............... 59

Pulsatilla.................. 154

Pulse Family. . . . . . . . . . . 212

Purslane................. 137

Purslane Family. . . . . . . . . . 136

Pyrola.................. 274

Pyrolaceae ............... 270

Pyrola Family. . . . . . . . . . . 270

Pyrus................. 200

Quack-grass............. 62
Quamasia................ 98

Quercus................... 121

Quillwort..................... 15

Quillwort Family............ 15

Rabbit's Ear Clover. . . . . . . . . 221

Radicula................. 179

Radish.................... 168

Wild............... 168

Rainiera............... 383

RANunCULACEAE.......... 151

Ranunculus.............. 156

Raphanus................. 168

Rapuntium............... 343

Rattlesnake Plantain.......... 112

Razoumofskya............. 123

Red Alder................. 120

Red Clover... . . . . . . . . . . . . 220

Red Fir................. 22

Red-flowering Currant.......... 187

Redtop................ 43

Reed Canary-grass........... 36

Reed Meadow-grass.......... 59

RHAMNACEAE............. 236

Rhamnus................ 236

Rhinanthus................ 326

Rhododendron............ . 282

Rhus.................. 233

Ribes... . . . . . . . . . . . . . 185

Rock Cress . . . . . . . . . . . . . 169

Rocket.................. 173

Rocky Mountain Juniper. . . . . . 18

Romanzoffia............... 297

Rosa................... 20t

RosaCEAE................. 197

Rose................... 2: 2i4

Rose Family. . . . . . . . . . . . . 197

Rotala.................... 246

Rough Meadow-grass........... 54

Rubiaceae................ 334

Rubus. . . . . . . . . . . . . . 203

Rudbeckia............... 375

Rumex................. 127

Running-pine............. 14

Ruppia................. 27

Rush................ 87

Scouring............ 12

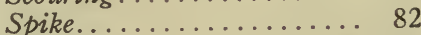

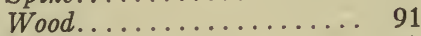

Rush Family.............. 87

Russian Thistle........... 133

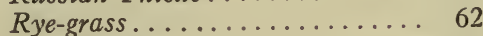

English.............. 61

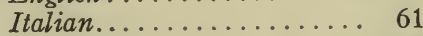

Perennial............................. 61

Rynchospora............. 82 
Sagebrush.............. 381

Sagina.................. 148

Sagittaria.............. 30

Salal...................... 278

SALICACEAE .............. 112

Salicornia................ 132

Salix. . . . . . . . . . . . . . . . 113

Salmon-berry............... 204

Salsify................ 353

Salsola................... 133

Saltbush................... 133

Salt-grass.............. 56

Sambucus................ 336

Samphire............... 133

Sandalwood Family. . . . . . . . . 124

Sandwort................. 149

Sanguisorba.............. 206

Sanicula................ 257

SANTALACEAE. . . . . . . . . . . 124

Saussurea . . . . . . . . . . . . . . 396

Saxifraga................. 189

Saxifragaceae............. 184

Saxifrage................ 189

Saxifrage Family. . . . . . . . . 184

Scheuchzeria.............. . 29

Scheuchzeriaceae . . . . . . . . 29

Scirpus.................. 83

Scoliopus................ 101

Scorzonella............... 353

Scouring Rush............. 12

Scrophularia.............. 319

SCROPHULARIACEAE.......... 315

Scutellaria................ . 309

Sea-blite................ 132

Sedge.................. 66

Sedge Family. ............. 65

Sedum................... 183

Seed Plants............... 16

Selaginella ................ 14

SelaginellaceaE........... 14

Senecio................. 386

Senecioneae............. 347

Sericocarpus... . . . . . . . . . 369

Service Berry. . . . . . . . . . . . . 200

Sheep Sorrel............... 127

Shepherd's Purse............ 181

Sherardia............... 334

Shield Fern................ 7

Shooting Star.............. 283

Sibbaldia . . . . . . . . . . . 210

Sidalcea................ 238

Sieversia. . . . . . . . . . . . . 207

Silene................... 142

Silver-top............... 47

Silybum . . . . . . . . . . . . . 394

Sisymbrium ............... 175

Sisyrinchium........... 105
Sitanion................ 64

Sitka Spruce................. 22

Sium.................. 267

Skullcap................. 309

Skunk Cabbage, Yellow........ 85

Skunk Weed.................. 295

Slender Wheat-grass.......... 62

Smartweed................ 131

Smelowskia................ . 174

Smooth Wild Oat............ 46

Snappers................ 123

Snowberry................ 338

SolanacEAE.............. 314

Solanum................. . 314

Solidago. . . . . . . . . . . . . . . 364

Solomon's Seal, False......... 103

Sorrel, Mountain............ 127

Sheep............... 127

Wood.................. 230

Sow Thistle................. 360

Sparganiaceae............. 24

Sparganium.............. 24

Spartina ................ 60

Spearmint.............. 308

Specularia . . . . . . . . . . . . . 344

Speedwell................. 322

Spergula.................... 145

SPERMATOPHYTA . . . . ......... 16

Sphaerostigma............ 253

Spike Rush.............. 82

Spiraea... . . . . . . . . . . . 202

Spirodela ............... 86

Spleenwort............... 6

Common.............. 6

Spraguea................. 138

Spruce................. 22

Douglas............. 22

Engelmann........... 22

Sitka................. 22

Tideland............... 22

Spurge................... 230

Spurge Family............ 230

Spurrey.................. 145

Squirrel Rail................ 64

Stachys.................. 313

Staffiree Family. . . . . . . . . . . 234

Star-flower............... 285

Starwort, Water............ 232

Statice.................. 286

Stellaria................ 146

Stenanthium ............... 99

Sticky Laurel. . . . . . . . . . . . . . . . 237

Stipa................. 38

St. Johnswort. . . . . . . . . . . . 240

St. Johnswort Family. . . . . . . . . . 239

Stonecrop.................. 183

Stonecrop Family........... 182 
Strawberry............... 210

Streptopus............... 101

Struthiopteris............ 5

Subalpine Fir............. 21

Subularia............... 178

Sugar Pine............... 20

Sullivantia .............. 192

Sundew.................. 182

Sundew Family. . ............... 182

Sweetbrier................ 205

Sweet Cicely................ 259

Sweet Clover............... 222

Sweet Coltsfoot.............. 382

Sweet Gale.................. 119

Sweet Gale Family.............. 118

Sweet Vernal-grass............ 37

Symphoricarpos............. 338

Synthyris............... 321

Syringa............... 188

Tall Oat-grass

Tanacetum.............. 381

Tansy................... 381

Taraxacum............... 355

Tares.................. 223

Tarweed..............303, 372

TAXACEAE .............. 16

Taxus................... 16

Teasel................... 341

Teasel Family.............. 341

Tellima................. 194

Thalesia................ 331

Thalictrum............... 154

Thelypodium............... 173

Thermopsis.............. 213

Therofon................ 192

Thimble Berry............. 204

Thistle................. 394

Bull................. 395

Napa................. 394

Russian.............. 133

Sow................. 360

Thlaspi ............... 180

Thorn.................. 200

Thrift................ 287

Thuja................ 18

Thysanocarpus............. 169

Tiarella.................. 193

Tideland Spruce............ 22

Tillaea................... 183

Timothy................. 38

Mountain............. 39

Tipton-weed................ 240

Tissa.................... 145

Tobacco................. 315

Tofieldia................ 100

Tonella................... 320
Touch-me-not........... 236

Tragopogon.............. 352

Trautvetteria............... 154

Trefoil, Yellow............. 222

Trichostema................ 307

Trientalis............... 285

Trifolium................ 218

Triglochin................. 29

Trillium.................. 100

Trisetum.............. 47

Trollius..................... 162

Tsuga................ 22

Tule................... 84

Tumbleweed ................. 135

Tumbling Mustard................. 176

Turkey Mullein .............. 231

Turnip................. 175

Twin-flower............... 338

Typha................ 24

TyPhaceae............. 23

Ulex..................... 217

UMBELLIFERAE . . . . . . . . . 255

Unifolium.................. 104

Urtica................... 122

URTICACEAE. . . . . . . . . . 122

Utricularia .............. 332

Vaccinium...............276

Vagnera................. 103

Valeriana................ 340

VALERIANACEAE . ............ 339

Valerinella.................. 340

Valerian Family. ............ 339

Vancouveria................. 164

Vanilla-grass............. 37

Vanilla-leaf.............. 164

Velvet-grass............... 44

Venus's Looking Glass. ........... 344

Veratrum.................. 103

Verbascum................. 316

Verbena................. 305

VERBENACEAE ............. 305

Verbena Family............... 305

Veronica.................... 322

Vervain................. 305

Vetch................... 222

Vetchling.............. 223

Viburnum.............. 337

Vicia................... 222

Vignea..................... 67

Vine Maple............... 235

Viola ................... 241

ViolaceAe. . . . . . . . . . . 241

Violet.................... 241

Violet Family. .............. 241 
Wake Robin............... 100

Wall Barley. . . . . . . . . . . . . 64

Wappato............... 30

Washingtonia............. 259

Water Buttercup............. 155

Water Crowfoot. . . . . . . . . . . 155

Water Hemlock. . . . . . . . . . . . 263

Waterleaf.................. 298

Waterleaf Family... . . . . . . . 287

Waterlily Family. . . . . . . . . . 150

Water Milfoil............. 254

Water Milfoil Family.......... 253

Water Plantain............ 30

Water Plantain Family... . . . . 30

Watershield.............. 151

Water Starwort............. 232

Water Starwort Family. . . . . . . 231

Waterweed............... 31

Waterwort Family........... 241

Western Bulrush.............. 84

Western Hemlock. . . . . . . . . . 23

Western White Pine.......... 19

Western Yew.............. 17

Wheat-grass................ 61

Slender.............. 62

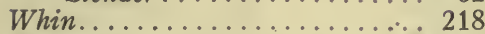

Whipplea................... 185

White-bark Pine............ 19

White Clover............... 220

White Fir. ............... 21

White Hellebore. . . . . . . . . . . 103

Wild Barley............... 63

Wild Carrot................. 258

Wild Cherry................... 199

Wild Crab-apple............. 201

Wild Geranium. . . . . . . . . . . 228

Wild Ginger.............. 125
Wild Hyacinth. . . . . . . . . . 94

Wild Lettuce. . . . . . . . . . . . . . . 359

Wild Mint. . . . . . . . . . . . 308

Wild Radish. . . . . . . . . . . . . . 168

Willow.................... 113

Willow Family. . . . . . . . . . . . . 112

Willow Herb. . . . . . . . . . . . . . 246

Windflower............... 153

Wokas................. 151

Wood Anemone............ 153

Wood Fern............... 7

Wood Rush................ 91

Woodsia................. 8

Wood Sorrel................ 230

Wood Sorrel Family... . . . . . . 229

Woodwardia............. 5

Wormwood.............. 381

Wyethia................... 376

Xanthium................ 361

Xerophyllum.............. 102

Yarrow................. 379

Yellow Dock.................. 128

Yellow Pine................ 20

Yellow Pond Lily............. 151

Yellow Skunk Cabbage.......... 85

Yellow Trefoil............... 222

Yerba Buena............... 309

Yew................. 16

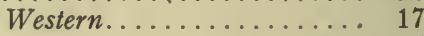

Yew Family............... 16

Zannichellia............. 27

Zigadenus............... 99

Zizia................... 265

Zostera................ 28 
- 
. 
$-$ 
